\title{
Assessment Report for Hanford Analytical Services Quality Assurance Plan
}

\author{
L. H. Taylor
}

Date Published

November 1994

Prepared for the U.S. Department of Energy Office of Environmental Restoration and Waste Management

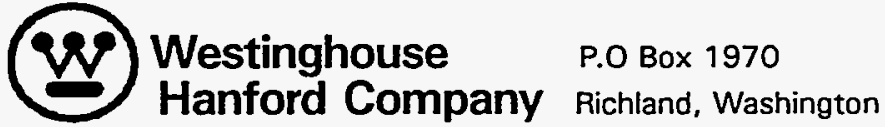

Hanford Operations and Engineering Contractor for the

U.S. Department of Energy under Contract DE-AC06-87RL10930 
LEGAL DISCLAIMER

This report was prepared as an account of work sponsored by an agency of the United States Government. Neither the

United States Government nor any agency thereof, nor any of their employees, nor any of their contractors, subcontractors or their employees, makes any warranty, express or implied, or assumes any legal liability or responsibility for the eccuracy, completeness, or any third party's use or the results of such use of any information, apparatus, product, or process disclosed, or represents that its use would not infringe privately owned rights. Reference herein to any specific commercial product, process, or senvice by trade name, trademark, manufacturer, or otherwise, does not necessarily constitute or imply its endorsement, recommendation, or favoring by the United States Government or any agency there of or its contractors or subcontractors. The views and opinions of authors expressed herein do not necessarily state or reflect those of the United States Government or any agency thereof.

This report has been reproduced from the best available copy. Available in paper copy and microfiche.

Available to the U.S. Department of Energy

and its contractors from

Office of Scientific and Technical Information

P.O. Box 62

Oak Ridge, TN 37831

(615) $576-8401$

Available to the public from the U.S. Department of Commerce National Technical Information Service 5285 Port Royal Road

Springfield, VA 22161

(703) $487-4650$

Printed in the United States of America

DISCLM-1.CHP (1-91) 


\section{RELEASE AUTHORIZATION}

Document Number: WHC-EP-0822

Document Title: Assessment Report for Hanford Analytical Services Quality Assurance Plan

Release Date: November 18, 1994

This document was reviewed following the procedures described in WHC-CM-3-4 and is:

APPROVED FOR PUBLIC RELEASE

WHC Information Release Administration Specialist:

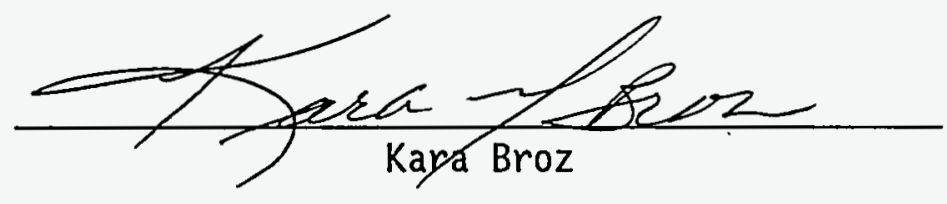

November 18,1994 


\section{DISCLAIMER}

\section{Portions of this document may be illegible in electronic image products. Images are produced from the best available original document.}




\section{WHC-EP-0822 \\ ASSESSMENT REPORT \\ for \\ HANFORD ANALYTICAL SERVICES \\ QUALITY ASSURANCE PLAN (HASQAP)}

This report documents the assessment results of DOE/RL-94-55, Hanford Analytical Services Quality Assurance Plan, against the following DOE Orders:

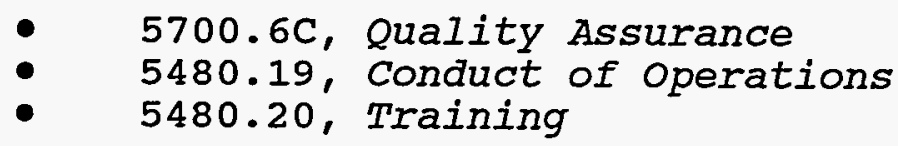

The assessment was conducted using the Requirement and selfAssessment Database (RSAD), which contains mandatory and nonmandatory DOE Order statements for the above orders.

The results of the assessment are summarized for each of the three Orders vs. the HASQAP in Attachments $\mathrm{A} 1, \mathrm{~A} 2$, and $\mathrm{A} 3$.

For the assessment of DOE 5700.6C, the HASQAP was evaluated for compliance against those statements designated as "mandatory" for contractors in the RSAD database. See Attachment B for the Assessment Data Collection (ADC) Forms for the RSAD statements evaluated.

For the assessment of DOE 5480.19, both "mandatory" and "nonmandatory" statements in the RSAD database were addressed on the Assessment Data Collection Forms because all but two of the statements were designated as "non-mandatory" for contractors.

However, DOE 5480.19 (Conduct of Operations) was written to provide guidance for facility operations primarily for DOE production and test facilities. The difficulty of correlating much of the guidance in the order to analytical laboratory services resulted in the determination of many of the areas and activities addressed by the order as being not applicable to analytical laboratory services.

Where correlations to analytical laboratory activities could be made, the HASQAP was assessed to those parts of the order. Due to the heavy emphasis and slant toward "operations" of production and test facilities, it was necessary to make the following interpretations or equivalencies to assess the intent of the guidance as applied to analytical laboratory activities: 


$$
\text { WHC-EP-0822 }
$$

(1) "operations" and

"operations activities" $\Rightarrow$ "analytical laboratory activities"

(2) "operator"

$\Rightarrow$ "laboratory analyst"

(3) "operations supervisor/manager"

$\Rightarrow \quad$ "laboratory supervisor/manager"

See Attachment $C$ for the ADC forms for the DOE 5480.19 RSAD statements evaluated.

For the assessment of DOE 5480.20, the HASQAP was evaluated for compliance against those statements designated as "mandatory" for contractors in the RSAD database. See Attachment D for the (ADC) Forms for the RSAD statements evaluated. 


\section{FINDINGS}

The HASQAP was found to not adequately comply with nine out of the twenty-five requirement statements assessed. See Attachment B of this report for the Assessment Data Collection forms that provide the details of the noncompliances. The nine noncompliances are summarized as follows:

(1) 4 noncompliances concern DOE administrative functions (e.g. approval, concurrence, responsibilities).

(2) 2 noncompliances address DOE mandates concerning records disposition (i.e. DOE 1324.2A and NARA GRS).

(3) 3 noncompliances deal with requirement statements not being adequately addressed. 2 of the noncompliances were specific to the procurement area, and 1 was specific to management systems.

\section{RECOMMENDATIONS}

(1) Determine the need or appropriateness to include or reference in the HASQAP the statements concerning DOE administrative functions.

(2) Revise the HASQAP to reference DOE records disposition requirement documents.

(3) Revise HASQAP to address the 3 noncompliances concerning procurement and management systems.

\section{CONCLUSIONS}

The HASQAP is in substantial compliance with DOE 5700.6C. The findings identified are:

(1) judged to be minor,

(2) primarily of an administrative nature,

(3) easily addressable and correctable, and

(4) not indicative of any programmatic weaknesses.

The Comparison Matrix on page 2 of this attachment illustrates the overal1 compliance of the HASQAP with the provisions of DOE 5700.6C. 
WHC-EP-0822

Attachment Al

DOE $5700.6 \mathrm{C}$ vs. HASQAP

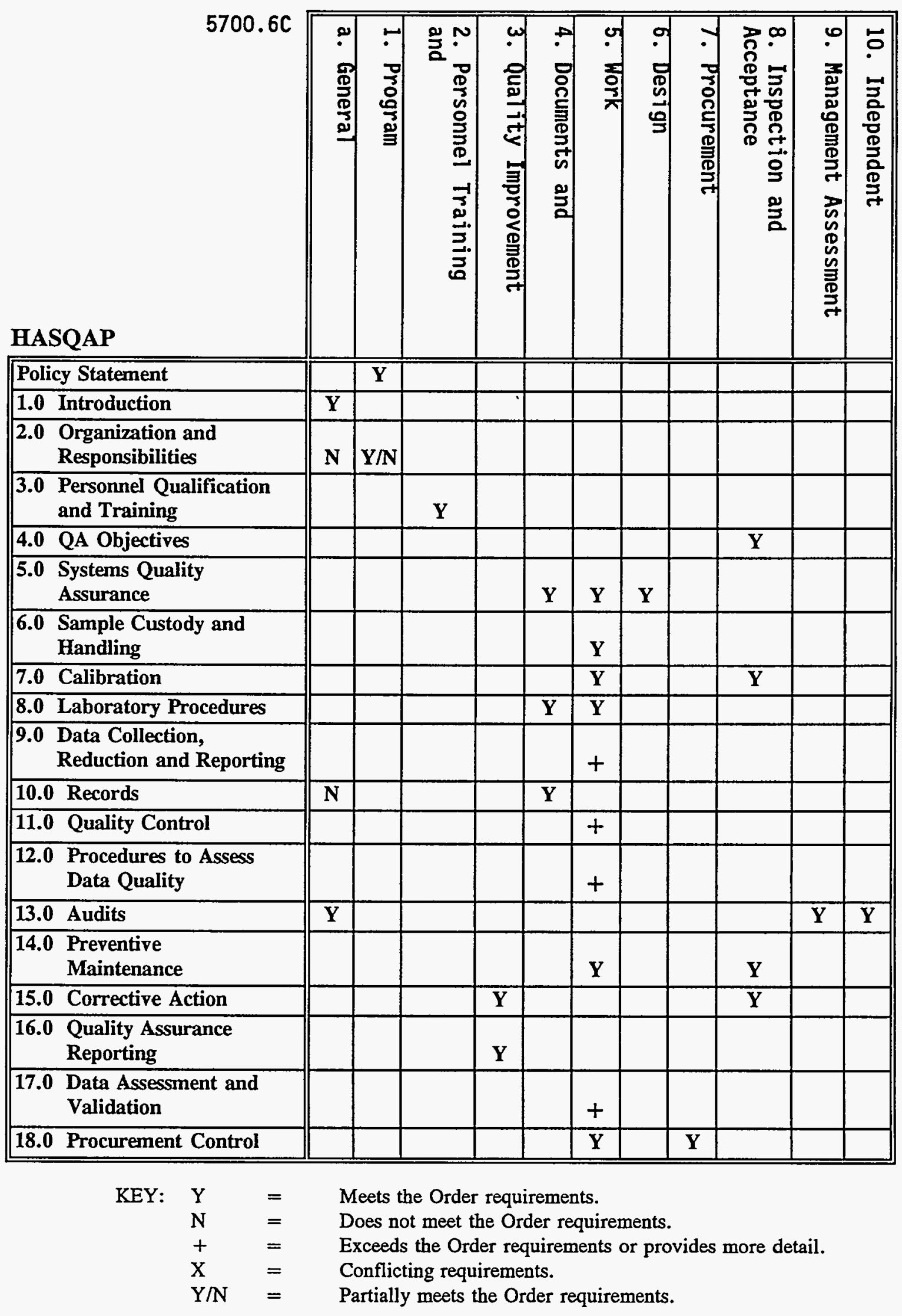




\section{WHC-EP-0822 \\ Attachment A2 \\ DOE 5480.19 vs. HASQAP}

\section{FINDINGS}

The HASQAP was found to not adequately comply with forty-one of the eighty-three requirement statements assessed. See Attachment $C$ of this report for the Assessment Data Collection forms that provide the details of the noncompliances. The forty-one noncompliances are summarized as follows:

(1) 8 noncompliances concern specific personnel protection requirements that are not detailed in the HASQAP.

(2) 11 noncompliances address requirements for the investigation of abnormal events that are not detailed in the HASQAP.

(3) 7 noncompliances deal with requirements for shift logs that are not detailed in the HASQAP.

(4) 5 noncompliances concern requirements for monitoring operating performance that are not detailed in the HASQAP.

(5) 3 noncompliances concern operating practices (safety planning, safety practices, and status practices) that are not detailed in the HASQAP.

(6) 3 noncompliances concern notification requirements that are not detailed in the HASQAP.

(7) 2 noncompliances concern use of the graded approach and an implementation matrix for the order that are not detailed in the HASQAP.

(8) 1 noncompliance requires physical security to DOE 5630.11 that is not covered in the HASQAP.

(9) 1 noncompliance concerns periodic reviews of procedures that are not detailed in the HASQAP. 


\section{WHC-EP-0822 \\ Attachment A2 \\ DOE 5480.19 vs. HASQAP}

\section{RECOMMENDATIONS}

Using the graded approach:

(1) Incorporate the applicable DOE 5480.19 requirements (or their intent as applied to analytical laboratory services) into the HASQAP

OR

(2) Develop an implementation listing or matrix for inclusion in the HASQAP that specifies those DOE 5480.19 sections/requirement statements (or their intent as applied to analytical laboratory services) that laboratory management must implement.

\section{CONCLUSIONS}

The large number of noncompliances may be somewhat misleading due to the assessment's methodology of conservatively trying to correlate the requirement statements of DOE 5480.19 to analytical 1aboratory operations.

Nevertheless, in order to bring the HASQAP into compliance with the applicable requirements of DOE 5480.19 , one of the recommendations above should be considered.

The Comparison Matrix on page 3 of this attachment is indicative of the relative incompatibility of Order 5480.19 requirements written for production or test facilities and the HASQAP written for analytical Taboratory services. 
WHC-EP-0822

Attachment A2

DOE 5480.19 vs. HASQAP

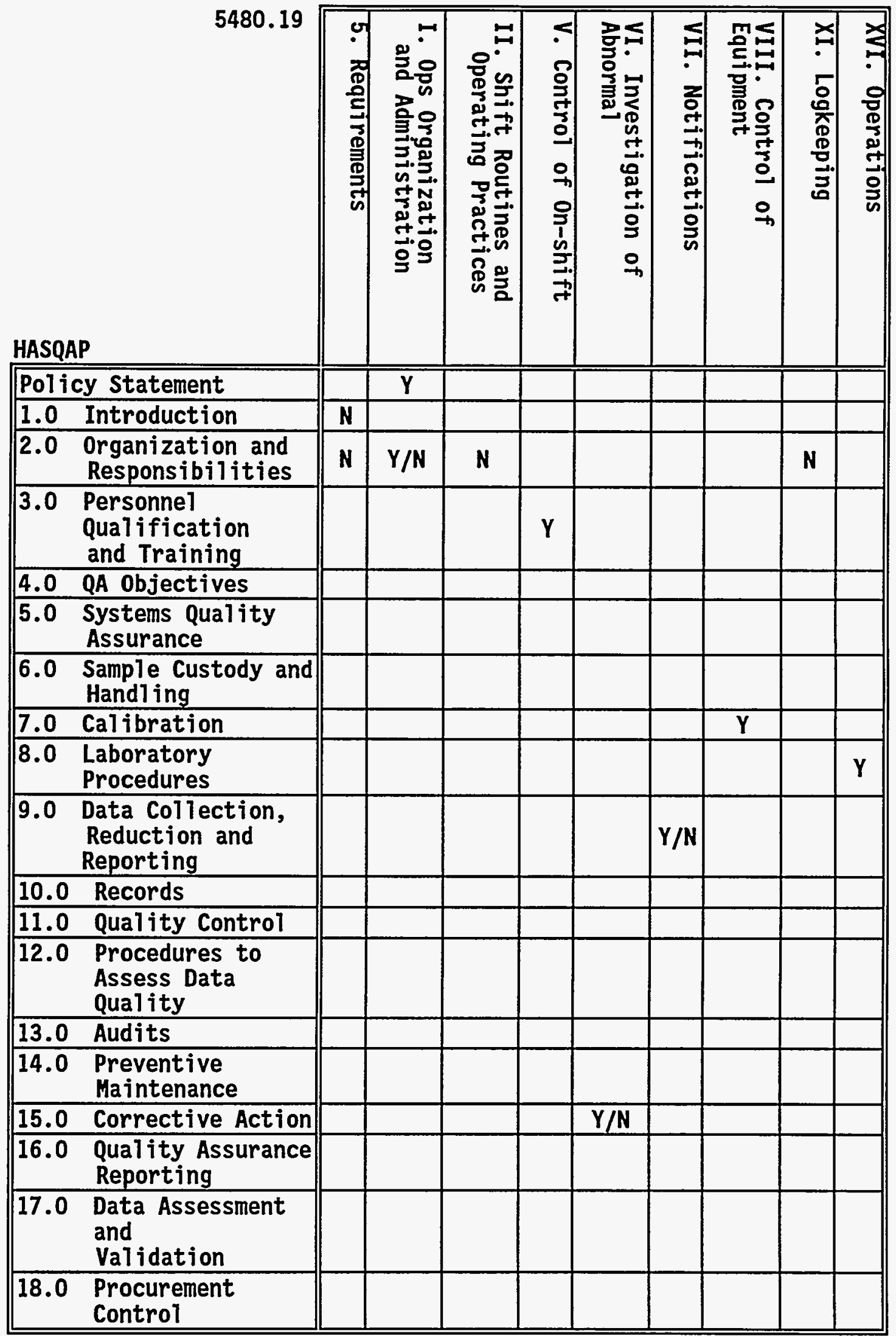


WHC-EP-0822

Attachment A2

DOE 5480.19 vS. HASQAP

KEY: $Y=$ Meets the Order requirements.

$\mathrm{N}=$ Does not meet the Order requirements.

$+\quad=\quad$ Exceeds the Order requirements.

$X=$ Conflicting requirements.

$Y / N=$ Partially meets the Order requirements. 


\section{WHC-EP-0822 \\ Attachment $A 3$ \\ DOE 5480.20 vs. HASQAP}

\section{FINDINGS}

The HASQAP was found to not adequately comply with twenty-eight out of the forty-nine requirement statements assessed. See Attachment D of this report for the Assessment Data Collection forms that provide the details of the noncompliances. The twenty-eight noncompliances are summarized as follows:

(1) 4 noncompliances concern specific GET training requirements that are not detailed in the HASQAP.

(2) 3 noncompliances address specific management and supervisor training requirements that are not detailed in the HASQAP.

(3) 5 noncompliances deal with specific entry-level requirements for specific job classifications that are not detailed in the HASQAP.

(4) 8 noncompliances concern specifics for exceptions or exemptions to training requirements, extensions to training requirements, and alternatives to educational and experience requirements that are not detailed in the HASQAP.

(5) 2 noncompliances concern specific requirements for records that are not detailed in the HASQAP.

(6) 3 noncompliances concern specific time limits for maintaining qualifications, re-certifying, and continuing training that are not detailed in the HASQAP.

(7) 2 noncompliances concern specific requirements for PRA training and safety-related systems training for technicians that are not detailed in the HASQAP.

(8) 1 noncompliance concerns a Training Implementation Matrix for Order 5480.20 that is not detailed in the HASQAP.

\section{RECOMHENDATIONS}

(1) Incorporate the applicable requirements of DOE 5480.20 into the HASQAP

OR

(2) Develop an implementation matrix or listing for inclusion in the HASQAP that specifies those sections/ requirement statements of DOE 5480.20 that laboratory management must implement.

\section{CONCLUSIONS}

Based on the number of noncompliances with DOE 5480.20, one might conclude that the HASQAP is seriously deficient in this area. However, The HASQAP's section on Personnel Qualification and Training is fairly 


\section{WHC-EP-0822 \\ Attachment A3 \\ DOE 5480.20 vs. HASQAP}

comprehensive; but the HASQAP's level of specifics and detail for personnel selection, qualification, and training is substantially less than that delineated in DOE 5480.20 .

In order to bring the HASQAP into compliance with the applicable specifics of DOE 5480.20 , one of the recommendations above should be considered.

The Comparison Matrix on page 3 of this attachment is indicative of the difference in the level of detail between the two documents. 
WHC-EP-0822

Attachment A3

DOE 5480.20 vs. HASQAP

HASQAP

\begin{tabular}{||ll||}
\hline Pol icy Statement \\
\hline 1.0 & Introduction \\
\hline 2.0 & $\begin{array}{l}\text { Organization and } \\
\text { Responsibilities }\end{array}$ \\
\hline 3.0 & $\begin{array}{l}\text { Personnel } \\
\text { Qual ification } \\
\text { and Training }\end{array}$ \\
\hline 4.0 & QA Objectives \\
\hline 5.0 & $\begin{array}{l}\text { Systems Quality } \\
\text { Assurance }\end{array}$ \\
\hline 6.0 & $\begin{array}{l}\text { Sample Custody and } \\
\text { Handling }\end{array}$ \\
\hline 7.0 & Calibration \\
\hline 8.0 & $\begin{array}{l}\text { Laboratory } \\
\text { Procedures }\end{array}$ \\
\hline 9.0 & $\begin{array}{l}\text { Data Collection, } \\
\text { Reduction and } \\
\text { Reporting }\end{array}$ \\
\hline 10.0 & Records \\
\hline 11.0 & Quality Control \\
\hline 12.0 & $\begin{array}{l}\text { Procedures to } \\
\text { Assess Data } \\
\text { Quality }\end{array}$ \\
\hline 13.0 & Audits \\
\hline 14.0 & $\begin{array}{l}\text { Preventive } \\
\text { Maintenance }\end{array}$ \\
\hline 15.0 & Corrective Action \\
\hline 16.0 & $\begin{array}{l}\text { Quality Assurance } \\
\text { Reporting }\end{array}$ \\
\hline 17.0 & $\begin{array}{l}\text { Data Assessment } \\
\text { and } \\
\text { Validation }\end{array}$ \\
\hline 18.0 & $\begin{array}{l}\text { Procurement } \\
\text { Control }\end{array}$ \\
\hline & \\
\hline
\end{tabular}

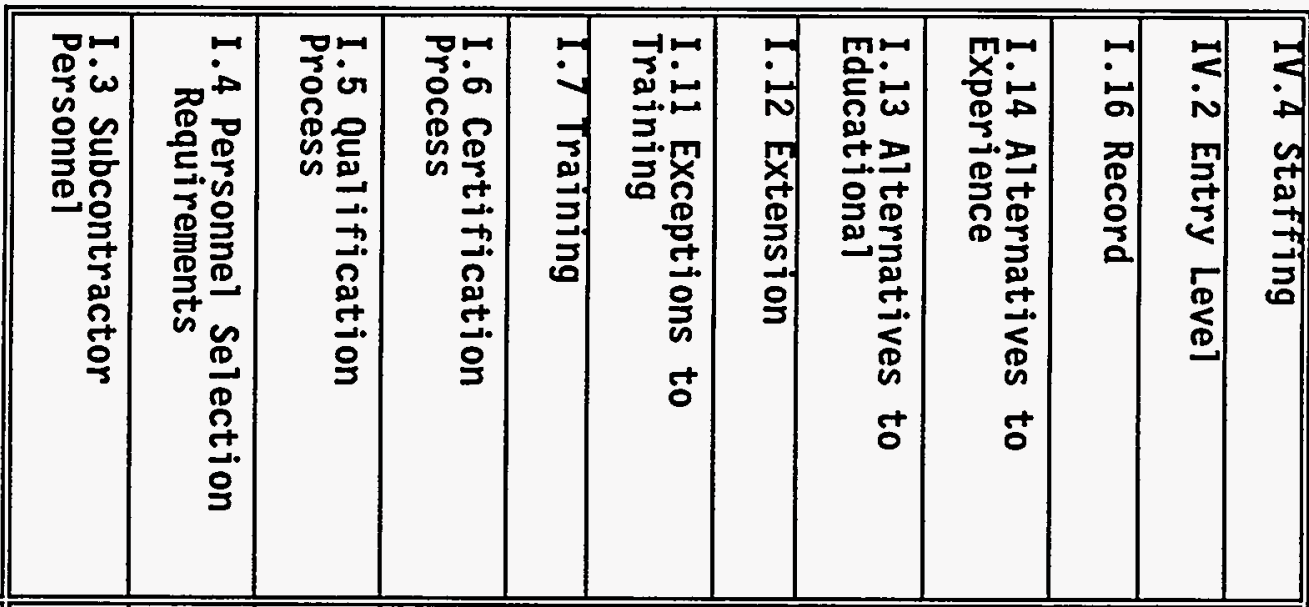

5480.20

\begin{tabular}{|l|l|l|l|l|l|l|}
\hline & & & & & & \\
\hline & & & & & & \\
\hline$Y$ & & & & & & \\
\hline$Y M$ & $Y / M$ & $Y / M$ & $Y / N$ & $Y / M$
\end{tabular}

\begin{tabular}{l|l|l|l|l}
$Y$ & $Y / N$ & $Y / N$ & $Y / N$ & $Y / N$ \\
\hline
\end{tabular}

$\mathbf{Y} / \mathrm{N}$

$\mid$

\begin{tabular}{|l|l|l|l|l|l|l|l|l|l|l|l|l||}
\hline & & & & & & & & & & & \\
\hline
\end{tabular}

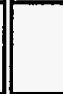

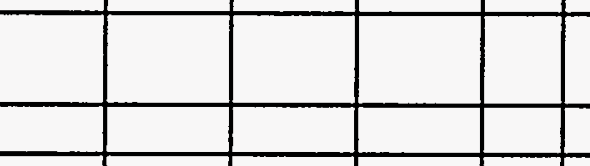


WHC-EP-0822

Attachment A3

DOE 5480.20 vS. HASQAP

KEY: $Y=$ Meets the Order requirements.

$\mathrm{N}=$ Does not meet the order requirements.

$+\quad=$ Exceeds the Order requirements or provides more detail.

$X=$ Conflicting requirements.

$\mathrm{Y} / \mathrm{N}=$ Partially meets the Order requirements. 
WHC-EP-0822

\section{ATTACHMENT B}

\section{ASSESSMENT DATA COLLECTION FORMS}

for

HASQAP ASSESSMENT

to

DOE ORDER 5700.6C

(Quality Assurance) 
WHC-EP-0822

ASSESSHENT DATA COLLECTION FORH

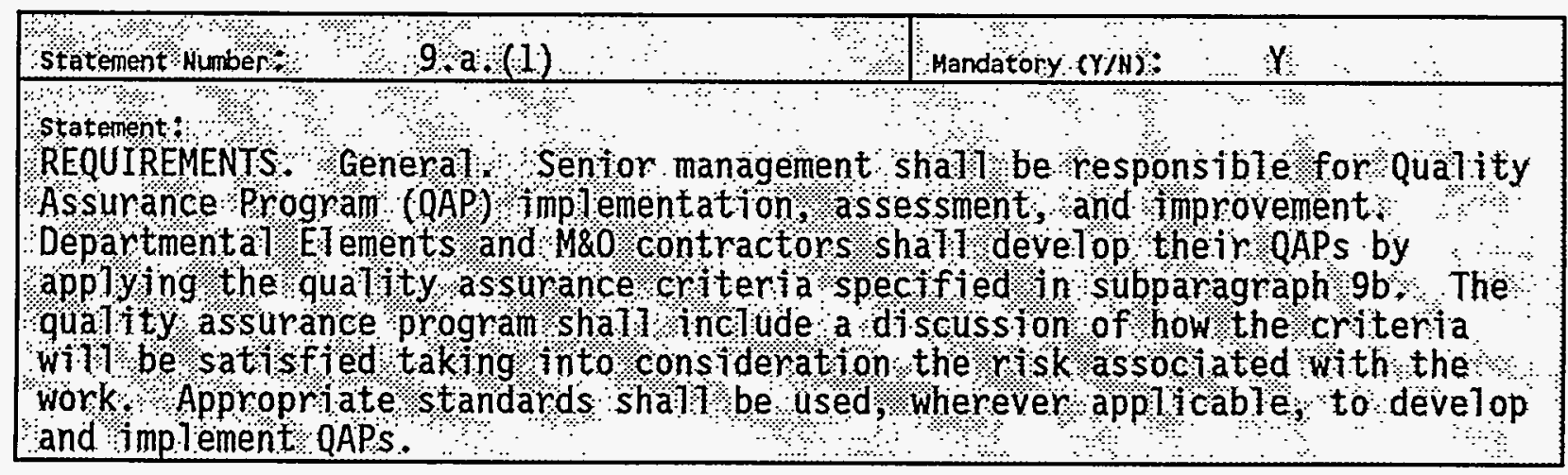

1.0 STATEMENT SATISFIEd BASED ON IMPLEMENTING EVIDENCE $(Y / N):$ YES

2.0 GENERAL DESCRIPTION OF EVIDENCE (DESCRIPTION OF NONCOMPLIANCE OR DEFICIENCY IF APPLICABLE):

HASQAP:

\subsection{Introduction}

This document, the Hanford Analytical Services Quality Assurance Plan (HASQAP), is issued by the U.S. Department of Energy, Richland Operations Office (RL). The HASQAP establishes quality requirements in response to U.S. Department of Energy (DOE) Order 5700.6C, Quality Assurance (10 CFR 830.120, "Quality Assurance Requirements"). The HASQAP is designed to meet the needs of the RL for controlling the analytical chemistry services provided by laboratory operations.

\subsection{Structure, Responsibility, and Authority}

Senior management shall be responsible for establishing the scope, implementing, assessing, and continually improving an effective qual ity system.

3.0 COMMENTS:

The concept of risk and/or graded-approach is not discussed in the HASQAP. This may be appropriate if the HASQAP is intended to apply only to regulatory-based analytical services. 
WHC-EP-0822

\section{ASSESSMENT DATA COLLECTION FORM}

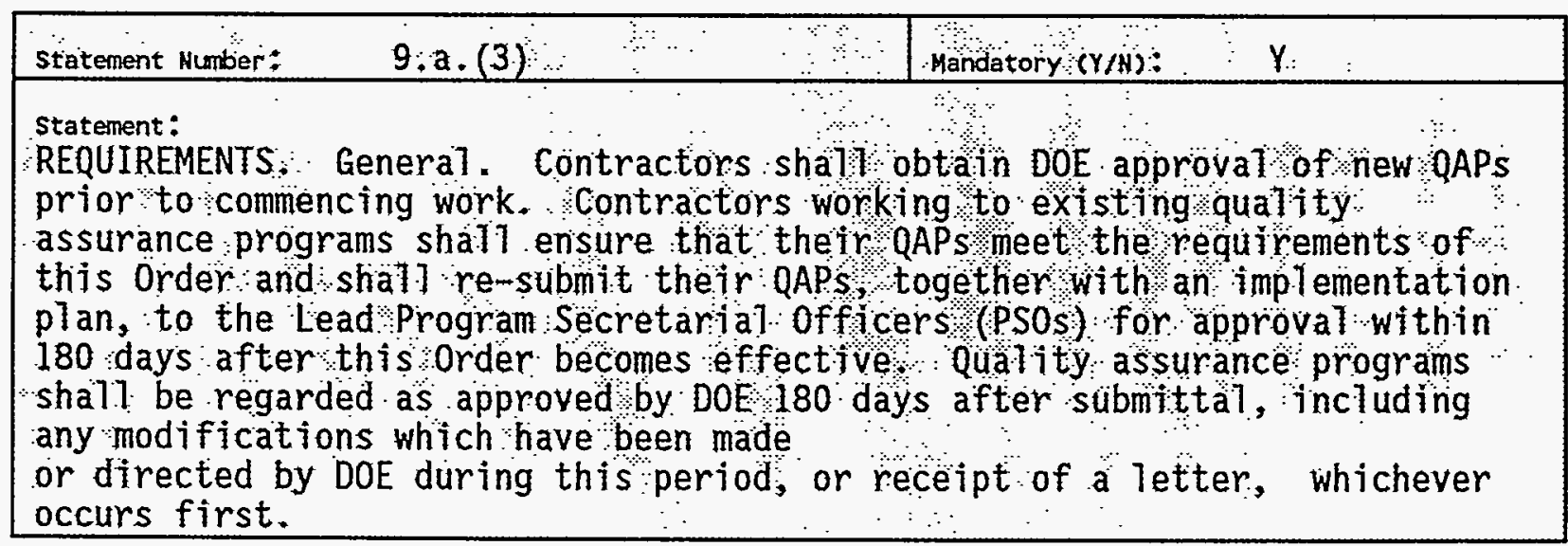

1.0 StATEMENT SATISFIEd BASED ON IMPLEMENTING EVIDENCE $(Y / N): \quad N 0$

2.0 GENERAL DESCRIPTION OF EVIDENCE (DESCRIPTION OF NONCOMPLIANCE OR DEFICIENCY IF APPLICABLE):

Requirement is not addressed in the HASQAP.

3.0 CORRECTIVE ACTION: 
WHC-EP-0822

\section{ASSESSMENT DATA COLLECTION FORM}

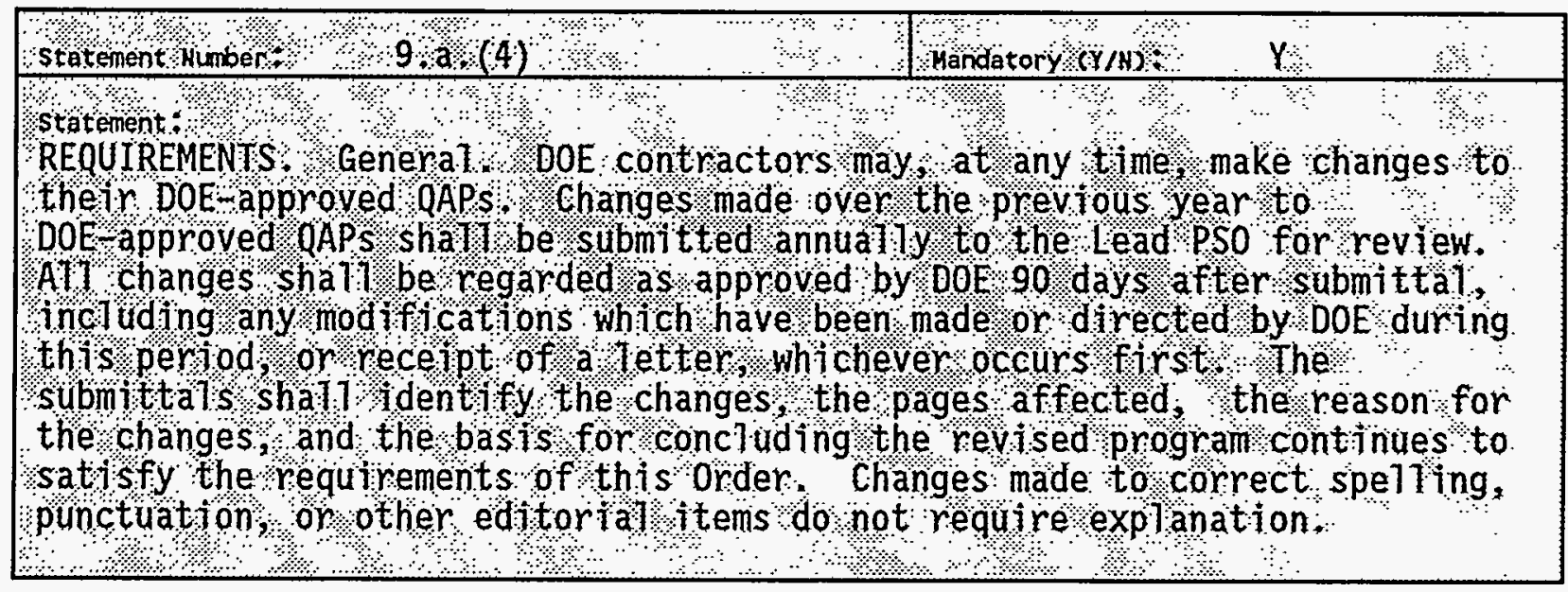

1.0 STATEMENT SATISFIED BASED ON IMPLEMENTING EVIDENCE (Y/N): NO

2.0 GeNERAL DESCRIPTION OF EVIDENCE (DESCRIPTION OF NONCOMPLIANCE OR DEFICIENCY IF APPLICABLE):

Requirement is not addressed in the HASQAP.

3.0 CORRECTIVE ACTION: 
WHC-EP-0822

\section{ASSESSMENT DATA COLLECTION FORM}

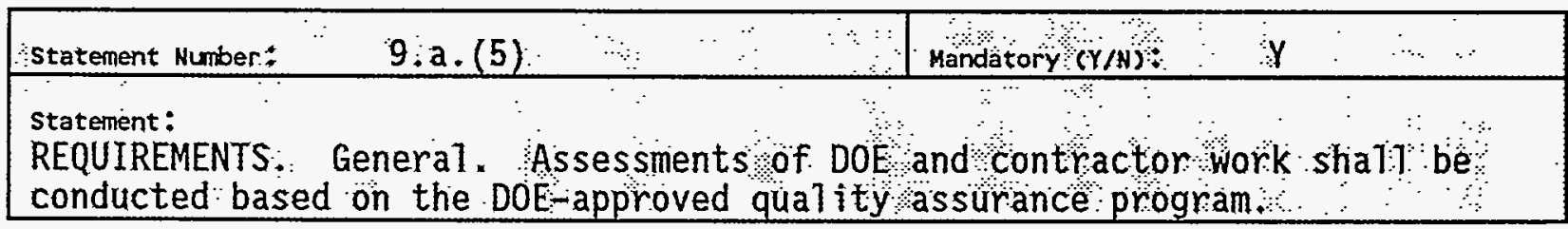

1.0 STATEMENT SATISFIED BASED ON IMPLEMENTING EVIDENCE $(Y / N):$ YES

2.0 GENERAL DESCRIPTION OF EVIDENCE (DESCRIPTION OF NONCOMPLIANCE OR DEFICIENCY IF APPLICABLE):

Requirement is met by HASQAP Section 13.0, "Audits." 
WHC-EP-0822

\section{ASSESSMENT DATA COLLECTION FORM}

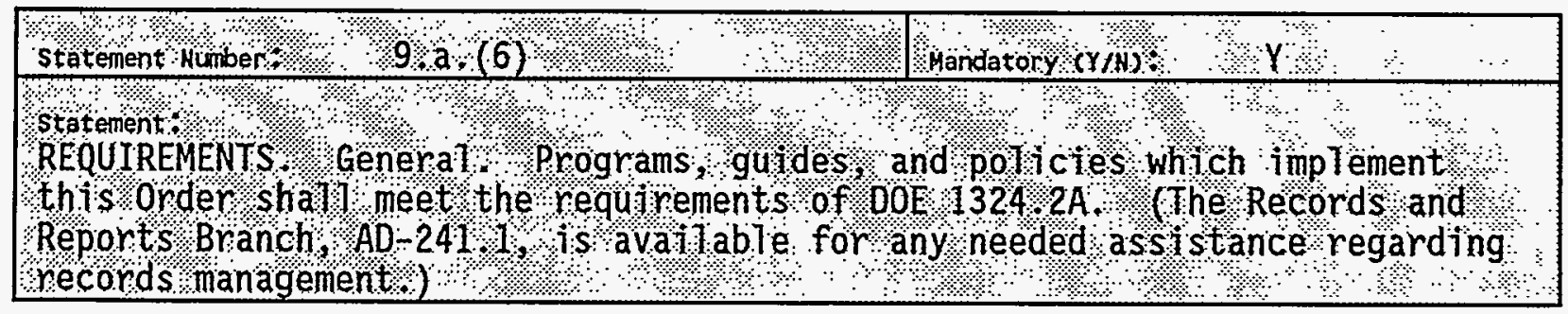

1.0 STATEMENT SATISFIED BASED ON IMPLEMENTING EVIDENCE (Y/N): NO

2.0 GENERAL DESCRIPTION OF EVIDENCE (DESCRIPTION OF NONCOMPLIANCE OR DEFICIENCY IF APPLICABLE):

Requirement is not addressed in the HASQAP.

3.0 CORRECTIVE ACTION: 
WHC-EP-0822

\section{ASSESSMENT DATA COLLECTION FORM}

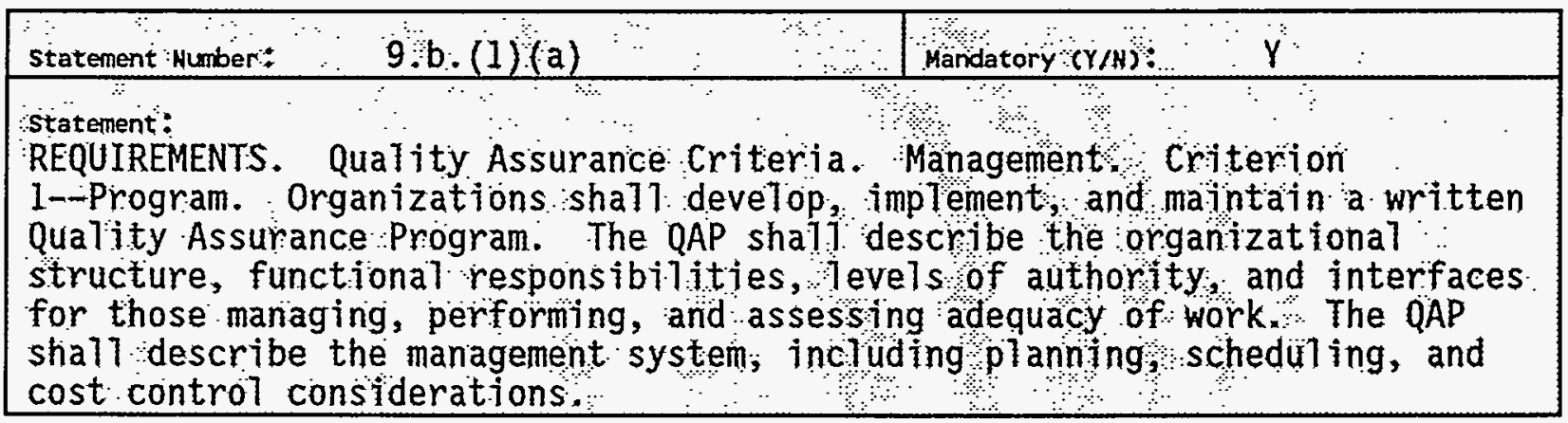

1.0 STATEMENT SATISFIED BASED ON IMPLEMENTING EVIDENCE $(Y / N)$ : NO

2.0 GENERAL DESCRIPTION OF EVIDENCE (DESCRIPTION OF NONCOMPLIANCE OR DEFICIENCY IF APPLICABLE):

Section 2.0, "Organization and Responsibility," adequately addresses most of the statement. However, the following sentence in the statement is not addressed in the HASQAP:

"The QAP shall describe the management system, including planning, scheduling, and cost control considerations."

3.0 CORRECTIVE ACTION: 


\section{ASSESSMENT DATA COLLECTION FORM}

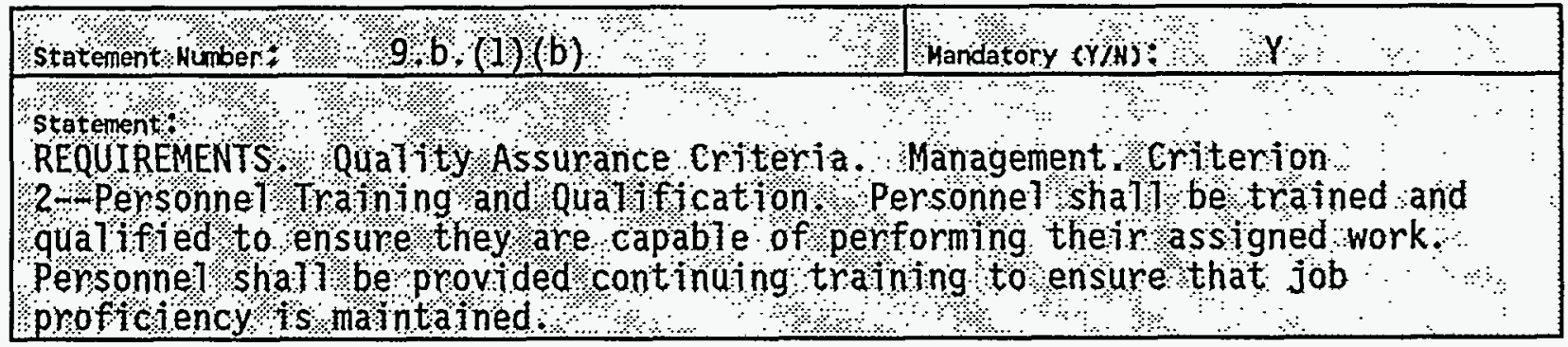

1.0 STATEMENT SATISFIED BASED ON IMPLEMENTING EVIDENCE $(Y / N)$ : YES

2.0 GENERAL DESCRIPTION OF EVIDENCE (DESCRIPTION OF HONCOMPLIANCE OR DEFICIENCY IF APPLICABLE):

HASQAP Section 3.0, "Personnel Qualification and Training," satisfactority addresses the statement. 
WHC-EP-0822

\section{ASSESSHENT DATA COLLECTION FORM}

\begin{tabular}{|c|c|}
\hline $9, b,(1)(c)$ & Mandatory $(y / N) \quad y$ \\
\hline 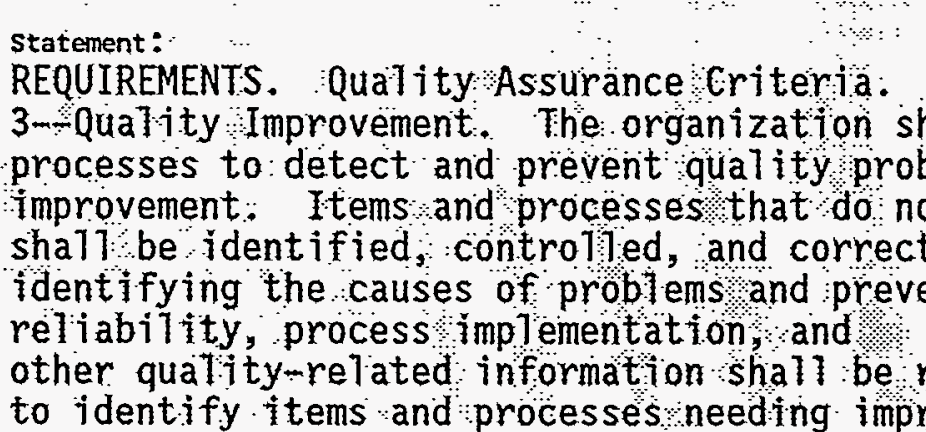 & 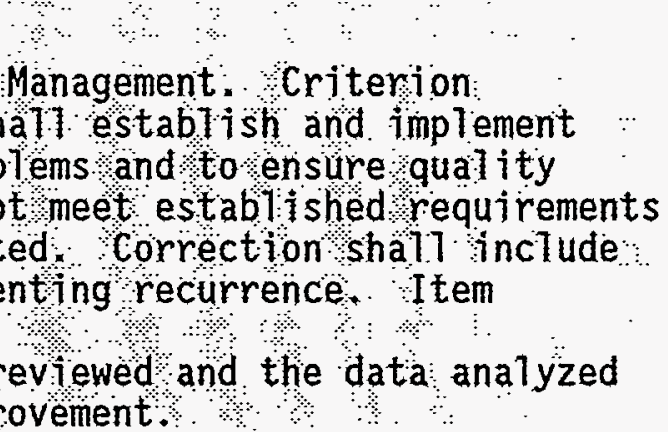 \\
\hline
\end{tabular}

1.0 STATEMENT SATISFIED BASED ON IMPLEMENTING EVIDENCE $(Y / N):$ YES

2.0 GENERAL DESCRIPTION OF EVIDENCE (DESCRIPTION OF NONCOMPLIANCE OR DEFICIENCY IF APPLICABLE):

HASQAP Section 15.0, "Corrective Action," and Section 16.0, "Quality Assurance Reporting," satisfactorily address the statement. 
WHC-EP-0822

\section{ASSESSMENT DATA COLLECTION FORM}

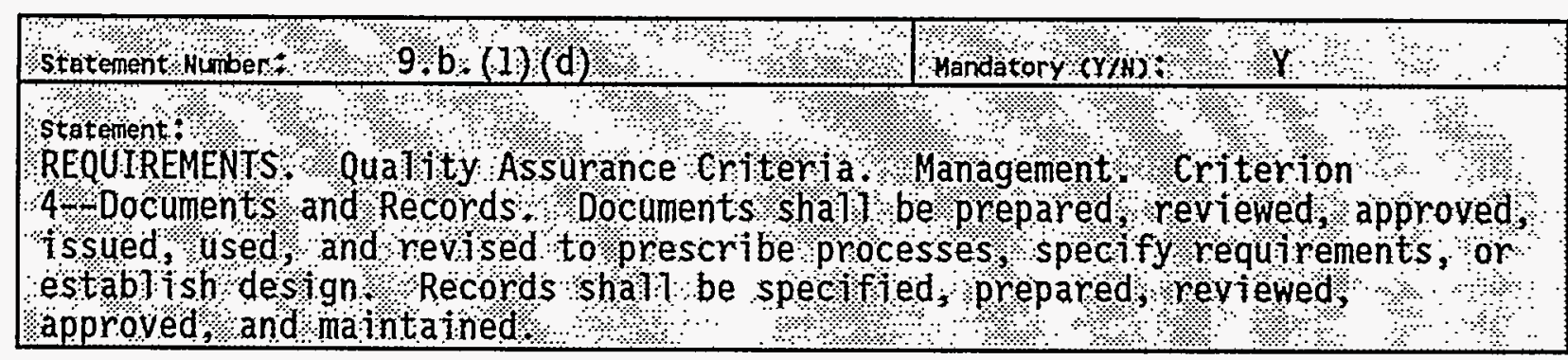

1.0 StATEMENT SATISFIEd BASED ON IMPLEMENTING EVIDENCE (Y/N): YES

2.0 GENERAL DESCRIPTION OF EVIDENCE (DESCRIPTION OF NONCOMPLIANCE OR DEFICIENCY IF APPLICABLE):

The statement is satisfactorily addressed by:

HASQAP subsection 5.2, "Administrative Systems"

HASQAP Section 10.0, "Records"

HASQAP Section 8.0, "Laboratory Procedures" 
WHC-EP-0822

\section{ASSESSMENT DATA COLLECTION FORM}

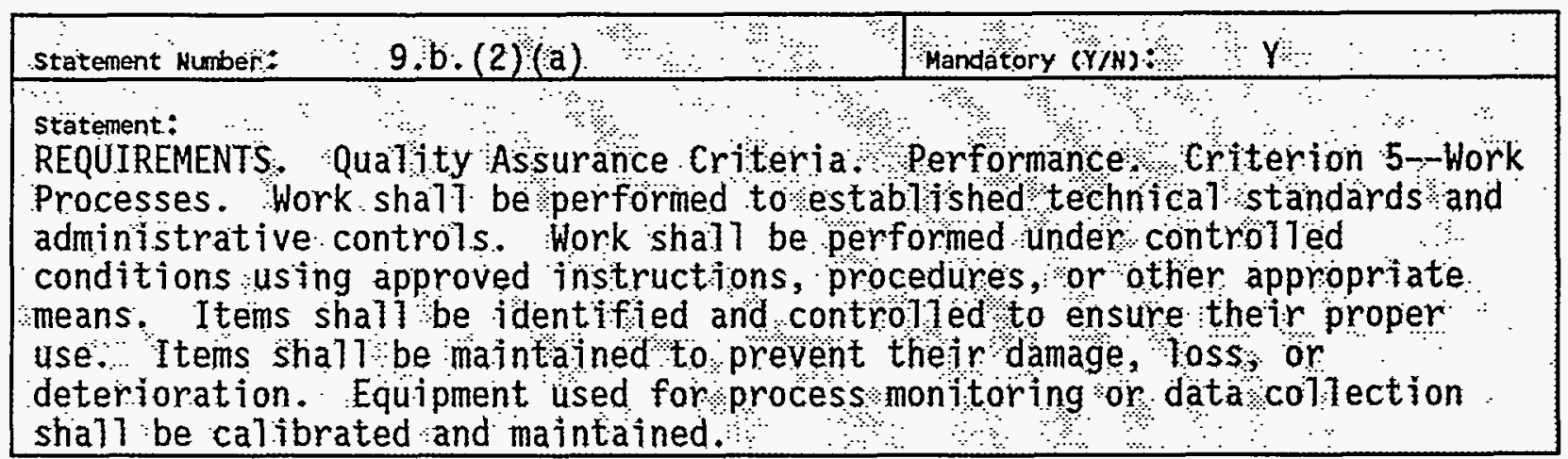

1.0 STATEMERT SATISFIED BASED ON IMPLEMENTING EVIDENCE (Y/N)：YES

2.0 GENERAL DESCRIPTION OF EVIDENCE (DESCRIPTION OF NONCOMPLIANCE OR DEFICIENCY IF APPLICABLE):

This statement is met by the following HASQAP sections:

8.0 Laboratory Procedures

6.0 Sample Custody and Handling

5.1 Software Systems

5.2 Administrative Systems

5.3 Technical Systems

5.4 Physical Facilities Systems

7.0 Calibration

14.0 Preventive Maintenance

9.0 Data Collection, Reduction, and Reporting

11.0 Quality Control

12.0 Procedures to Assess Data Quality

17.0 Data Assessment and Validation

18.0 Procurement Control 
WHC-EP-0822

ASSESSMENT DATA COLLECTION FORH

\begin{tabular}{|c|c|}
\hline 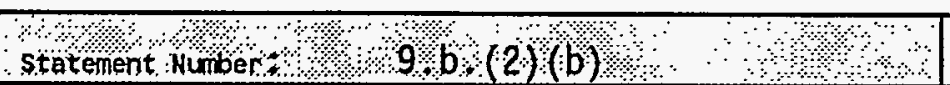 & Mandatory (Y) \\
\hline 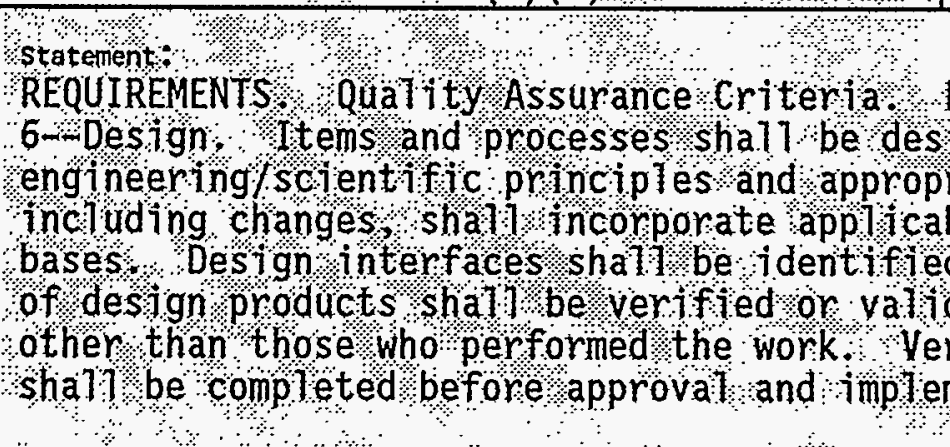 & 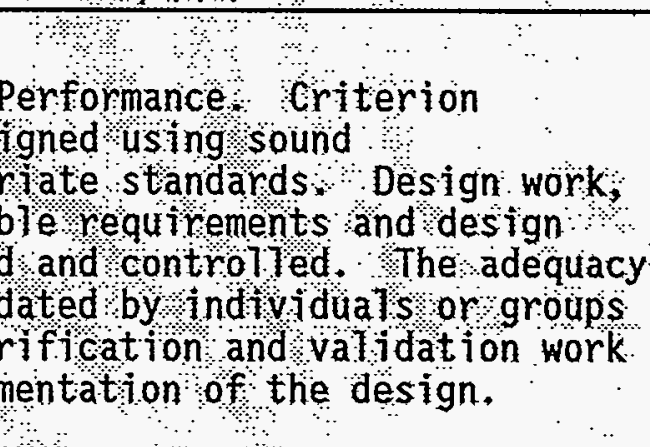 \\
\hline
\end{tabular}

1.0 StATEMENT SATISFIED BASED ON IMPLEMENTING EVIDENCE (Y/N): YES

2.0 GENERAL DESCRIPTION OF EVIDENCE (DESCRIPTION OF NONCOMPLIANCE OR DEFICIENCY IF APPLICABLE):

Classical design activities (i.e. design of physical systems and components) are not applicable to analytical laboratory operations. However, the design of software, administrative, and technical processes is covered under HASQAP Section 5.0, "Systems Quality Assurance." 
WHC-EP-0822

\section{ASSESSMENT DATA COLLECTION FORM}

\begin{tabular}{|c|c|}
\hline $9 b(2)(c))$ & Mandatory $(\gamma / H)$ \\
\hline $\begin{array}{l}\text { statement: } \\
\text { REQUIREMENTS Q Quality Assurance criteria. } \\
\text { 7--Procurement. The organization shall ensy } \\
\text { services meet established requirements and } \\
\text { Prospective suppliers shall be evaluated an } \\
\text { specified criteria. The organization shall } \\
\text { can continue to provide acceptable items and }\end{array}$ & $\begin{array}{l}\text { Performance ocriterion } \\
\text { Pe that procured items and } \\
\text { erformas spectfied } \\
\text { selected on the basis of } \\
\text { ensure that approved suppliers } \\
\text { services. }\end{array}$ \\
\hline
\end{tabular}

1.0 STATEMENT SATISFIED BASED ON IMPLEMENTING EVIDENCE $(Y / N)$ : YES

2.0 GENERAL DESCRIPTION OF EVIDENCE (DESCRIPTION OF NONCOMPLIANCE OR DEFICIENCY IF APPLICABLE):

The statement is met by HASQAP Section 18.0, "Procurement Controls." 


\section{ASSESSMENT DATA COLLECTION FORM}

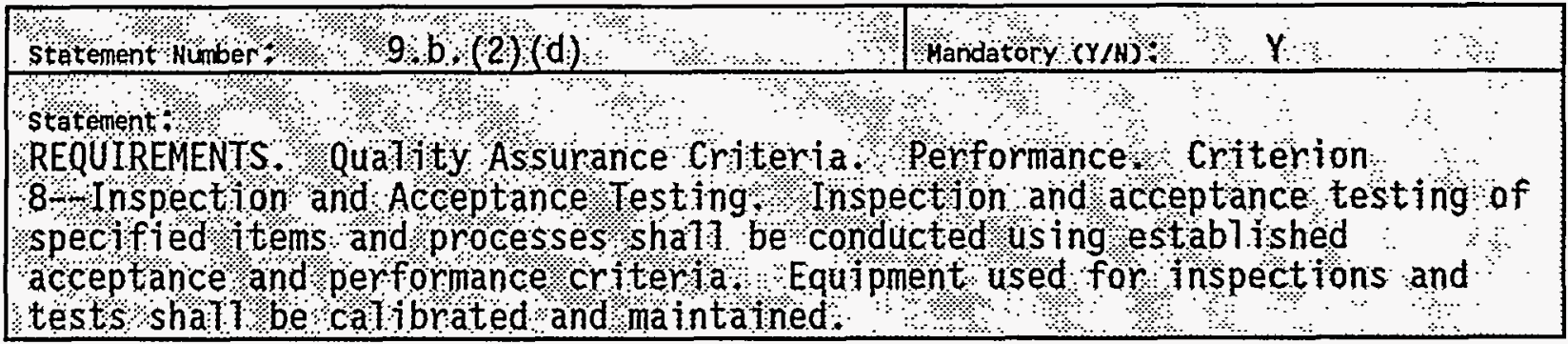

1.0 STATEMENT SATISFIED BASED ON IMPLEMENTING EVIDENCE (Y/N)：YES

2.0 GENERAL DESCRIPTION OF EVIDENCE (DESCRIPTION OF NONCOMPLIANCE OR DEFICIENCY IF APPLICABLE):

The portion of the statement concerning acceptance and performance criteria is met by HASQAP subsection 4.1, "Data Quality Objectives."

The portion of the statement concerning calibrated and maintained testing equipment is met by HASQAP Section 7.0, "Calibration", and Section 14.0, "Preventive Maintenance." 
WHC-EP-0822

\section{ASSESSMENT DATA COLLECTION FORM}

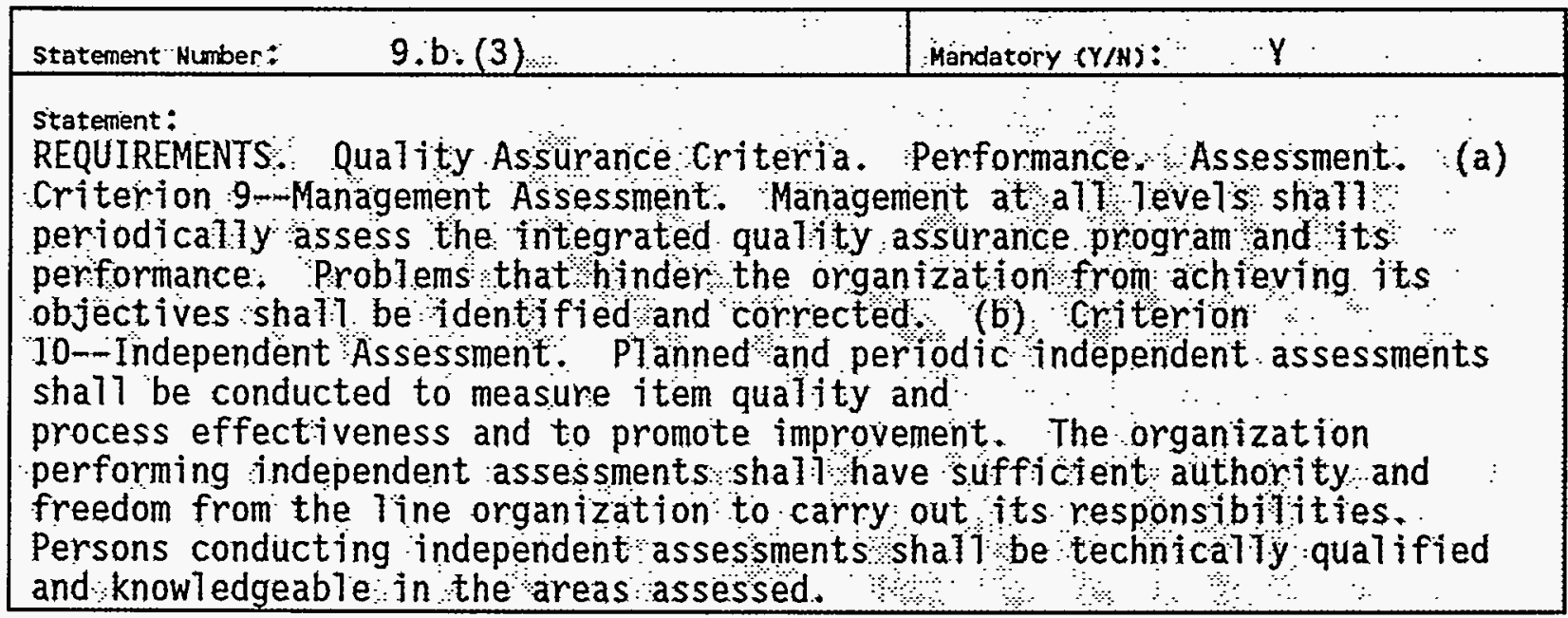

1.0 STATEMENT SATISFIED BASED ON IMPLEMENTING EVIDENCE $(Y / \mathrm{N}):$ YES

2.0 GENERAL DESCRIPTION OF EVIDENCE (DESCRIPTION OF NONCOMPLIANCE OR DEFICIENCY IF APPLICABLE):

The statement is met by HASQAP Section 13.0, "Audits." 
WHC-EP-0822

\section{ASSESSMENT DATA COLLECTION FORM}

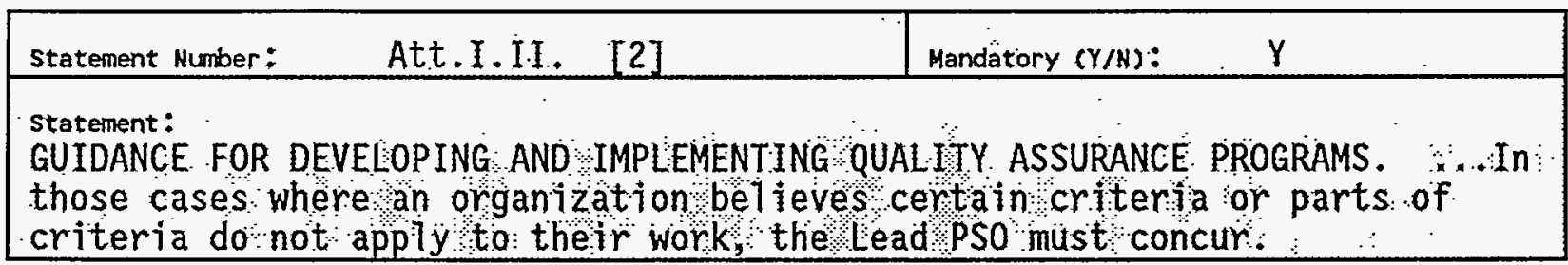

1.0 STATEMENT SATISFIED BASED ON IMPLEMENTING EVIDENCE (Y/N): NO

2.0 GENERAL DESCRIPTION OF EVIDENCE (DESCRIPTION OF NONCOMPLIANCE OR DEFICIENCY IF APPLICABLE):

Statement is not addressed in the HASQAP.

3.0 CORRECTIVE ACTION: 
WHC-EP-0822

ASSESSHENT DATA COLLECTION FORM

\begin{tabular}{|c|c|}
\hline 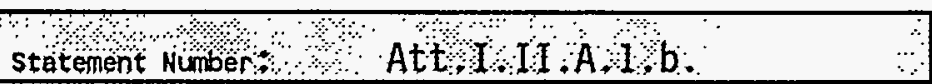 & Handatory $(Y / N):$ \\
\hline 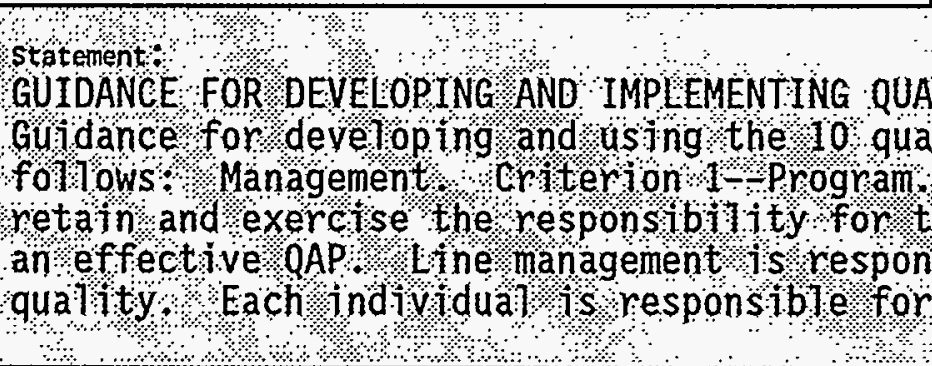 & 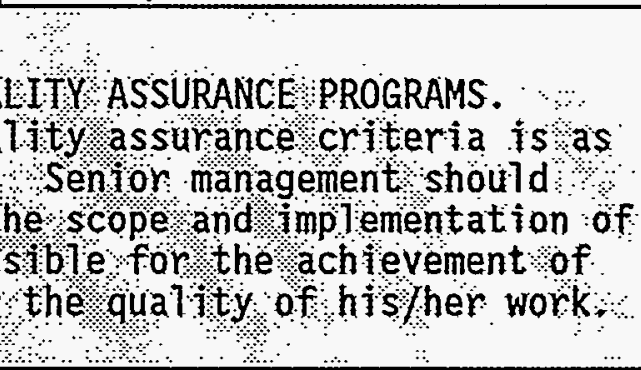 \\
\hline
\end{tabular}

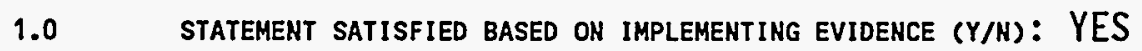

2.0 GENERAL DESCRIPTION OF EVIDENCE (DESCRIPTION OF NONCOMPLIANCE OR DEFICIENCY IF APPLICABLE):

Statement is met by the HASQAP "Policy Statement" and subsection 2.2, "Structure, Responsibility, and Authority." 
WHC-EP-0822

\section{ASSESSMENT DATA COLLECTION FORM}

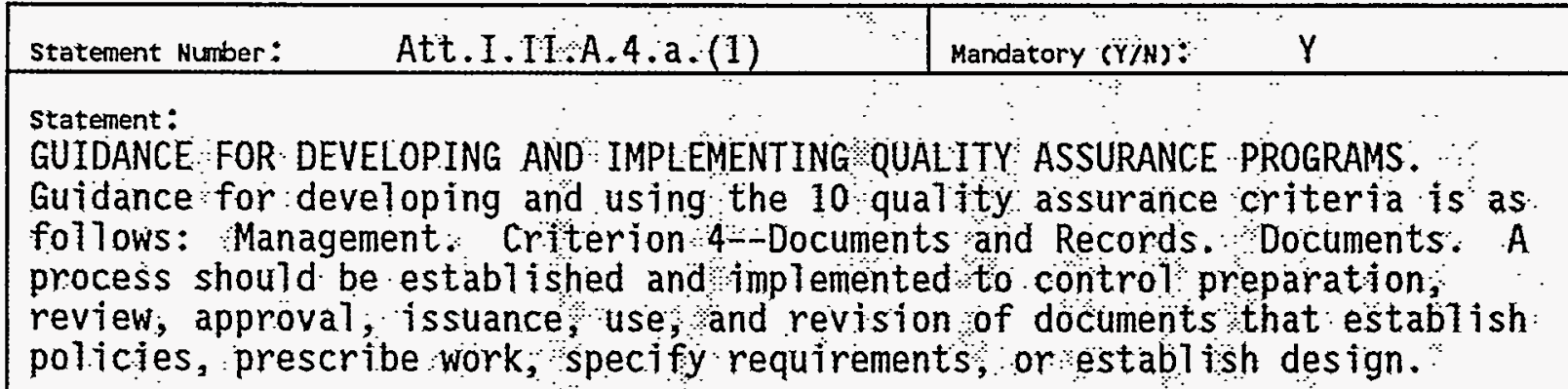

1.0 STATEMENT SATISFIED BASED ON IMPLEMENTING EVIDENCE $(Y / N):$ YES

2.0 GENERAL DESCRIPTION OF EVIDENCE (DESCRIPTION OF NONCOMPLIANCE OR DEFICIENCY IF APPLICABLE):

Statement is met by HASQAP subsection 5.2, "Administrative Systems." 
ASSESSHENT DATA COLLECTION FORM

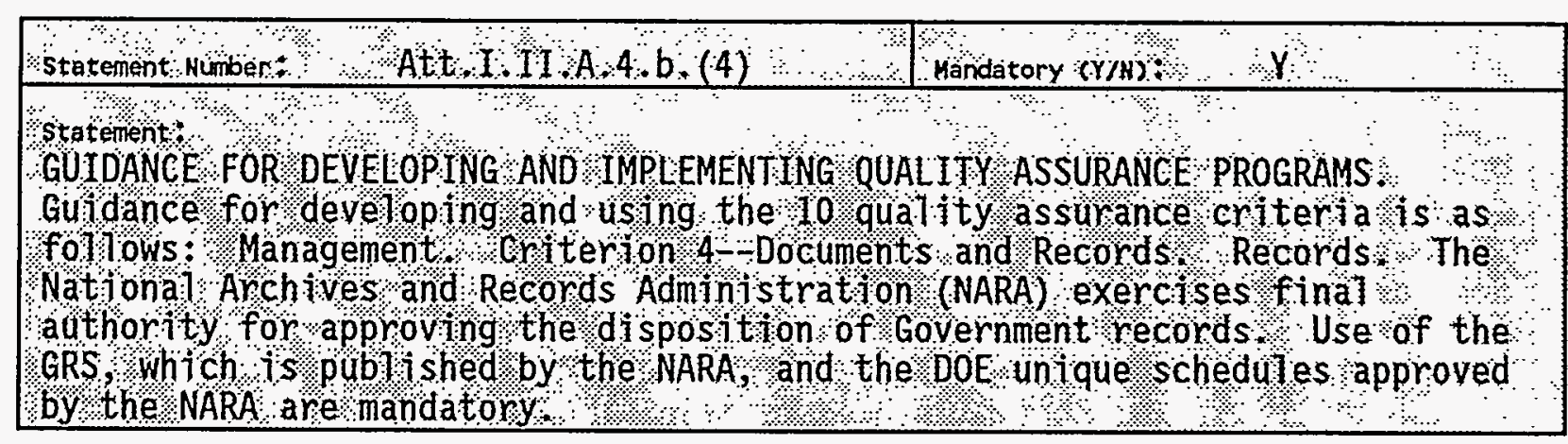

1.0 STATEMENT SATISFIED BASED ON IMPLEMENTING EVIDENCE $(Y / N):$ NO

2.0 GENERAL DESCRIPTION OF EVIDENCE (DESCRIPTION OF NONCOMPLIANCE OR DEFICIENCY IF APPLICABLE):

Statement is not addressed in the HASQAP.

3.0 CORRECTIVE ACTION: 
WHC-EP-0822

ASSESSMENT DATA COLLECTION FORM

\begin{tabular}{|c|c|}
\hline Att I II B I B b. & Mandatory $(Y / N):$ \\
\hline 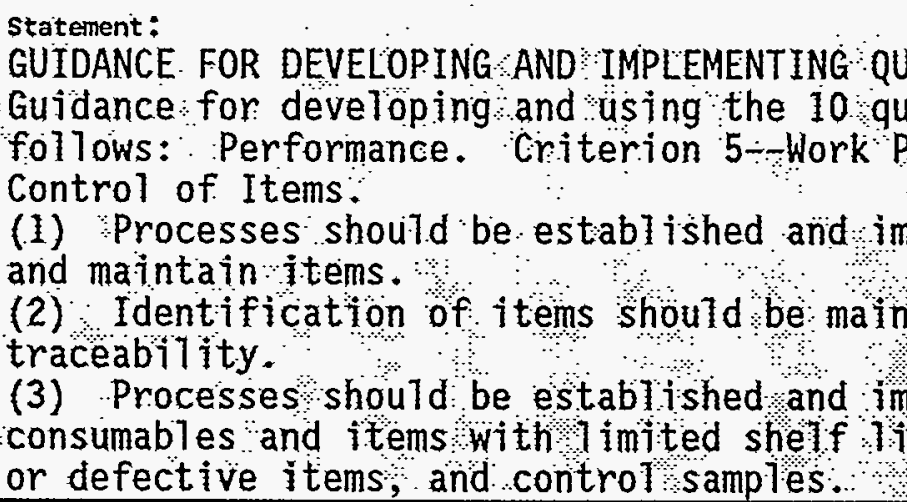 & $\begin{array}{l}\text { HTYASSURANCE PROGRAMS } \\
\text { THty assurance criteria is as } \\
\text { ocesses. Tdentification and } \\
\text { Temented to fdentify, control, } \\
\text { a ned to ensure appropriate } \\
\text { Temented to control } \\
\text { e, prevent the ouse of incorrect }\end{array}$ \\
\hline
\end{tabular}

1.0 STATEMENT SATISFIED BASED ON IMPLEMENTING EVIDENCE (Y/N): YES

2.0 GENERAL DESCRIPTION OF EVIDENCE (DESCRIPTION OF NONCOMPLIANCE OR DEFICIENCY IF APPLICABLE):

Statement is met by HASQAP subsection 5.4, "Physical Facilities Systems, "Section 6.0, "Sample Custody and Handling," subsection 7.2, "Specifications of Standards Used for Calibration," and subsection 18.2.5, "Acceptance of Items or Services." 


\section{ASSESSMENT DATA COLLECTION FORH}

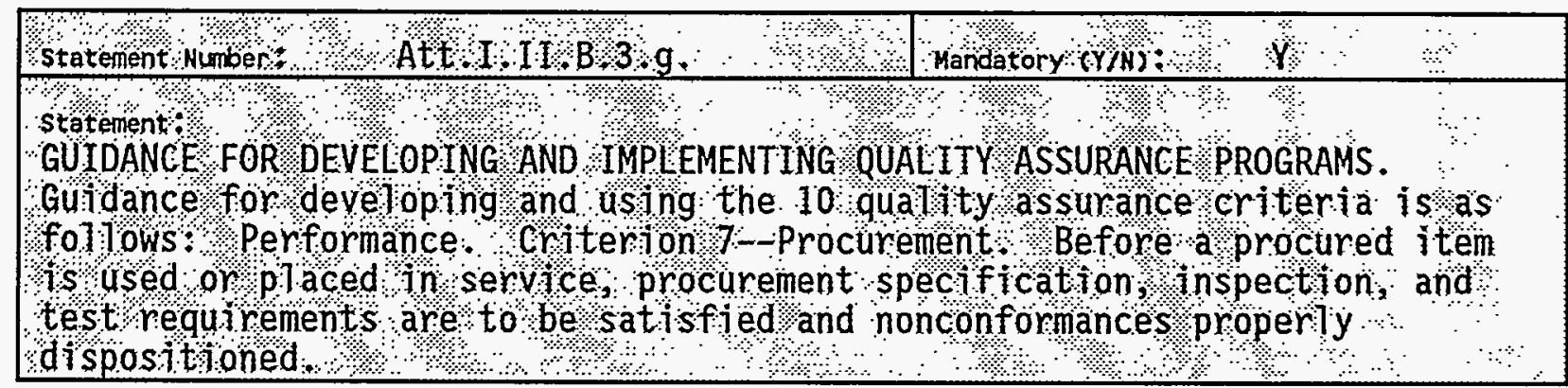

1.0 STATEhENT SATISFIED BASED ON IMPLEMENTING EVIDENCE $(Y / N): \quad$ NO

2.0 GENERAL DESCRIPTION OF EVIDENCE (DESCRIPTION OF NONCOMPLIANCE OR DEFICIENCY IF APPLICABLE):

HASQAP subsections 18.2.5 and 18.2.6 do not adequately address the following parts of the statement:

"Before a procured item is used or placed in service ... inspection, and test requirements are to be satisfied and nonconformances properly dispositioned."

3.0 CORRECTIVE ACTION: 
WHC-EP-0822

\section{ASSESSMENT DATA COLLECTION FORM}

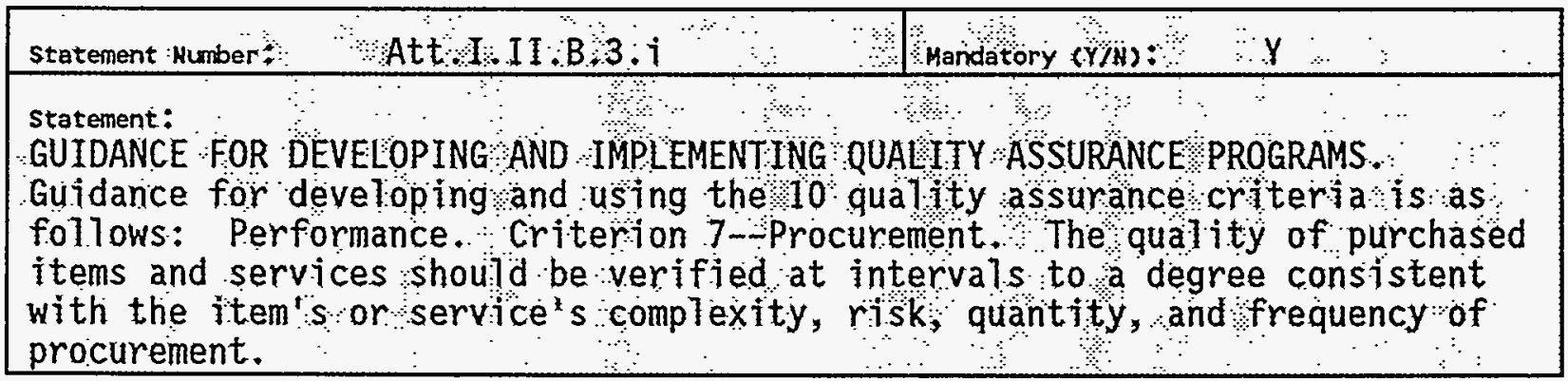

1.0 STATEMENT SATISFIED BASED ON IMPLEMENTING EVIDENCE $(Y / N)$ : NO

2.0 GENERAL DESCRIPTION OF EVIDENCE (DESCRIPTION OF NONCOMPLIANCE OR DEFICIENCY IF APPLICABLE):

Statement is not addressed in the HASQAP.

3.0 CORRECTIVE ACTION: 


\section{ASSESSMENT DATA COLLECTION FORM}

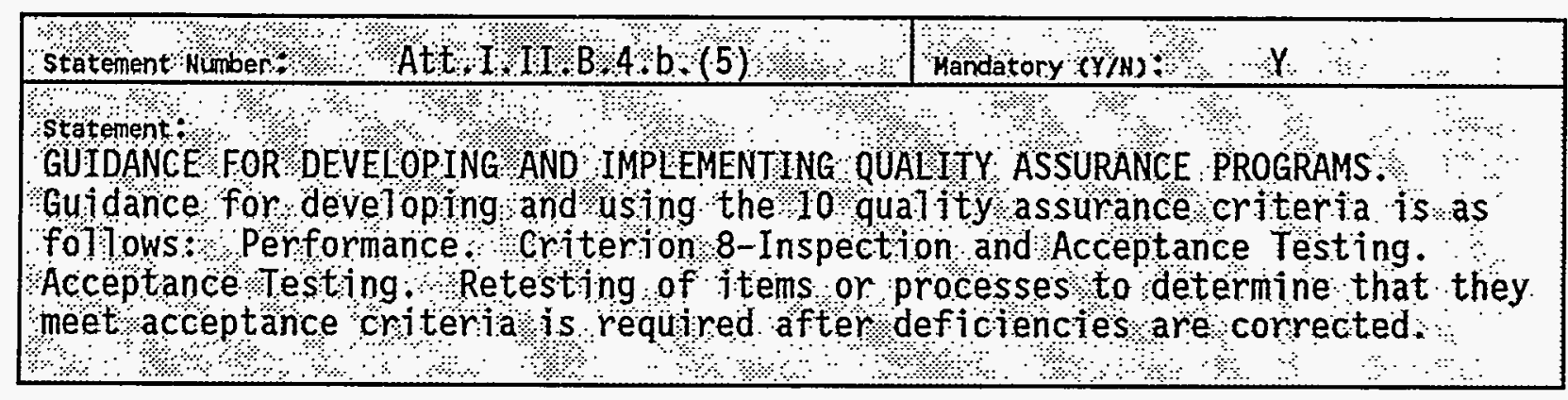

1.0 STATEMENT SATISFIED BASED ON IMPLEMENTING EVIDENCE (Y/N): YES

2.0 GENERAL DESCRIPTION OF EVIDENCE (DESCRIPTION OF NONCOMPLIANCE OR DEFICIENCY IF APPLICABLE):

For analytical laboratory testing the intent of this statement is met by the data quality objective (DQ0) process described in HASQAP subsection 4.1, "Data Quality Objectives," and HASQAP Section 15.0, "Corrective Action." 
WHC-EP-0822

\section{ASSESSMENT DATA COLLECTION FORM}

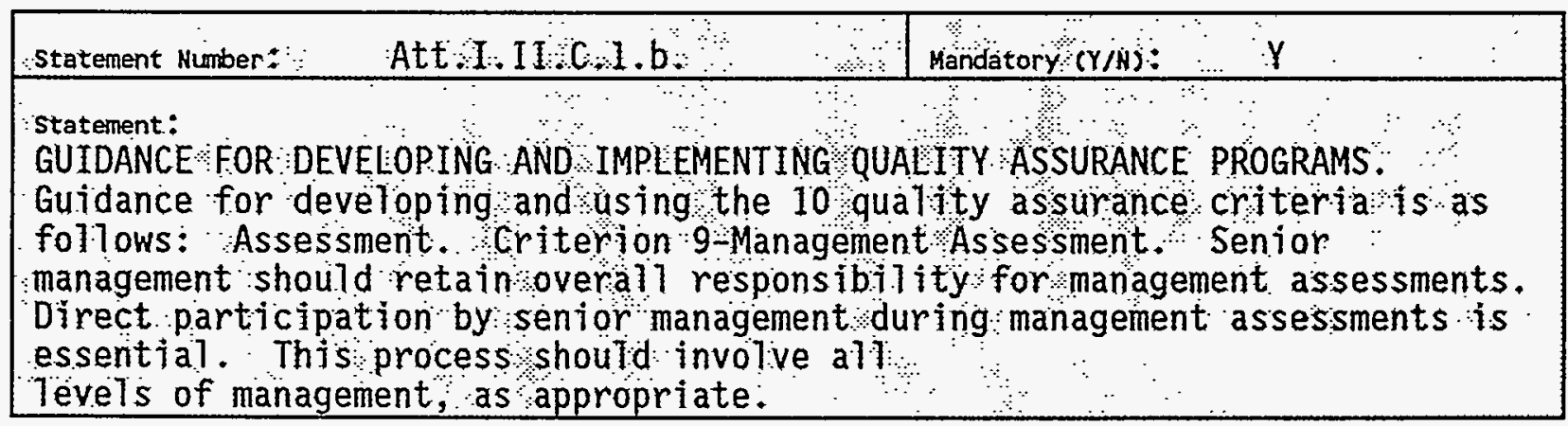

1.0 Statement SATISFIED BASEd ON IMPLEMENTING EVIDENCE (Y/N): YES

2.0 GENERAL DESCRIPTION OF EVIDENCE (DESCRIPTION OF NONCOMPLIANCE OR DEFICIENCY IF APPLICABLE):

This statement is met by HASQAP subsection 13.1, "Management System Audits." 
ASSESSMENT DATA COLLECTION FORM

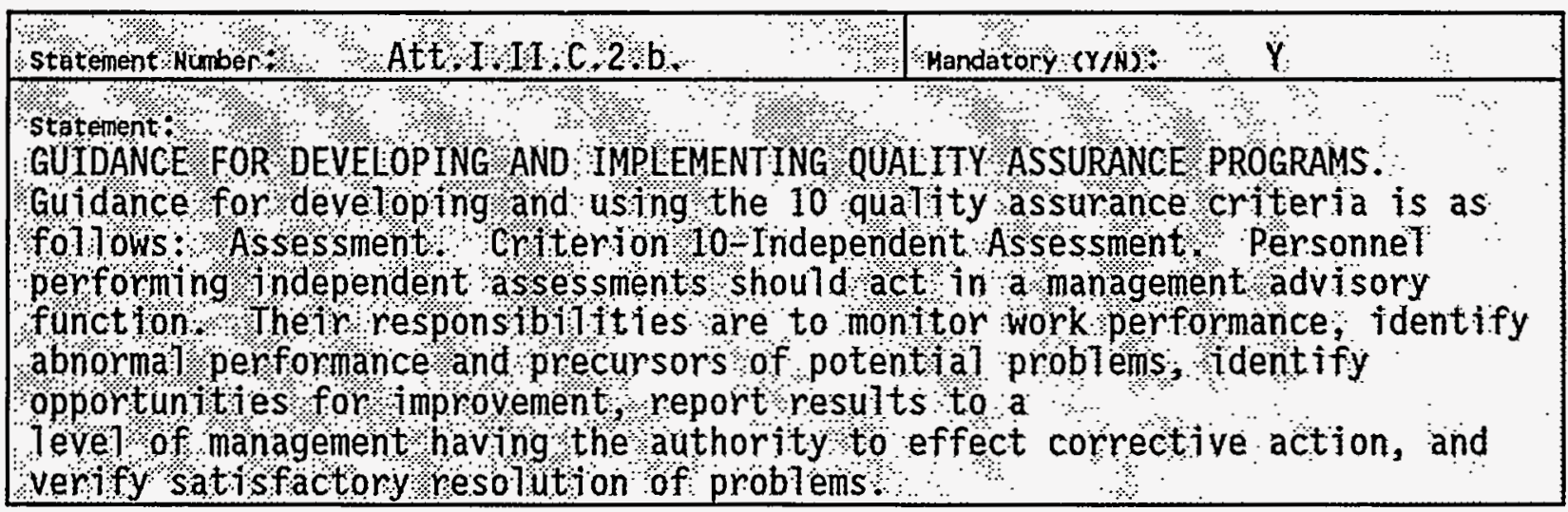

1.0 StATEMENT SATISFIED BASED ON IMPLEMENTING EVIDENCE (Y/N)：YES

2.0 GENERAL DESCRIPTION OF EVIDENCE (DESCRIPTION OF NONCOMPLIANCE OR DEFICIENCY IF APPLICABLE):

Statement is met by HASQAP Section 13.0, "Audits." 
WHC-EP-0822

\section{ATTACHMENT C}

\section{ASSESSMENT DATA COLLECTION FORMS}

for

HASQAP ASSESSMENT

to

DOE ORDER 5480.19

(Conduct of Operations) 
WHC-EP-0822

\section{ASSESSMENT DATA COLLECTION FORM}

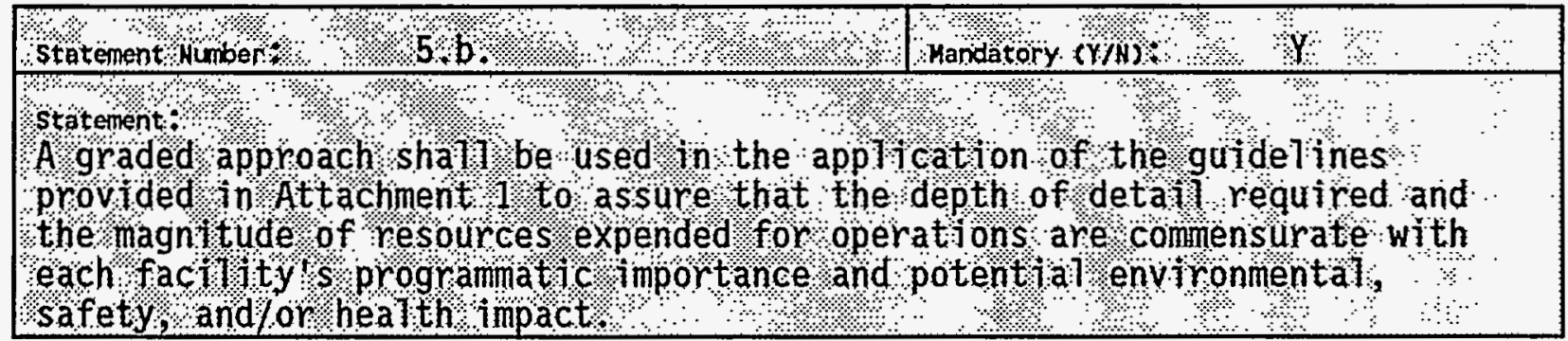

1.0 STATEMENT SATISFIED BASED ON IMPLEMENTING EVIDENCE $(Y / N):$ NO

2.0 GENERAL DESCRIPTION OF EVIDENCE (DESCRIPTION OF NONCOMPLIANCE OR DEFICIENCY IF APPLICABLE):

The HASQAP does not address the graded approach for application of the guidelines of DOE 5480.19 for analytical 1aboratory "operations."

3.0 CORRECTIVE ACTION: 
WHC-EP-0822

\section{ASSESSMENT DATA COLLECTION FORM}

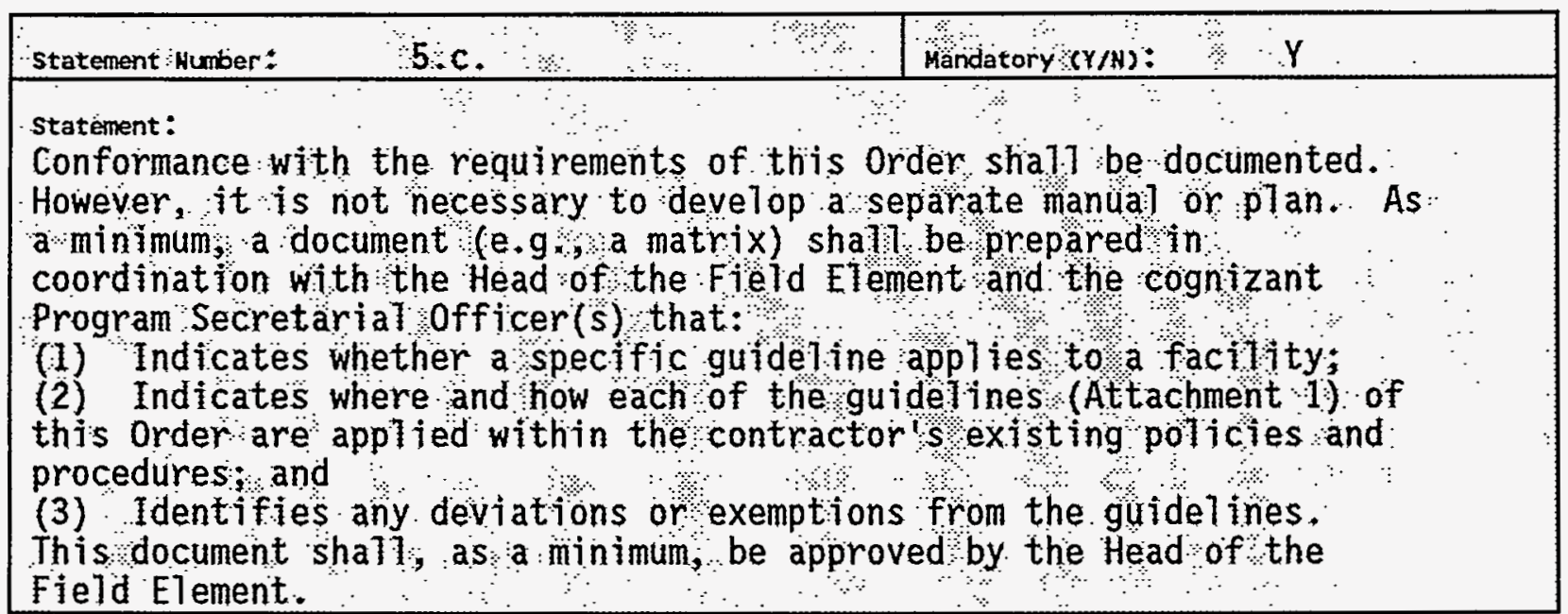

1.0 STATEMENT SATISFIED BASED ON IMPLEMENTING EVIDENCE (Y/N): NO

2.0 GENERAL DESCRIPTION OF EVIDENCE (DESCRIPTION OF NONCOMPLIANCE OR DEFICIENCY IF APPLICABLE):

Not addressed in the HASQAP.

3.0 COMMENTS: :

This assessment may meet the intent of this statement.

4.0 CORRECTIVE ACTION: 
WHC-EP-0822

\section{ASSESSMENT DATA COLLECTION FORM}

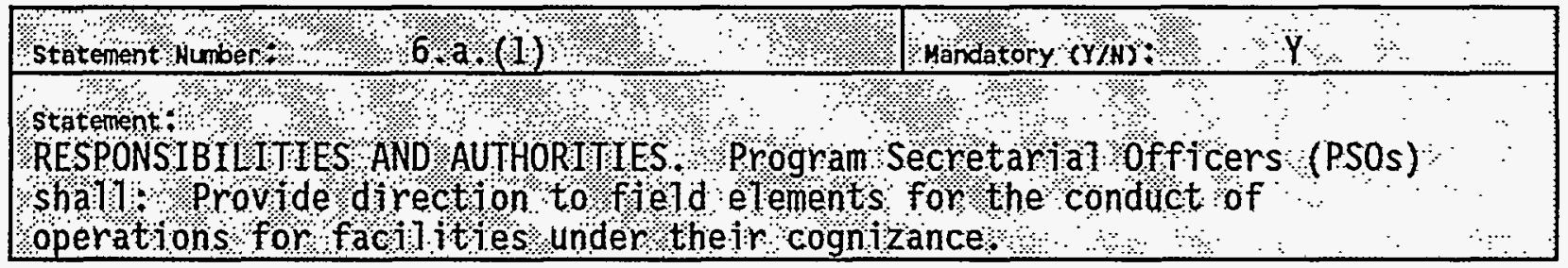

\section{N/A}

\begin{tabular}{|c|c|}
\hline 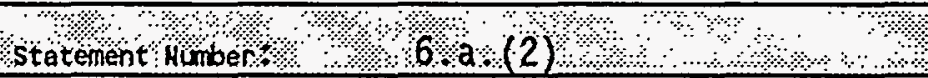 & Handatory $(Y / N)$, $)$ \\
\hline 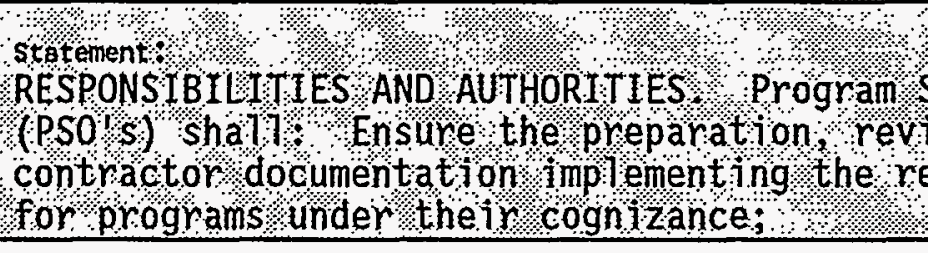 & $\begin{array}{l}\text { ecretarial officers } \\
\text { ewrandapproval of } \\
\text { aulrements of this order }\end{array}$ \\
\hline
\end{tabular}

\section{N/A}

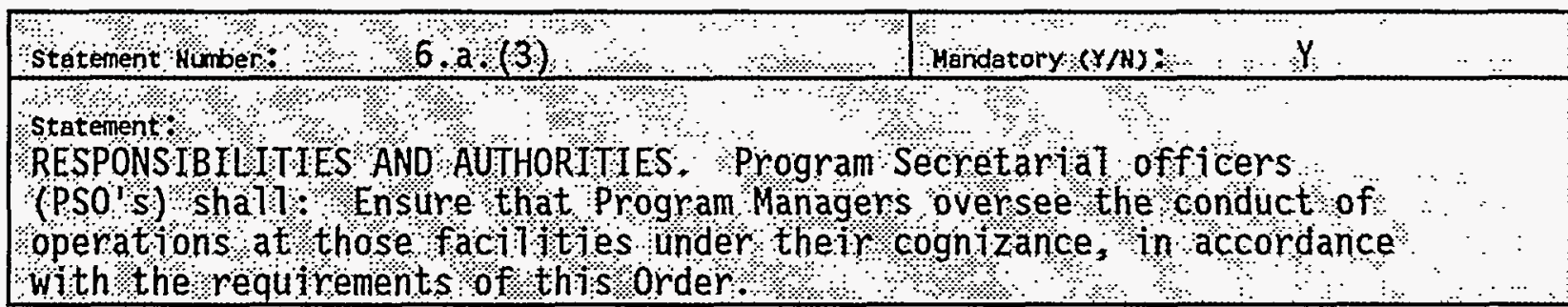

\section{N/A}


WHC-EP-0822

\section{ASSESSMENT DATA COLLECTION FORM}

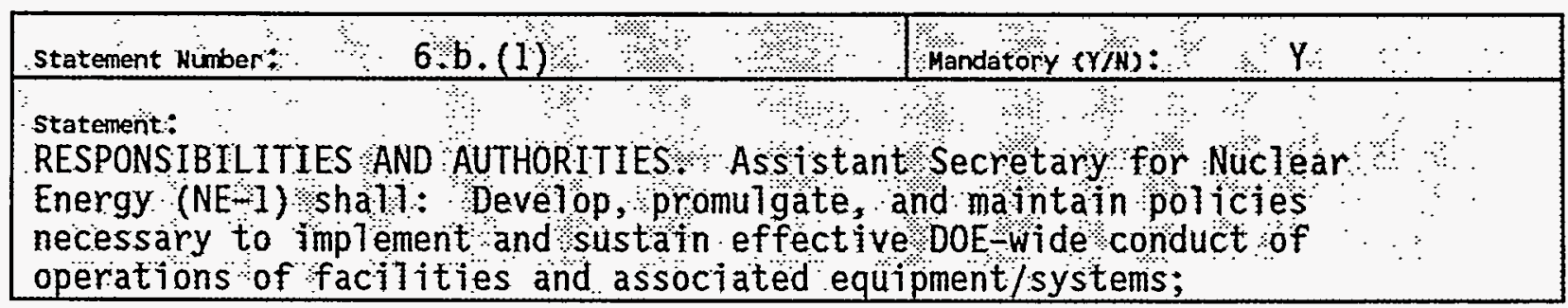

\section{$\mathbf{N} / \mathbf{A}$}

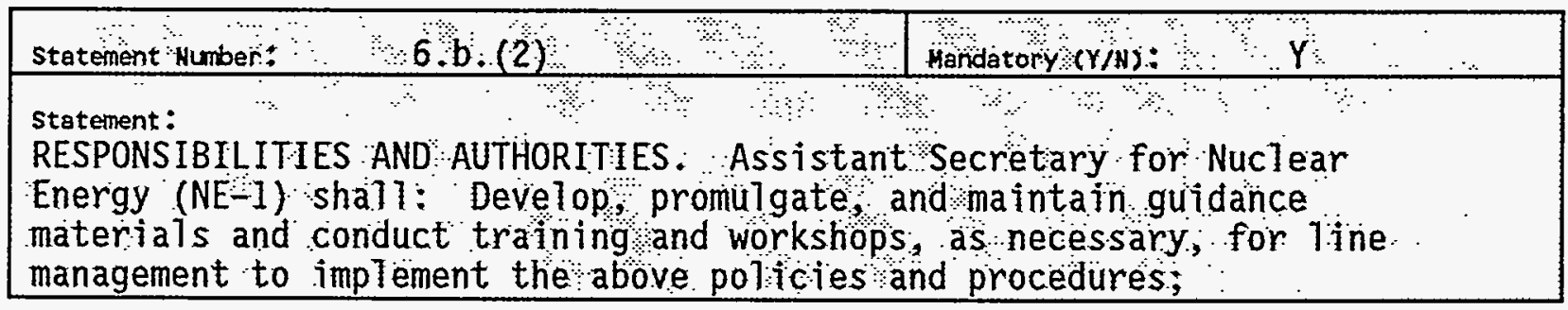

\section{N/A}

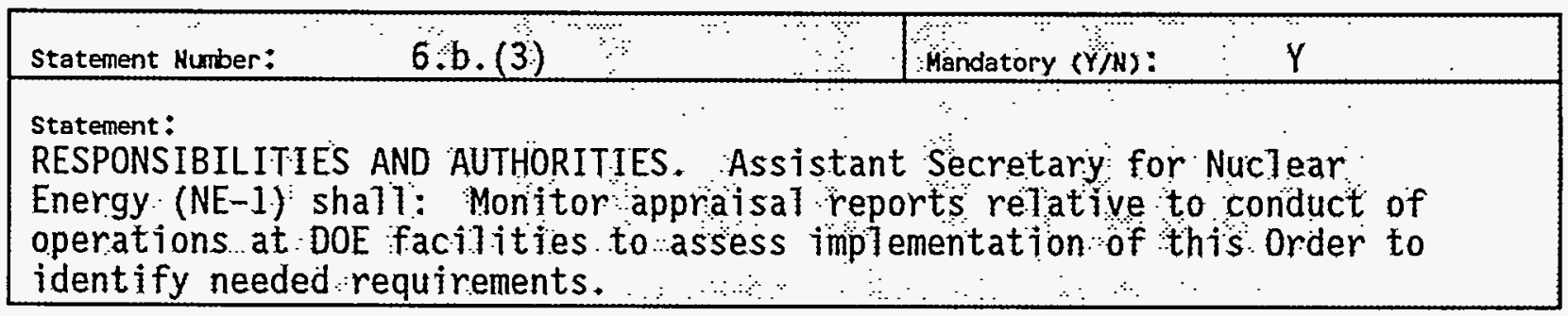

\section{N/A}


WHC-EP-0822

\section{ASSESSMENT DATA COLLECTION FORM}

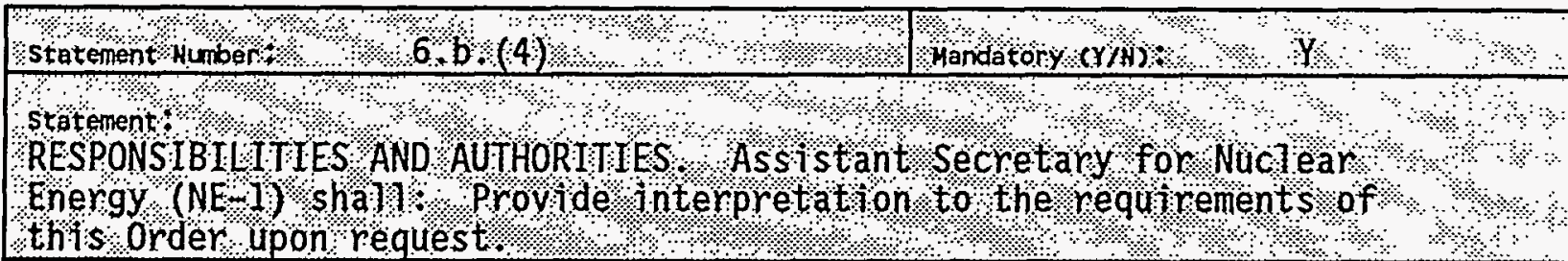

\section{N/A}

\begin{tabular}{|c|c|c|}
\hline 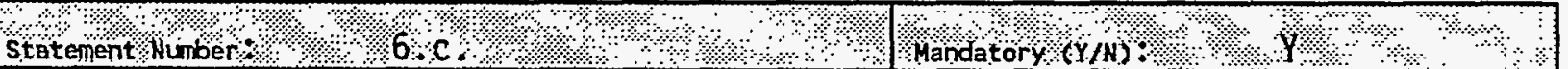 & 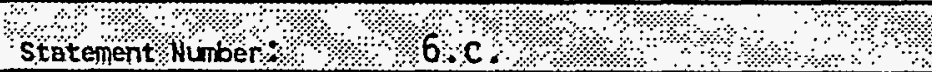 & Mandatory $(x, N)$ ? $+1 \%$ \\
\hline 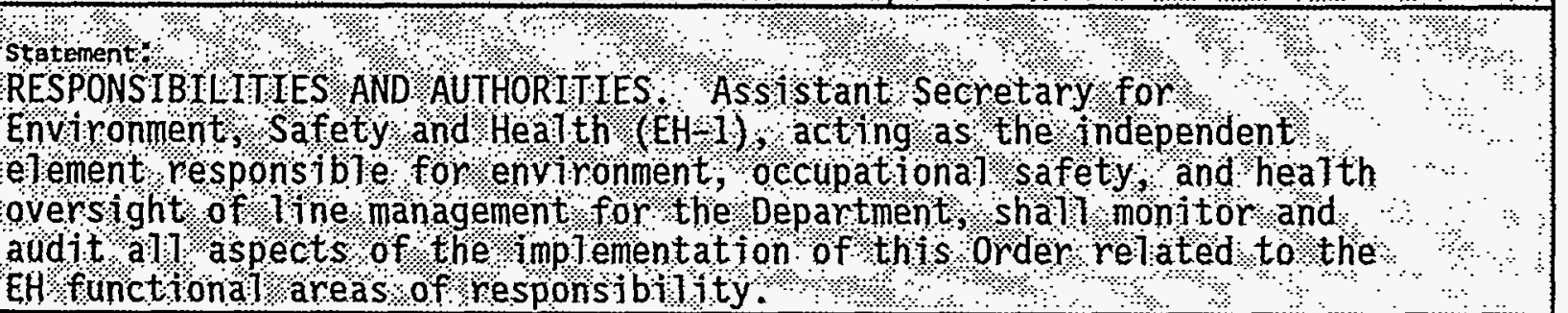 & 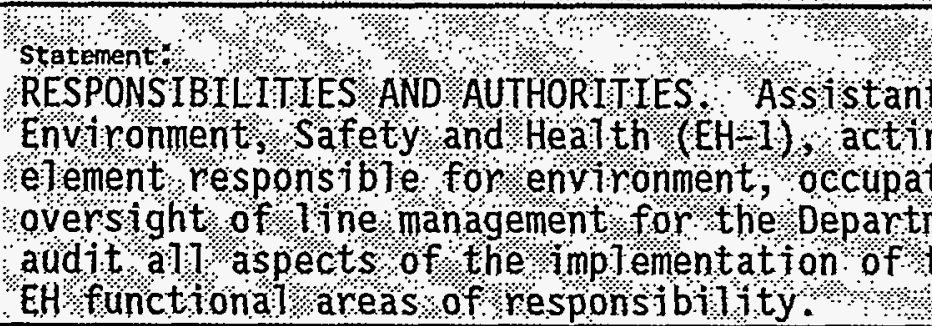 & 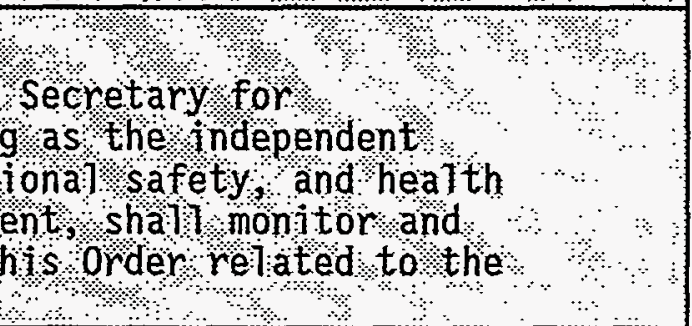 \\
\hline
\end{tabular}

\section{N/A}

\begin{tabular}{|l} 
Statement minber \\
statement
\end{tabular}

\section{N/A}


WHC-EP-0822

ASSESSMENT DATA COLLECTION FORM

\begin{tabular}{l}
\hline Statement Number: 6.e.(1) \\
\hline Statement: \\
RESPONSIBILITIES AND AUTHORITIES. Heads of Field ETements shal1: \\
Ensure that adequate contractor plans, procedures, and programs are in \\
place and assess the effectiveness of the ir implementation st sites \\
under their jurisdiction, consistent with the provistons of this \\
Order;
\end{tabular}

\section{N/A}

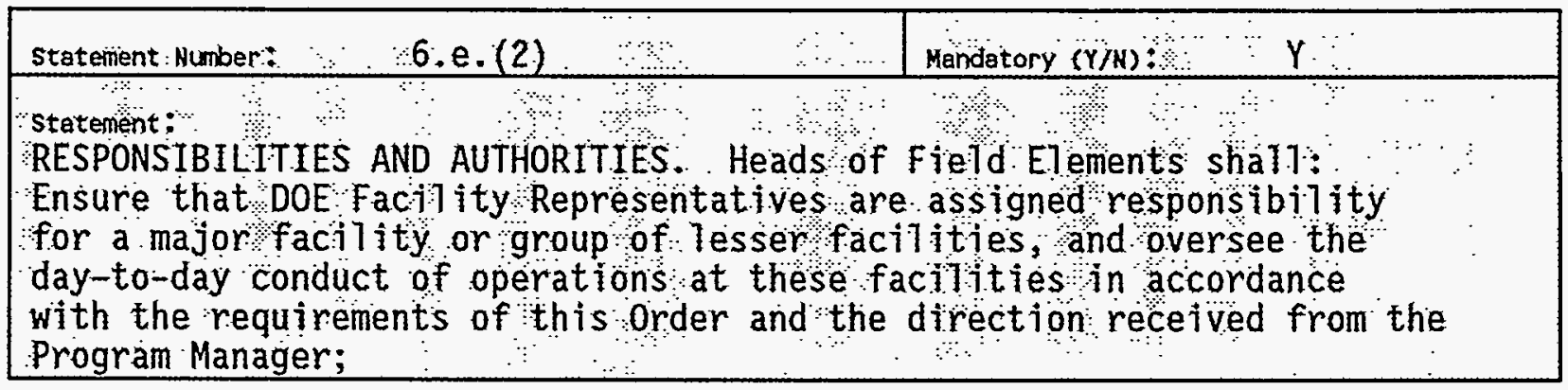

\section{N/A}

\begin{tabular}{|c|c|c|}
\hline Statement Number: & Mandatory $(Y / N)$; & .Y. \\
\hline \multicolumn{3}{|c|}{$\begin{array}{l}\text { Statement: } \\
\text { RESPONSIBILITIES AND AUTHORITIES, Heads of Field Elements sha11 } \\
\text { Approve documentation prepared by the contractor to demonstrate } \\
\text { conformance to the quidelines in Attachment } 1\end{array}$} \\
\hline
\end{tabular}

\section{N/A}

\begin{tabular}{|c|c|}
\hline$\therefore \because \ldots \quad \therefore \quad \therefore \quad \quad \because$ & Mandatory $(\mathrm{Y} / \mathrm{H}) \quad \because \mathrm{N}$ \\
\hline $\begin{array}{l}\text { Statement: } \\
\text { RESPONSIBILITIES AND AUTHORITIES Heads of } \\
\text { the shal1 determine the appropriate operation } \\
\text { their facilities, which wit } \mathrm{include} \text { conside } \\
\text { parts of the criteria set forth by this orde }\end{array}$ & $\begin{array}{l}\text { Poweradiministrations: } \\
\text { s management program for } \\
\text { ration of appropriate }\end{array}$ \\
\hline
\end{tabular}

N/A 


\section{ASSESSHENT DATA COLLECTION FORM}

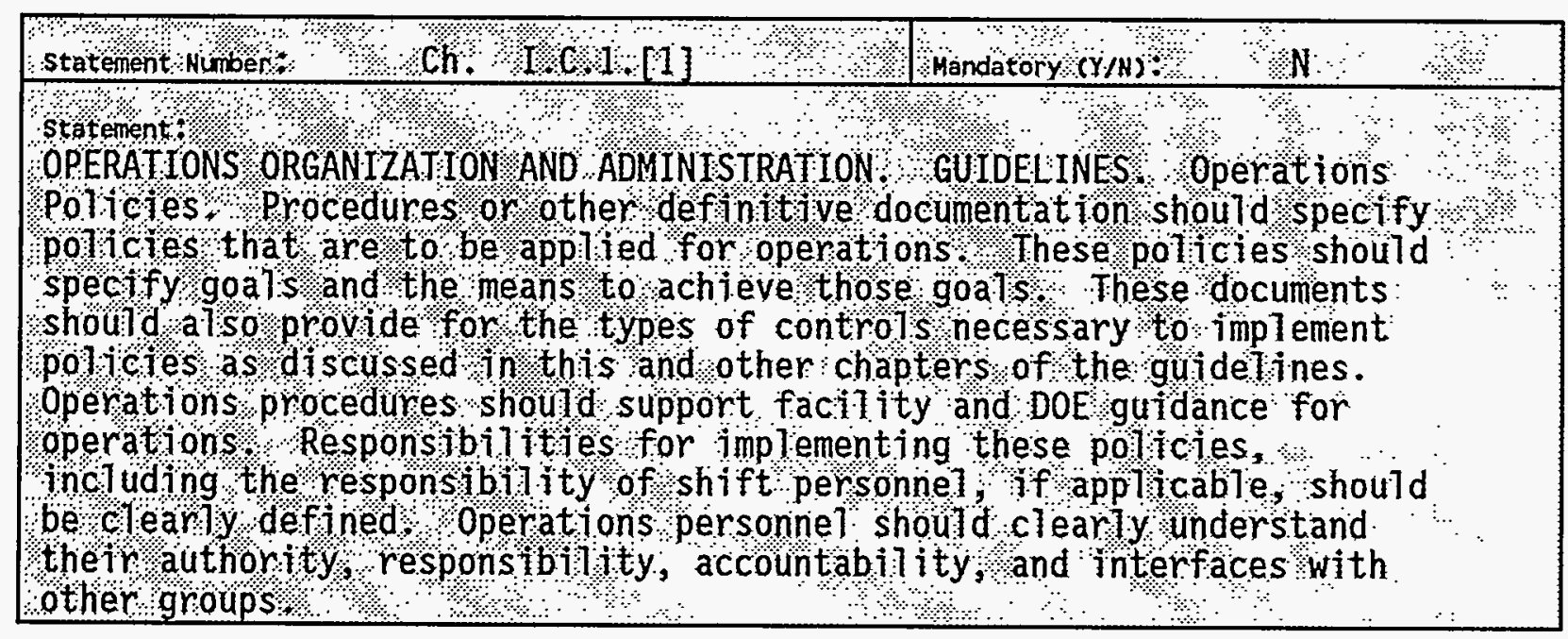

1.0 StATEMENT SATISFied BASEd ON IMPLEMENTING EVIDENCE $(Y / N)$ : YES

2.0 GEMERAL DESCRIPTION OF EVIDENCE (DESCRIPTION OF NONCOMPLIANCE OR DEFICIENCY IF APPLICABLE):

The HASQAP in its entirety fulfills this statement. 
WHC-EP-0822

\section{ASSESSMENT DATA COLLECTION FORM}

\begin{tabular}{|c|c|c|c|c|}
\hline Statement Number: & Ch. I:C. 1:[2] & Mandatory $\mathrm{CY} / \mathrm{N})$ : & N...: & $\therefore$ \\
\hline
\end{tabular}

1.0 STATEMENT SATISFIEd BASEd ON IMPLeMENTING EVIDENCE $(Y / N):$ NO

2.0 GENERAL DESCRIPTION OF EVIDENCE (DESCRIPTION OF NONCOMPLIANCE OR DEFICIENCY IF APPLICABLE):

Not addressed in the HASQAP.

3.0 CORRECTIVE ACTION: 


\section{ASSESSMENT DATA COLLECTION FORM}

\begin{tabular}{|c|c|}
\hline statement tulumber: & ndatory.s \\
\hline 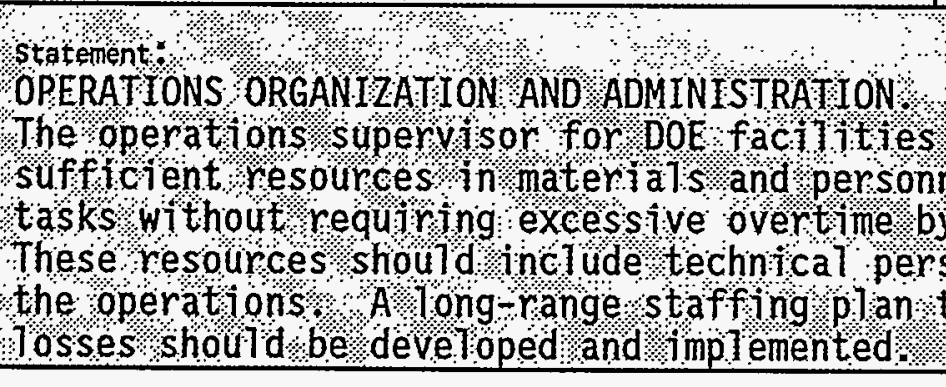 & $\begin{array}{l}\text { Resources. } \\
\text { provided with } \\
\text { mplosh ass igned } \\
\text { tons staff } \\
\text { od to support } \\
\text { pates personnel }\end{array}$ \\
\hline
\end{tabular}

1.0 Statement SATISFied BASED ON IMPLEMENTING EVIDENCE (Y/N): YES

2.0 GENERAL DESCRIPTION OF EVIDENCE (DESCRIPTION OF NONCONPLIANCE OR DEFICIENCY IF APPLICABLE):

The intent of this statement is met by the HASQAP "Policy Statement" and Section 2.0, "Organization and Responsibility." 
WHC-EP-0822

ASSESSMENT DATA COLLECTION FORM

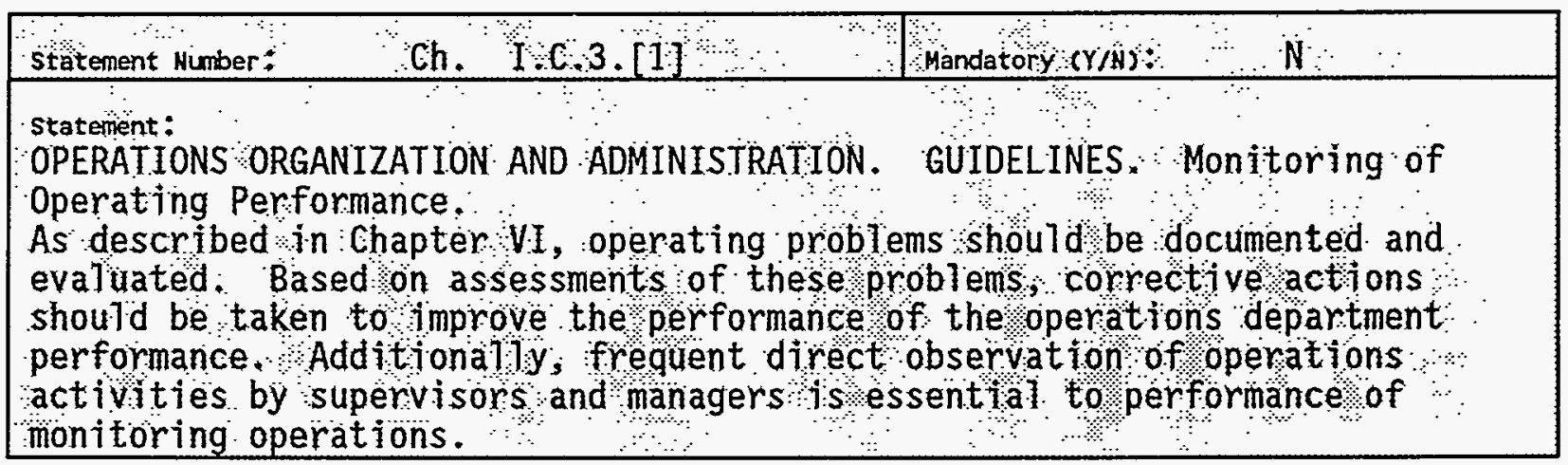

1.0 STATEMENT SATISFIED BASED ON IMPLEMENTING EVIDENCE (Y/N): YES

2.0 GENERAL DESCRIPTION OF EVIDENCE (DESCRIPTION OF NONCOMPLIANCE OR DEFICIENCY IF APPLICABLE):

This statement is met by the HASQAP Section 15.0, "Corrective Action." 


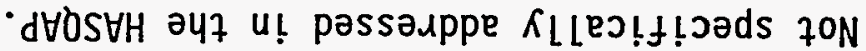

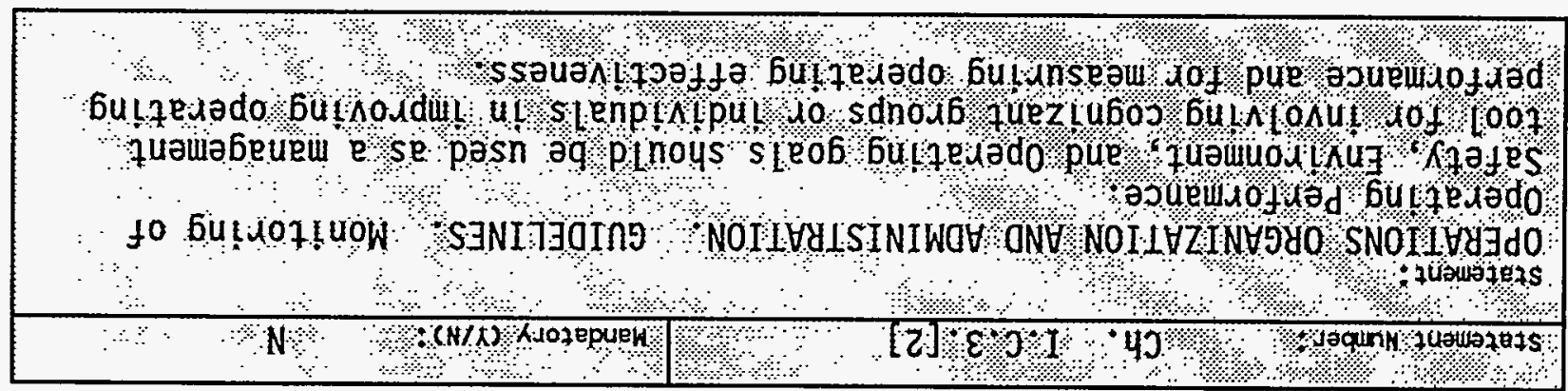

WYOA NOILJ7ר70ว $\forall I \forall O$ LNGWSSISSH

2280- $\mathrm{d} 3-J H M$ 
WHC-EP-0822

\section{ASSESSMENT DATA COLLECTION FORM}

\begin{tabular}{|c|}
\hline 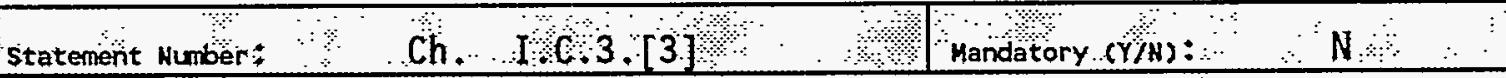 \\
\hline 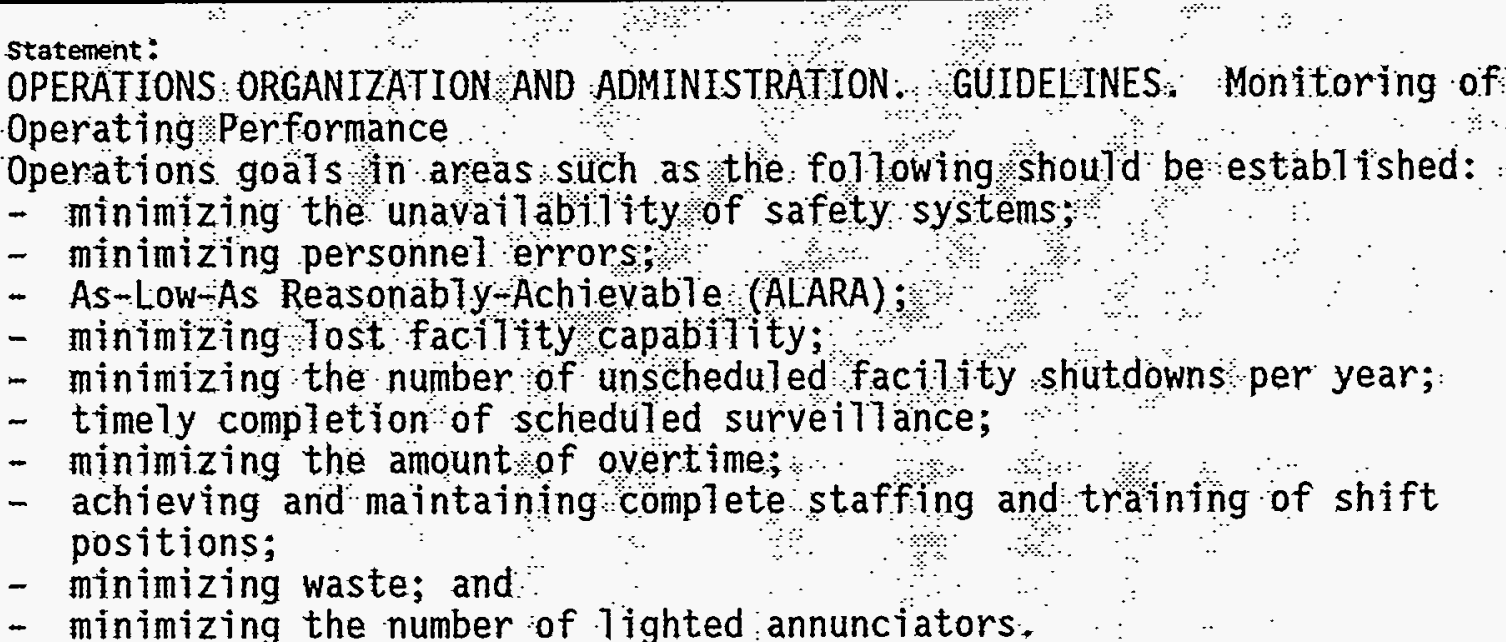 \\
\hline
\end{tabular}

1.0 STATEMENT SATISFIED BASED ON IMPLEMENTING EVIOENCE (Y/N): NO

2.0 GENERAL DESCRIPTION OF EVIDENCE (DESCRIPTION OF NONCOMPLIANCE OR DEFICIENCY IF APPLICABLE):

Although many of the "operations goals" listed in the statement are questionable for laboratory operations, the HASQAP does not address specific laboratory operations goals.

3.0 CORRECTIVE ACTION: 


\section{ASSESSMENT DATA COLLECTION FORM}

\begin{tabular}{|c|}
\hline 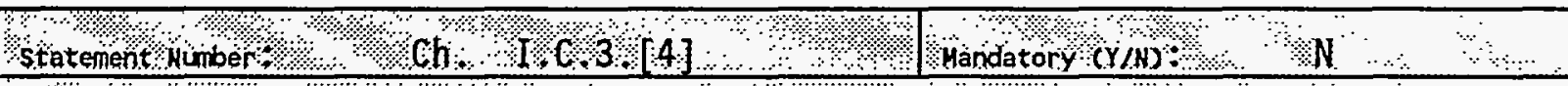 \\
\hline 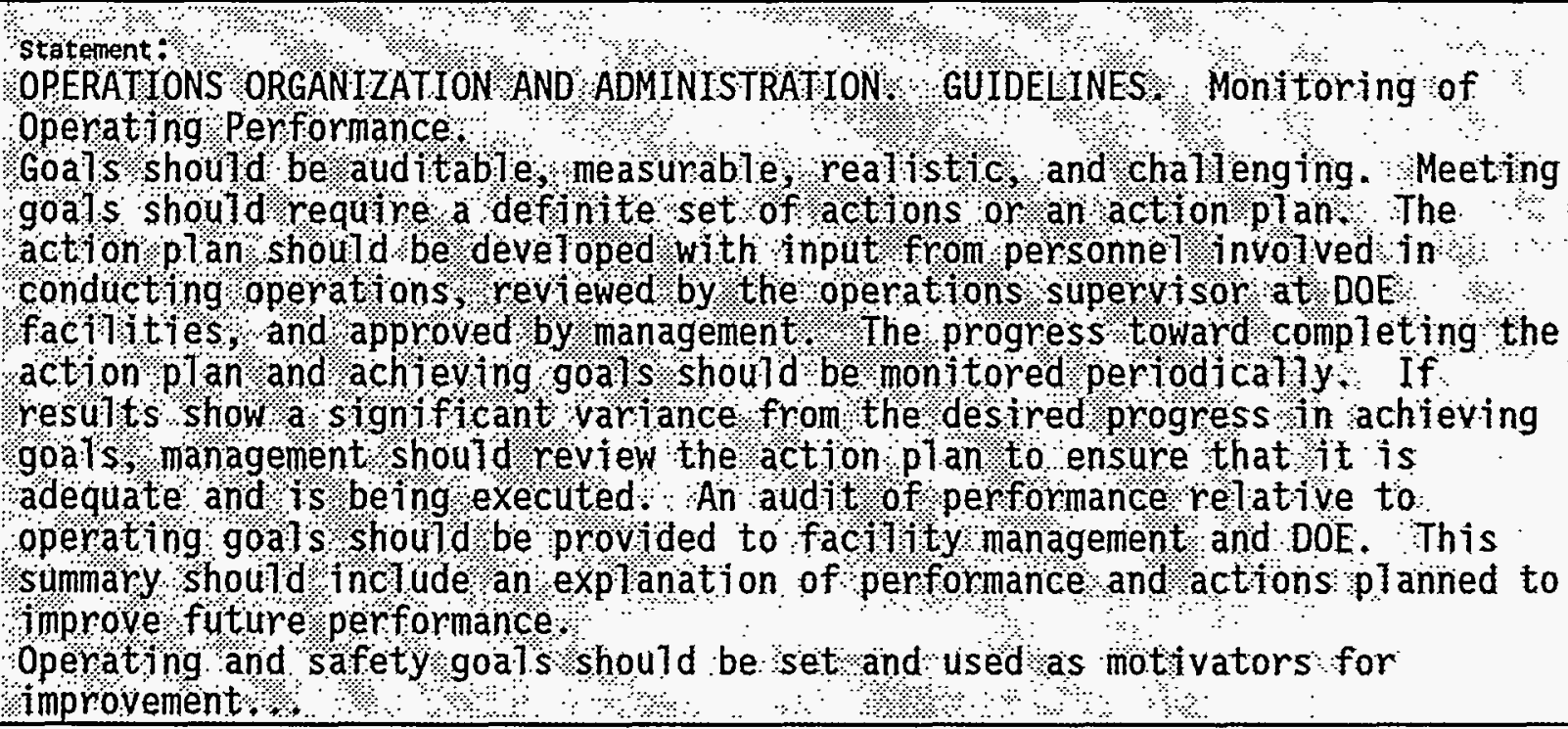 \\
\hline
\end{tabular}

1.0 Statement SATISFIED BASEd ON IMPLEMENTING EVIDENCE (Y/N): NO

2.0 GENERAL DESCRIPTION OF EVIDENCE (DESCRIPTION OF NONCOMPLIANCE OR DEFICIENCY IF APPLICABLE):

The HASQAP does not specifically address operating goals and action plans.

3.0 CORRECTIVE ACTION: 
ASSESSHENT DATA COLLECTION FORM

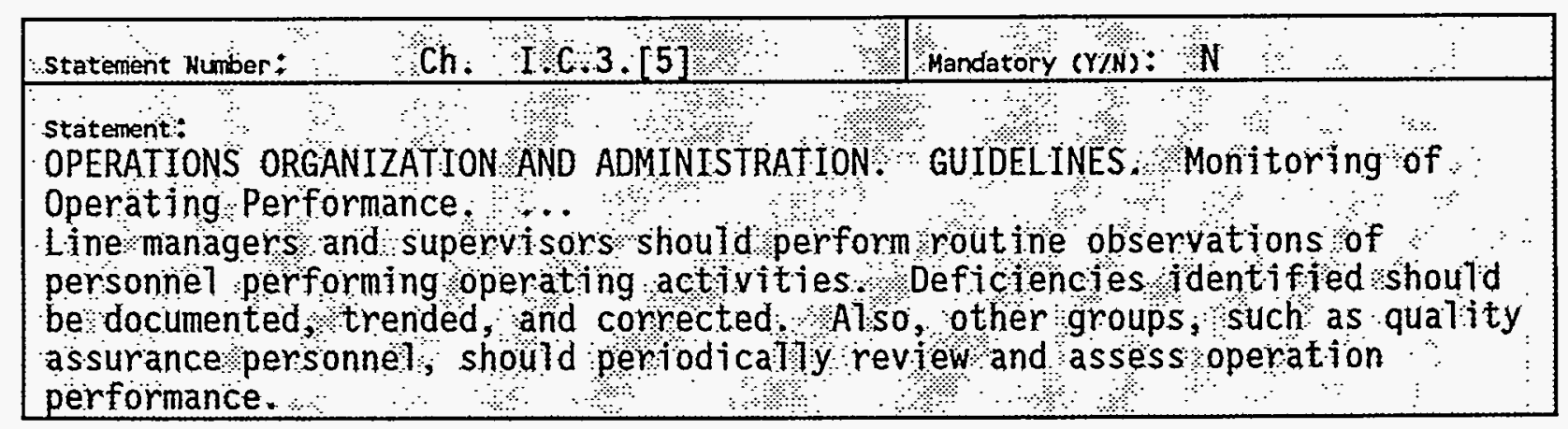

1.0 STATEMENT SATISFIED BASED ON IMPLEMENTING EVIDENCE $(Y / N):$ NO

2.0 GENERAL DESCRIPTION OF EVIDENCE (DESCRIPTION OF NONCOMPLIANCE OR DEFICIENCY IF APPLICABLE):

The statement is partially met:

(1) "Line managers and supervisors should perform routine observations of personne] performing operating activities."

The HASQAP does not specifically address routine observations by line managers and supervisors.

(2) "Deficiencies identified should be documented, trended, and corrected."

This statement is met by HASQAP Section 15.0, "Corrective Action."

(3) "Also, other groups, such as quality assurance personnel, should periodically review and assess operation performance."

This statement is met by HASQAP Section 13.0, "Audits."

3.0 CORRECTIVE ACTION: 
WHC-EP-0822

ASSESSMENT DATA COLLECTION FORM

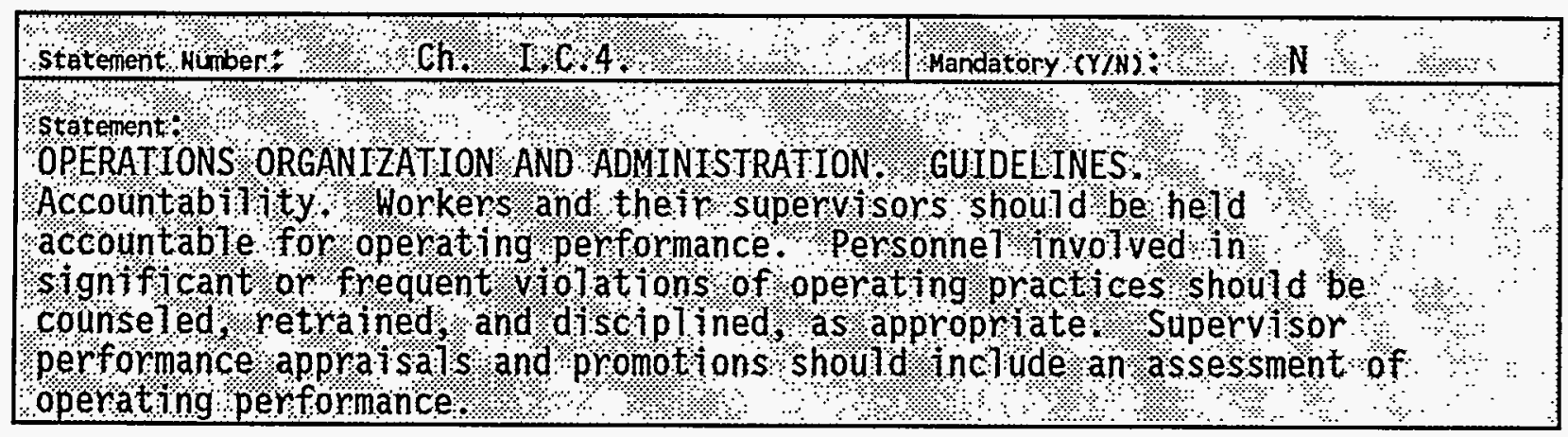

1.0 StATEMENT SATISFied BASED ON IMPLEMENTING EVIDENCE (Y/N): NO

2.0 GENERAL DESCRIPTION OF EVIDENCE (DESCRIPTION OF NONCOMPLIANCE OR DEFICIENCY IF APPLICABLE):

The statement is partially met:

(1) "Workers and their supervisors should be held accountable for operating performance."

The intent of this statement is met by the HASQAP "Policy

Statement" and Section 2.0, "Organization and

Responsibility."

(2) "Personnel involved in significant or frequent violations of operating practices should be counseled, retrained, and disciplined, as appropriate. Supervisor performance appraisals and promotions should include an assessment of operating performance."

The specifics of this statement are not addressed in the HASQAP.

3.0 CORRECTIVE ACTION: 
WHC-EP-0822

ASSESSMENT DATA COLLECTION FORM

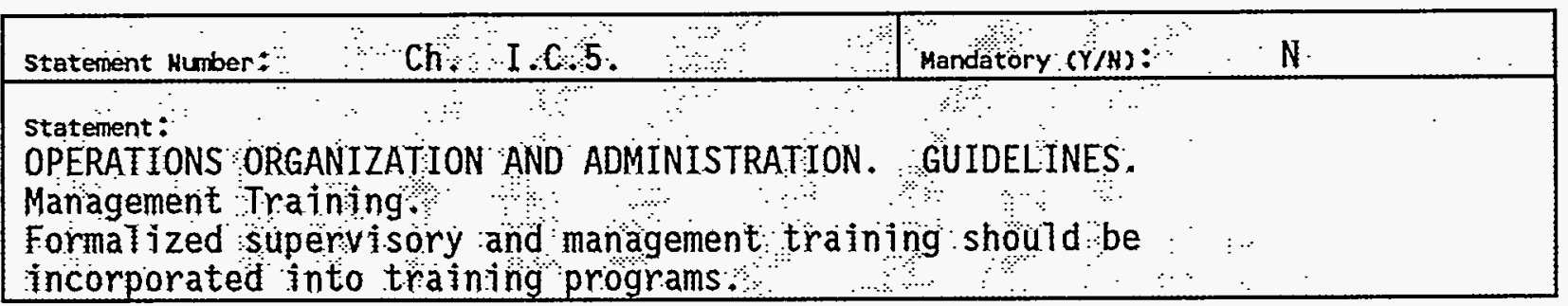

1.0 StATEMENT SATISFIED BASED ON IMPLEMENTING EVIDENCE $(Y / N)$ : YES

2.0 GENERAL DESCRIPIION OF EVIDENCE (DESCRIPTION OF NONCOMPLIANCE OR DEFICIENCY IF APPLICABLE):

This statement is met by HASQAP Section 3.5, "Management Training." 


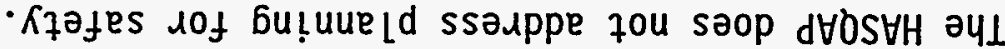

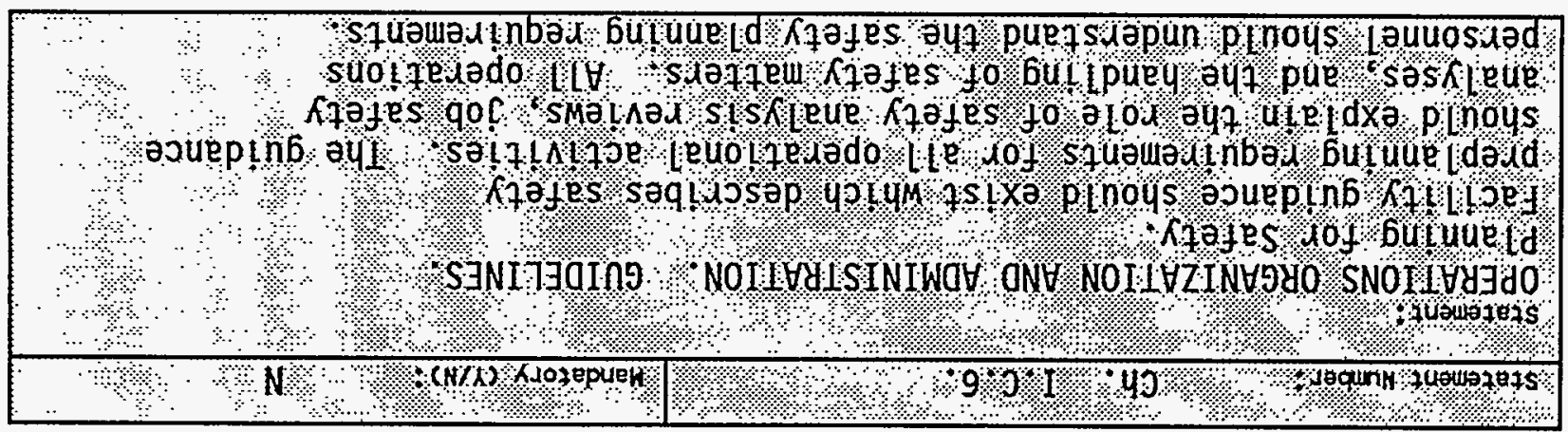

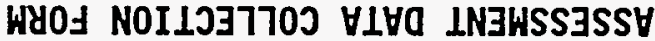

$2280-\mathrm{d} \exists-3 H M$ 


\section{ASSESSMENT DATA COLLECTION FORM}

\begin{tabular}{|c|c|}
\hline $\mathrm{Ch}$ II.C I. & Mandatory (Ÿ/N): \\
\hline 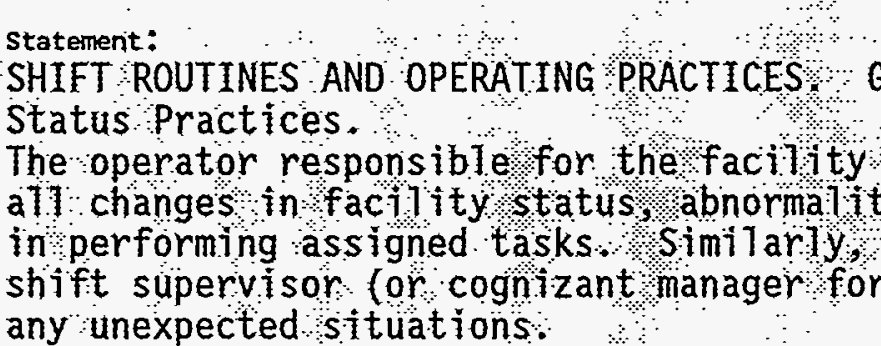 & $\begin{array}{l}\text { DELINES } \\
\text { olld be promptly notified of } \\
\text { s. or difficulties encountered } \\
\text { e operator should notify the } \\
\text { esearch and test facilities) of }\end{array}$ \\
\hline
\end{tabular}

1.0 Statement SATISfied Based on Implementing EVIDence (Y/N): NO

2.0 GENERAL DESCRIPTION OF EVIDENCE (DESCRIPTION OF NONCOMPLIANCE OR DEFICIENCY IF APPLICABLE):

The statement is not addressed in the HASQAP.

3.0 CORRECTIVE ACTION: 
WHC-EP-0822

\section{ASSESSMENT DATA COLLECTION FORM}

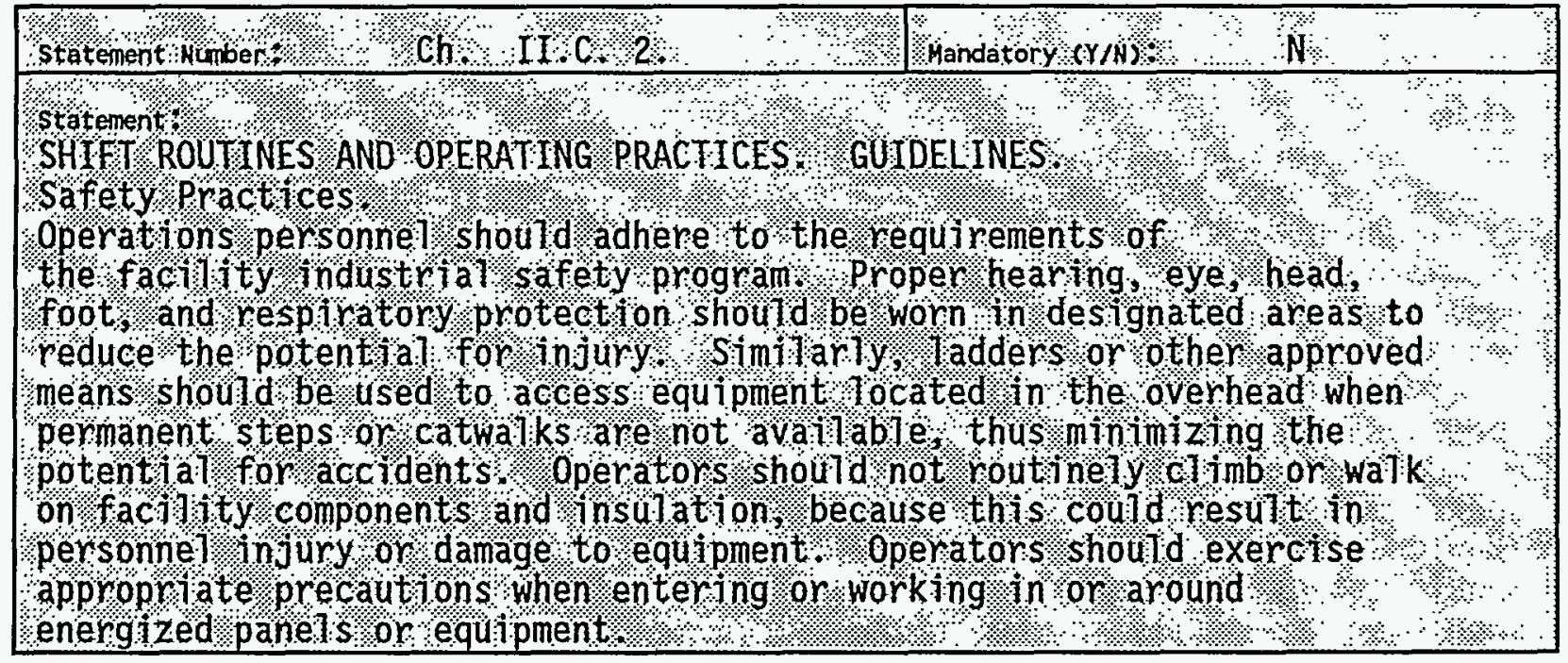

1.0 STATEMENT SATISFIED BASED ON IMPLEMENTING EVIDENCE (Y/N): NO

2.0 GENERAL DESCRIPTION OF EVIDENCE (DESCRIPTION OF NONCOMPLIANCE OR DEFICIENCY IF APPLICABLE):

Safety practices are not addressed in the HASQAP.

3.0 CORRECTIVE ACTION: 
WHC-EP-0822

\section{ASSESSMENT DATA COLLECTION FORM}

\begin{tabular}{|c|}
\hline Mandatory (YY/N) $\quad \mathrm{N}$ \\
\hline 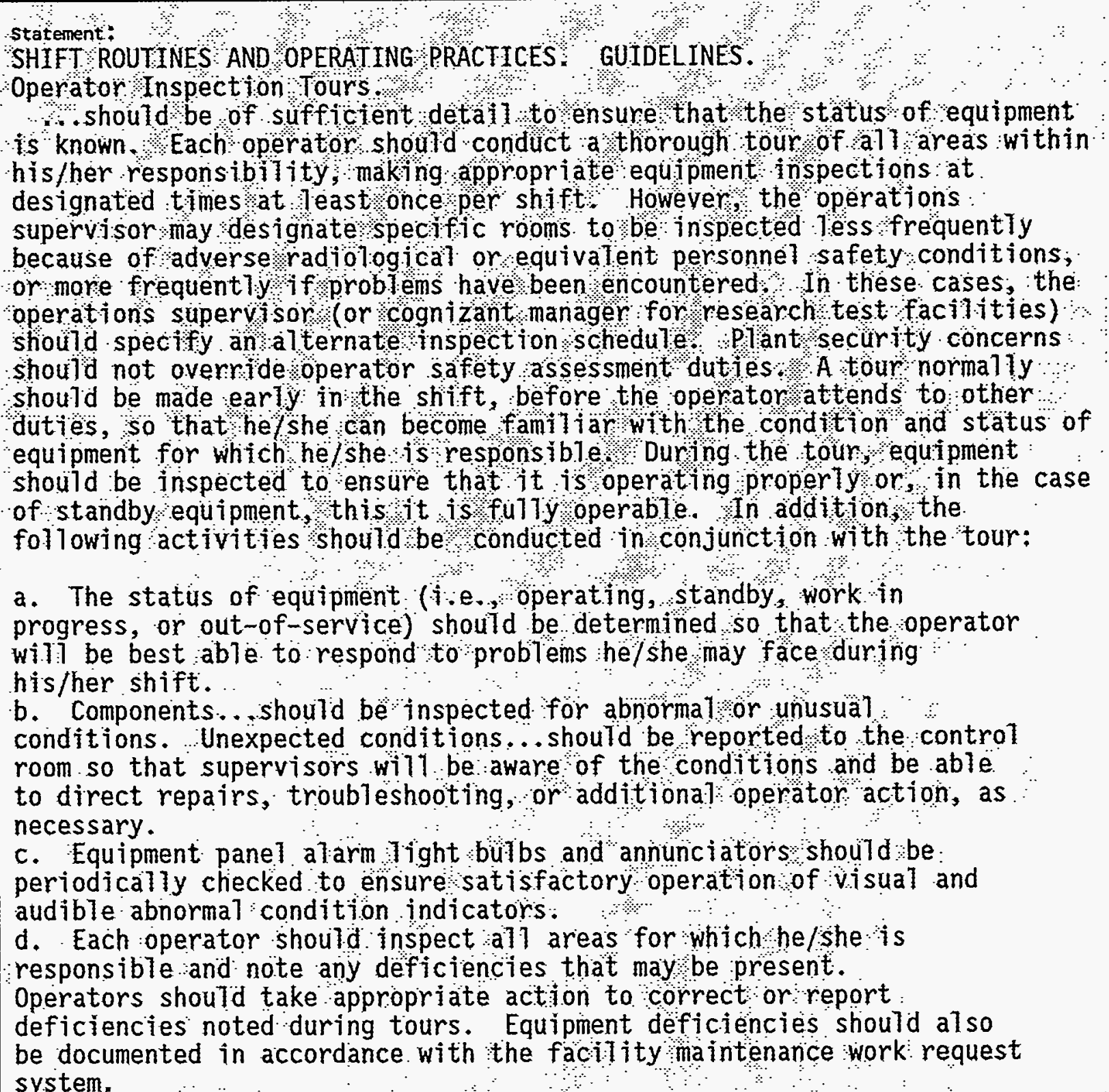 \\
\hline
\end{tabular}

\section{N/A}




\section{ASSESSMENT DATA COLLECTION FORM}

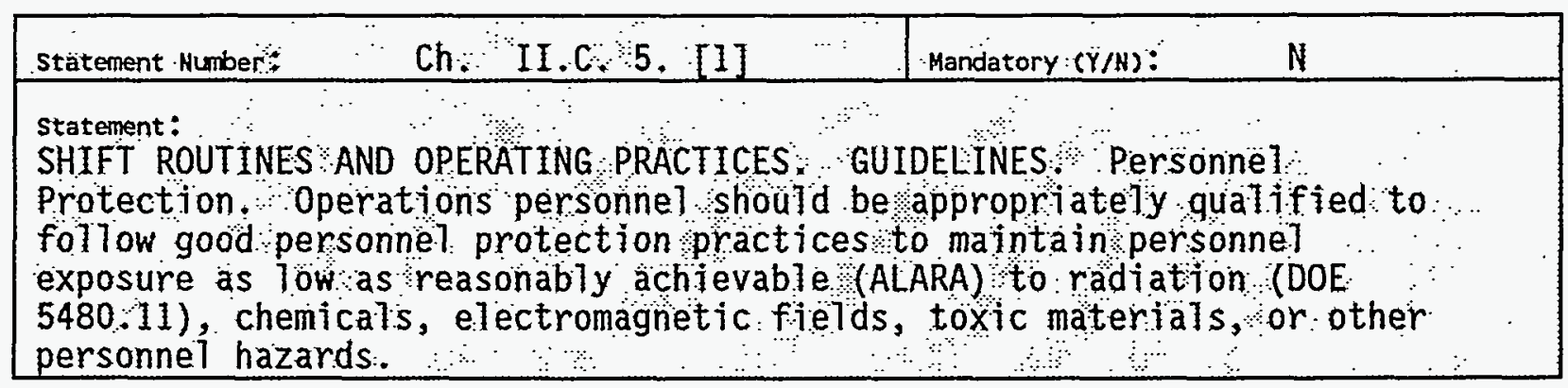

1.0 StateMENT SATISFied BASED ON IMPLemENting EVIDENCE (Y/N): NO

2.0 GENERAL DESCRIPTION OF EVIDENCE (DESCRIPTION OF NONCOMPLIANCE OR DEFICIENCY IF APPLICABLE):

Personnel protection is not addressed in the HASQAP.

3.0 CORRECTIVE ACTION: 


\section{ASSESSHENT DATA COLLECTION FORM}

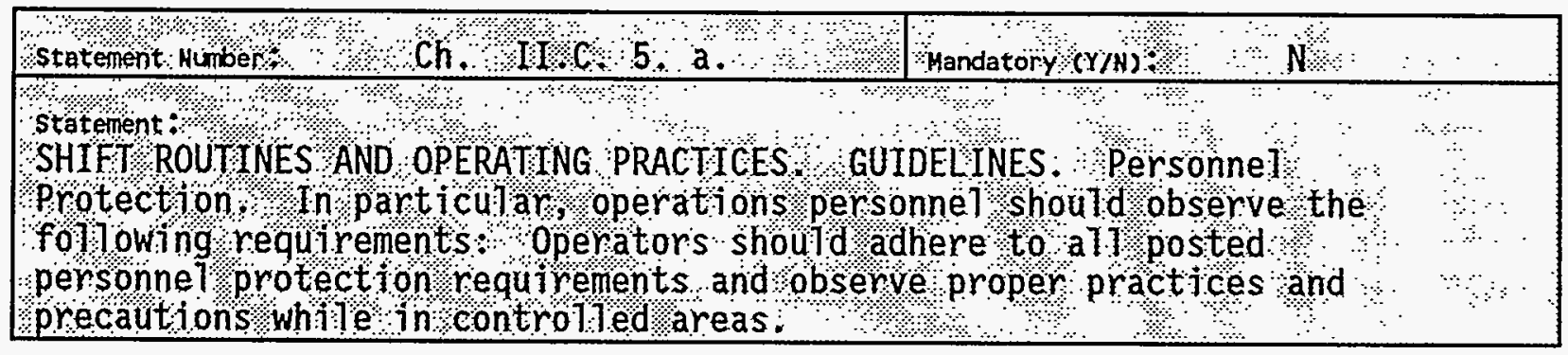

1.0 STATEMENT SATISFIED BASED ON IMPLEMENTING EVIDENCE $(Y / N):$ NO

2.0 GENERAL DESCRIPTION OF EVIDENCE (DESCRIPTION OF NONCOMPLIANCE OR DEFICIENCY IF APPLICABLE):

Personnel protection is not addressed in the HASQAP.

3.0 CORRECTIVE ACTION: 
WHC-EP-0822

\section{ASSESSMENT DATA COLLECTION FORM}

\begin{tabular}{|c|c|}
\hline Statement Number $\quad \because \mathrm{Ch}, \mathrm{II} \mathrm{C}, \mathrm{b}, \mathrm{b}$ & Hañdatory $(\gamma / \mathrm{N}): \quad \because$ \\
\hline $\begin{array}{l}\text { Statement: } \\
\text { SHIFT ROUTINES AND OPERATING PRACTICES } \\
\text { Protect jon In part icular, operations } p \\
\text { following requirements : Operators shoul } \\
\text { appropriate monitoring instruments when }\end{array}$ & 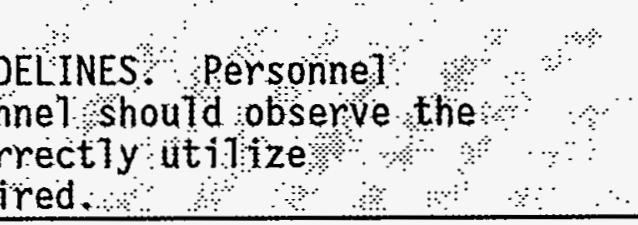 \\
\hline
\end{tabular}

1.0 STATEMENT SATISfIEd BASED ON IMPLEMENTING EVIDENCE (Y/N): NO

2.0 GENERAL DESCRIPTION OF EVIDENCE (DESCRIPTION OF NONCOMPLIANCE OR DEFICIENCY IF APPLICABLE):

Personnel protection is not addressed in the HASQAP.

3.0 CORRECTIVE ACTION: 
WHC-EP-0822

\section{ASSESSMENT DATA COLLECTION FORM}

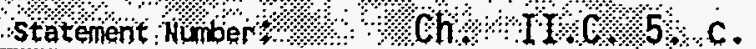

Mandatory $(7 / N)$

N.

४॰

statement

SHTFT ROUTINES AND OPERATING PRACTICES, GUIDELINES.

Protection. In particular, operations personnel shoutd observe the

following requirements: Operators shouid be cognizant of the ir own

exposure Tevels and take ap propriate action to minimize exposures.

1.0 STATEMENT SATISFIED BASED ON IMPLEMENTING EVIDENCE $(Y / N)$ : NO

2.0 GENERAL DESCRIPTION OF EVIDENCE (DESCRIPTION OF NONCOMPLIANCE OR DEFICIENCY IF APPLICABLE):

Personnel protection is not addressed in the HASQAP.

3.0 CORRECTIVE ACTION: 
WHC-EP-0822

\section{ASSESSMENT DATA COLLECTION FORM}

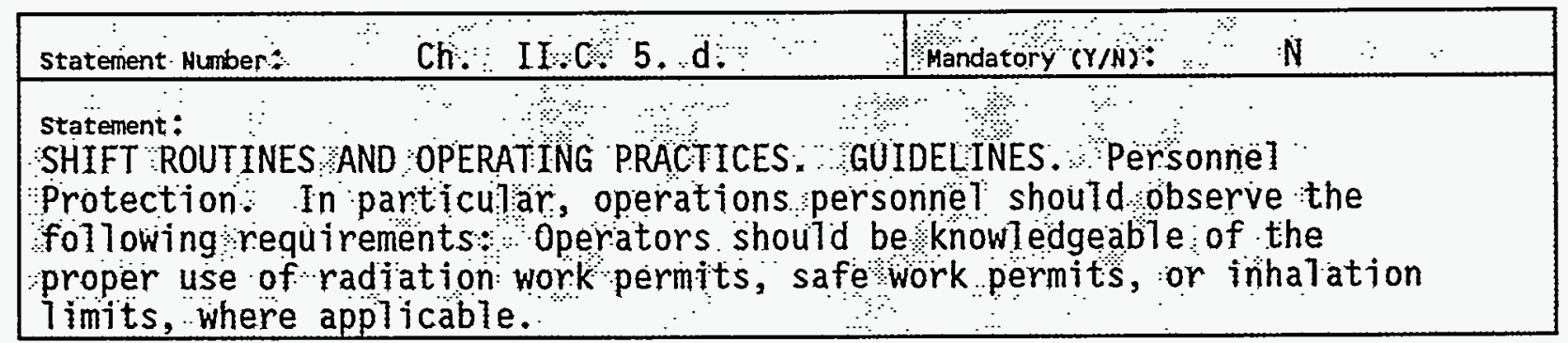

1.0 Statement SATISFied based ON IMPLEMENTING EVIDENCE $(Y / N)$ : NO

2.0 GENERAL DESCRIPTION OF EVIDENCE (DESCRIPTION OF NONCOMPLIANCE OR DEFICIENCY IF APPLICABLE):

Personnel protection is not addressed in the HASQAP.

3.0 CORRECTIVE ACTION: 


\section{ASSESSMENT DATA COLLECTION FORM}

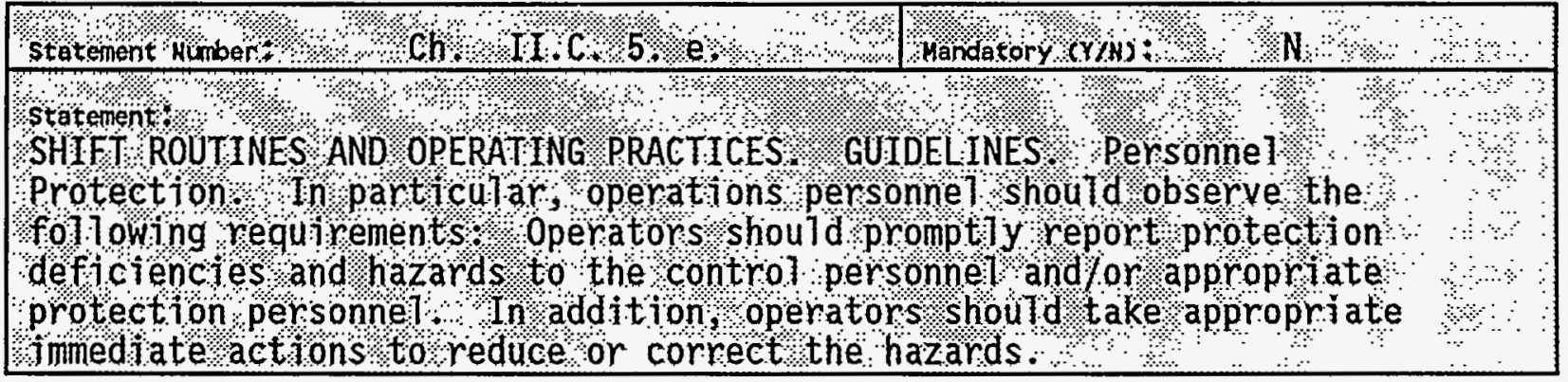

1.0 STATEMENT SATISFIED BASED ON IMPLEMENTING EVIDENCE $(Y / N):$ NO

2.0 GENERAL DESCRIPTION OF EVIDENCE (DESCRIPTION OF NONCOMPLIANCE OR DEFICIENCY IF APPLICABLE):

Personnel protection is not addressed in the HASQAP.

3.0 CORRECTIVE ACTION: 
WHC-EP-0822

\section{ASSESSMENT DATA COLLECTION FORM}

\begin{tabular}{|c|c|c|}
\hline $\mathrm{Ch}$ II $C$ C 5 . $\mathrm{f}, \mathrm{L}$ & Mandatory CY/NS: & \\
\hline $\begin{array}{l}\text { Statement: } \\
\text { SHIFT ROUTINES AND OPERATING PRACTICES } \\
\text { Protection GUI I I particular, operations perso } \\
\text { following requirements: Appropriate protect } \\
\text { informed prior to evolutions or activities } \\
\text { significantly change conditions in the facil }\end{array}$ & $\begin{array}{l}\text { DELINES Personnel } \\
\text { nne should observe the } \\
\text { ion personnel should be } \\
\text { hat have a potential to } \\
\text { ity }\end{array}$ & \\
\hline
\end{tabular}

1.0 Statement SATISFIED BASED ON IMPLEMENTING EVIDENCE (Y/N): NO

2.0 GENERAL DESCRIPTION OF EVIDENCE (DESCRIPTION OF NONCOMPLIANCE OR DEFICIENCY IF APPLICABLE):

Personnel protection is not addressed in the HASQAP.

3.0 CORRECTIVE ACTION: 
WHC-EP-0822

\section{ASSESSMENT DATA COLLECTION FORM}

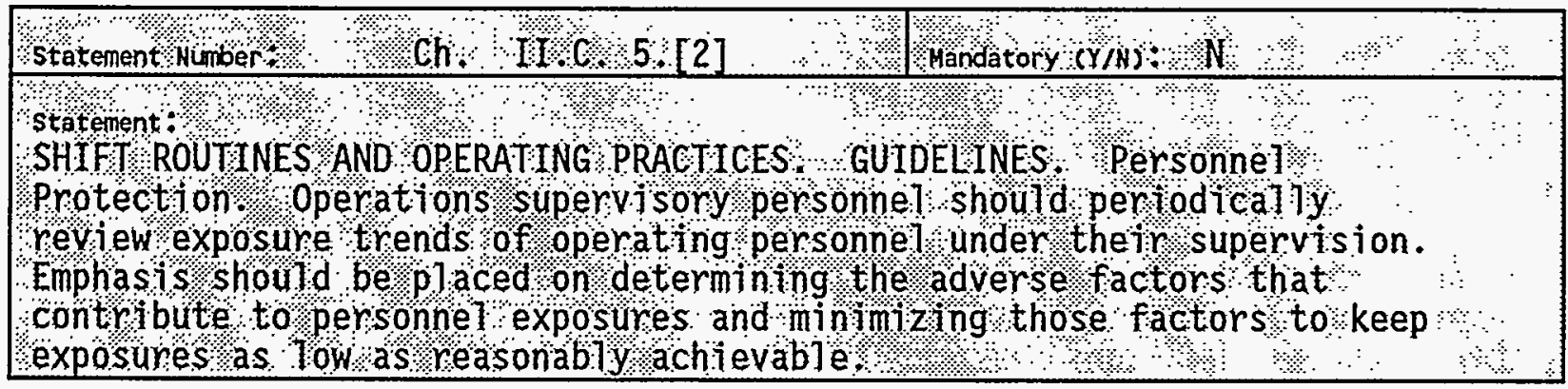

1.0 STATEMENT SATISFIEd BASED ON IMPLEMENTING EVIDENCE (Y/N): NO

2.0 GENERAL DESCRIPTION OF EVIDENCE (DESCRIPTION OF NONCOMPLIANCE OR DEFICIENCY IF APPLICABLE):

Review of exposure trends is not specifically addressed in the HASQAP.

3.0 CORRECTIVE ACTION: 
WHC-EP-0822

\section{ASSESSMENT DATA COLLECTION FORM}

\begin{tabular}{|c|c|}
\hline Ch. $\mathrm{MC}, 6 . \mathrm{Q}$ & Mandatory (Y/N) $:$ a $\quad$ N \\
\hline 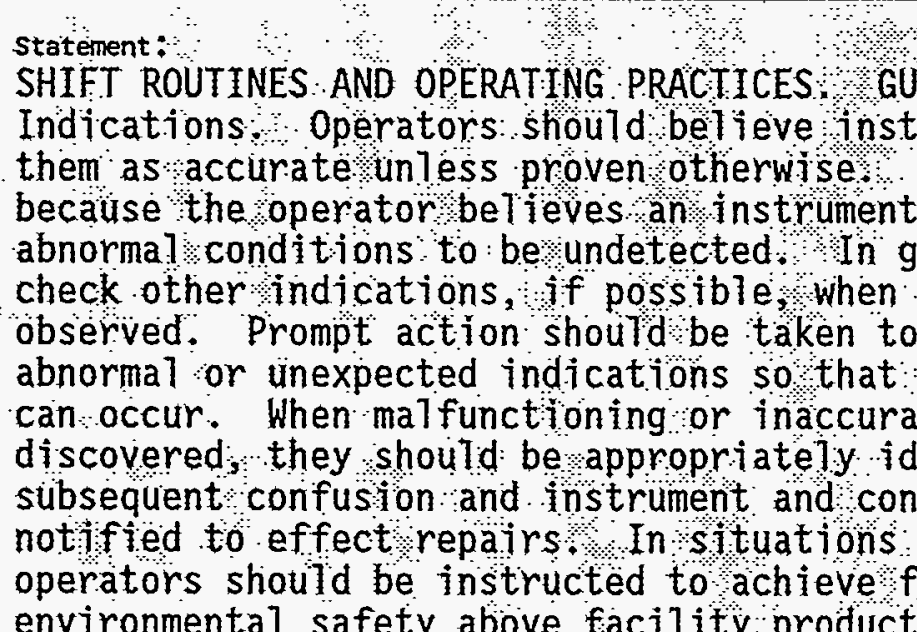 & $\begin{array}{l}\text { DELINES, Response to } \\
\text { ument readings and treat } \\
\text { gnoring an unusual reading } \\
\text { ss fautity can cause } \\
\text { neral, operators should } \\
\text { inexpected readings are } \\
\text { nnvestigate the cause of } \\
\text { rompt corrective action } \\
\text { instruments are } \\
\text { ntified to prevent } \\
\text { rol personnel should be } \\
\text { f operator doubt, } \\
\text { cility, personnel, and }\end{array}$ \\
\hline
\end{tabular}

1.0 STATEMENT SATISFIED BASED ON IMPLEMENTING EVIDENCE $(Y / N):$ YES

2.0 GENERAL DESCRIPTION OF EVIDENCE (DESCRIPTION OF NONCOMPLIANCE OR DEFICIENCY IF APPLICABLE):

The intent of this statement is met by HASQAP Section 7.0, "Calibration." 
WHC-EP-0822

ASSESSMENT DATA COLLECTION FORM

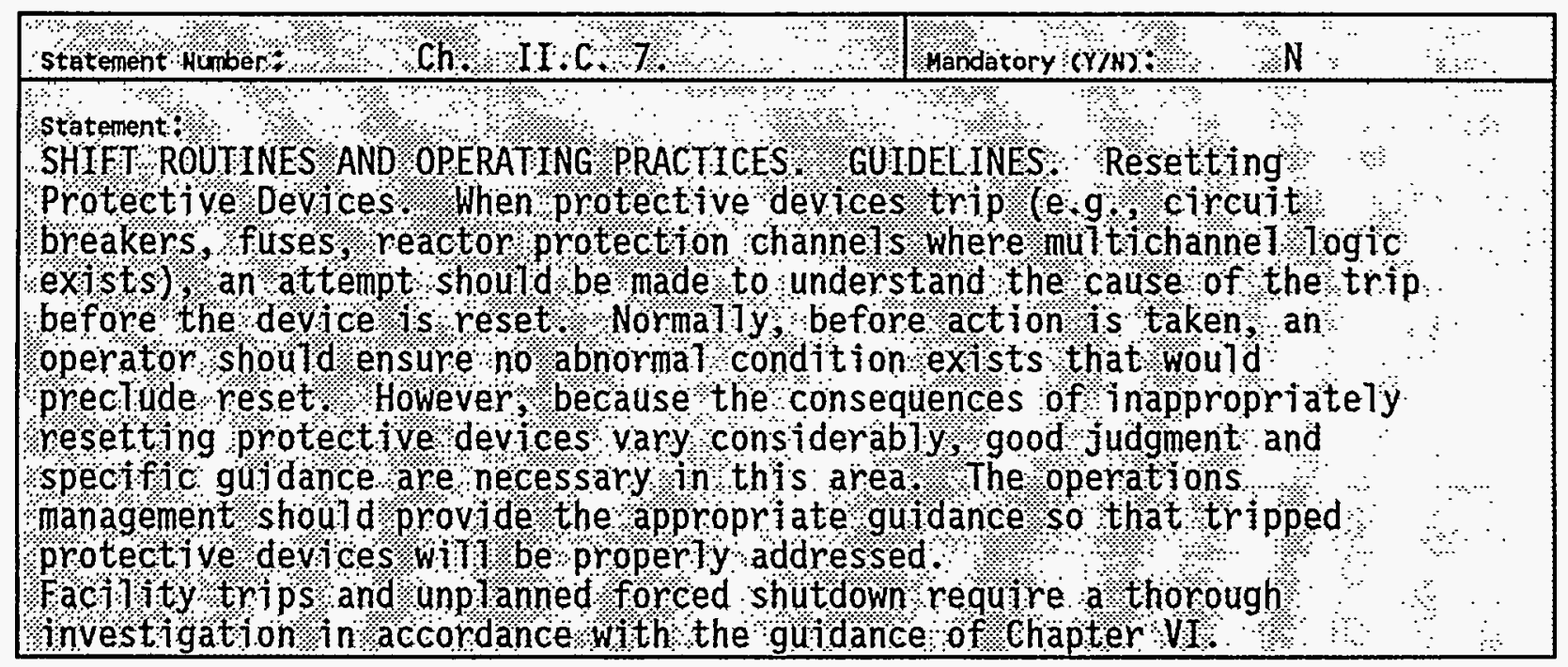

\section{N/A}

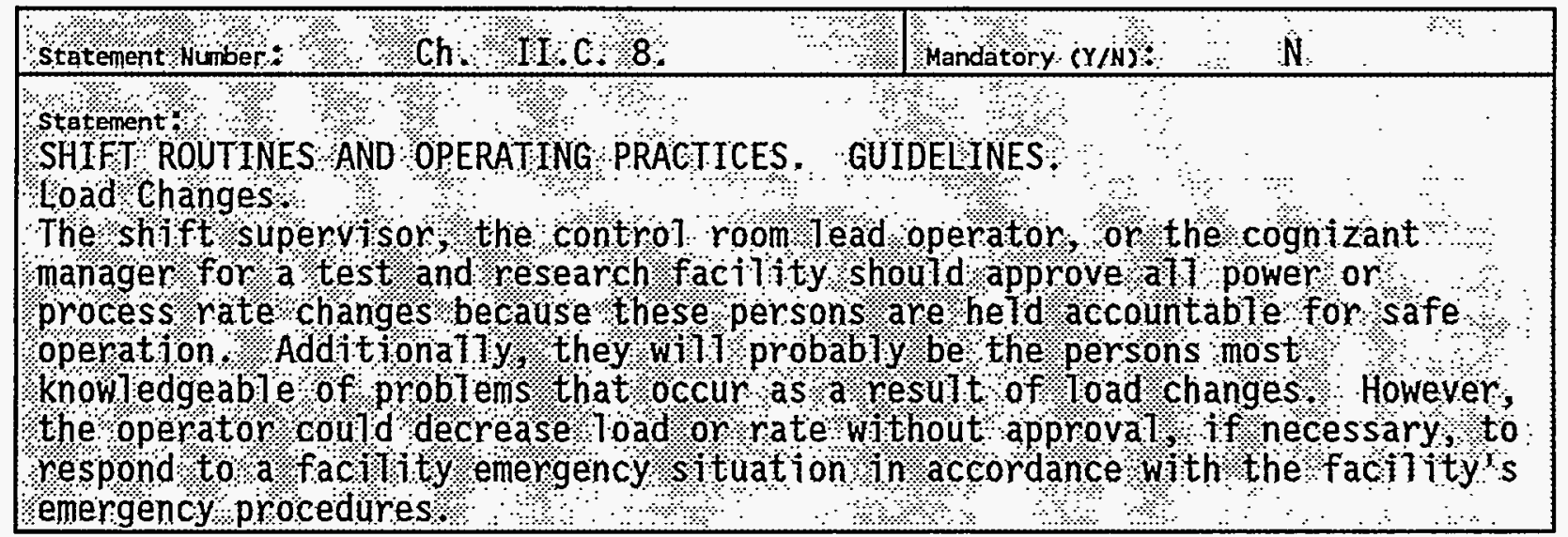

\section{N/A}

\begin{tabular}{|c|c|}
\hline statenent Nunber: $/ \mathrm{Ch}$. $[\mathrm{C} / 9,[1] \cdots$ & Mandatory $(Y / N):$ \\
\hline 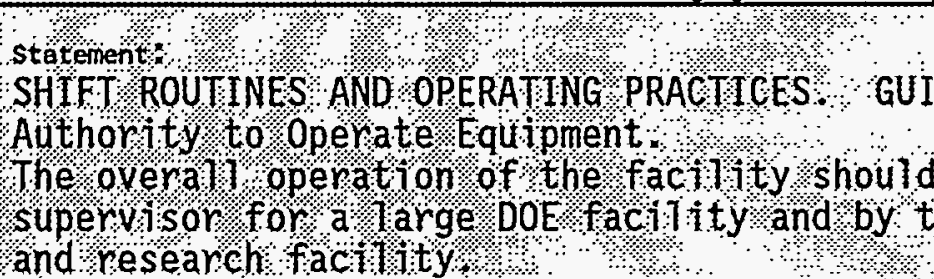 & $\begin{array}{l}\text { ElNES } \\
\text { be directed by the } 0 \\
\text { eqognizant manager }\end{array}$ \\
\hline
\end{tabular}

\section{N/A}


WHC-EP-0822

ASSESSMENT DATA COLLECTION FORM

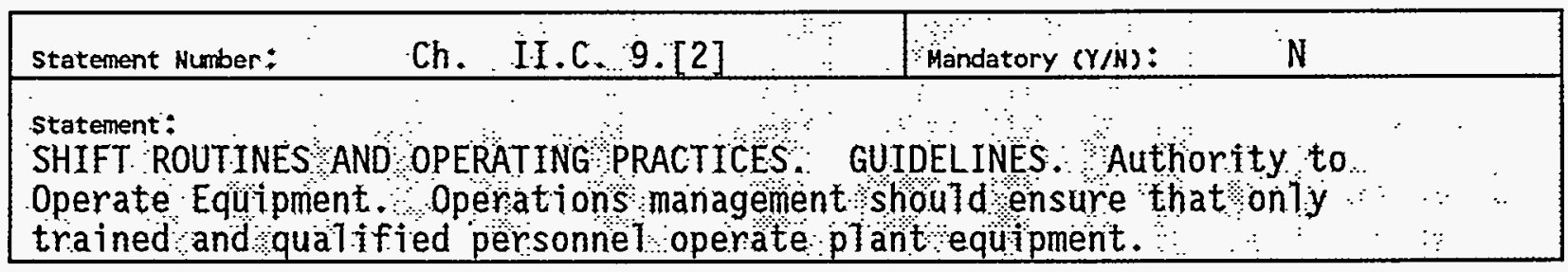

\section{N/A}

\begin{tabular}{|c|c|c|}
\hline 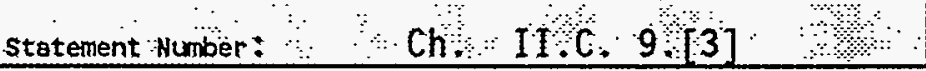 & Mandätory $(Y \%$ ) & \\
\hline $\begin{array}{l}\text { Statement: } \\
\text { SHIFT ROUTINES AND OPERATING PRACTICES } \\
\text { Operate Equipment In general, the operator } \\
\text { supervisor should be aware of a } 17 \text { act }\end{array}$ & $\begin{array}{l}\text { OELNES Authority to } \\
\text { and the operations } \\
\text { affecting equipment: }\end{array}$ & $\because$ \\
\hline
\end{tabular}

\section{N/A}

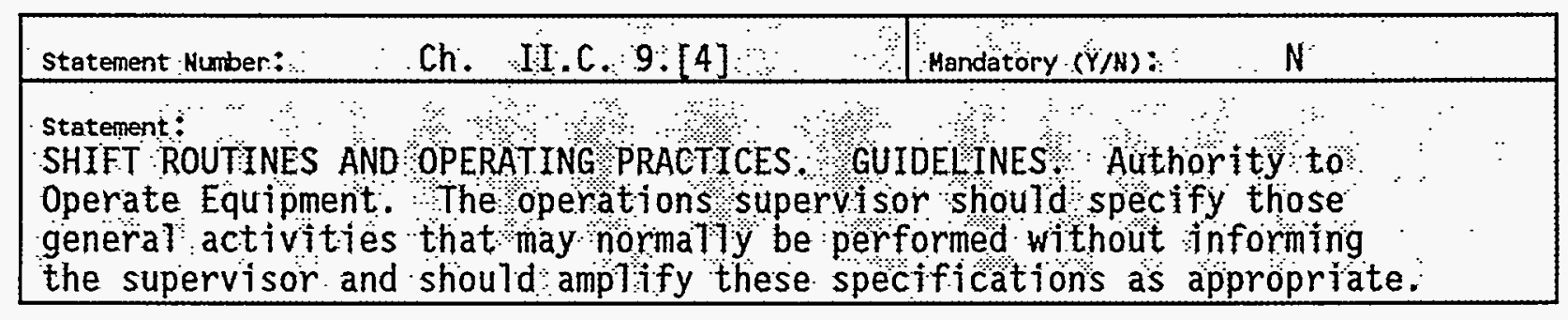

\section{N/A}




\section{ASSESSMENT DATA COLLECTION FORM}

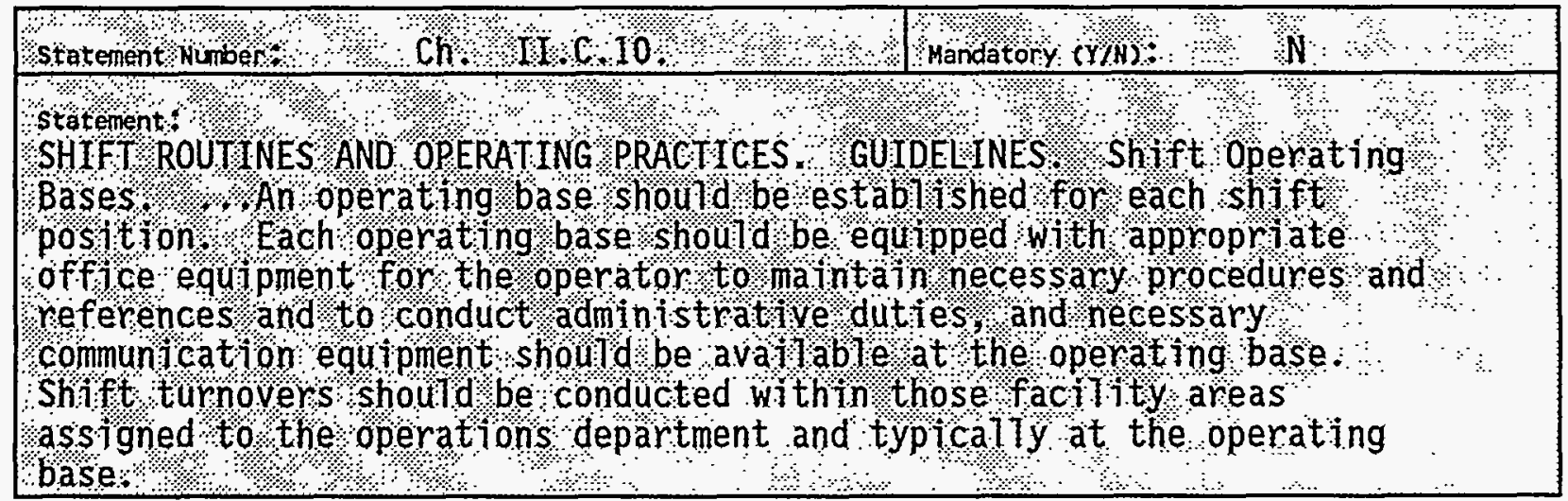

N/A 
WHC-EP-0822

\section{ASSESSMENT DATA COLLECTION FORM}

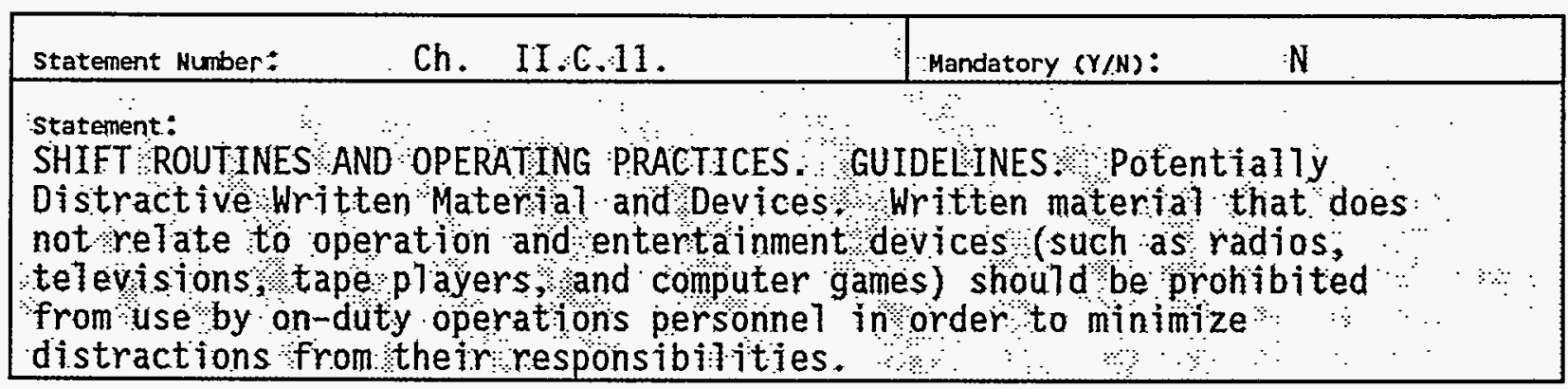

\section{N/A}

\begin{tabular}{l}
\hline Statement Number: $\quad$ Ch. III.C.I. \\
\hline Statement: \\
CONTROL AREA ACTIVITIES FOR DOEFACILITIES. GUIDELINES Control Area \\
Access. \\
only. The "at-the-control s" area of the control room should be \\
clearly identified, and its boundary should be understood by all \\
persons who are granted access to the controt room. Access to the \\
"at-the-controls" area should be: restricted to persons who need to be \\
in the area. Entry into this area should be granted by designated \\
individuals, and persons. who might need to enter this area should know \\
who can grant access.
\end{tabular}

\section{N/A}

\begin{tabular}{|c|c|}
\hline $\mathrm{Ch} . \mathrm{IIICC} 2 \mathrm{O}$ & Mandatory $(Y / N):$ \\
\hline $\begin{array}{l}\text { Statement: } \\
\text { CONTROL AREA ACTIVITIES FOR DOE FACILITIES } \\
\text { Behavior. .. should be displayed in the c } \\
\text { Only activities essential to supporting op } \\
\text { authorized by management should be conduct } \\
\text { Potentially distracting activities (such a } \\
\text { playing, and horseplay) should be prohibit } \\
\text { discussions should be minimjzed so as not } \\
\text { the shift or monitoring of key parameters }\end{array}$ & $\begin{array}{l}\text { GUIDELINES. Professional } \\
\text { trol area at al } 1 \text { times. } \\
\text { ation and activities } \\
\text { in the control area. } \\
\text { radio } 1 \text { istening, game } \\
\text { Non- job-related } \\
\text { interfere with conduct of } \\
\end{array}$ \\
\hline
\end{tabular}

\section{N/A}


WHC-EP-0822

ASSESSMENT DATA COLLECTION FORM

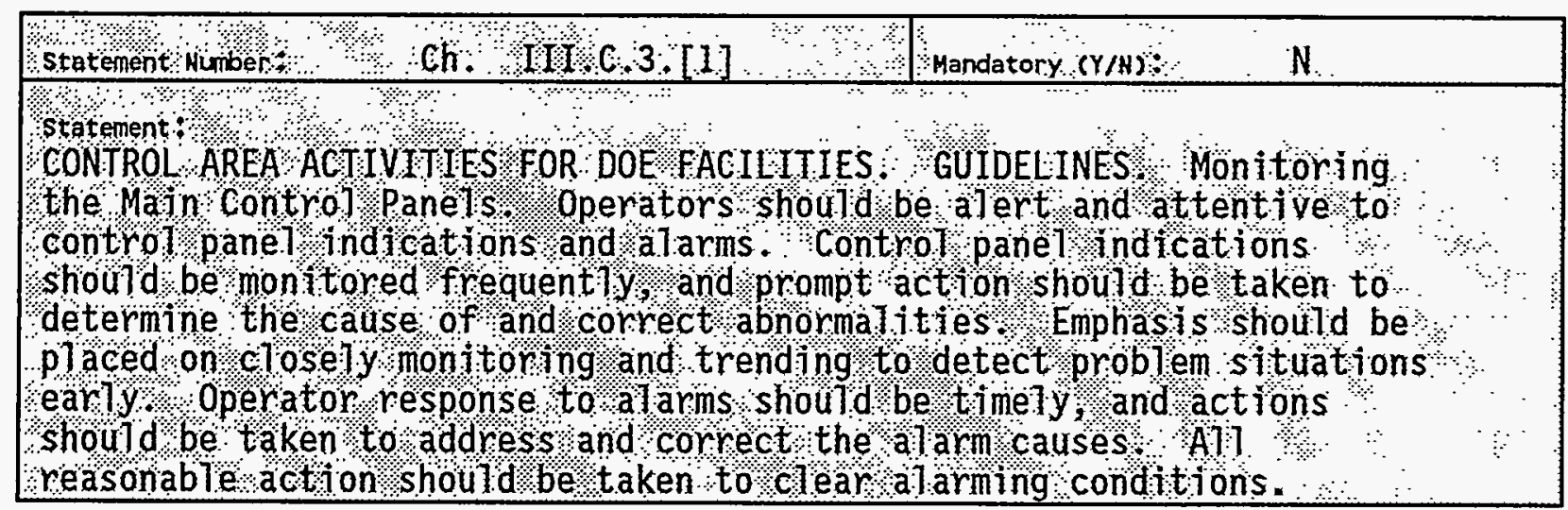

\section{N/A}

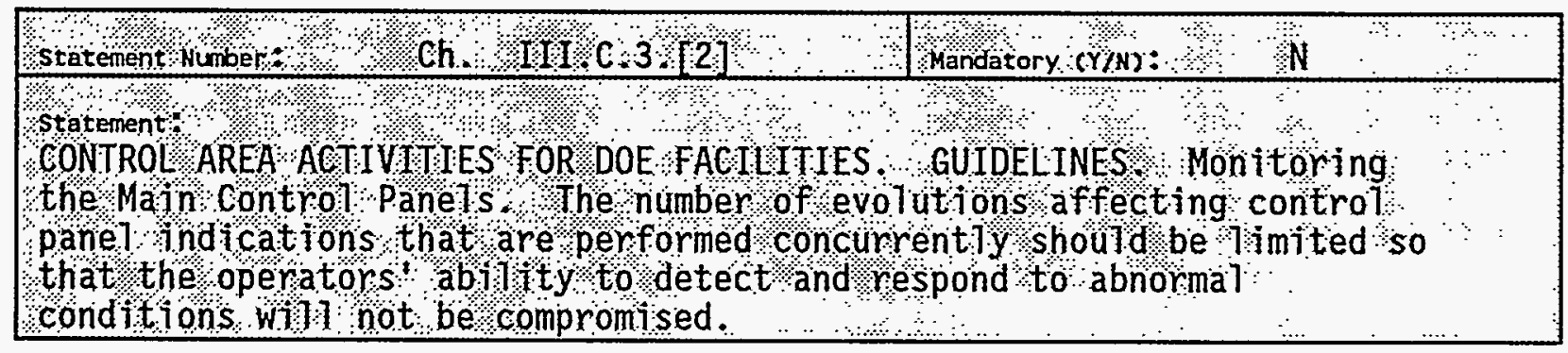

\section{N/A}

\begin{tabular}{|c|c|}
\hline statement Nümber $\%$ \% $/$, III, C $3,[3]$ & Mândatory $(Y / N) \div: N$ \\
\hline 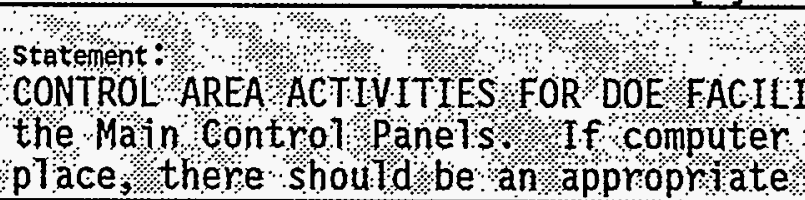 & $\begin{array}{l}\text { GUIDEL INES Monitoring } \\
\text { omated systems are fri } \\
\text { to those systems }\end{array}$ \\
\hline
\end{tabular}

\section{N/A}


WHC-EP-0822

ASSESSMENT DATA COLLECTION FORM

\begin{tabular}{|c|c|}
\hline $\mathrm{Ch}, \mathrm{LI}, \mathrm{C.4}, \mathrm{U}$ & Mandatory $(Y / N):=\mathrm{N}$ \\
\hline $\begin{array}{l}\text { Statement: } \\
\text { CONTROLAREA ACTIVITIES FOR DOE FACILITIE } \\
\text { Operator. AncilTary Duties D Duties assign } \\
\text { interfere with their ability to monitor } \\
\text { such as preparation of tagging orders re } \\
\text { required reading, and review of maintenan } \\
\text { comprise a major port on of these operato } \\
\text { administrat ive workioad of operators resp } \\
\text { operating the control board should be } \\
\text { minimized. }\end{array}$ & $\begin{array}{l}\text { GUIDELINES Control } \\
\text { to operators shoüld not } \\
\text { lity parameters Activities } \\
\text { ws of operating procedures, } \\
\text { work activities should not } \\
\text { shlft responsibitities. The } \\
\text { ible for monitoring and }\end{array}$ \\
\hline
\end{tabular}

N/A

\begin{tabular}{|c|c|}
\hline $\mathrm{Ch}, \mathrm{I}+\mathrm{I} \mathrm{C}, 5$, & Mandatory $(Y / N), \quad N \quad N$ \\
\hline $\begin{array}{l}\text { Statement: } \\
\text { CONTROL AREA ACTIVITIES FOR DOE FACILITIES, } \\
\text { Control Area Equipment on y persons spec } \\
\text { administrative procedures of the operations } \\
\text { control area equipment when trainees oper } \\
\text { should be supervised and controlled by the } \\
\text { perform the operations }\end{array}$ & $\begin{array}{l}\text { GUIDELINES operation of } \\
\text { jcal]y authorized by the } \\
\text { department should operate } \\
\text { te this equipment, they } \\
\text { perator who normal yy would }\end{array}$ \\
\hline
\end{tabular}

N/A

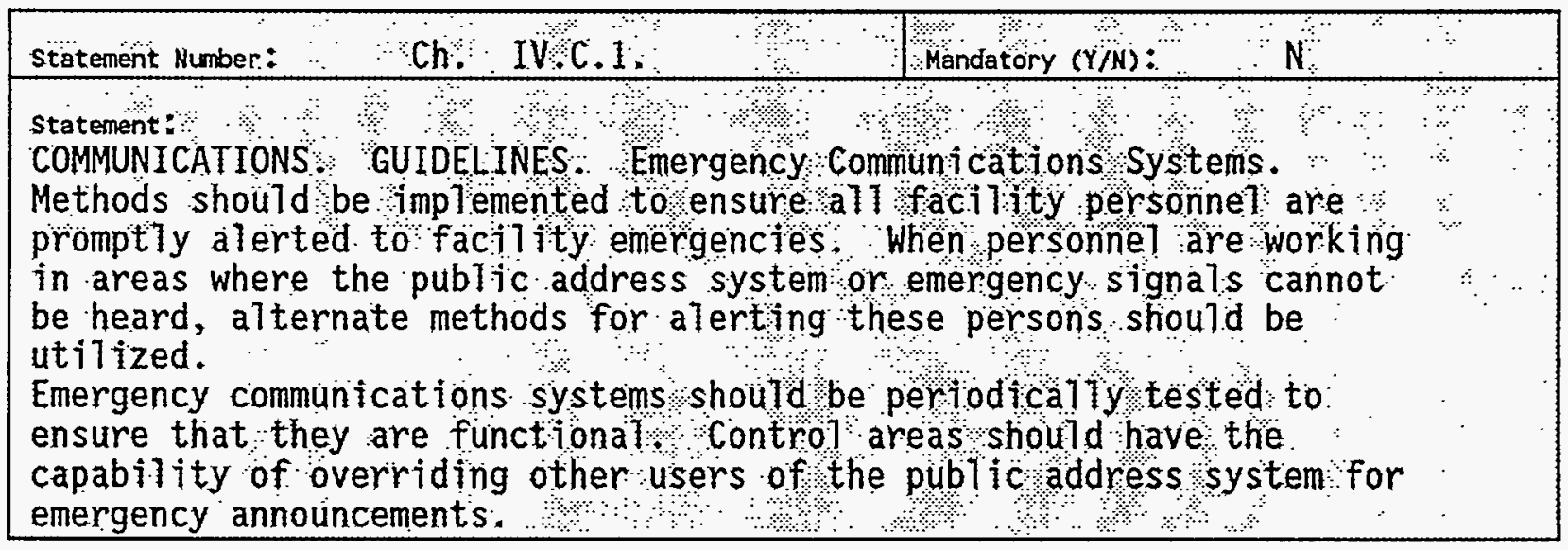

\section{N/A}




\section{ASSESSMENT DATA COLLECTION FORM}

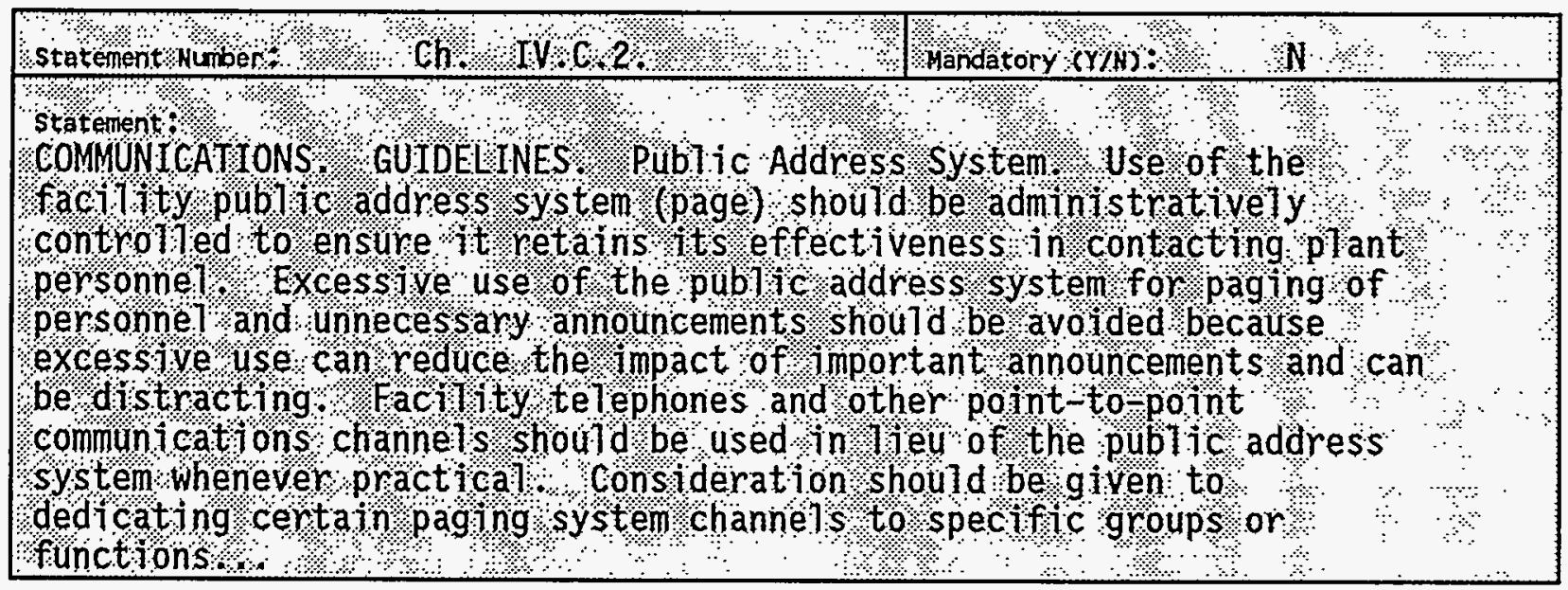

\section{N/A}




\section{ASSESSMENT DATA COLLECTION FORM}

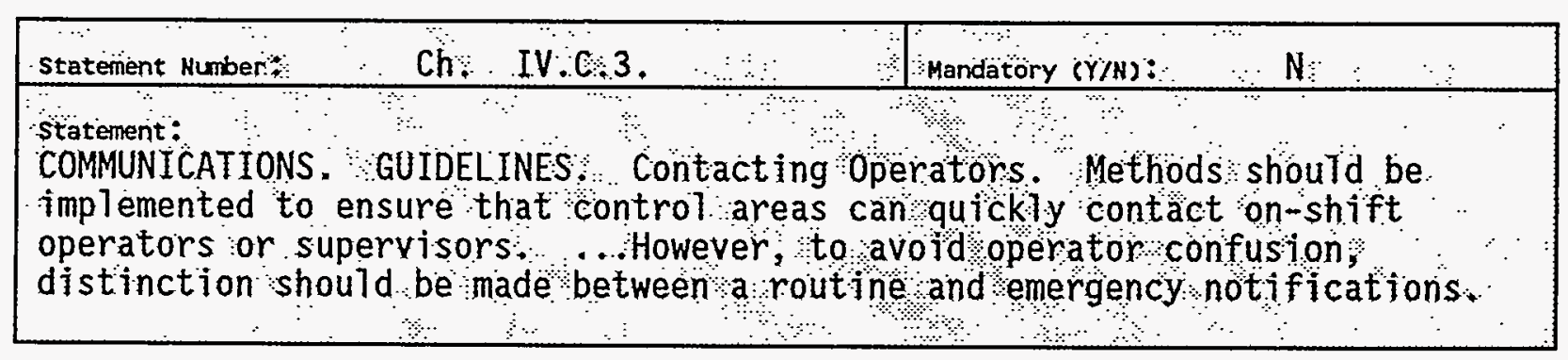

\section{N/A}

\begin{tabular}{|c|c|}
\hline statement Number $\quad$ ch $\quad \mathrm{IV}, \mathrm{C}, 4$. & 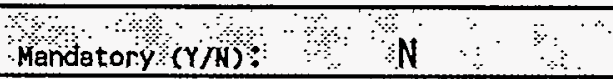 \\
\hline $\begin{array}{l}\text { statement: } \\
\text { COMMUNICATIONS: GUIDELINES, Radios. Port } \\
\text { effective means of providing mobile point } \\
\text { may be used for this purpose. However, rac } \\
\text { in areas where electronic interference with } \\
\text { Areas where radio use is prohibited should } \\
\text { regarding frequencies (channels) and postin } \\
\text { Consideration should be given to dedicating } \\
\text { specific groups or functions... }\end{array}$ & $\begin{array}{l}\text { ble radios can be an } \\
\text { - point communications and } \\
\text { o usage should not be allowed } \\
\text { plant equipment may result. } \\
\text { e defineated. Instructions } \\
\text { S should be provided } \\
\text { certain radio channels to }\end{array}$ \\
\hline
\end{tabular}

\section{N/A}

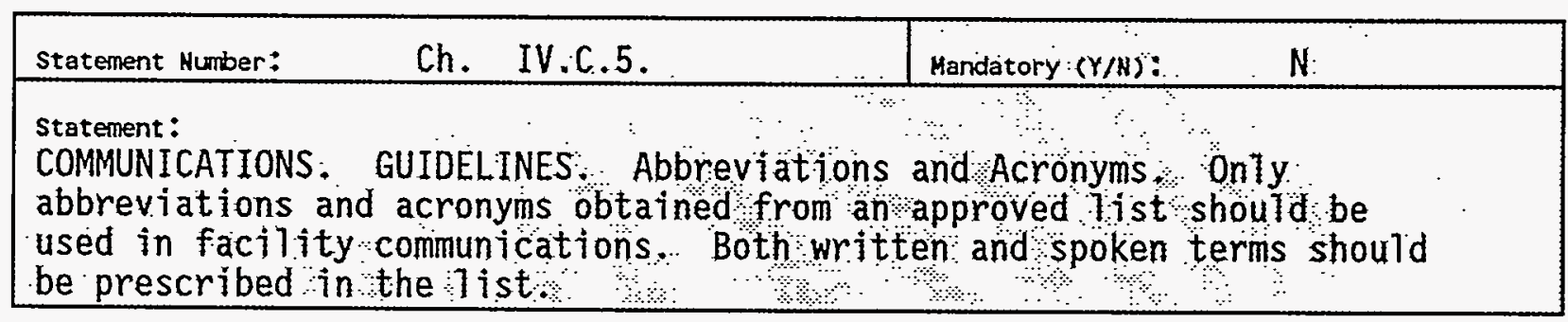

\section{N/A}


WHC-EP-0822

\section{ASSESSHENT DATA COLLECTION FORM}

\begin{tabular}{|c|c|}
\hline statement=Number: & Mandatory (Y, $N$ ) \\
\hline 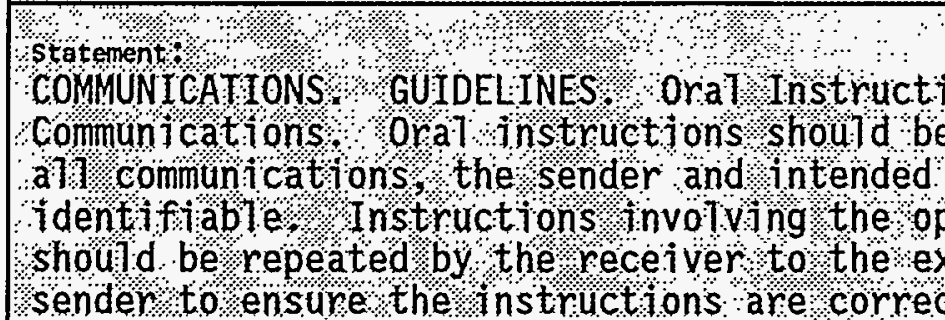 & 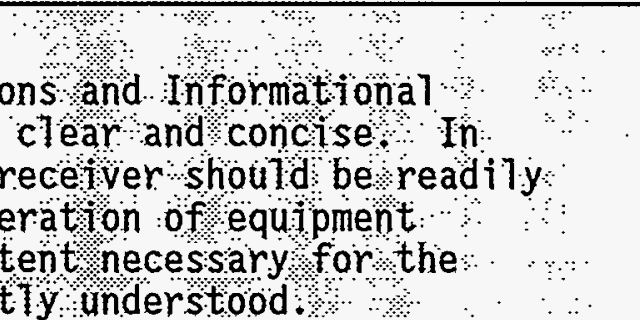 \\
\hline
\end{tabular}

\section{N/A}

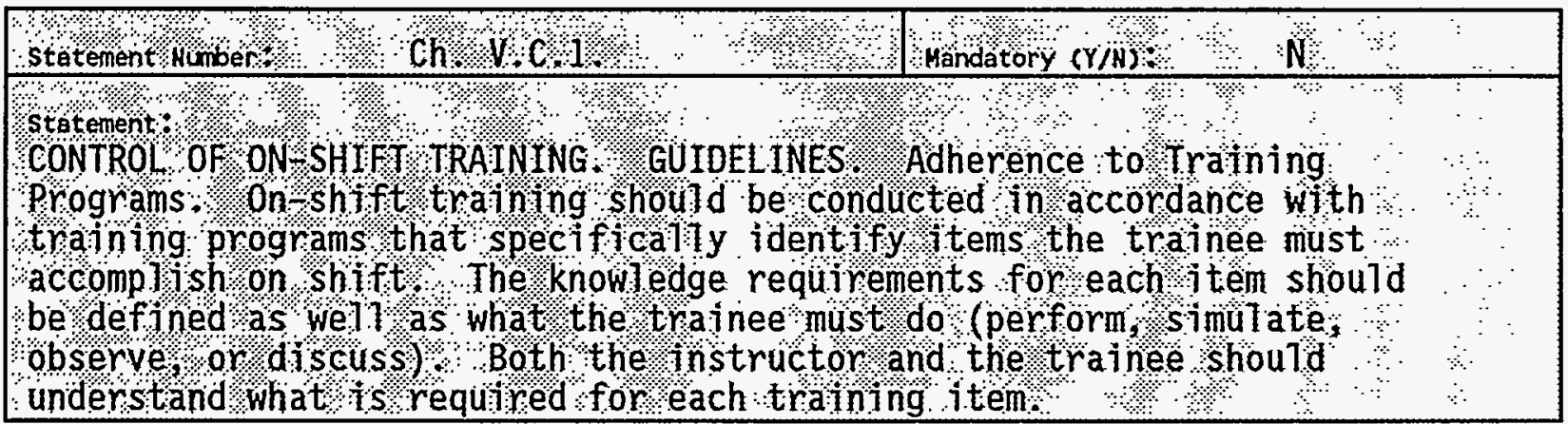

1.0 STATEMENT SATISFIED BASED ON IMPLEMENTING EVIDENCE $(Y / N)$ : YES

2.0 GENERAL DESCRIPTION OF EVIDENCE (DESCRIPIION OF NONCOMPLIANCE OR DEFICIENCY IF APPLICABLE):

The intent of this statement is met by HASQAP Section 3.0, "Personne] Qualification and Training." However, the HASQAP does not contain the specificity of this statement. 
WHC-EP-0822

\section{ASSESSMENT DATA COLLECTION FORM}

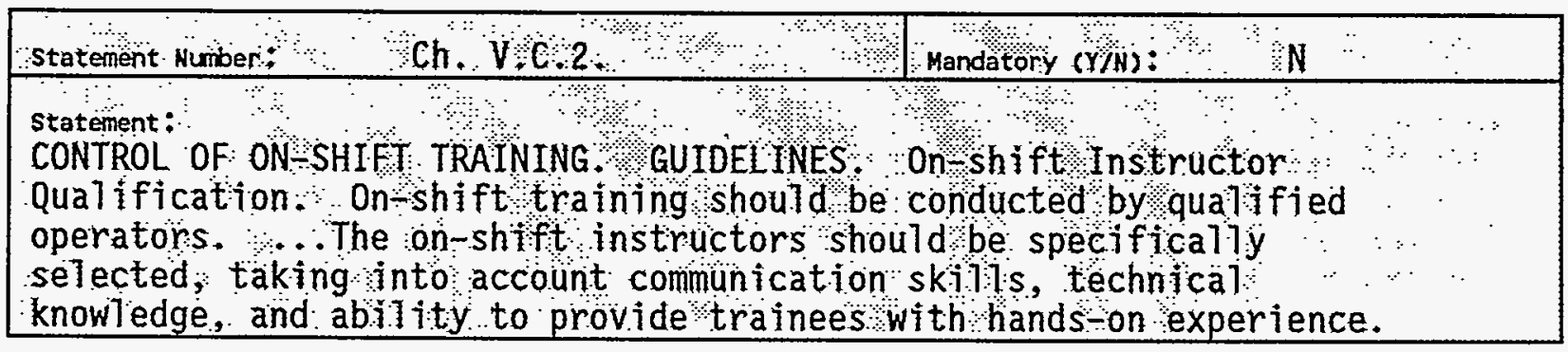

1.0 STATEMENT SATISFIED BASED ON IMPLEMENTING EVIDENCE (Y/N): YES

2.0 GENERAL DESCRIPTION OF EVIDENCE (DESCRIPTION OF NONCOMPLIANCE OR DEFICIENCY IF APPLICABLE):

The intent of this statement is met by HASQAP Section 3.0, "Personne] Qualification and Training." However, the HASQAP does not contain the specificity of this statement. 
WHC-EP-0822

\section{ASSESSMENT DATA COLLECTION FORM}

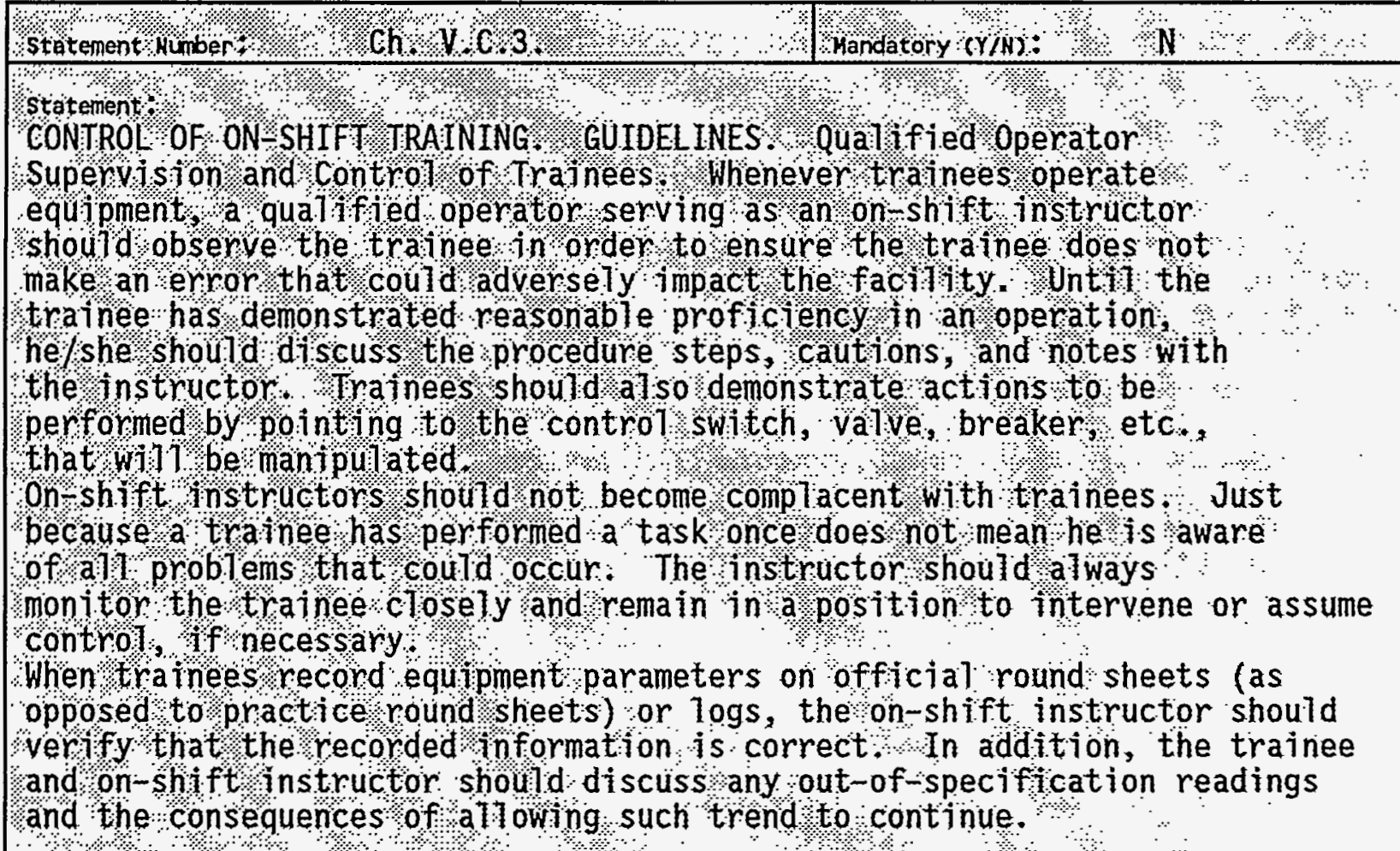

1.0 STATEMENT SATISFIED BASED ON IMPLEMENTING EVIDENCE $(Y / N):$ YES

2.0 GENERAL DESCRIPTION OF EVIDENCE (DESCRIPTION OF NONCOMPLIANCE OR DEFICIENCY IF APPLICABLE):

The intent of this statement is met by HASQAP Section 3.0, "Personne] Qualification and Training." However, the HASQAP does not contain the specificity of this statement. 
WHC-EP-0822

\section{ASSESSMENT DATA COLLECTION FORH}

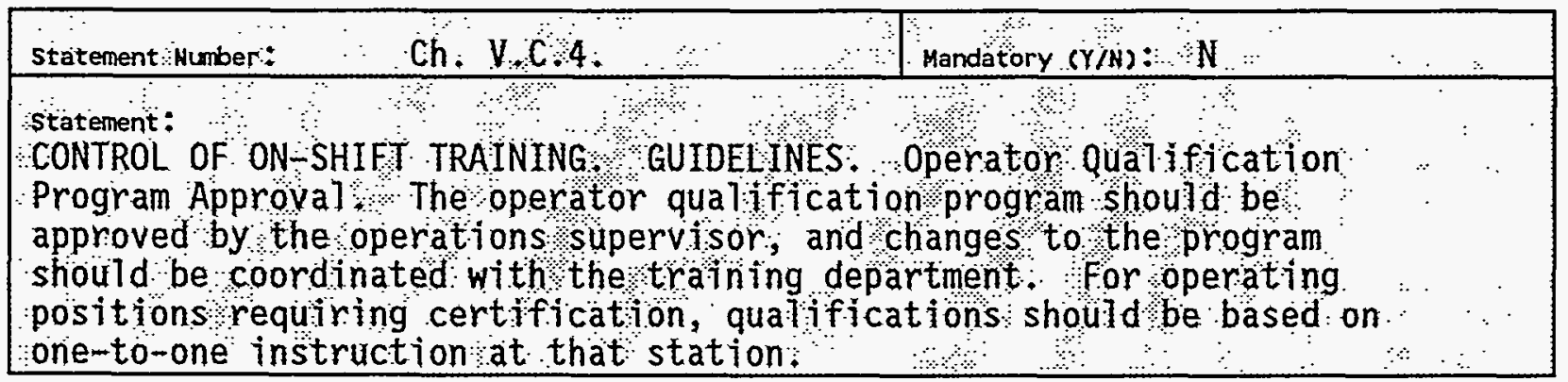

1.0 StATEMENT SATISFIEd BASED ON IMPLEMENTING EVIDENCE $(Y / N)$ : YES

2.0 GENERAL DESCRIPTION OF EVIDENCE (DESCRIPTION OF NONCOMPLIANCE OR DEFICIENCY IF APPLICABLE):

The intent of this statement is met by HASQAP Section 3.0, "Personnel Qualification and Training." 


\section{ASSESSHENT DATA COLLECTION FORM}

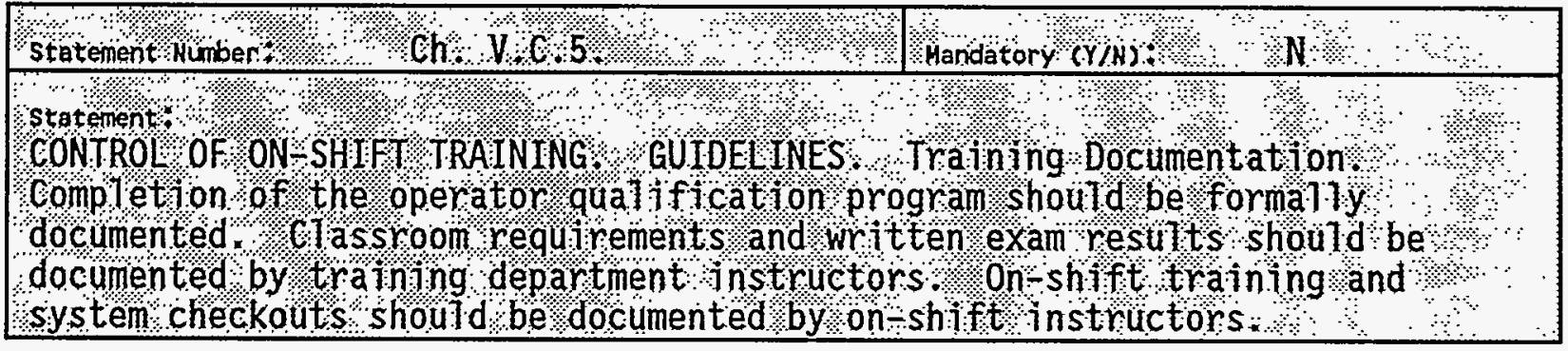

1.0 STATEMENT SATISFied BASED ON IMPLEMENTING EVIDENCE (Y/N): YES

2.0 GENERAL DESCRIPTION OF EVIDENCE (DESCRIPTION OF NONCOMPLIANCE OR DEFICIENCY IF APPLICABLE):

The intent of this statement is met by HASQAP Section 3.7, "Training Records." 
WHC-EP-0822

\section{ASSESSMENT DATA COLLECTION FORM}

\begin{tabular}{|c|c|}
\hline Ch. YC. 6. & Mandatory:CY/N) $\quad \because \quad N$ \\
\hline 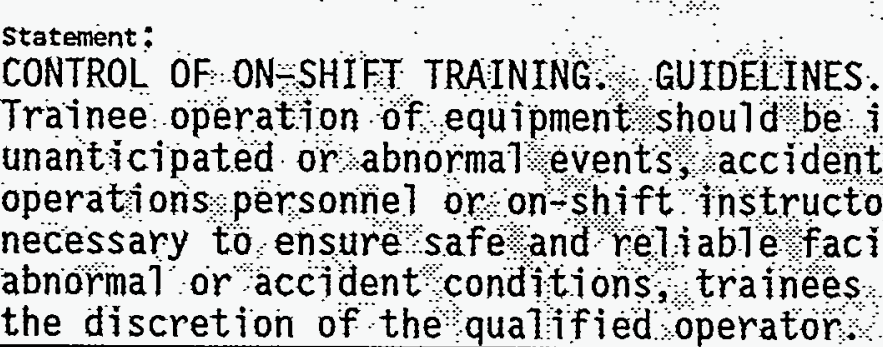 & 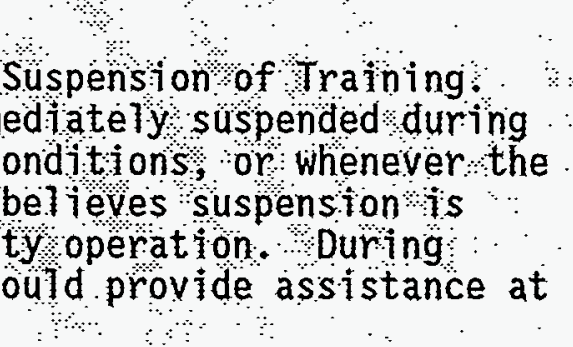 \\
\hline
\end{tabular}

\section{N/A}

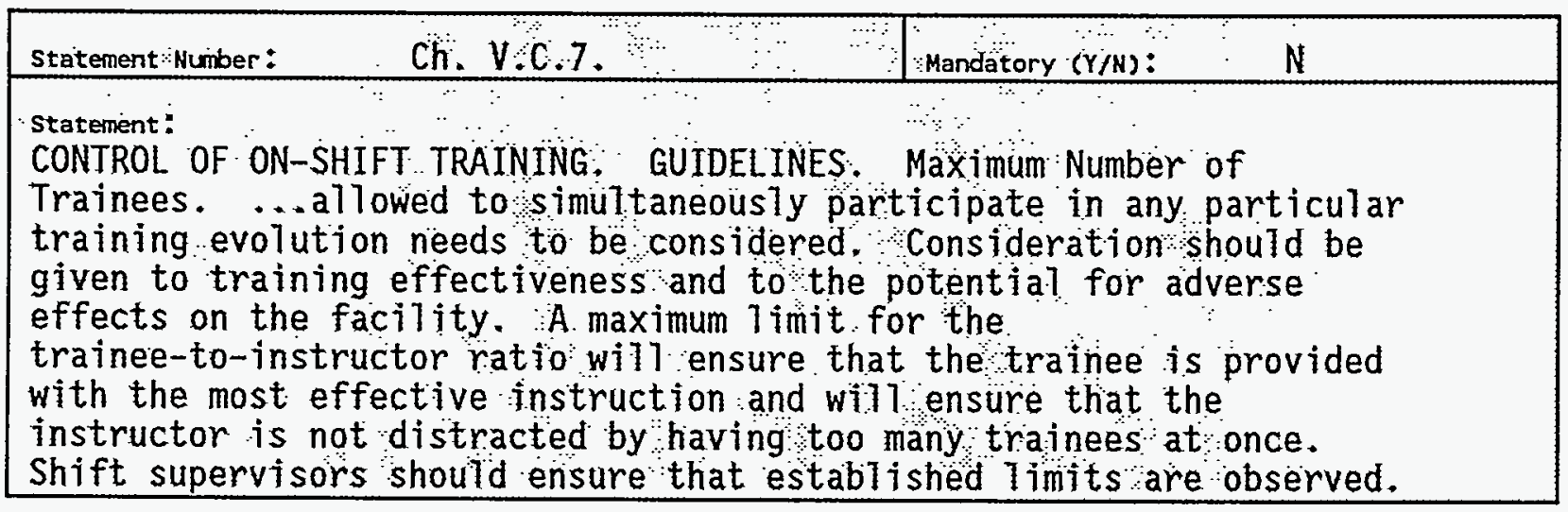

\section{N/A}




\section{ASSESSMENT DATA COLLECTION FORM}

\begin{tabular}{|c|c|}
\hline 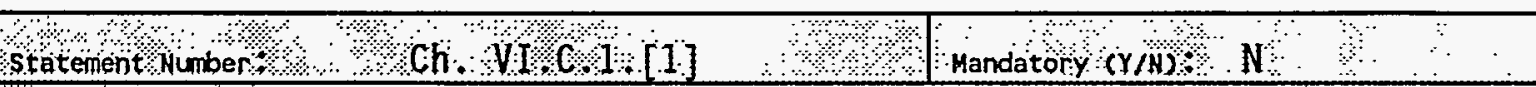 & $\because$ \\
\hline 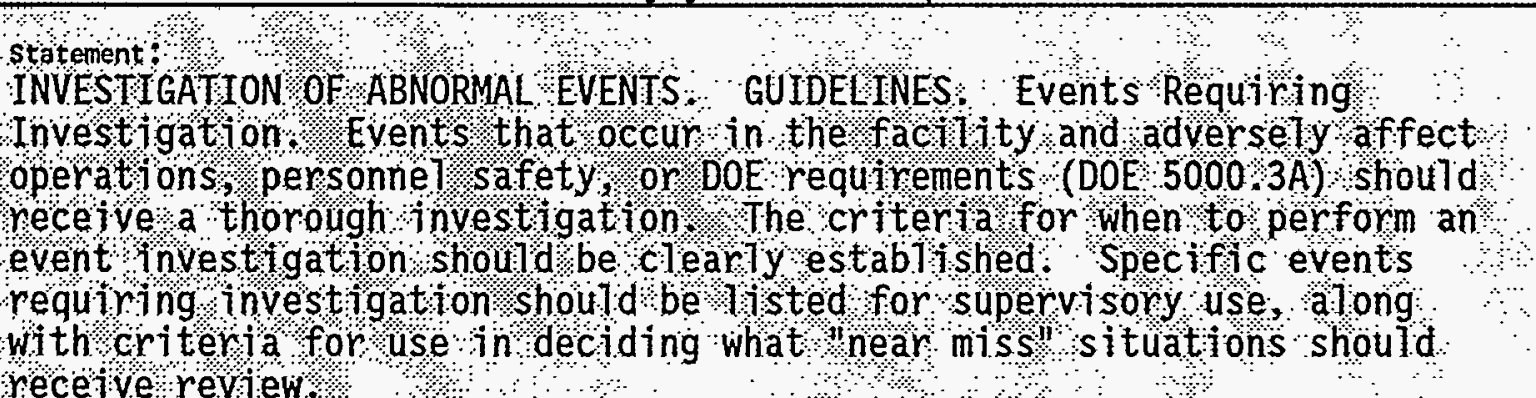 & \\
\hline
\end{tabular}

1.0 StATEMENT SATISFIED BASED ON IMPLeMENTING EVIDENCE (Y/N): NO

2.0 GENERAL DESCRIPTION OF EVIDENCE (DESCRIPTION OF NONCOMPLIANCE OR DEFICIENCY IF APPLICABLE):

HASQAP Section 15.0, "Corrective Action," emphasizes data quality rather than abnormal events.

3.0 CORRECTIVE ACTION: 
WHC-EP-0822

\section{ASSESSMENT DATA COLLECTION FORM}

\begin{tabular}{|c|}
\hline Mandatory $(\gamma / N) \leqslant N$ \\
\hline 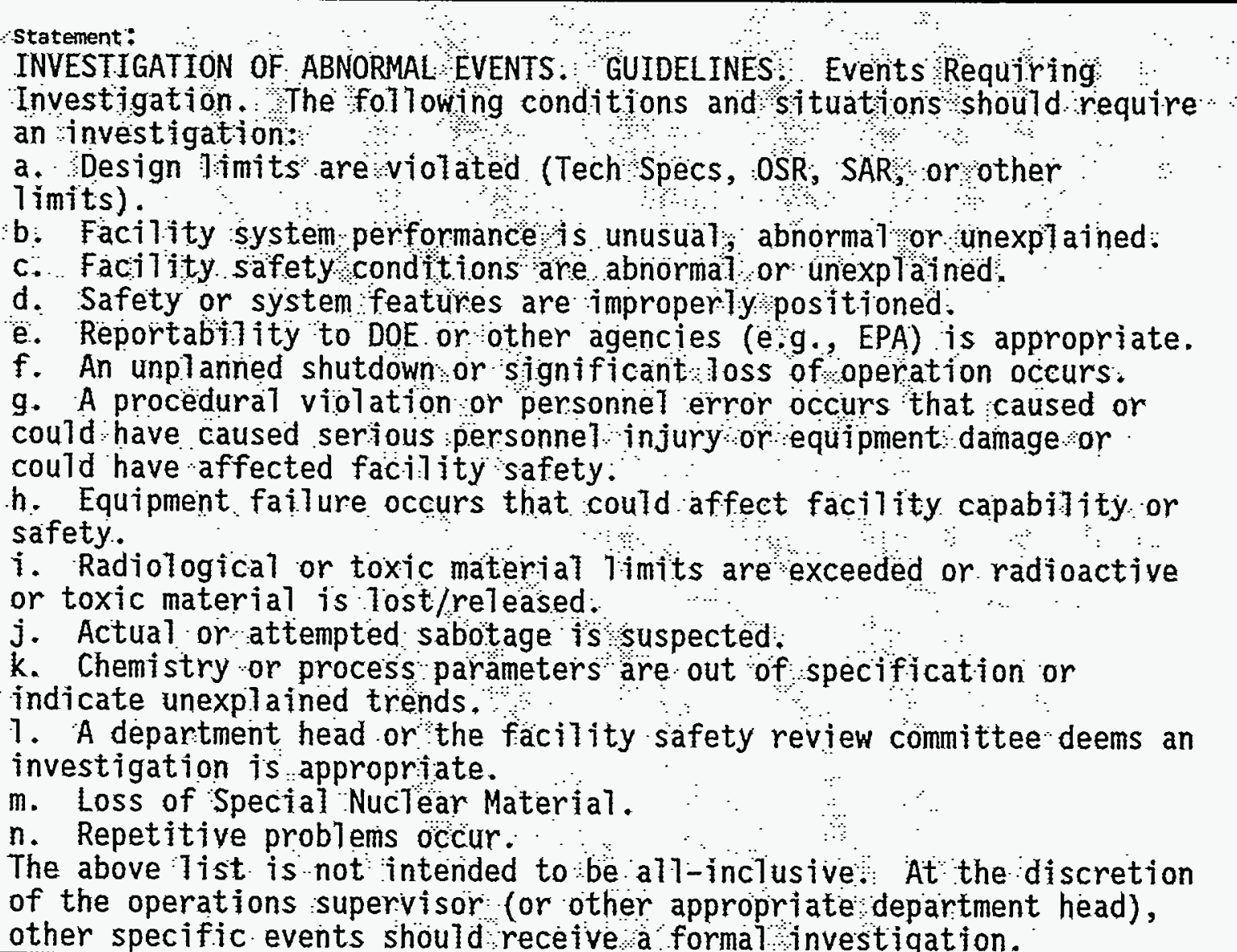 \\
\hline
\end{tabular}

1.0 STATEMENT SATISFIED BASED ON IMPLEMENTING EVIDENCE $(Y / N): \quad$ NO

2.0 GENERAL DESCRIPTION OF EVIDENCE (DESCRIPTION OF NONCOMPLIANCE OR DEFICIENCY IF APPLICABLE):

This statement (or its intent) is not met by the HASQAP.

3.0 CORRECTIVE ACTION: 
WHC-EP-0822

\section{ASSESSMENT DATA COLLECTION FORM}

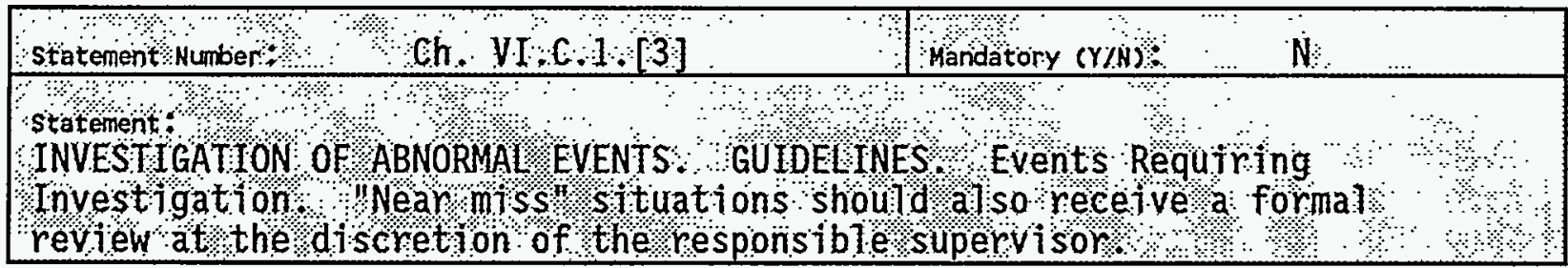

1.0 STATEMENT SATISFIED BASED ON IMPLEMENTING EVIDENCE $(Y / N)$ NO

2.0 GENERAL DESCRIPTION OF EVIDENCE (DESCRIPTION OF NONCOMPLIANCE OR DEFICIENCY IF APPLICABLE):

Statement not addressed in the HASQAP.

3.0 CORRECTIVE ACTION: 
WHC-EP-0822

ASSESSMENT DATA COLLECTION FORM

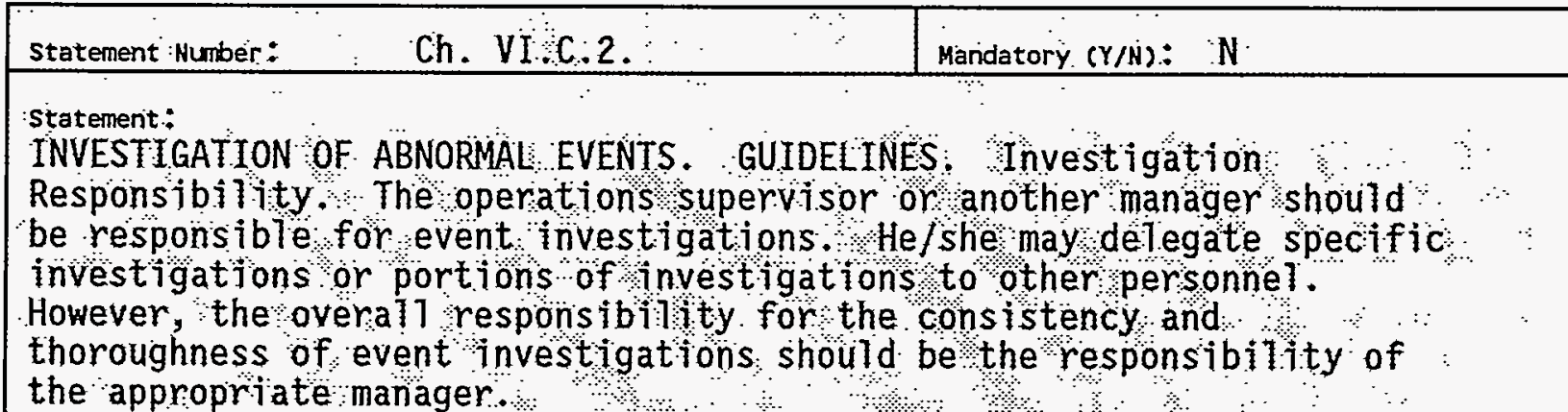

1.0 STATEMENT SATISFIED based ON IMPLEMENTING EVIDENCE (Y/N): NO

2.0 GENERAL DESCRIPTION OF EVIDENCE (DESCRIPTION OF NONCOMPLIANCE OR DEFICIENCY IF APPLICABLE):

Statement not addressed in the HASQAP.

3.0 CORRECTIVE ACTION: 
WHC-EP-0822

\section{ASSESSHENT DATA COLLECTION FORM}

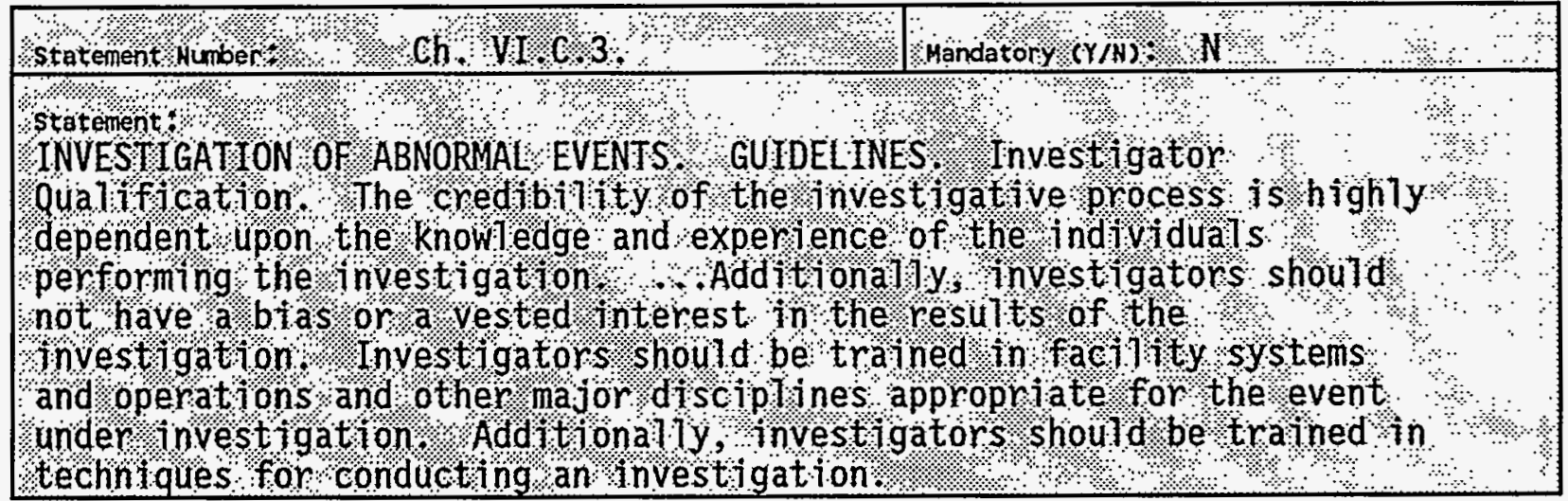

1.0 STATEMENT SATISFIED BASED ON IMPLEMENTING EVIDENCE (Y/N): NO

2.0 GENERAL DESCRIPTION OF EVIDENCE (DESCRIPTION OF NONCOMPLIANCE OR DEFICIENCY IF APPLICABLE):

Statement not addressed in the HASQAP.

3.0 CORRECTIVE ACTION: 
WHC-EP-0822

\section{ASSESSMENT DATA COLLECTION FORM}

\begin{tabular}{|c|}
\hline 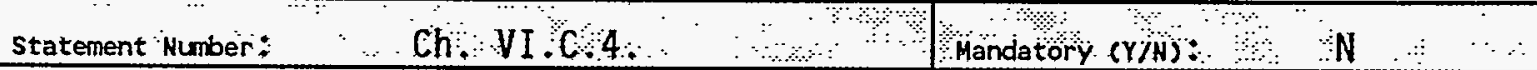 \\
\hline 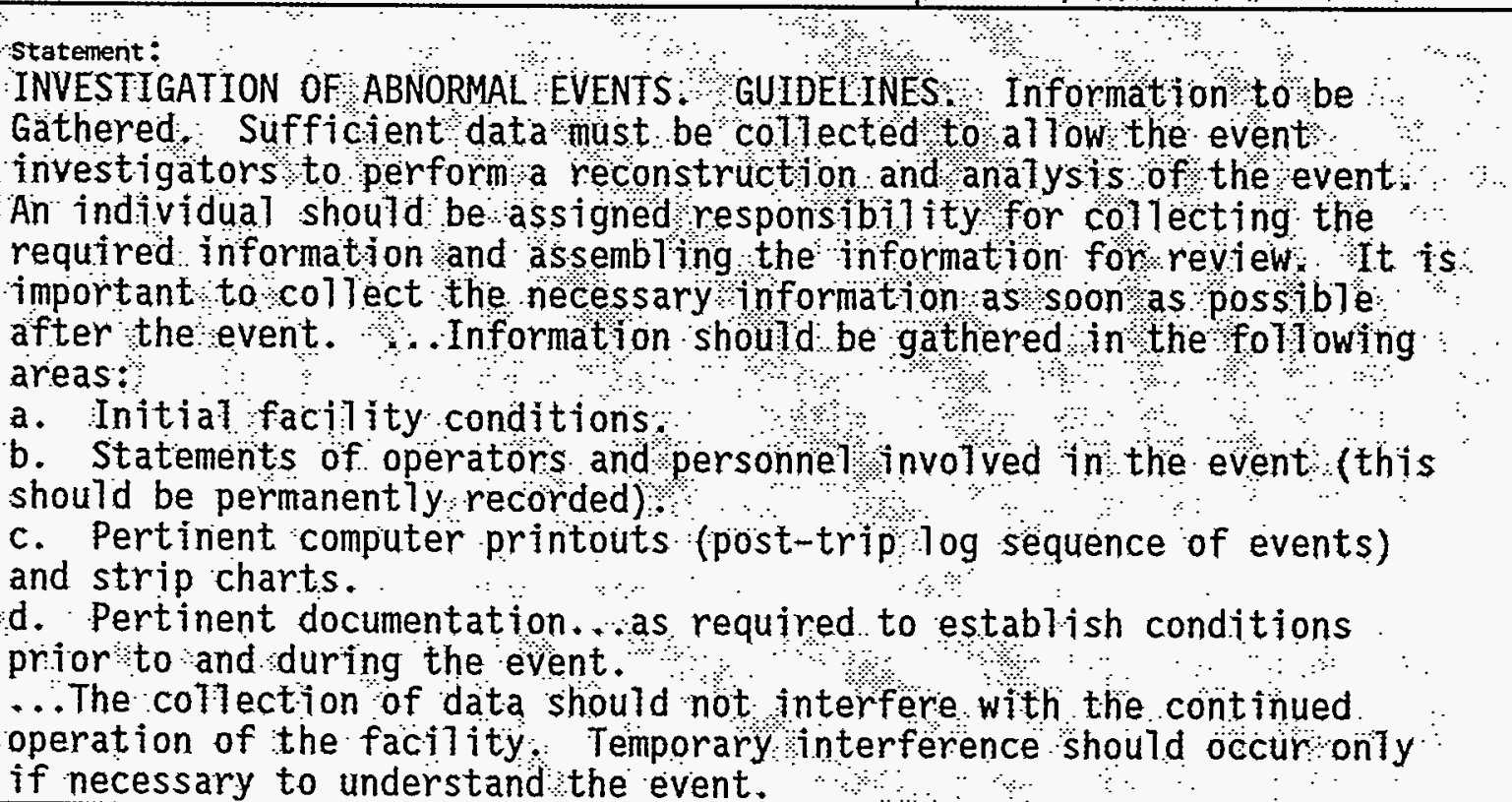 \\
\hline
\end{tabular}

1.0 STATEMENT SATISFIED BASED ON IMPLEMENTING EVIDENCE $(Y / N):$ NO

2.0 GENERAL DESCRIPTION OF EVIDENCE (DESCRIPTION OF NONCOMPLIANCE OR DEFICIENCY IF APPLICABLE):

Statement not addressed in the HASQAP.

3.0 CORRECTIVE ACTION: 
WHC-EP-0822

\section{ASSESSMENT DATA COLLECTION FORM}

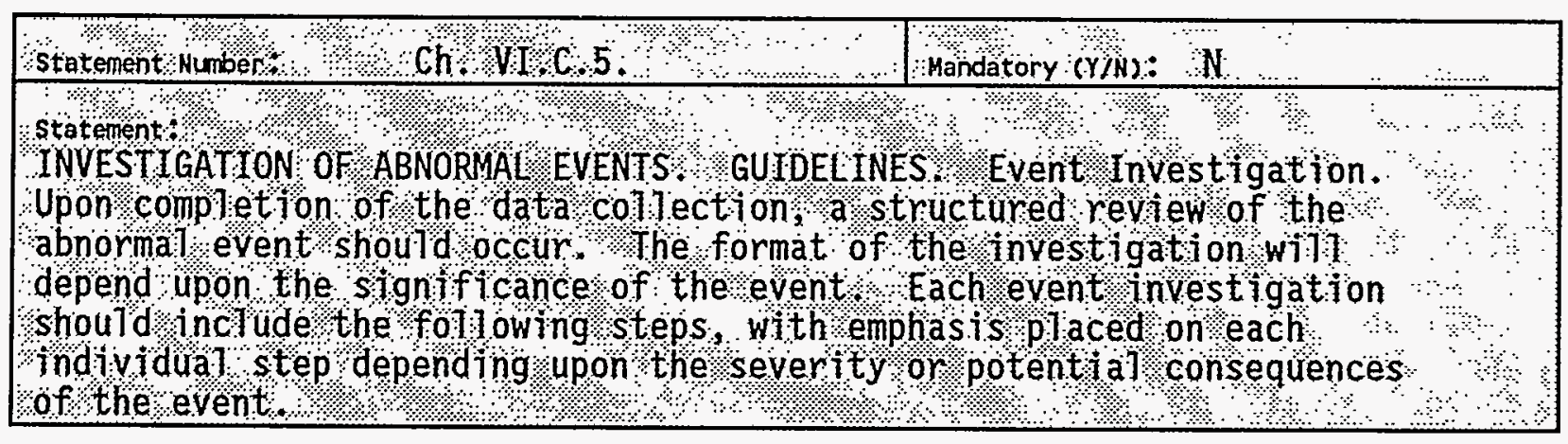

1.0 STATEMENT SATISFIED BASED ON IMPLEMENTING EVIDENCE (Y/N): NO

2.0 GENERAL DESCRIPTION OF EVIDENCE (DESCRIPTION OF NONCOMPLIANCE OR DEFICIENCY IF APPLICABLE):

Statement not addressed in the HASQAP.

3.0 CORRECTIVE ACTION: 
WHC-EP-0822

ASSESSMENT DATA COLLECTION FORM

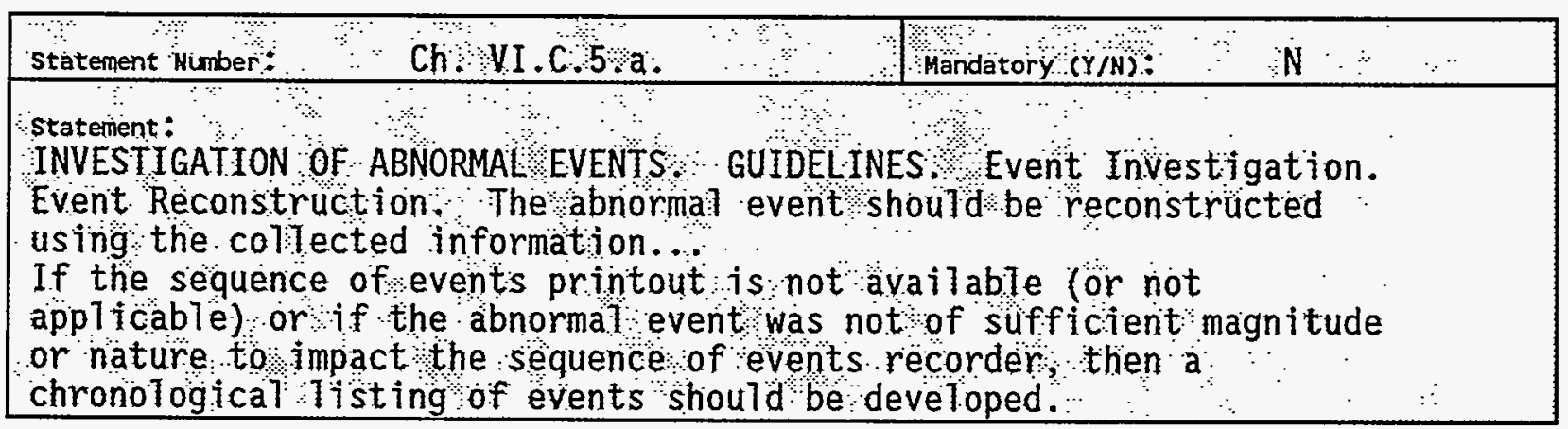

1.0 STATEMENT SATISFIED BASED ON IMPLEMENTING EVIDENCE (Y/N): NO

2.0 GENERAL DESCRIPTION OF EVIDENCE (DESCRIPTION OF NONCOMPLIANCE OR DEFICIENCY IF APPLICABLE):

Statement not addressed in the HASQAP.

3.0 CORRECTIVE ACTION: 


\section{ASSESSHENT DATA COLLECTION FORM}

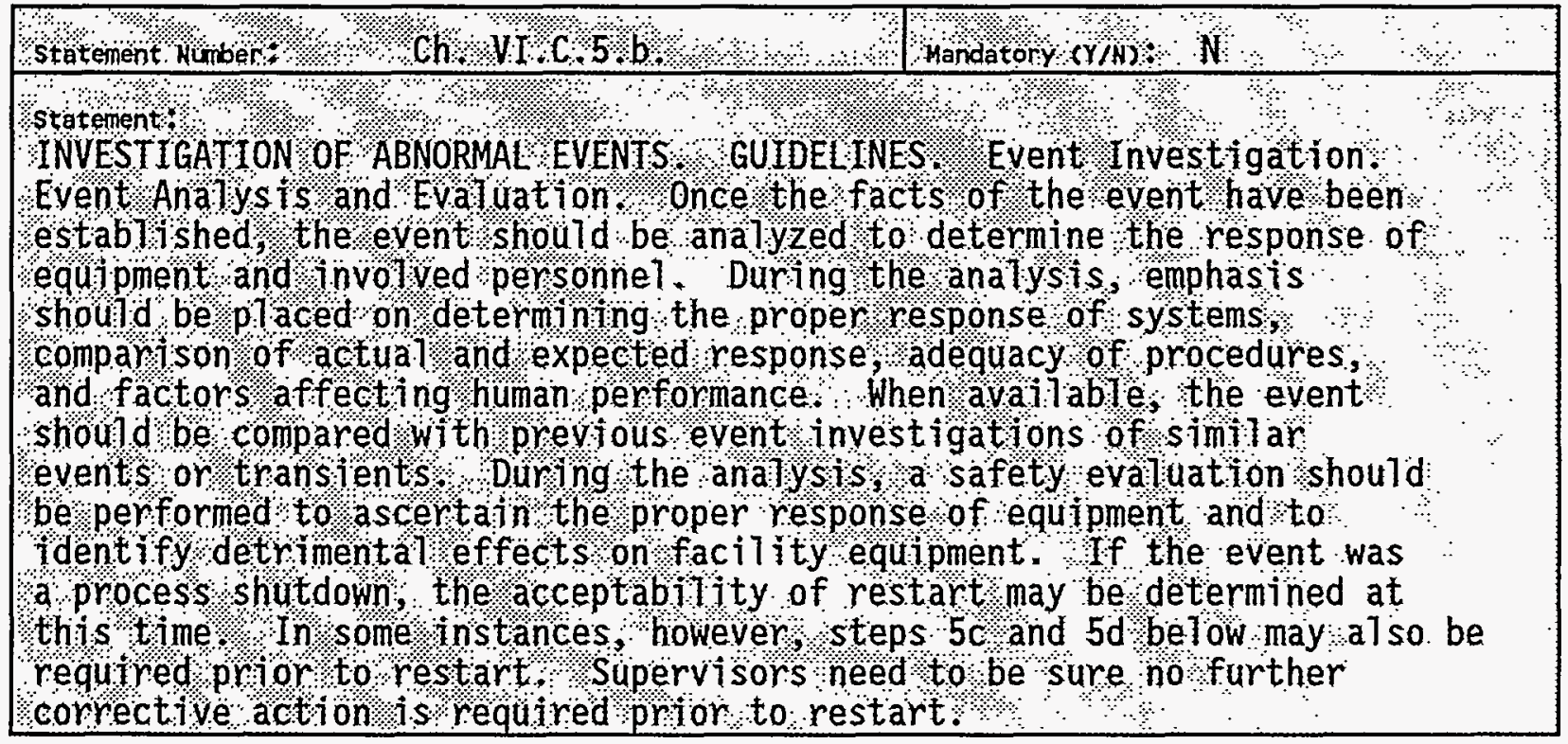

1.0 STATEMENT SATISFIED BASED ON IMPLEMENTING EVIDENCE (Y/N): NO

2.0 GENERAL DESCRIPTION OF EVIDENCE (DESCRIPTION OF NONCOMPLIANCE OR DEFICIENCY IF APPLICABLE):

Statement not addressed in the HASQAP.

3.0 CORRECTIVE ACTION: 
WHC-EP-0822

ASSESSMENT DATA COLLECTION FORM

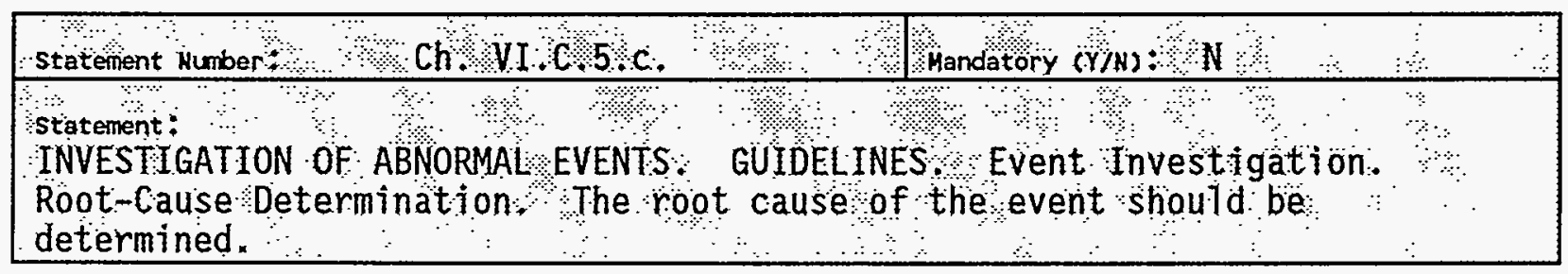

1.0 STATEMENT SATISFIED BASED ON IMPLEMENTING EVIDENCE $(Y / H):$ YES

2.0 GENERAL DESCRIPTION OF EVIDENCE (DESCRIPTION OF NONCOMPLIANCE OR DEFICIENCY IF APPLICABLE):

Root cause analysis is provided for in HASQAP Section 15.4, "Root Cause Analysis." 


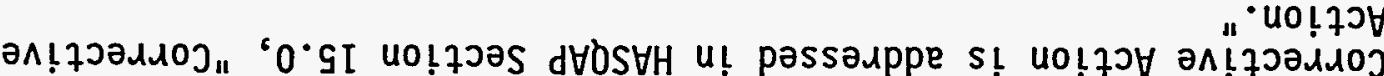

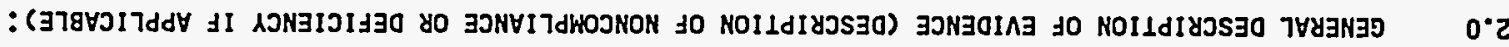

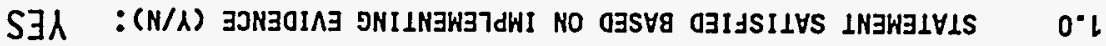

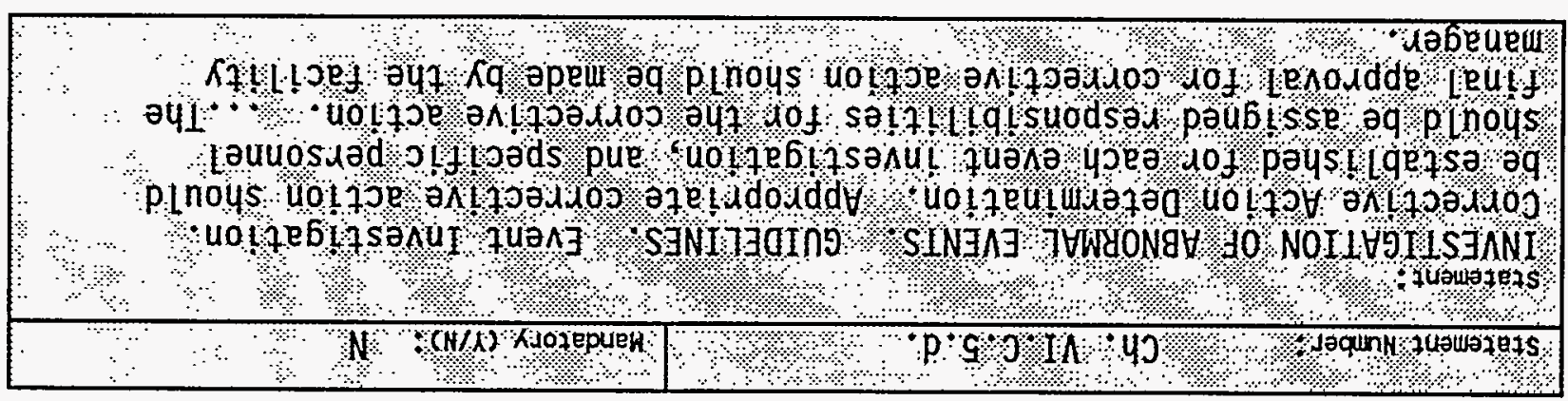

WYOA NOILJ

$2 Z 80-\mathrm{d} 3-\mathrm{JHM}$ 
WHC-EP-0822

ASSESSMENT DATA COLLECTION FORM

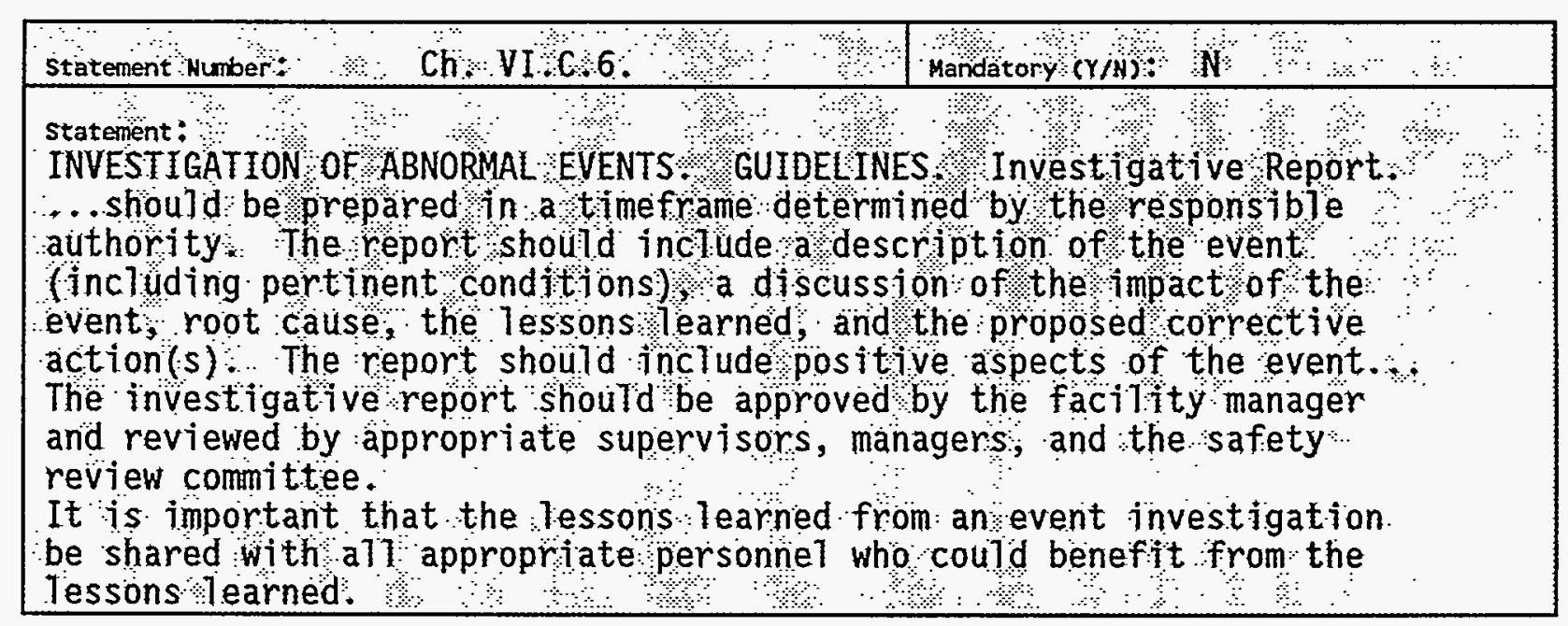

1.0 STATEMENT SATISFIED BASED ON IMPLEMENTING EVIDENCE (Y/N): YES

2.0 GENERAL DESCRIPTION OF EVIDENCE (DESCRIPTION OF NONCOMPLIANCE OR DEFICIENCY IF APPLICABLE):

The intent of this statement is met by HASQAP Section 15.0, "Corrective Action." 
WHC-EP-0822

\section{ASSESSMENT DATA COLLECTION FORM}

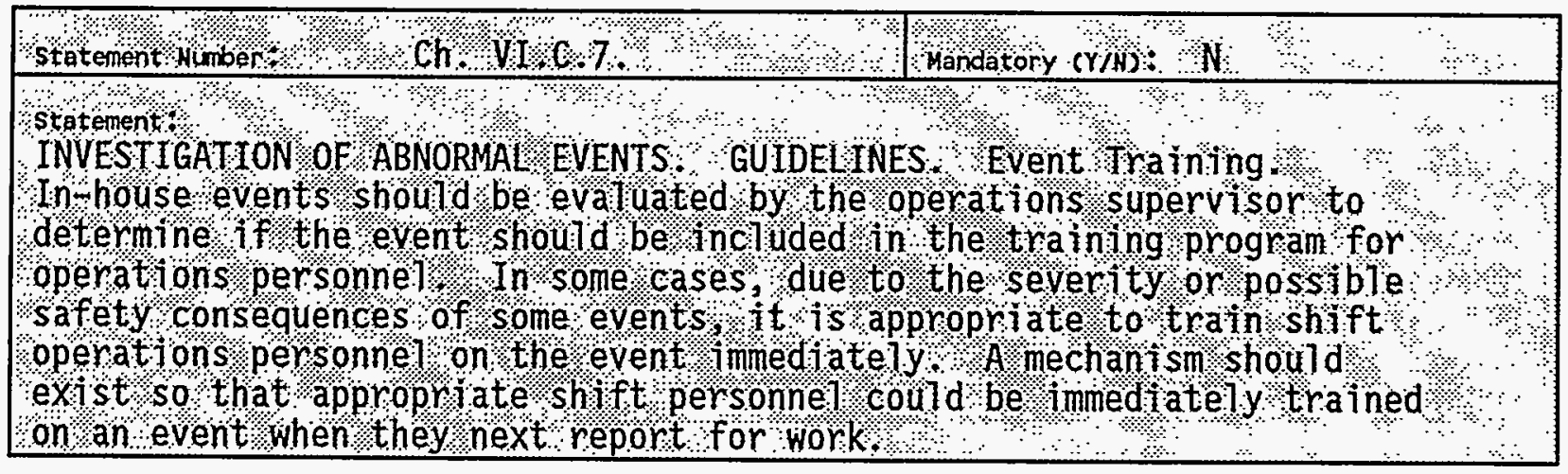

1.0 STATEMENT SATISFIED BASED ON IMPLEMENTING EVIDENCE (Y/N): NO

2.0 GENERAL DESCRIPTION OF EVIDENCE (DESCRIPTION OF NONCOMPLIANCE OR DEFICIENCY IF APPLICABLE):

Statement is not addressed by the HASQAP.

3.0 CORRECTIVE ACTION: 
WHC-EP-0822

ASSESSMENT DATA COLLECTION FORM

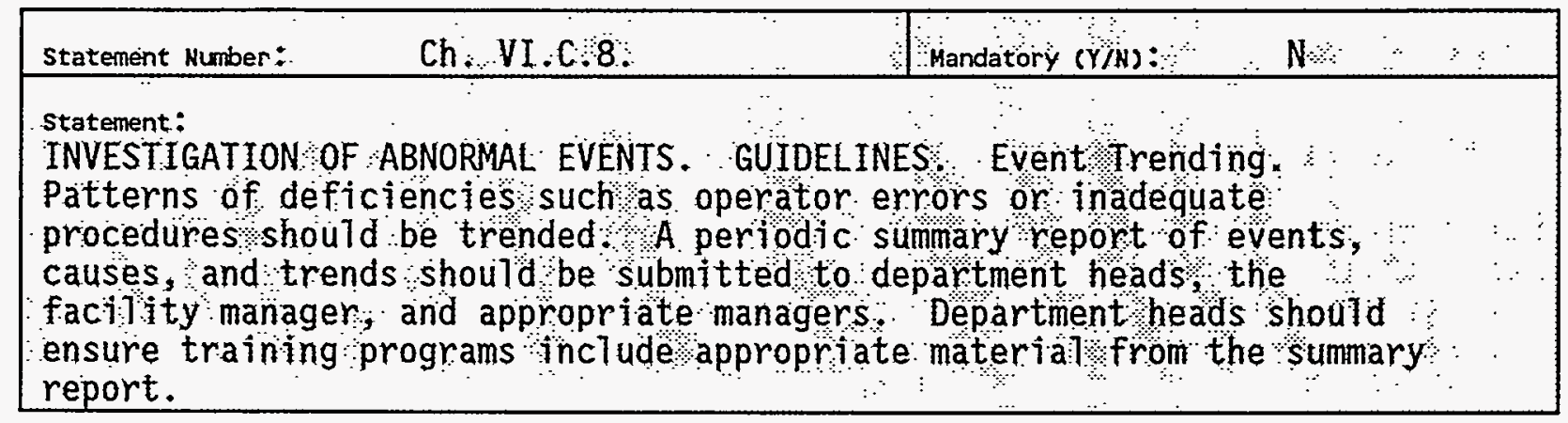

1.0 STATEMENT SATISFIED BASED ON IMPLEMENTING EVIDENCE (Y/N): YES

2.0 GENERAL DESCRIPTION OF EVIDENCE (DESCRIPTION OF NONCOMPLIANCE OR DEFICIENCY IF APPLICABLE):

The intent of this statement is met by HASQAP Section 15.3, "Trend Analysis." 


\section{ASSESSMENT DATA COLLECTION FORM}

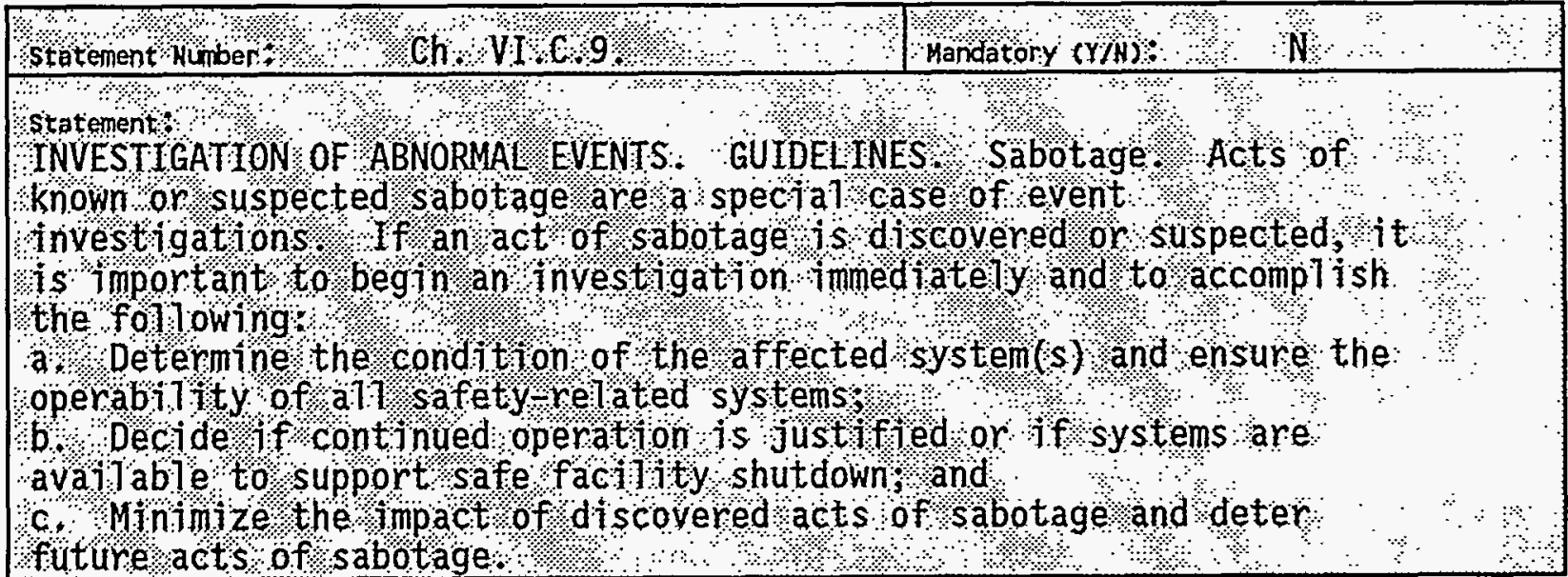

1.0 StATEMENT SATISFIED BASED ON IMPLEMENTING EVIDENCE $(Y / N)$ : NO

2.0 GENERAL DESCRIPTION OF EVIDENCE (DESCRIPTION OF NONCOMPLIANCE OR DEFICIENCY IF APPLICABLE):

Statement is not addressed by the HASQAP.

3.0 CORRECTIVE ACTION: 
WHC-EP-0822

\section{ASSESSMENT DATA COLLECTION FORM}

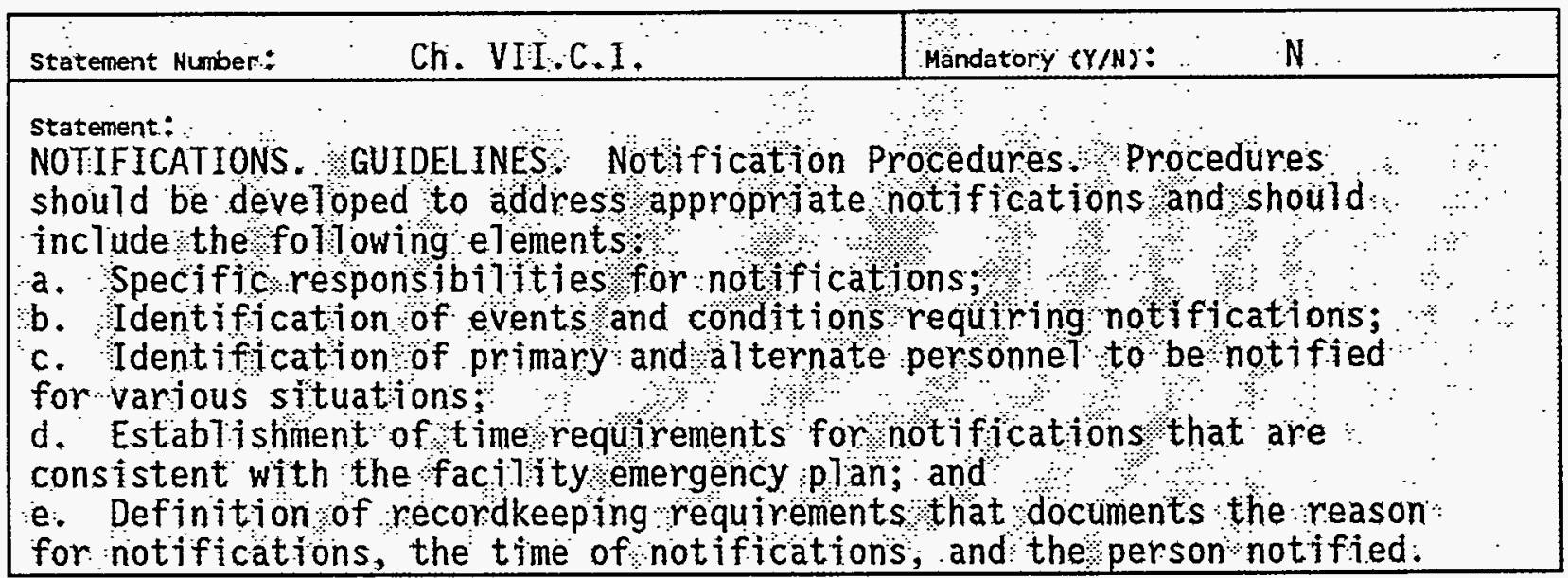

1.0 STATEMENT SATISFIED BASED ON IMPLEMENTING EVIDENCE $(Y / N)$ : YES

2.0 GENERAL DESCRIPTION OF EVIDENCE (DESCRIPTION OF NONCOMPLIANCE OR DEFICIENCY IF APPLICABLE):

The intent of this statement is met by HASQAP subsection 9.3.2, "Immediate Reporting," for analytical laboratory operations. 
WHC-EP-0822

\section{ASSESSMENT DATA COLLECTION FORM}

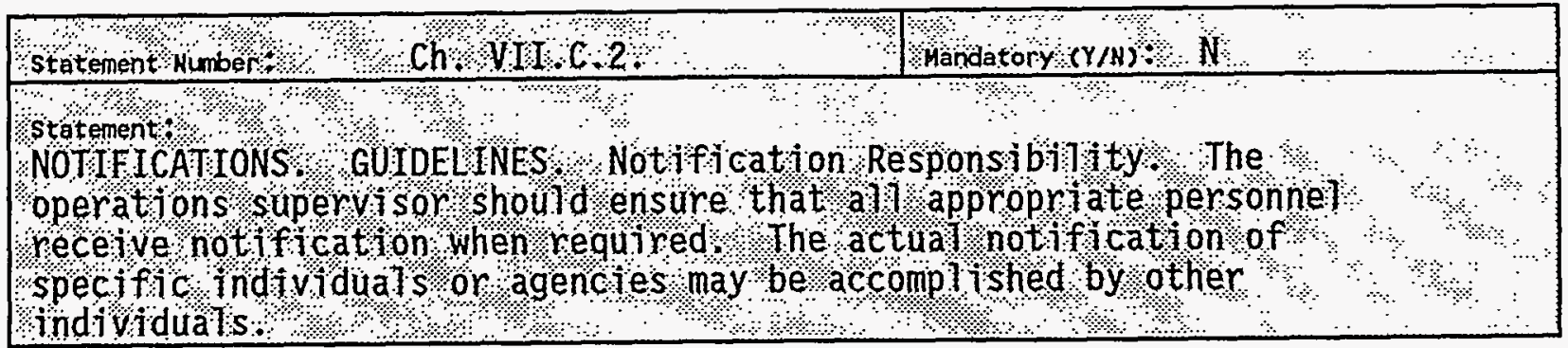

1.0 STATEMENT SATISFIED BASED ON IMPLEMENTING EVIDENCE (Y/N): NO

2.0 GENERAL DESCRIPTION OF EVIDENCE (DESCRIPTION OF NONCOMPLIANCE OR DEFICIENCY IF APPLICABLE):

The specifics of this statement are not addressed by HASQAP subsection 9.3.2, "Immediate Reporting."

3.0 CORRECTIVE ACTION: 
WHC-EP-0822

\section{ASSESSMENT DATA COLLECTION FORM}

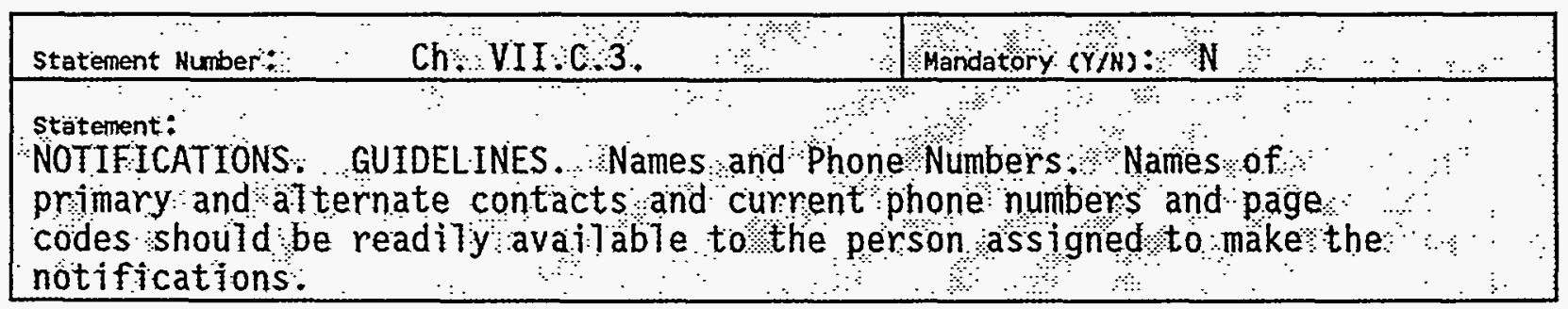

1.0 STATEMENT SATISFIED BASED ON IMPLEMENTING EVIDENCE (Y/N): NO

2.0 GENERAL DESCRIPTION OF EVIDENCE (DESCRIPTION OF NONCOMPLIANCE OR DEFICIENCY IF APPLICABLE):

The specifics of this statement are not addressed by HASQAP subsection 9.3.2, "Immediate Reporting."

3.0 CORRECTIVE ACTION: 
WHC-EP-0822

\section{ASSESSHENT DATA COLLECTION FORM}

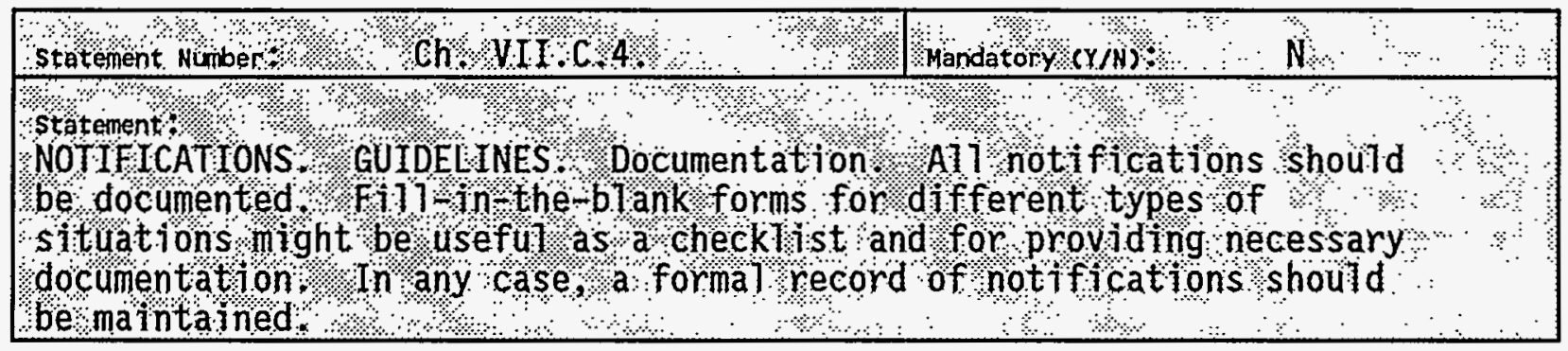

1.0 StATEMENT SATISFIEd BASED ON IMPLEMENTING EVIDENCE $(Y / N)$ : NO

2.0 GENERAL DESCRIPTION OF EVIDENCE (DESCRIPTION OF NONCOMPLIANCE OR DEFICIENCY IF APPLICABLE):

The specifics of this statement are not addressed by HASQAP subsection 9.3.2, "Immediate Reporting."

3.0 CORRECTIVE ACTION: 
WHC-EP-0822

\section{ASSESSMENT DATA COLLECTION FORM}

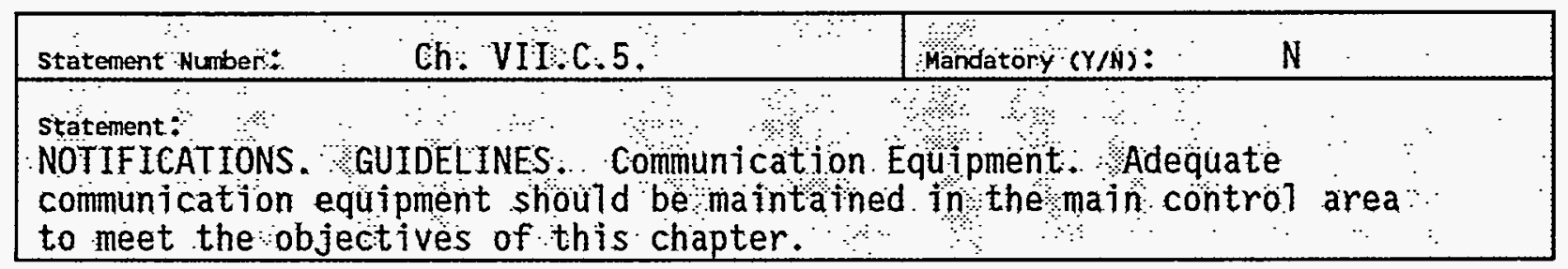

\section{N/A}

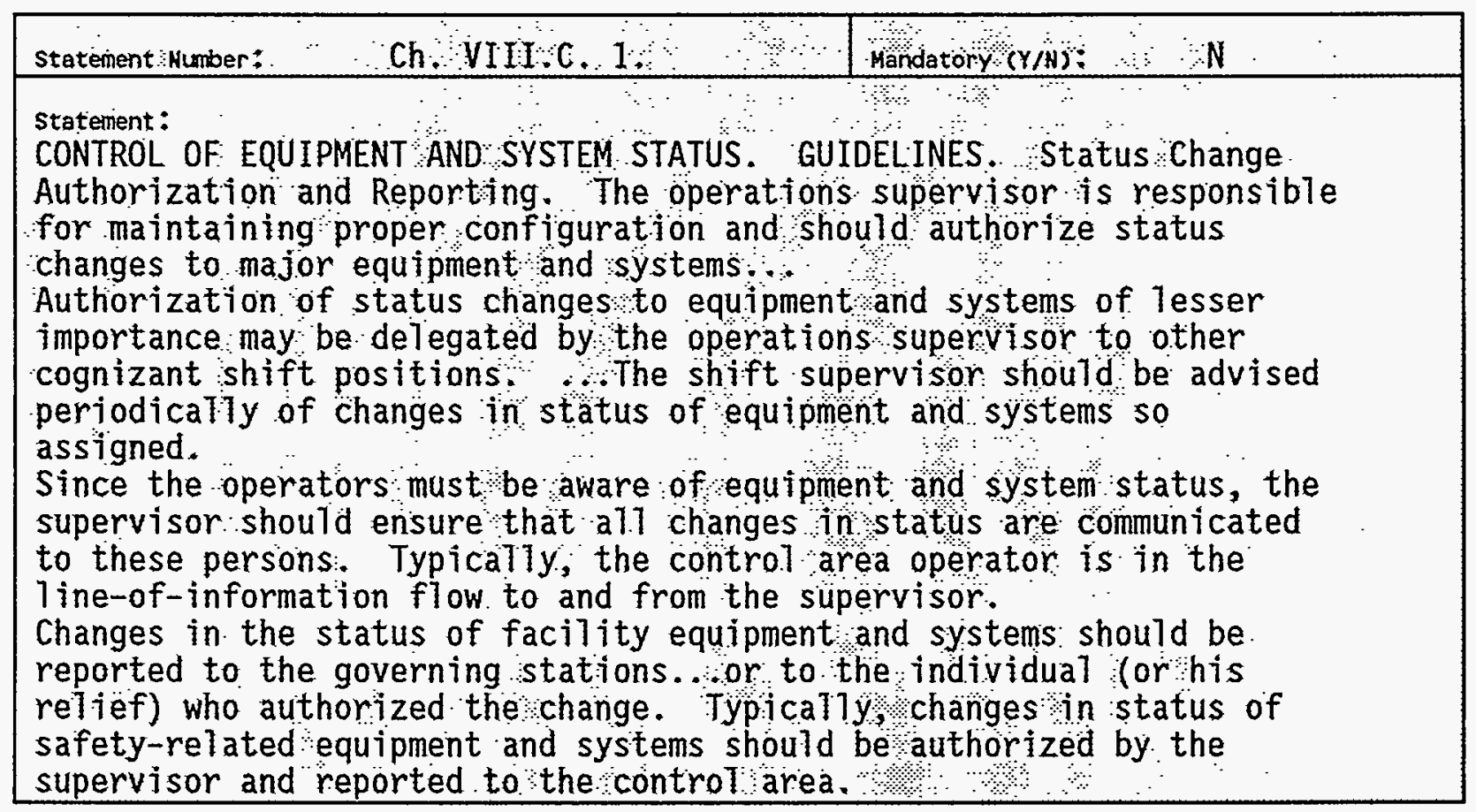

\section{N/A}




\section{ASSESSMENT DATA COLLECTION FORM}

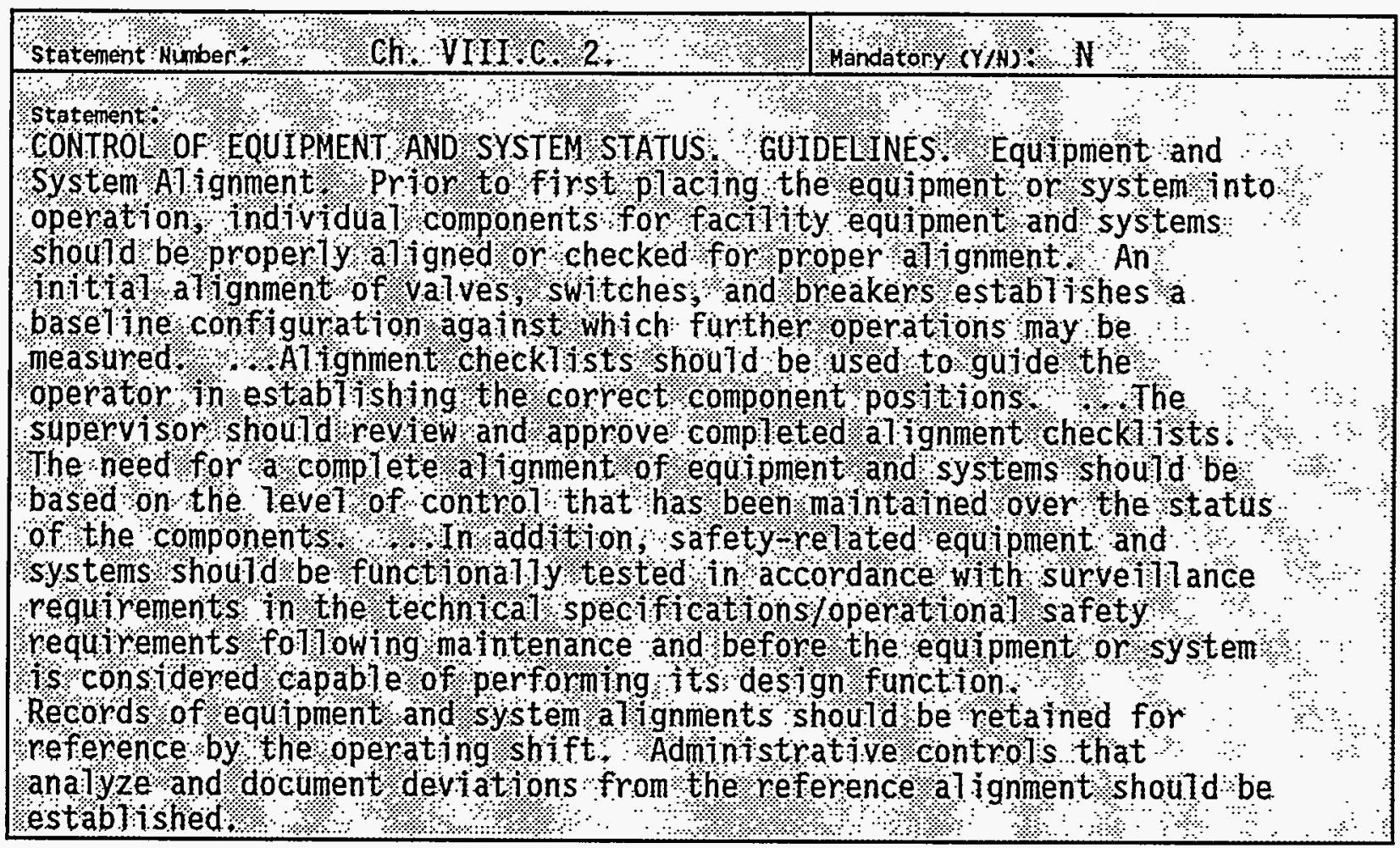

\section{N/A}

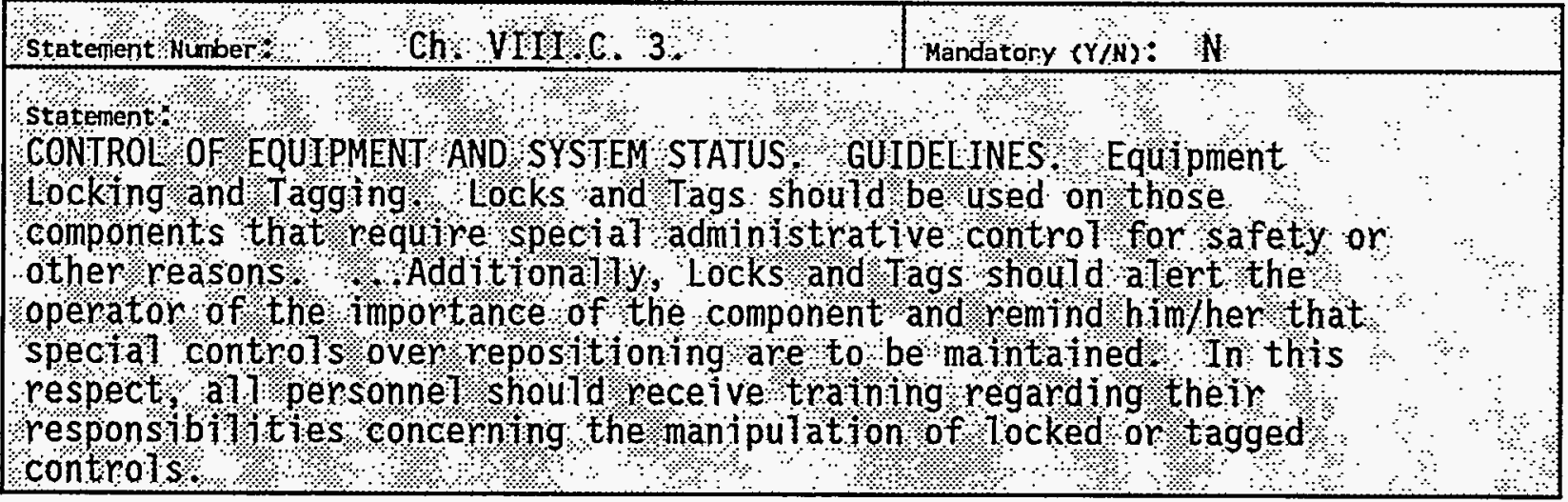

\section{N/A}


WHC-EP-0822

\section{ASSESSMENT DATA COLLECTION FORM}

\begin{tabular}{|c|c|}
\hline $\mathrm{Ch}, \mathrm{YIII} \mathrm{O}_{4}$ & Mandatory $(Y / W): N$ \\
\hline 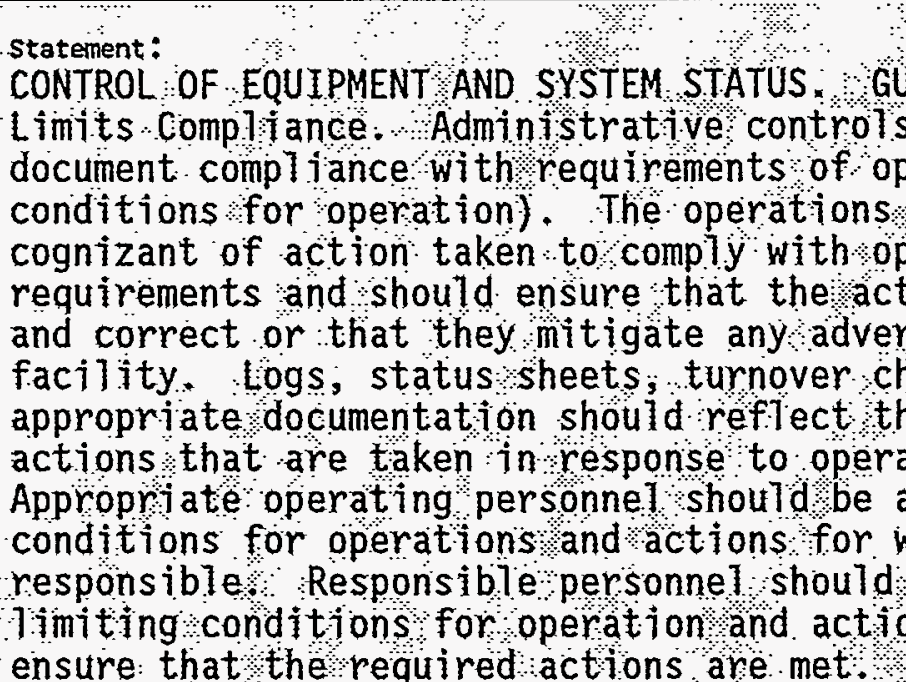 & 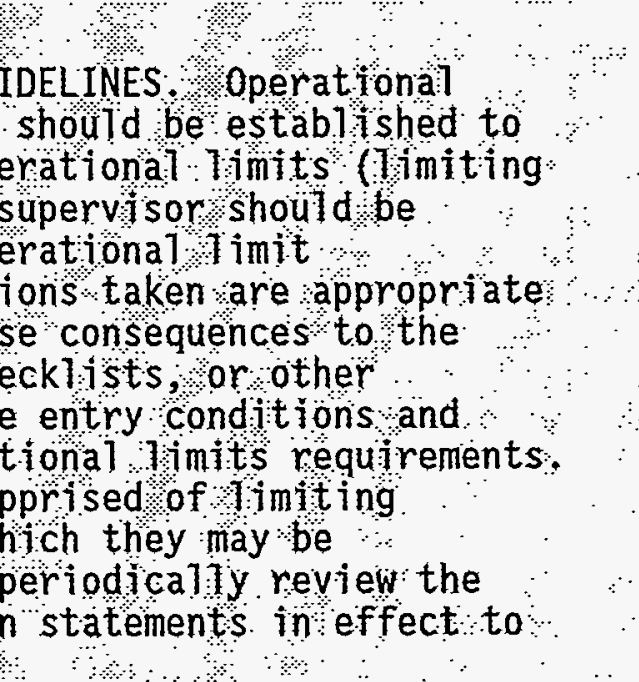 \\
\hline
\end{tabular}

\section{N/A}


ASSESSHENT DATA COLLECTION FORM

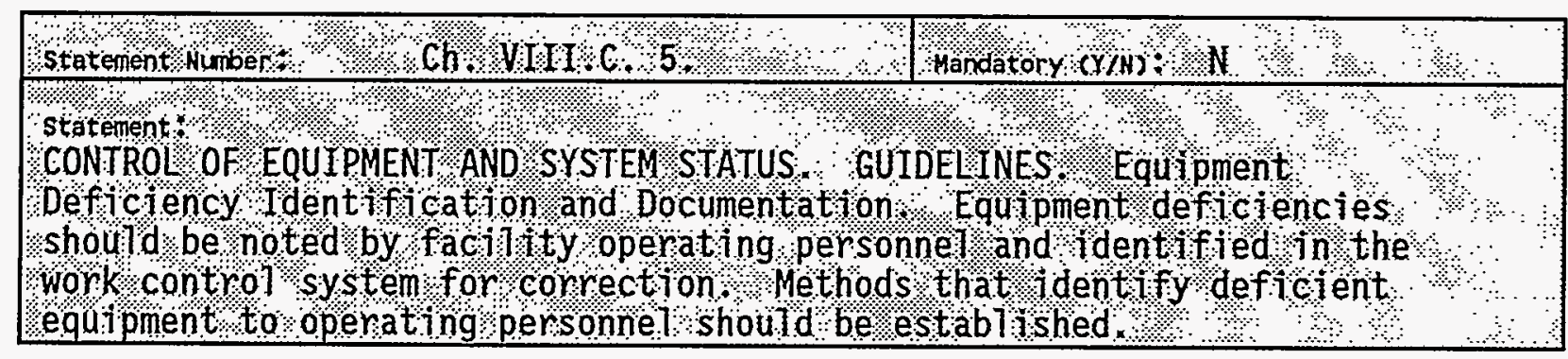

1.0 StATEMENT SATISFIED BASEd ON IMPLEMENTING EVIDENCE (Y/N): YES

2.0 GENERAL DESCRIPTION OF EVIDENCE (DESCRIPTION OF NONCOMPLIANCE OR DEFICIENCY IF APPLICABLE):

The intent of this statement is met by HASQAP Section 14.0, "Preventive Maintenance." 


\section{ASSESSMENT DATA COLLECTION FORM}

\begin{tabular}{|c|}
\hline Ch, VIII.C, 6. \\
\hline 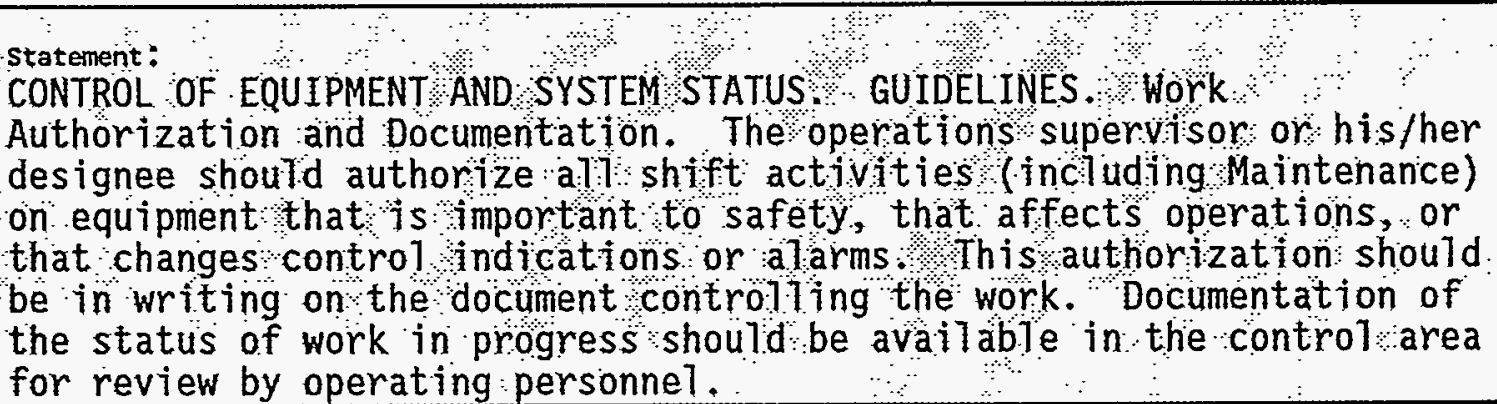 \\
\hline
\end{tabular}

\section{$\mathbf{N} / \mathbf{A}$}




\section{ASSESSMENT DATA COLLECTION FORM}

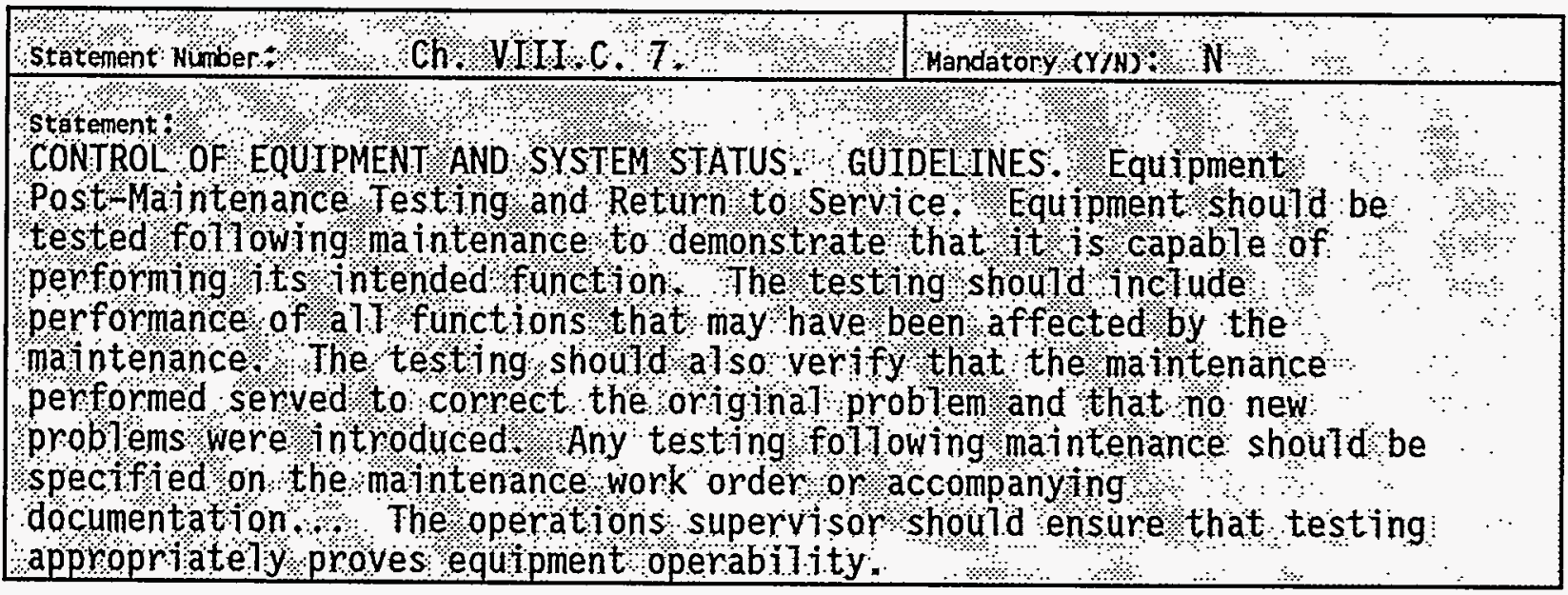

1.0 STATEMENT SATISFIED BASED ON IMPLEMENTING EVIDENCE (Y/N): YES

2.0 GENERAL DESCRIPTION OF EVIDENCE (DESCRIPTION OF NONCOMPLIANCE OR DEFICIENCY IF APPLICABLE):

The intent of the statement is met by HASQAP Section 7.0, "Calibration." 
WHC-EP-0822

ASSESSMENT DATA COLLECTION FORM

\begin{tabular}{|c|c|}
\hline Ch SVIII C .8 & Mandatory $(\gamma / N): \mathrm{N}$ \\
\hline 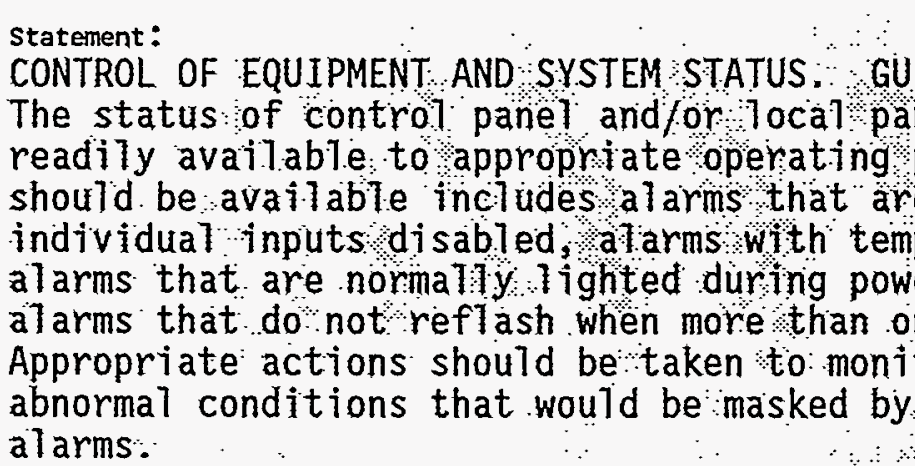 & 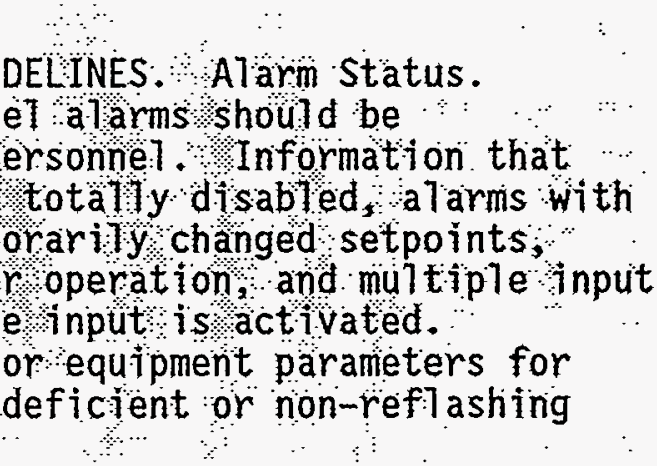 \\
\hline
\end{tabular}

\section{N/A}

\begin{tabular}{|c|c|}
\hline Ch. VIIIC. 9 & Mandatory $(\gamma / \mathrm{N}): \mathrm{N}$ \\
\hline $\begin{array}{l}\text { Statement: } \\
\text { CONTROL OF EQUIPMENT AND SYSTEM ST } \\
\text { Modification Control. Administrat } \\
\text { established for installation of te } \\
\text { modification, these controls shoul } \\
\text { installation of temporary modifica } \\
\text { allow for technical oversight and } \\
\text { current design activities, and app } \\
\text { These controlesystems should make } \\
\text { installation approval, independent } \\
\text { installation and removal, document } \\
\text { operating procedures and documents } \\
\text { modifications, and periodic audits }\end{array}$ & $\begin{array}{l}\text { DEINES, Temporary } \\
\text { systems should be } \\
\text { difications. Prior to } \\
\text { for communicating the } \\
\text { he design authority to } \\
\text { ion of the impact on } \\
\text { he des ign modification. } \\
\text { for safety reviews, } \\
\text { ion of correct } \\
\text { he modification, update of } \\
\text { marking of installed } \\
\text { nding modifications. }\end{array}$ \\
\hline
\end{tabular}

\section{N/A}


WHC-EP-0822

\section{ASSESSMENT DATA COLLECTION FORM}

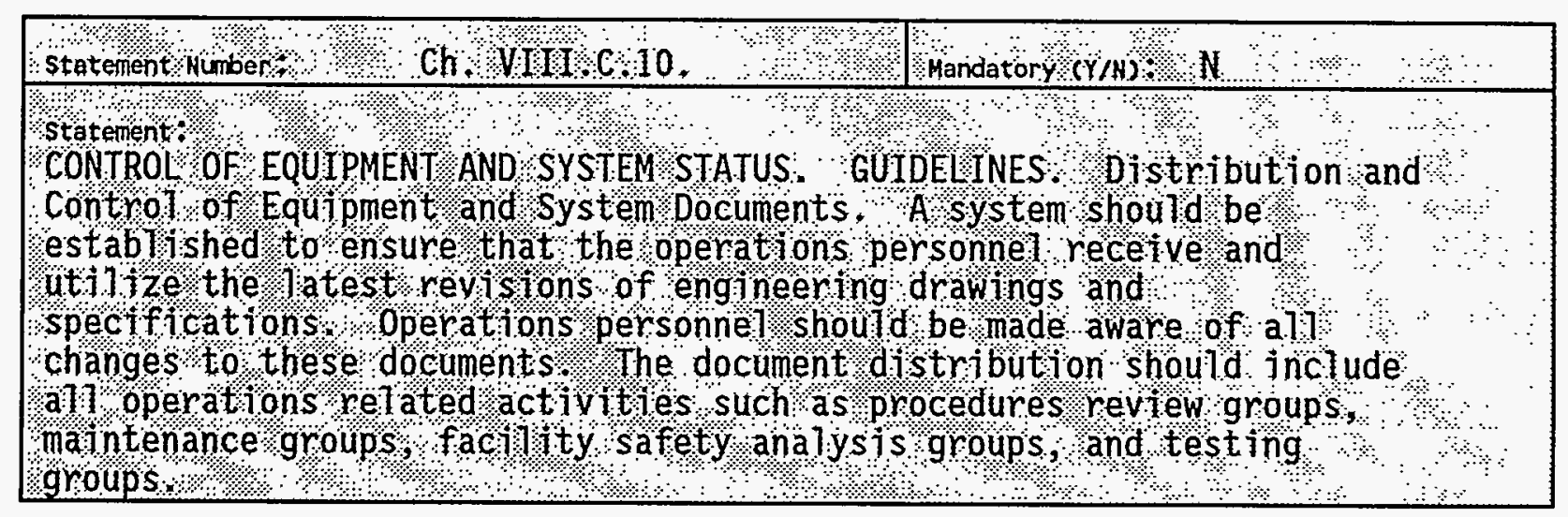

N/A

The following statements concerning "LOCKOUTS AND TAGOUTS" are N/A:

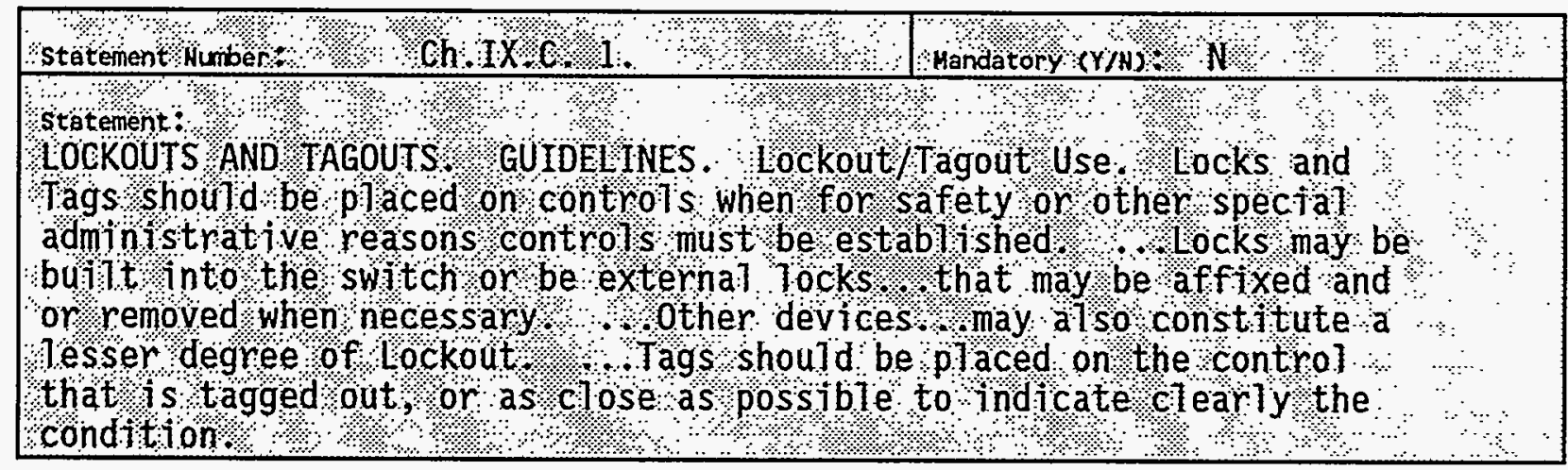

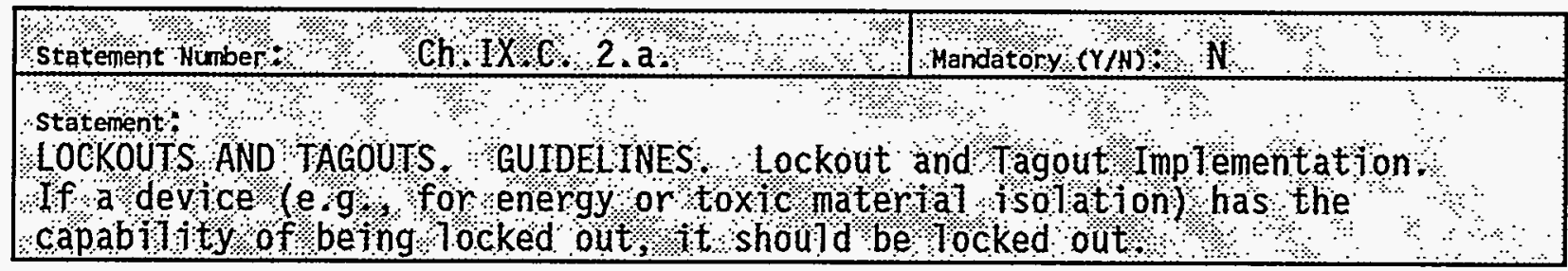

\begin{tabular}{|c|c|}
\hline 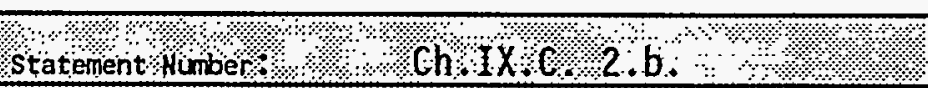 & Handator.y $(Y / N)$ \% $N$ : \\
\hline 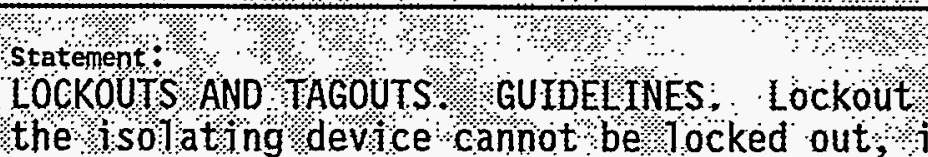 & $\begin{array}{l}\text { a } \\
\text { and Jagout Implementation. If }\end{array}$ \\
\hline
\end{tabular}


WHC-EP-0822

ASSESSMENT DATA COLLECTION FORM

\begin{tabular}{|c|c|}
\hline$C h . I X, C, 2 . C$. & Mandatory $(Y / N): N$ \\
\hline $\begin{array}{l}\text { Statement: } \\
\text { LOCKOUTS AND TAGOUTS GUIDELINES lockout } \\
\text { New equipment design and major modificat fons } \\
\text { shoüld be destgned to provide the capabitity }\end{array}$ & $\begin{array}{l}\text { and Tagout Implementation. } \\
\text { to existing equipment } \\
\text { of being locked out. }\end{array}$ \\
\hline Statement Humber: $\quad \mathrm{ch}, \mathrm{IX}, \mathrm{C}, 3 \mathrm{a} / \mathrm{Q}$ & Mandatory $(Y / N)$ N $\mathrm{N}:$ \\
\hline 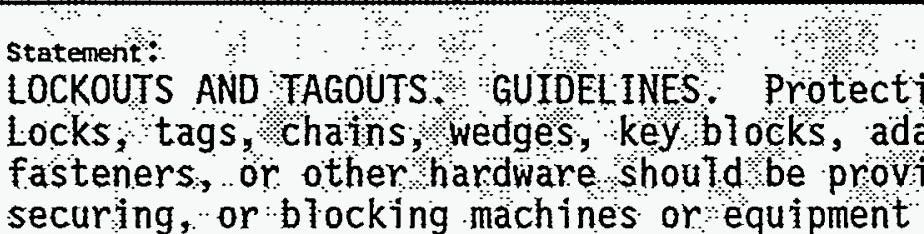 & $\begin{array}{l}\text { a } \\
\text { ve Materials and Hardware. } \\
\text { pter pins, self tocking } \\
\text { ded for isolating, }\end{array}$ \\
\hline
\end{tabular}

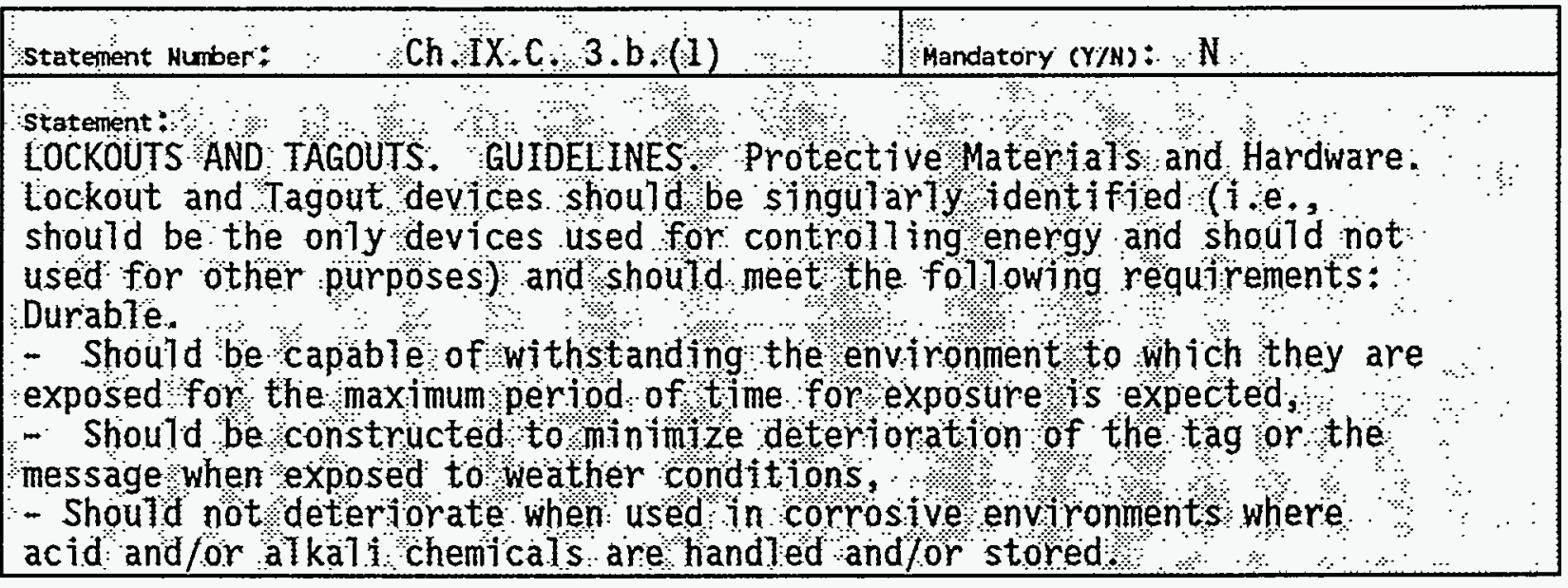

\begin{tabular}{|c|c|}
\hline Statement Number $\quad \mathrm{Ch}, \mathrm{IX}, \mathrm{C}, 3, \mathrm{~b},(2)$ & Mandatory $(\mathrm{Y} / \mathrm{N}) \mathrm{s}$ ) $\mathrm{N} \quad \therefore$ \\
\hline 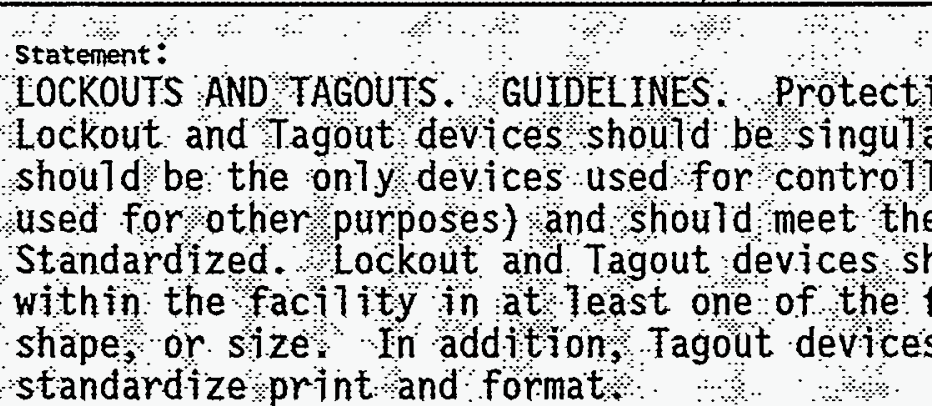 & 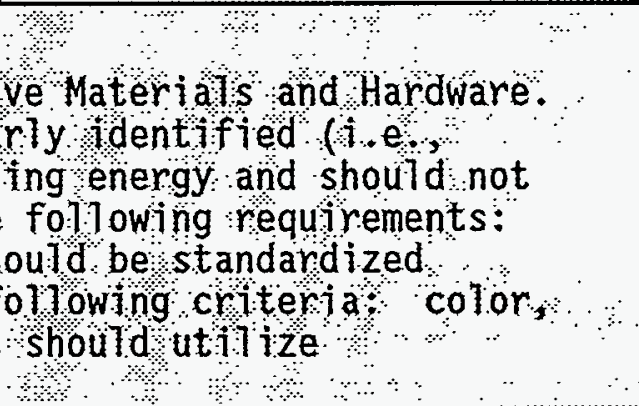 \\
\hline
\end{tabular}


WHC-EP-0822

\section{ASSESSHENT DATA COLLECTION FORM}

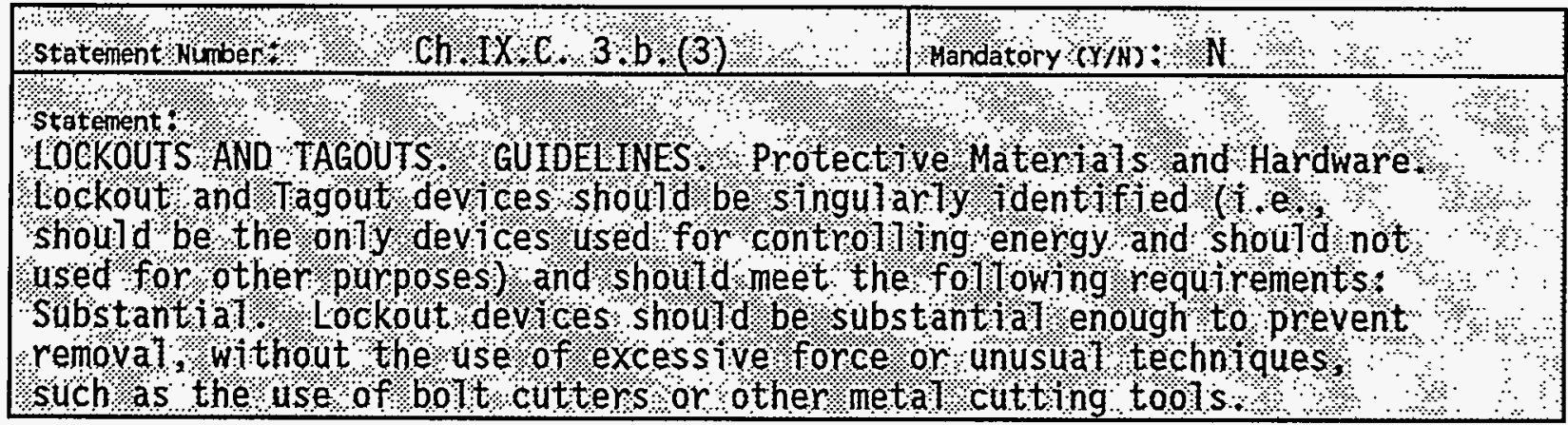

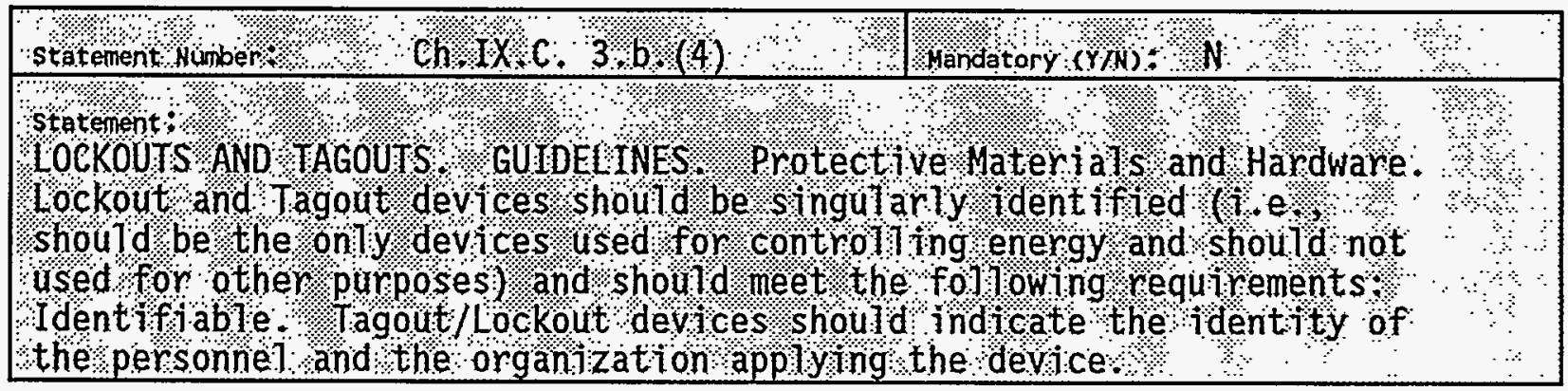

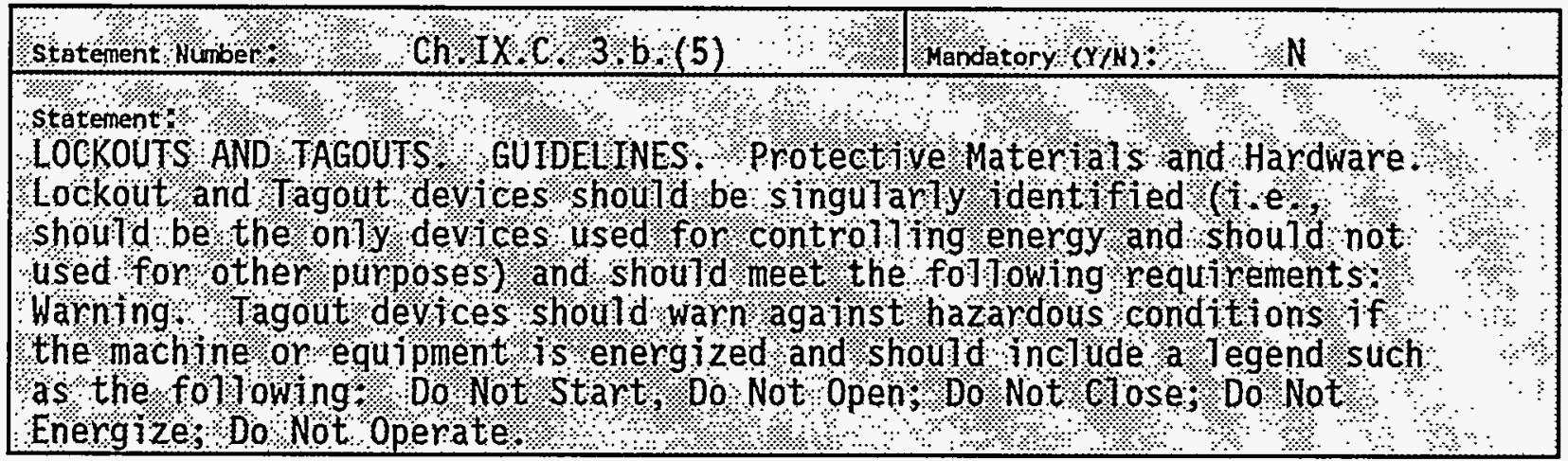

\begin{tabular}{|l} 
statement Humber \\
statement.
\end{tabular}


WHC-EP-0822

\section{ASSESSMENT DATA COLLECTION FORM}

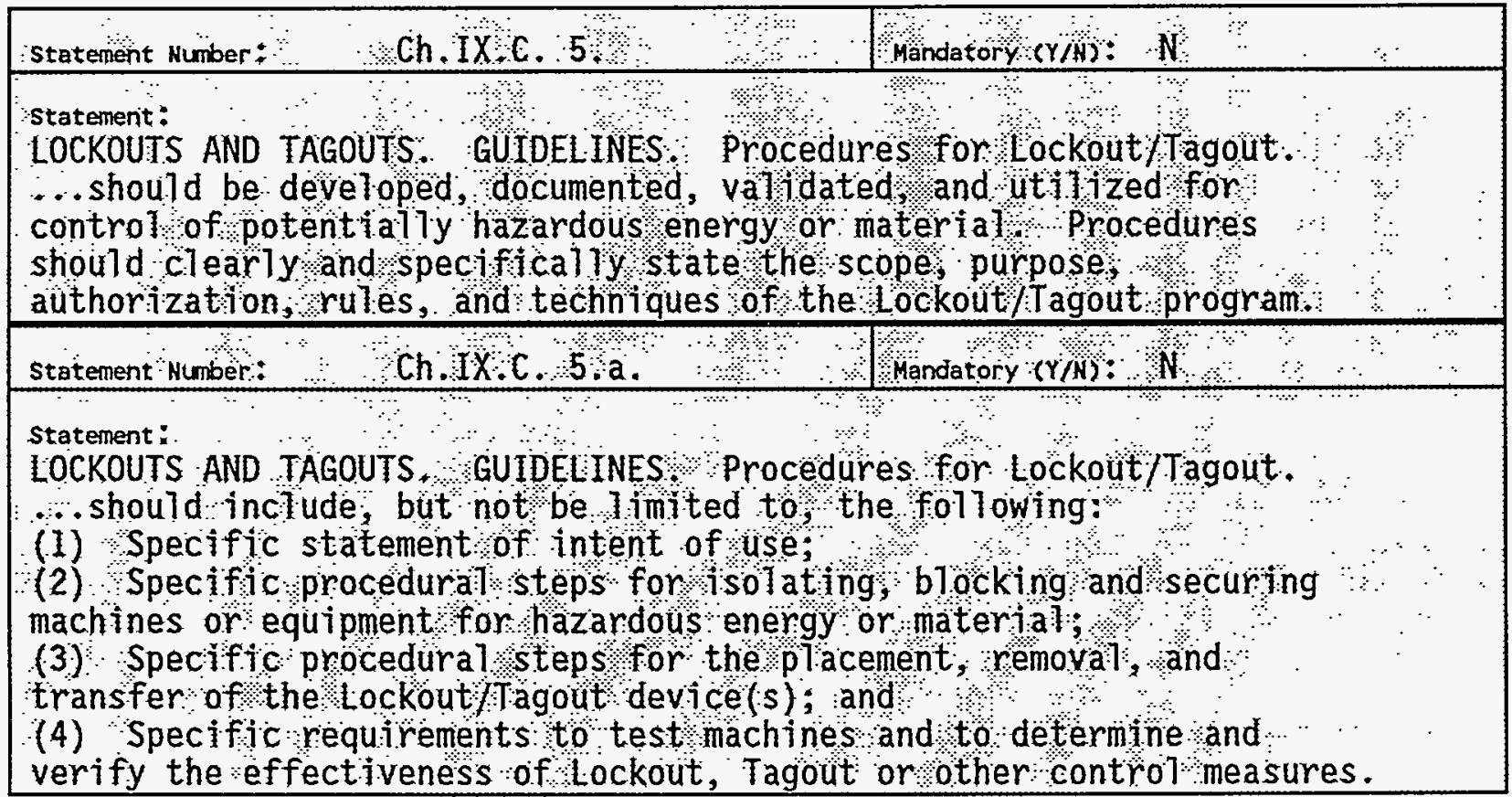

\begin{tabular}{|c|}
\hline Mandatory $(Y / N) \cap N$ \\
\hline 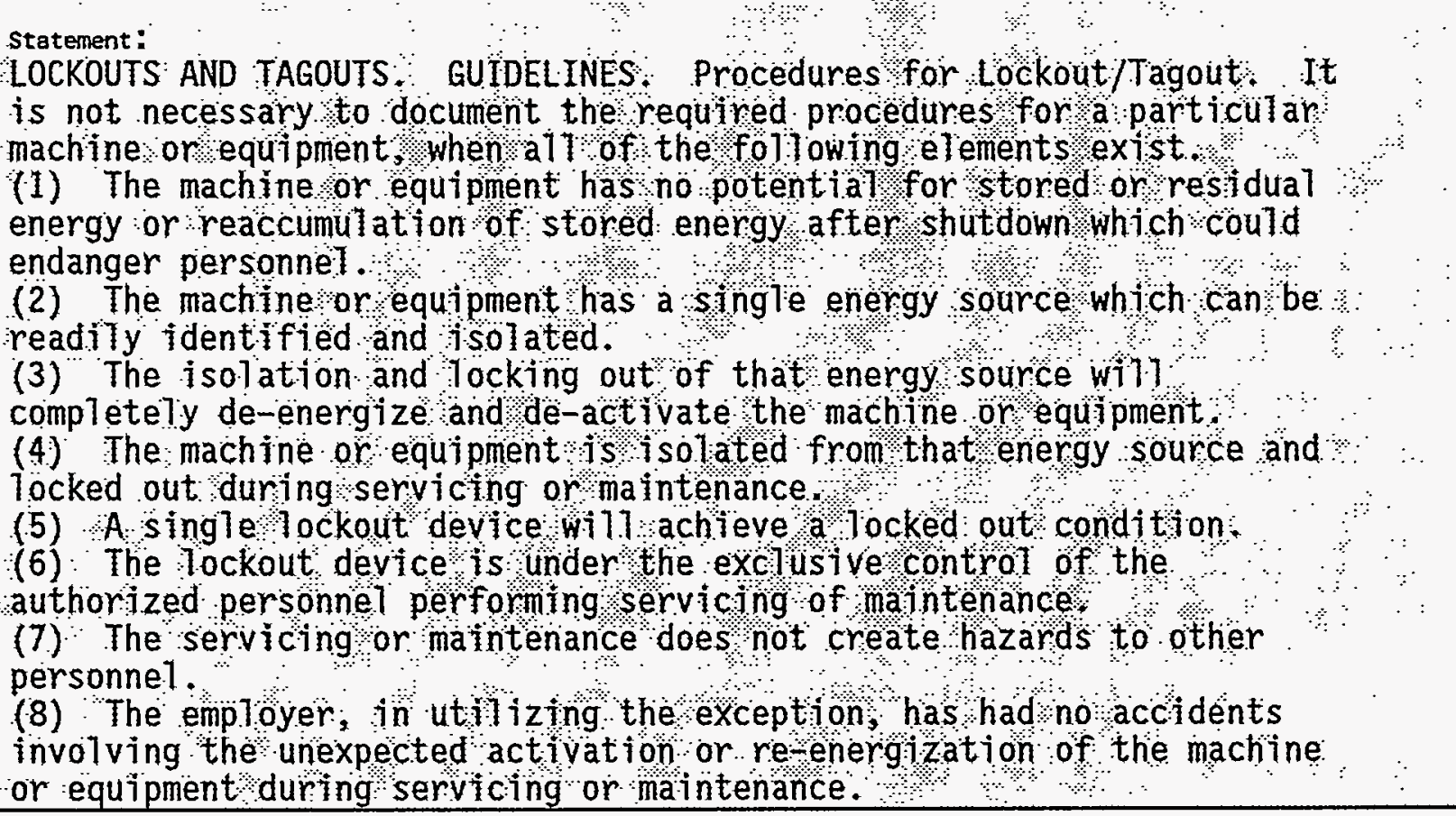 \\
\hline
\end{tabular}


WHC-EP-0822

\section{ASSESSMENT DATA COLLECTION FORM}

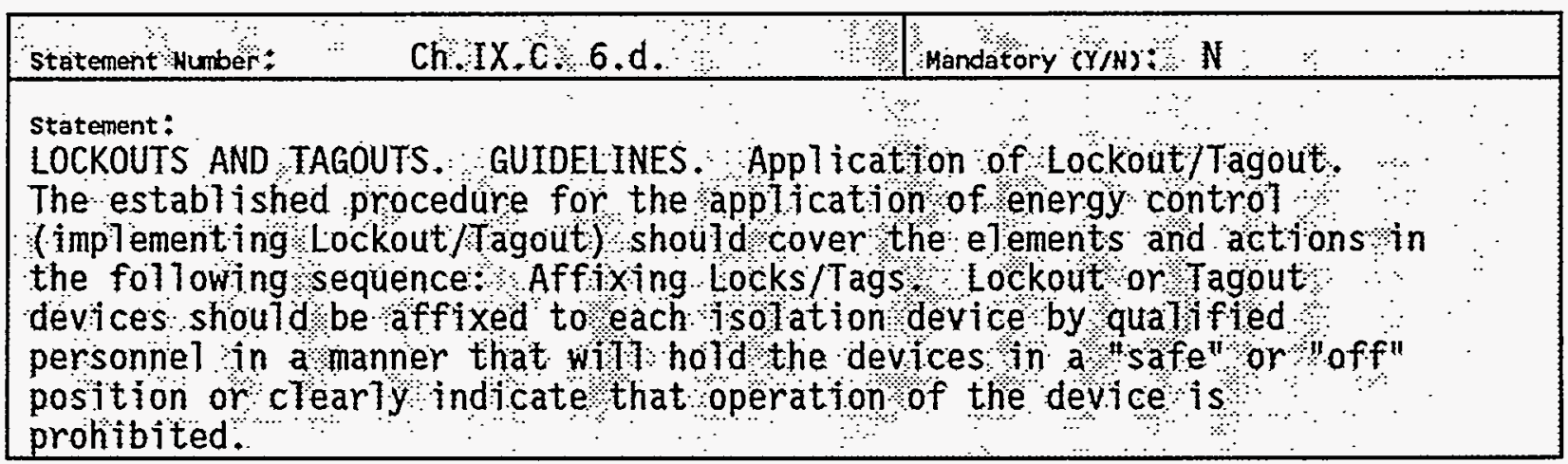

\begin{tabular}{|c|c|c|}
\hline Ch. IX.C. $6 . \mathrm{e}^{\mathrm{e}}$ & Mandatory $(Y / N), / \mathrm{N}: \quad \therefore$ & \\
\hline 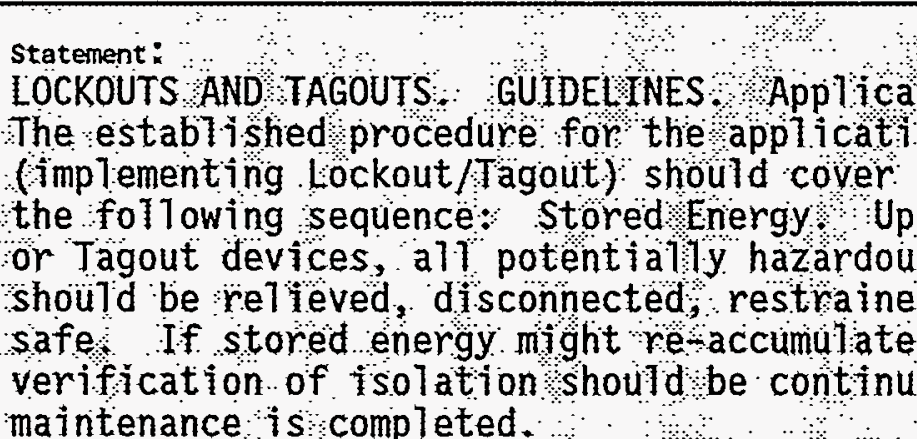 & 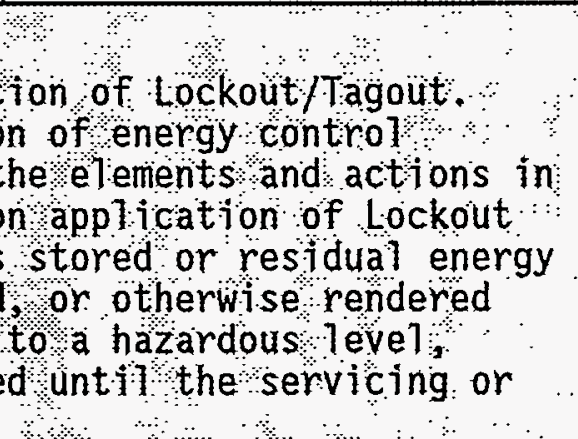 & \\
\hline
\end{tabular}

\begin{tabular}{|c|c|}
\hline Statement Number: $\quad$ Ch. IX.C.f. 6. & Mandatory $(Y / \mathrm{N}): \mathrm{N}$ \\
\hline 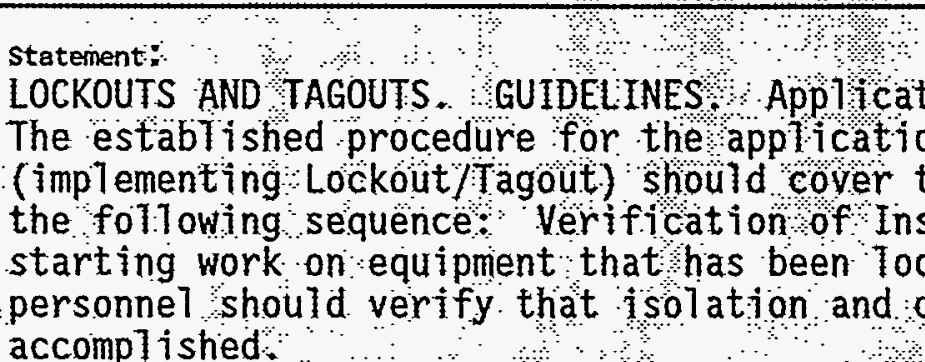 & 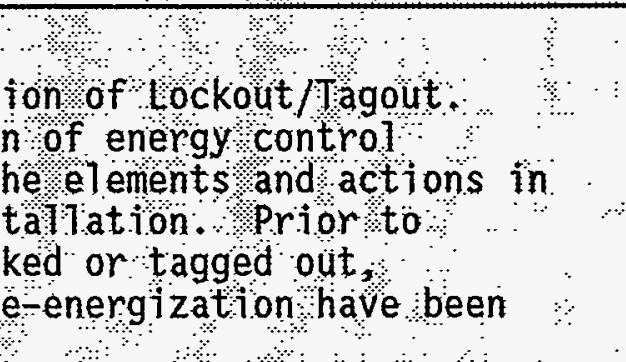 \\
\hline
\end{tabular}


WHC-EP-0822

\section{ASSESSMENT DATA COLLECTION FORM}

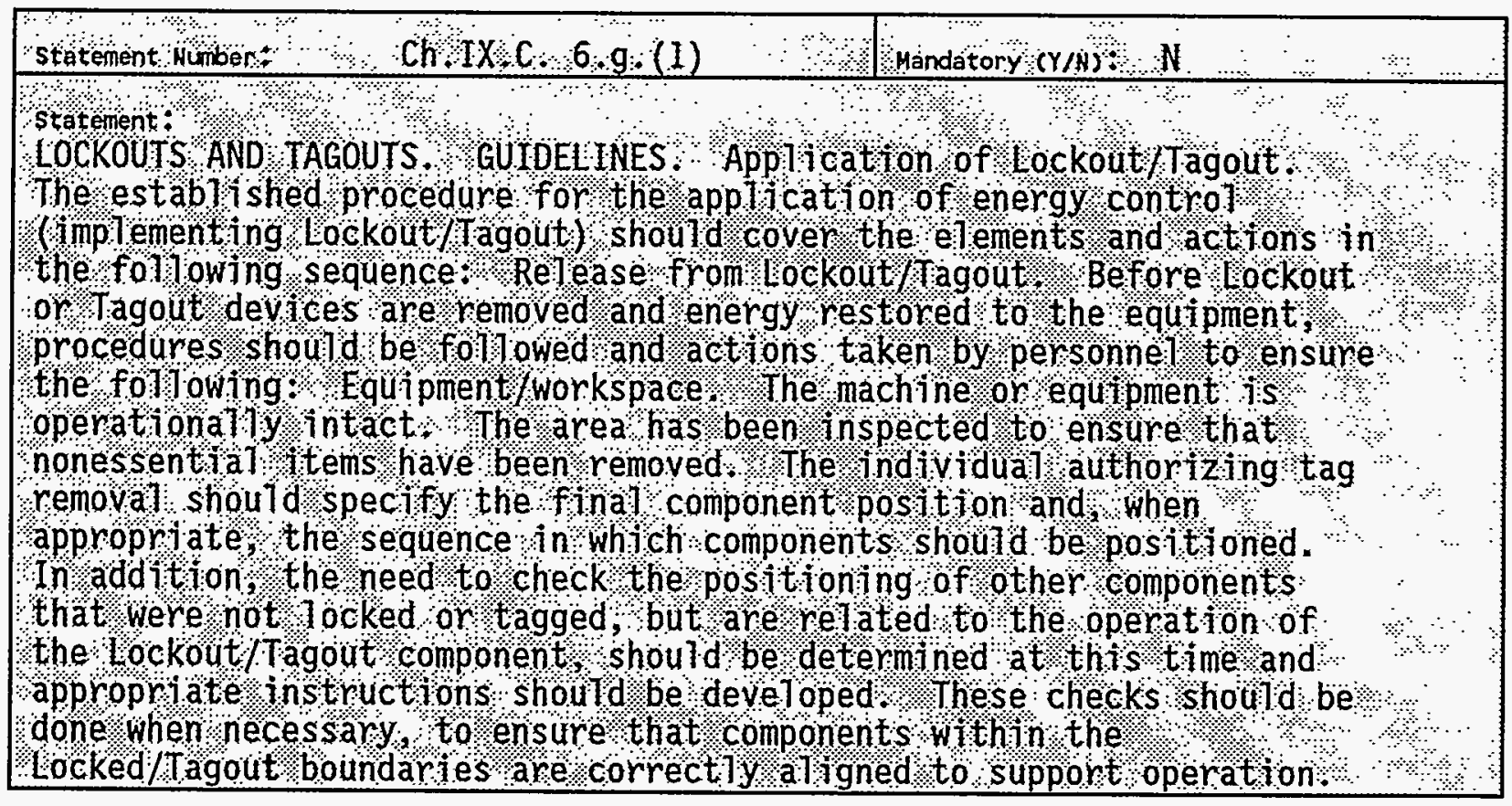

Statement Number:

(ch $I X, C, 6 \%(2)$

Handatory (Y) $/ \mathrm{H}) \mathrm{H}$

statement:

COCKOUTS AND TAGOUTS \&GUDELINES App 1 ication of 1 Lockout/Tagout.

The establi shed procedure for the applocation of energy control

Timplement ing lockout/ Tagout) should cover the elements and act tons in the following sequence. Rel ea se from lockout $/$ Tagout of bre Lockout: or Tagout devoces are removed and senergy restored to the equ pment: procedüres shoúld be fol 10 wed and actions taken by personnel to ensure the following? Personnel The workspace should be checked to ensure that a 17 personnel have been positjoned sa f el y or removed from the area. Before Lockout/Tagout devices are removedsand equipment: energ zed, affected personnel should be not if ted that equipment will be energized: 
WHC-EP-0822

ASSESSMENT DATA COLLECTION FORM

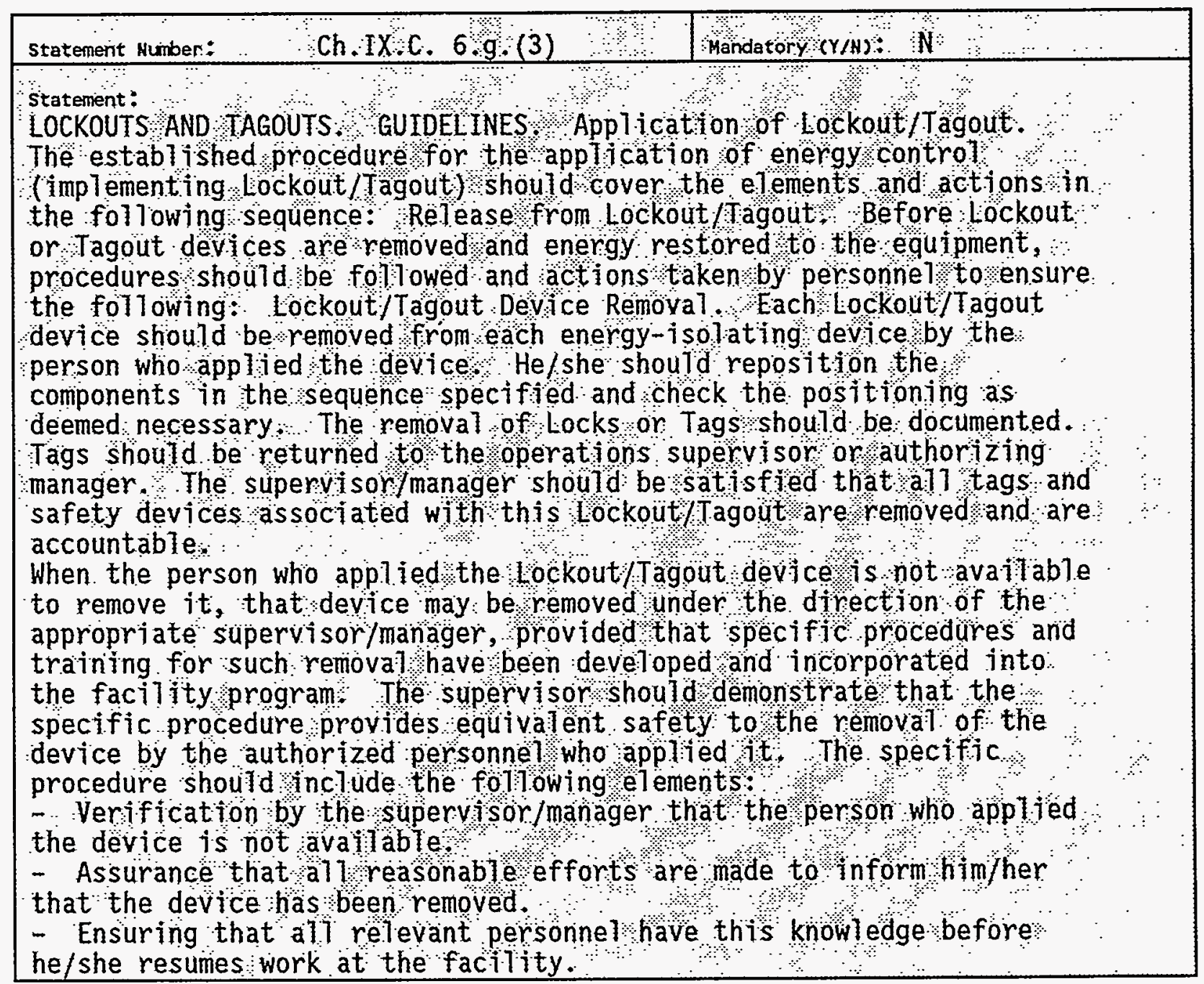


WHC-EP-0822

\section{ASSESSMENT DATA COLLECTION FORM}

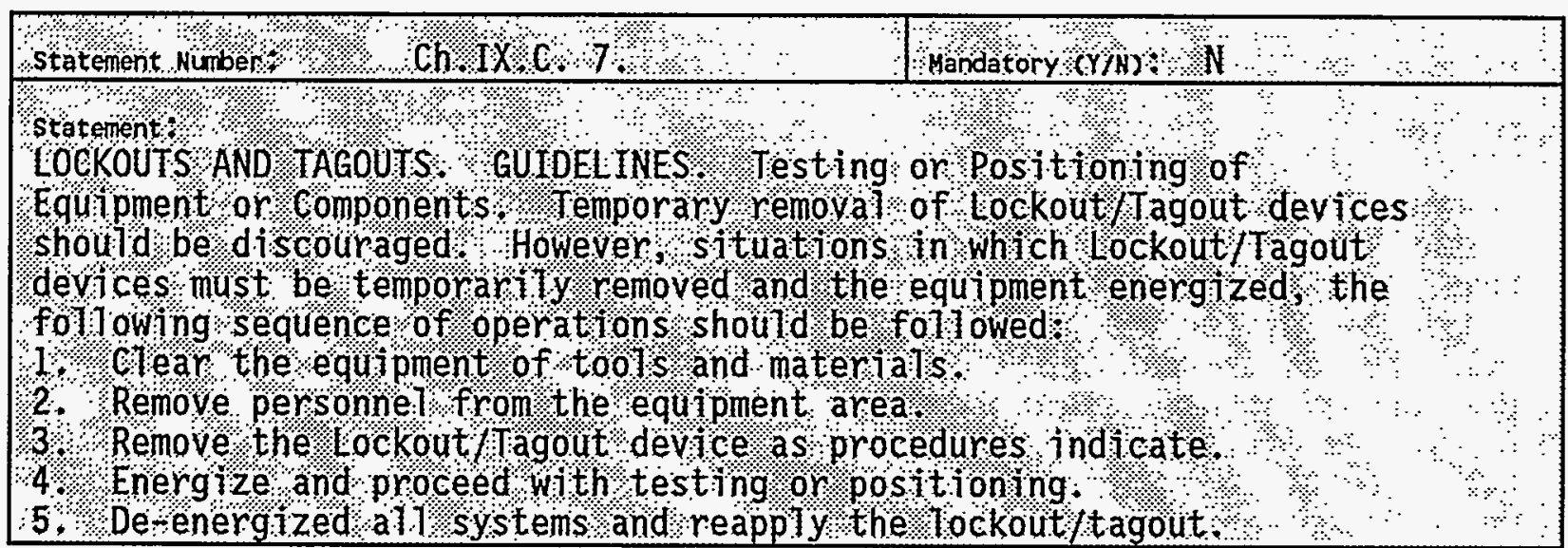

\begin{tabular}{|c|c|}
\hline statement & \\
\hline 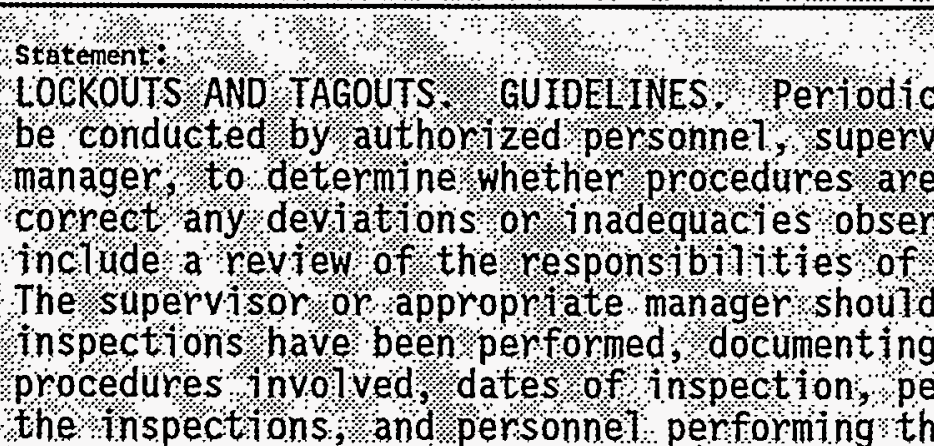 & 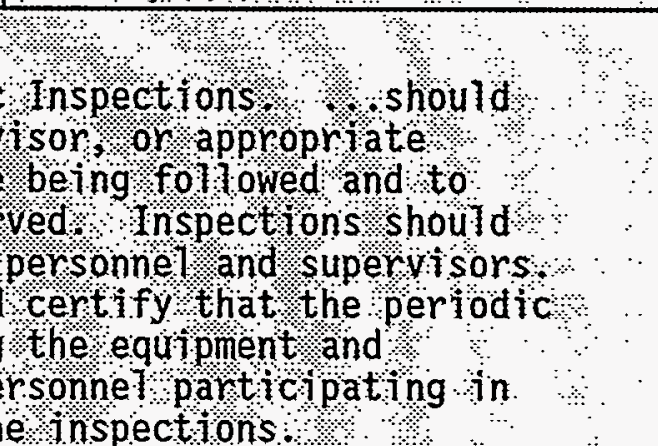 \\
\hline
\end{tabular}

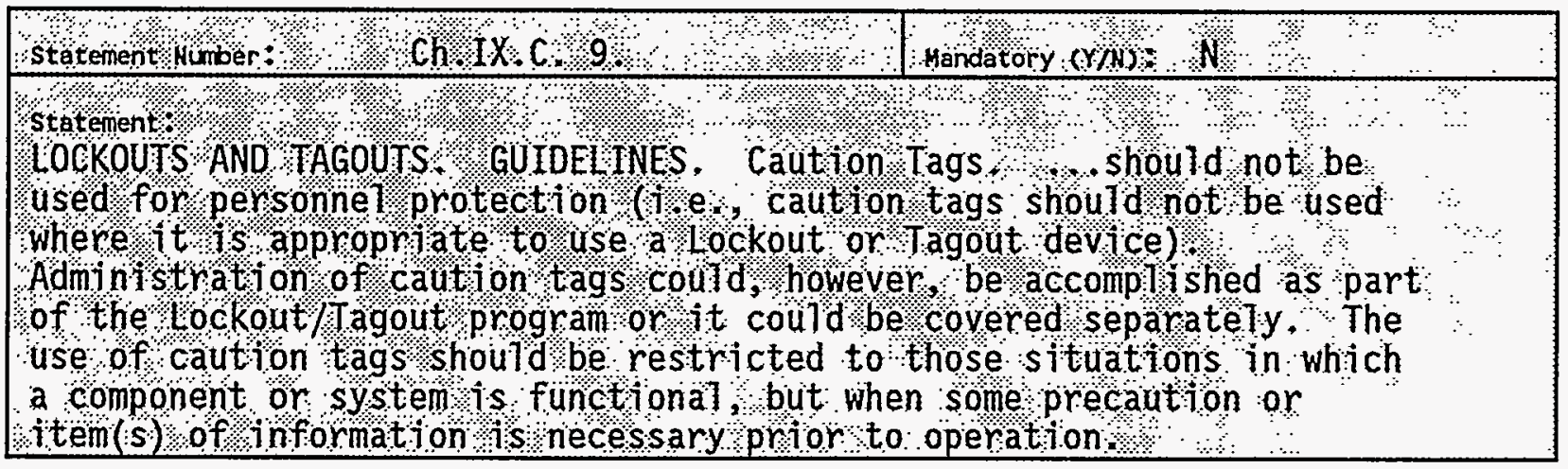


WHC-EP-0822

\section{ASSESSMENT DATA COLLECTION FORM}

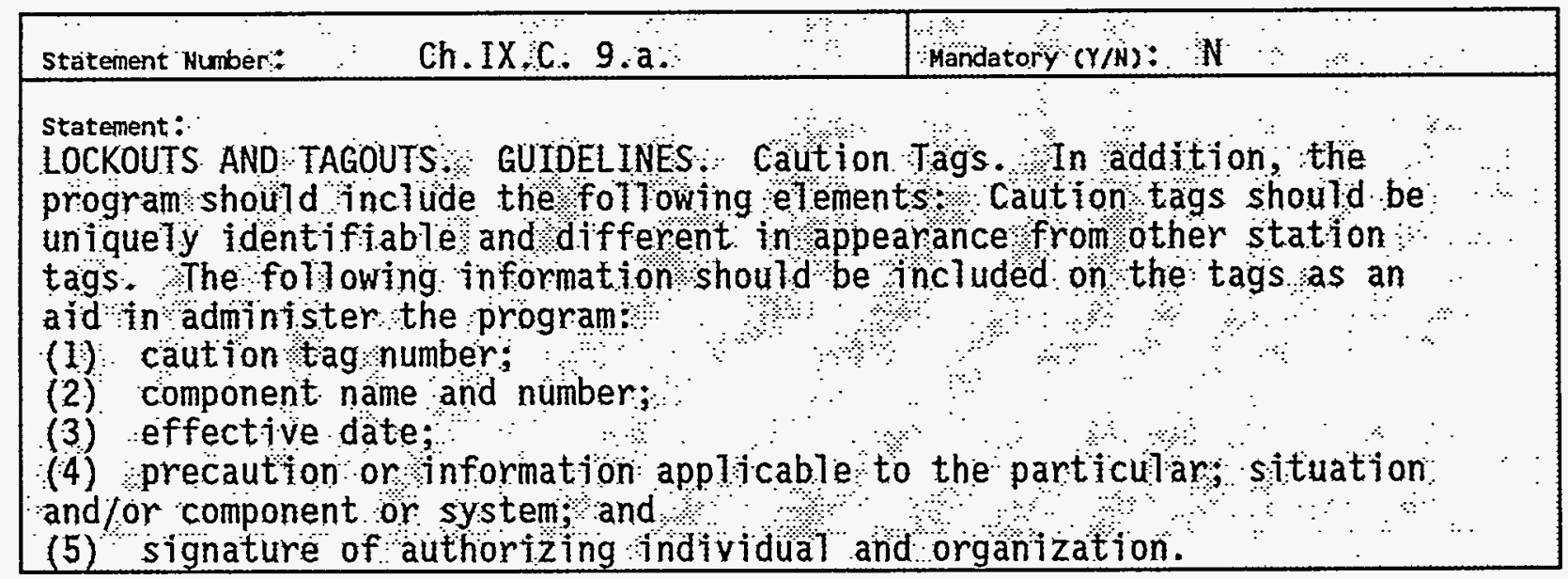

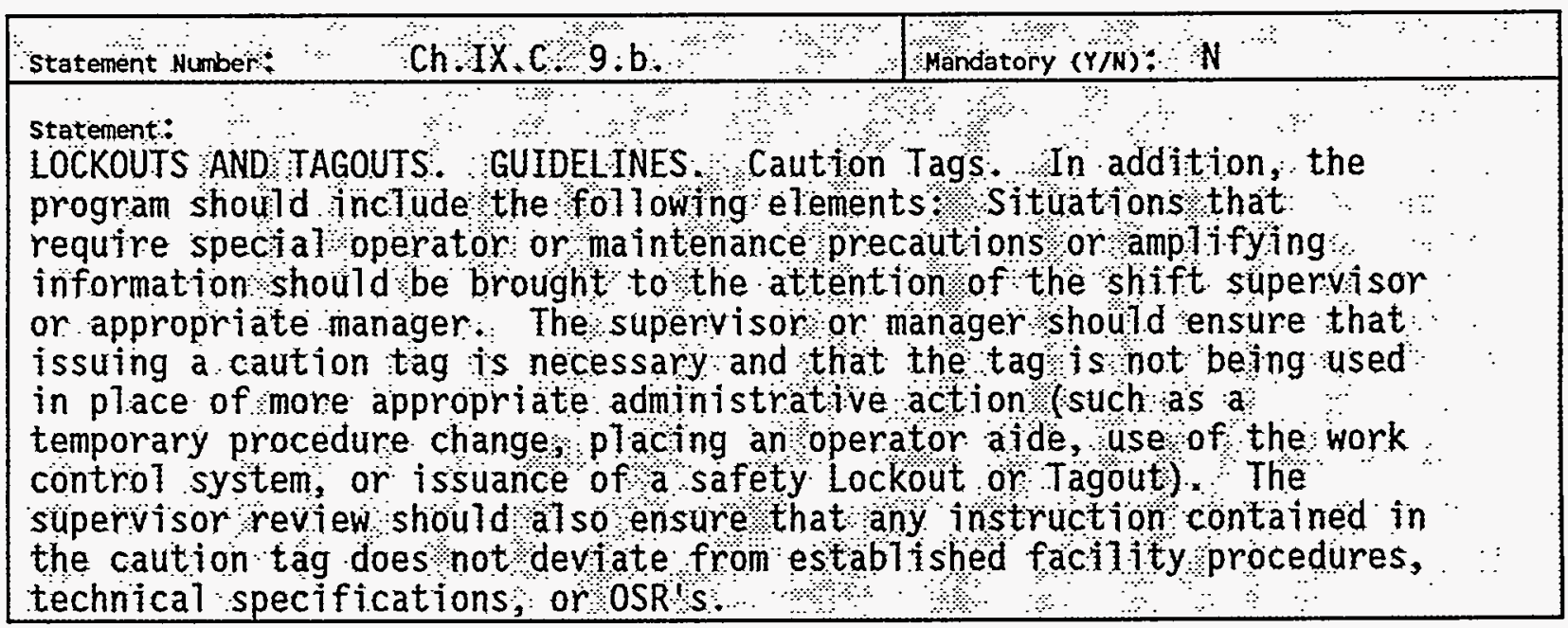




\section{ASSESSMENT DATA COLLECTION FORM}

\begin{tabular}{|c|c|}
\hline 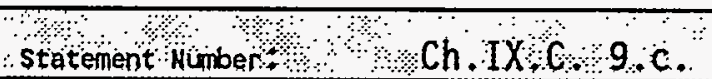 & Handatory $(Y / N)=N$ \\
\hline 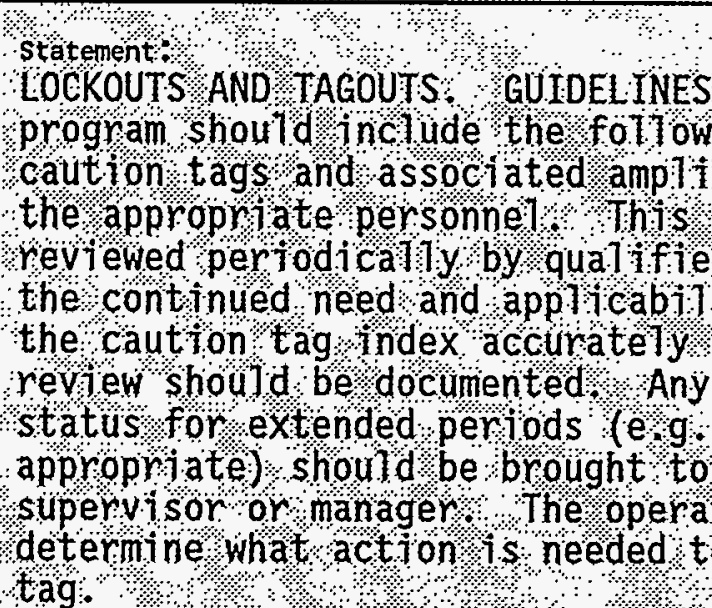 & 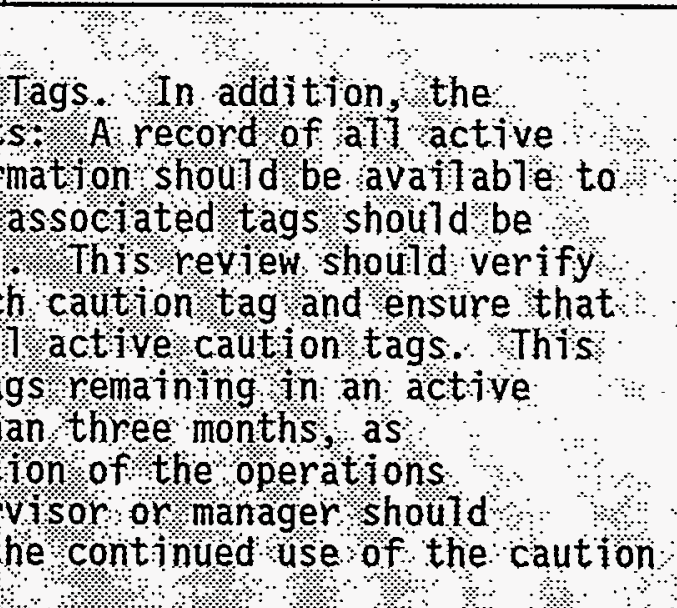 \\
\hline
\end{tabular}

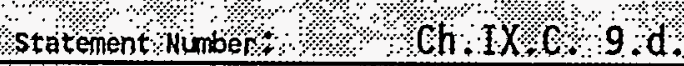

Mandator: oris: : N

statement.

LOCKOUTS AND TAGOUTS, GUIDEINES, Caution Tags. In addition, the program should include the following elements. Caution Tag Pl acement. \%. should be placed in such a way that they do not interfere with or obscure indications, switches, or other control devices but are. readfly apparent to an individuall prior to the operat ton of the tagged device. Placement of caut ton tags should be documented. 
WHC-EP-0822

ASSESSMENT DATA COLLECTION FORM

\begin{tabular}{|c|c|}
\hline Ch. IX.C. $10 \mathrm{a}$. & Mandatory (Y/N): N \\
\hline 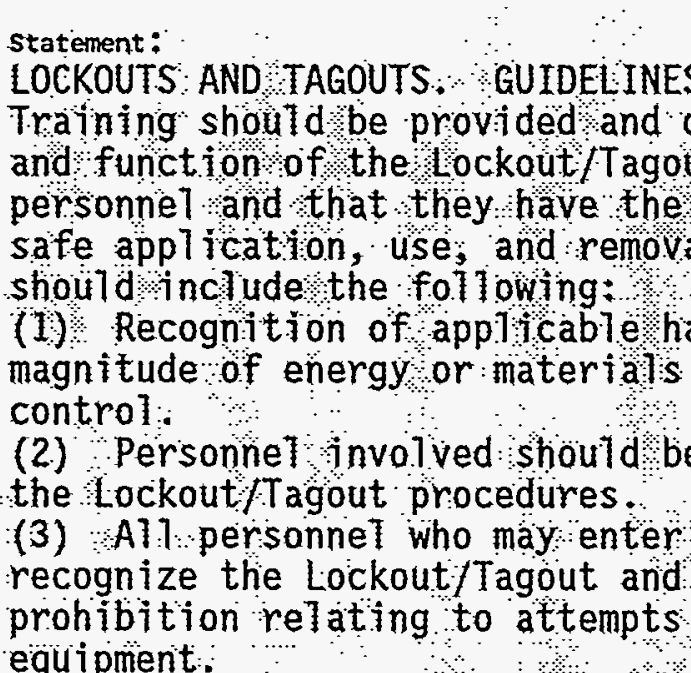 & 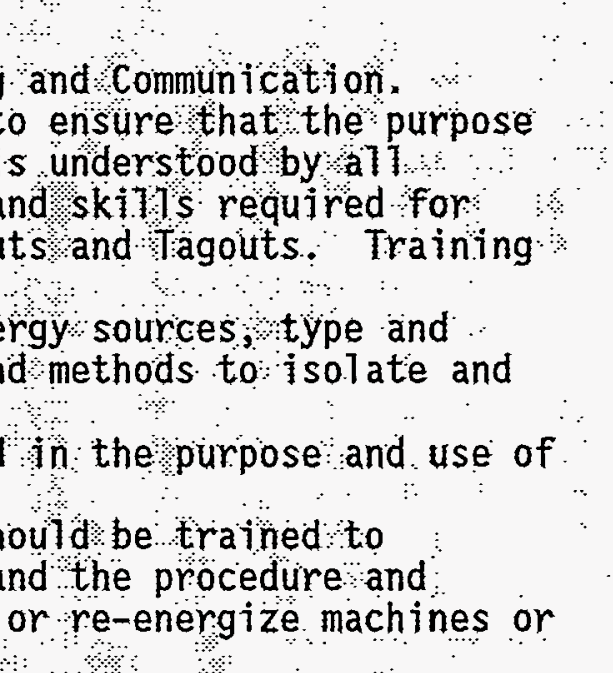 \\
\hline
\end{tabular}

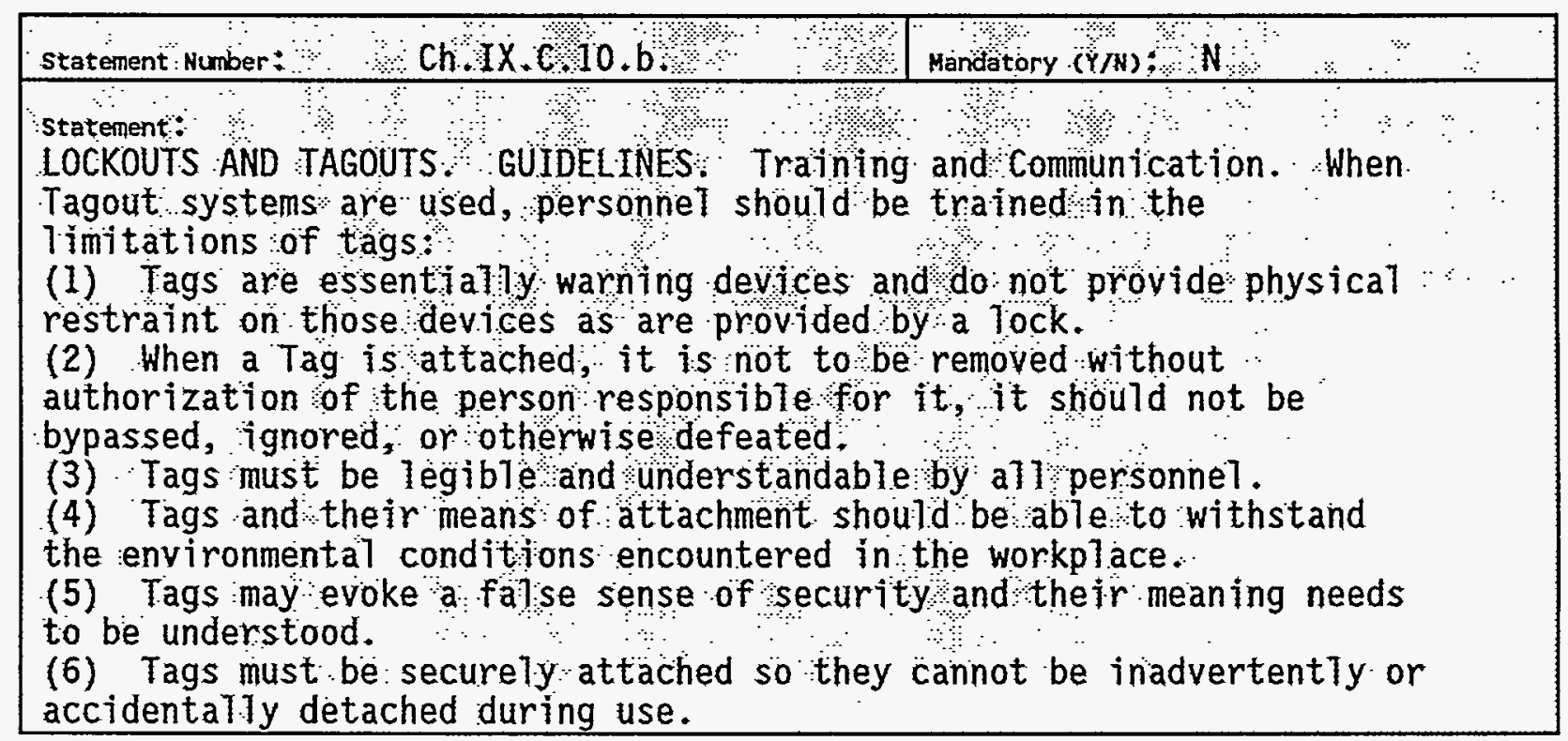




\section{ASSESSMENT DATA COLLECTION FORM}

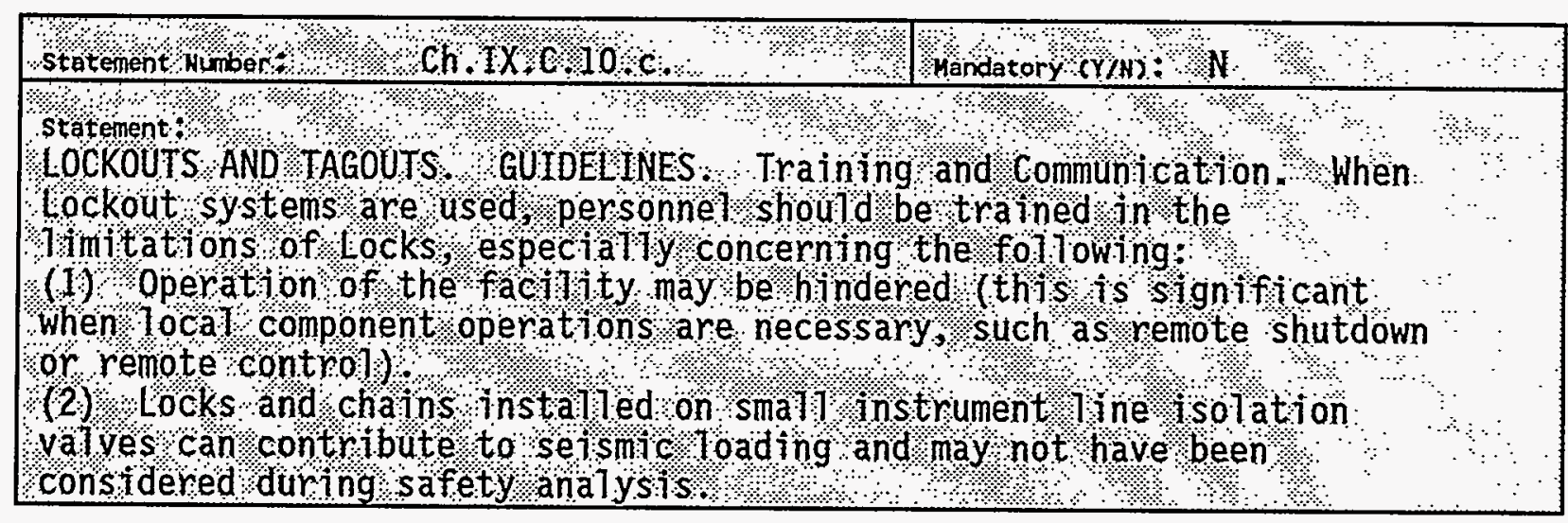

\begin{tabular}{|c|c|}
\hline \multicolumn{2}{|l|}{ statement Humber } \\
\hline 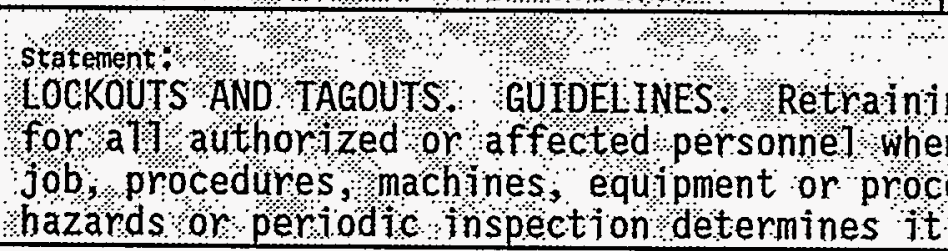 & 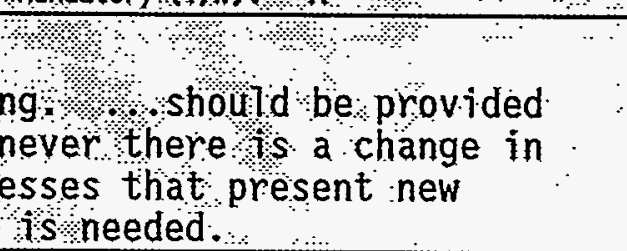 \\
\hline
\end{tabular}

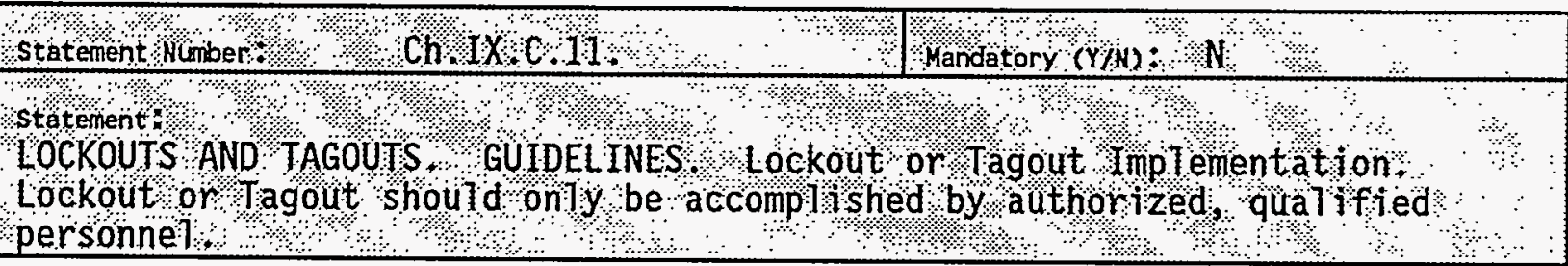

\begin{tabular}{|c|}
\hline 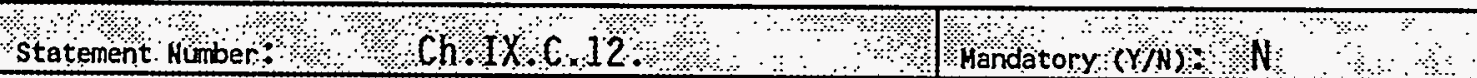 \\
\hline 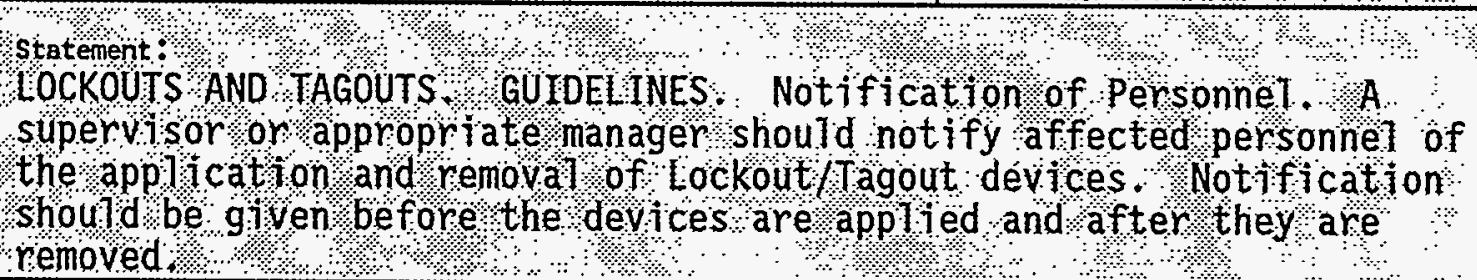 \\
\hline
\end{tabular}

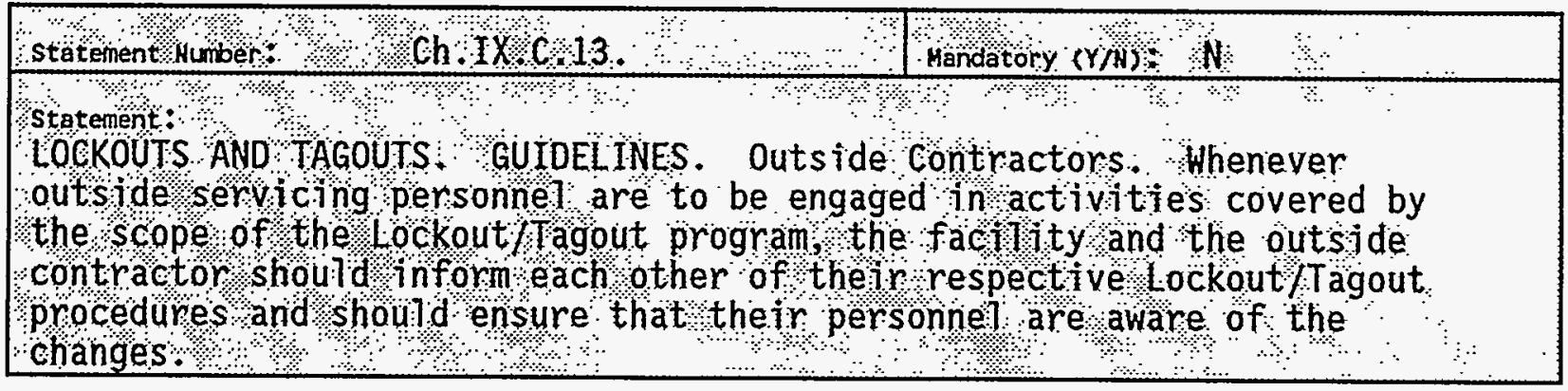


WHC-EP-0822

\section{ASSESSMENT DATA COLLECTION FORM}

\begin{tabular}{|c|c|}
\hline $\mathrm{Ch}$ IX:C 14 & Mandatory $(Y / N)$ N \\
\hline $\begin{array}{l}\text { Statement: } \\
\text { lOCKOUTS AND TAGOUTS GUTDELINES. Group } \\
\text { servicing or maintenance i sperformed by a } \\
\text { other group, they should utitize a procedur } \\
\text { equivalent safety provided by the personal }\end{array}$ & $\begin{array}{l}\text { ckouts or Tagouts. When } \\
\text { rew, craft odepartment, or } \\
\text { that w17 provide for } \\
\text { ockout or Tagout device; }\end{array}$ \\
\hline 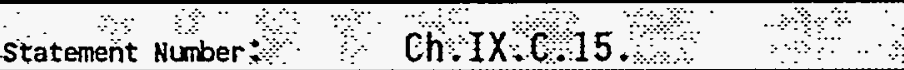 & Mandatory $(Y / N):$ N \\
\hline 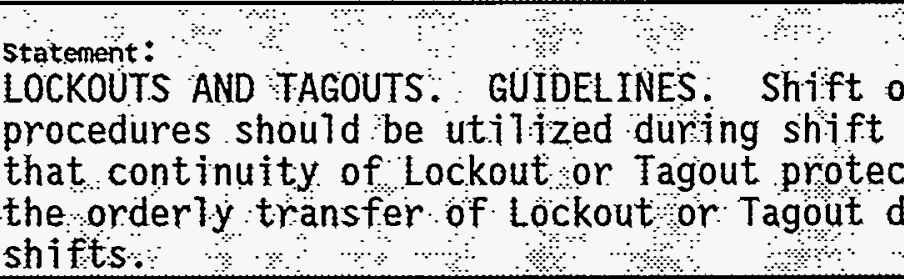 & $\begin{array}{l}\text { o } \\
\text { Personnel changes. Specific } \\
\text { foersonnef changes to ensure } \\
\text { ion including provis ion for } \\
\text { vices between personnel or }\end{array}$ \\
\hline
\end{tabular}

The following statements concerning "INDEPENDENT VERIFICATION" are N/A:

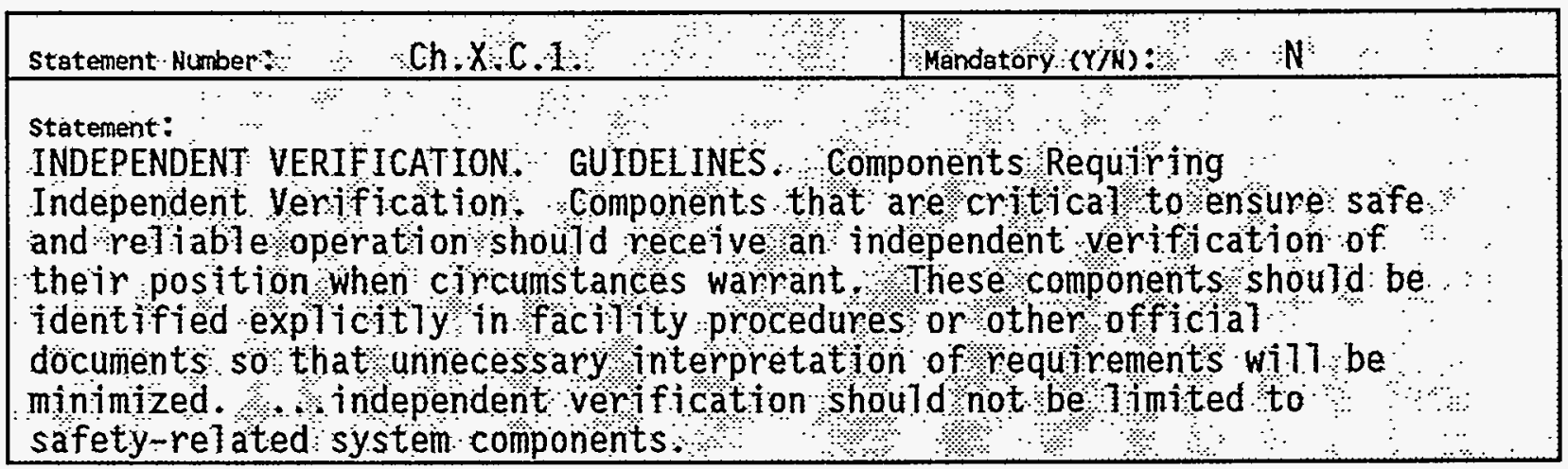


WHC-EP-0822

ASSESSMENT DATA COLLECTION FORM

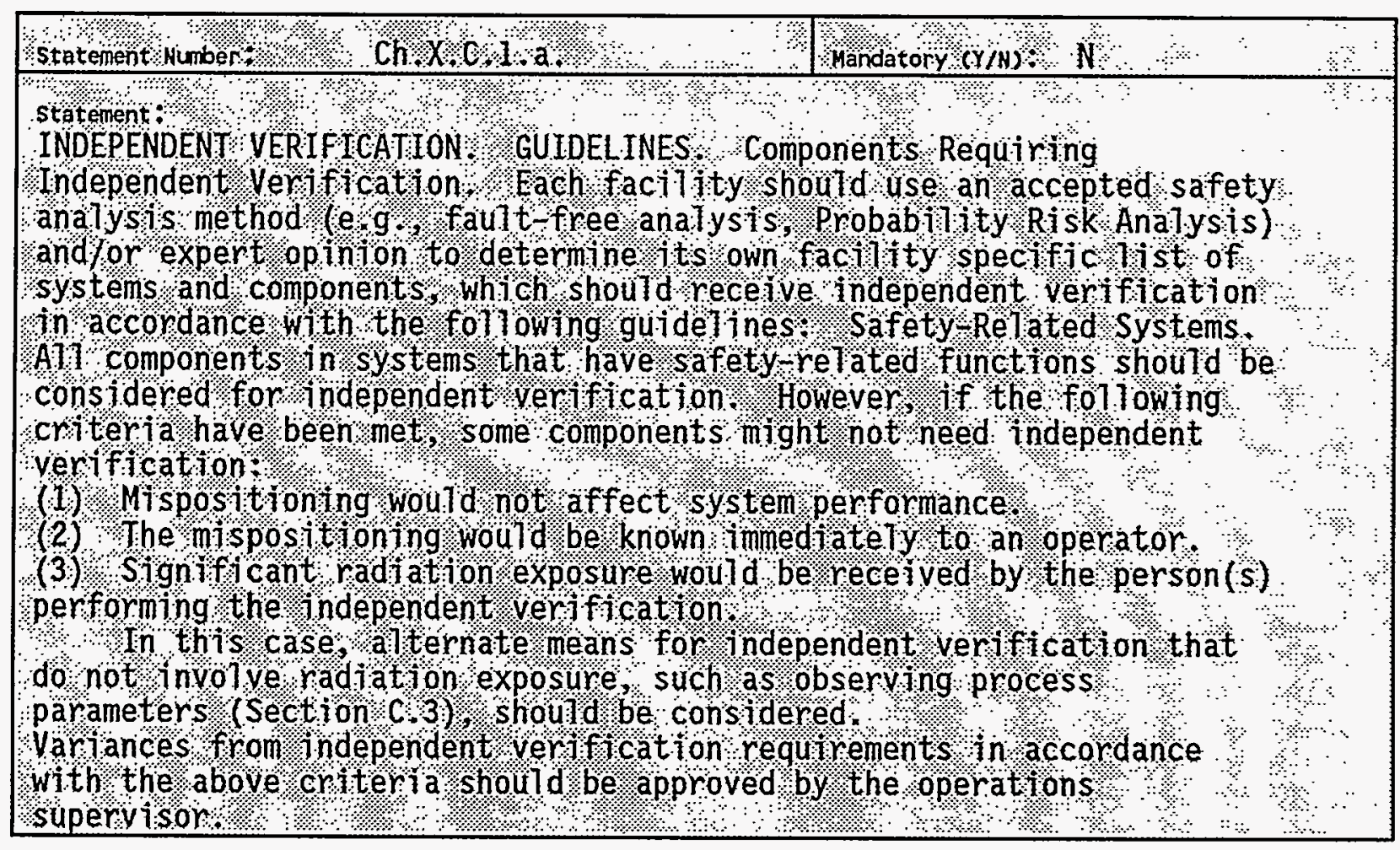

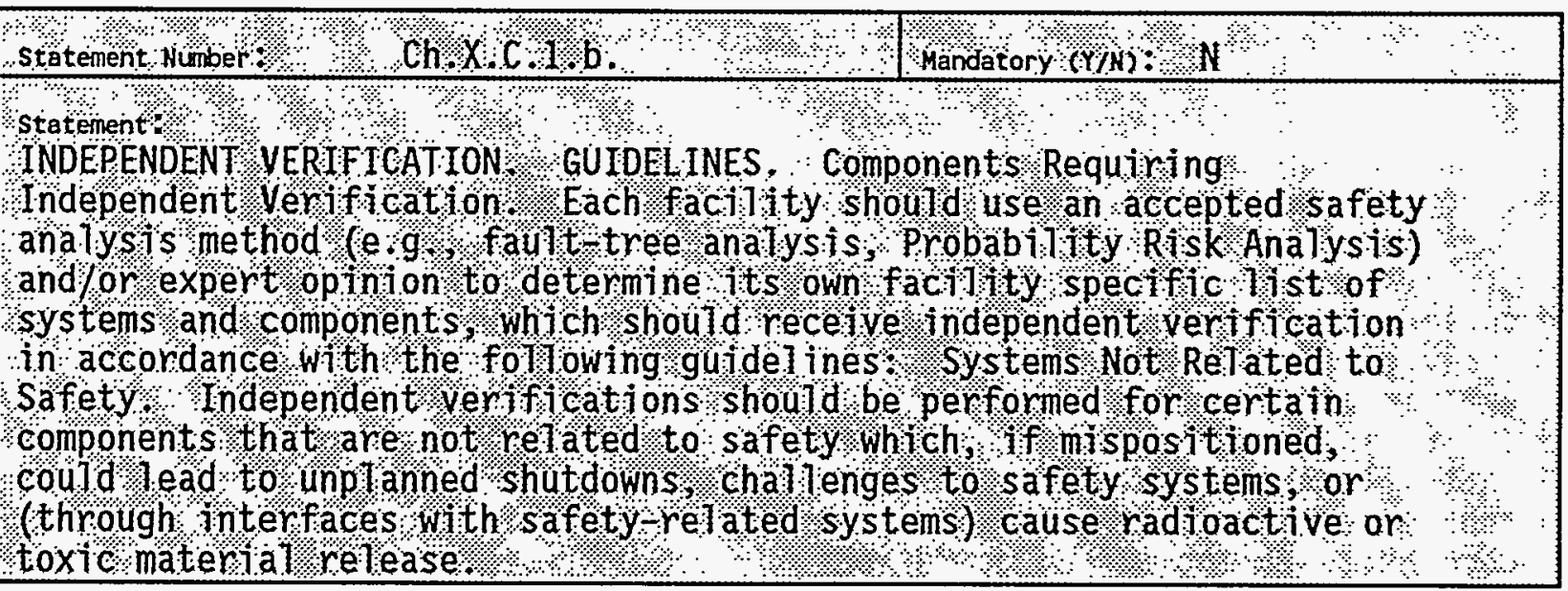


WHC-EP-0822

ASSESSMENT DATA COLLECTION FORM

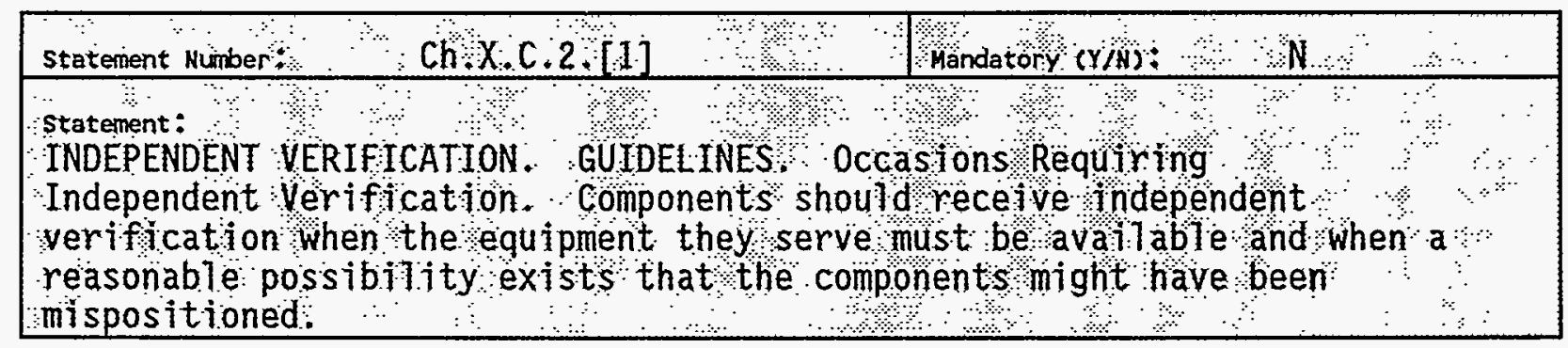

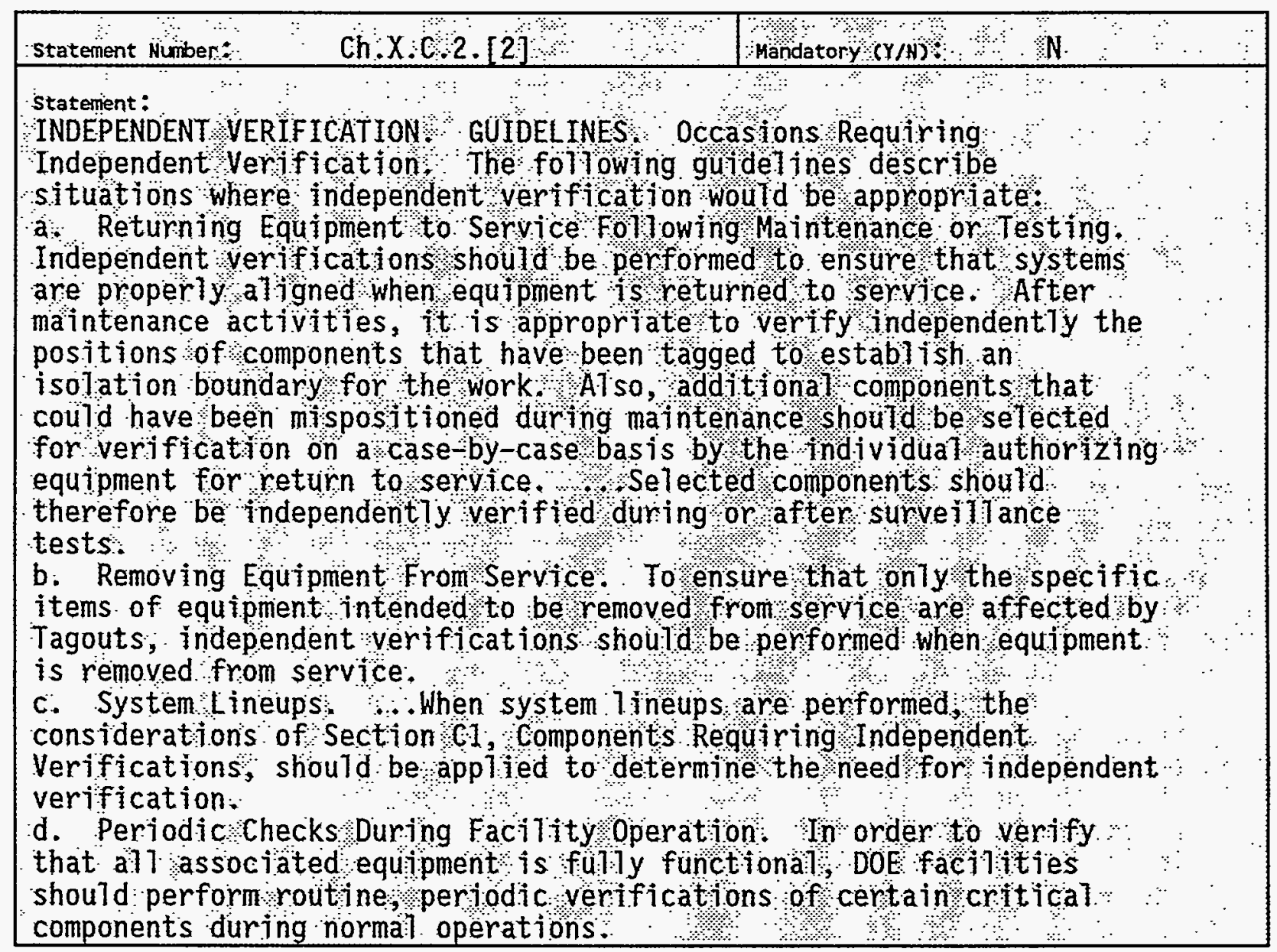


WHC-EP-0822

ASSESSMENT DATA COLLECTION FORM

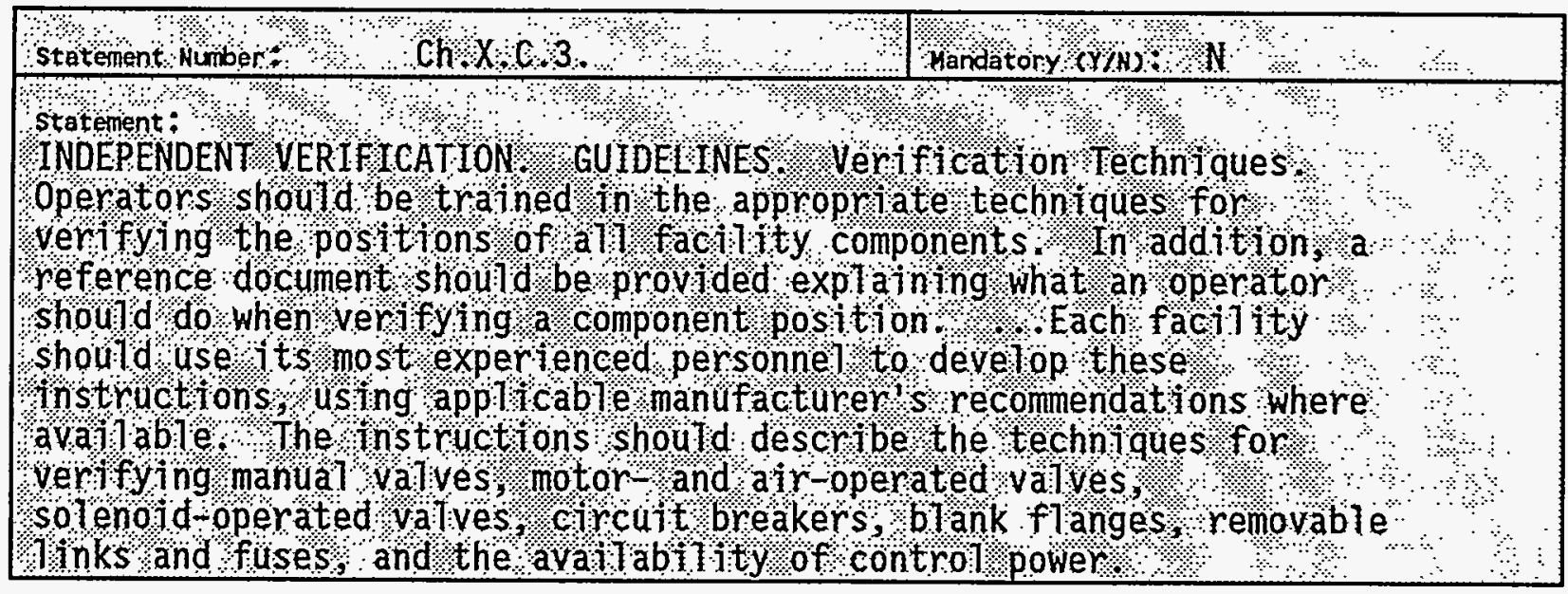

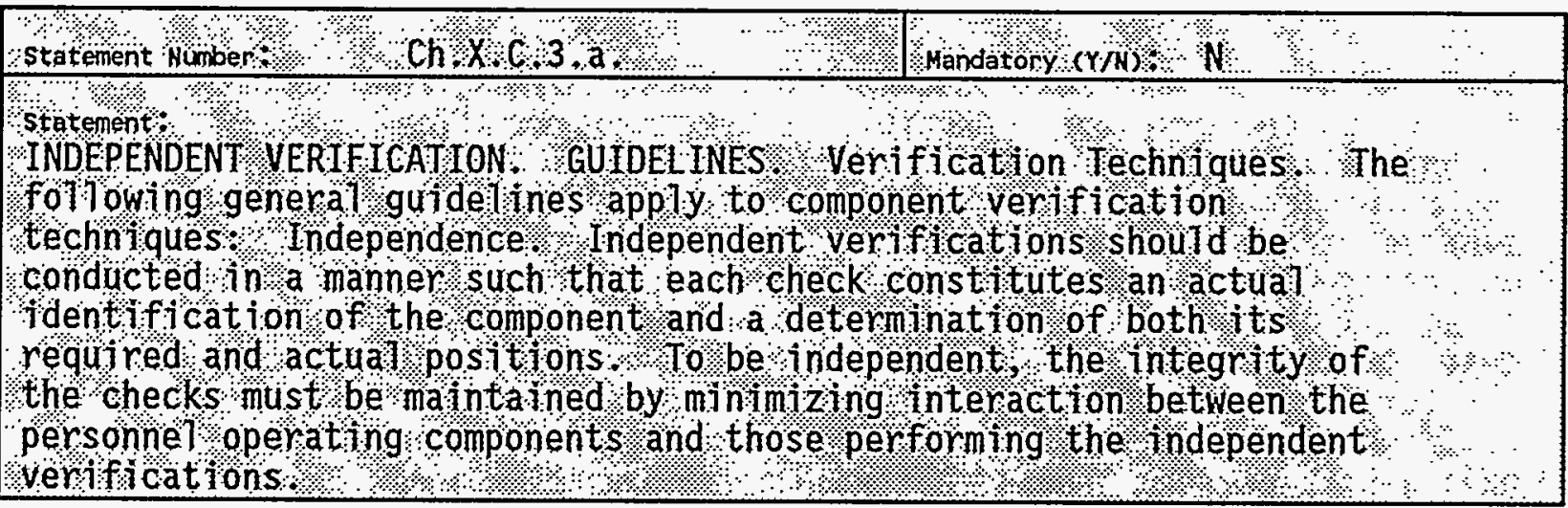

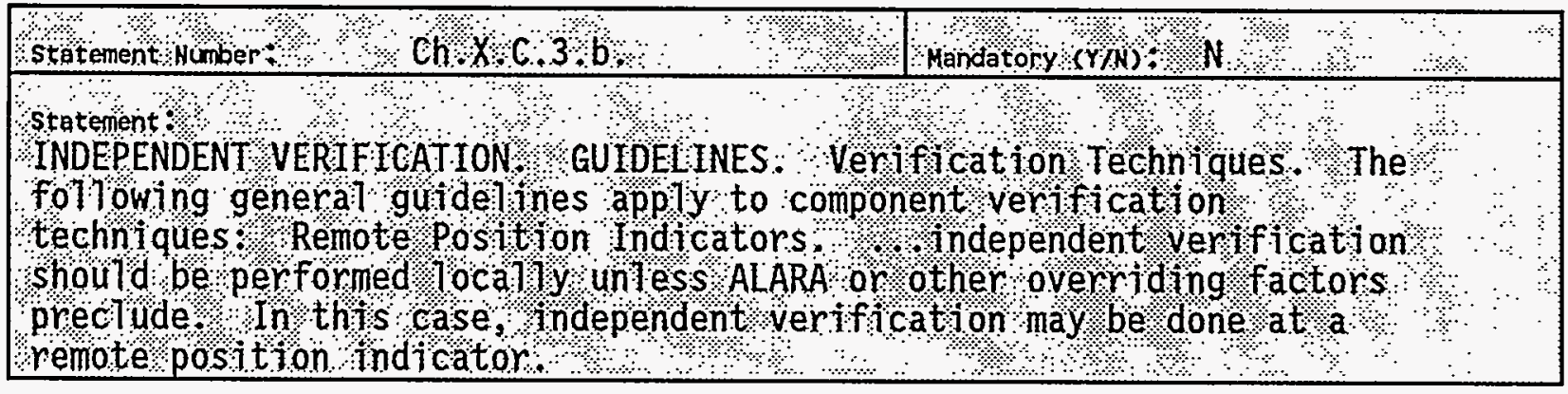


WHC-EP-0822

ASSESSMENT DATA COLLECTION FORM

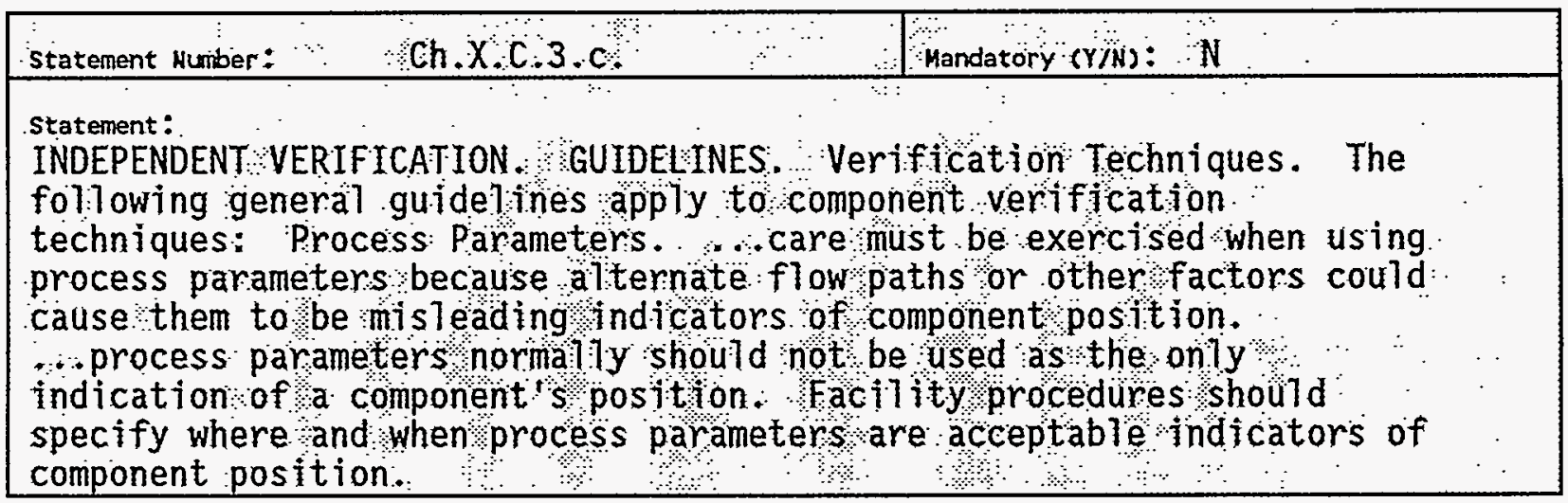

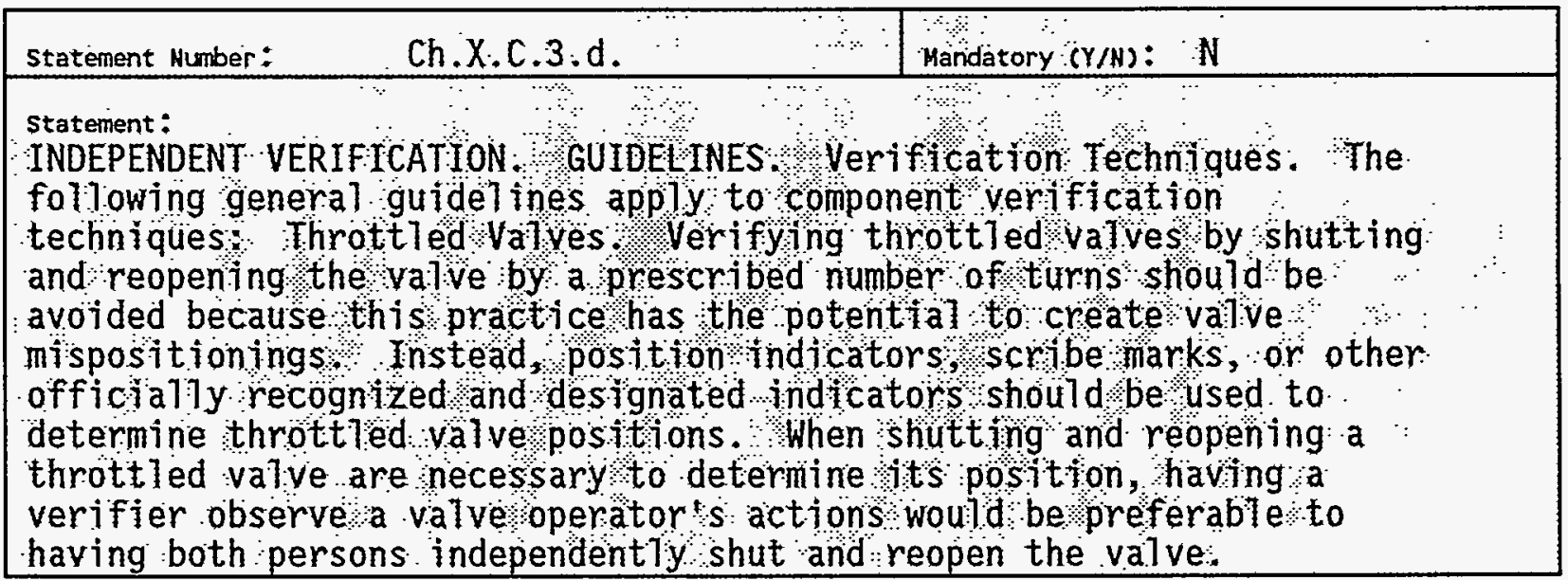

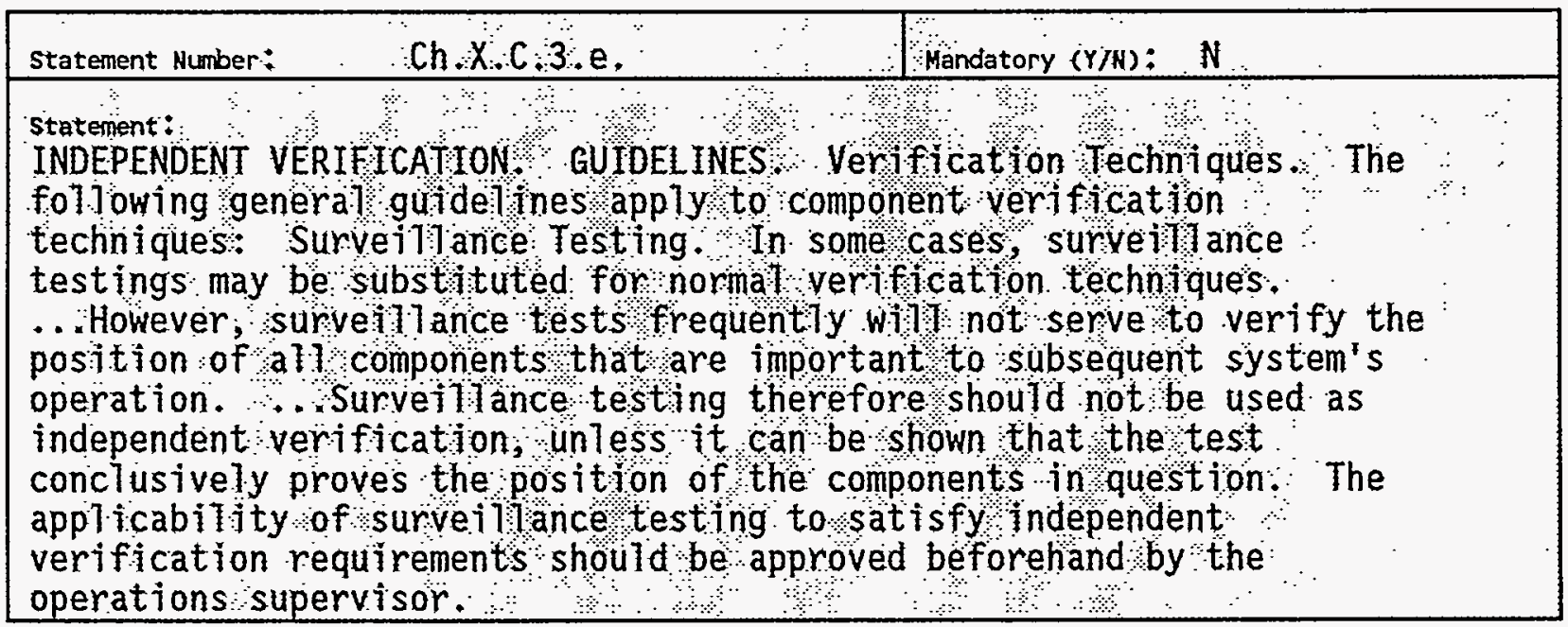




\section{ASSESSMENT DATA COLLECTION FORM}

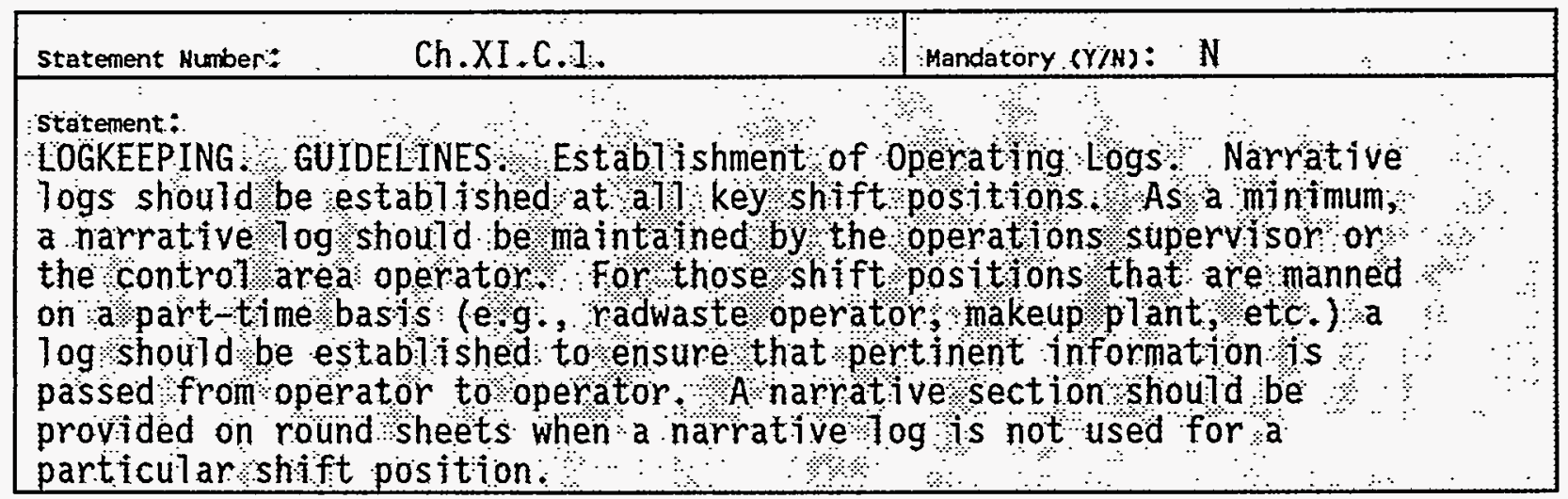

1.0 STATEMENT SATISFIED BASED ON IMPLEMENTING EVIDENCE (Y/N): NO

2.0 GENERAL DESCRIPTION OF EVIDENCE (DESCRIPTION OF NONCOMPLIANCE OR DEFICIENCY IF APPLICABLE):

The HASQAP does not address shift logs.

3.0 CORRECTIVE ACTION: 


\section{ASSESSHENT DATA COLLECTION FORM}

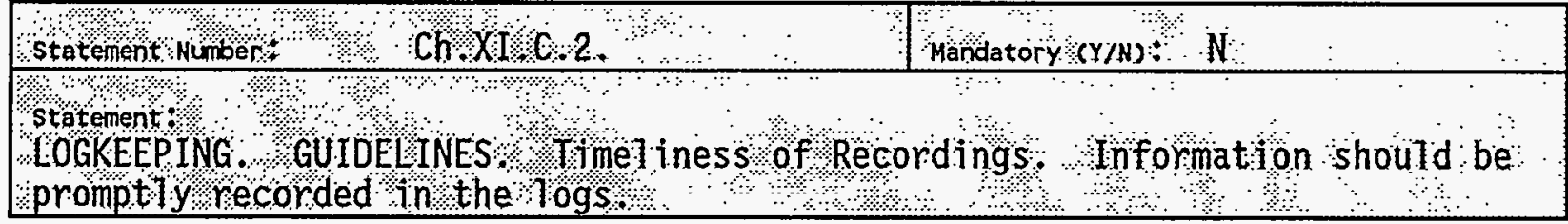

1.0 STATEMENT SATISFIED BASED ON IMPLEMENTING EVIDENCE (Y/N): NO

2.0 GENERAL DESCRIPTION OF EVIDENCE (DESCRIPTION OF NONCOMPLIANCE OR DEFICIENCY IF APPLICABLE):

The HASQAP does not address shift logs.

3.0 CORRECTIVE ACTION: 
WHC-EP-0822

\section{ASSESSHENT DATA COLLECTION FORM}

\begin{tabular}{|c|}
\hline \% Mandatory $(Y / N)=\ldots$ \\
\hline 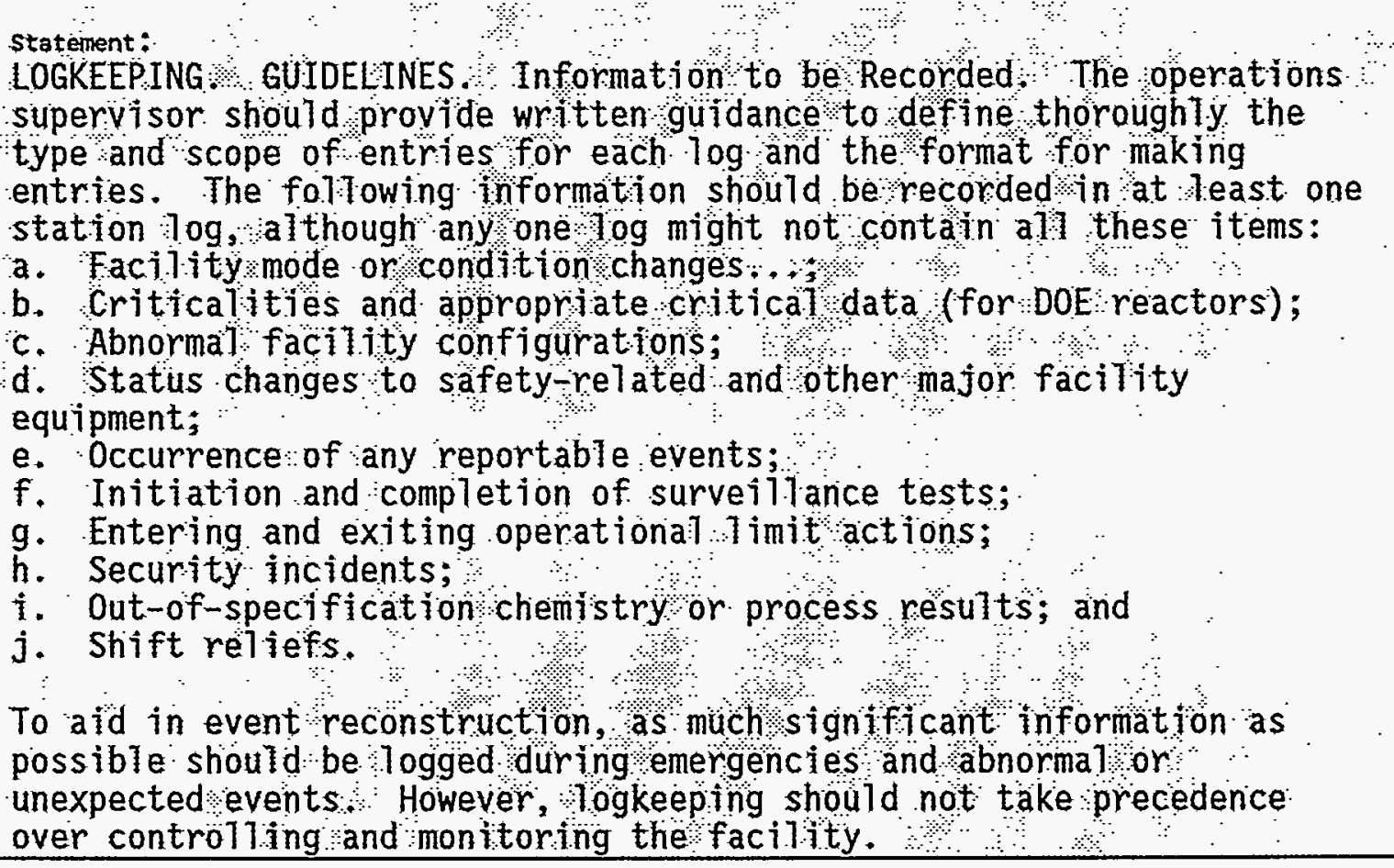 \\
\hline
\end{tabular}

1.0 Statement SATISFied based on IMPLementing EVIDENCE (Y/N): NO

2.0 GENERAL DESCRIPTION OF EVIDENCE (DESCRIPTION OF NONCOMPLIANCE OR DEFICIENCY IF APPLICABLE):

The HASQAP does not address the intent of this statement.

3.0 CORRECTIVE ACTION: 
WHC-EP-0822

\section{ASSESSMENT DATA COLLECTION FORM}

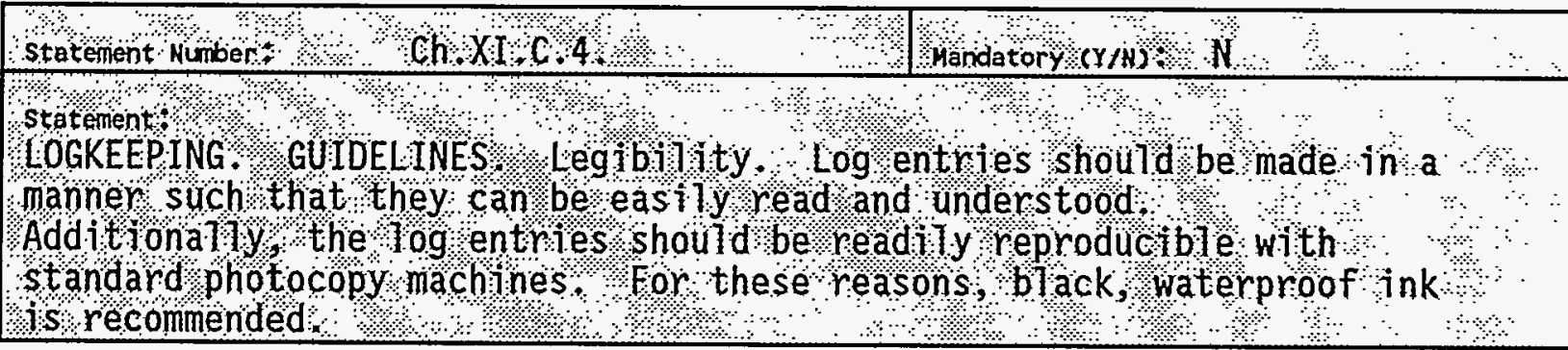

1.0 STATEMENT SATISFIED BASED ON IMPLEMENTING EVIDENCE $(Y / N)$ N NO

2.0 GENERAL DESCRIPTION OF EVIDENCE (DESCRIPTION OF NONCOMPLIANCE OR DEFICIENCY IF APPLICABLE):

This statement is not addressed in the HASQAP.

3.0 CORRECTIVE ACTION: 
WHC-EP-0822

\section{ASSESSMENT DATA COLLECTION FORM}

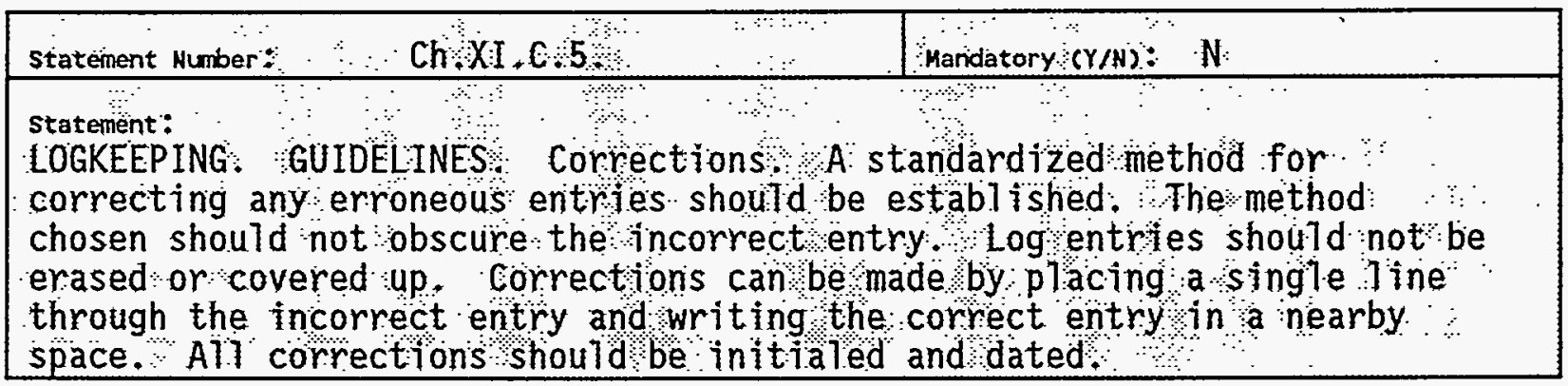

1.0 STATEMENT SATISFIED BASED ON IMPLEMENTING EVIDENCE (Y/N): NO

2.0 GENERAL DESCRIPTION OF EVIDENCE (DESCRIPTION OF NONCOMPLIANCE OR DEFICIENCY IF APPLICABLE):

The HASQAP does not address corrections to logs.

3.0 CORRECTIVE ACTION: 
WHC-EP-0822

\section{ASSESSMENT DATA COLLECTION FORM}

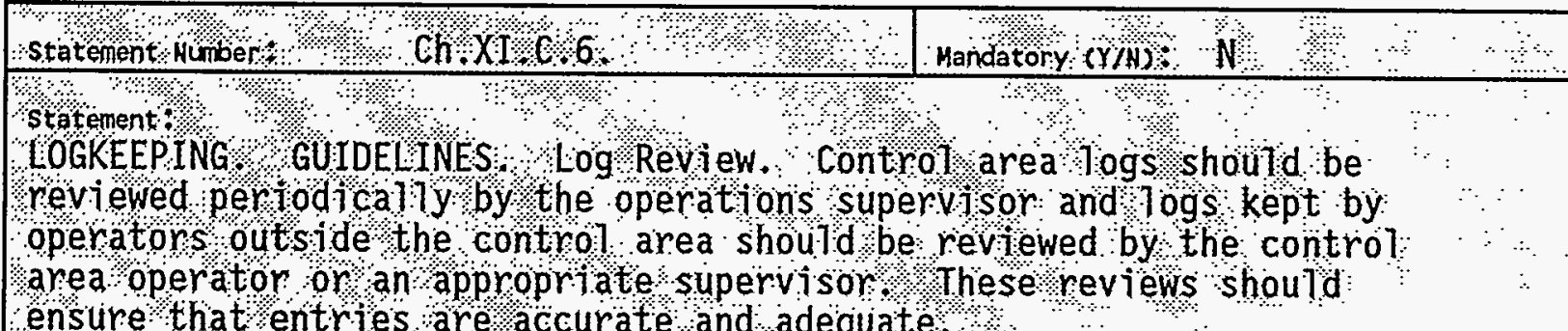
ensure that entries are accurate and adequate

1.0 STATEMENT SATISFIED BASED ON IMPLEMENTING EVIDENCE (Y/N): NO

2.0 GENERAL DESCRIPTION OF EVIDENCE (DESCRIPIION OF NONCOMPLIANCE OR DEFICIENCY IF APPLICABLE):

The HASQAP does not address the intent of this statement.

3.0 CORRECTIVE ACTION: 
WHC-EP-0822

\section{ASSESSMENT DATA COLLECTION FORM}

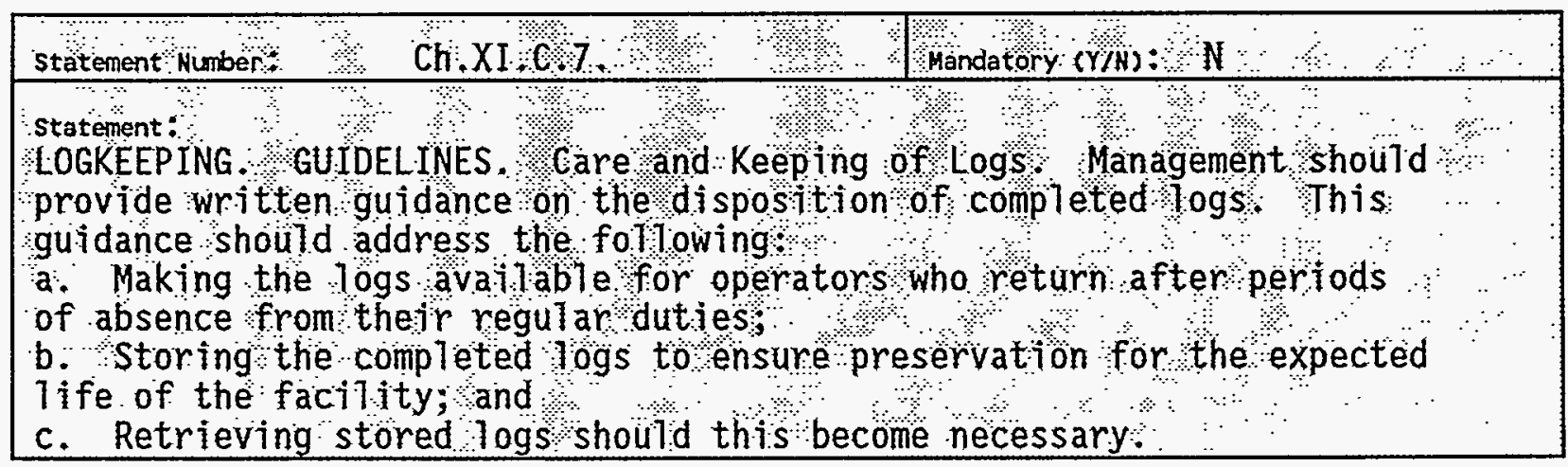

1.0 STATEMENT SATISFIED BASED ON IMPLEMENTING EVIDENCE (Y/N): NO

2.0 GENERAL DESCRIPTION OF EVIDENCE (DESCRIPTION OF NONCOMPLIANCE OR DEFICIENCY IF APPLICABLE):

The HASQAP does not address this statement.

3.0 CORRECTIVE ACTION: 
WHC-EP-0822

ASSESSMENT DATA COLLECTION FORM

\section{The following statements concerning "OPERATIONS TURNOVER" are N/A:}

\begin{tabular}{|c|c|}
\hline 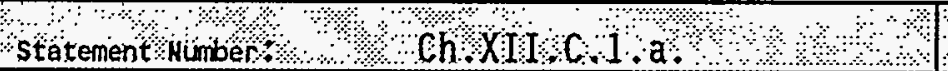 & Mandatory $(Y / N)$ ) N \\
\hline 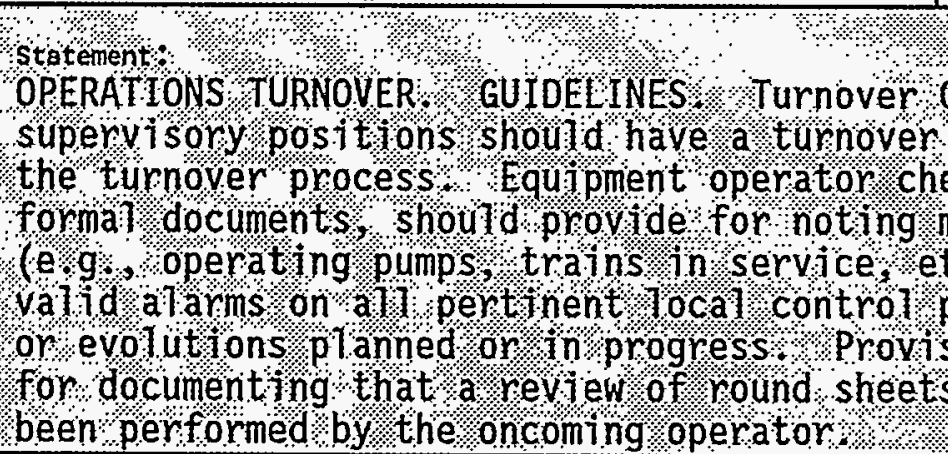 & $\begin{array}{l}\text { Checklists As a minin } \\
\text { checklist to be used } \\
\text { ecklists }\end{array}$ \\
\hline
\end{tabular}


WHC-EP-0822

ASSESSMENT DATA COLLECTION FORM

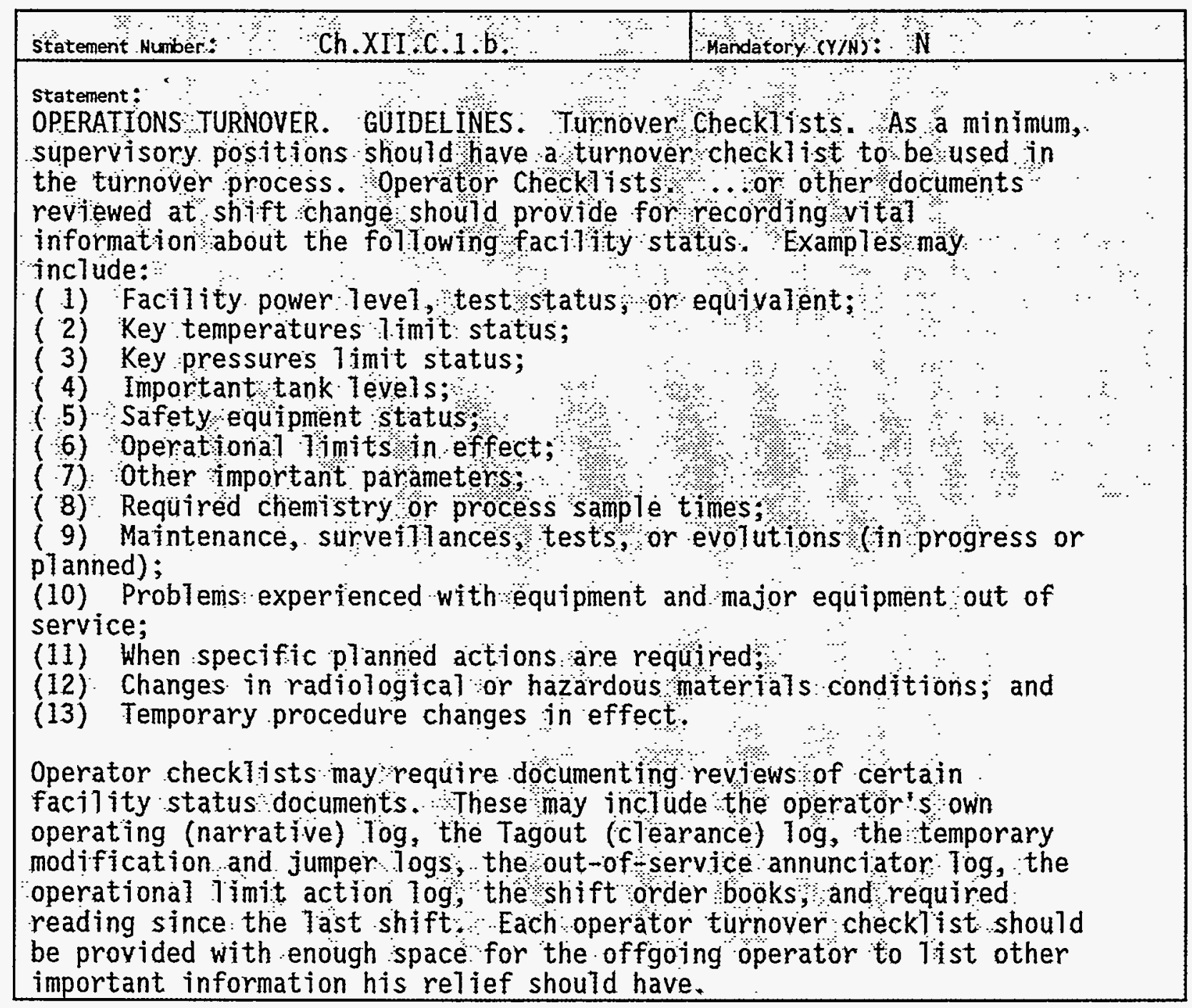


WHC-EP-0822

\section{ASSESSMENT DATA COLLECTION FORM}

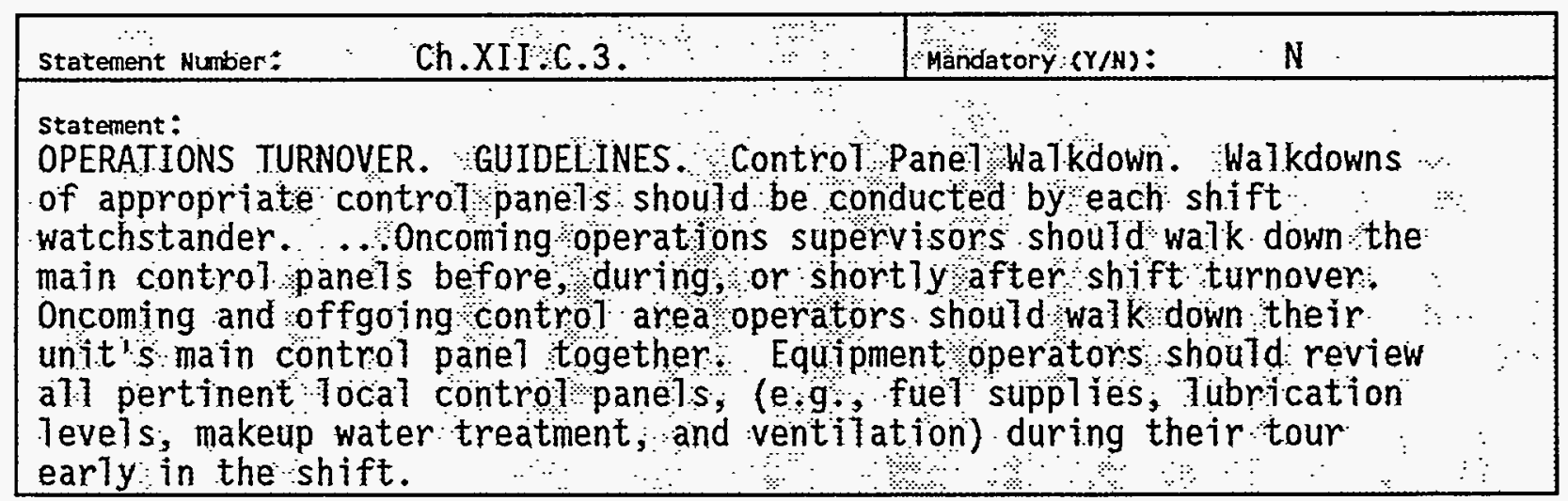

\begin{tabular}{|c|c|}
\hline Ch:XII.CH 4 & Mandatory $(Y / N)=$ \\
\hline 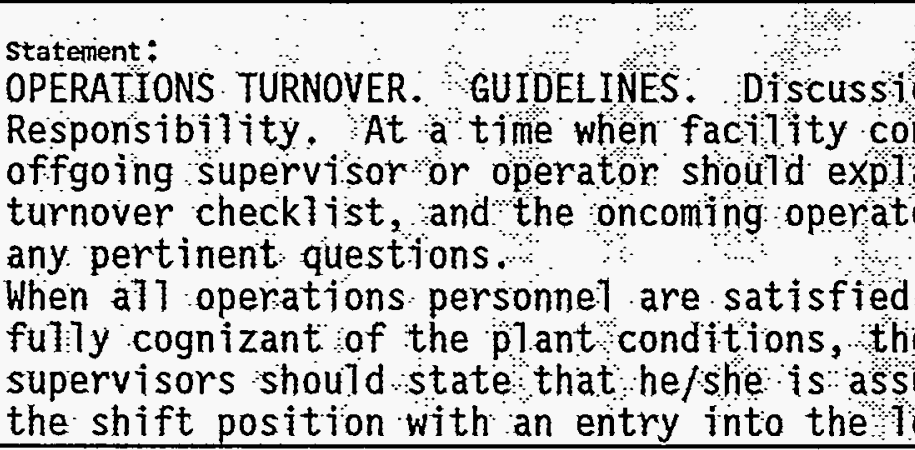 & $\begin{array}{l}\text { and Exchange of } \\
\text { ditions are stable, the } \\
\text { in ali items noted on the } \\
\text { r or supervisor should ask } \\
\text { that the oncoming crew is } \\
\text { oncoming operators and } \\
\text { iming responsibility for } \\
\text { g. }\end{array}$ \\
\hline
\end{tabular}

\begin{tabular}{|c|c|}
\hline$\therefore$ ch.XIIC.5 & Mandatory $(Y / N)$ \\
\hline $\begin{array}{l}\text { Statement: } \\
\text { OPERATIONS TURNovER a guDELLINES } \\
\text { conducted by the operat ons supe } \\
\text { conducted after he has accepted } \\
\text { briefing shoutd include a review } \\
\text { equipment, and evolutions in pro } \\
\text { add thon to shift operators, per } \\
\text { contractors, vendors, and test } \\
\text { when their act ivities can direct }\end{array}$ & 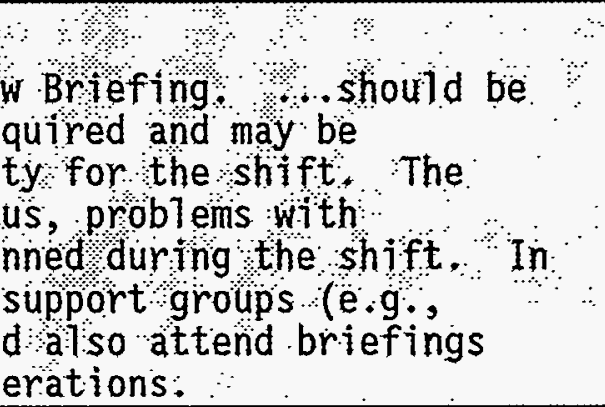 \\
\hline
\end{tabular}


WHC-EP-0822

ASSESSMENT DATA COLLECTION FORM

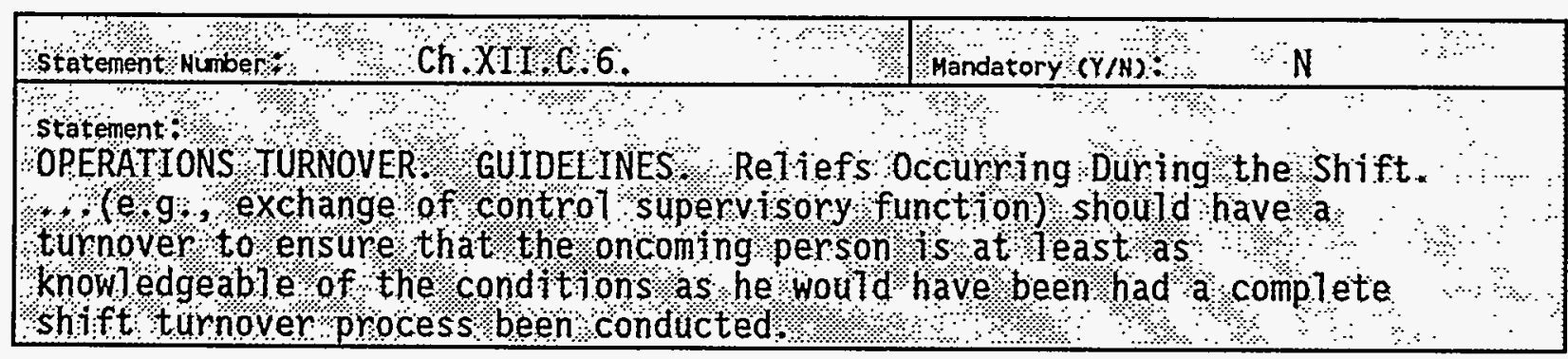

\section{The above statements concerning "OPERATIONS TURNOVER" are N/A:}


WHC-EP-0822

ASSESSMENT DATA COLLECTION FORM

\section{The following statements concerning "OPERATIONS ASPECTS OF FACILITY CHEMISTRY AND UNIQUE PROCESSES" are N/A:}

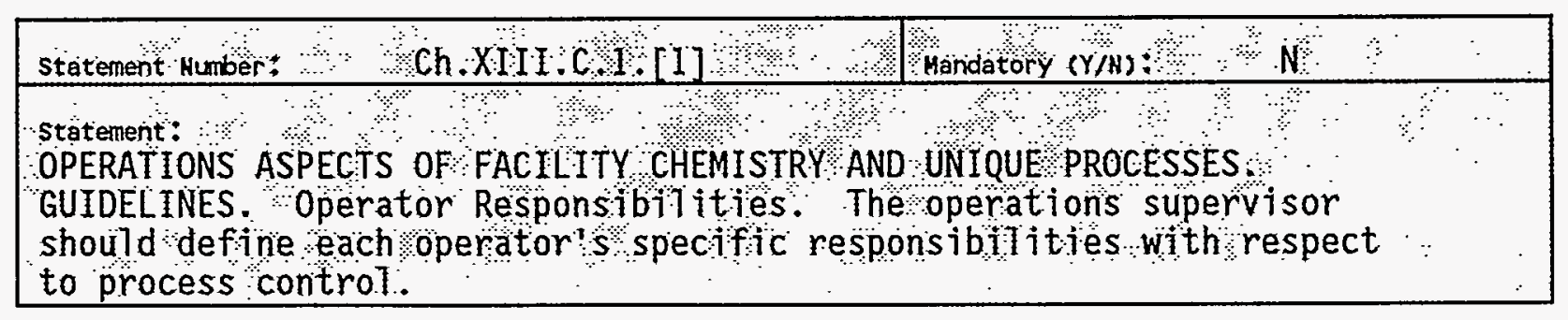

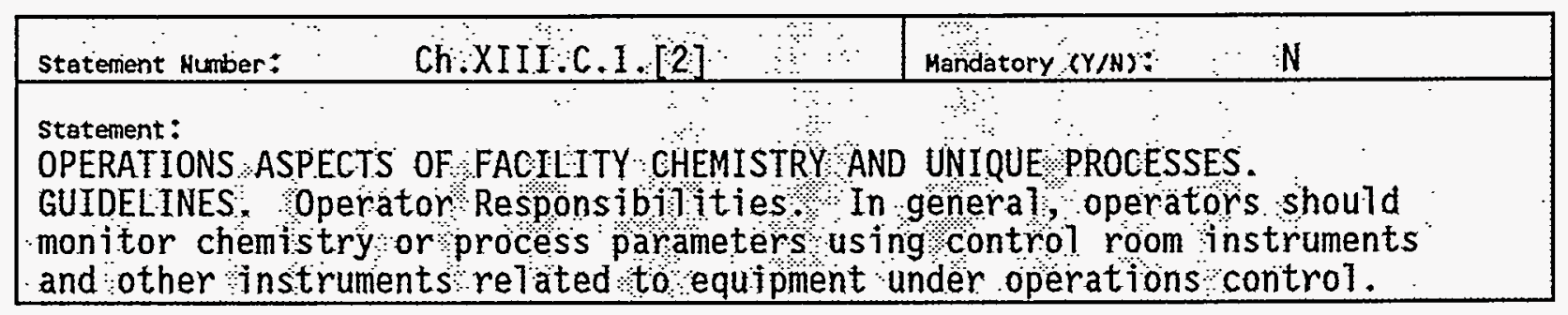

\begin{tabular}{|c|c|}
\hline Ch XIII CI. [ 3$]$ & Mandatory $(Y / N): \cdots$ \\
\hline $\begin{array}{l}\text { Statement: } \\
\text { OPERATIONS ASPECTS OF FACILITY CHEMIS } \\
\text { GUIDELINES. Operator Responsibilitie } \\
\text { recognize out-of-specification cond it } \\
\text { familiar with correct ive act ons as } \\
\text { problems. }\end{array}$ & $\begin{array}{l}\text { UNIQUE PROCESSES } \\
\text { rators should be able to } \\
\text { adverse trends and be } \\
\text { with chemistryor process }\end{array}$ \\
\hline
\end{tabular}

\begin{tabular}{|c|c|c|}
\hline 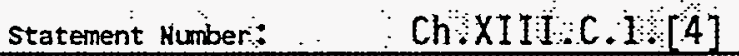 & Hendatory $(Y / N)$ : & $N$ \\
\hline $\begin{array}{l}\text { Statement: } \\
\text { OPERATIONS ASPECTS OF FACILITY CHEP } \\
\text { GUIDELINES. Operator Responsibilit } \\
\text { advised by chemistry or techinical }\end{array}$ & $\begin{array}{l}\text { STRY AND UNIQUE PROCES } \\
\text { es. Operators should } \\
\text { ocess department perso }\end{array}$ & $\begin{array}{l}\text { SES } \\
\text { consult and be }\end{array}$ \\
\hline
\end{tabular}


WHC-EP-0822

\section{ASSESSMENT DATA COLLECTION FORM}

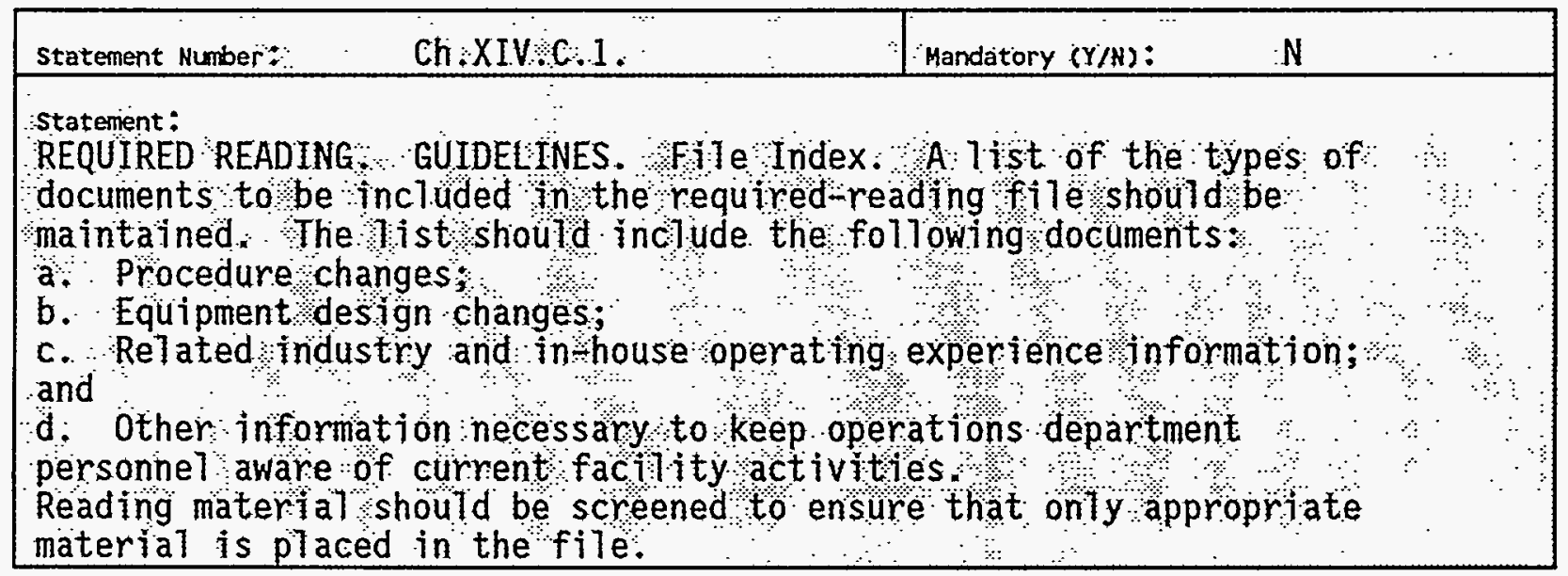

\section{N/A}

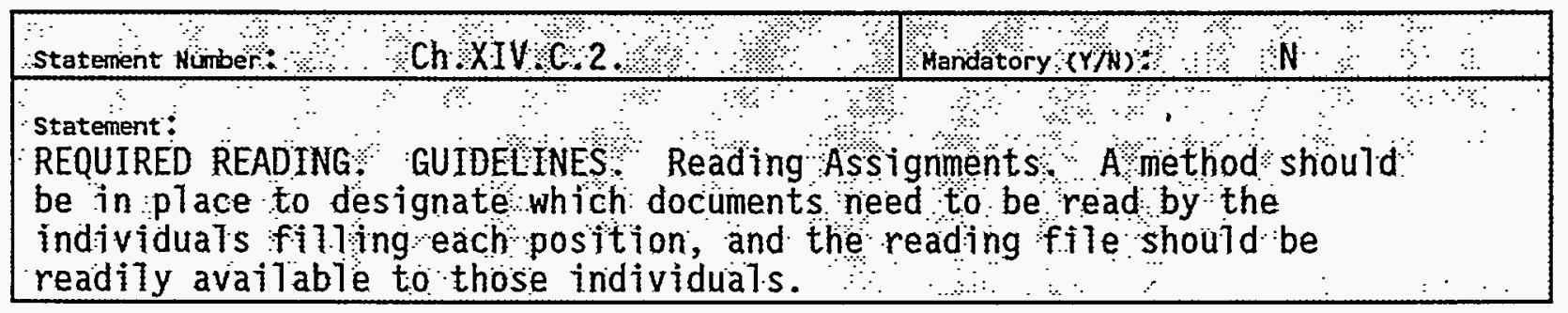

\section{N/A}

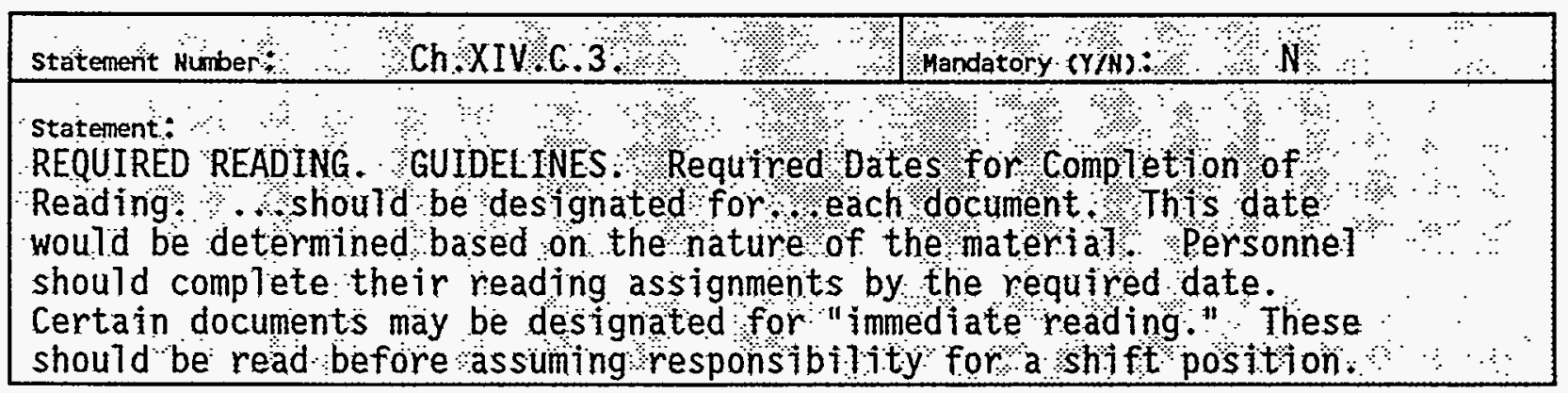

\section{N/A}


WHC-EP-0822

\section{ASSESSHENT DATA COLLECTION FORM}

\begin{tabular}{|c|c|}
\hline 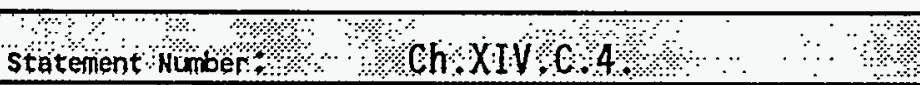 & Mandatory $(Y / N): \quad \cdots N \quad N \quad \ldots \ldots$ \\
\hline 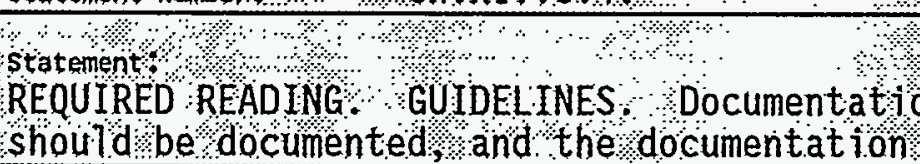 & $\begin{array}{l}\text { na Completion of reading } \\
\text { should be retained }\end{array}$ \\
\hline
\end{tabular}

\section{N/A}

\begin{tabular}{|c|c|}
\hline 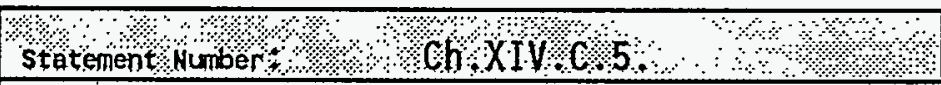 & Mandatory $(\mathrm{Y} / \mathrm{N})$ : $\quad \mathrm{N}$ \\
\hline 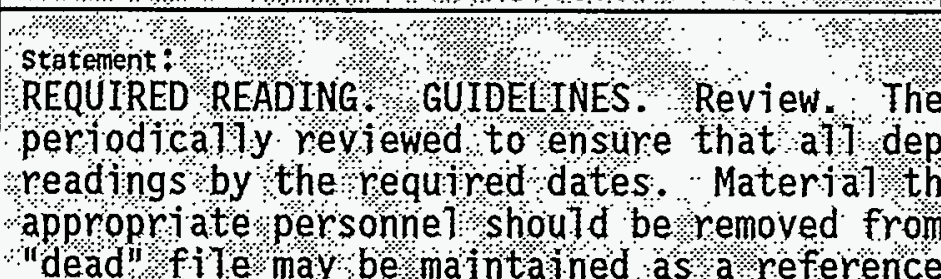 & $\begin{array}{l}\text { reading file shoutd be } \\
\text { artment personnel complete } \\
\text { at has been read by all } \\
\text { the active fille A }\end{array}$ \\
\hline
\end{tabular}

\section{N/A}

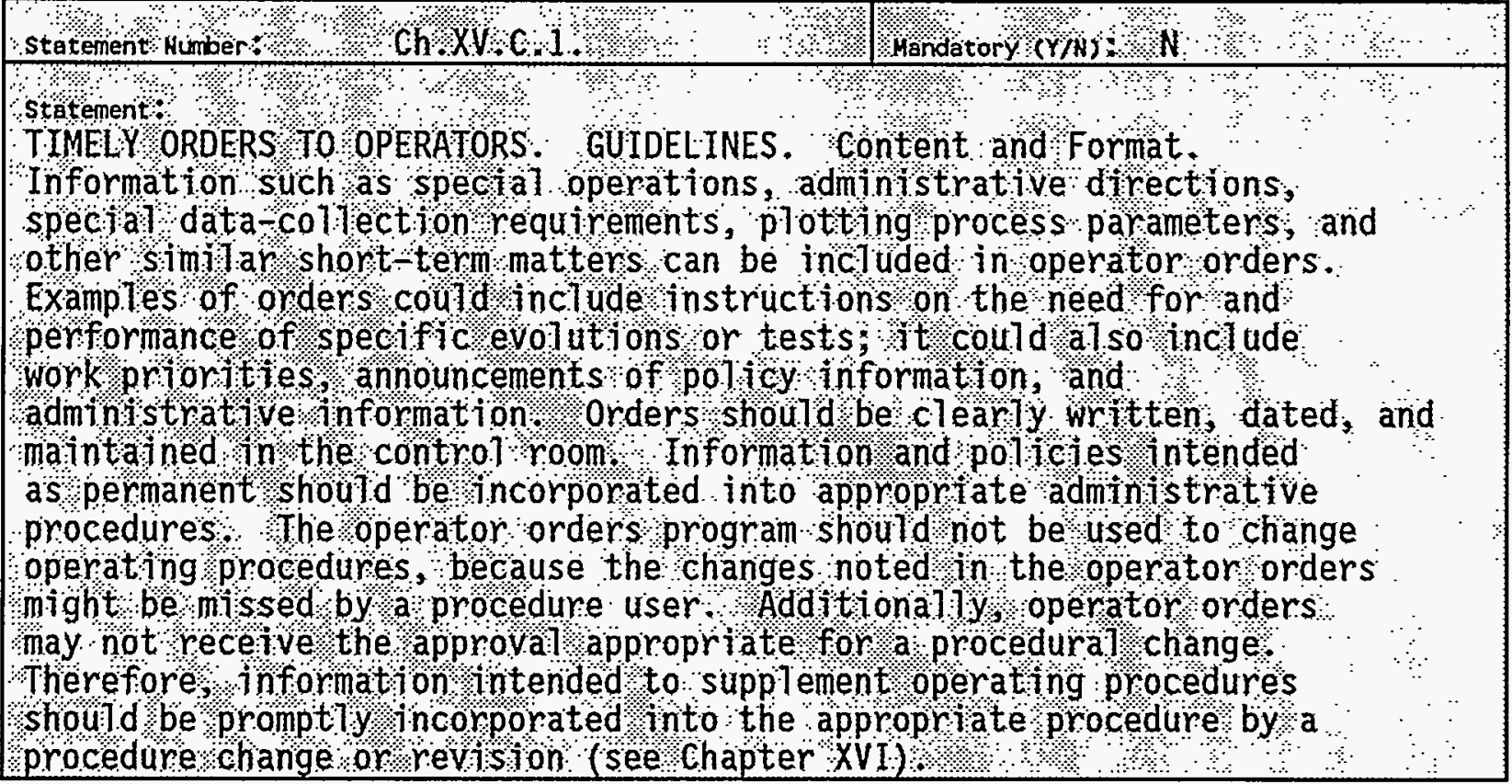

N/A- Laboratory Analysts work to procedures, not temporary orders. 
WHC-EP-0822

ASSESSMENT DATA COLLECTION FORM

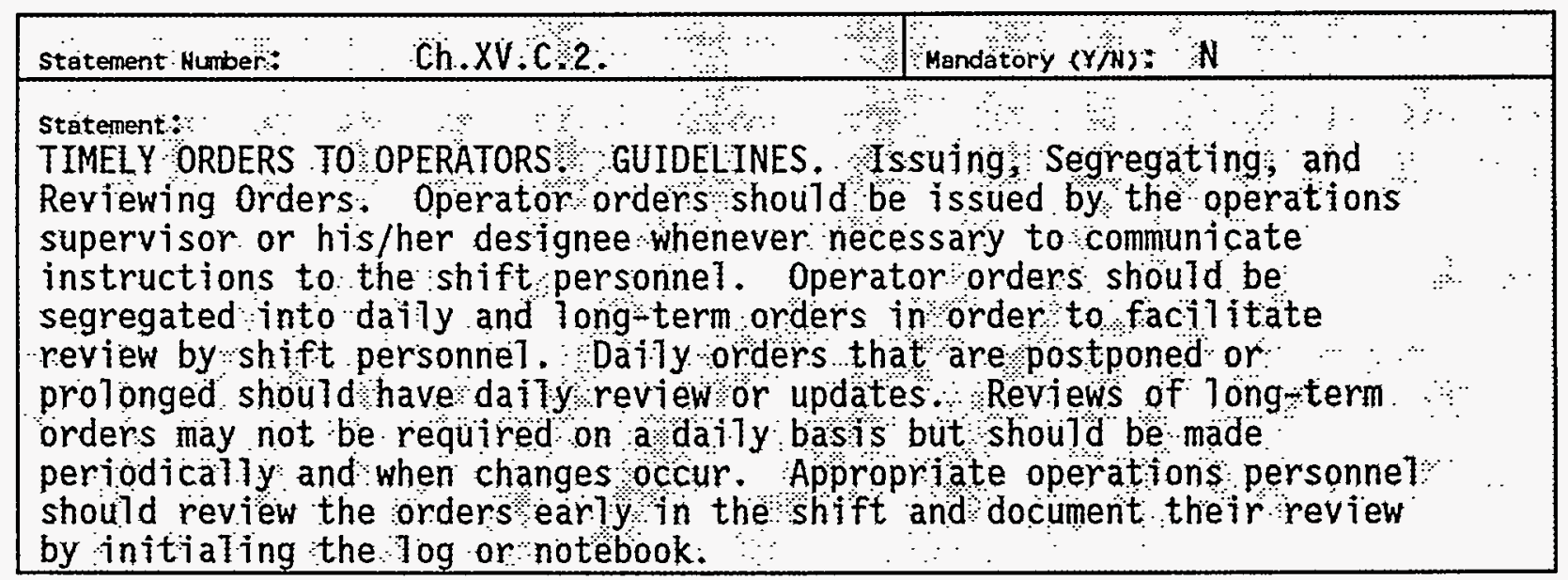

N/A- Laboratory Analysts work to procedures, not temporary orders.

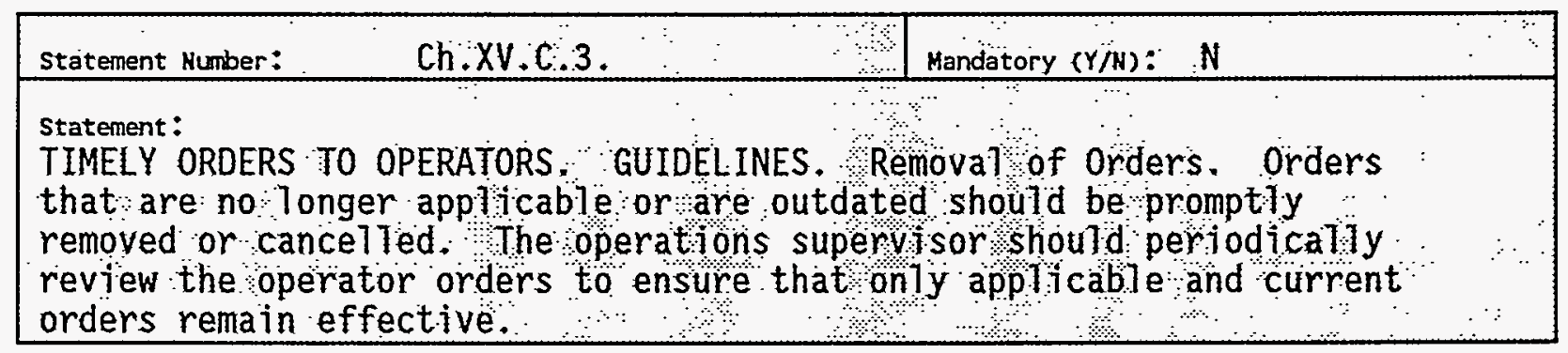

N/A- Laboratory Analysts work to procedures, not temporary orders. 


\section{ASSESSMENT DATA COLLECTION FORH}

\begin{tabular}{|c|c|}
\hline 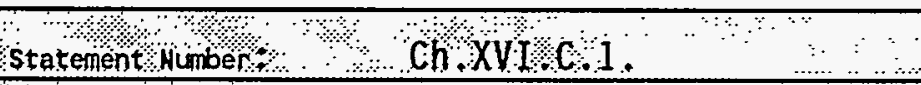 & Mandatory $(Y / N)$. \\
\hline 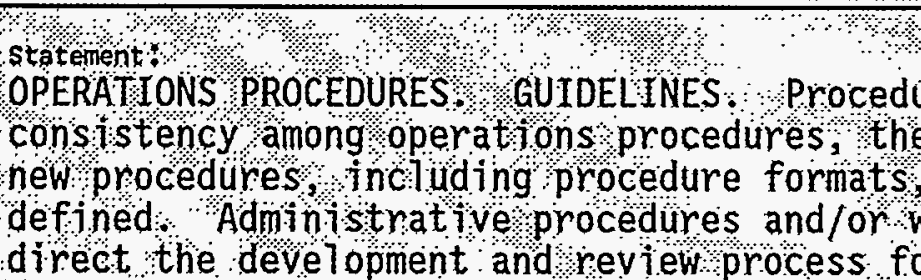 & $\begin{array}{l}\text { la } \\
\text { e Development. To sensure } \\
\text { methods for developing } \\
\text { shoutd be clearly } \\
\text { ters guides should } \\
\text { procedures. }\end{array}$ \\
\hline
\end{tabular}

1.0 StATEMENT SATISFIEd BASED ON IMPLEMENTING EVIDENCE (Y/N): YES

2.0 GENERAL DESCRIPTION OF EVIDENCE (DESCRIPTION OF NONCOMPLIANCE OR DEFICIENCY IF APPLICABLE):

\subsection{Procedure Requirements}

Each page at a minimum shall have a unique code, title, and revision number traceable to the date issued. Each page shall carry the code and revision, at a minimum. The following information is recommended for analytical and technical procedures:

- title.

- scope: parameters measured, range, matrix, expected precision, and accuracy.

- referenced documents: title, author(s), year published, publisher, document code.

- terminology used.

- summary of method.

- interferences.

- apparatus and instrumentation.

- reagents and materials.

- hazards and precautions [Material Safety Data Sheet (MSDS) references].

- sample preparation.

- apparatus and instrumentation set-up.

- calibration and standardization. 
WHC-EP-0822

\section{ASSESSMENT DATA COLLECTION FORM}

- $\quad$ procedural steps.

- demonstration of statistical control or quality control criteria.

- calculations.

- assignment of uncertainty. 


\section{ASSESSMENT DATA COLLECTION FORM}

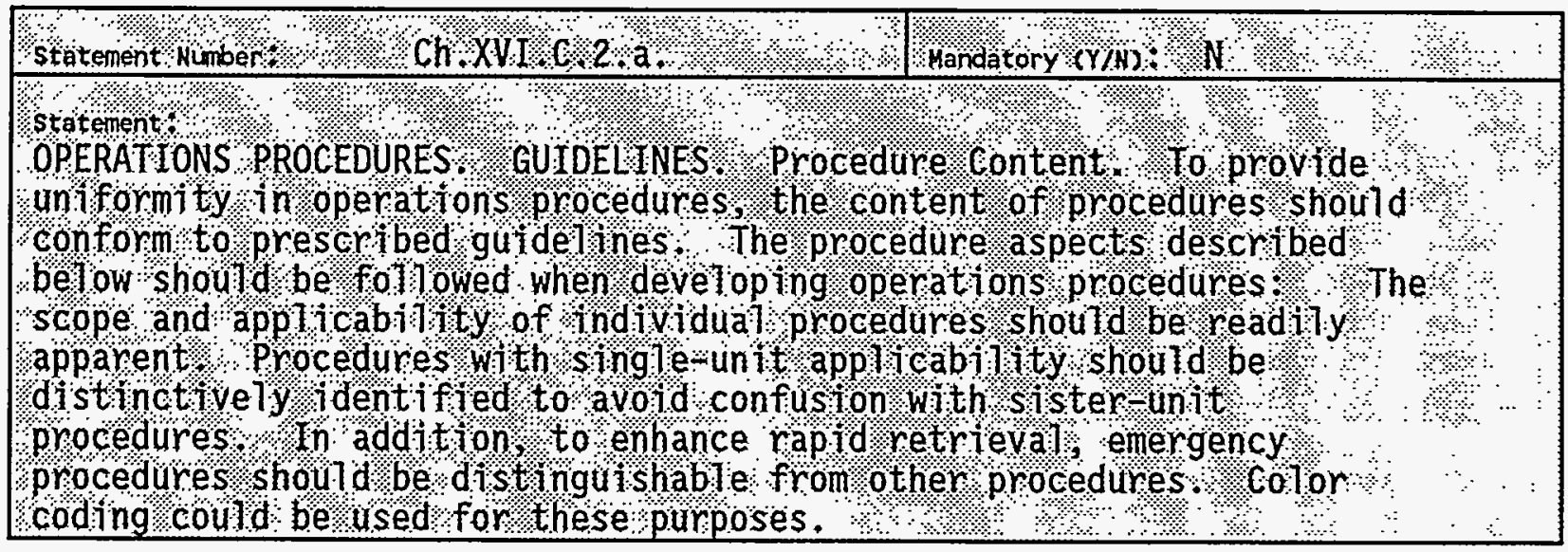

1.0 STATEMENT SATISFIED BASED ON IMPLEMENTING EVIDENCE $(Y / N):$ YES

2.0 GENERAL DESCRIPTION OF EVIDENCE (DESCRIPTION OF NONCOMPLIANCE OR DEFICIENCY IF APPLICABLE):

The intent of the above statement as it applies to analytical services is met in HASQAP Section 8.2, "Procedure Requirements." (See Statement Number Ch.XVI.C.1 above.) 


\section{ASSESSMENT DATA COLLECTION FORH}

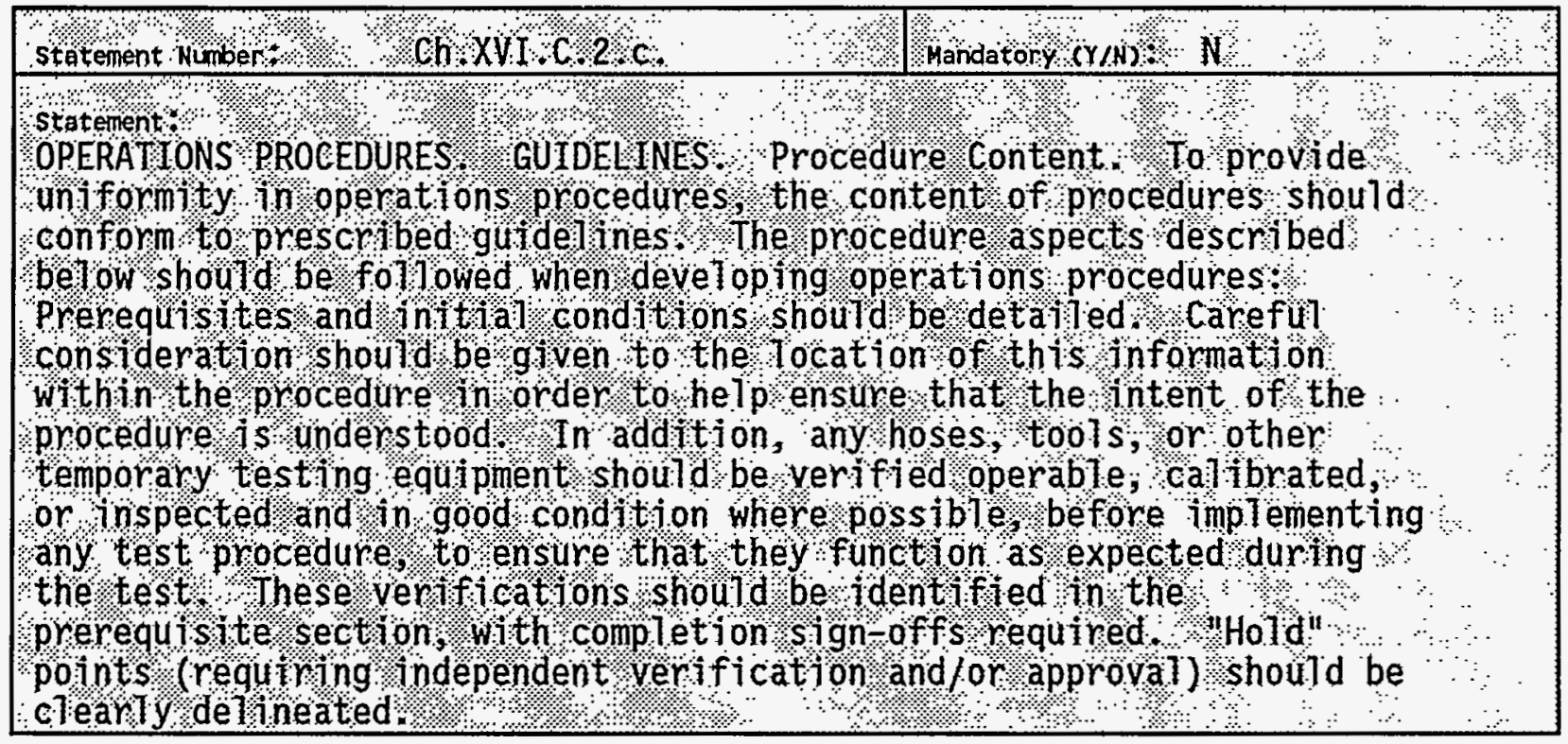

1.0 STATEMENT SATISFIED BASED ON IMPLEMENTING EVIDENCE (Y/N): YES

2.0 GENERAL DESCRIPTION OF EVIDENCE (DESCRIPTION OF NONCOMPLIANCE OR DEFICIENCY IF APPLICABLE):

The intent of the above statement as it applies to analytical services is met in HASQAP Section 8.2, "Procedure Requirements." (See Statement Number Ch.XVI.C.I above.) 
ASSESSMENT DATA COLLECTION FORM

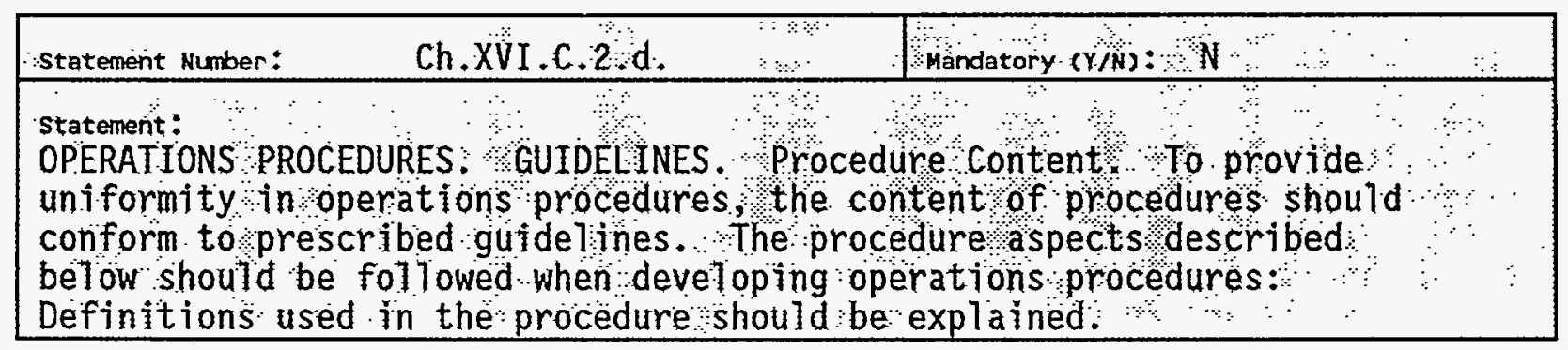

1.0 STATEMENT SATISFIED BASED ON IMPLEMENTING EVIDENCE $(Y / N):$ YES

2.0 GENERAL DESCRIPTION OF EVIDENCE (DESCRIPTION OF NONCOMPLIANCE OR DEFICIENCY IF APPLICABLE):

The intent of the above statement as it applies to analytical services is met in HASQAP Section 8.2, "Procedure Requirements." (See Statement Number Ch.XVI.C.1 above.) 


\section{ASSESSMENT DATA COLLECTION FORM}

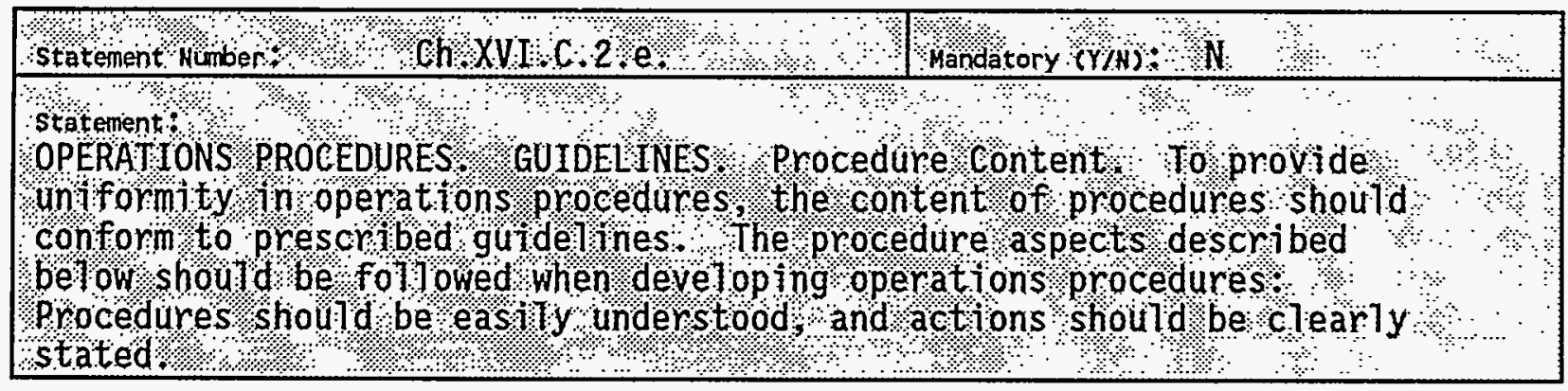

1.0 Statement SATISFIEd based ON IMPLEMENTing EVIDENCE $(Y / N)$ Y YES

2.0 GENERAL DESCRIPTION OF EVIDENCE (DESCRIPTION OF NONCOMPLIANCE OR DEFICIENCY IF APPLICABLE):

The intent of the above statement as it applies to analytical services is met in HASQAP Section 8.2, "Procedure Requirements." (See Statement Number Ch.XVI.C.1 above.) 
WHC-EP-0822

\section{ASSESSMENT DATA COLLECTION FORM}

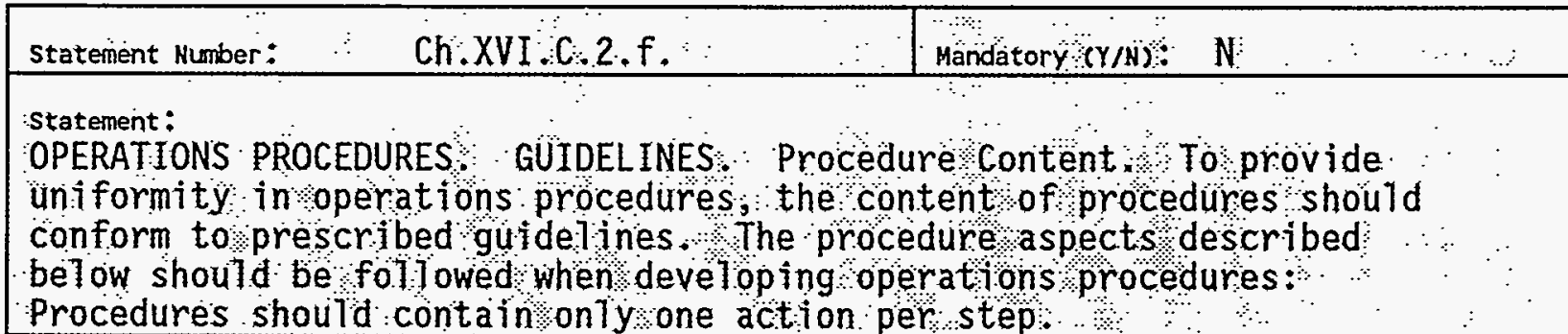

1.0 STATEMENT SATISFIEd BASED ON IMPLEMENTING EVIDENCE $(Y / N):$ YES

2.0 GENERAL DESCRIPTION OF EVIDENCE (DESCRIPTION OF NONCOMPLIANCE OR DEFICIENCY IF APPLICABLE):

The intent of the above statement as it applies to analytical services is met in HASQAP Section 8.2, "Procedure Requirements." (See Statement Number Ch.XVI.C.1 above.) 
WHC-EP-0822

\section{ASSESSMENT DATA COLLECTION FORM}

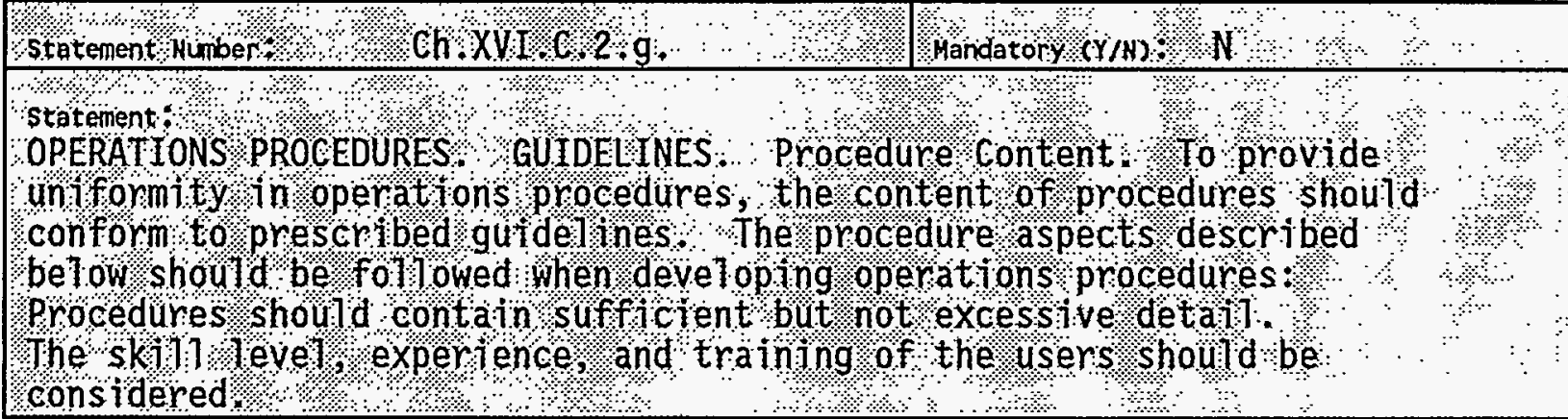

1.0 STATEMENT SATISFIED BASED ON IMPLEMENTING EVIDENCE (Y/N): YES

2.0 GENERAL DESCRIPTION OF EVIDENCE (DESCRIPTION OF NONCOMPLIANCE OR DEFICIENCY IF APPLICABLE):

The intent of the above statement as it applies to analytical services is met in HASQAP Section 8.2, "Procedure Requirements." (See Statement Number Ch.XVI.C.1 above.) 
WHC-EP-0822

\section{ASSESSMENT DATA COLLECTION FORM}

\begin{tabular}{|c|c|c|}
\hline Statement Number: & Ch.XVI:C.2.h: & Mandatory $(Y / N)$ : \\
\hline \multicolumn{3}{|c|}{ 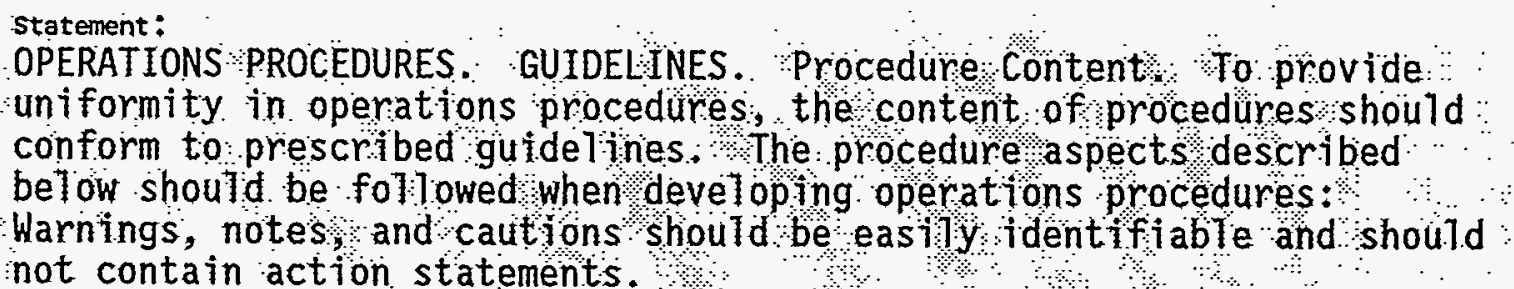 } \\
\hline
\end{tabular}

1.0 STATEMENT SATISFIED BASED ON IMPLEMENTING EVIDENCE $(Y / N):$ YES

2.0 GENERAL DESCRIPTION OF EVIDENCE (DESCRIPTION OF NONCOMPLIANCE OR DEFICIENCY IF APPLICABLE):

The intent of the above statement as it applies to analytical services is met in HASQAP Section 8.2, "Procedure Requirements." (See Statement Number Ch.XVI.C.I above.) 
WHC-EP-0822

\section{ASSESSMENT DATA COLLECTION FORM}

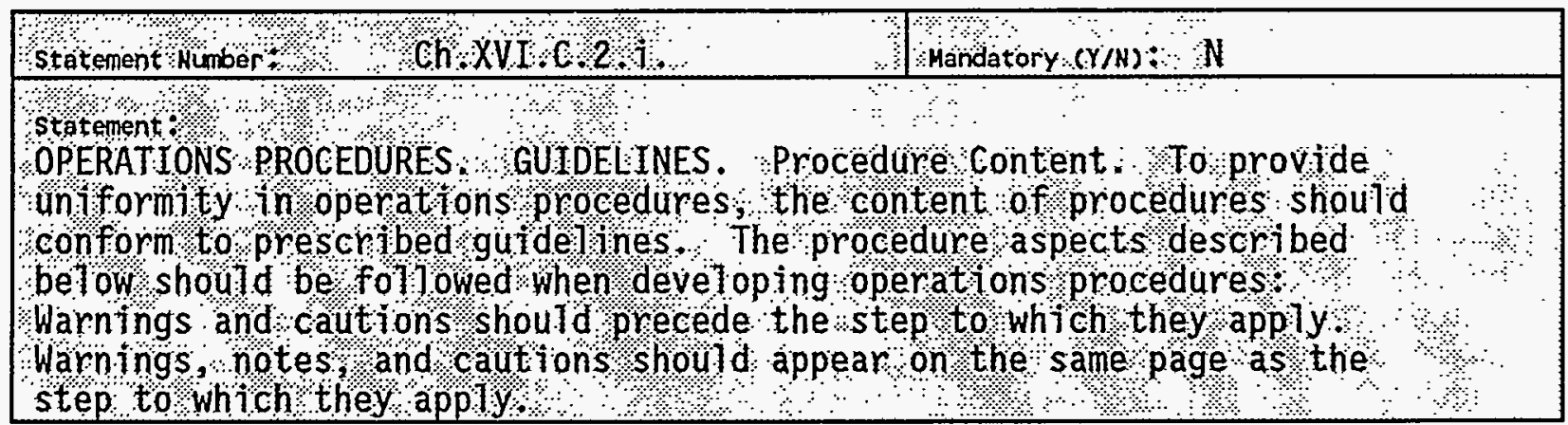

1.0 Statement SATISFIEd BASEd ON IMPLEMENTING EVIdenCE $(Y / N)$ : YES

2.0 GENERAL DESCRIPTION OF EVIDENCE (DESCRIPTION OF NONCOMPLIANCE OR DEFICIENCY IF APPLICABLE):

The intent of the above statement as it applies to analytical services is met in HASQAP Section 8.2, "Procedure Requirements." (See Statement Number Ch.XVI.C.1 above.) 
ASSESSMENT DATA COLLECTION FORM

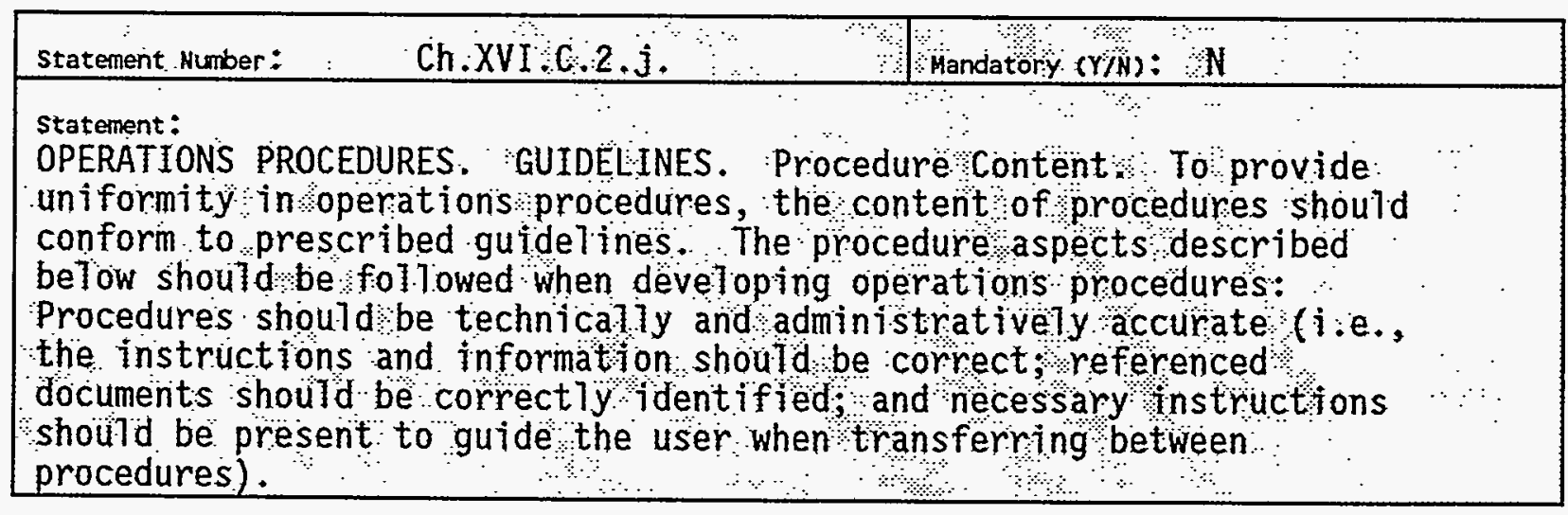

1.0 Statement SATISFied based on IMPLEMENTing EVIDENCE $(Y / N)$ : YES

2.0 GENERAL DESCRIPTION OF EVIDENCE (DESCRIPTION OF NONCOMPLIANCE OR DEFICIENCY IF APPLICABLE):

The intent of the above statement as it applies to analytical services is met in HASQAP Section 8.2, "Procedure Requirements." (See Statement Number Ch.XVI.C.1 above.) 
WHC-EP-0822

\section{ASSESSHENT DATA COLLECTION FORM}

\begin{tabular}{|c|c|}
\hline statement number $*$ क $\mathrm{Ch}$ XVI $, \mathrm{C}, 2 \mathrm{~K}, \cdots$ & Mandatory $(Y / N), N \mathrm{~N}$ \\
\hline 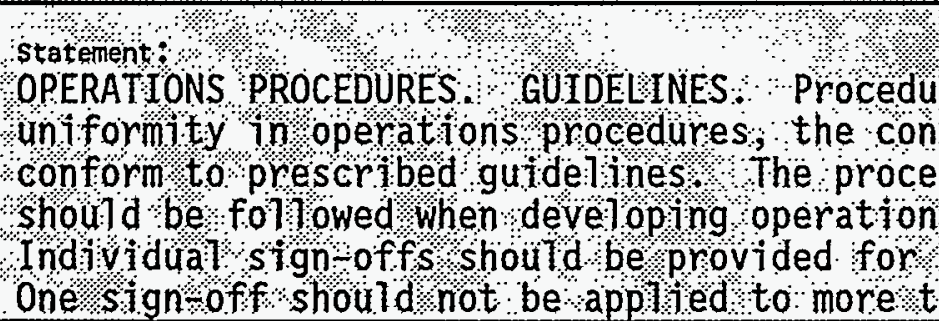 & $\begin{array}{l}\text { recontent } \\
\text { tent of procedures should } \\
\text { dure aspects described betow } \\
\text { stprocedures } \\
\text { selected critucal steps } \\
\text { han one action }\end{array}$ \\
\hline
\end{tabular}

1.0 StATEMENT SATISFIEd BASED ON IMPLEMENTING EVIDENCE (Y/N): YES

2.0 GENERAL DESCRIPTION OF EVIDENCE (DESCRIPTION OF NONCOMPLIANCE OR DEFICIENCY IF APPLICABLE):

The intent of the above statement as it applies to analytical services is met in HASQAP Section 8.2, "Procedure Requirements." (See Statement Number Ch.XVI.C.1 above.) 
WHC-EP-0822

\section{ASSESSMENT DATA COLLECTION FORM}

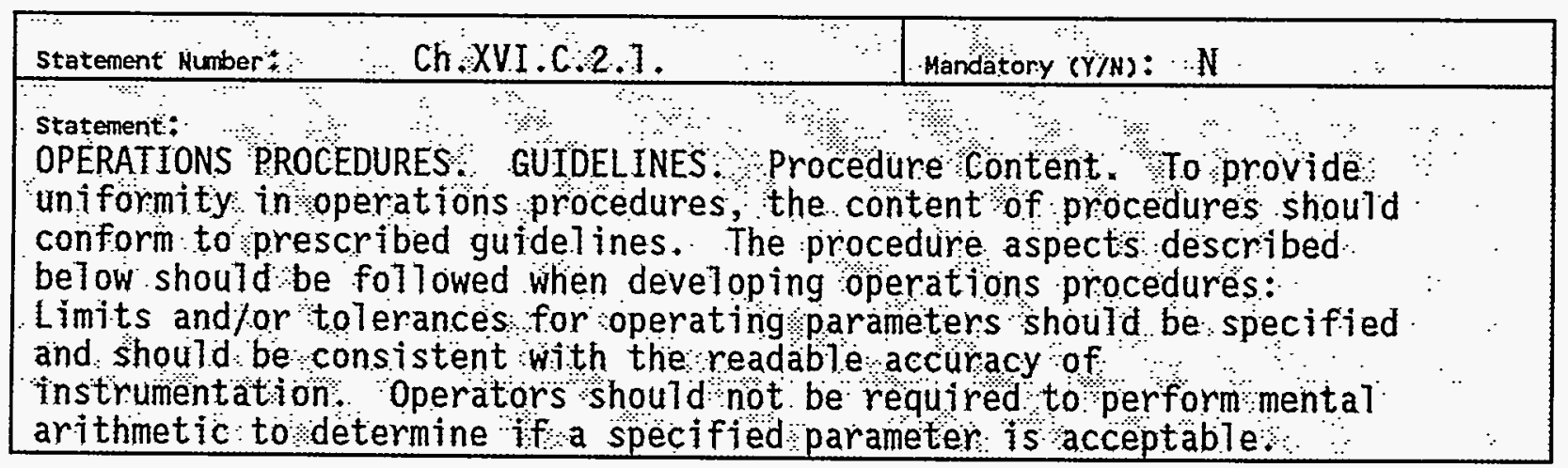

1.0 STATEMENT SATISFIED BASED ON IMPLEMENTING EVIDENCE (Y/N): YES

2.0 GENERAL DESCRIPTION OF EVIDENCE (DESCRIPTION OF NONCOMPLIANCE OR DEFICIENCY IF APPLICABLE):

The intent of the above statement as it applies to analytical services is met in HASQAP Section 8.2, "Procedure Requirements." (See Statement Number Ch.XVI.C.1 above.) 


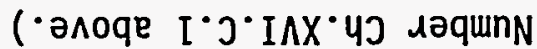

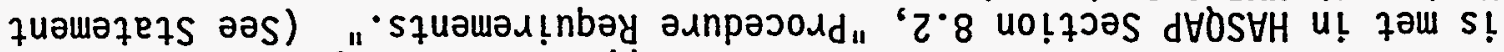

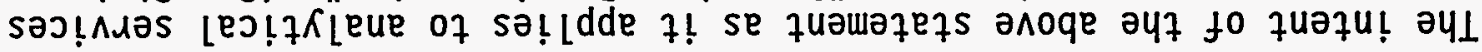

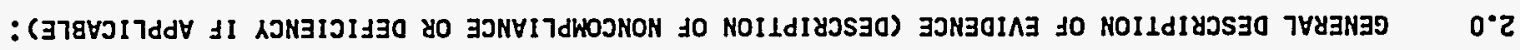

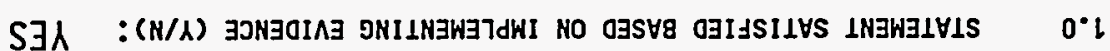

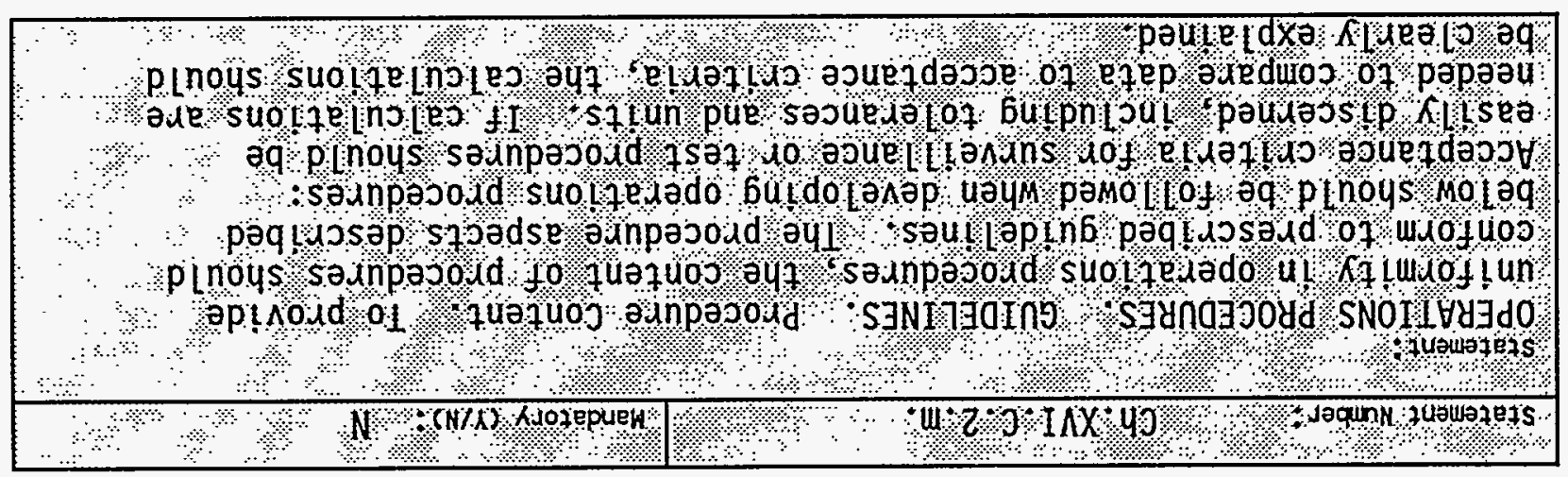

\section{WYOJ NOIIJ3770J YIHO INJWSSJSSH}


WHC-EP-0822

\section{ASSESSMENT DATA COLLECTION FORM}

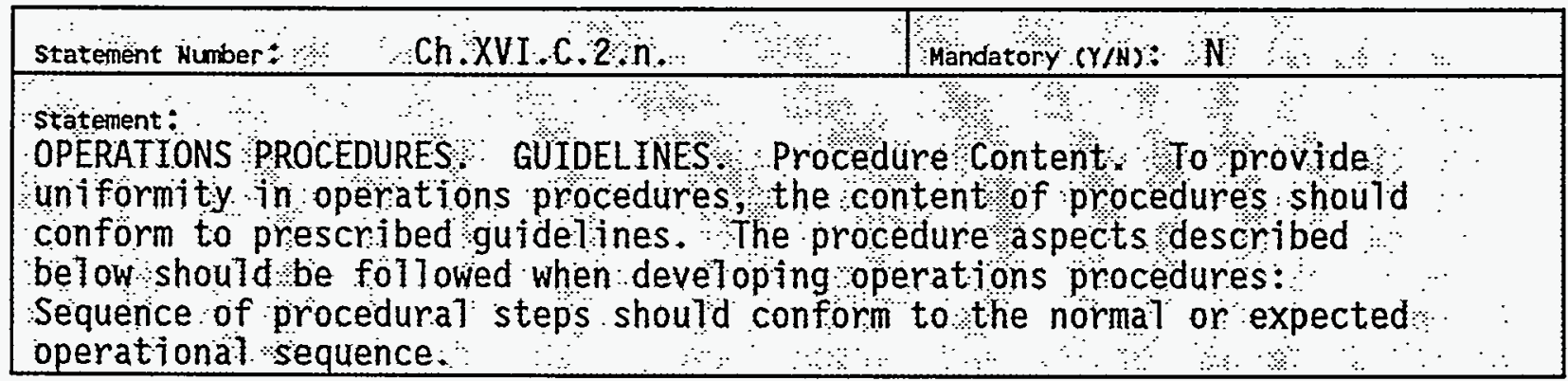

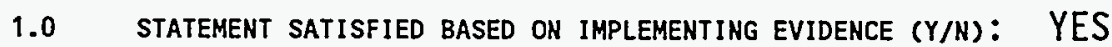

2.0 GENERAL DESCRIPTION OF EVIDENCE (DESCRIPTION OF NONCOMPLIANCE OR DEFICIENCY IF APPLICABLE):

The intent of the above statement as it applies to analytical services is met in HASQAP Section 8.2, "Procedure Requirements." (See Statement Number Ch.XVI.C.I above.) 
WHC-EP-0822

\section{ASSESSMENT DATA COLLECTION FORM}

\begin{tabular}{|c|}
\hline atement number $\quad$ aCh XVI $\mathrm{C}, 2 \mathrm{O}$ \\
\hline 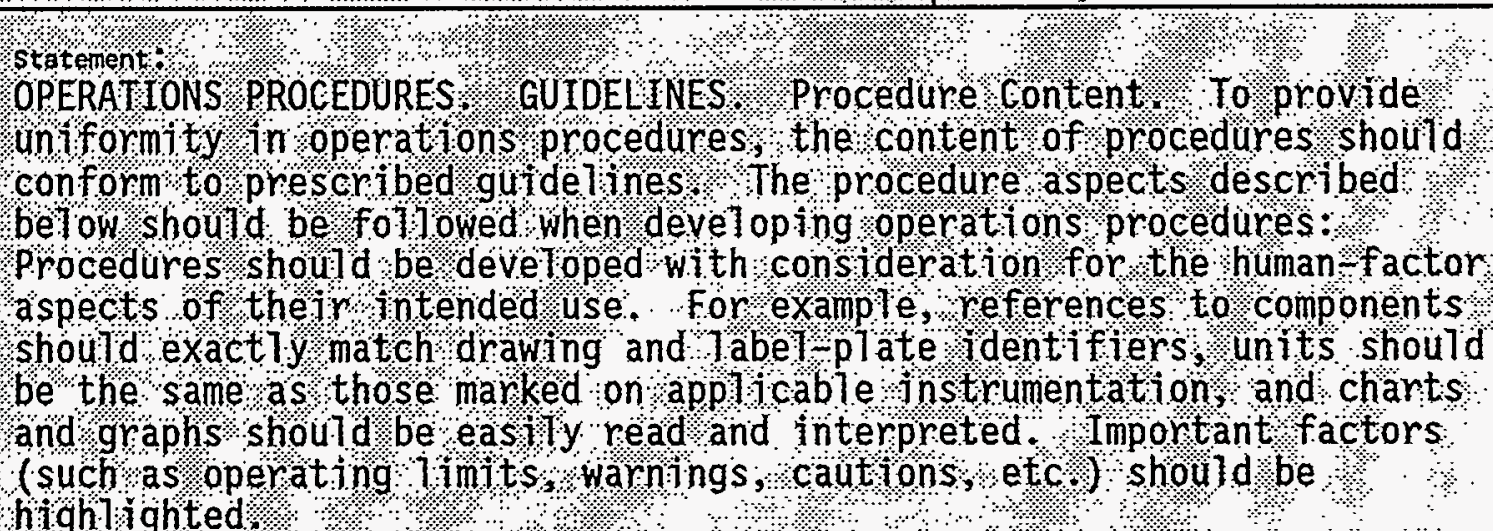 \\
\hline
\end{tabular}

1.0 STATEMENT SATISFIED BASED ON IMPLEMENTING EVIDENCE (Y/N): YES

2.0 GENERAL DESCRIPTION OF EVIDENCE (DESCRIPTION OF NONCOMPLIANCE OR DEFICIENCY IF APPLICABLE):

The intent of the above statement as it applies to analytical services is met in HASQAP Section 8.2, "Procedure Requirements." (See Statement Number Ch.XVI.C.I above.) 
WHC-EP-0822

\section{ASSESSMENT DATA COLLECTION FORM}

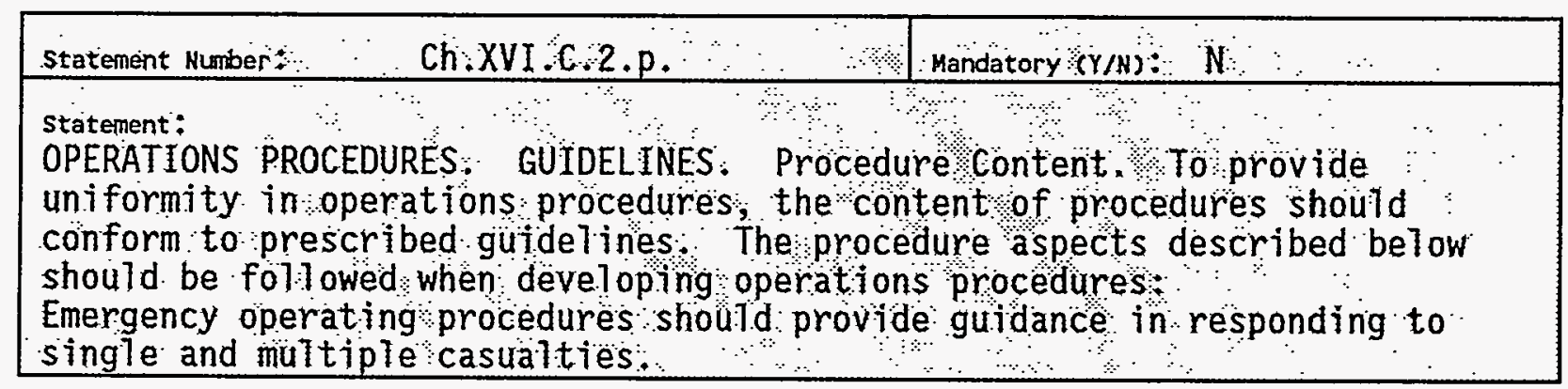

1.0 STATEMENT SATISFIED BASED ON IMPLEMENTING EVIDENCE (Y/N): YES

2.0 GENERAL DESCRIPTION OF EVIDENCE (DESCRIPTION OF NONCOMPLIANCE OR DEFICIENCY IF APPLICABLE):

The intent of the above statement as it applies to analytical services is met in HASQAP Section 8.2, "Procedure Requirements." (See Statement Number Ch.XVI.C.1 above.) 
$(\cdot \partial \wedge$ oqe $I \cdot J \cdot I \Lambda X \cdot 4 J$ uaqunn quәшә7е

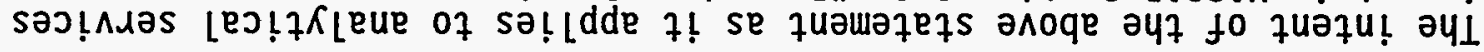

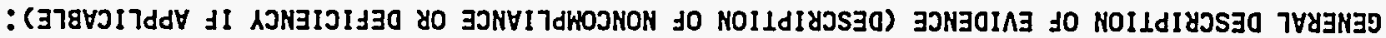

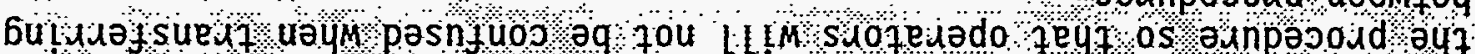

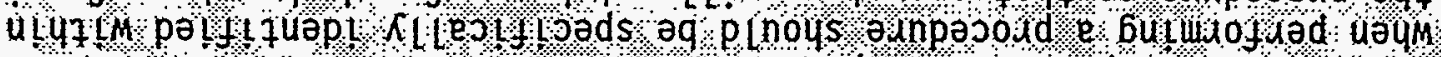

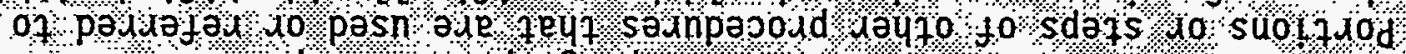

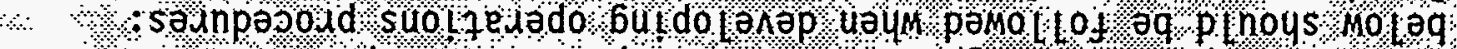

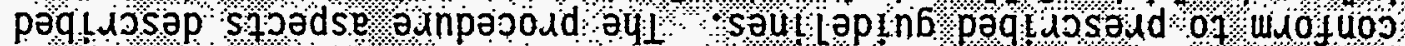

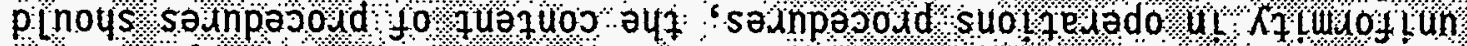

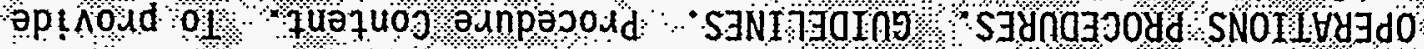

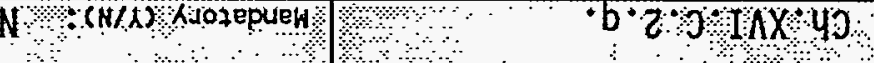
quoustets

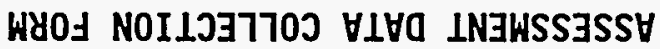


WHC-EP-0822

\section{ASSESSMENT DATA COLLECTION FORM}

\begin{tabular}{|c|}
\hline $\mathrm{N}$ \\
\hline 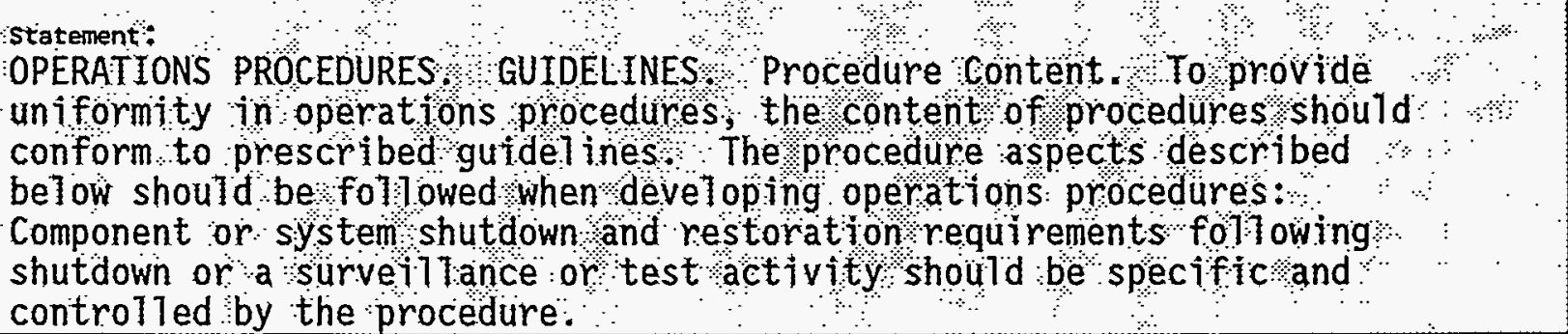 \\
\hline
\end{tabular}

1.0 STATEMENT SATISFIED BASED ON IMPLEMENTING EVIDENCE $(Y / N):$ YES

2.0 GENERAL DESCRIPTION OF EVIDENCE (DESCRIPTION OF NONCOMPLIANCE OR DEFICIENCY IF APPLICABLE):

The intent of the above statement as it applies to analytical services is met in HASQAP Section 8.2, "Procedure Requirements." (See Statement Number Ch.XVI.C.I above.) 
WHC-EP-0822

\section{ASSESSMENT DATA COLLECTION FORM}

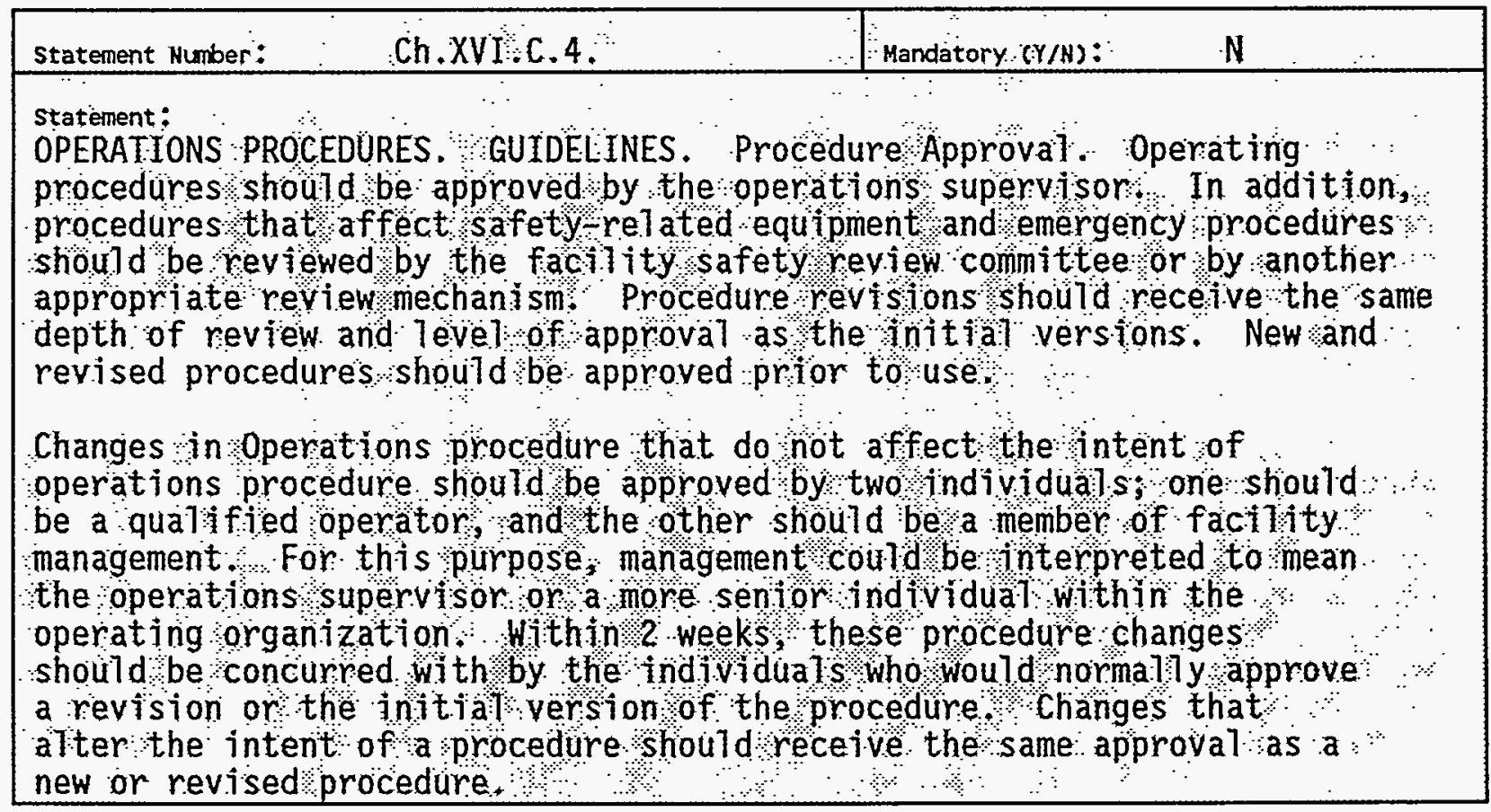

1.0 STATEMENT SATISFIED BASED DN IMPLEMENTING EVIDENCE $(Y / N):$ YES

2.0 GENERAL DESCRIPTION OF EVIDENCE (DESCRIPTION OF NONCOMPLIANCE OR DEFICIENCY IF APPLICABLE):

The intent of the above statement is met by HASQAP subsection 5.2, "Administrative Systems," and HASQAP subsection 8.5, "Change Control." 


\section{ASSESSMENT DATA COLLECTION FORM}

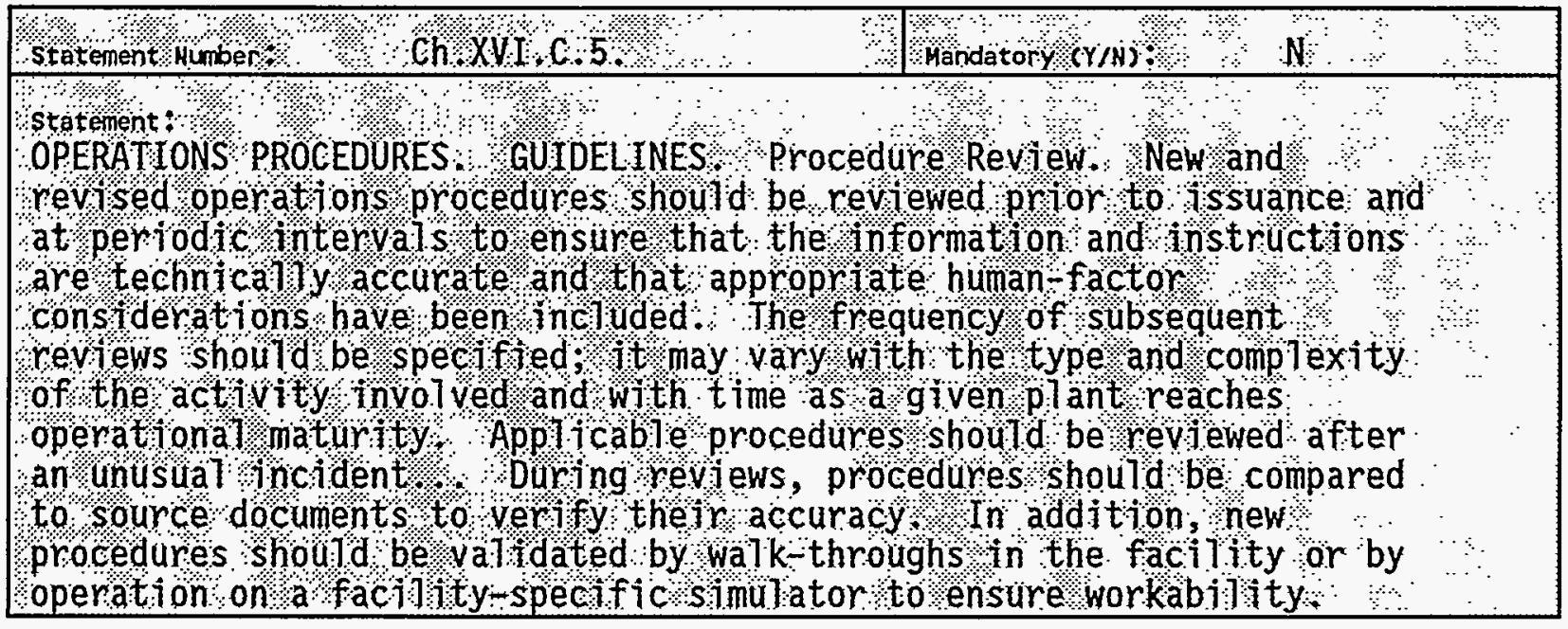

1.0 Statement SATISFied based ON IMPLementing Evidence $(Y / N)$ : NO

2.0 GENERAL DESCRIPTION OF EVIDENCE (DESCRIPTION OF NONCOMPLIANCE OR DEFICIENCY IF APPLICABLE):

The intent of the above statement as it applies to review of procedures for analytical services is not addressed in the HASQAP.

3.0 CORRECTIVE ACTION: 
WHC-EP-0822

\section{ASSESSMENT DATA COLLECTION FORM}

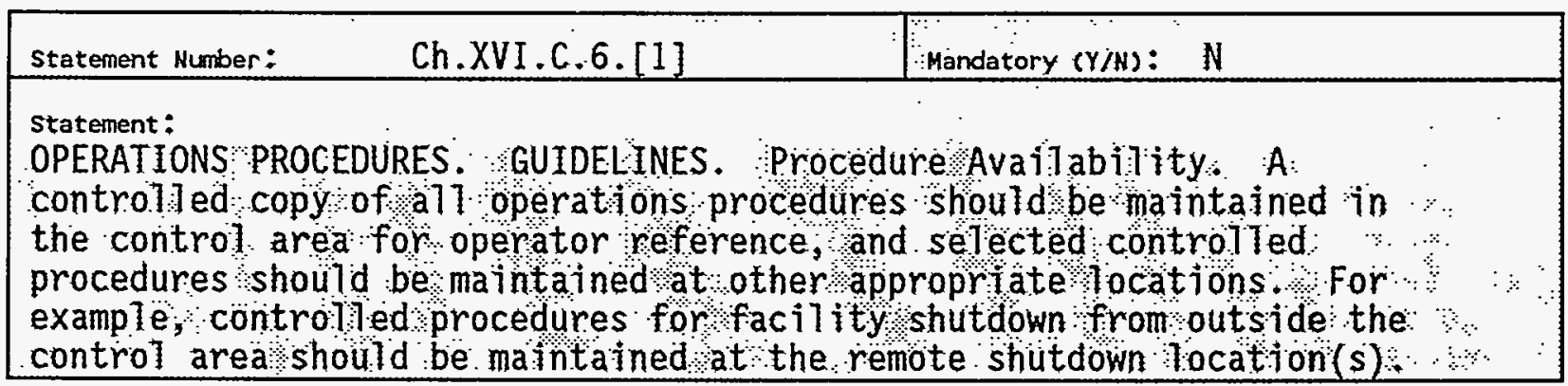

1.0 STATEMENT SATISFIED BASED ON IMPLEMENTING EVIDENCE $(Y / N)$ : YES

2.0 GENERAL DESCRIPTION OF EVIDENCE (DESCRIPTION OF NONCOMPLIANCE OR DEFICIENCY IF APPLICABLE):

The intent of the above statement as it applies to availability of procedures for analytical services is addressed in HASQAP Section 8.1. 
WHC-EP-0822

\section{ASSESSHENT DATA COLLECTION FORM}

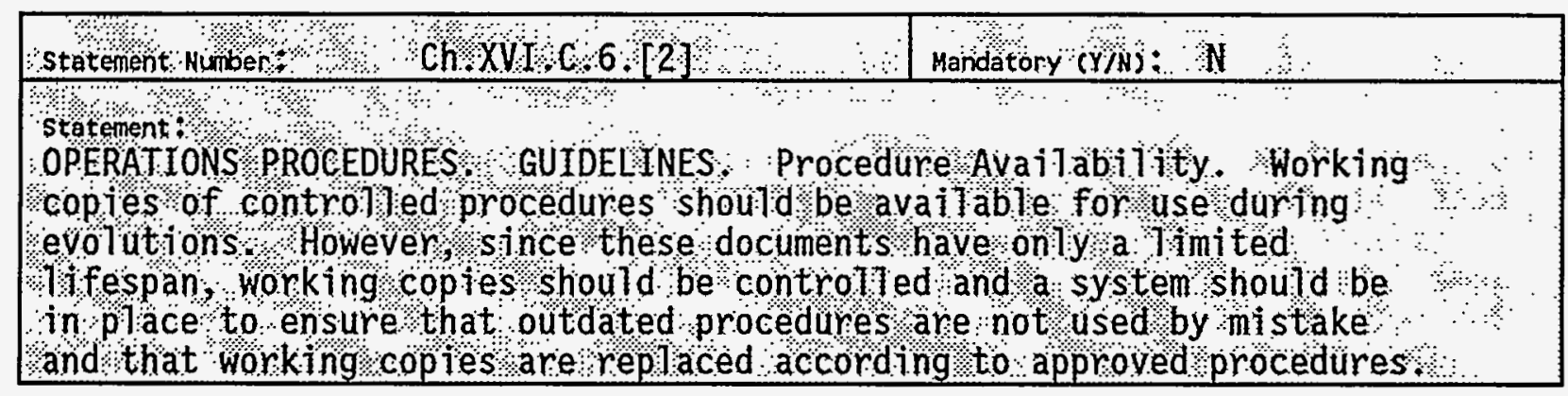

1.0 STATEMENT SATISFIED BASED ON IMPLEMENTING EVIDENCE (Y/N): YES

2.0 GENERAL DESCRIPTION OF EVIDENCE (DESCRIPTION OF NONCOMPLIANCE OR DEFICIENCY IF APPLICABLE):

The intent of the above statement as it applies to availability of procedures for analytical services is addressed in HASQAP Section 8.1. 
WHC-EP-0822

\section{ASSESSMENT DATA COLLECTION FORM}

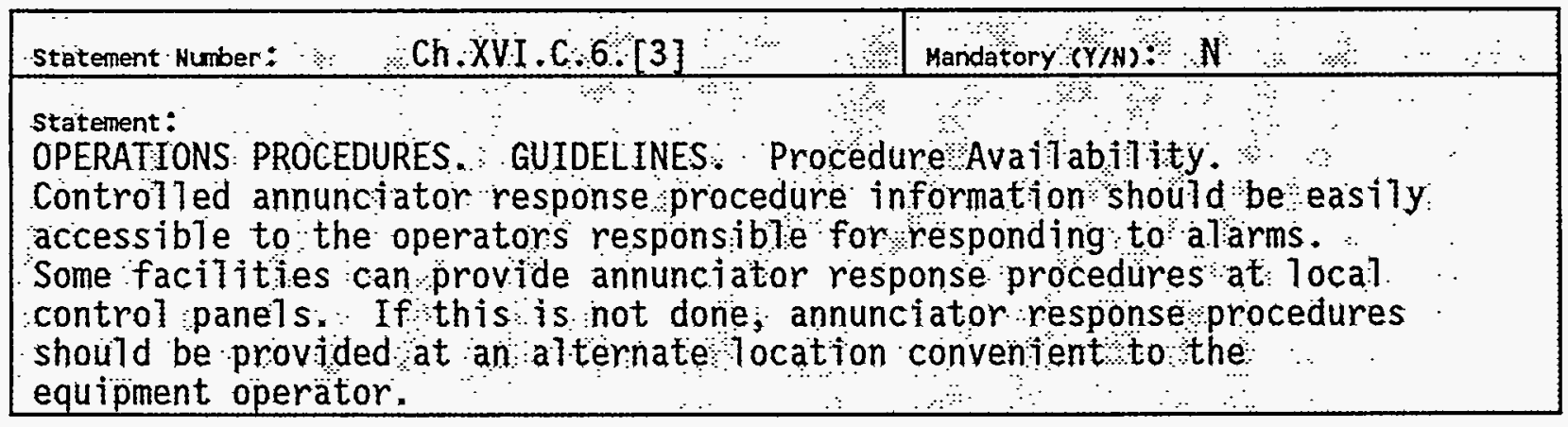

N/A 


\section{ASSESSHENT DATA COLLECTION FORM}

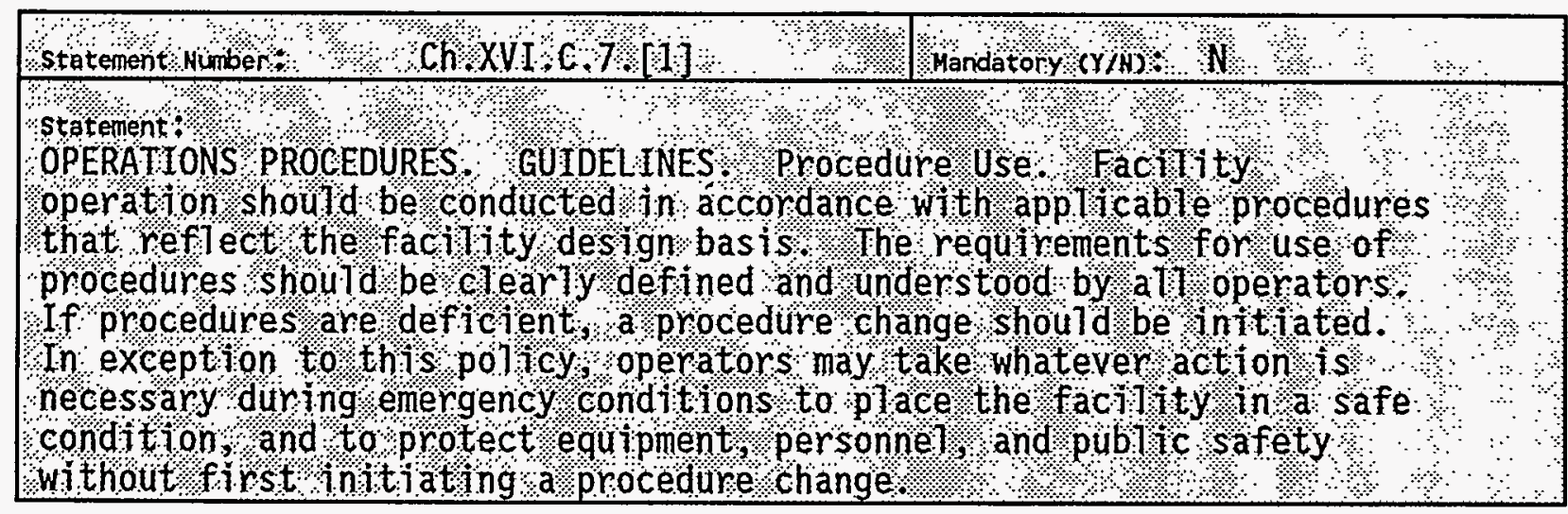

1.0 STATEMENT SATISFIEd BASED ON IMPLEMENTING EVIDENCE (Y/N): YES

2.0 GENERAL DESCRIPTION OF EVIDENCE (DESCRIPTION OF NONCOMPLIANCE OR DEFICIENCY IF APPLICABLE):

The intent of the above statement as it applies to use of procedures for analytical services is addressed in HASQAP Section 8.0 . 
WHC-EP-0822

ASSESSMENT DATA COLLECTION FORM

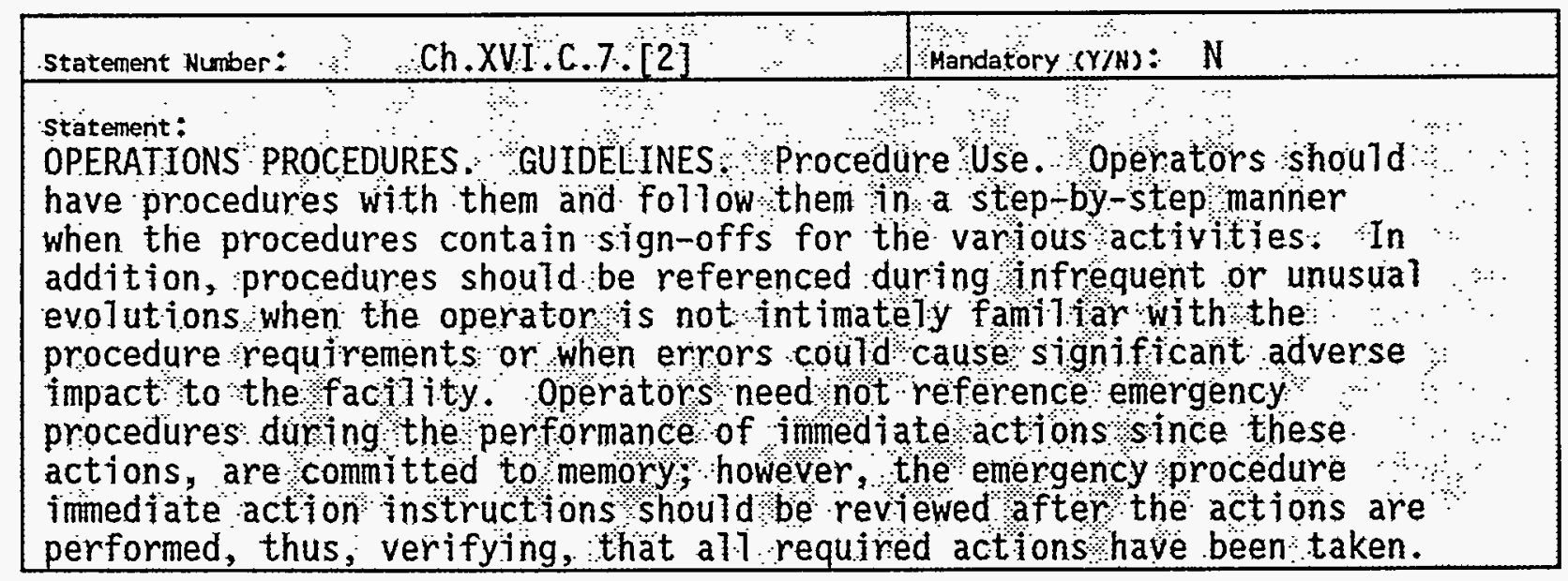

1.0 Statement SATISFied BASED ON IMPLEMENTING EVIDENCE (Y/N): YES

2.0 GENERAL DESCRIPTION OF EVIDENCE (DESCRIPTION OF NONCOMPLIANCE OR DEFICIENCY IF APPLICABLE):

The intent of the above statement as it applies to use of procedures for analytical services is addressed in HASQAP Section 8.1. 
WHC-EP-0822

\section{ASSESSMENT DATA COLLECTION FORM}

\begin{tabular}{|c|c|}
\hline Stratement Numbert & Mandator $Y$ (YYN) $\&$ N \\
\hline 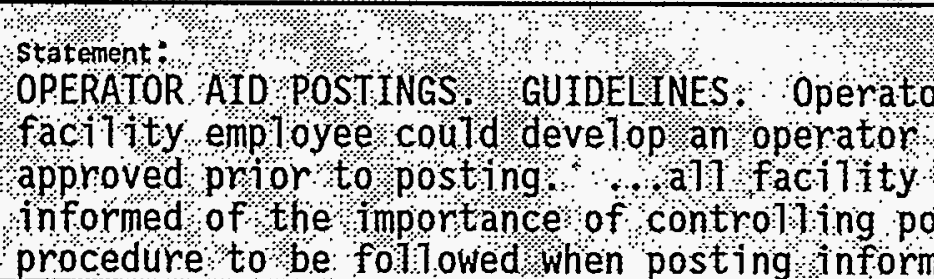 & 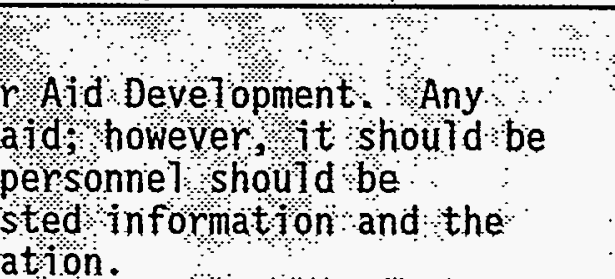 \\
\hline
\end{tabular}

\section{N/A}

\begin{tabular}{|c|c|}
\hline Statement Humbê" $\mathrm{CCh}$ XVII $\mathrm{C}: 2$ & Handatory $(Y / N) / \mathrm{N}$ \\
\hline 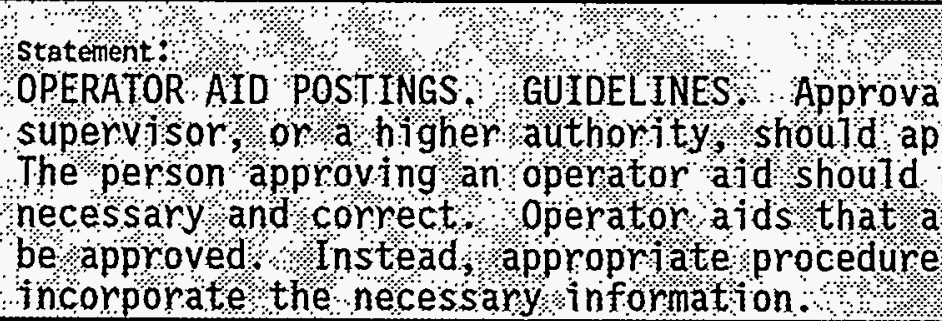 & $\begin{array}{l}\text { 1\% The operattons } \\
\text { prove alt operator a ids } \\
\text { ensure that the a jd ts } \\
\text { iter procedures should not } \\
\text { s should be changed to }\end{array}$ \\
\hline
\end{tabular}

\section{N/A}

\begin{tabular}{|c|c|}
\hline statement Nunber ${ }^{2}$ o Ch.XVII C 3 & Mandatory (Y.A $)$ \\
\hline 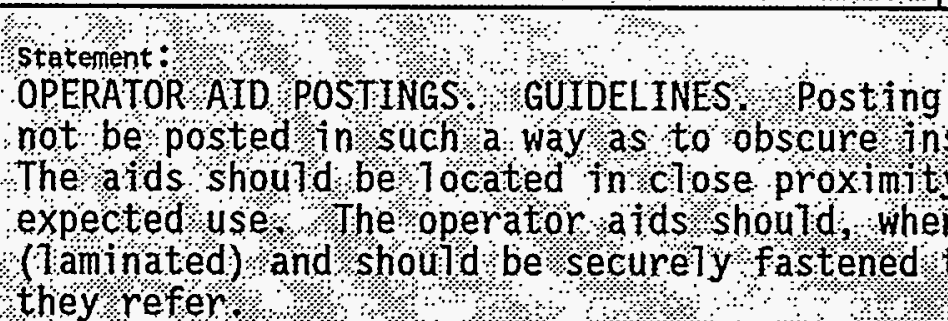 & 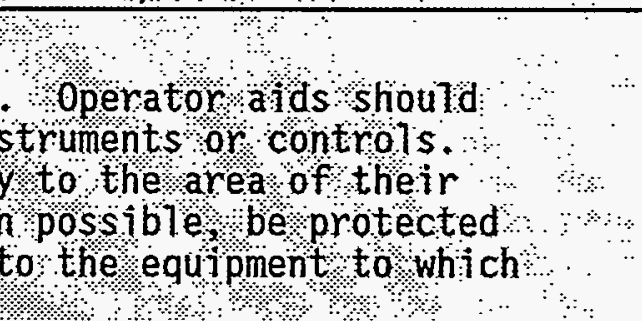 \\
\hline
\end{tabular}

\section{N/A}


WHC-EP-0822

ASSESSMENT DATA COLLECTION FORM

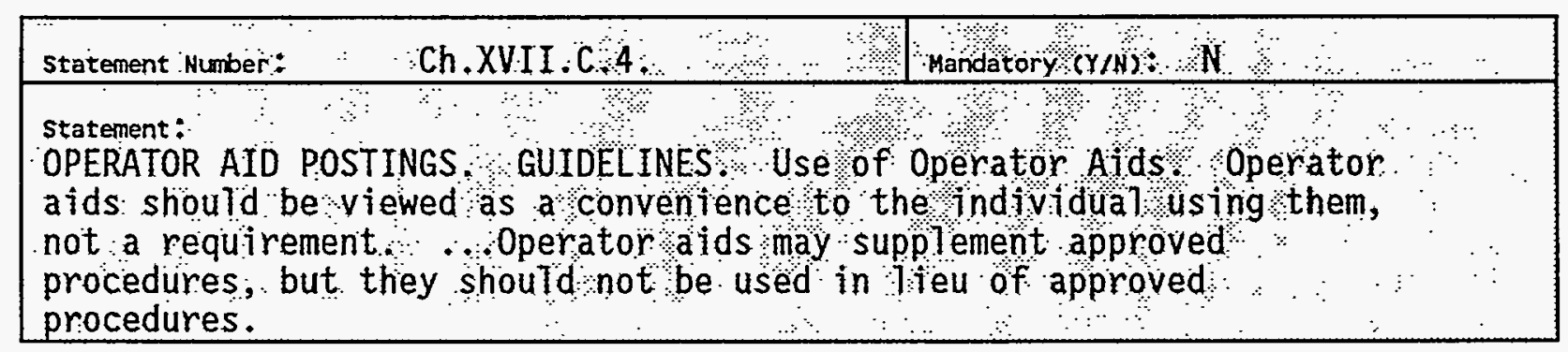

\section{N/A}

\begin{tabular}{|c|c|}
\hline $\mathrm{Ch}$ XVIIC. 5, & Mandatory $(Y / N): N$ \\
\hline 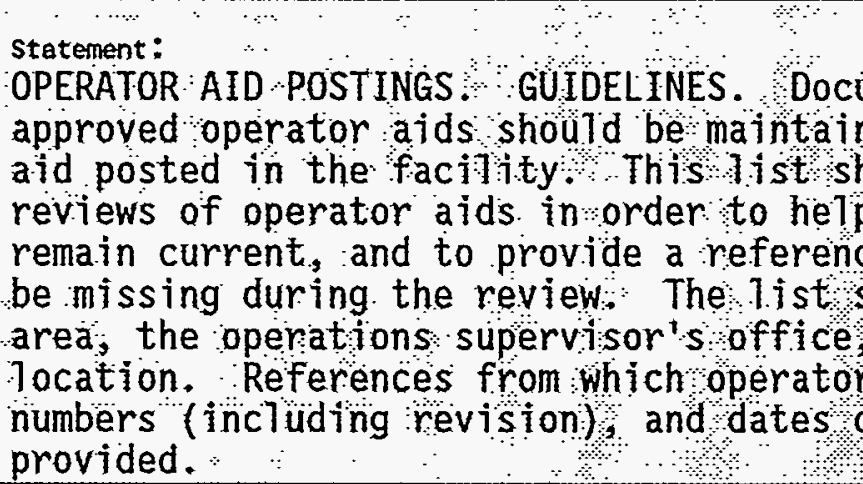 & $\begin{array}{l}\text { tation a } 1 \text { isting of ali } \\
\text { along with a copy of each } \\
\text { d be uised during periodic } \\
\text { sure that the posted aids } \\
\text { opy should an operator aid } \\
\text { 7d be kept in the control } \\
\text { other appropriate } \\
\text { ds were derived, control } \\
\text { pproval should be }\end{array}$ \\
\hline
\end{tabular}

\section{N/A}

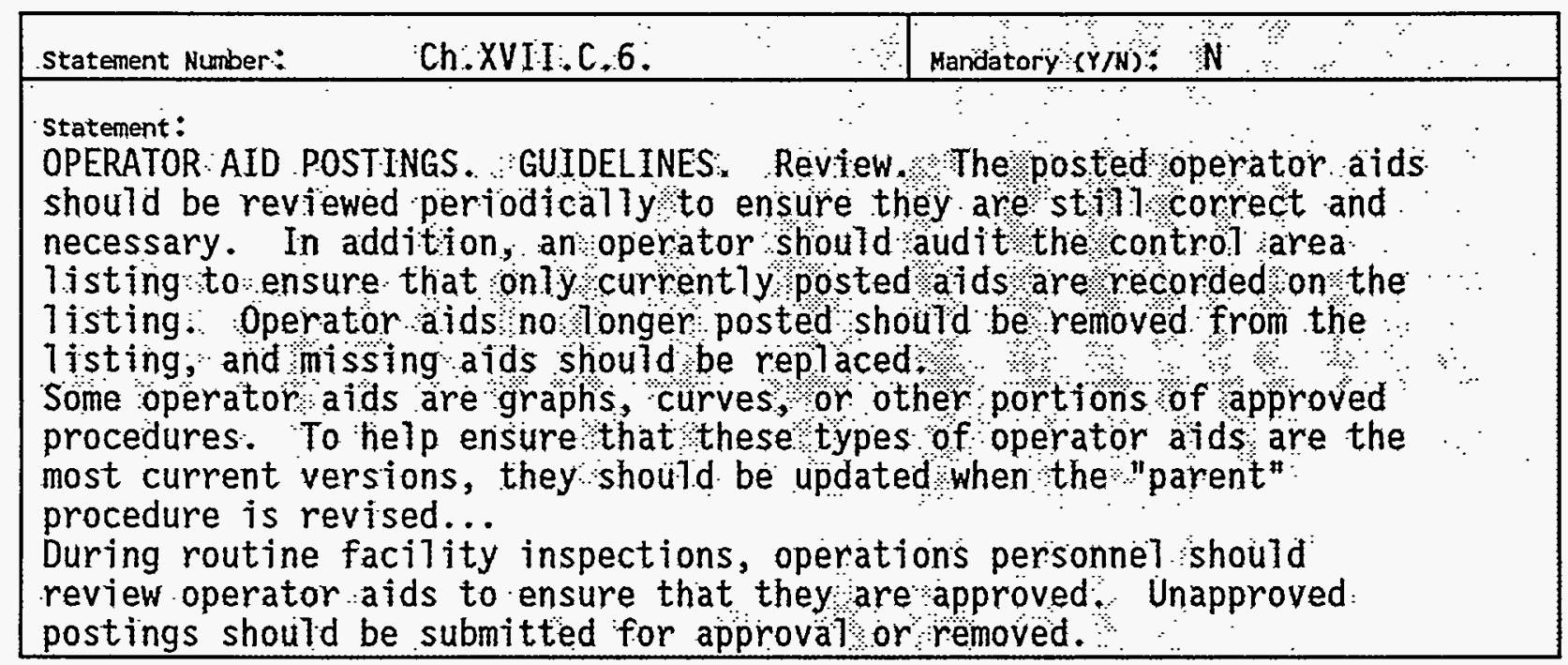

\section{N/A}


WHC-EP-0822

ASSESSMENT DATA COLLECTION FORM

The following statements concerning "EQUIPMENT AND PIPING LABELING" are N/A:

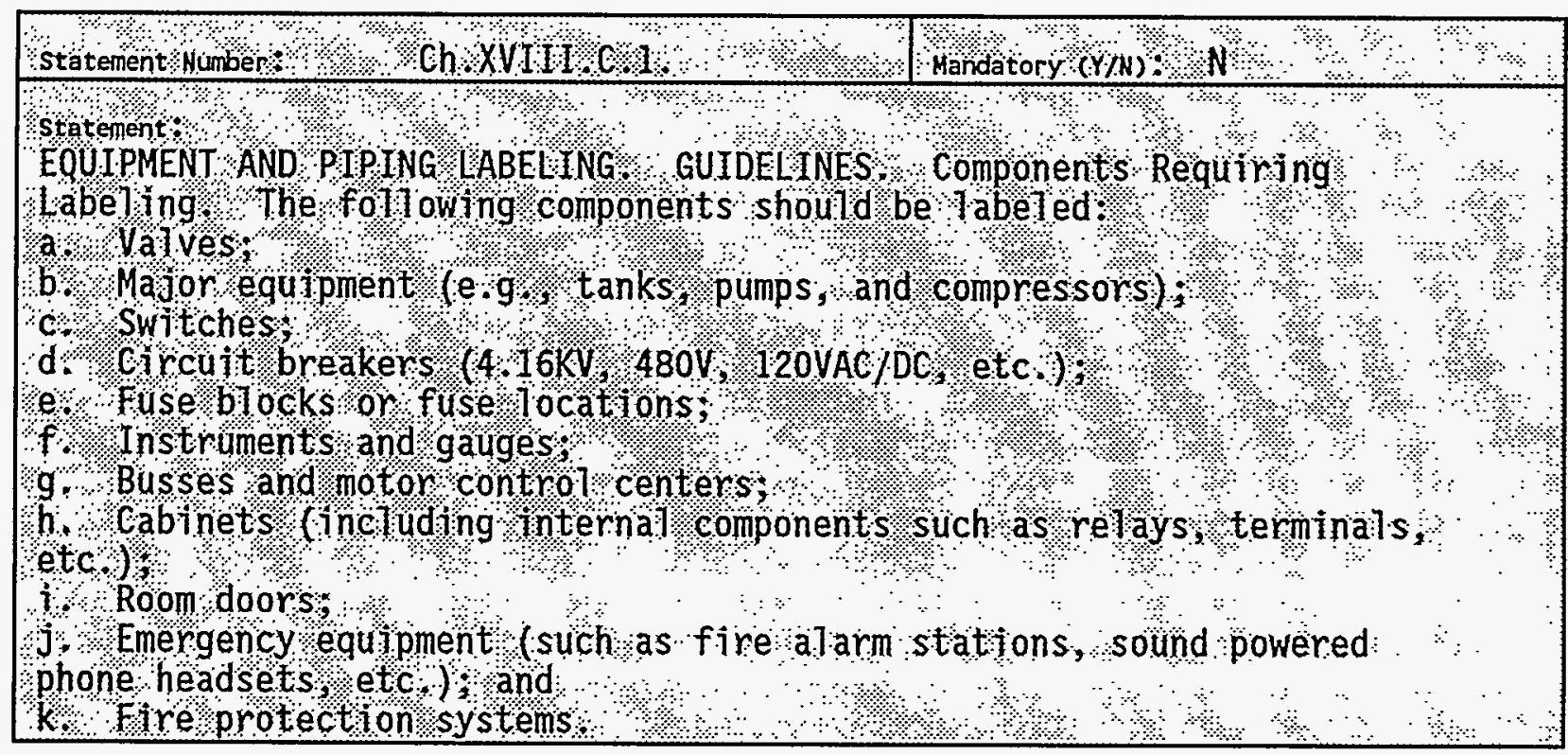


WHC-EP-0822

ASSESSMENT DATA COLLECTION FORM

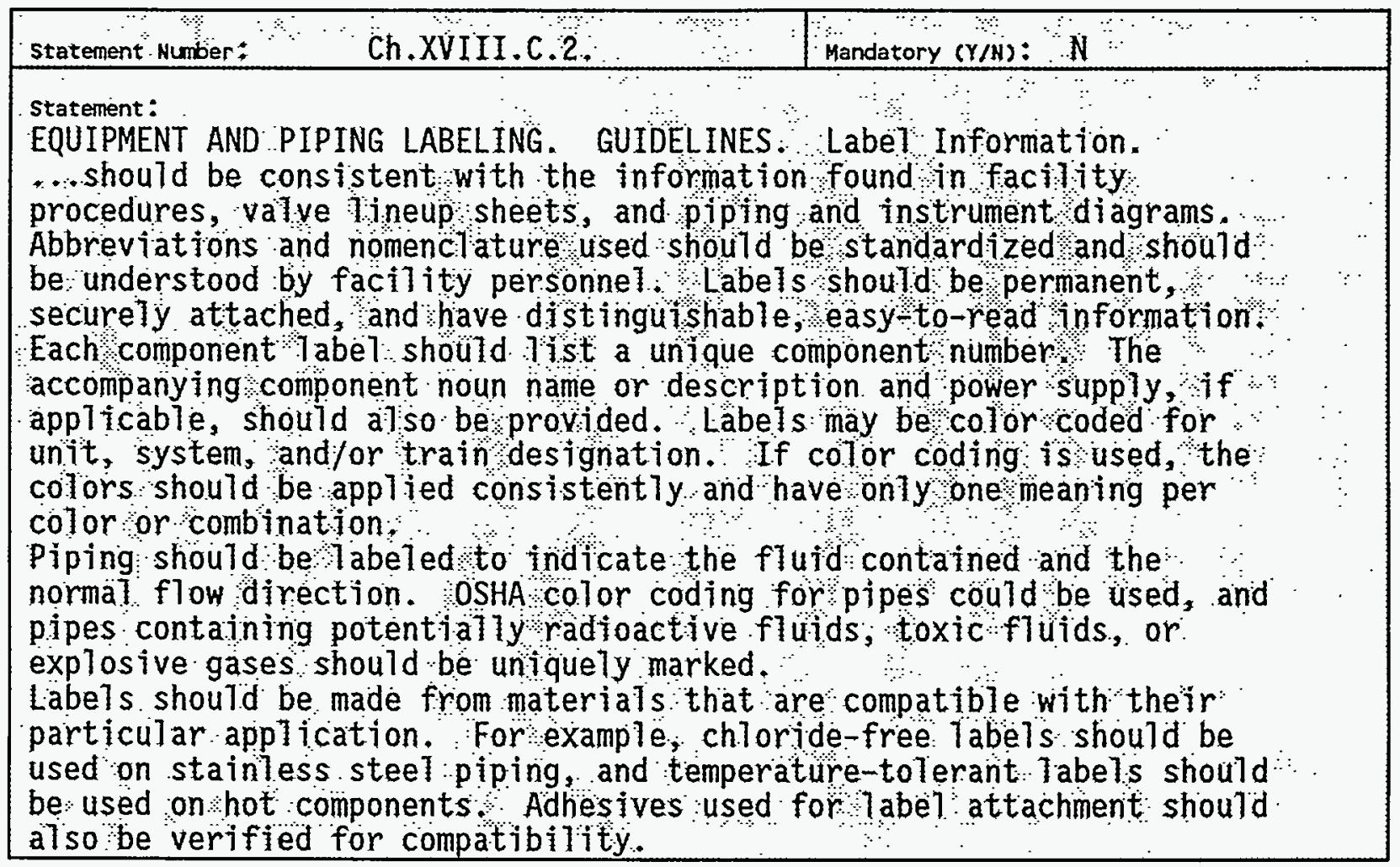

\begin{tabular}{|c|}
\hline Mandatory $(Y / N): \quad N$ \\
\hline $\begin{array}{l}\text { Etatement: } \\
\text { EQUIPMENT AND PIPING LABELING. GUIDELINES Label Placement Labels } \\
\text { should be placed on or as near as pract icable to the equipment to be } \\
\text { labeled. The label should be oriented in a manner that is easy to } \\
\text { read and so that the correct component is easy to identify. } \\
\text { For example, labels for switches, indications, and breakers on control } \\
\text { or power panels should be placed closer to the tdent fied component } \\
\text { than any other component so that the label clearly identifies the } \\
\text { correct component. Label placement should not interfere with } \\
\text { equipment operation or obscure indicators. }\end{array}$ \\
\hline
\end{tabular}


WHC-EP-0822

ASSESSMENT DATA COLLECTION FORM

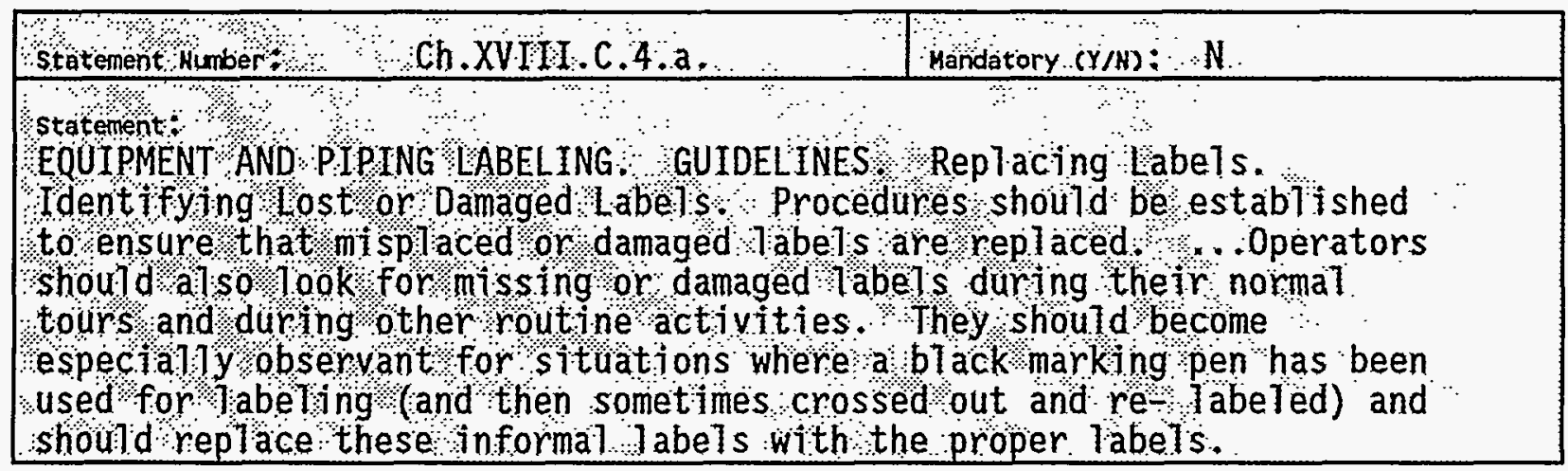

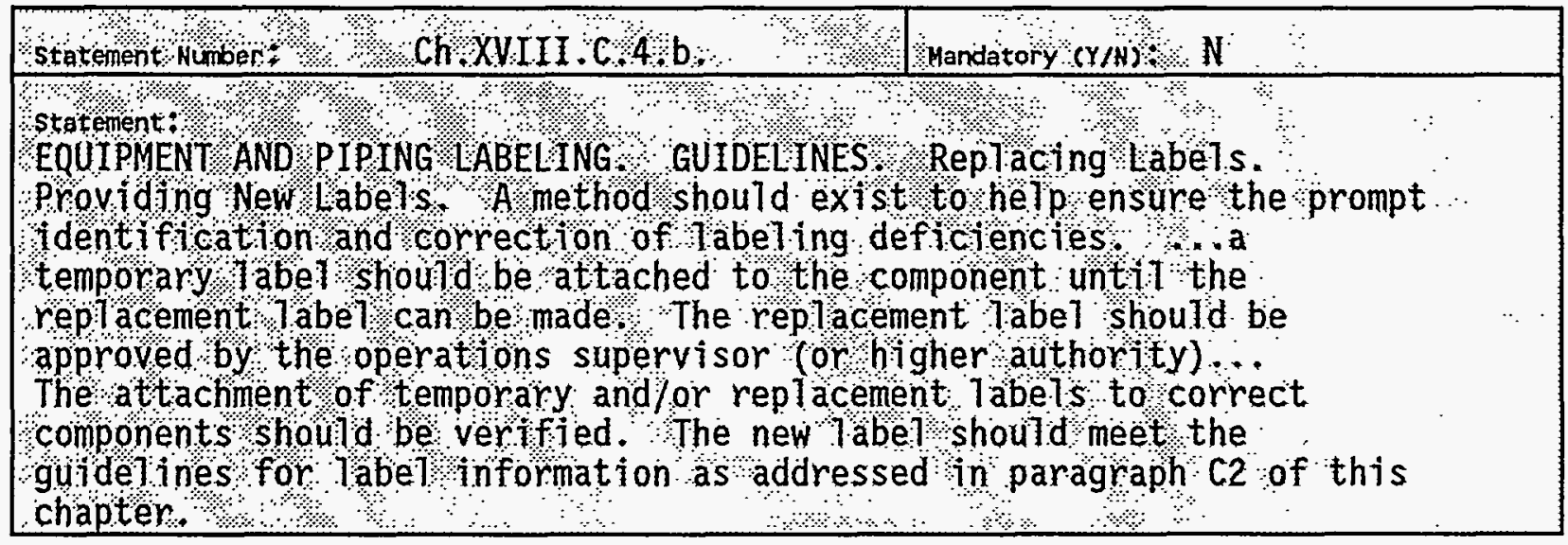

The above statements concerning "EQUIPMENT AND PIPING LABELING" are $N / A$ : 


\section{ATTACHMENT D}

\section{ASSESSMENT DATA COLLECTION FORMS \\ for}

HASQAP ASSESSMENT

to

DOE ORDER 5480.20

(Training) 


\section{ASSESSMENT DATA COLLECTION FORM}

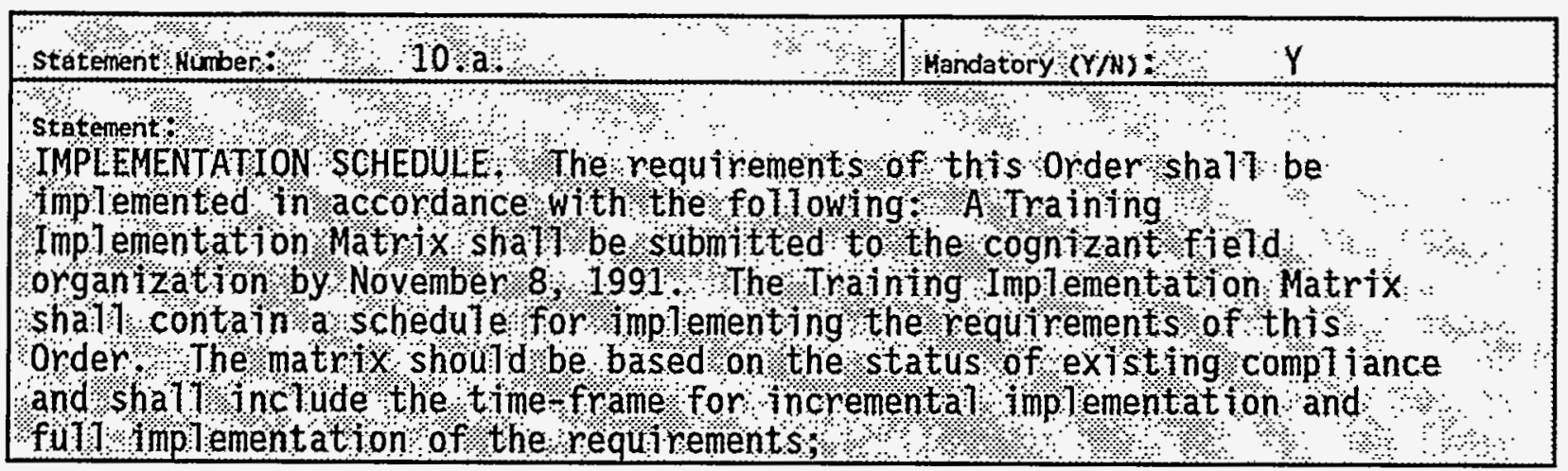

\section{N/A}

\begin{tabular}{|c|}
\hline 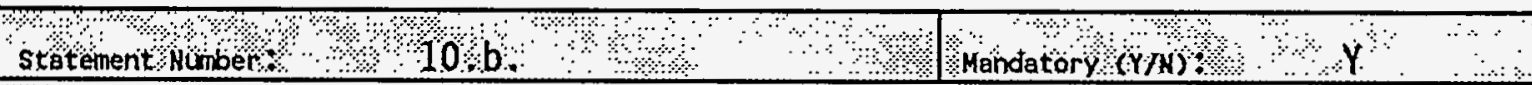 \\
\hline 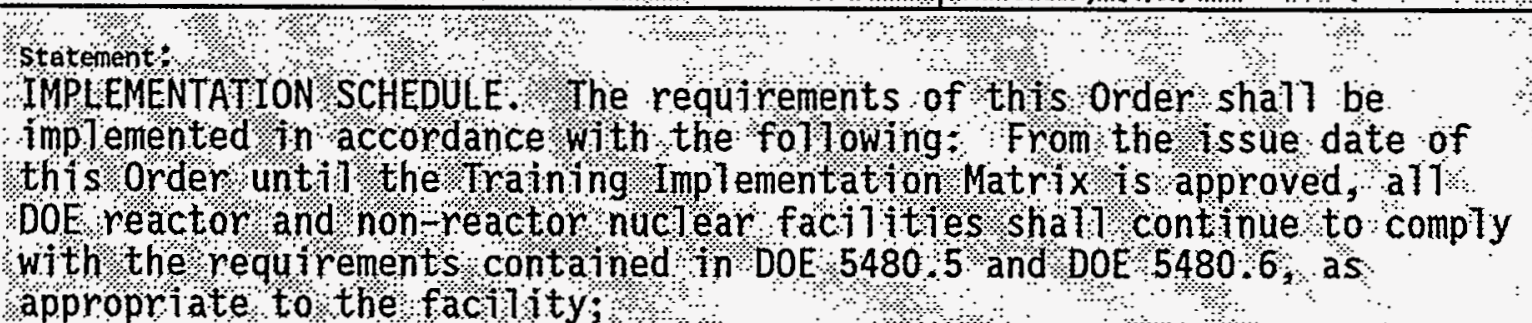 \\
\hline
\end{tabular}

\section{N/A}

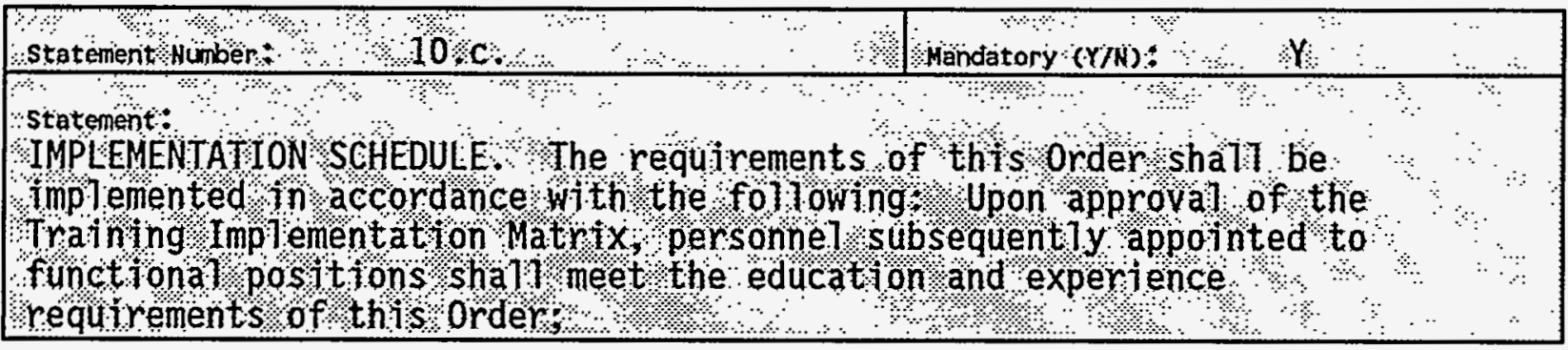

\section{N/A}

\begin{tabular}{|c|}
\hline 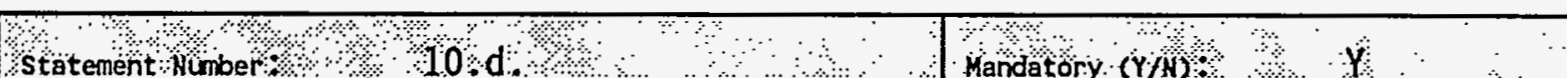 \\
\hline 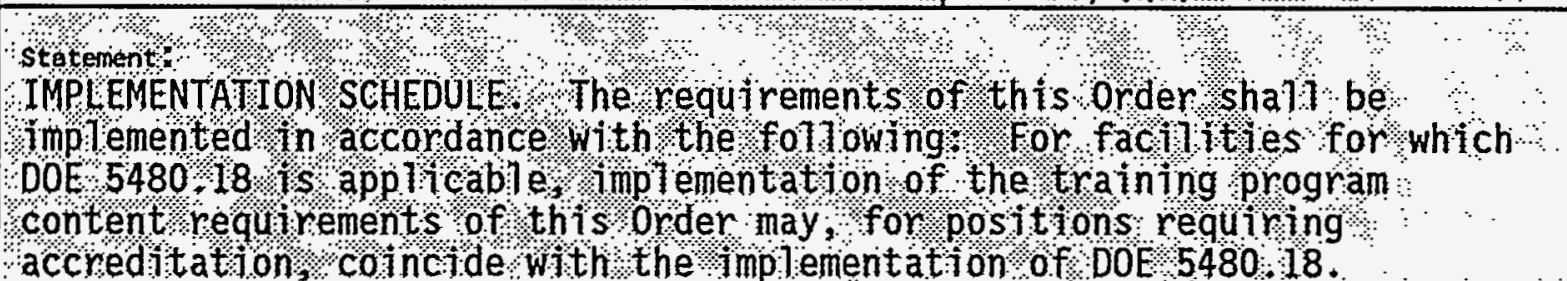 \\
\hline
\end{tabular}

\section{N/A}




\begin{tabular}{|c|}
\hline 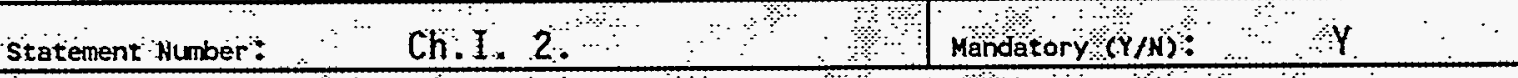 \\
\hline 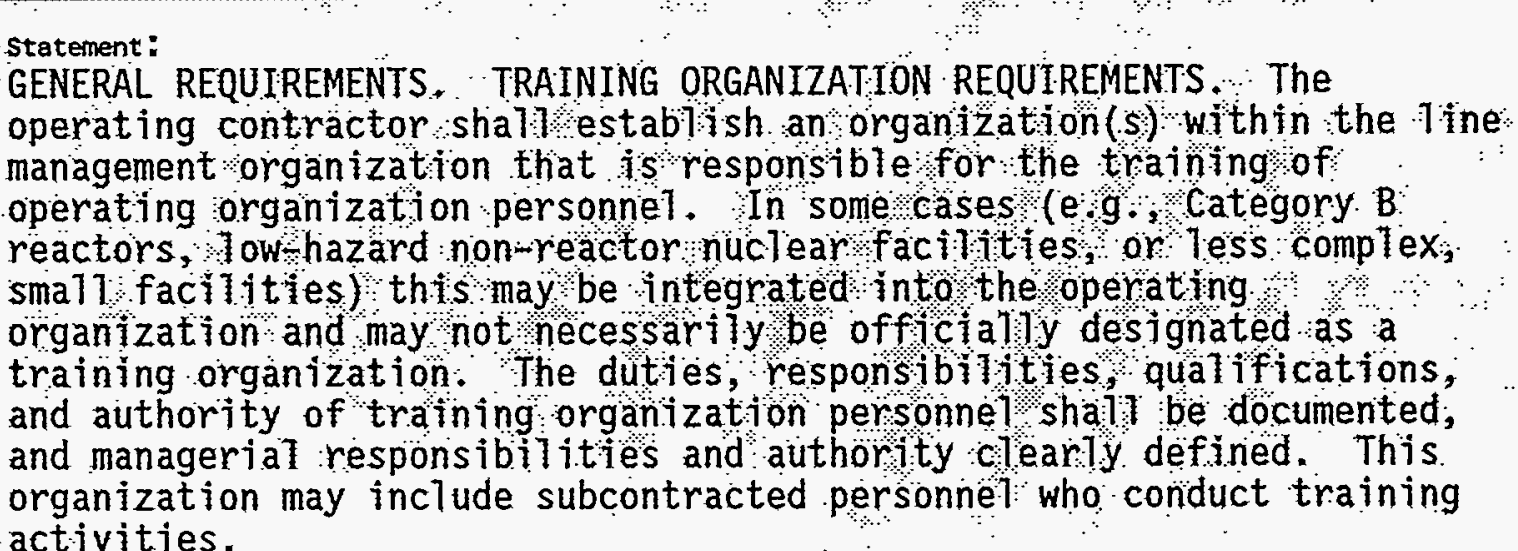 \\
\hline
\end{tabular}

\section{N/A}


WHC-EP-0822

\section{ASSESSMENT DATA COLLECTION FORM}

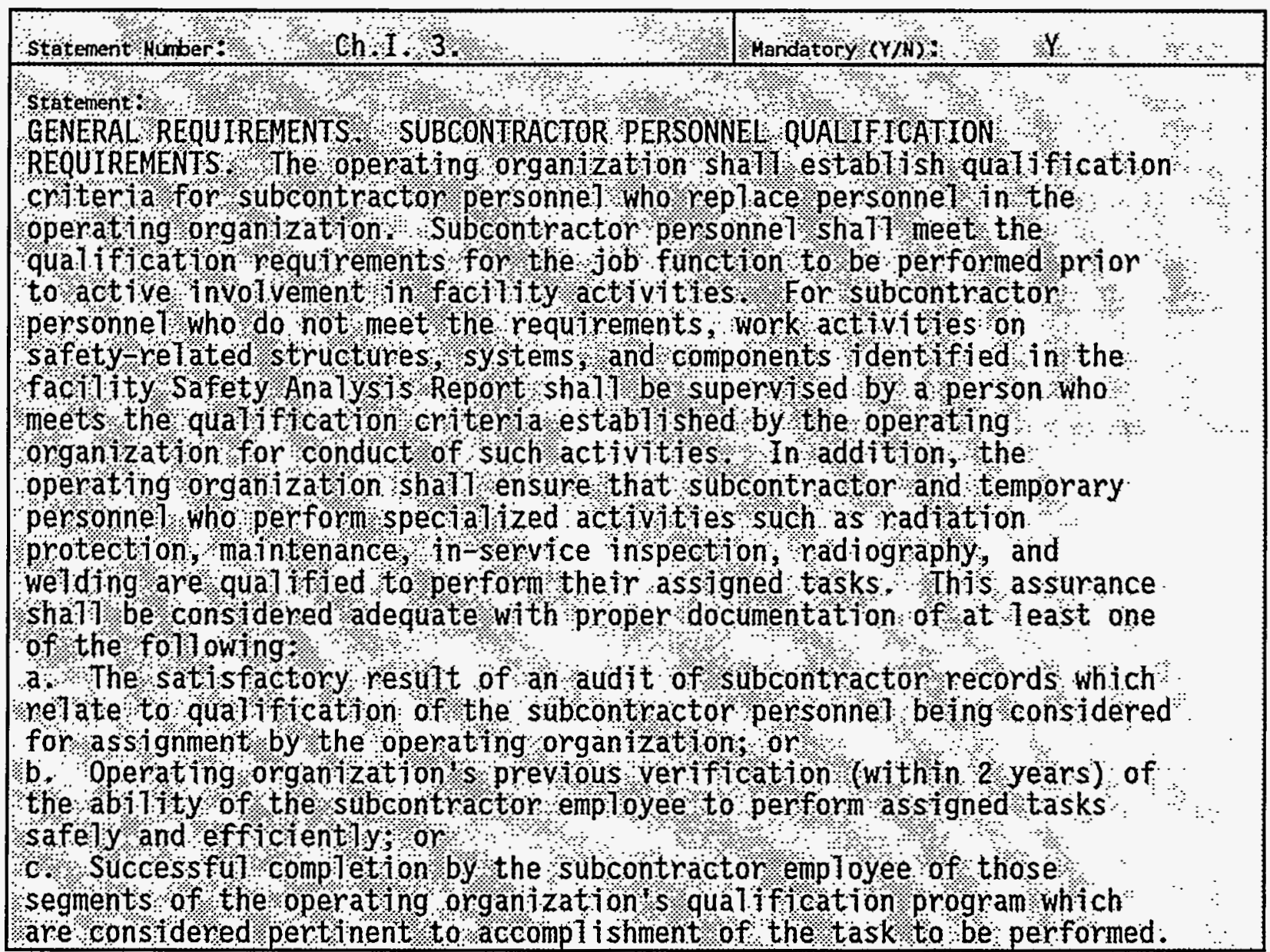

1.0 STATEMENT SATISFIED BASED ON IMPLEMENTING EVIDENCE (Y/N): YES

2.0 GENERAL DESCRIPTION OF EVIDENCE (DESCRIPTION OF NONCOMPLIANCE OR DEFICIEMCY IF APPLICABLE):

The intent of this statement is met by HASQAP Section 3.0, "Personnel Qualification and Training," and subsection 18.2, "Control of Subcontractors." 


\section{ASSESSMENT DATA COLLECTION FORM}

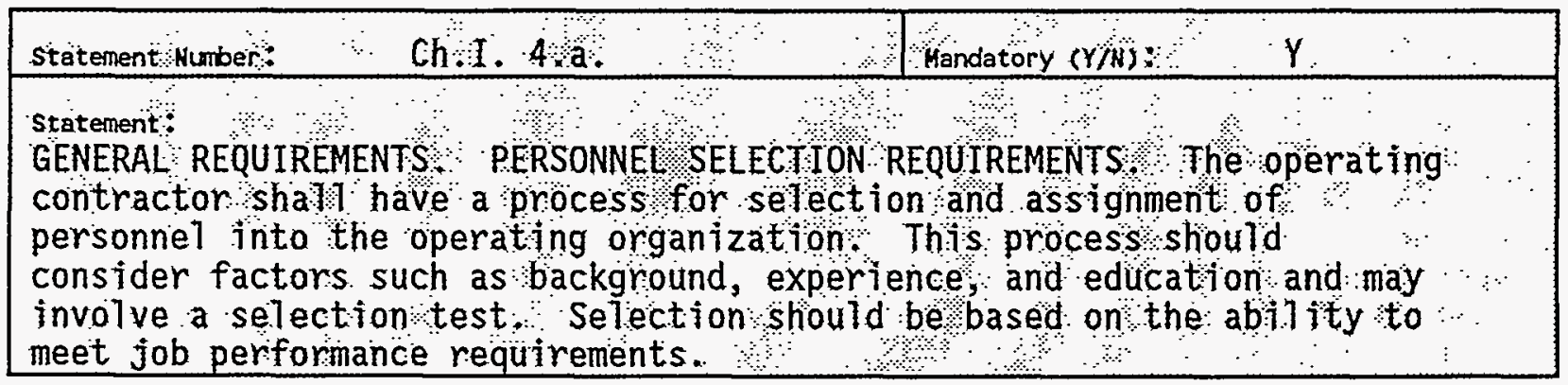

1.0 STATEMENT SATISFIED BASED ON IMPLEMENTING EVIDENCE $(Y / N):$ YES

2.0 GENERAL DESCRIPTION OF EVIDENCE (DESCRIPTION OF NONCOMPLIANCE OR DEFICIENCY IF APPLICABLE):

This statement is met by HASQAP subsection 3.2, "Personnel Selection." 
WHC-EP-0822

\section{ASSESSHENT DATA COLLECTION FORM}

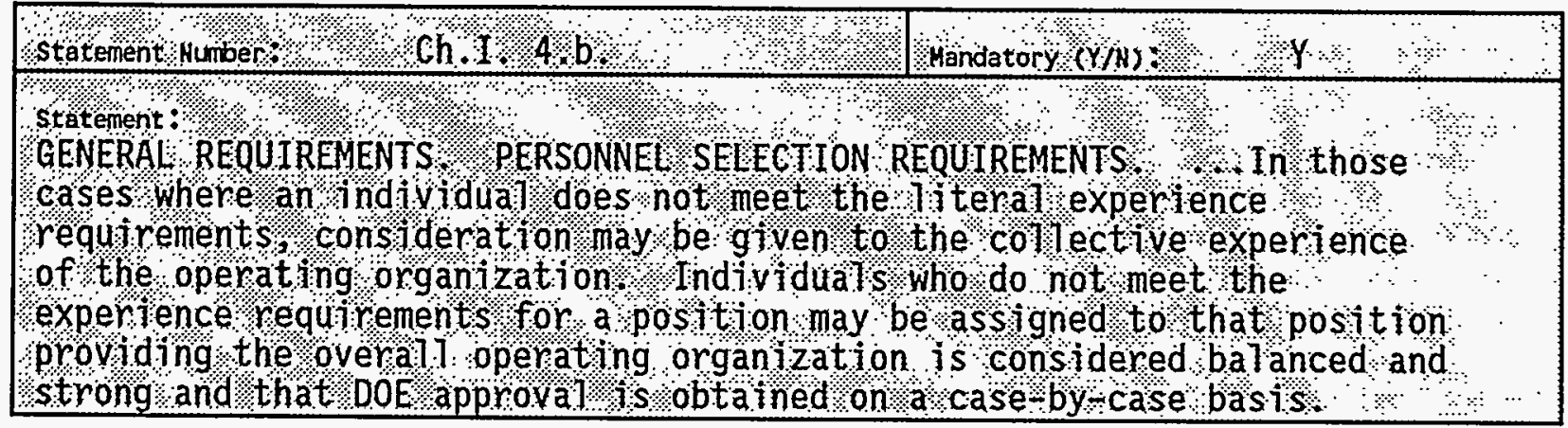

1.0 STATEMENT SATISFIEd BASED ON IMPLEMENTING EVIDENCE $(Y / N):$ NO

2.0 GENERAL DESCRIPTION OF EVIDENCE (DESCRIPTION OF NONCOMPLIANCE OR DEFICIENCY IF APPLICABLE):

Statement not addressed by the HASQAP.

3.0 CORRECTIVE ACTION: 


\section{ASSESSMENT DATA COLLECTION FORM}

\begin{tabular}{|c|c|}
\hline Statement Number: & Mandatory $(Y / N)$ \\
\hline $\begin{array}{l}\text { Statement: } \\
\text { GENERAL REQUIREMENTS QUALIFICATION PROCES } \\
\text {...Personnel at DOE reactor and non-reactor } \\
\text { possess qualifications which provide reason } \\
\text { decisions and actions willensure that ass } \\
\text { conducted properiy and safely. }\end{array}$ & $\begin{array}{l}\text { REQUIREMENIS } \\
\text { nucTear factitities shall } \\
\text { ble assurance that their: } \\
\text { ned responsibilities are }\end{array}$ \\
\hline
\end{tabular}

1.0 STATEMENT SATISFIED BASED ON IMPLEMENTING EVIDENCE $(Y / N)$ Y YES

2.0 GENERAL DESCRIPTION OF EVIDENCE (DESCRIPIION OF NONCOMPLIANCE OR DEFICIENCY IF APPLICABLE):

This statement is met by HASQAP subsection 3.1.1, "Initial Qual ification," and subsection 3.1.2, "Maintaining Qualification." 


\section{ASSESSMENT DATA COLLECTION FORM}

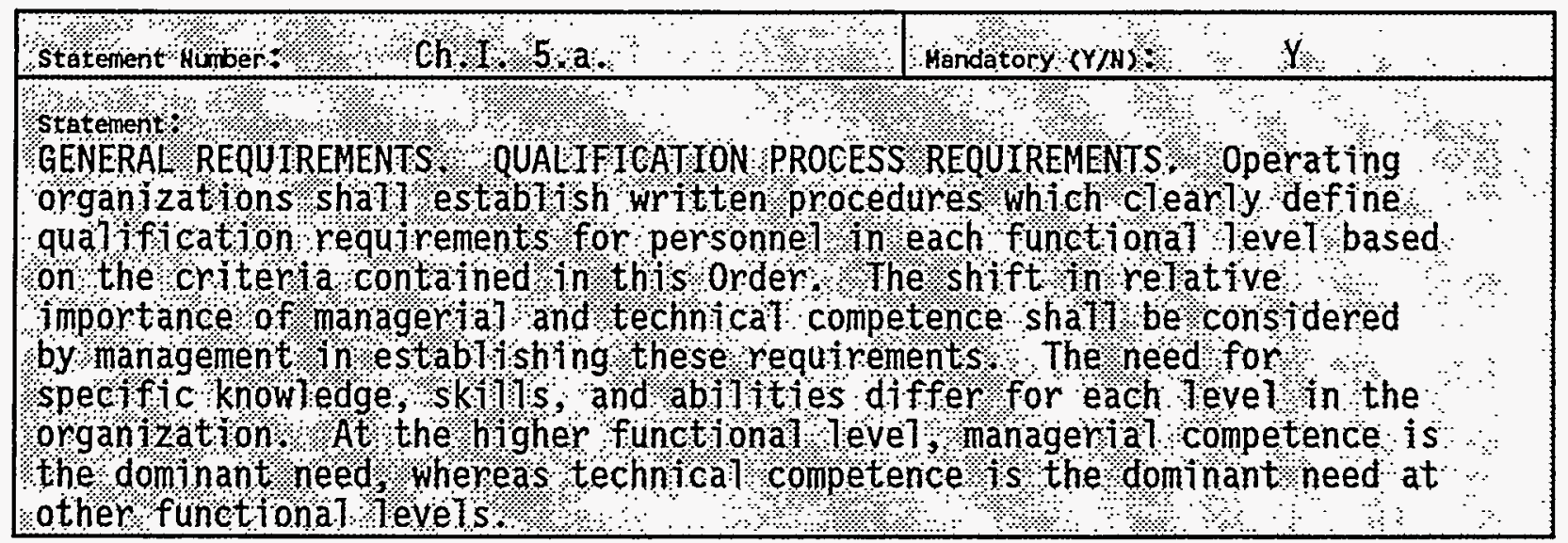

1.0 StATEMENT SATISFIED BASED ON IMPLEMENTING EVIDENCE $(Y / N)$ : YES

2.0 GENERAL DESCRIPTION OF EVIDENCE (DESCRIPTION OF NONCOMPLIANCE OR DEFICIENCY IF APPLICABLE):

This statement is met by HASQAP subsection 3.1, "Qualification, "which states: "Qualification requirements shall be established and reevaluated by laboratory management on a scheduled basis for specific job categories, including managers, analysts, technicians, and data reviewers." 
WHC-EP-0822

\section{ASSESSMENT DATA COLLECTION FORM}

\begin{tabular}{|c|c|c|}
\hline Statement Number: & ChII. $5 \mathrm{~b}$ & Mandatory $(Y / N):$ \\
\hline $\begin{array}{l}\text { Statement: } \\
\text { GENERAL REQUI } \\
\text { Qualificat ion } \\
\text { fincluding tr } \\
\text { requirements }\end{array}$ & $\begin{array}{l}\text { QQUALIFICATION PROCESS } \\
\text { granted only after assu } \\
\text { andoexaminations as requ } \\
\text { been sattsfactority comp }\end{array}$ & $\begin{array}{l}\text { REQUIREMENTS } \\
\text { ring that a 1 requirements } \\
\text { ired) and other specified } \\
\text { leted: }\end{array}$ \\
\hline
\end{tabular}

1.0 STATEMENT SATISFIED BASED ON IMPLEMENTING EVIDENCE $(Y / N):$ YES

2.0 GENERAL DESCRIPTION OF EVIDENCE (DESCRIPTION OF NONCOMPLIANCE OR DEFICIENCY IF APPLICABLE):

This statement is met by HASQAP subsection 3.1, "Qualification," and subsection 3.1.1, "Initial Qualification." 


\section{ASSESSMENT DATA COLLECTION FORM}

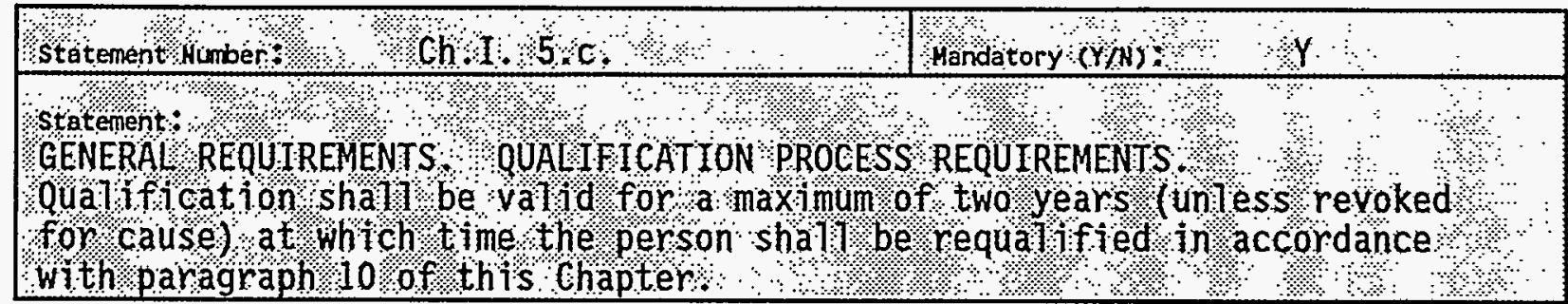

1.0 STATEMENT SATISFIEd BASED ON IMPLEMENTING EVIDENCE $(Y / N)$ N NO

2.0 GENERAL DESCRIPTION OF EVIDENCE (DESCRIPTION OF NONCOMPLIANCE OR DEFICIENCY IF APPLICABLE):

The HASQAP does not address specific time limits for maintaining qualifications.

3.0 CORRECTIVE ACTION: 


\section{ASSESSMENT DATA COLLECTION FORH}

\begin{tabular}{|c|c|c|}
\hline cement Number: & Handatory $(\mathrm{Y} / \mathrm{N})$ & $Y$ \\
\hline \multicolumn{3}{|c|}{ 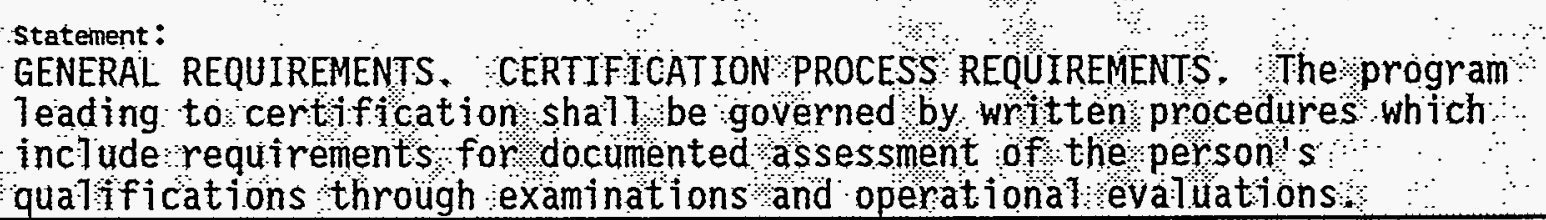 } \\
\hline
\end{tabular}

1.0 STATEMENT SATISFied BASED ON IMPLEMENTING EVIDENCE $(Y / N)$ Y YES

2.0 GENERAL DESCRIPTION OF EVIDENCE (DESCRIPTION OF NONCOMPLIANCE OR DEFICIENCY IF APPLICABLE):

The intent of this statement is met by HASQAP Section 3.0, "Personnel Qualification and Training."

3.0 COMMENTS:

The term "certification" does not appear in Section 3.0 until the 7ast bullet in subsection 3.7 where it is used to define "formal qualification." 


\section{ASSESSMENT DATA COLLECTION FORM}

\begin{tabular}{|c|c|}
\hline statement Number $/ \mathrm{ch} \mathrm{r}: 6, \mathrm{~b}$ & Handatory $(Y \% N) \times$ \\
\hline 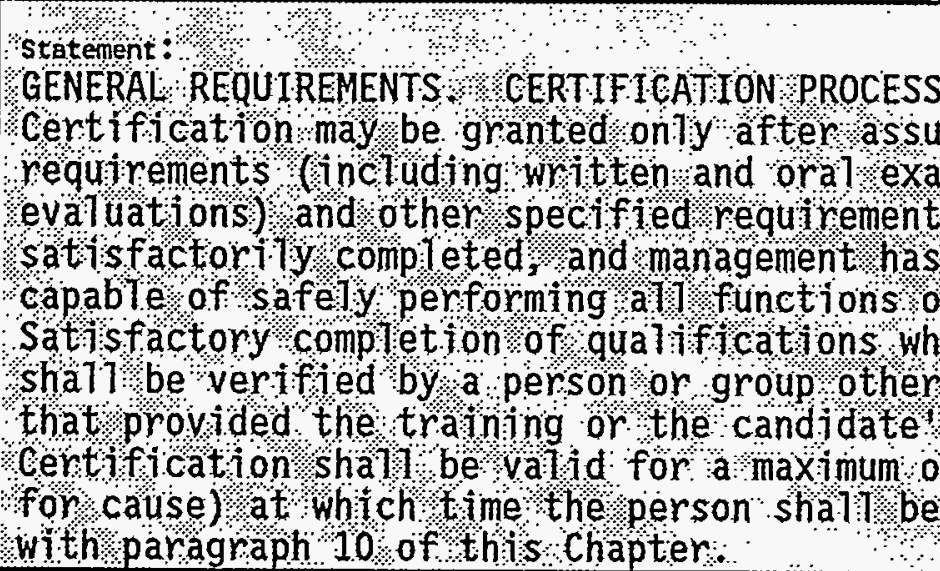 & 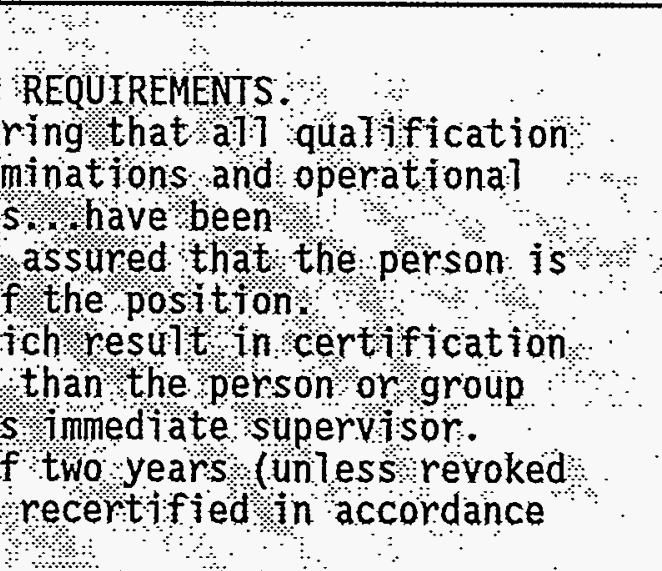 \\
\hline
\end{tabular}

1.0 StATEMENT SATISFIED BASED ON IMPLEMENTING EVIDENCE (Y/N): NO

2.0 GENERAL DESCRIPTION OF EVIDENCE (DESCRIPTION OF NONCONPLIANCE OR DEFICIENCY IF APPLICABLE):

The following portion of the statement is not addressed in the HASQAP:

Satisfactory completion of qualifications which result in certification shall be verified by a person or group other than the person or group that provided the training or the candidate's immediate supervisor. Certification shall be valid for a maximum of two years (unless revoked for cause) at which time the person shall be recertified in accordance with paragraph 10 of this Chapter.

\subsection{CORRECTIVE ACTION:}




\section{ASSESSMENT DATA COLLECTION FORM}

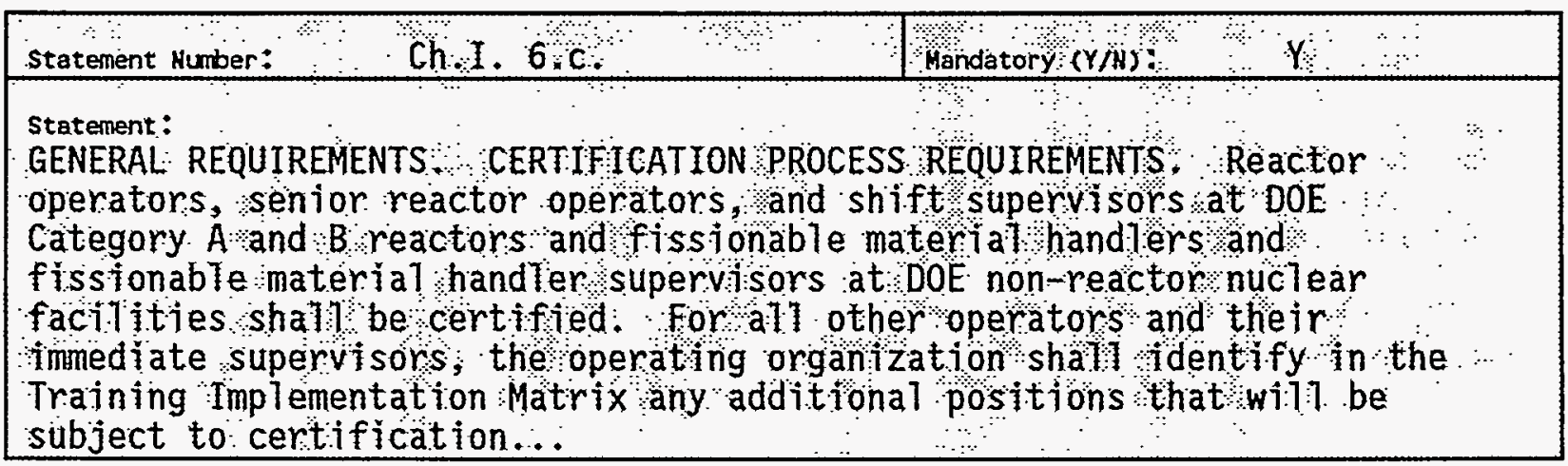

\section{N/A}


WHC-EP-0822

\section{ASSESSMENT DATA COLLECTION FORM}

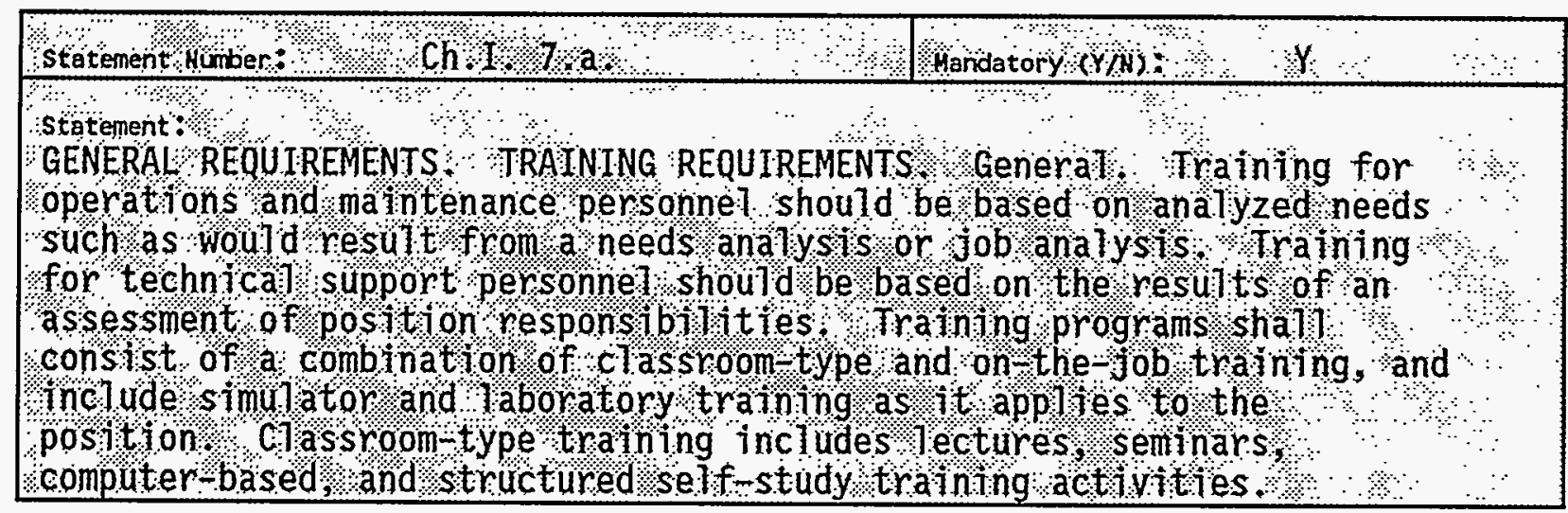

1.0 StATEMENT SATISFied BASEd ON IMPLEMENTing EVIDENCE (Y/N): YES

2.0 GENERAL DESCRIPTION OF EVIDENCE (DESCRIPTION OF NONCOMPLIANCE OR DEFICIENCY IF APPLICABLE):

This statement is met by HASQAP Section 3.0, "Personnel Qualification and Training." 
WHC-EP-0822

\section{ASSESSMENT DATA COLLECTION FORM}

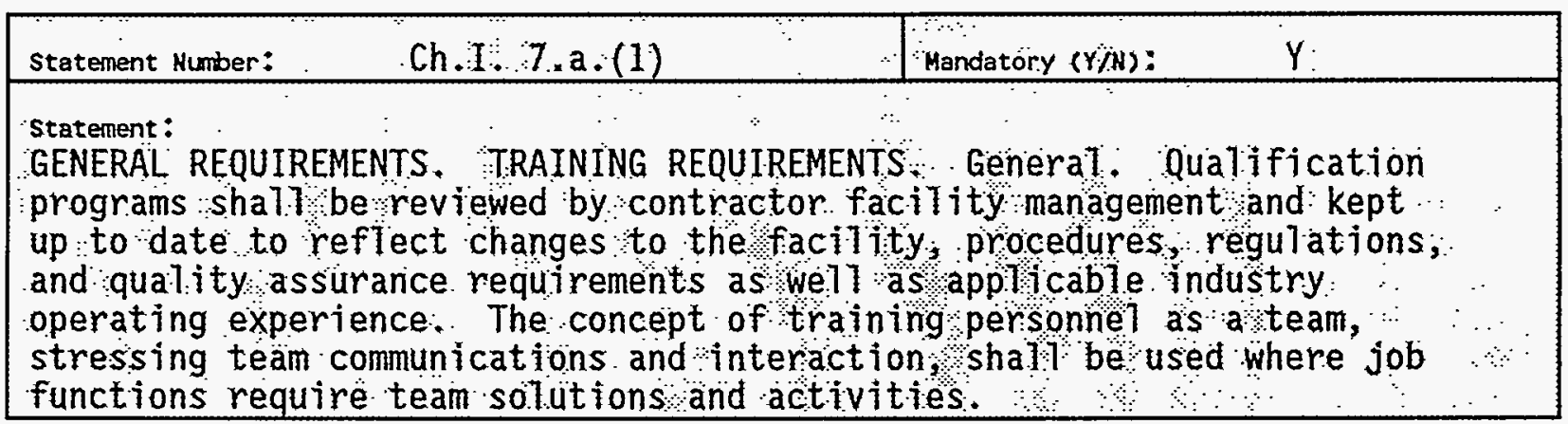

1.0 STATEMENT SATISFIED BASED ON IMPLEMENTING EVIDENCE $(Y / N):$ YES

2.0 GENERAL DESCRIPTION OF EVIDENCE (DESCRIPTION OF NONCOMPLIANCE OR DEFICIENCY IF APPLICABLE):

This statement is met by HASQAP subsection 3.1, "Qualification," 


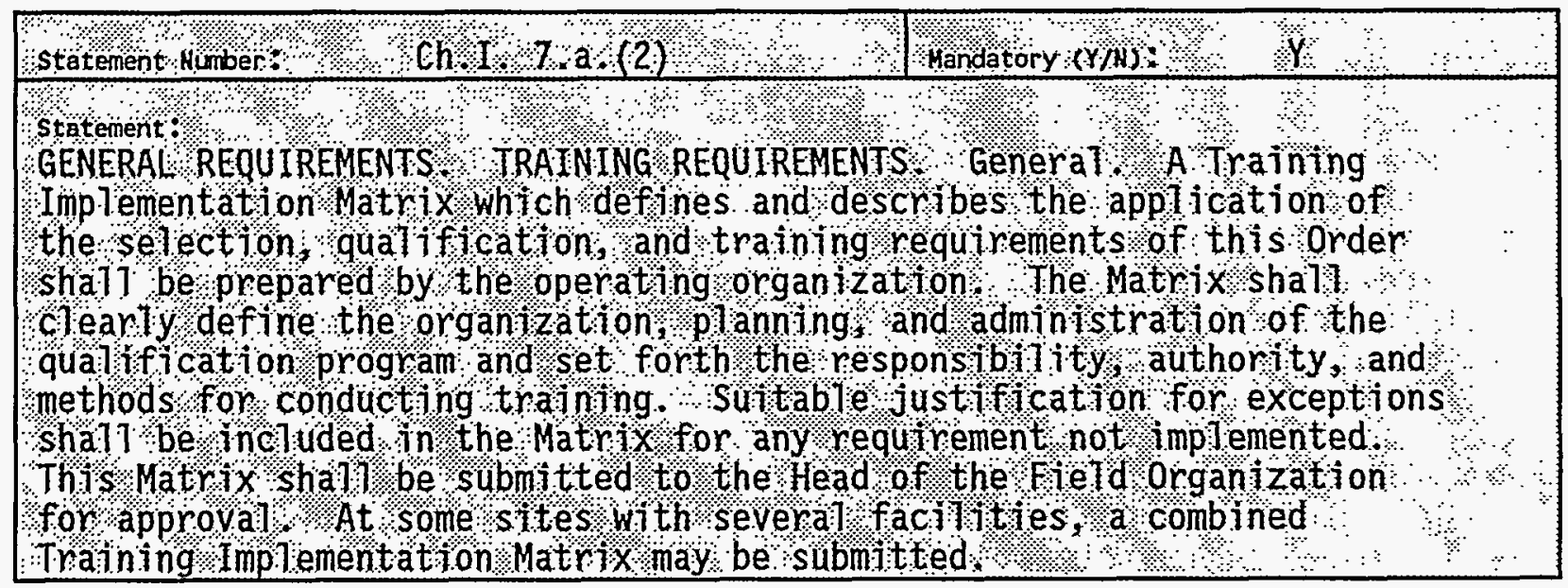

1.0 STATEMENT SATISFIED BASEd ON IMPLEMENTING EVIDENCE $(Y / N)$ : NO

2.0 GENERAL DESCRIPTION OF EVIDENCE (DESCRIPTION OF NONCOMPLIANCE OR DEFICIENCY IF APPLICABLE):

This statement is not addressed by the HASQAP.

3.0 CORRECTIVE ACTION: 
WHC-EP-0822

ASSESSHENT DATA COLLECTION FORM

\begin{tabular}{|c|}
\hline Mandatory $(Y / N)$ : \\
\hline 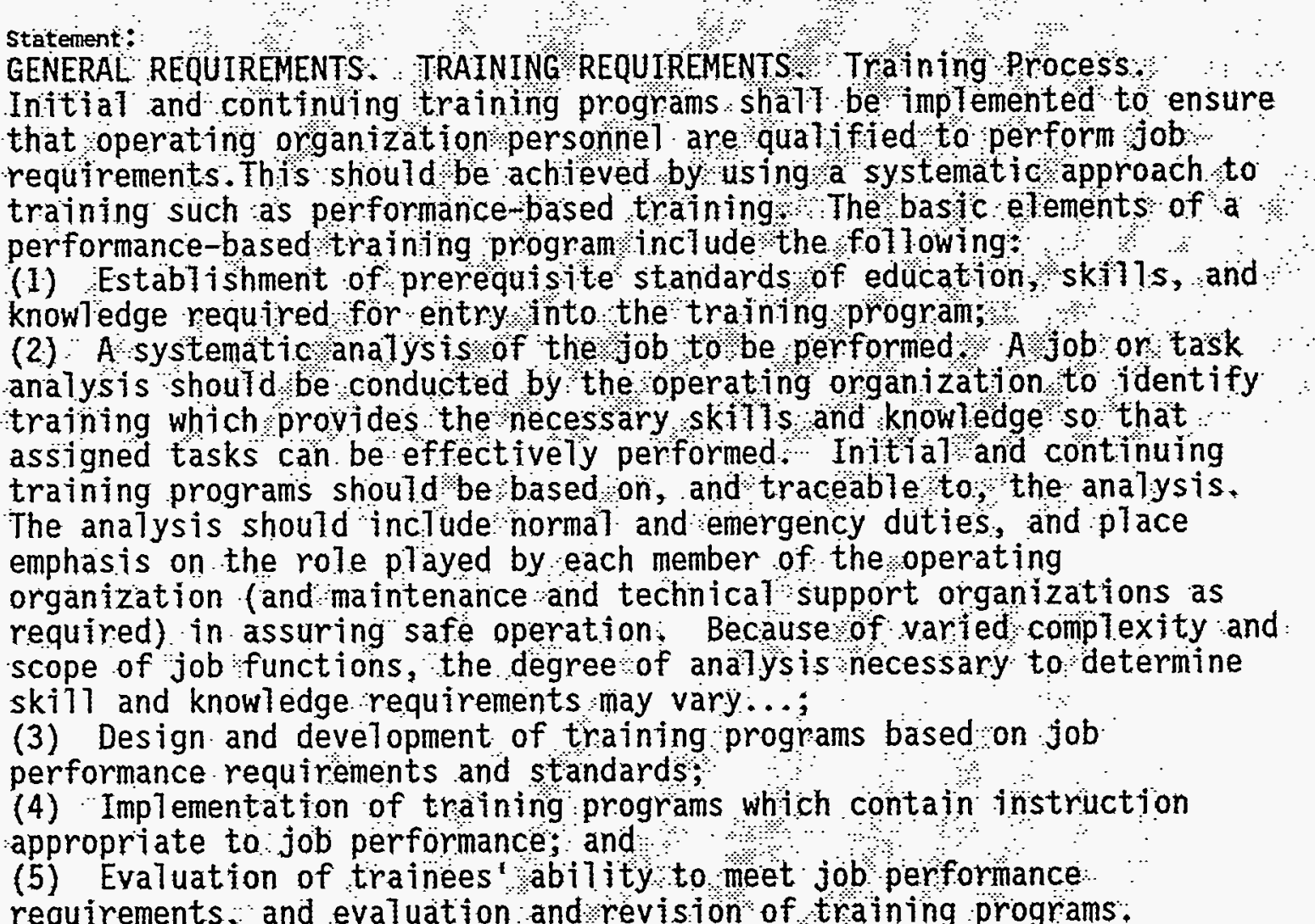 \\
\hline
\end{tabular}

1.0 STATEMENT SATISFIED BASED ON IMPLEMENTING EVIDENCE (Y/N): YES

2.0 GENERAL DESCRIPTION OF EVIDENCE (DESCRIPTION OF NONCOMPLIANCE OR DEFICIENCY IF APPLICABLE):

This statement is met by HASQAP Section 3.0, "Personnel Qualification and Training." 
WHC-EP-0822

\section{ASSESSMENT DATA COLLECTION FORM}

\begin{tabular}{|c|}
\hline 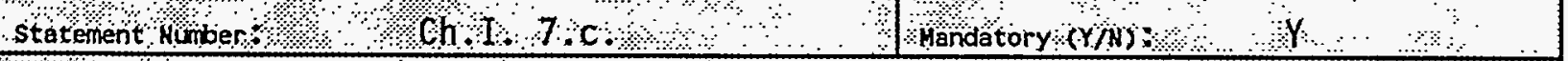 \\
\hline 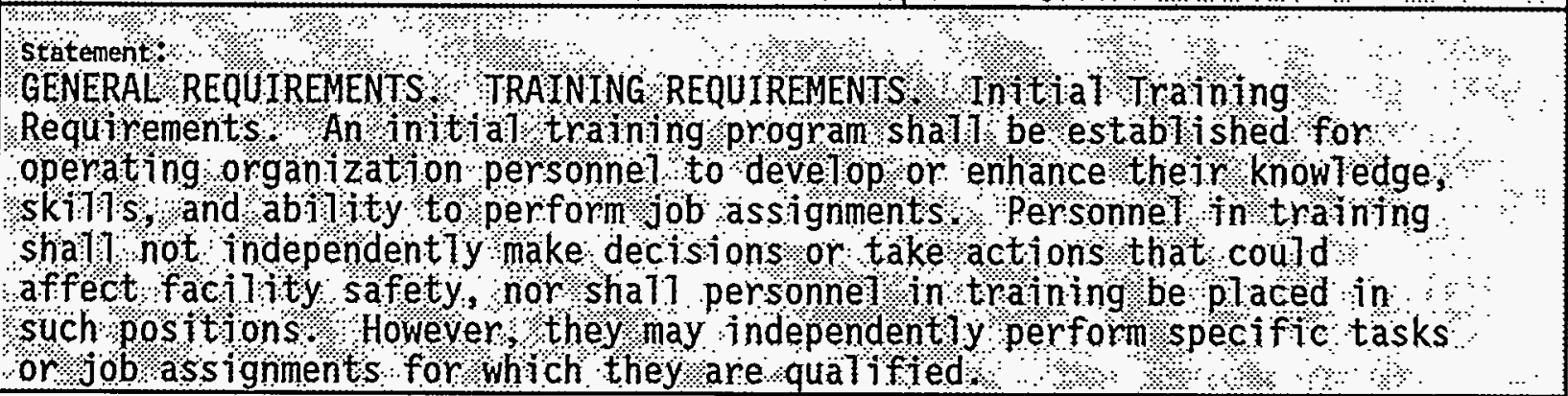 \\
\hline
\end{tabular}

1.0 STATEMENT SATISFIED BASED ON IMPLEMENTING EVIDENCE (Y/N): YES

2.0 GENERAL DESCRIPTION OF EVIDENCE (DESCRIPTION OF NONCOMPLIANCE OR DEFICIENCY IF APPLICABLE):

This statement is met by HASQAP subsection 3.6.1, "Initial Training Requirements." 
WHC-EP-0822

\section{ASSESSMENT DATA COLLECTION FORM}

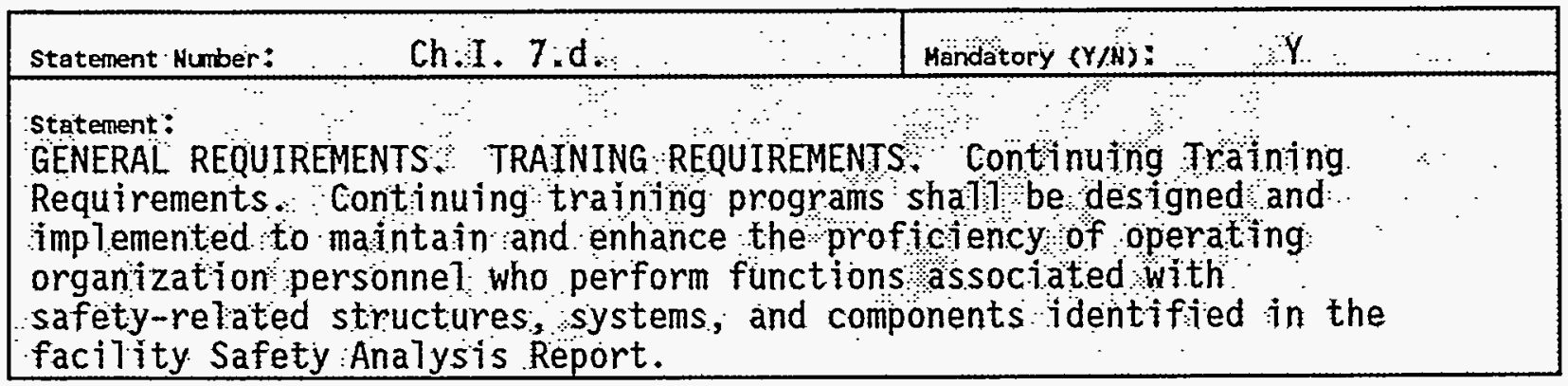

1.0 StATEMENT SATISFied BASEd ON IMPLEMENTING EVIDENCE $(Y / N)$ : YES

2.0 GENERAL DESCRIPTION OF EVIDENCE (DESCRIPTION OF NONCOMPLIANCE OR DEFICIENCY IF APPLICABLE):

This statement is met by HASQAP subsection 3.6.2, "Continuing Training Requirements." 


\section{ASSESSHENT DATA COLLECTION FORM}

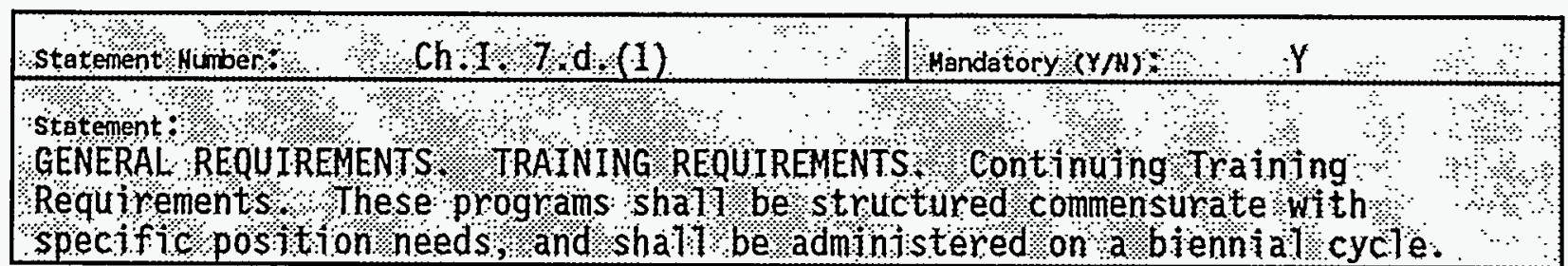

1.0 STATEMENT SATISFIED BASED ON IMPLEMENTING EVIDENCE $(Y / N)$ : NO

2.0 GENERAL DESCRIPTION OF EVIDENCE (DESCRIPTION OF NONCOMPLIANCE OR DEFICIENCY IF APPLICABLE):

The portion of the statement that states "shall be administered on a biennial cycle" is not addressed in HASQAP subsection 3.6.2.

3.0 COMMENTS:

Administering a continuing training program per the statement implies a different meaning than appraising performance and evaluating personnel as stated in subsection 3.6.2.

4.0 CORRECTIVE ACTION: 


\section{ASSESSMENT DATA COLLECTION FORM}

\begin{tabular}{|c|c|c|}
\hline Statement Number: & Handatory. $(Y / N):$ & $Y$ \\
\hline \multicolumn{3}{|c|}{ 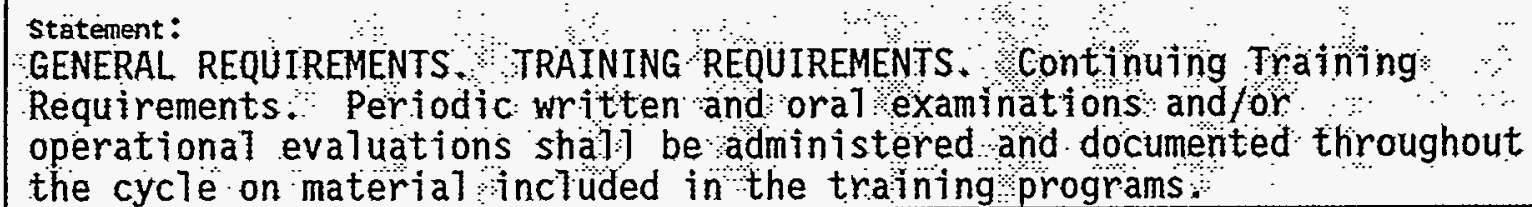 } \\
\hline
\end{tabular}

1.0 STATEMENT SATISFIED BASED ON IMPLEMENTING EVIDENCE $(Y / N)$ : YES

2.0 GENERAL DESCRIPTION OF EVIDENCE (DESCRIPTION OF NONCOMPLIANCE OR DEFICIENCY IF APPLICABLE):

The intent of this statement is met by HASQAP subsection 3.6.2, "Continuing Training Requirements."

3.0 CORRECTIVE ACTION: 


\section{ASSESSMENT DATA COLLECTION FORM}

\begin{tabular}{|c|c|}
\hline atement numbers $/$ (h) $7 \mathrm{~d}(3)$ & Mandatory $(y / \mathrm{N})$ \\
\hline 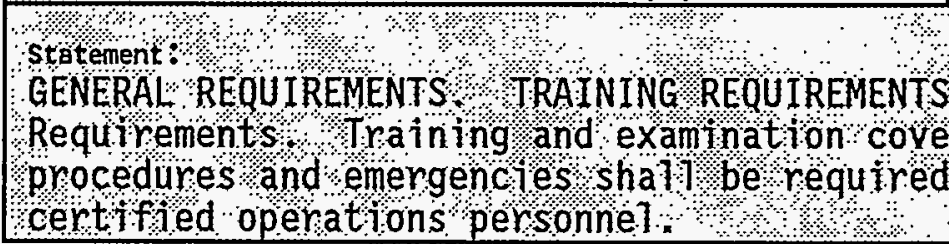 & 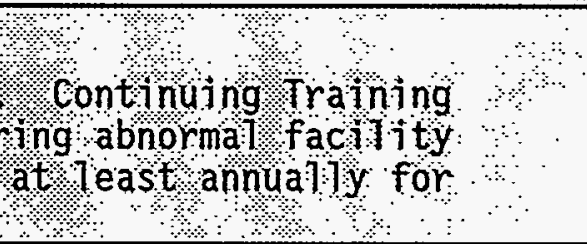 \\
\hline
\end{tabular}

1.0 STATEMENT SATISFIED BASED ON IMPLEMENTING EVIDENCE (Y/N): NO

2.0 GENERAL DESCRIPTION OF EVIDENCE (DESCRIPTION OF NONCOMPLIANCE OR DEFICIENCY IF APPLICABLE):

Abnormal facility procedures and emergencies as a part of the continuing training program is not specifically addressed in the HASQAP.

3.0 CORRECTIVE ACTION: 


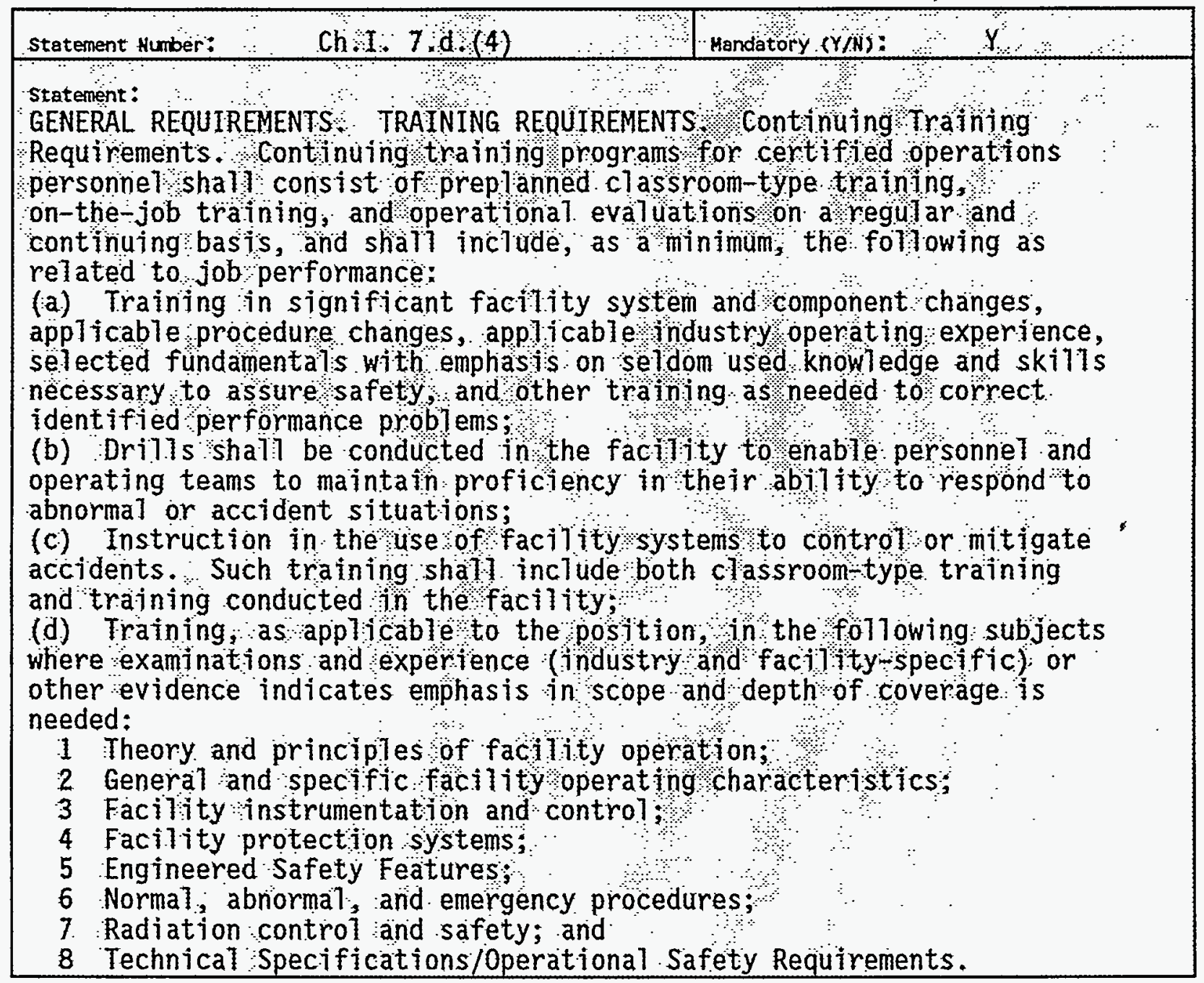

1.0 STATEMENT SATISFIED BASED ON IMPLEMENTING EVIDENCE $(Y / N):$ Yes

2.0 GENERAL DESCRIPTION OF EVIOENCE (DESCRIPTION OF NONCOMPLIANCE OR DEFICIENCY IF APPLICABLE):

The intent of this statement is met by HASQAP Section 3.0, "Personne] Qualification and Training." 


\section{ASSESSMENT DATA COLLECTION FORM}

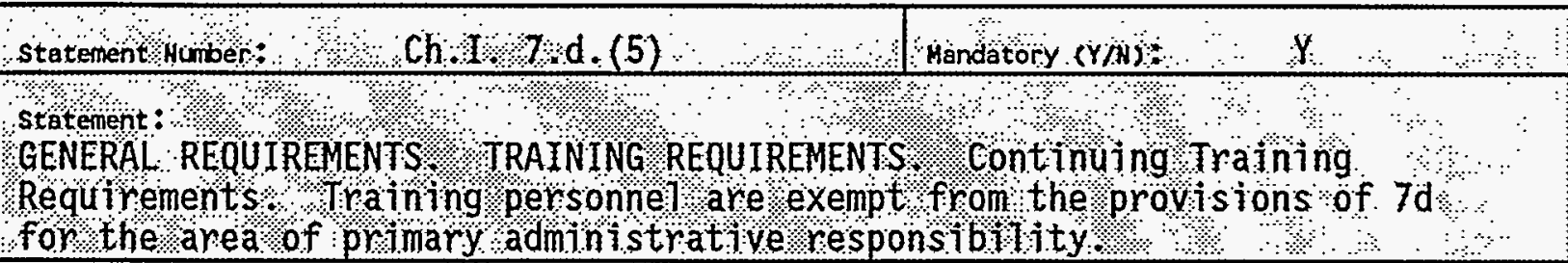

1.0 STATEMENT SATISFIED BASED ON IMPLEMENTING EVIDENCE (Y/N): NO

2.0 GENERAL DESCRIPTION OF EVIDENCE (DESCRIPTION OF NONCOMPLIANCE OR DEFICIENCY IF APPLICABLE):

Not addressed in the HASQAP.

3.0 CORRECTIVE ACTION: 
ASSESSHENT DATA COLLECTION FORM

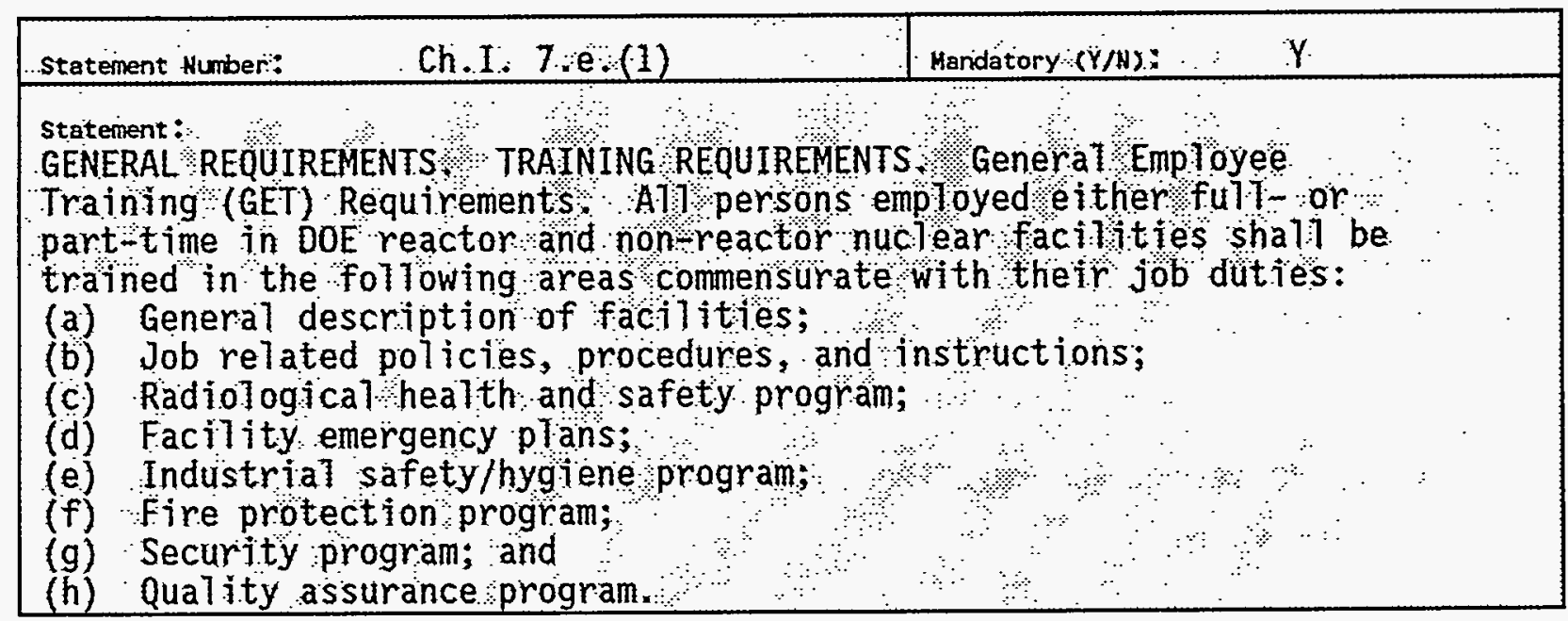

1.0 STATEMENT SATISFIED BASED ON IMPLEMENTING EVIDENCE (Y/N): NO

2.0 GENERAL DESCRIPTION OF EVIDENCE (DESCRIPTION OF NONCOMPLIANCE OR DEFICIENCY IF APPLICABLE):

GET training is not addressed in the HASQAP.

3.0 CORRECTIVE ACTION: 


\section{ASSESSMENT DATA COLLECTION FORM}

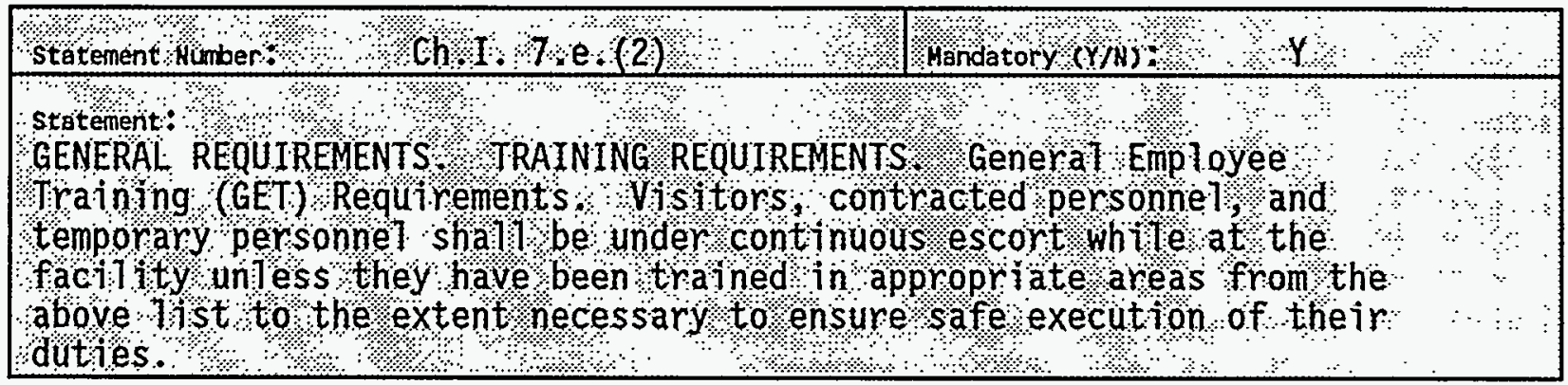

1.0 STATEMENT SATISFIED BASED ON IMPLEMENTING EVIDENCE $(Y / N)$ : NO

2.0 GENERAL DESCRIPTION OF EVIDENCE (DESCRIPTION OF NONCOMPLIANCE OR DEFICIENCY IF APPLICABLE):

GET training is not addressed in the HASQAP.

3.0 CORRECTIVE ACTION: 


\section{ASSESSMENT DATA COLLECTION FORM}

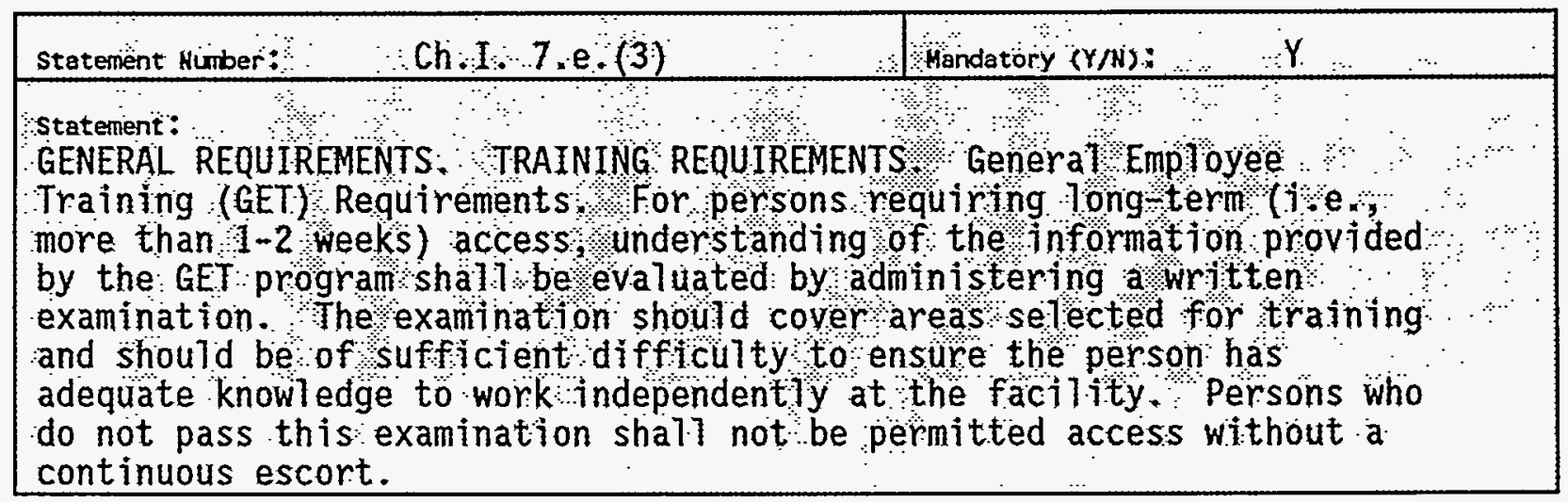

1.0 STATEMENT SATISFIED BASEd ON IMPLEMENTING EVIDENCE (Y/N): NO

2.0 GENERAL DESCRIPTION OF EVIDENCE (DESCRIPTION OF NONCOMPLIANCE OR DEFICIENCY IF APPLICABLE):

GET training is not addressed in the HASQAP.

3.0 CORRECTIVE ACTION: 
WHC-EP-0822

\section{ASSESSMENT DATA COLLECTION FORM}

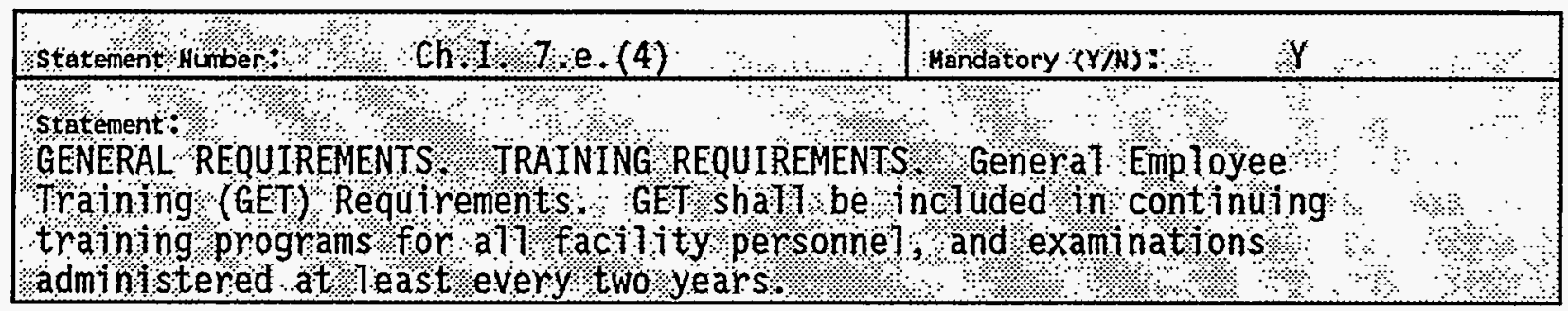

1.0 STATEMENT SATISFIED BASED ON IMPLEMENTING EVIDENCE $(Y / N):$ NO

2.0 GENERAL DESCRIPTION OF EVIDENCE (DESCRIPTION OF NONCOMPLIANCE OR DEFICIENCY IF APPLICABLE):

GET training is not addressed in the HASQAP.

3.0 CORRECTIVE ACTION: 


\section{ASSESSMENT DATA COLLECTION FORM}

\begin{tabular}{|c|c|}
\hline Statement Nimber: & Mandatory $(Y / N):$ \\
\hline $\begin{array}{l}\text { Statement: } \\
\text { GENERAL REQUIREMENTS. TRAININ } \\
\text { AsSessment (PRA) Training Requ } \\
\text { a PRA has been performed, init } \\
\text { operations and technical suppo } \\
\text { the principaT restilts of the P } \\
\text { following: } \\
\text { (1) The importance of facili it } \\
\text { accidents; } \\
\text { (2) Locations of all signific } \\
\text { hazardous materials, and measu } \\
\text { (3) The importance of maintai } \\
\text { and the consequences of violat }\end{array}$ & $\begin{array}{l}\text { Probabilistic Risk } \\
\text { those facilities for which } \\
\text { ding training programs for } \\
\text { all include trating on } \\
\text { ing shalt address the } \\
\text { reventing damage or severe } \\
\text { radioactive and other } \\
\text { its release; and } \\
\text { t. limits and conditions, } \\
\text { t. }\end{array}$ \\
\hline
\end{tabular}

1.0 STATEMENT SATISFIED BASED ON IMPLEMENTING EVIDENCE $(Y / N):$ NO

2.0 GENERAL DESCRIPTION OF EVIDENCE (DESCRIPTION OF NONCOMPLIANCE OR DEFICIENCY IF APPLICABLE):

PRA training is not addressed in the HASQAP.

3.0 CORRECTIVE ACTION: 


\section{ASSESSMENT DATA COLLECTION FORM}

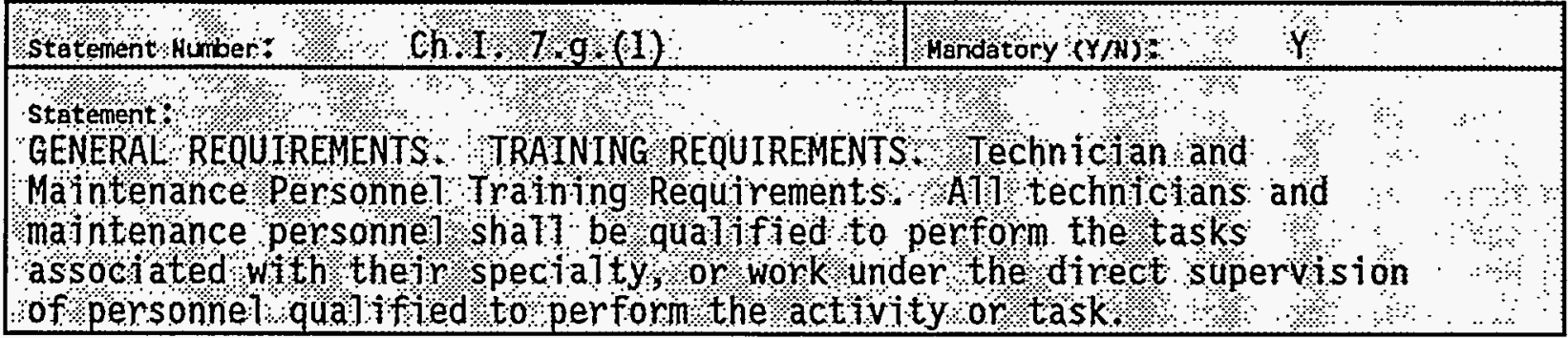

1.0 STATEMENT SATISFIEd BASED ON IMPLEMENTING EVIDENCE $(Y / N)$ : YES

2.0 GENERAL DESCRIPTION OF EVIDENCE (DESCRIPTION OF NONCOMPLIANCE OR DEFICIENCY IF APPLICABLE):

This statement is met by HASQAP Section 3.0, "Personnel Qualification and Training." 


\section{ASSESSMENT DATA COLLECTION FORM}

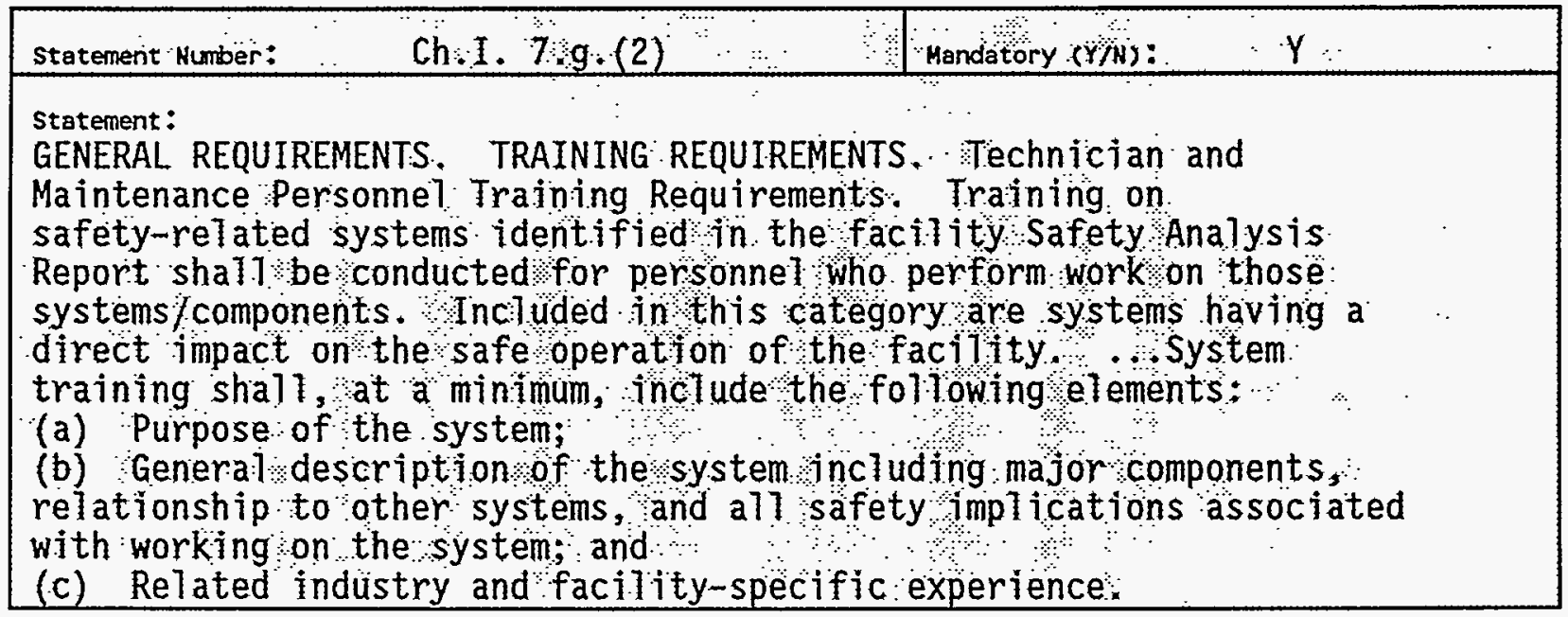

1.0 STATEMENT SATISFIED BASED ON IMPLEMENTING EVIDENCE $(Y / N):$ NO

2.0 GENERAL DESCRIPTION OF EVIDENCE (DESCRIPTION OF NONCOMPLIANCE OR DEFICIENCY IF APPLICABLE):

Statement is not addressed in the HASQAP.

3.0 CORRECTIVE ACTION: 


\section{ASSESSMENT DATA COLLECTION FORM}

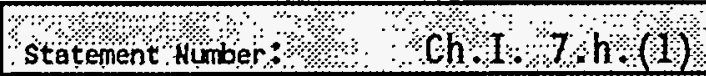

Mandatory $(Y)$ is:

$Y$

Stratement:

GENERAL REQUIREMENTS, TRAINING REQUIREMENTS: Technica' Support

Personnel Training Requitrements. Training stal1 be provided to

entry level personnel who provide technical support to the operating

organization

1.0 STATEMENT SATISFIED BASED ON IMPLEMENTING EVIDENCE $(Y / N):$ YES

2.0 GENERAL DESCRIPTION OF EVIDENCE (DESCRIPTION OF NONCOMPLIANCE OR DEFICIENCY IF APPLICABLE):

This statement is met by HASQAP subsection 3.6, "Laboratory Training." 
WHC-EP-0822

\section{ASSESSMENT DATA COLLECTION FORM}

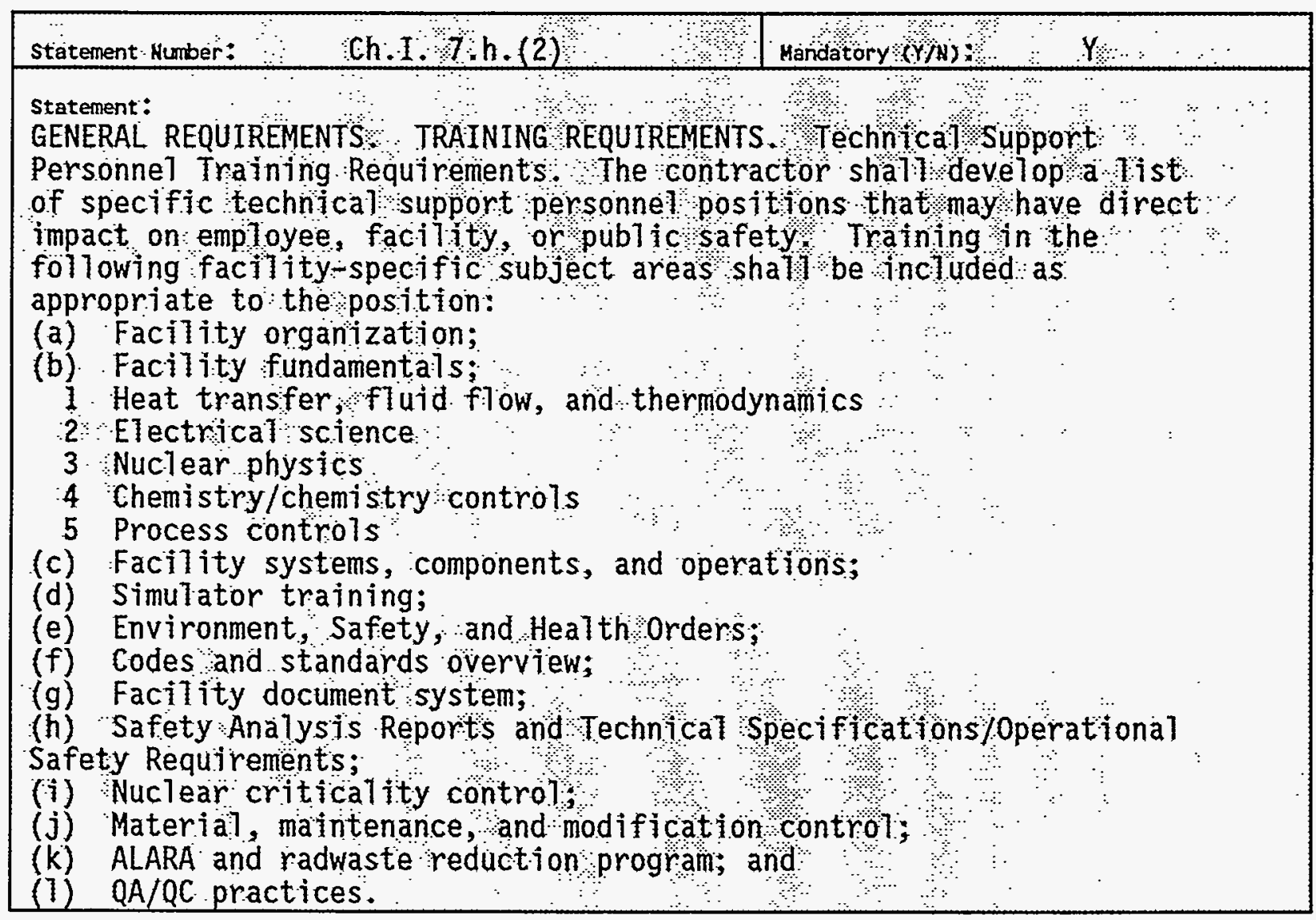

1.0 STATEMENT SATISFIEd BASED ON IMPLEMENTING EVIDENCE $(Y / N)$ : YES

2.0 GENERAL DESCRIPTION OF EVIDENCE (DESCRIPTION OF NONCOMPLIANCE OR DEFICIENCY IF APPLICABLE):

The intent of this statement is met by HASQAP subsection 3.6 , "Laboratory Training." 


\section{ASSESSMENT DATA COLLECTION FORM}

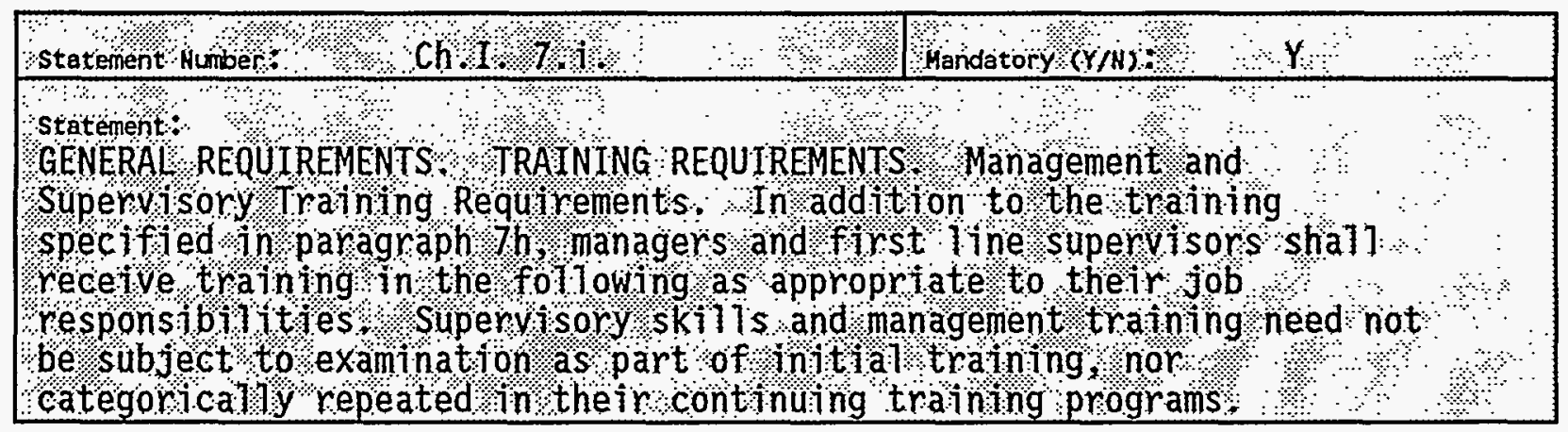

1.0 STATEMENT SATISFIED BASED ON IMPLEMENTING EVIDENCE (Y/N): NO

2.0 GENERAL DESCRIPTION OF EVIDENCE (DESCRIPTION OF NONCOMPLIANCE OR DEFICIENCY IF APPLICABLE):

The specifics of the statement are not addressed in subsection 3.5 , "Management Training," of the HASQAP.

3.0 CORRECTIVE ACTION: 
WHC-EP-0822

\section{ASSESSHENT DATA COLLECTION FORM}

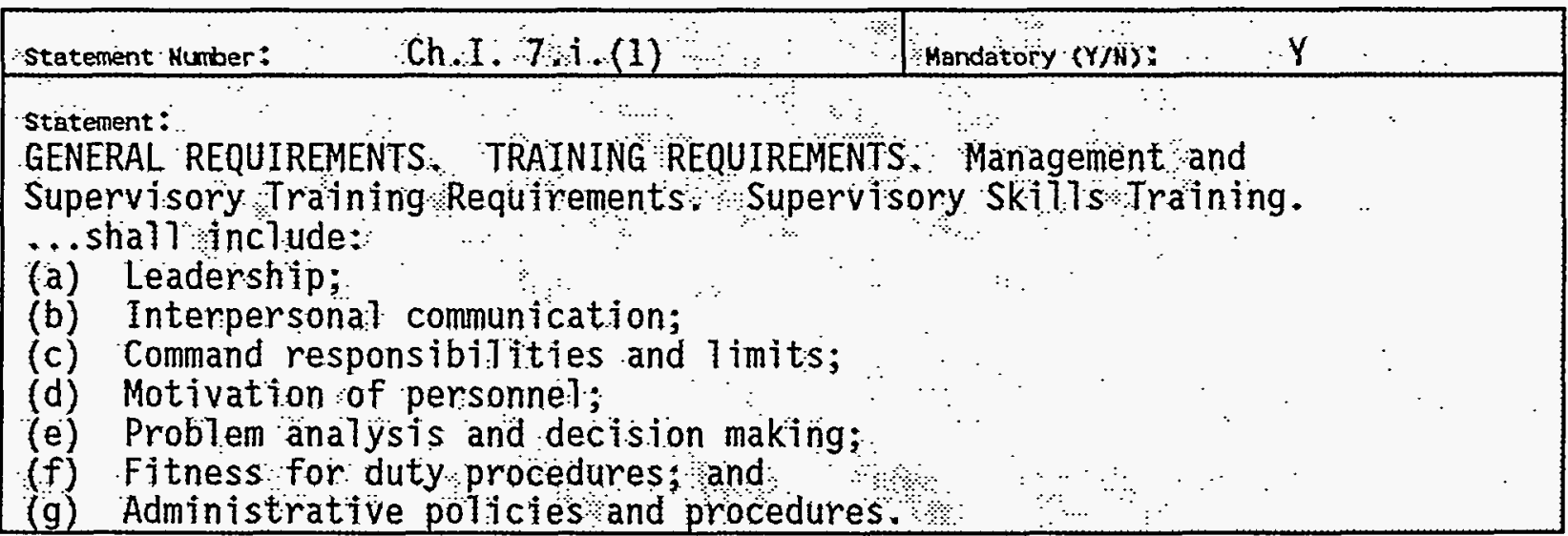

1.0 STATEMENT SATISFIED BASED ON IMPLEMENTING EVIDENCE $(Y / N):$ NO

2.0 GENERAL DESCRIPTION OF EVIDENCE (DESCRIPTION OF NONCOMPLIANCE OR DEFICIENCY IF APPLICABLE):

The specifics of the statement are not addressed in subsection 3.5 , "Management Training," of the HASQAP.

3.0 CORRECTIVE ACTION: 


\section{ASSESSMENT DATA COLLECTION FORM}

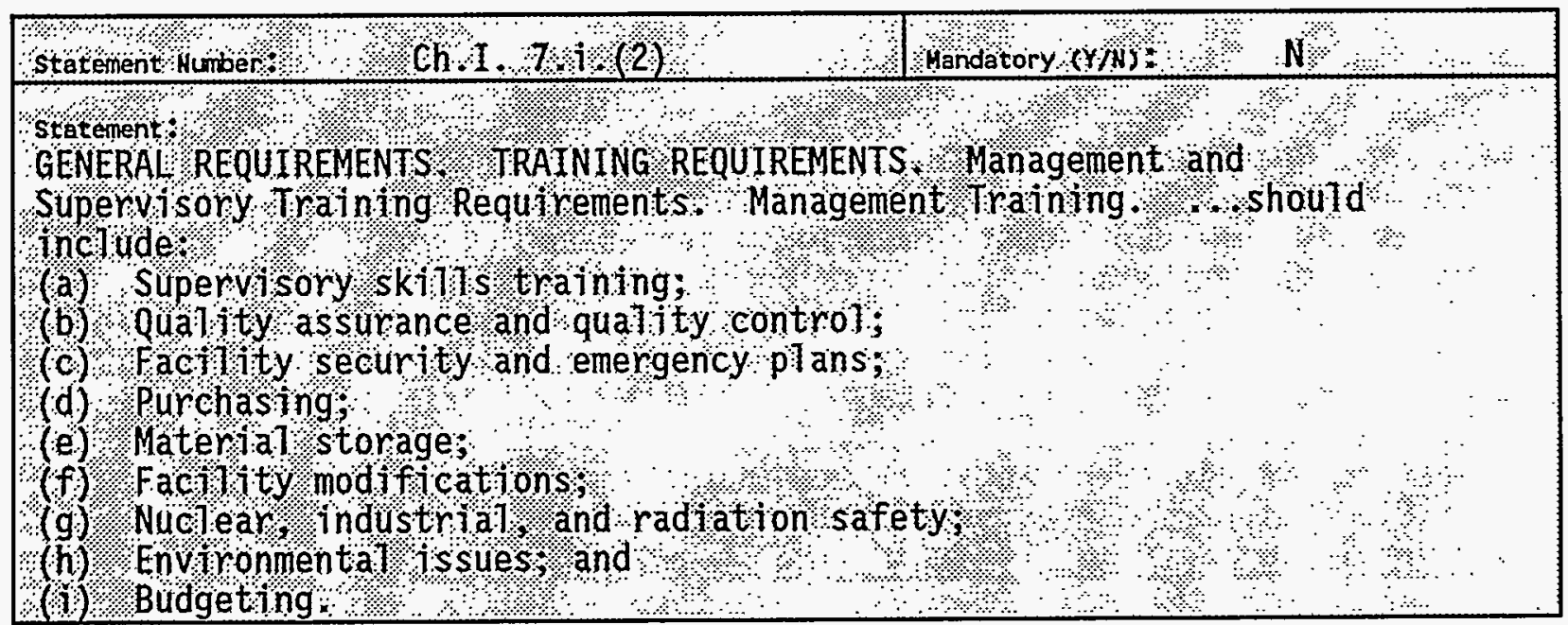

1.0 STATEMENT SATISFIED BASED ON IMPLEMENTING EVIDENCE $(Y / N):$ NO

2.0 GENERAL DESCRIPTION OF EVIDENCE (DESCRIPTION OF NONCOMPLIANCE OR DEFICIENCY IF APPLICABLE):

The specifics of the statement are not addressed in subsection 3.5 , "Management Training," of the HASQAP.

3.0 CORRECTIVE ACTION: 
WHC-EP-0822

\section{ASSESSMENT DATA COLLECTION FORM}

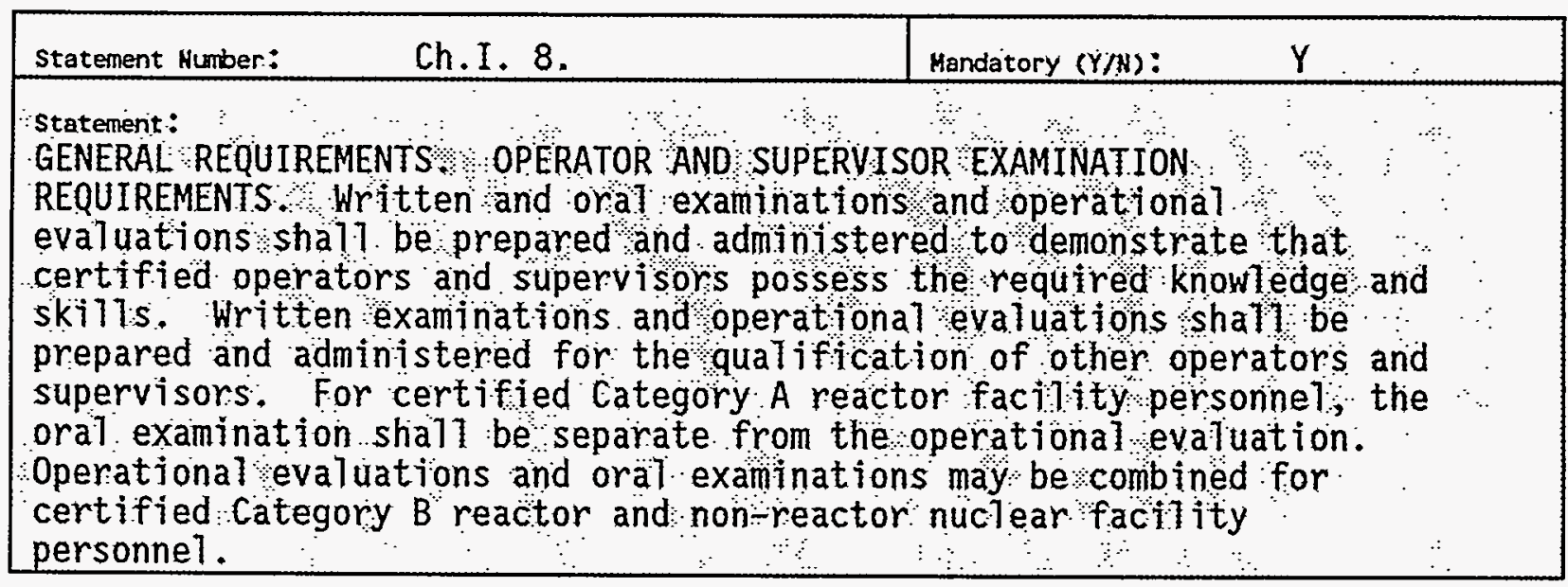

\section{N/A}

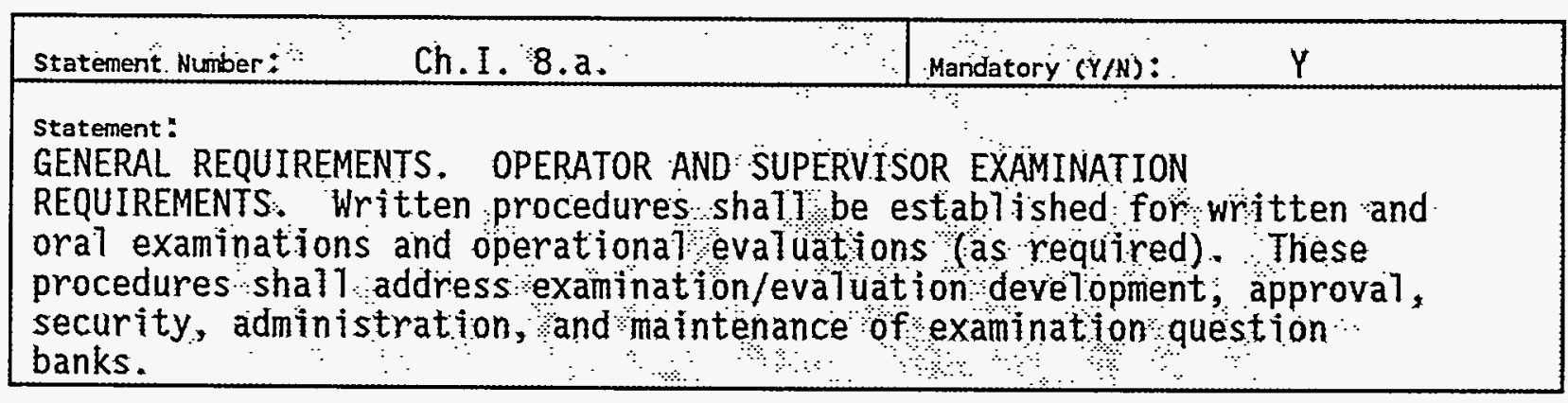

\section{N/A}

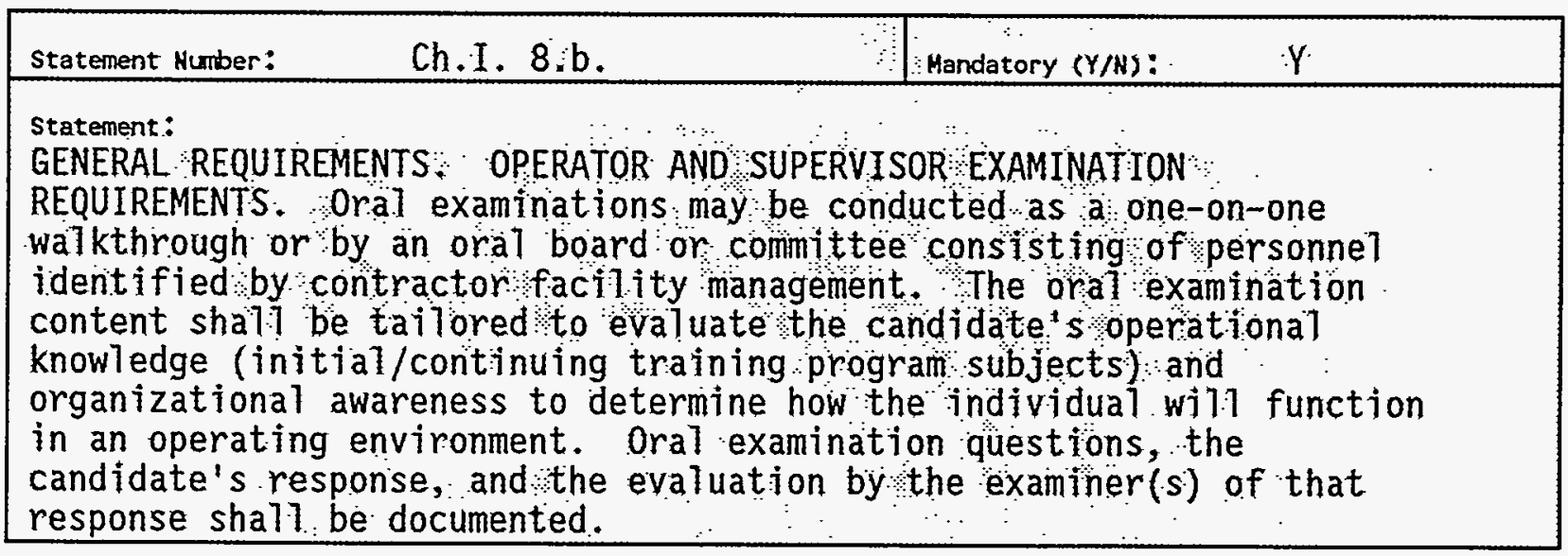

\section{N/A}


WHC-EP-0822

ASSESSHENT DATA COLLECTION FORM

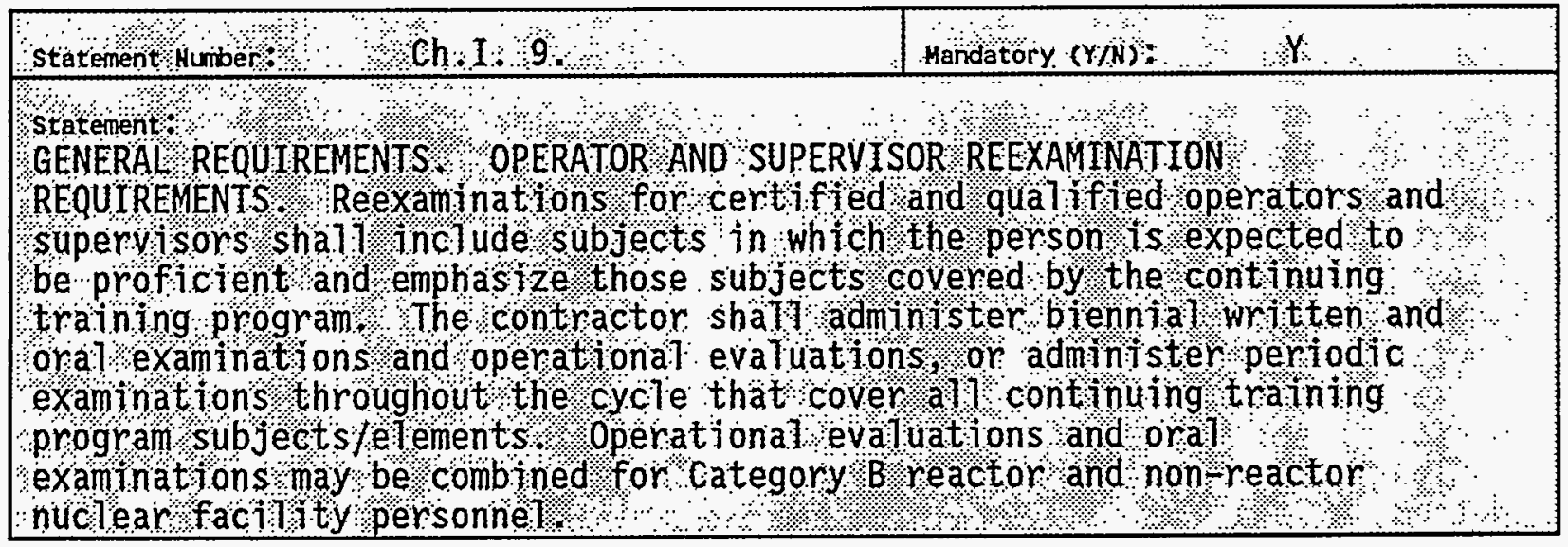

\section{N/A}

statement Numbero
statement

\section{N/A}

\begin{tabular}{|c|c|}
\hline StatementhHumbers & Mandatory Y Y $)$ ? $\mathrm{N}$ \\
\hline 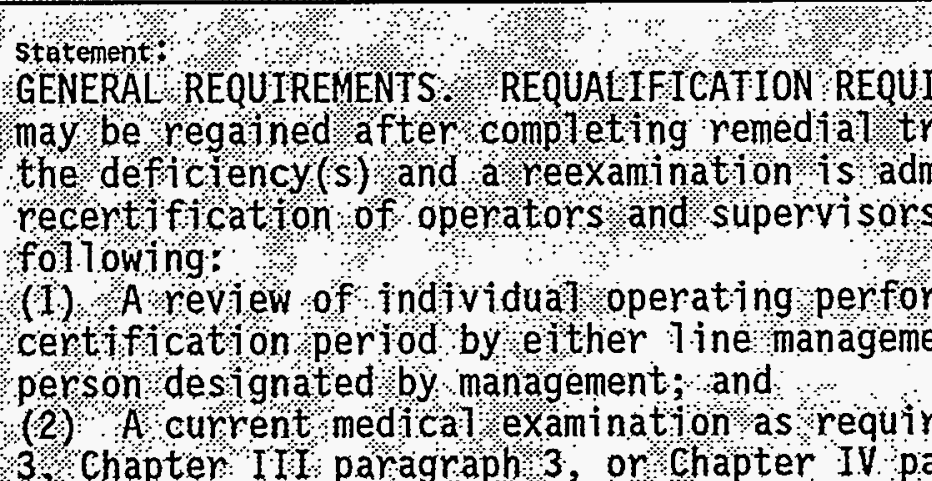 & 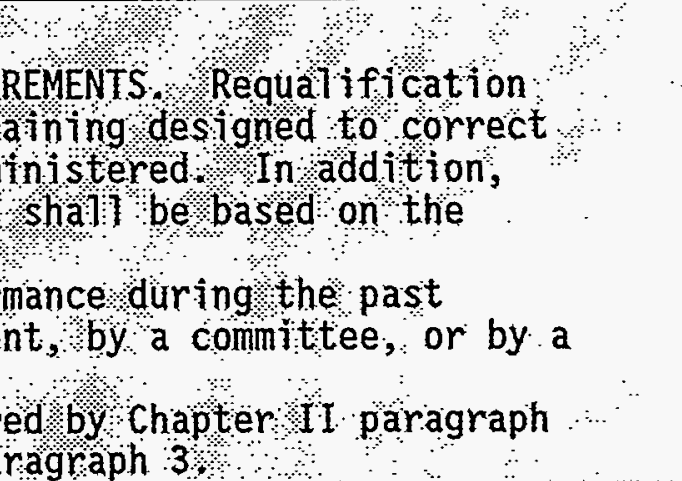 \\
\hline
\end{tabular}

\section{N/A}


WHC-EP-0822

\section{ASSESSMENT DATA COLLECTION FORM}

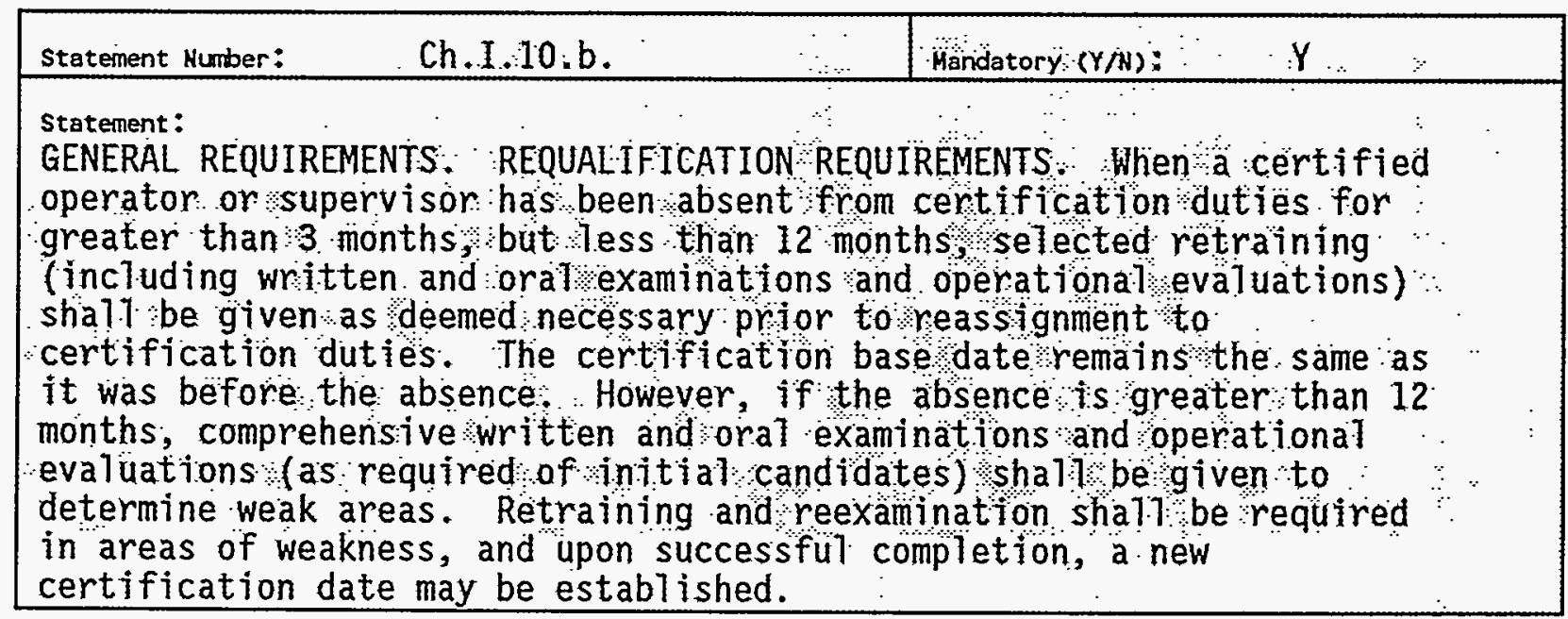

\section{N/A}


WHC-EP-0822

\section{ASSESSHENT DATA COLLECTION FORH}

अ०

statement Hüber., $\mathrm{Ch}+\mathrm{HI}$

Handatory (Y)

$\dot{Y}$

Statement:

GENERAL REQUIREMENTS EXCEPTIONS TO IRAINING REQUIREMENTS O InIt $1 a 1$

tranno programs are developed for persons whth entry level knowledge

and sk11s. Some candidates may an ready possess the necessary

know1edge and sk17 s for therr $10 \mathrm{~b}$, and may be excepted from areas of the training program on the bast s of prob education, experience, and training, Proficiency testing 1 s the preferred method of excepting persons from spectfic areas of trajning $1 \mathrm{n}$ all cases, the requis ite examinations to establish qual ification shall be completed.

1.0 STATEMENT SATISFIEd BASED ON IMPLEMENTING EVIDENCE (Y/N): YES

2.0 GENERAL DESCRIPTION OF EVIDENCE (DESCRIPTION OF NONCONPLIANCE OR DEFICIENCY IF APPLICABLE):

The statement is met by HASQAP subsection 3.6.1, "Initial Training Requirements," and subsection 3.1.1, "Initial Qualification." 
WHC-EP-0822

\section{ASSESSMENT DATA COLLECTION FORM}

\begin{tabular}{|c|c|}
\hline Statement Number: & Mandatory $(Y / N)$ : \\
\hline 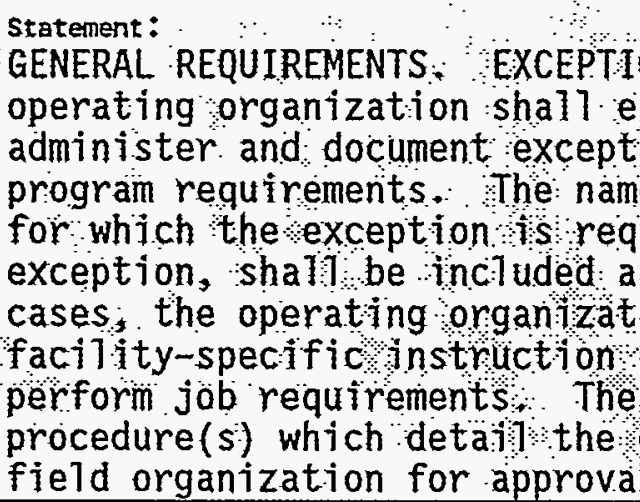 & $\begin{array}{l}\text { GREQUIREMENTS The } \\
\text { dures and criteria to } \\
\text { and continuing training } \\
\text { and the specific subject } \\
\text { with justification for the } \\
\text { documentation In alt } \\
\text { re that sufficient } \\
\text { enable the candidate to } \\
\text { anization shall submit the } \\
\text { ranting an exception to the }\end{array}$ \\
\hline
\end{tabular}

1.0 STATEMENT SATISFIED BASED ON IMPLEMENTING EVIDENCE (Y/N): NO

2.0 GENERAL DESCRIPTION OF EVIDENCE (DESCRIPTION OF NONCOMPLIANCE OR DEFICIENCY IF APPLICABLE):

Although the HASQAP addresses the statement in a general sense, the specific details of the statement are not met concerning procedures, criteria, documentation, and field organization approval.

3.0 CORRECTIVE ACTION: 
WHC-EP-0822

\section{ASSESSMENT DATA COLLECTION FORM}

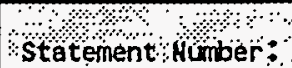

Ch. $111 \mathrm{~b}$

Hondatory $(Y / N)$ :

Y.

Statement $\%$ :

GENERAL REQUIREMENTS EXCEPTIONS TO TRAINING REQUIREMENTS A ANY exception from certificat on or qualificat ton requitements shall be approyed by contractor management.

1.0 STATEMENT SATISFIED BASED ON IMPLEMENTING EVIDENCE $(Y / N)$ : NO

2.0 GENERAL DESCRIPTION OF EVIDENCE (DESCRIPTION OF NONCOMPLIANCE OR DEFICIENCY IF APPLICABLE):

Statement not addressed in the HASQAP.

3.0

CORRECTIVE ACTION: 
WHC-EP-0822

\section{ASSESSHENT DATA COLLECTION FORH}

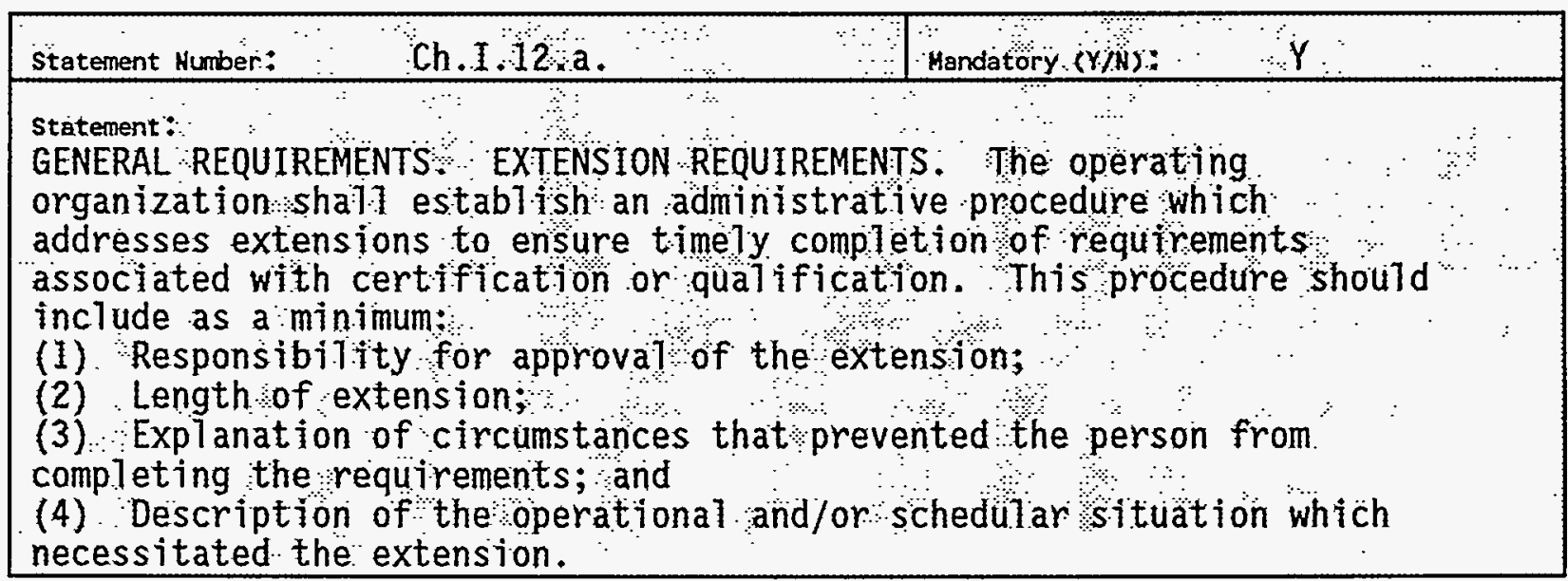

1.0 STATEMENT SATISFIED BASED ON IMPLEMENTING EVIDENCE $(Y / N):$ NO

2.0 GENERAL DESCRIPTION OF EVIDENCE (DESCRIPTION OF NONCOMPLIANCE OR DEFICIENCY IF APPLICABLE):

Extensions are not addressed in the HASQAP.

3.0 CORRECTIVE ACTION: 


\section{ASSESSHENT DATA COLLECTION FORM}

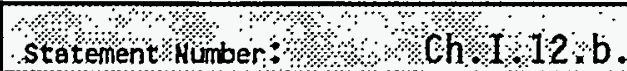

Handatory $(Y / W)$

statement:

GENERAL REQUTREMENTS EXTENSTON REQUTREMENTS, EXtens Ion S of certuficat on of operators and supervisors shal be approved by the fleld organization Extensions of qualification of other personnel

shal 1 be approved by contractor fac $171 t y$ management.

1.0 STATEMENT SATISFIED BASED ON IMPLEMENTING EVIDENCE $(Y / N): \quad N O$

2.0 GENERAL DESCRIPTION OF EVIDENCE (DESCRIPTION OF NONCOMPLIANCE OR DEFICIENCY IF APPLICABLE):

Extensions are not addressed in the HASQAP.

3.0 CORRECTIVE ACTION: 
WHC-EP-0822

\section{ASSESSHENT DATA COLLECTION FORM}

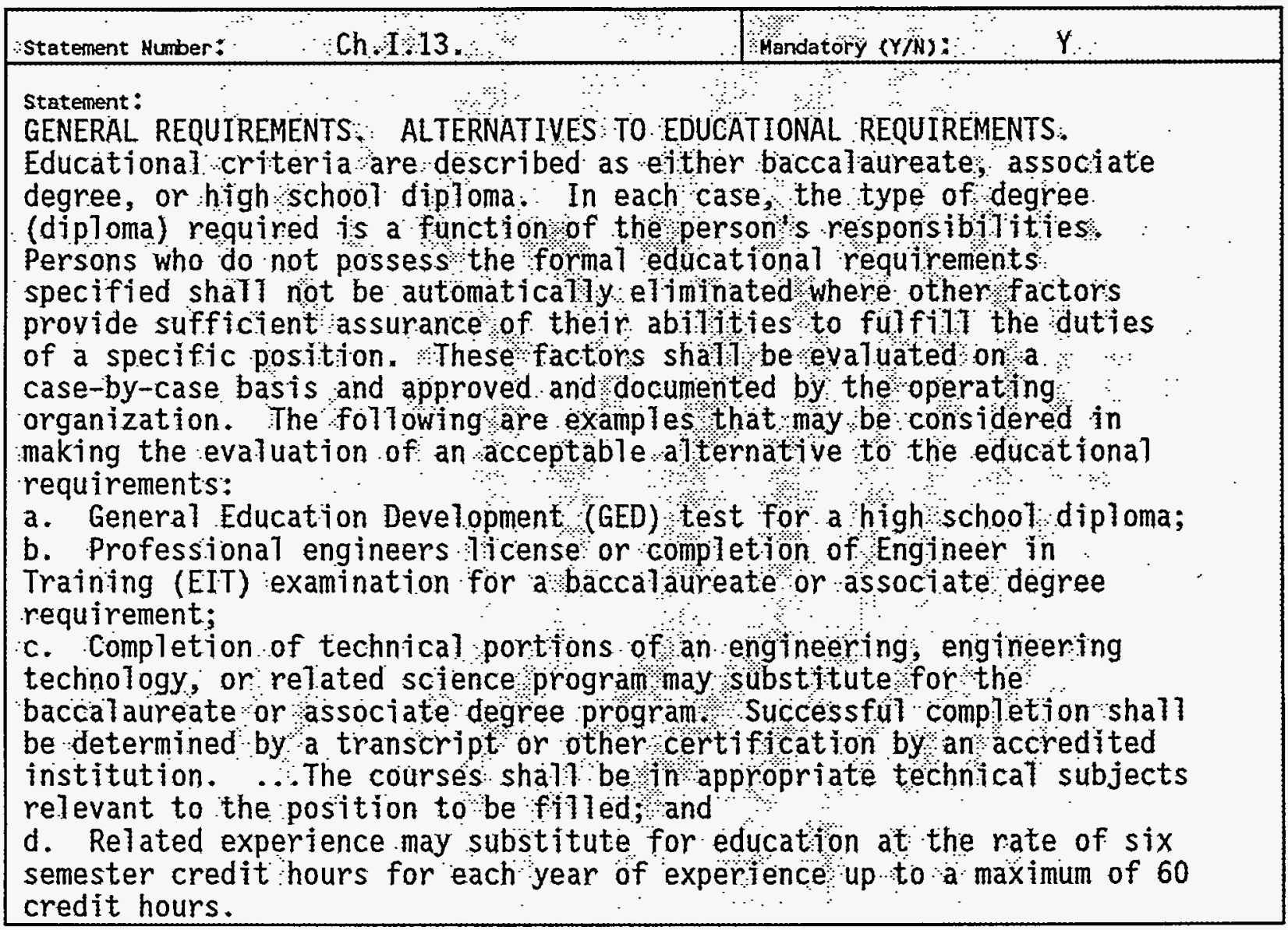

1.0 STATEMENT SATISFIED BASED ON IMPLEMENTING EVIDENCE $(Y / N): \quad$ NO

2.0 GENERAL DESCRIPTION OF EVIDENCE (DESCRIPTION OF NONCOMPLIANCE OR DEFICIENCY IF APPLICABLE):

Alternatives to education requirements are not addressed in the HASQAP.

3.0 CORRECTIVE ACTION: 
WHC-EP-0822

\section{ASSESSMENT DATA COLLECTION FORM}

\begin{tabular}{|c|c|}
\hline 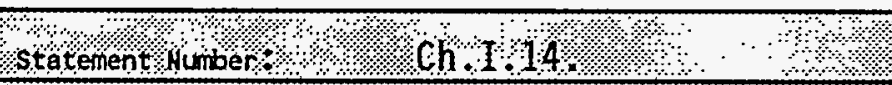 & Handatory $(Y, N), \quad y$ \\
\hline 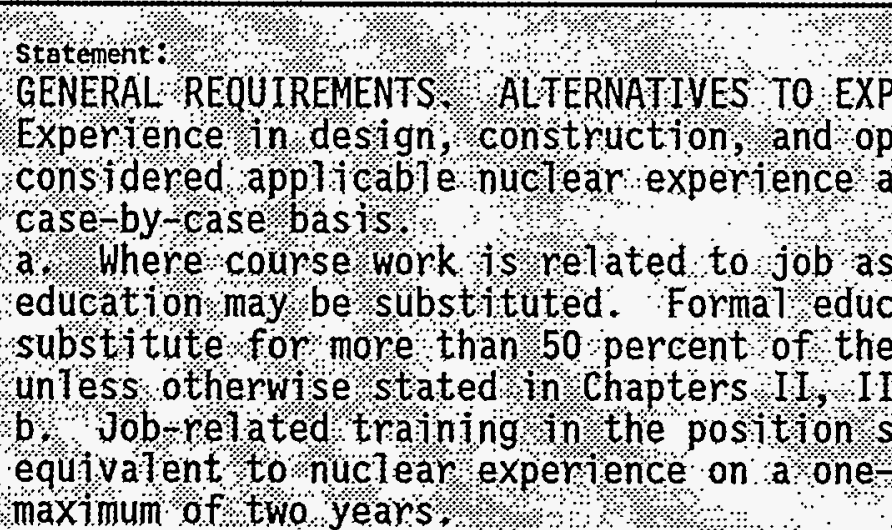 & 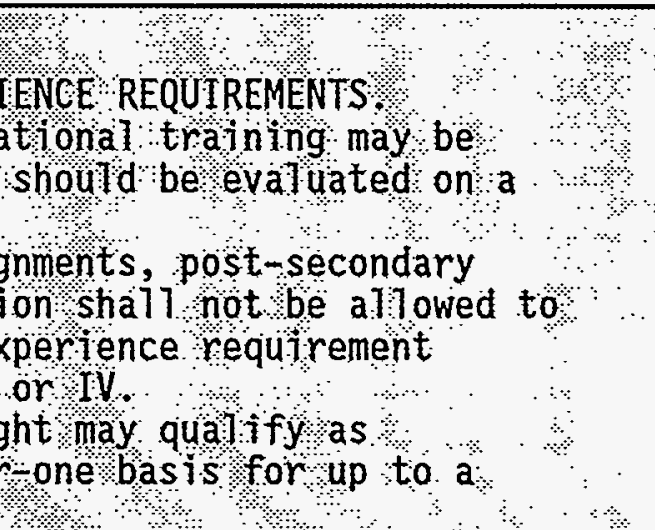 \\
\hline
\end{tabular}

1.0 STATEMENT SATISFIED BASED ON IMPLEMENTING EVIDENCE (Y/N): NO

2.0 GENERAL DESCRIPTION OF EVIDENCE (DESCRIPTION OF NONCOMPLIANCE OR DEFICIENCY IF APPLICABLE):

Alternatives to experience requirements are not addressed in the HASQAP.

3.0 CORRECTIVE ACTION: 
WHC-EP-0822

ASSESSMENT DATA COLLECTION FORM

\begin{tabular}{|c|c|}
\hline$\because$ Ch.1.1.5. $\because:$ & Mandatory $(Y / N)$ : \\
\hline $\begin{array}{l}\text { Statement: } \\
\text { GENERAL REQUIREMENTS } \\
\text { procedures shal } 7 \text { be developed and implement } \\
\text { hours of operating organization personnel } \\
\text { functions. }\end{array}$ & $\begin{array}{l}\text { IME WORKED Administrative } \\
\text { dto limit the working } \\
\text { operform safetyorelated }\end{array}$ \\
\hline
\end{tabular}

N/A

\begin{tabular}{|c|}
\hline \begin{tabular}{l|l} 
& Mandatory $(Y / N): Y$
\end{tabular}$\quad$ bY \\
\hline 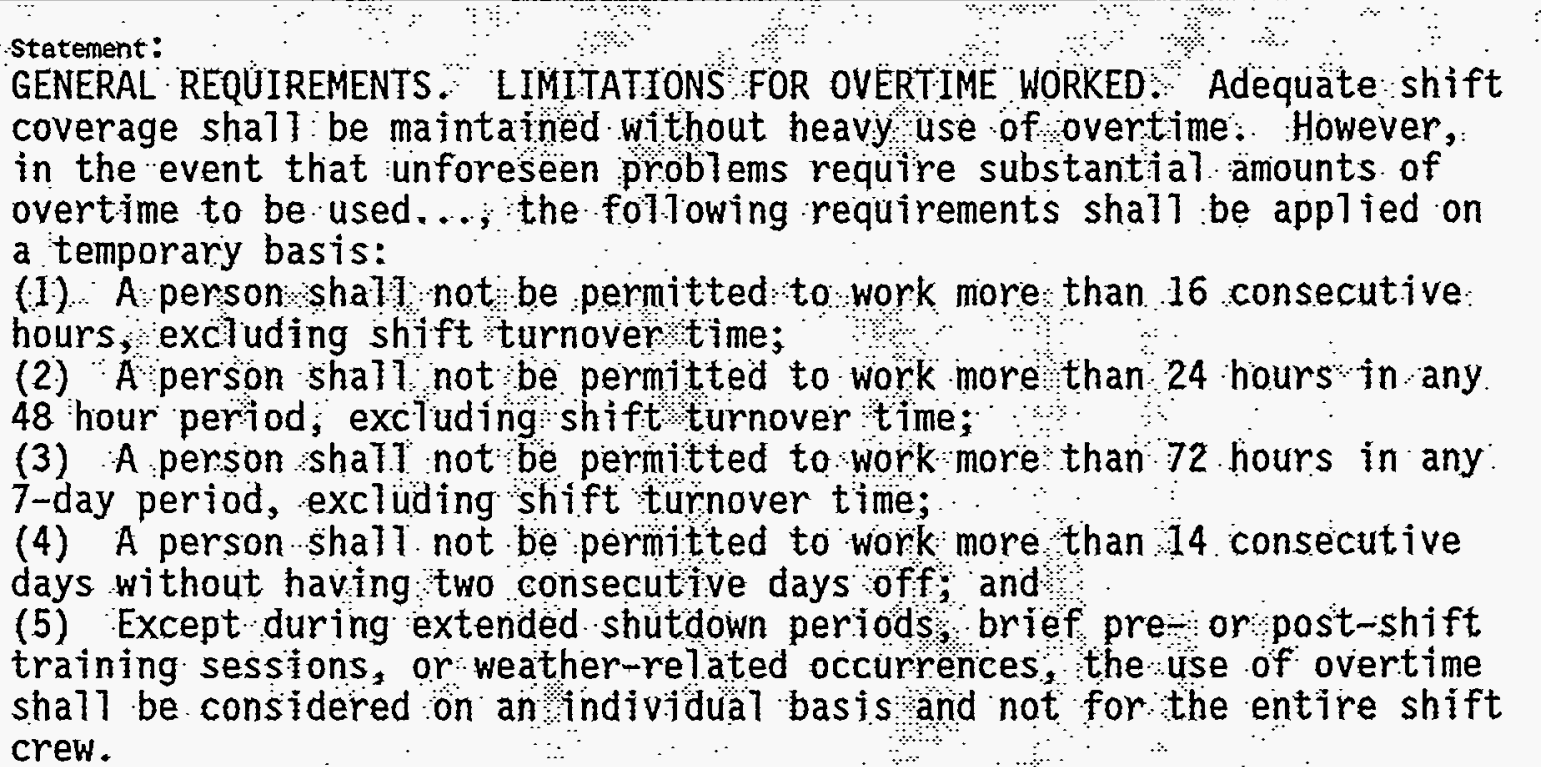 \\
\hline
\end{tabular}

N/A

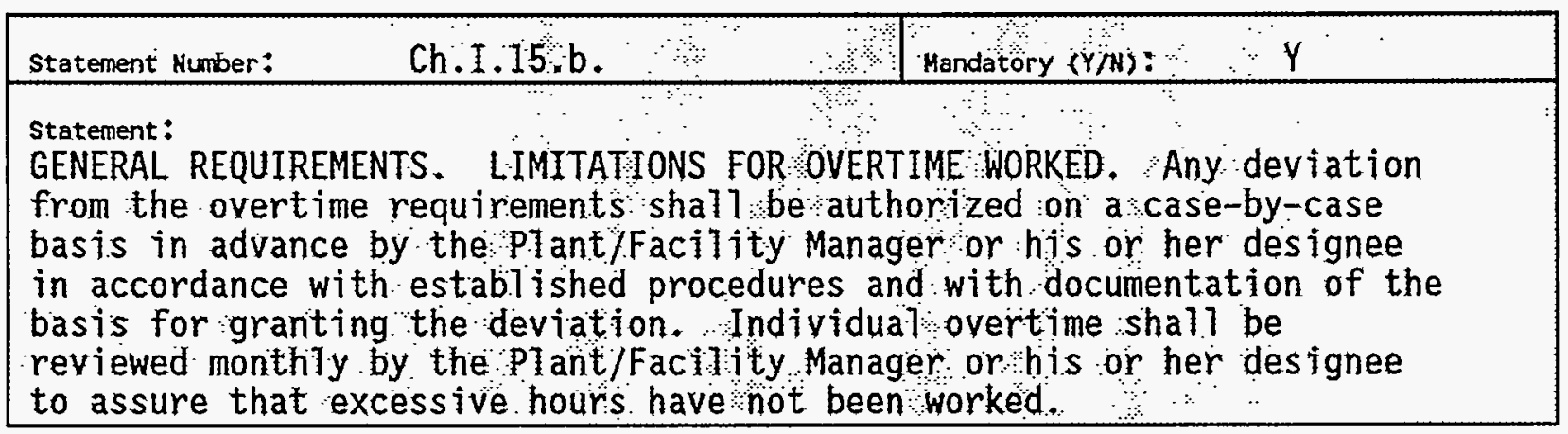

N/A 


\section{ASSESSMENT DATA COLLECTION FORM}

\begin{tabular}{|c|c|}
\hline Statement Humber & Mandatory $(Y / N)$ : $N$ \\
\hline 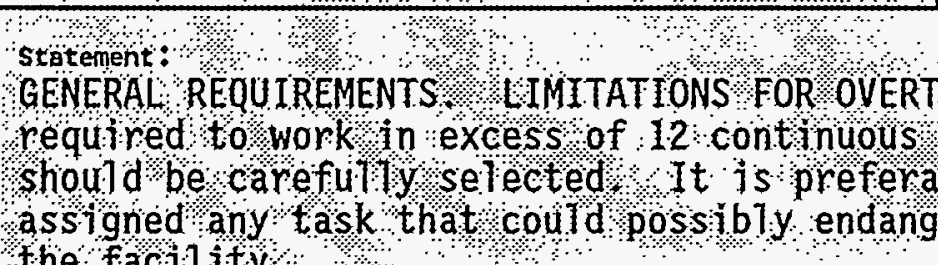 & $\begin{array}{l}\text { ME WORKED, If a person is } \\
\text { TME } \\
\text { hours, his or her duties } \\
\text { ble that this person not be } \\
\text { er the safe operation of }\end{array}$ \\
\hline
\end{tabular}

\section{N/A}


WHC-EP-0822

ASSESSMENT DATA COLLECTION FORM

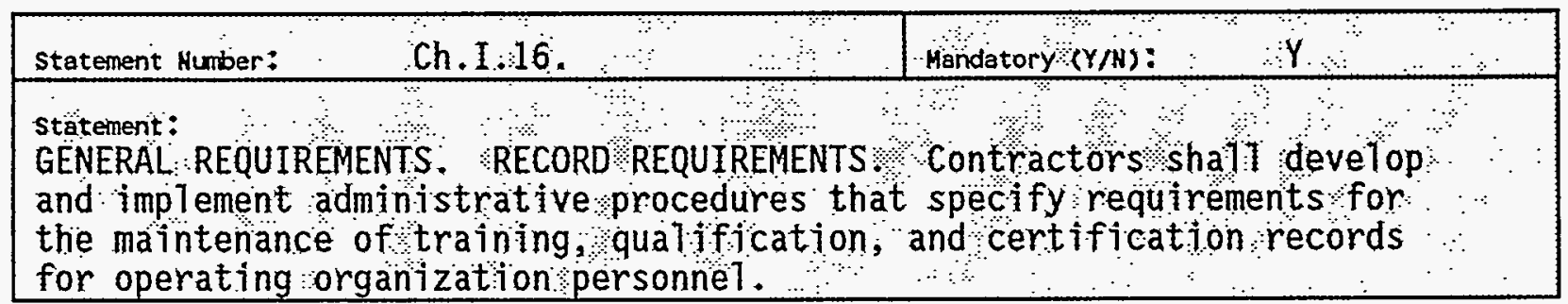

1.0 STATEMENT SATISFIED BASED ON IMPLEMENTING EVIDENCE $(Y / N):$ YES

2.0 GENERAL DESCRIPTION OF EVIDENCE (DESCRIPTION OF NONCOMPLIANCE OR DEFICIENCY IF APPLICABLE):

Statement is met by HASQAP subsection 3.7, "Training Records." 
WHC-EP-0822

\section{ASSESSMENT DATA COLLECTION FORM}

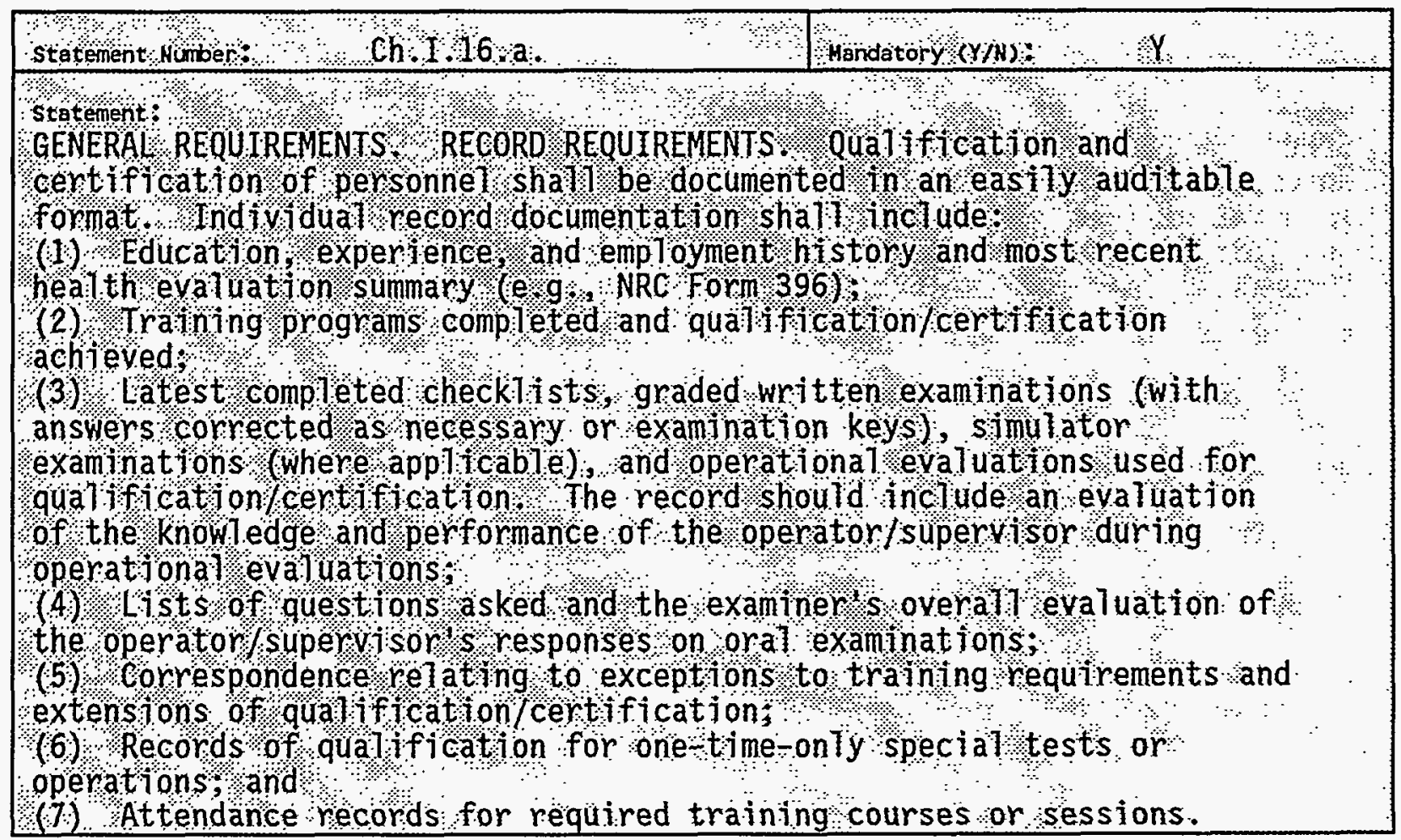

1.0 Statement SATISFied BASEd ON IMPLementing EVIDENCE $(Y / N)$ : NO

2.0 GENERAL DESCRIPTION OF EVIDENCE (DESCRIPTION OF NONCOMPLIANCE OR DEFICIENCY IF APPLICABLE):

A11 specifics of the statement are not addressed in HASQAP subsection 3.7 .

3.0 CORRECTIVE ACTION: 


\section{ASSESSMENT DATA COLLECTION FORM}

\begin{tabular}{|c|c|c|}
\hline ent & Mandatory $(Y / N)$ : & $Y$ \\
\hline \multicolumn{3}{|c|}{ 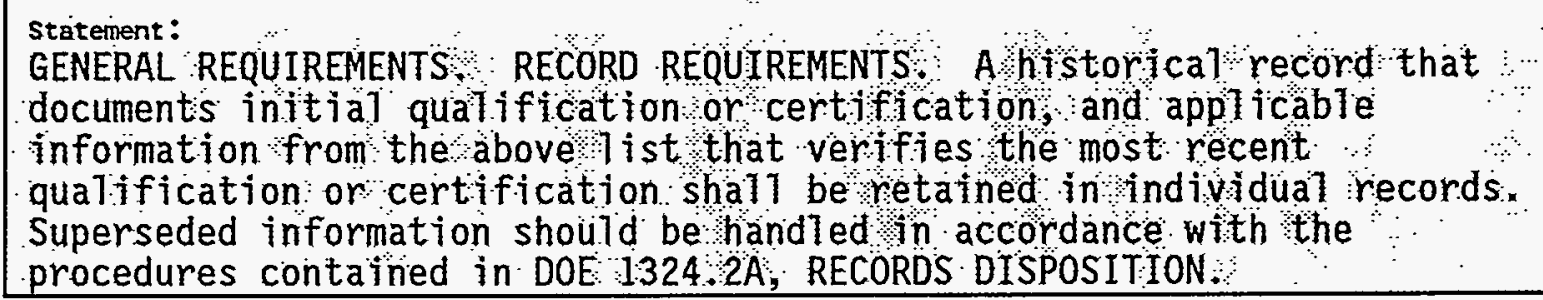 } \\
\hline
\end{tabular}

1.0 STATEMENT SATISFIED BASED ON IMPLEMENTING EVIDENCE (Y/N): NO

2.0 GENERAL DESCRIPTION OF EVIDENCE (DESCRIPTION OF NONCOMPLIANCE OR DEFICIENCY IF APPLICABLE):

The following portion of the statement is not addressed in the HASQAP:

Superseded information should be handled in accordance with the procedures contained in DOE 1324.2A, RECORDS DISPOSITION.

3.0 CORRECTIVE ACTION: 


\section{ASSESSMENT DATA COLLECTION FORH}

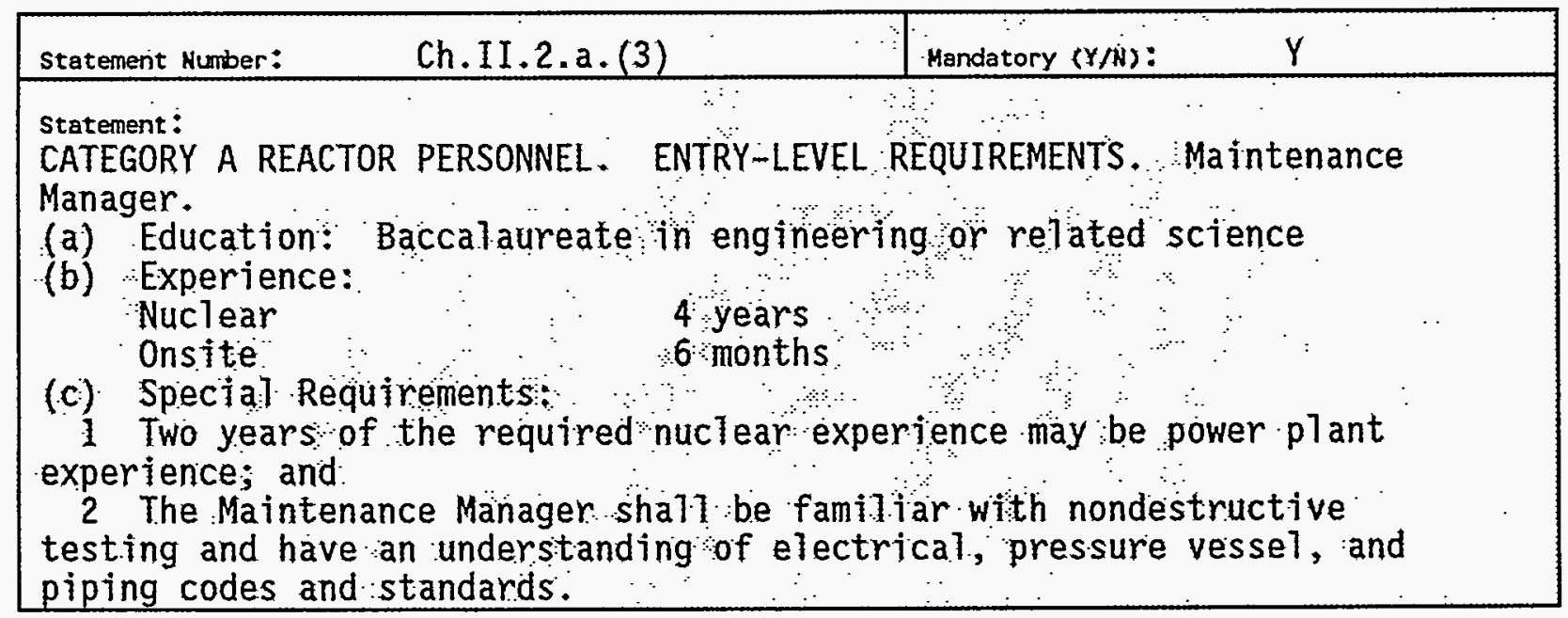

\begin{tabular}{|c|c|}
\hline Mandatory (Y/N): & \\
\hline 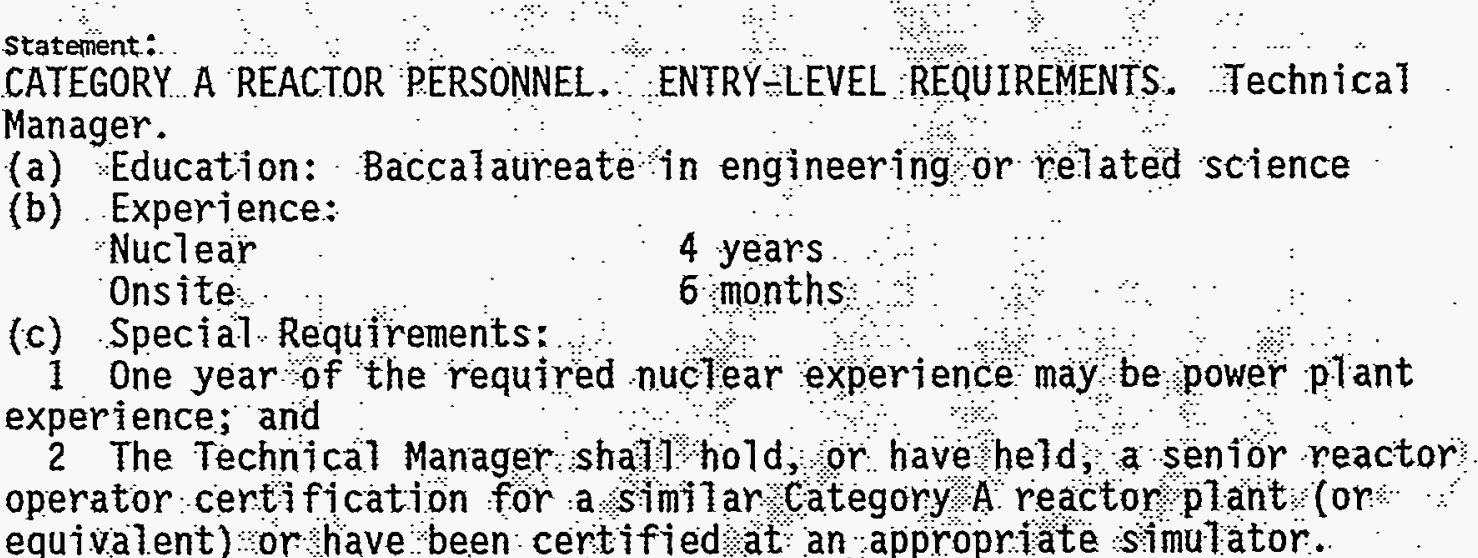 & .. \\
\hline
\end{tabular}

\begin{tabular}{|c|}
\hline Ch.II. $2, a$ (5) \\
\hline 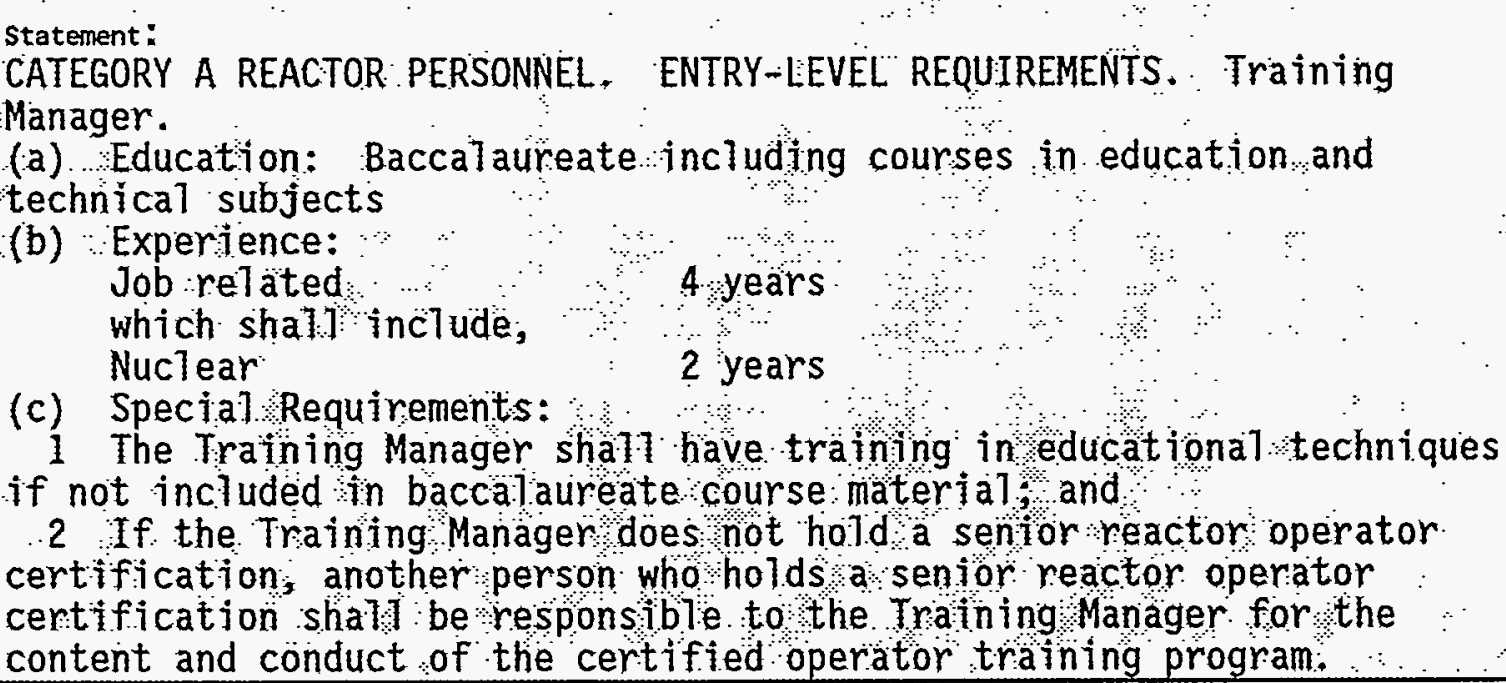 \\
\hline
\end{tabular}




\section{ASSESSMENT DATA COLLECTION FORM}

\begin{tabular}{|c|c|}
\hline Statement Nomber $\quad$ a $\mathrm{Ch}, 1 \mathrm{l}, 2 \mathrm{~b}$ & Mandatory $(Y / N)$ : \\
\hline 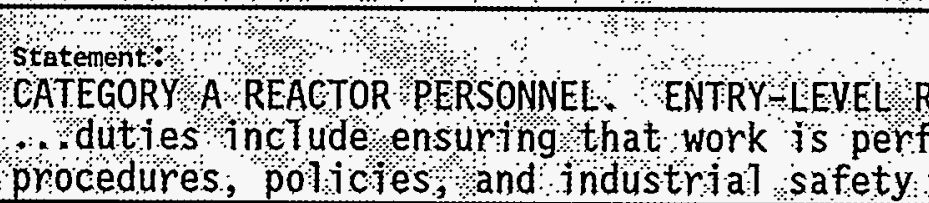 & $\begin{array}{l}\text { EOUIREMENTS Supervisors } \\
\text { Ormed In compliance with } \\
\text { oractaces }\end{array}$ \\
\hline
\end{tabular}

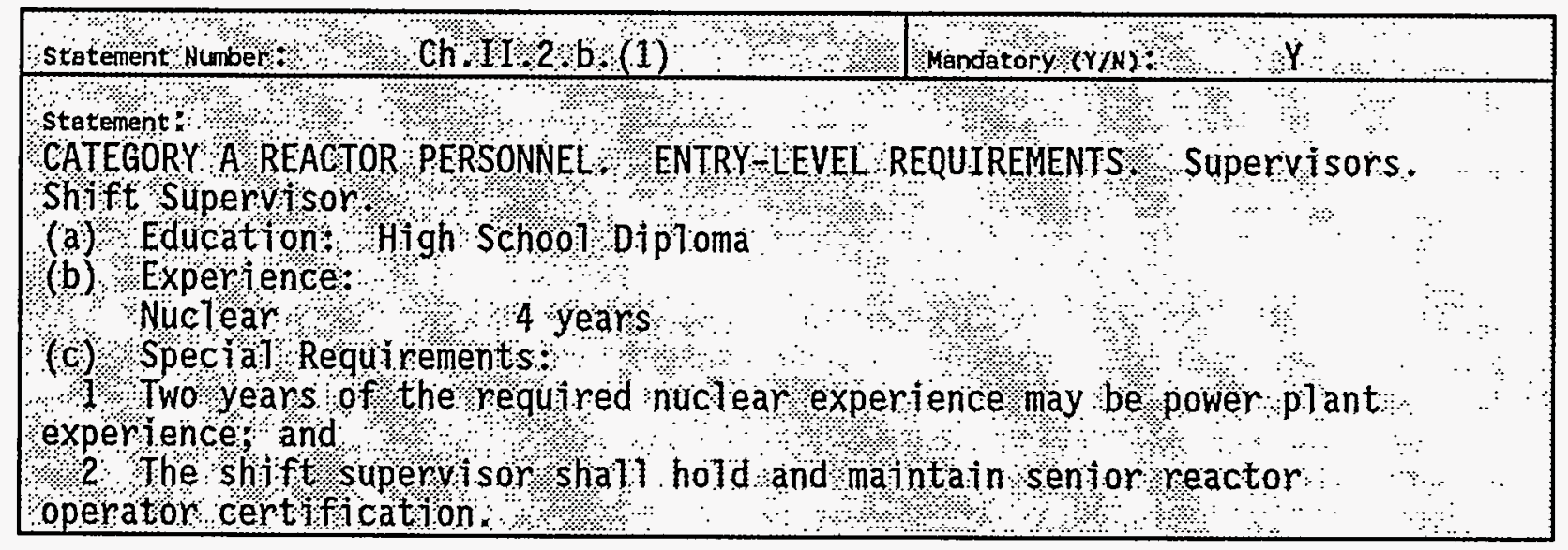

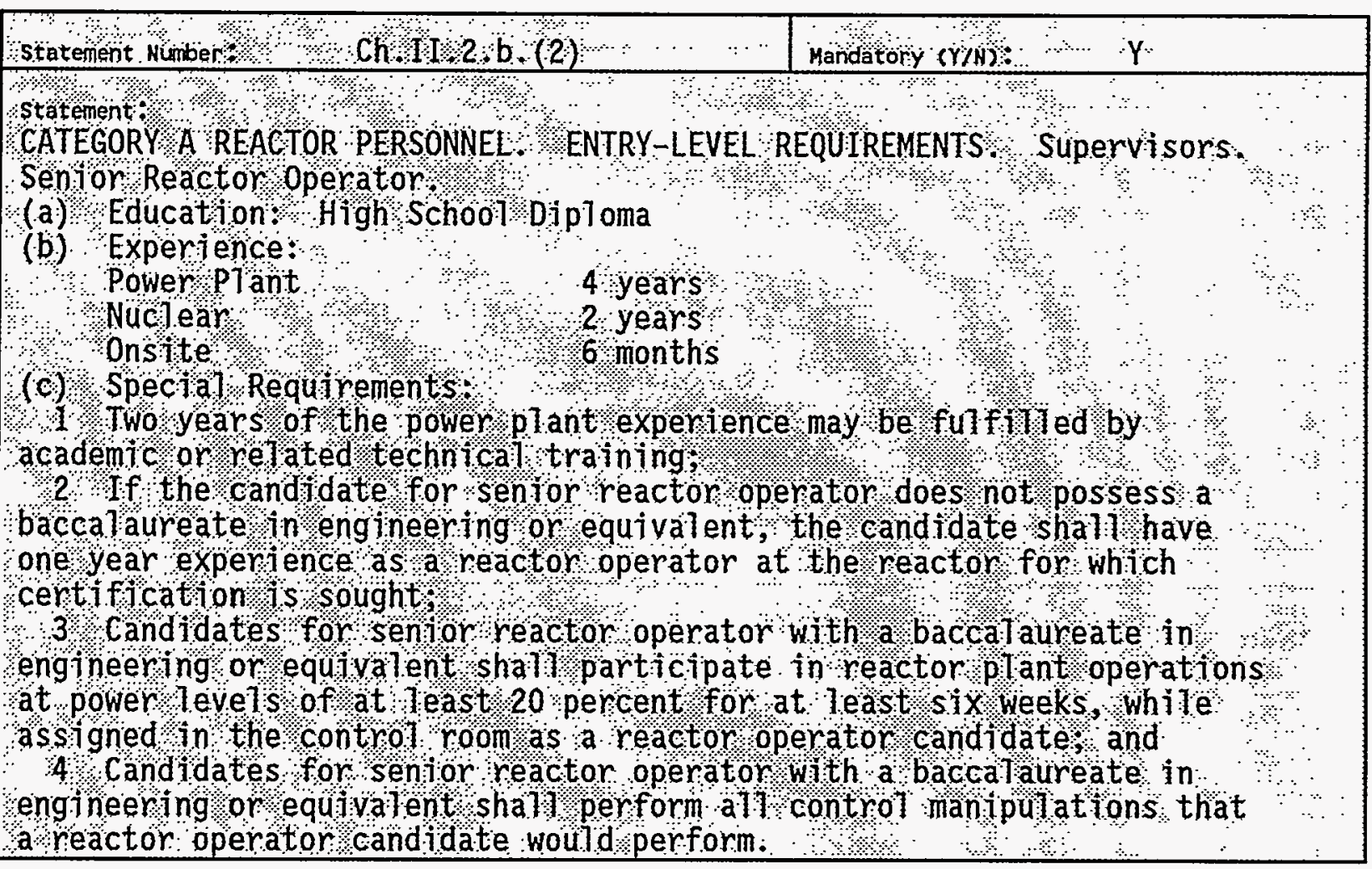


WHC-EP-0822

ASSESSMENT DATA COLLECTION FORM

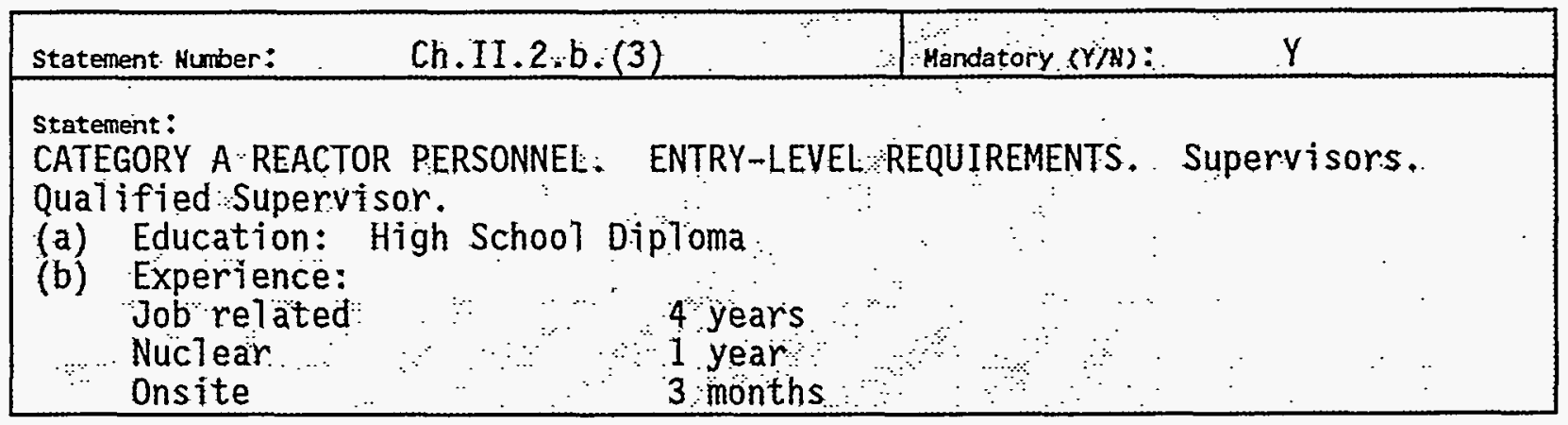

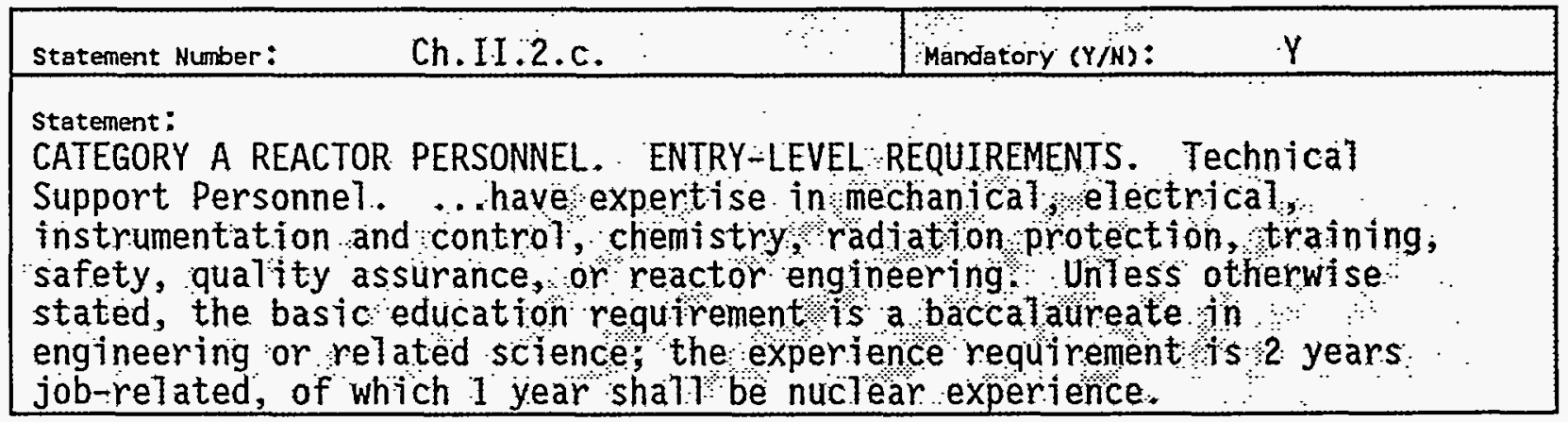

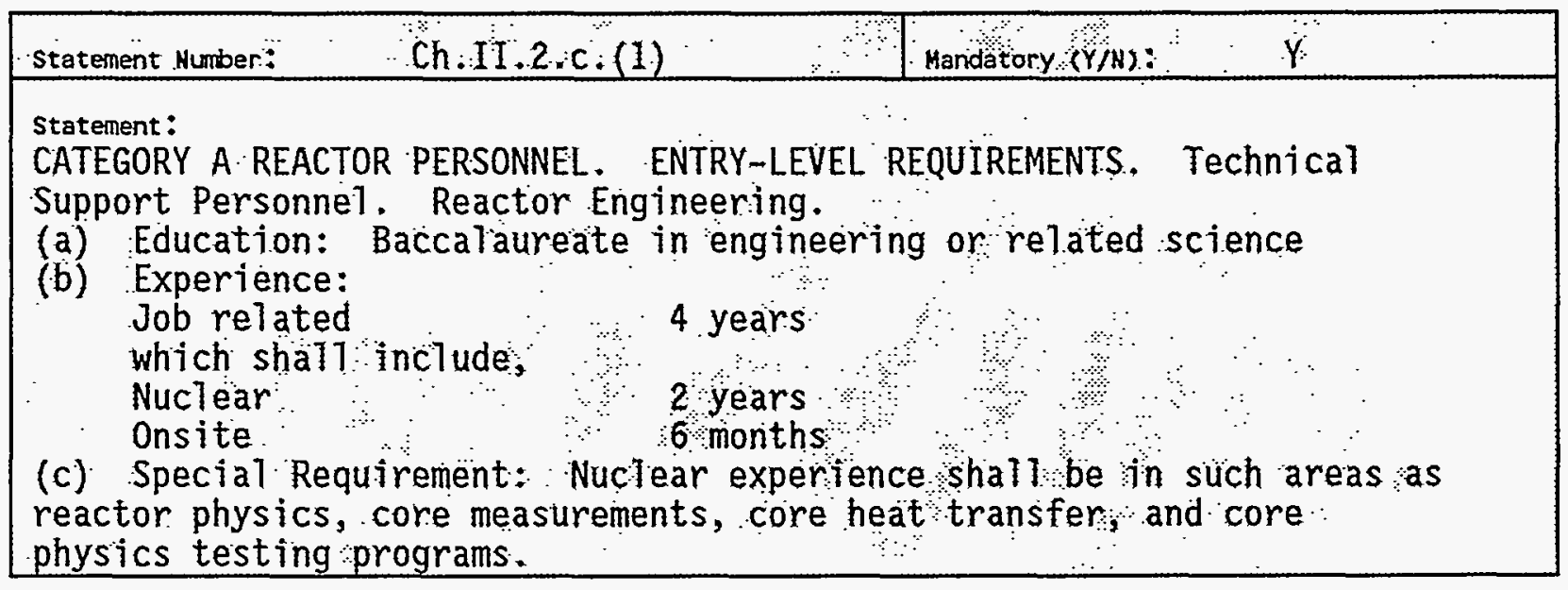

\begin{tabular}{|c|}
\hline 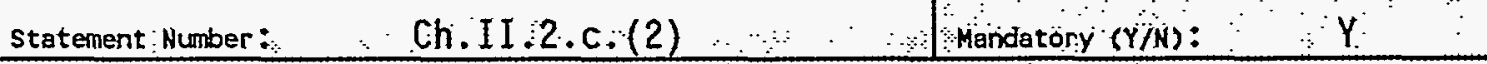 \\
\hline 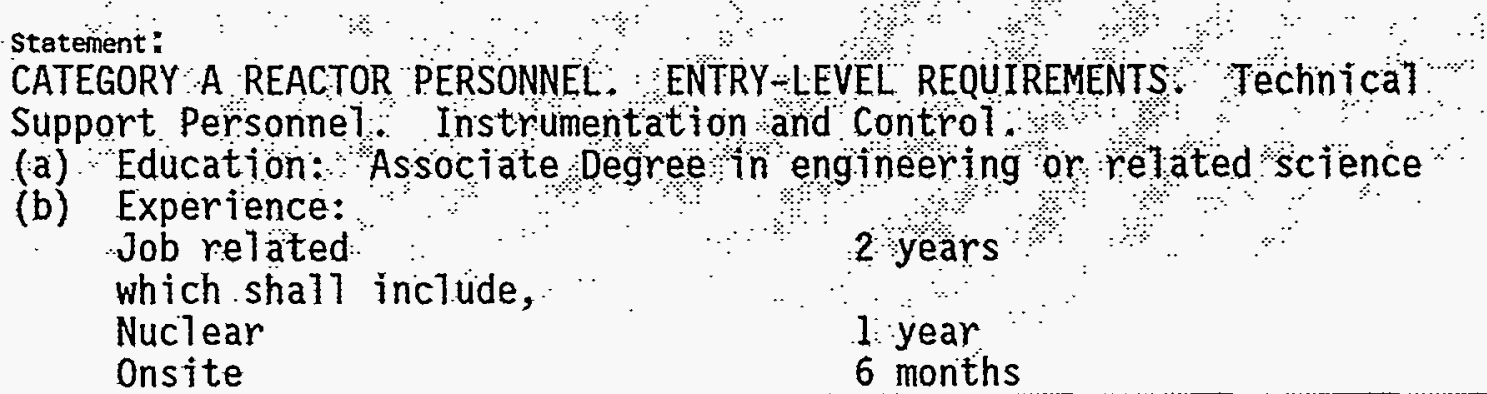 \\
\hline
\end{tabular}




\section{ASSESSMENT DATA COLLECTION FORM}

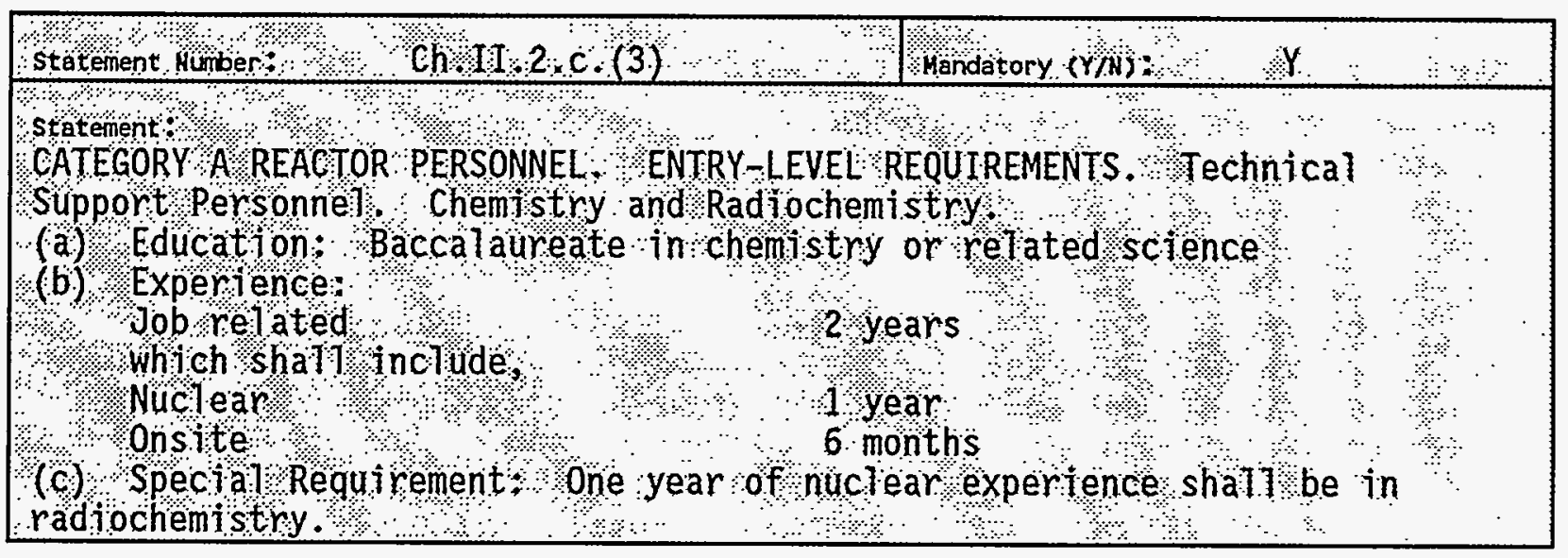

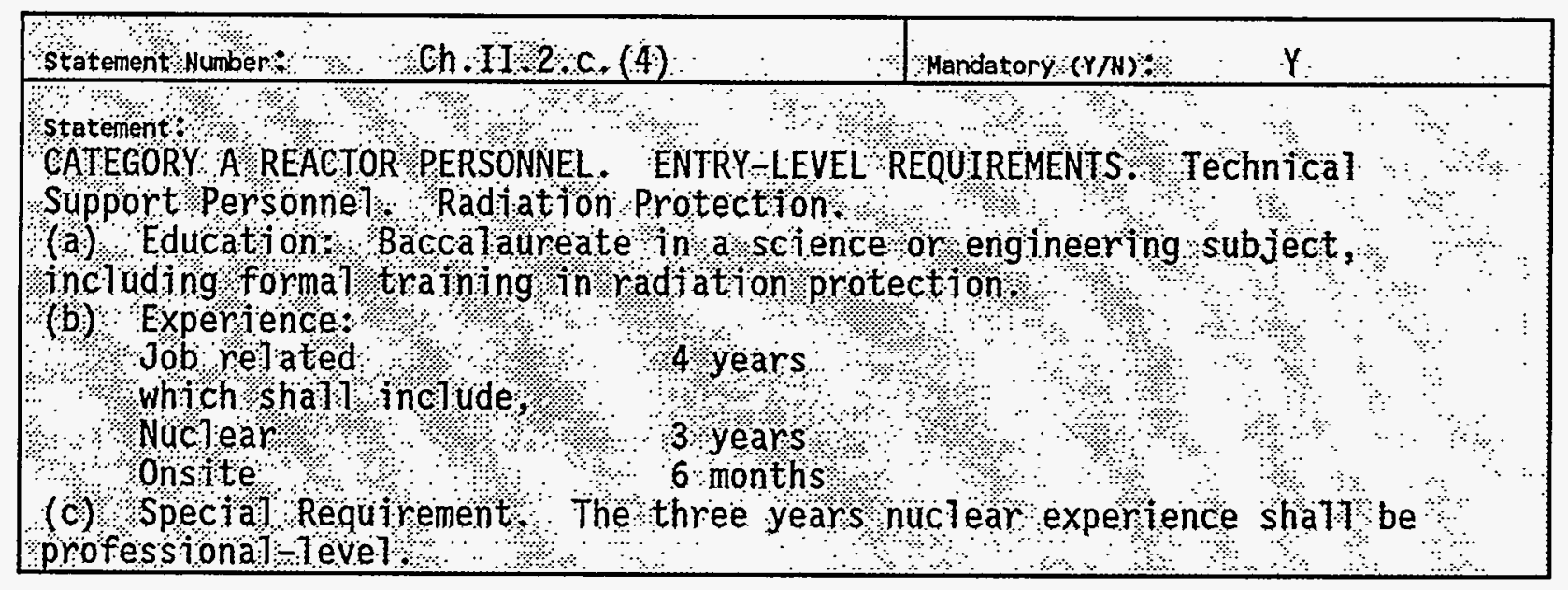

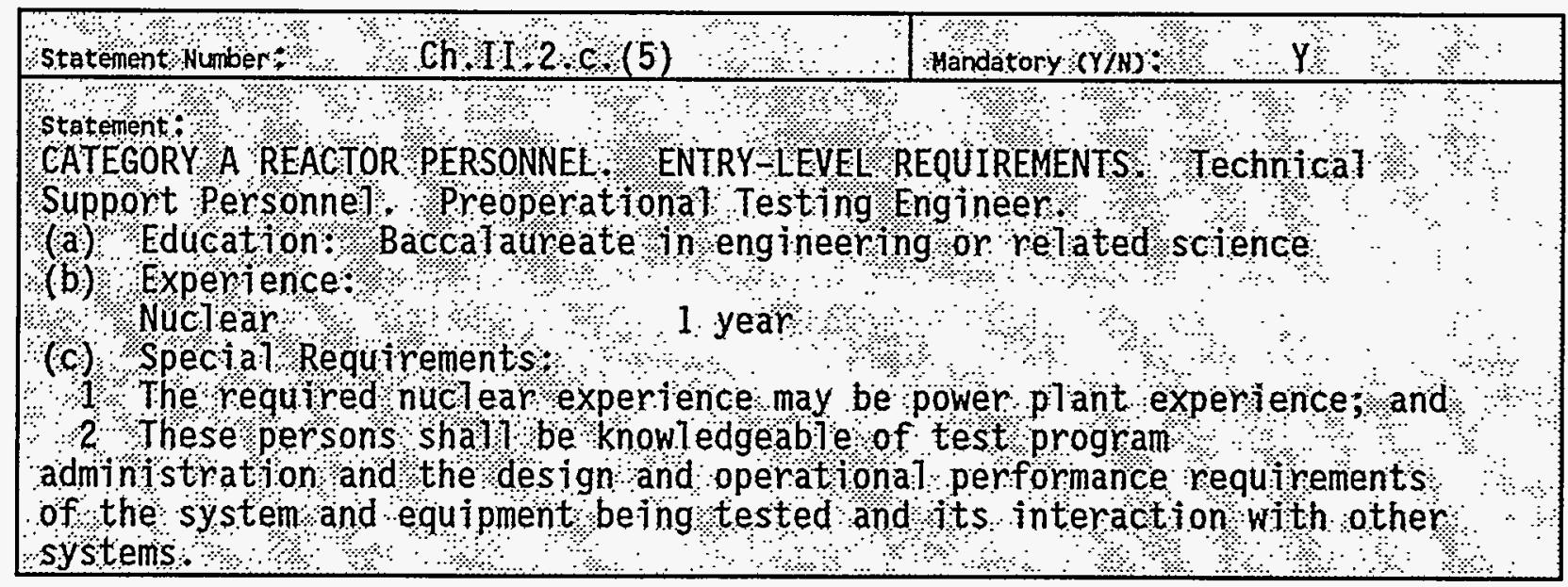


WHC-EP-0822

\section{ASSESSMENT DATA COLLECTION FORM}

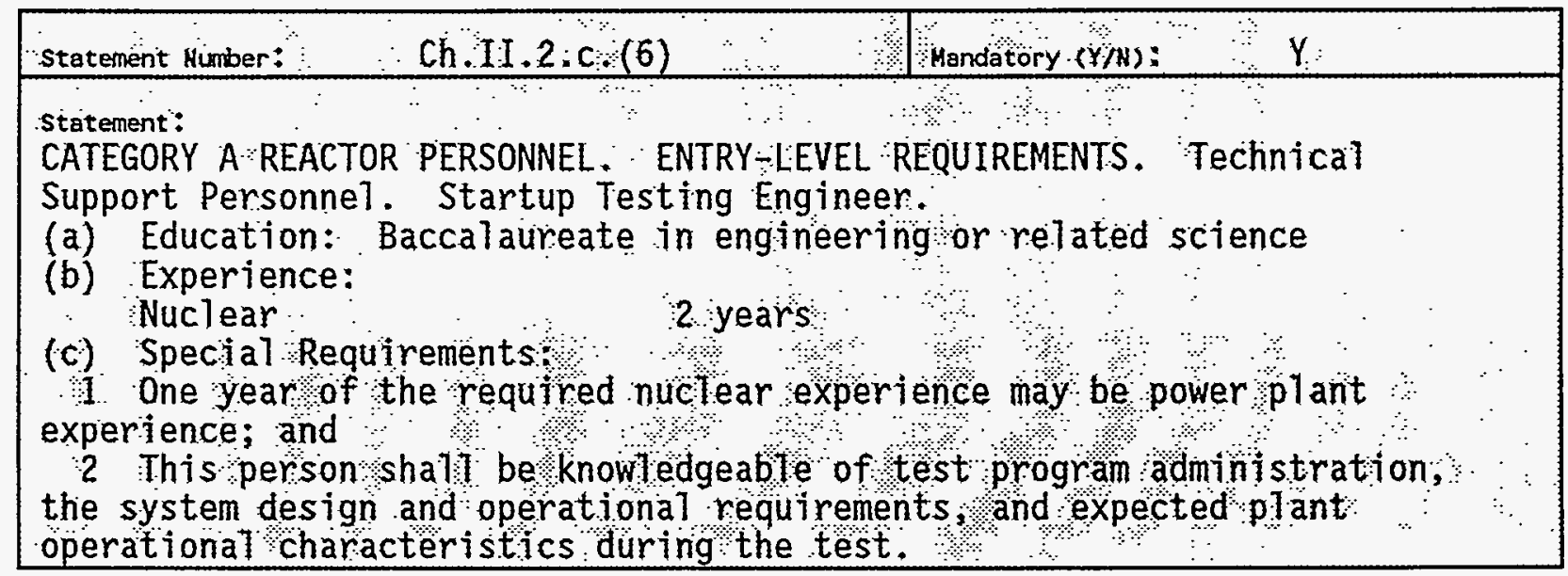

\begin{tabular}{|c|c|}
\hline Ch.II.2.c. (7) & Mandatory $(Y / N)$ : \\
\hline 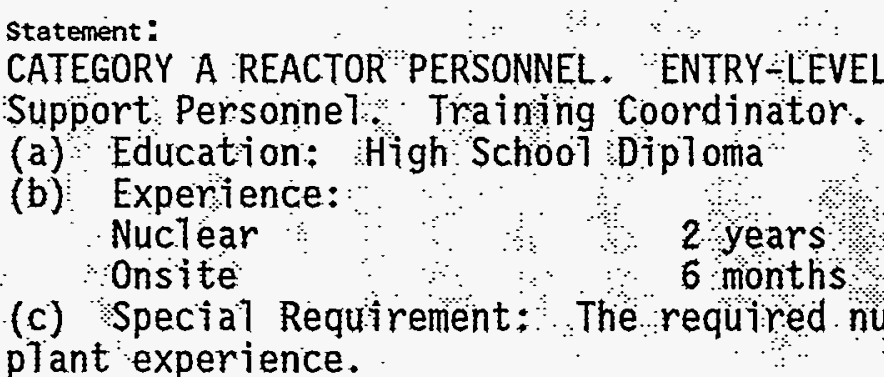 & 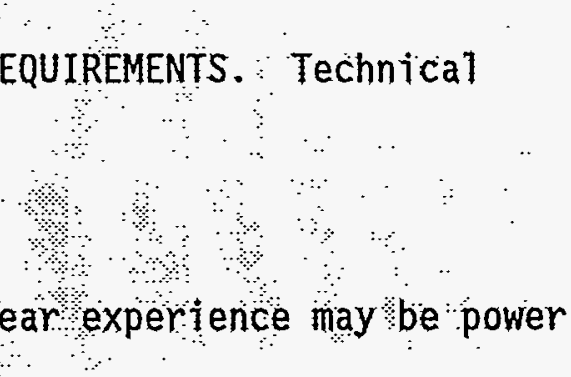 \\
\hline
\end{tabular}

Statement Number:

Ch.II. $2: C:(8)$

Mandatory $(Y / N):$

Y

Statement:

CATEGORY A REACTOR PERSONNEL. ENTRY-LEVEL REQUIREMENTS, Technical

Support Personne1. Training: Instructor.

(a) Education: High School Diploma

(b) Experience: Consistent with the material being presented.

(c) Speciał:Requirements:

1 Instructors who provide instruction on the reactor plant simulator

to certified personnel shal thold, or have held, asentor reactor operator certification for a similar category A reactor plant (or equivalent) or have been certified on the reactor plant simulator;

2 Instructors who are responsible for instruction of subjects such

as technical specifications, operating practice, and control

manipulations shall have received senior reactor operator for: equivalent) training; and

3 Instructors shall have demonstrated knowledge of instructional techniques throughtraining or experience and be qualif led by the

Training Manager for the material being presented: 
WHC-EP-0822

\section{ASSESSMENT DATA COLLECTION FORM}

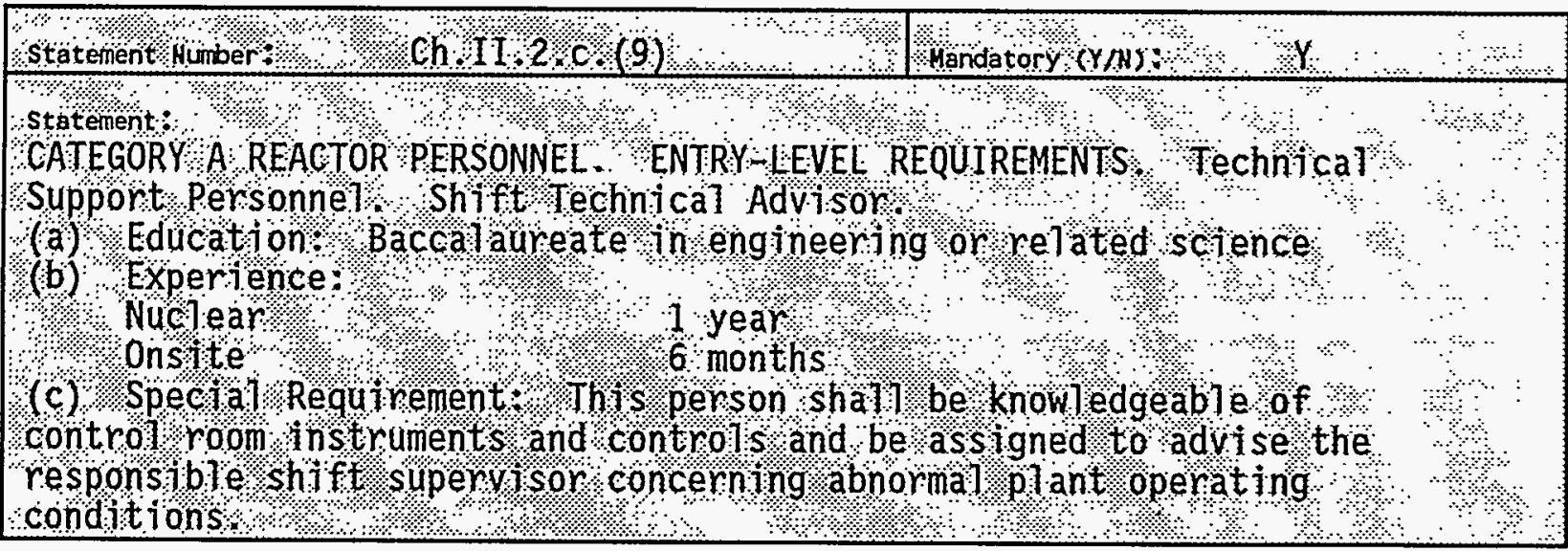

Statement Number

Ch.11.2.d:

Mandatory (Y,

r

stätement:

CATEGORY A REACTOR PERSONNEL EENTRY LEVEL EREQUIREMENTS Operators:

Technlotans, and Maintenance personnel, of persons intraining or: apprenttce posittons shall not be considered operators technicians, or mantenance personnel but may perform work th the specific tasks for Which qualf fication has been achieved. Persons in trajning or

apprentice positions may perform tasks under the immediate supervision of a person qualified to perform that speciftic task.

\begin{tabular}{|c|c|c|}
\hline aCh $1 \mathrm{~L} 2 \mathrm{~d}(1)$ & 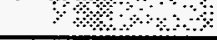 & Mandator y $(Y / f N)$ \\
\hline
\end{tabular}

Stôtement:

CATEGORY A REAGTOR PERSONNEL ENTRY LEVEL REQUIREMENTS, Operators,

Technictans, and Mantenance Personnel Qual f fed Auxillary operators.

(a) Education $/ H$ igh School ol pioma

(b) Experience. Qualt Tied aux 17 ary operators whose actions coutd: affect the qual 1 ty of structires, systems and components important to safety shal thave 1 year of nuclear experience.

(6) Spectal Requirement t the requitred nuclear experience may be power plant experiences

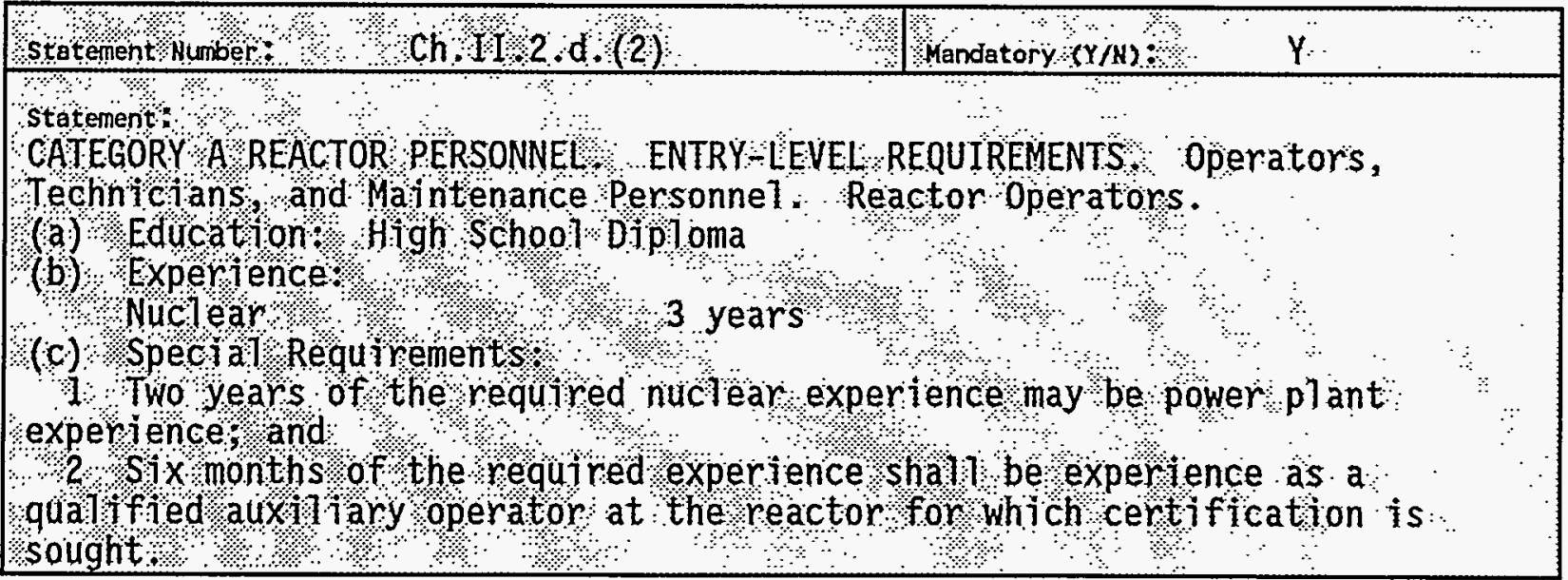


WHC-EP-0822

ASSESSMENT DATA COLLECTION FORM

\begin{tabular}{|c|c|c|}
\hline Ch.II.2.d.(3) & Mandatory $(Y / N)$ : & $Y$ \\
\hline $\begin{array}{l}\text { Statement: } \\
\text { CATEGORY A REACTOR PERSONNEL. ENTRY-LEVE } \\
\text { Techinicians, and Maintenance Personnel. } \\
\text { (a) Education: High School Diploma } \\
\text { (b) Experience: Job related experience }\end{array}$ & $\begin{array}{l}\text { EQUIREMENTS. } \\
\text { hnicians: } \\
\vdots \\
3 \text { years }\end{array}$ & ors, \\
\hline
\end{tabular}

\begin{tabular}{|c|c|c|c|}
\hline Statement Number: & Ch.II.2.d.(4) & Mandatory: $(Y / N)$ : & $y$ \\
\hline \multicolumn{4}{|c|}{$\begin{array}{l}\text { Statement: } \\
\text { CATEGORY A REACTOR PERSONNEL, ENTRY-LEVEL REQUIREMENTS, Operators, } \\
\text { Technicians, and Maintenance Personnel. Maintenance Personnel. } \\
\text { (a) Education: Journeyman level } \\
\text { (b) Experience: ReTated maintenance experience } 3 \text { years }\end{array}$} \\
\hline
\end{tabular}

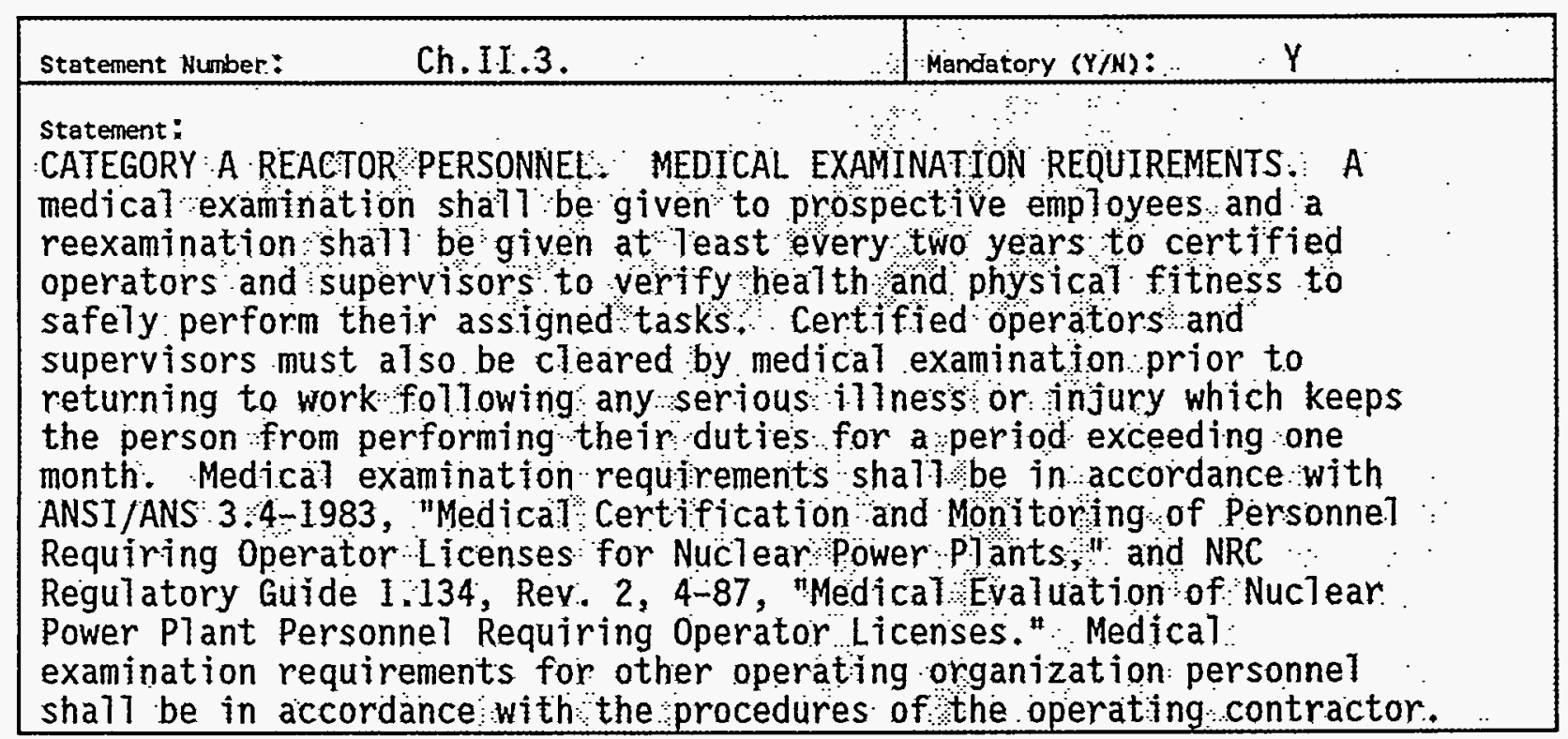




\section{ASSESSMENT DATA COLLECTION FORM}

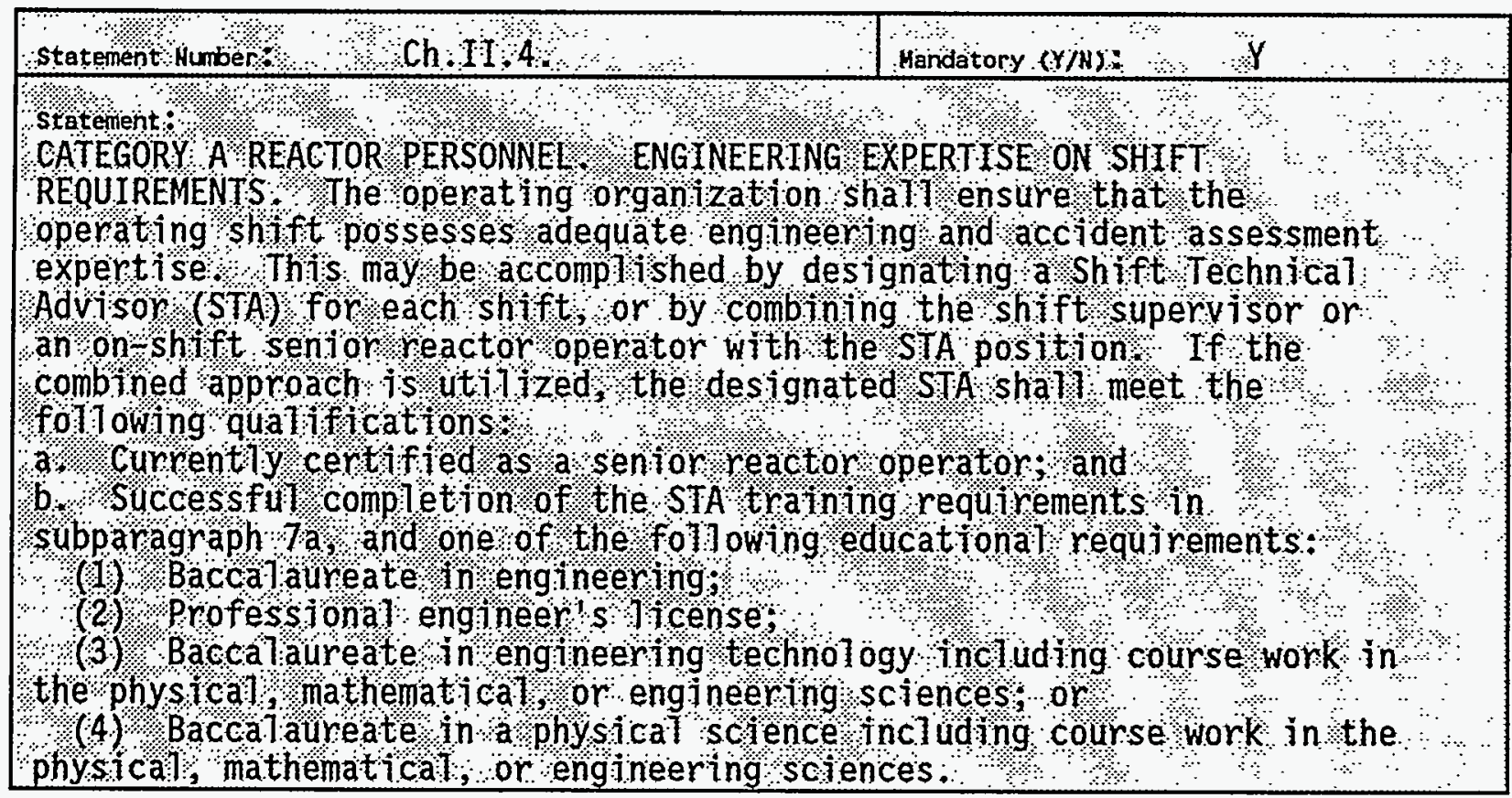

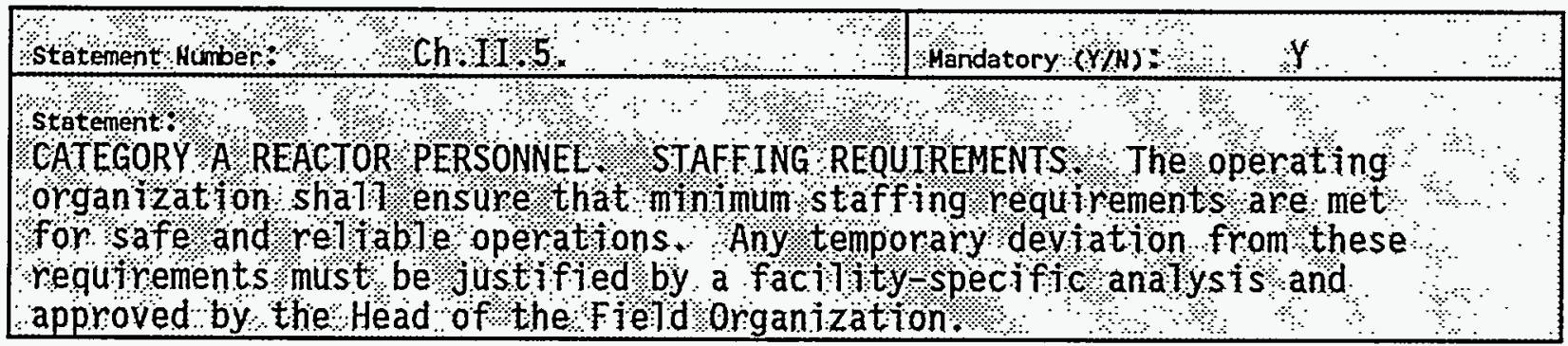

\begin{tabular}{|c|c|}
\hline 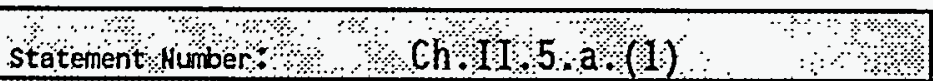 & Handatory $(Y$ N $) \times$ \\
\hline 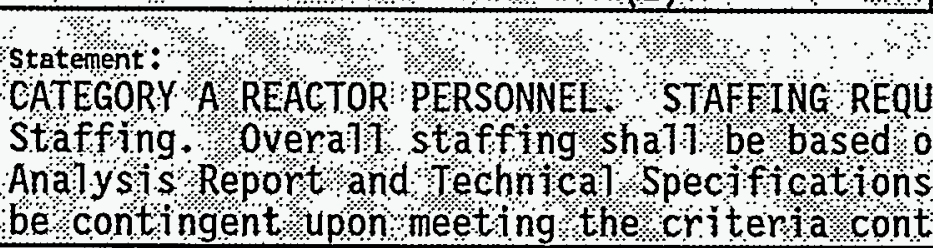 & 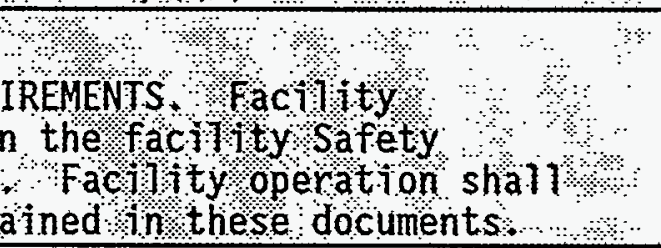 \\
\hline
\end{tabular}

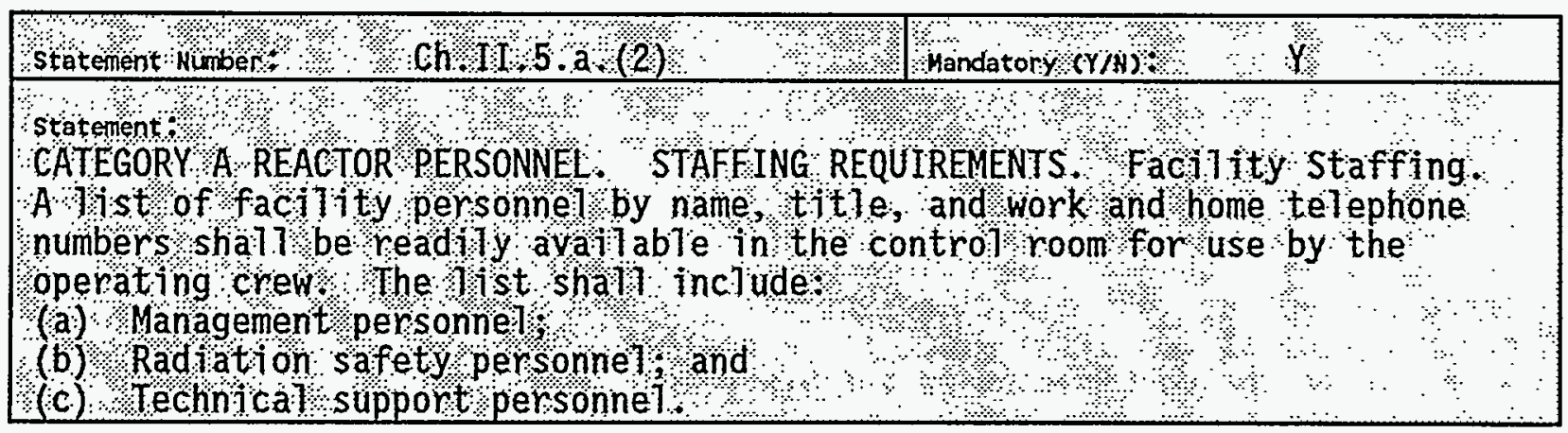


WHC-EP-0822

\section{ASSESSMENT DATA COLLECTION FORM}

\begin{tabular}{|c|c|}
\hline Ch.1 1,5, b. (1) & Mandatory $\mathrm{NY} / \mathrm{N} S \mathrm{Y}$ : \\
\hline $\begin{array}{l}\text { Statemint: } \\
\text { CATEGORY A REACTORPERSONNEL STAFFING REQ } \\
\text { Staffing. A certified reactor operator or } \\
\text { shal7 be at the controls in the control roo } \\
\text { reactor is fueled. }\end{array}$ & $\begin{array}{l}\text { IREMENTS Control Room } \\
\text { senior reactor operator } \\
\text { at a T t imes when the }\end{array}$ \\
\hline
\end{tabular}

\begin{tabular}{|c|c|c|c|}
\hline Statement Number: & $\mathrm{Ch} \times \mathrm{I} \cdot 5 \mathrm{~b} \cdot(2)$ & Mandatory $\mathrm{CY} / \mathrm{N}):$ & \\
\hline \multicolumn{4}{|c|}{$\begin{array}{l}\text { Statement: } \\
\text { CATEGORY AREACTOR PERSONNEL STAFFING REQUIREMENTS Controf Room } \\
\text { Staffing. A cert If ied senior reactor operator shal be in the control } \\
\text { room at al1 times when the reactor is operating or in an operationa } \\
\text { mode other than cold shutdown or refueling as defined by the Technical } \\
\text { Specifications. }\end{array}$} \\
\hline
\end{tabular}

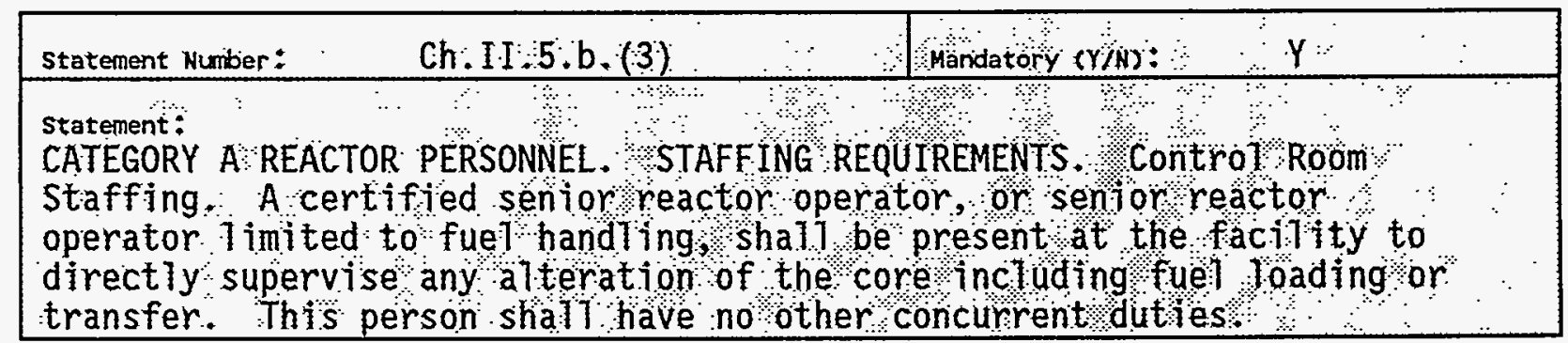

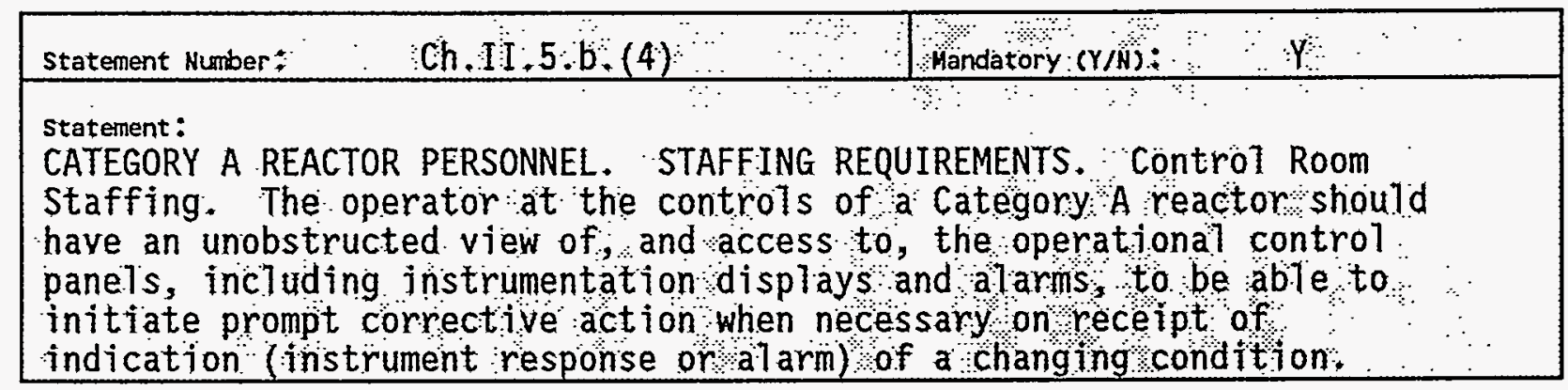

\begin{tabular}{|c|}
\hline Mandatory $(Y / N)=$ \\
\hline 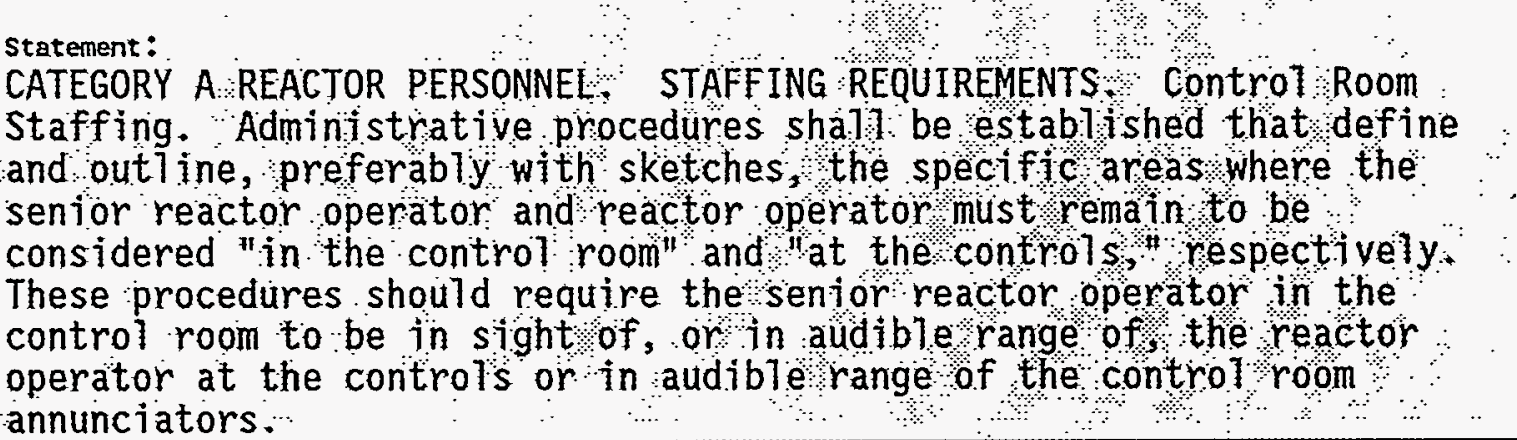 \\
\hline
\end{tabular}


WHC-EP-0822

ASSESSMENT DATA COLLECTION FORM

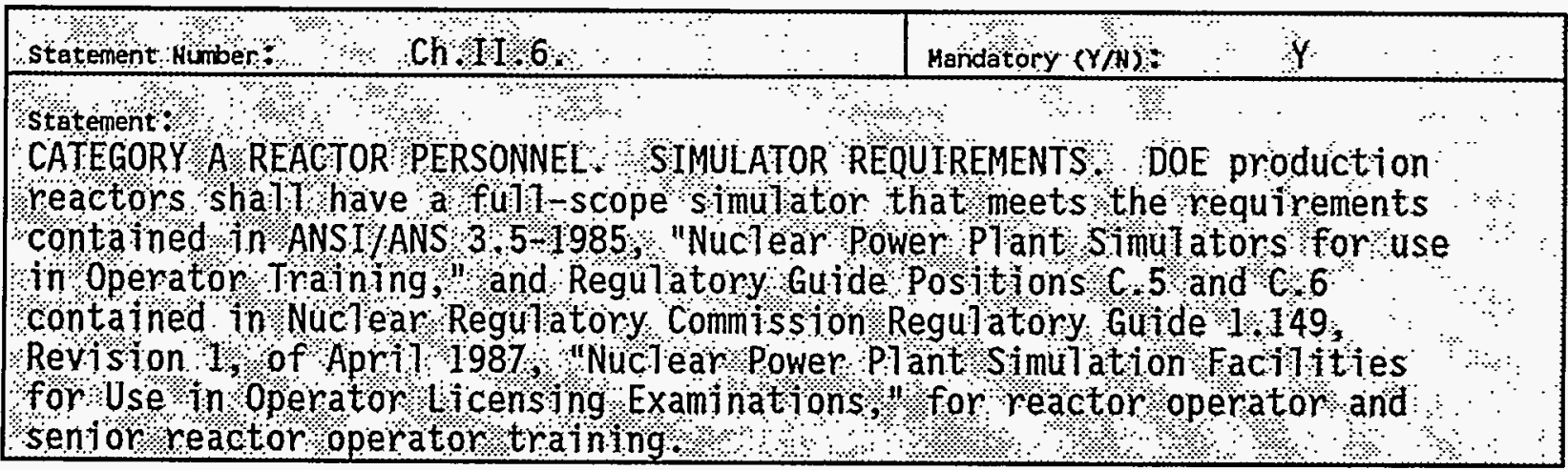

\begin{tabular}{|c|c|}
\hline 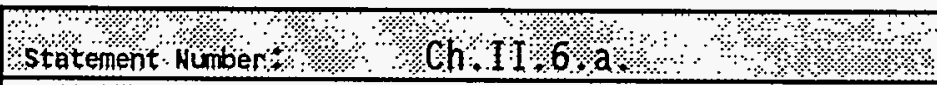 & 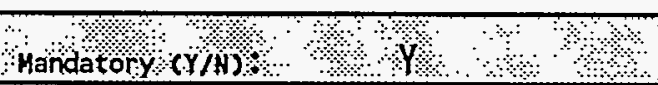 \\
\hline 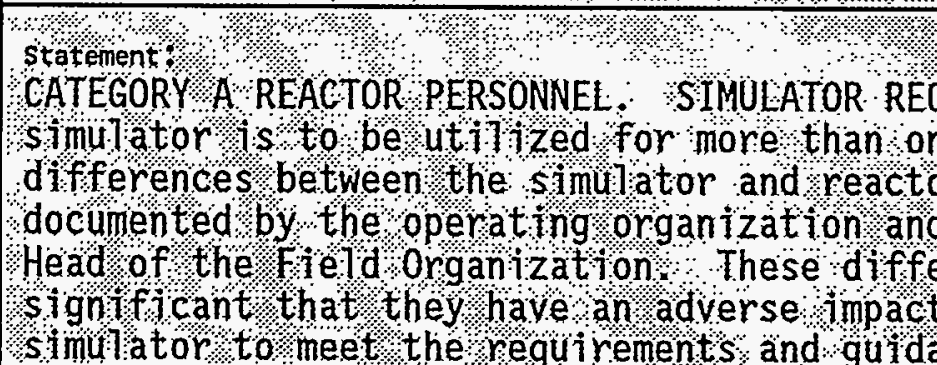 & 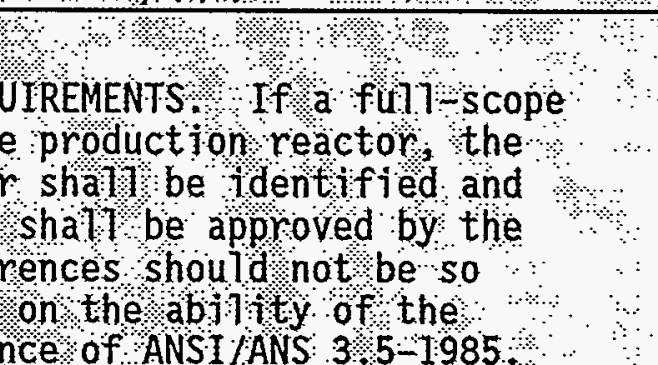 \\
\hline
\end{tabular}

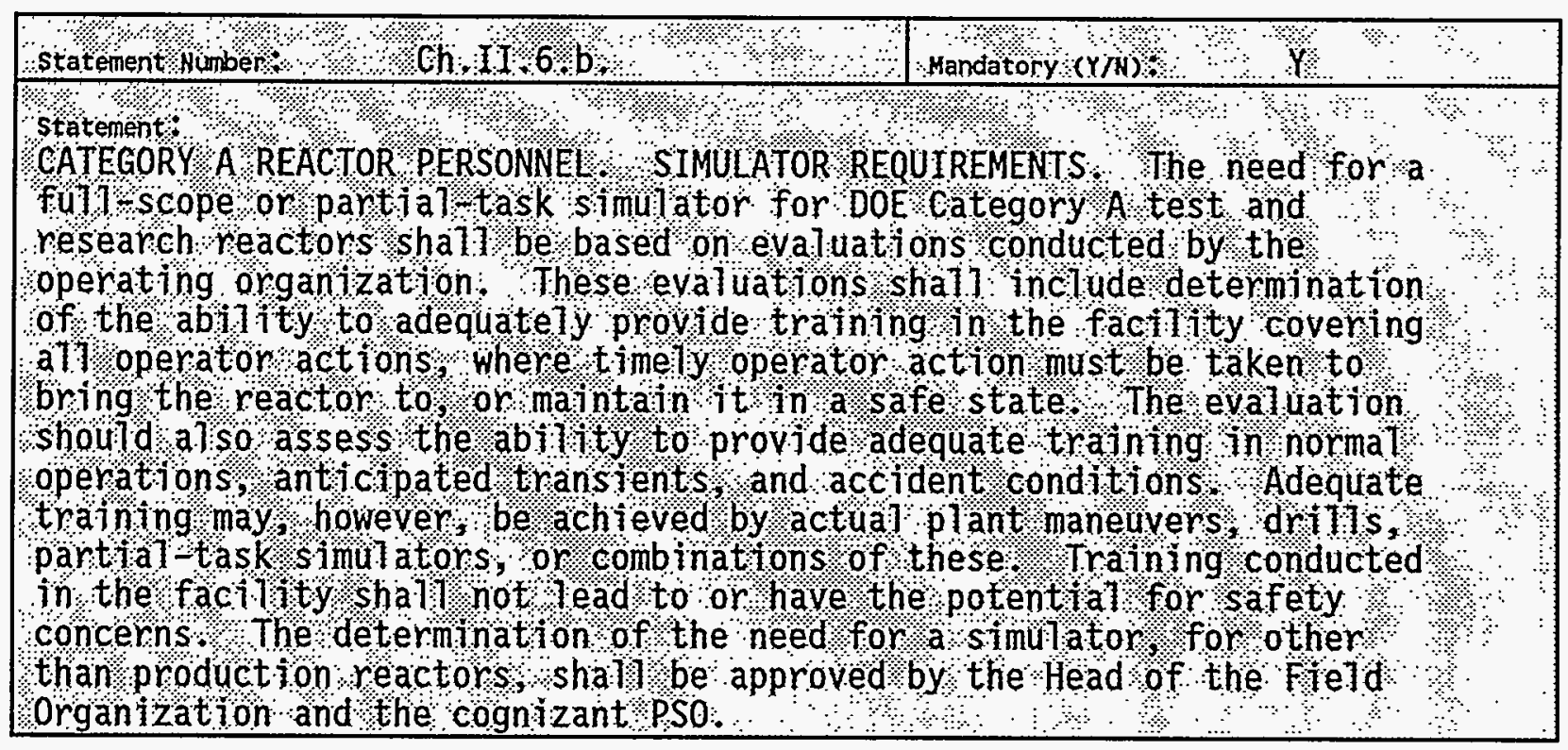


WHC-EP-0822

\section{ASSESSHENT DATA COLLECTION FORM}

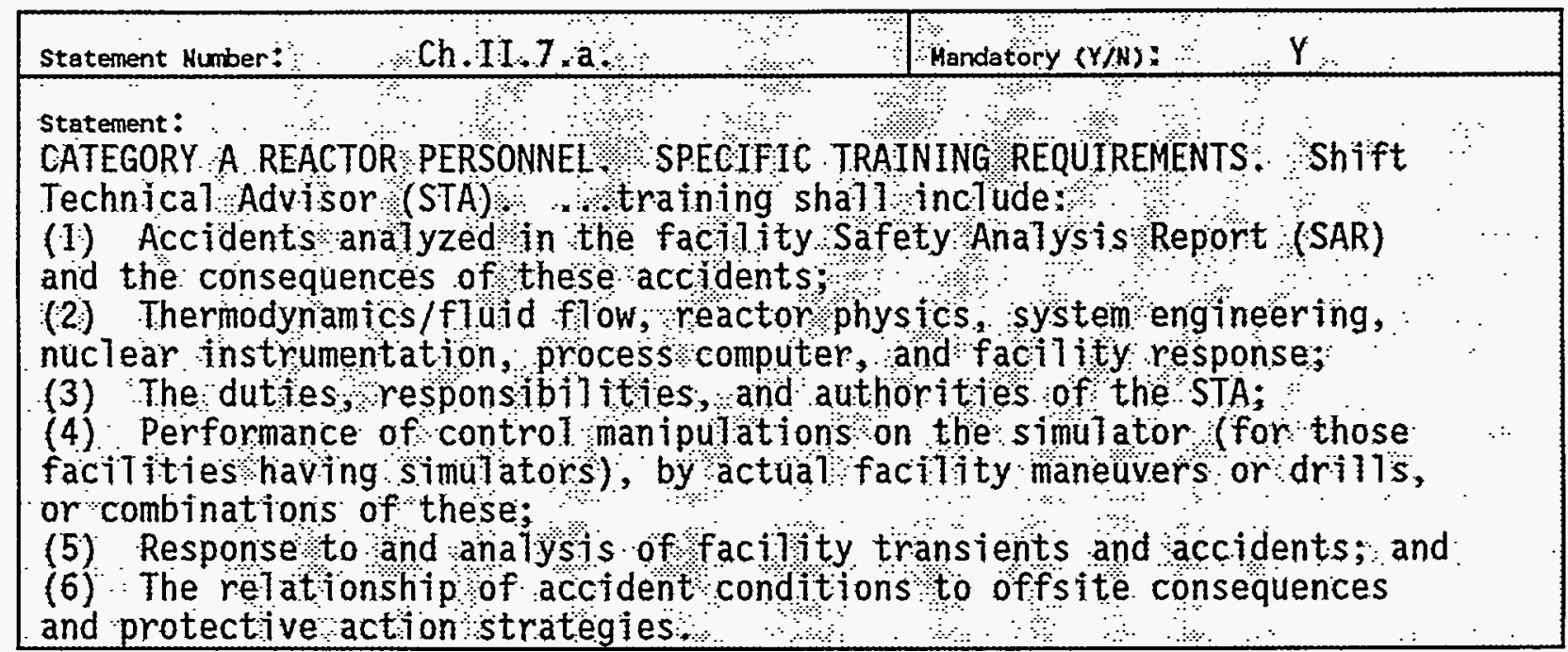

\begin{tabular}{|c|c|}
\hline $\operatorname{ch} 1 \mathrm{I} .7 \mathrm{~b}$ & Handatory $(Y / N):$ \\
\hline 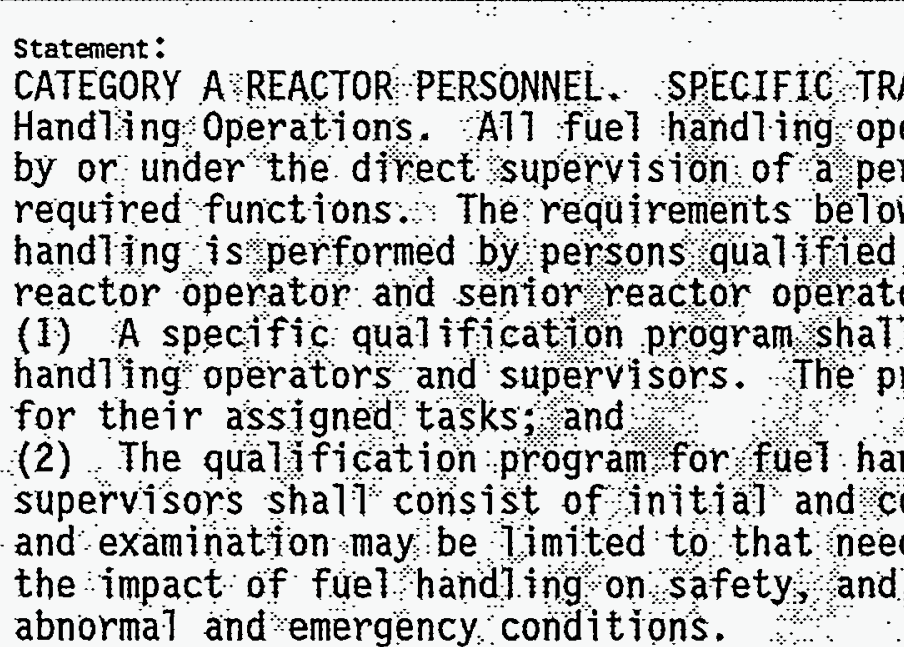 & 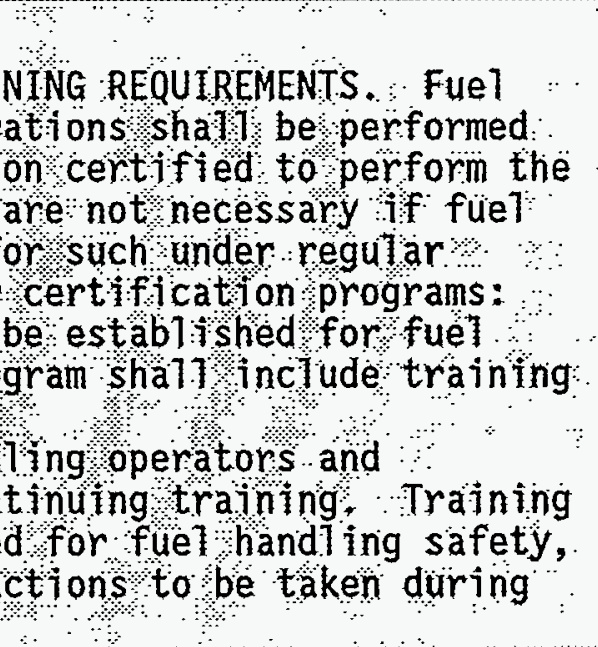 \\
\hline
\end{tabular}

\begin{tabular}{|c|}
\hline 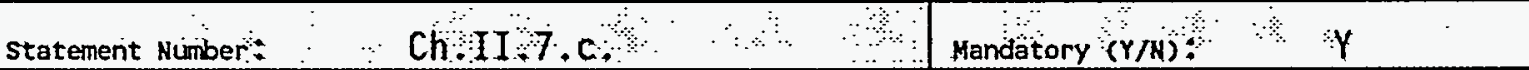 \\
\hline 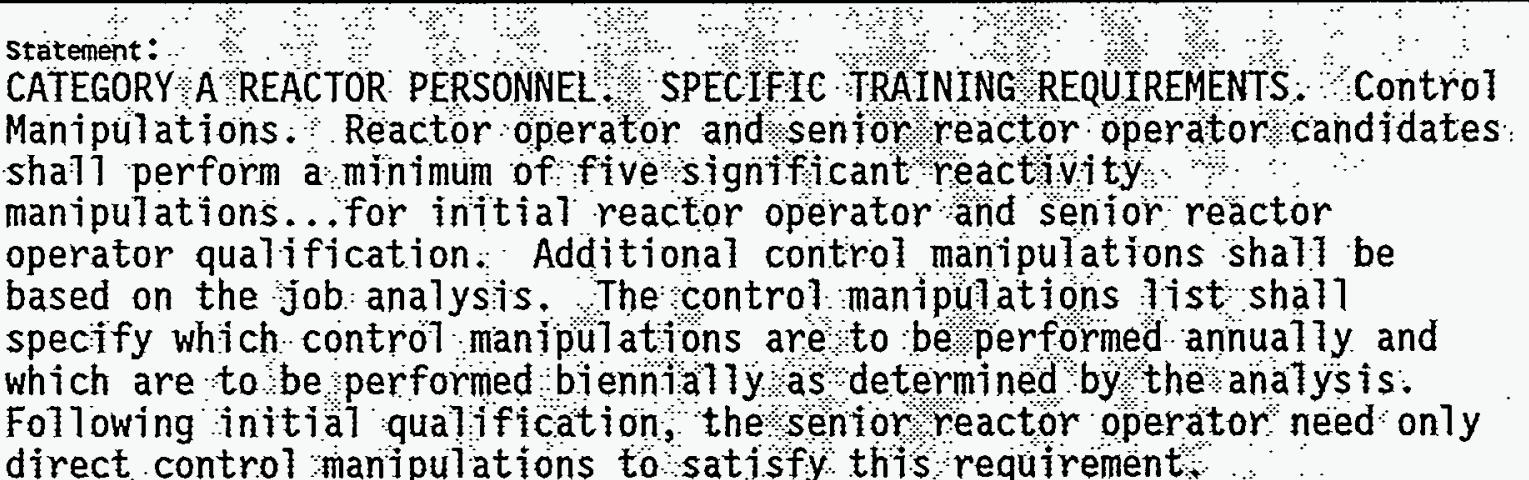 \\
\hline
\end{tabular}




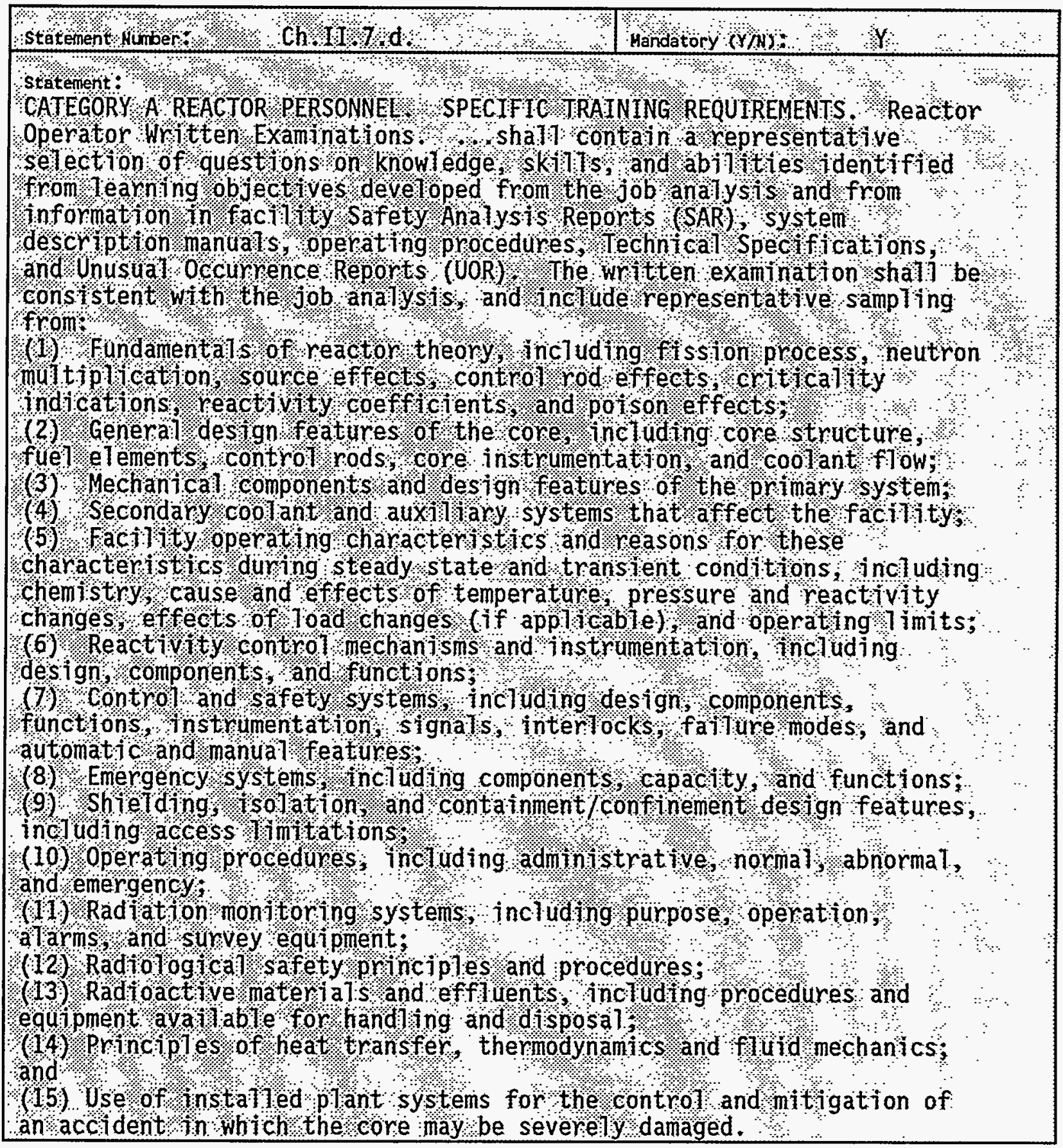




\section{ASSESSMENT DATA COLLECTION FORM}

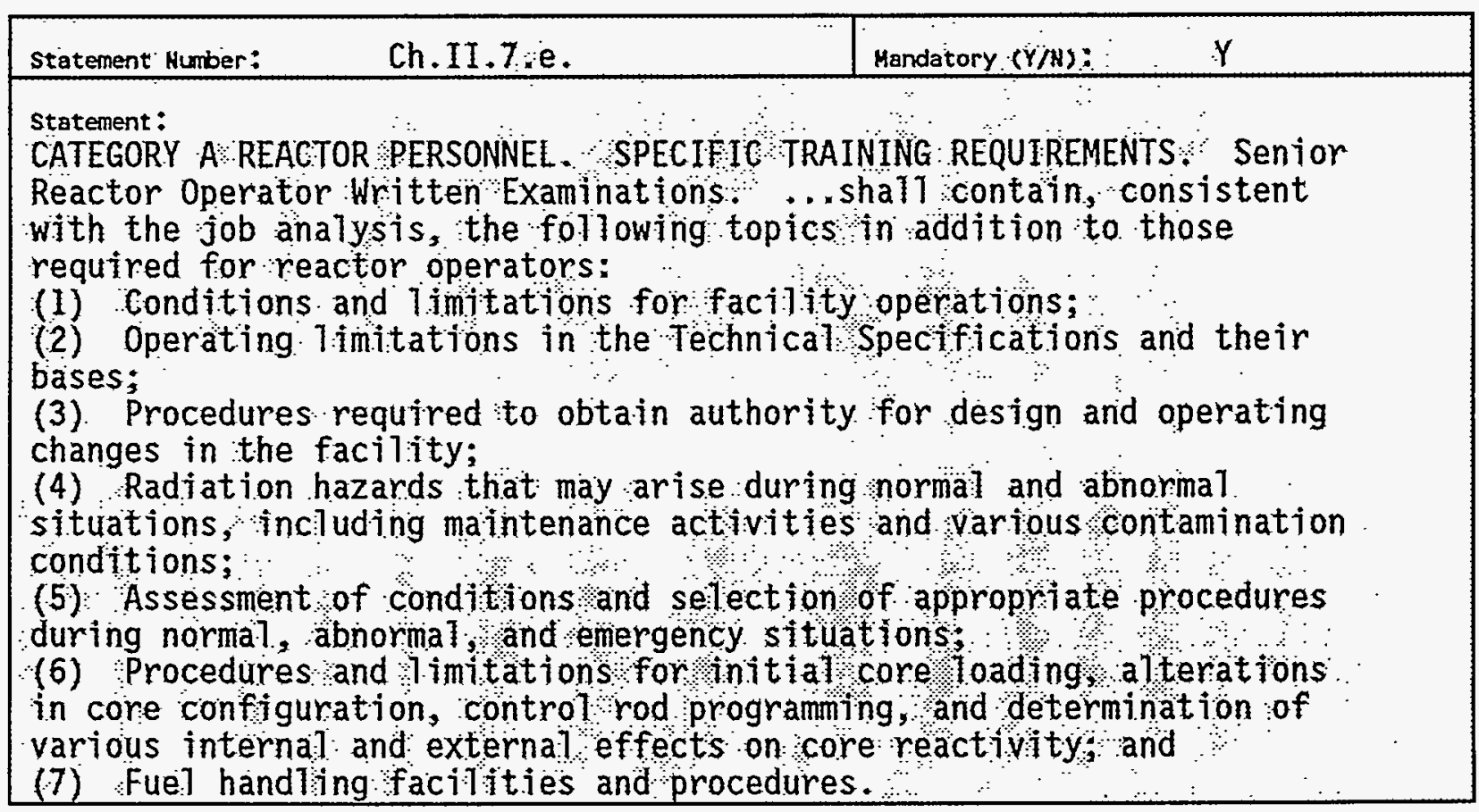


WHC-EP-0822

\section{ASSESSMENT DATA COLLECTION FORH}

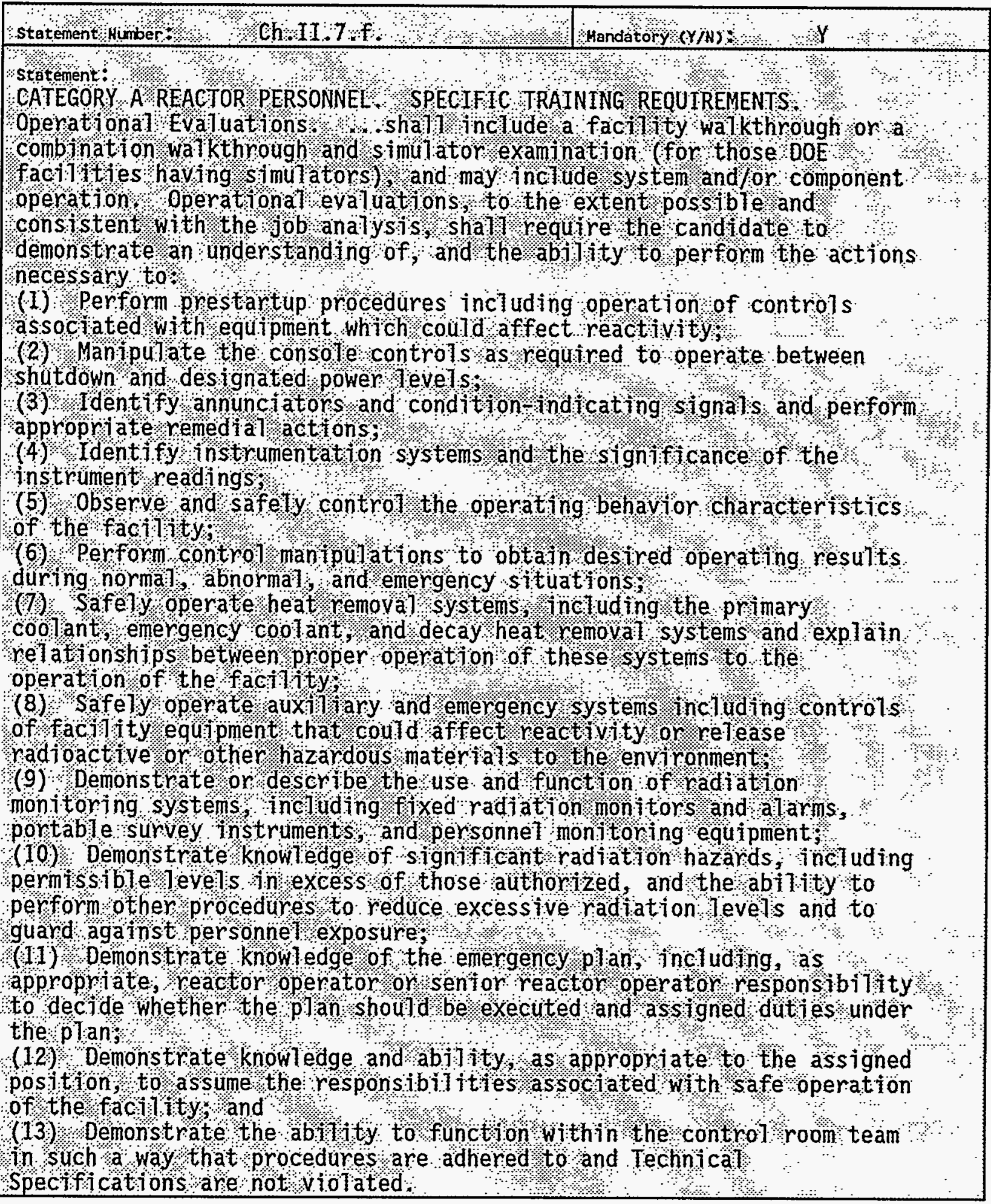


WHC-EP-0822

\section{ASSESSMENT DATA COLLECTION FORM}

\begin{tabular}{|c|c|}
\hline Ch.II.7. $\mathrm{g} .(1)$ & Mandatory $(Y / N)$ : \\
\hline \multicolumn{2}{|c|}{ 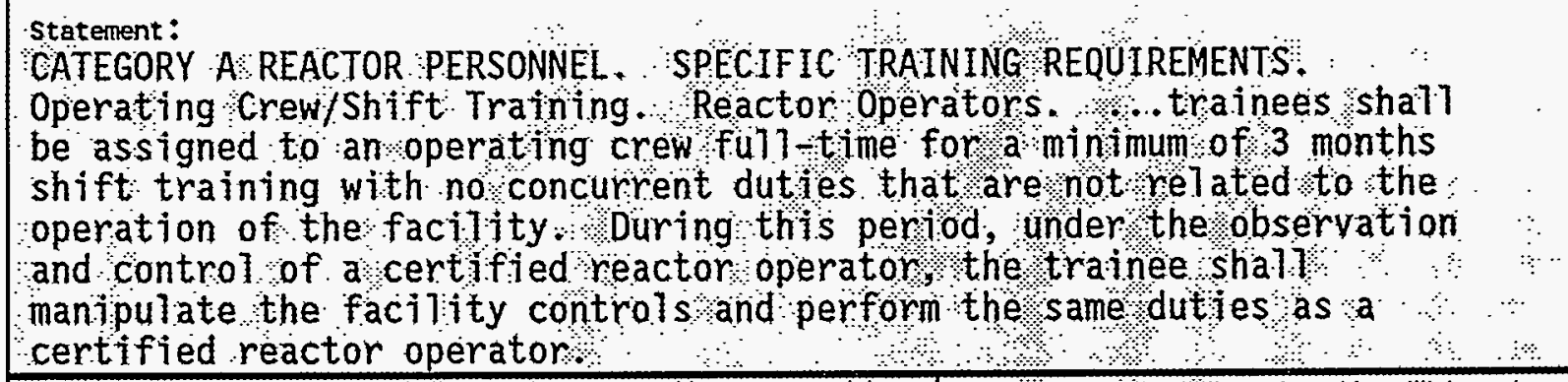 } \\
\hline Ch $117.9 \cdot(2)$ & Mandatory $(Y / A)$ : \\
\hline 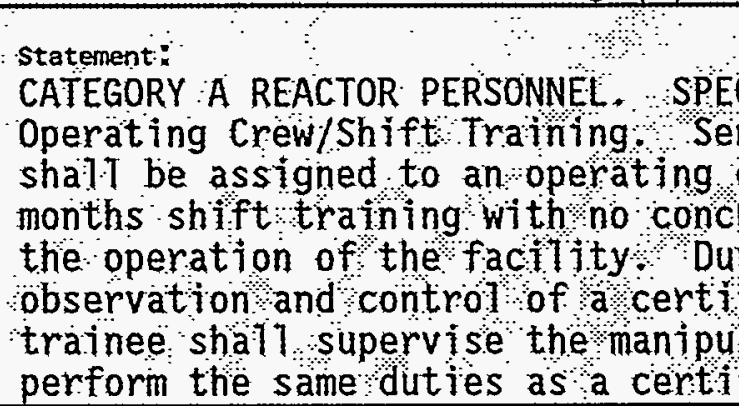 & 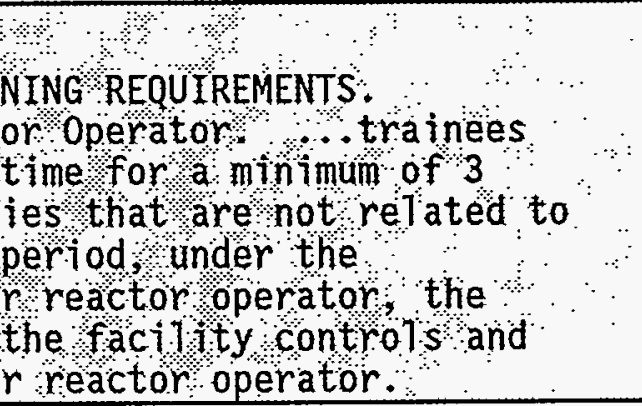 \\
\hline
\end{tabular}

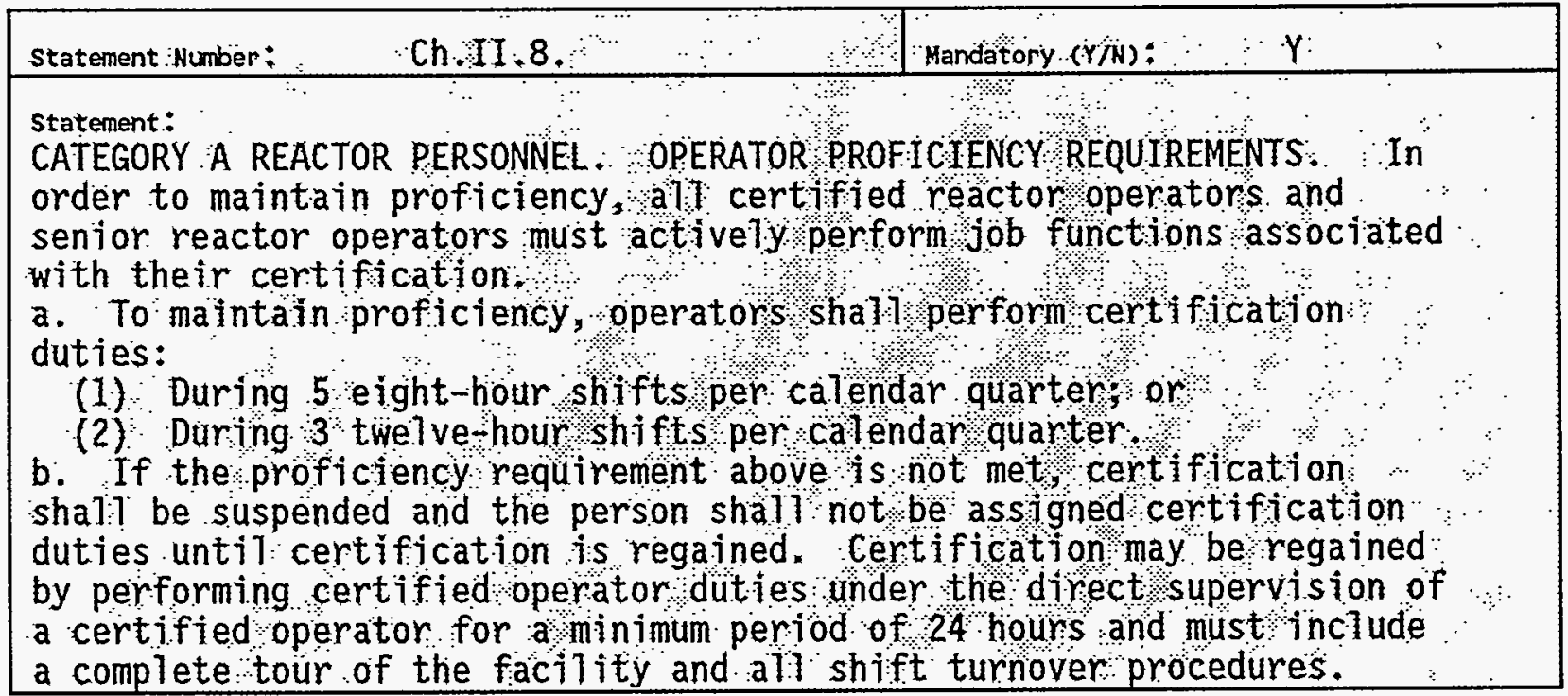

The above Chapter Il statements are specific to DOE Category A reactor facilities and are, therefore, N/A to analytical laboratories. 
WHC-EP-0822

\section{ASSESSHENT DATA COLLECTION FORM}

\section{The following Chapter III statements are specific to DOE Category B reactor facilities and are, therefore, N/A to analytical laboratories.}

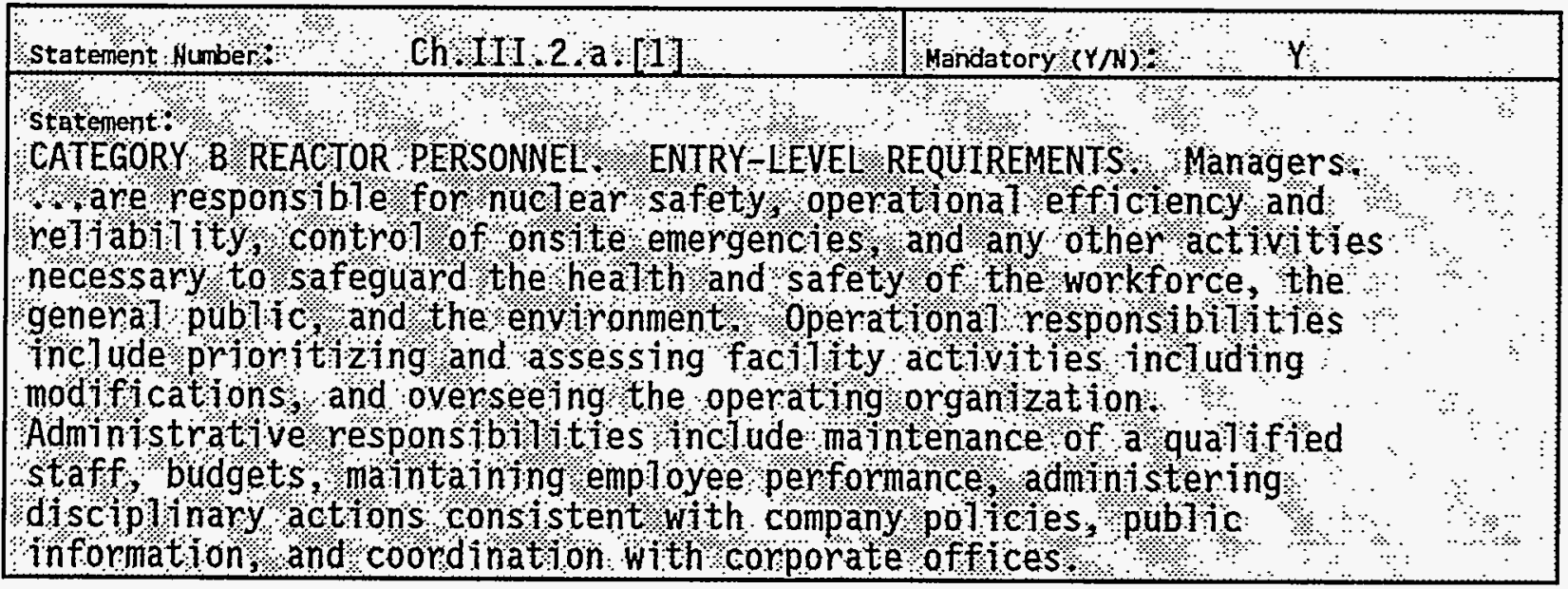

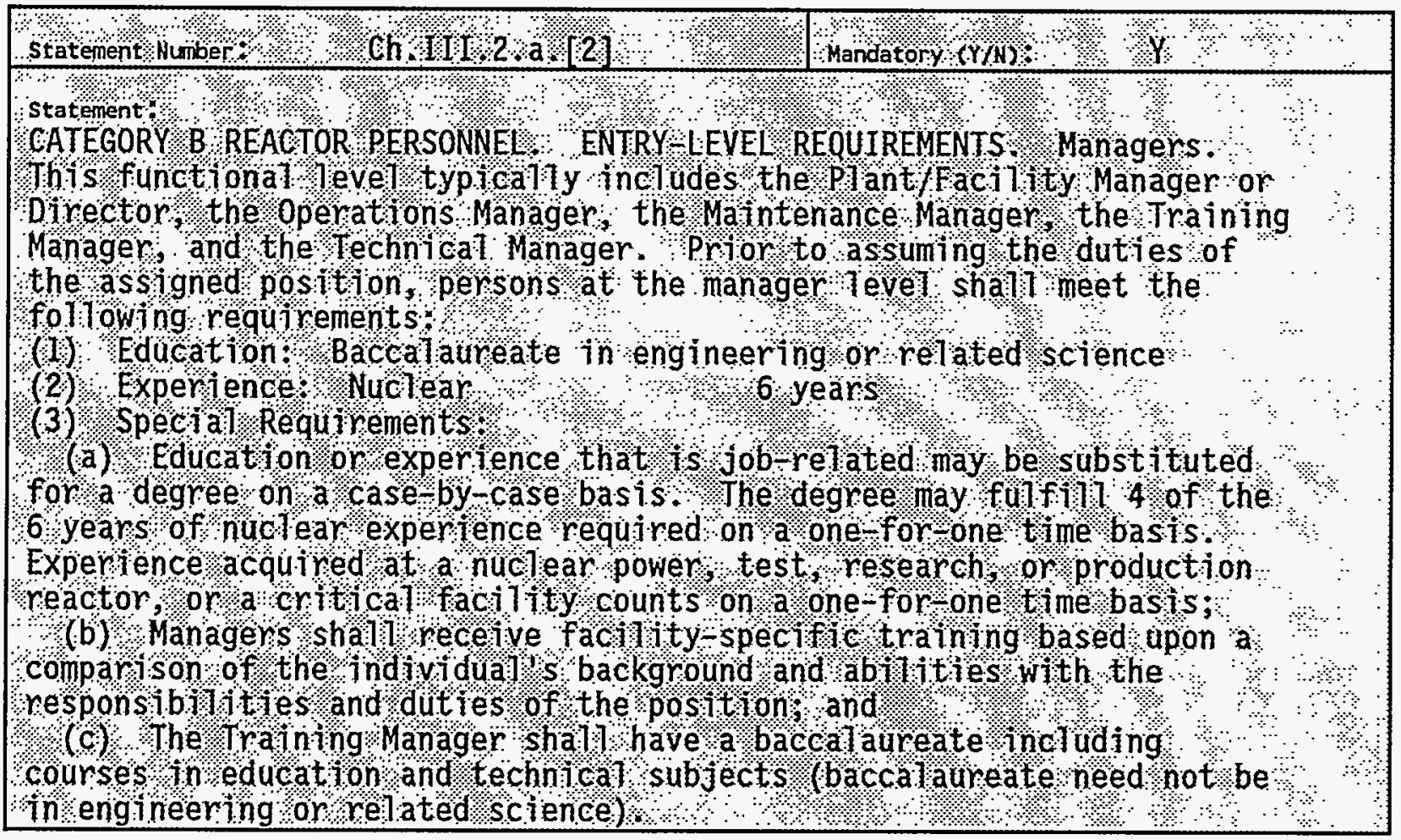

\begin{tabular}{|c|c|}
\hline 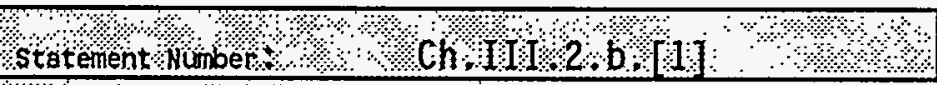 & 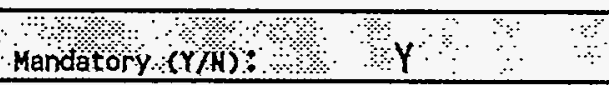 \\
\hline 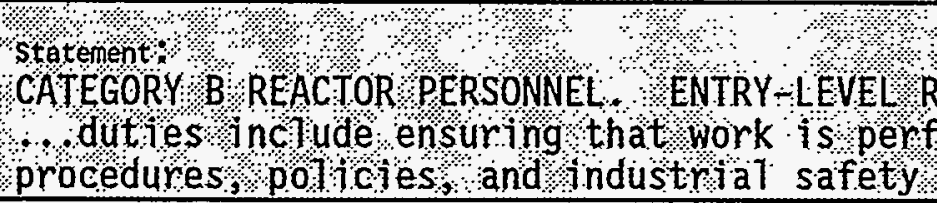 & $\begin{array}{l}\text { EQUIREMENTS supervisors } \\
\text { ormed in compt ance with } \\
\text { practices }\end{array}$ \\
\hline
\end{tabular}


WHC-EP-0822

ASSESSMENT DATA COLLECTION FORM

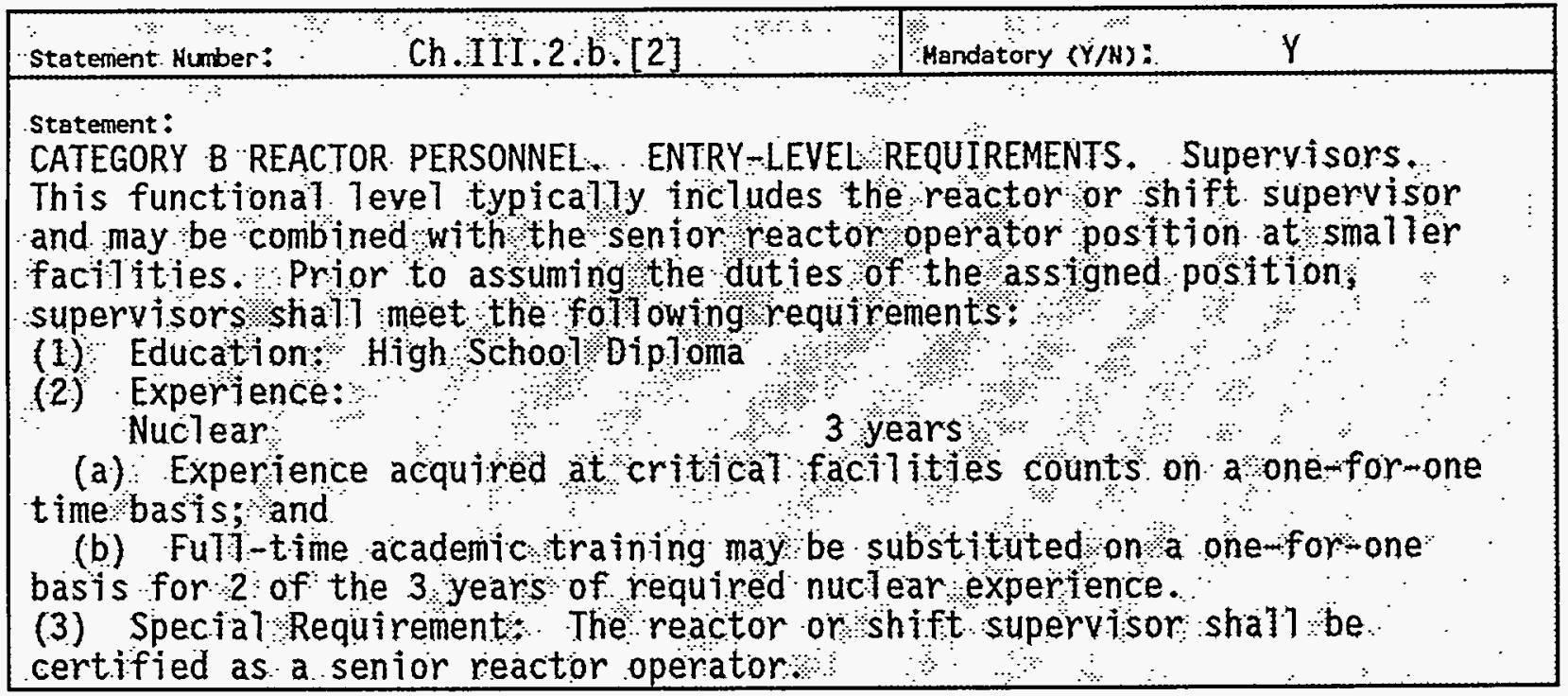

\begin{tabular}{|c|c|}
\hline Statement Númber $::$ & Mandatory $(Y / N) 4 \cdots \quad Y$ \\
\hline $\begin{array}{l}\text { Statement: } \\
\text { CATEGORY B REACTOR PERSONNE } \\
\text { OAt Category B reactor facilities this po } \\
\text { operator and senior reactor operator } \\
\text { (1) Education: High School Diploma. }\end{array}$ & $\begin{array}{l}\text { SEQUIREMENTS operators } \\
\text { Sttion includes the reactor }\end{array}$ \\
\hline
\end{tabular}

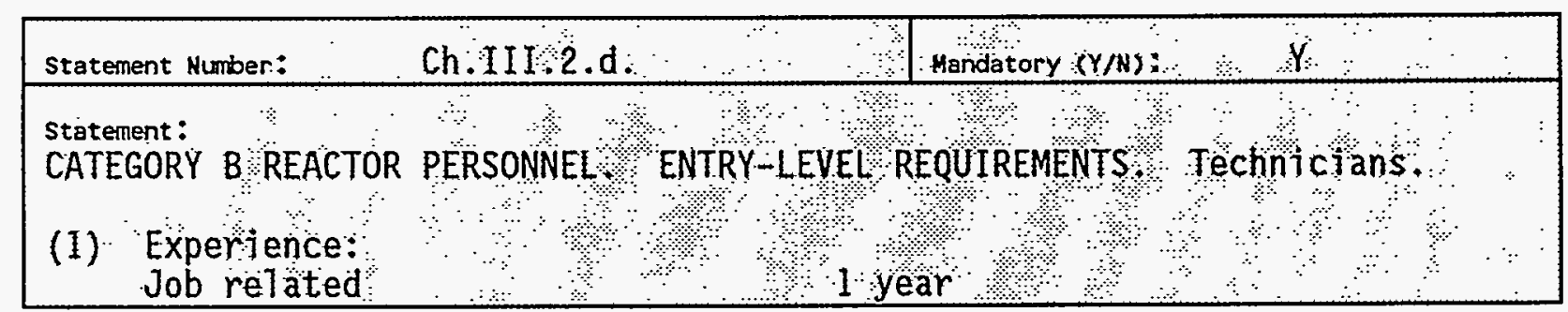

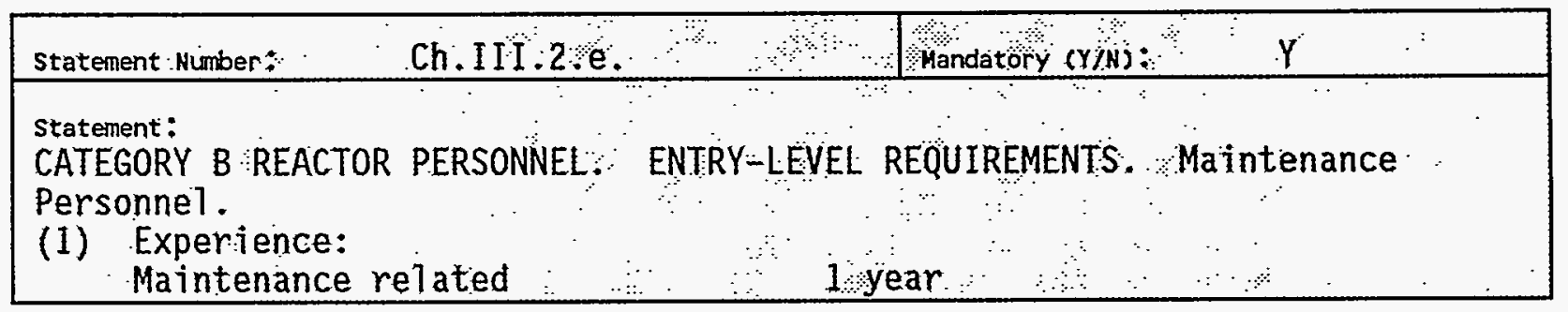




\section{ASSESSMENT DATA COLLECTION FORM}

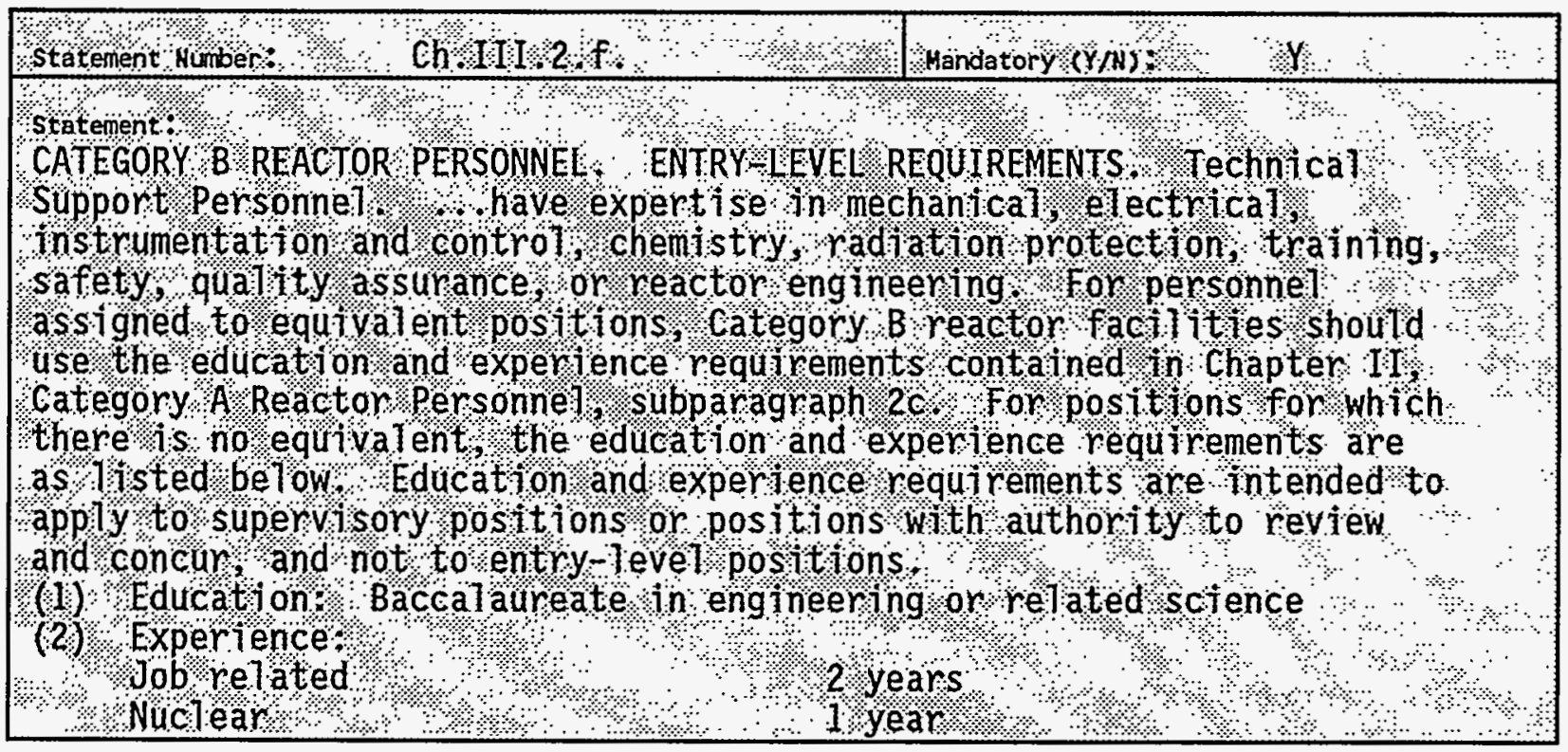

Stutement Humber.;

Ch. III. 3 .

Mandatory $y(Y, k)$

Y.

statement:

CATEGORY B REACTOR PERSONNE IMEDTCAL EXAMINATION REQUIREMENTS: $A$ : medical examinathon sha 7 be given to prospective semployees and a reexamination shal be glven at least every two years to cert f fted operators and supervisors to verify health and phys ical fitness to safely perform their assigned tasks, cert ff led operators and supervisors must a 150 be cleared by medica examinat ton prar to returning to work following any serious 1 lness or 7 th ury which keeps the person from performing their dut les for a per $10 \mathrm{~d}$ exceeding one month Medical examinat 10 s shat 1 be 10 accordance with reguirements conta ned $1 n$ ANSI ANS $15.4-1988$. Med tal examinat ton requirements for other operating organlzat 10 on prsonnet sha 1 besin accordance with the procedures of the operatting contractor.

\begin{tabular}{|c|}
\hline statement Number Ch III 4 . \\
\hline 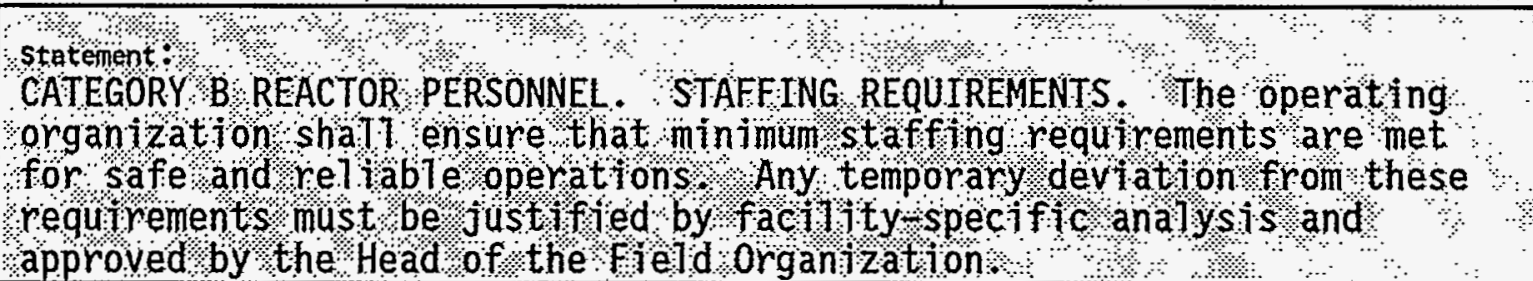 \\
\hline
\end{tabular}

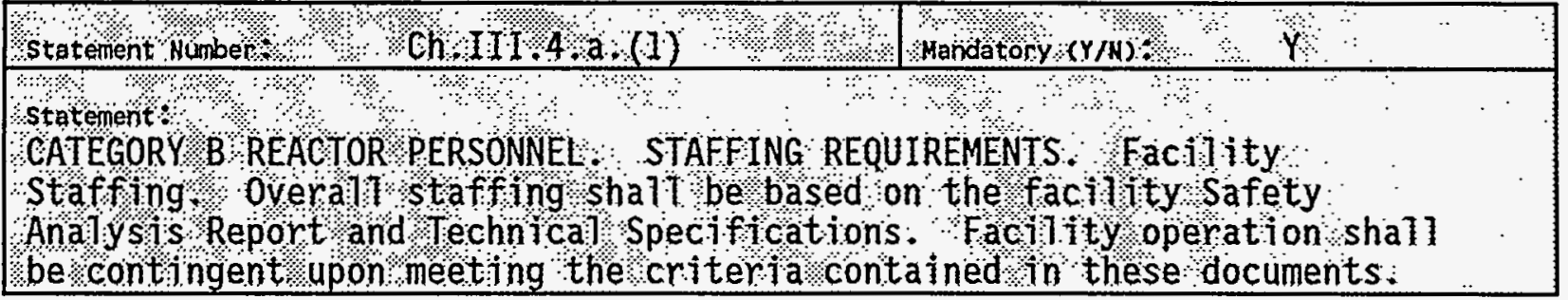




\section{ASSESSNENT DATA COLLECTION FORM}

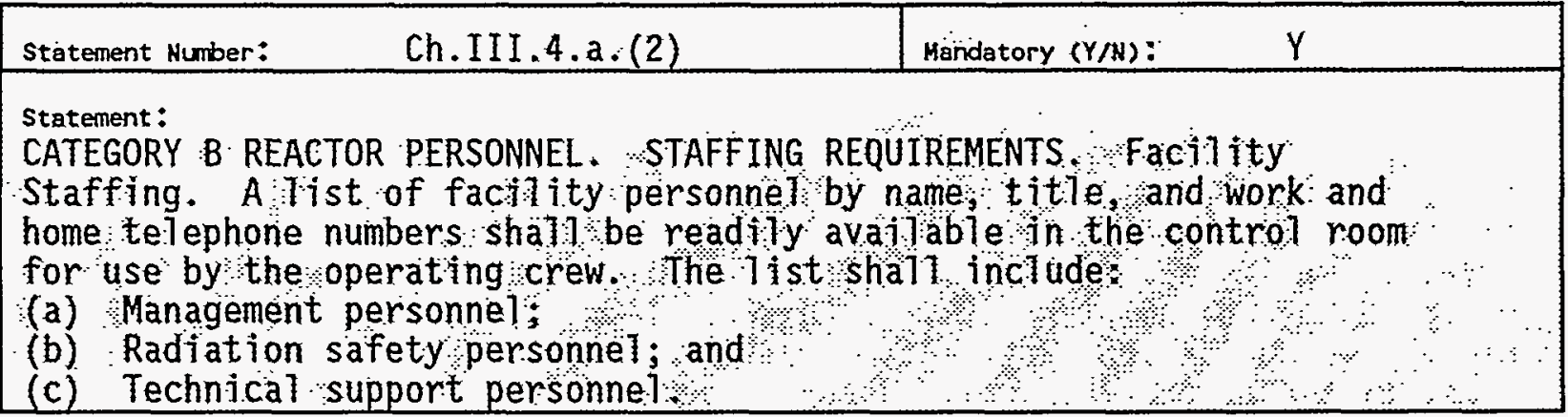

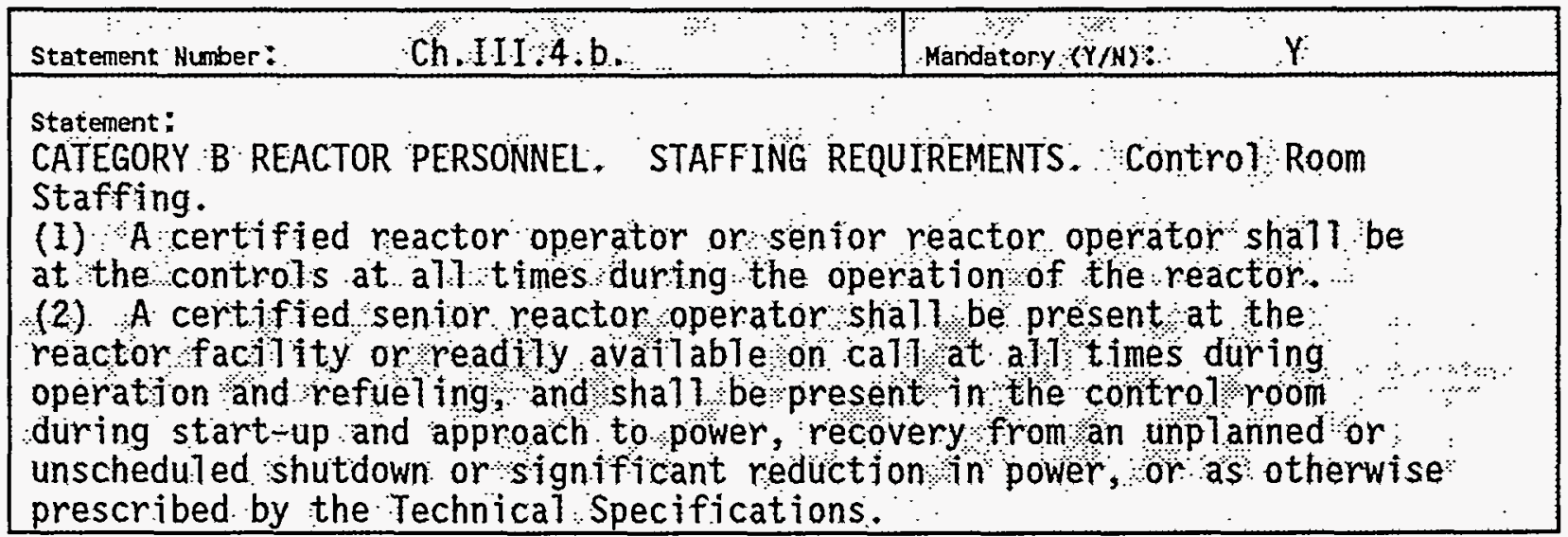

\begin{tabular}{|c|c|}
\hline Ch:IIII5, $\therefore$ & Mandatory $(Y)$ u $\mathrm{Y}$ \\
\hline 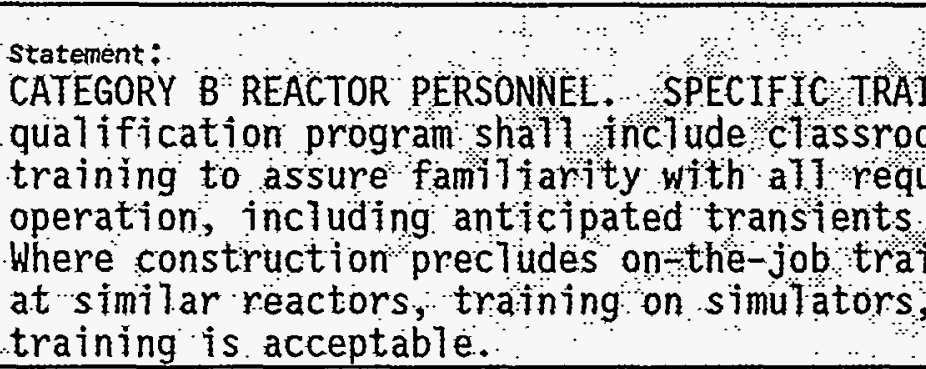 & $\begin{array}{l}\text { NING REQUIREMENTS, The } \\
\text { mtype and on the job } \\
\text { ired a spects of reactor } \\
\text { and accident conditions } \\
\text { ning, practical expertence } \\
\text { and other appropriate: }\end{array}$ \\
\hline
\end{tabular}


ASSESSMENT DATA COLLECTION FORM

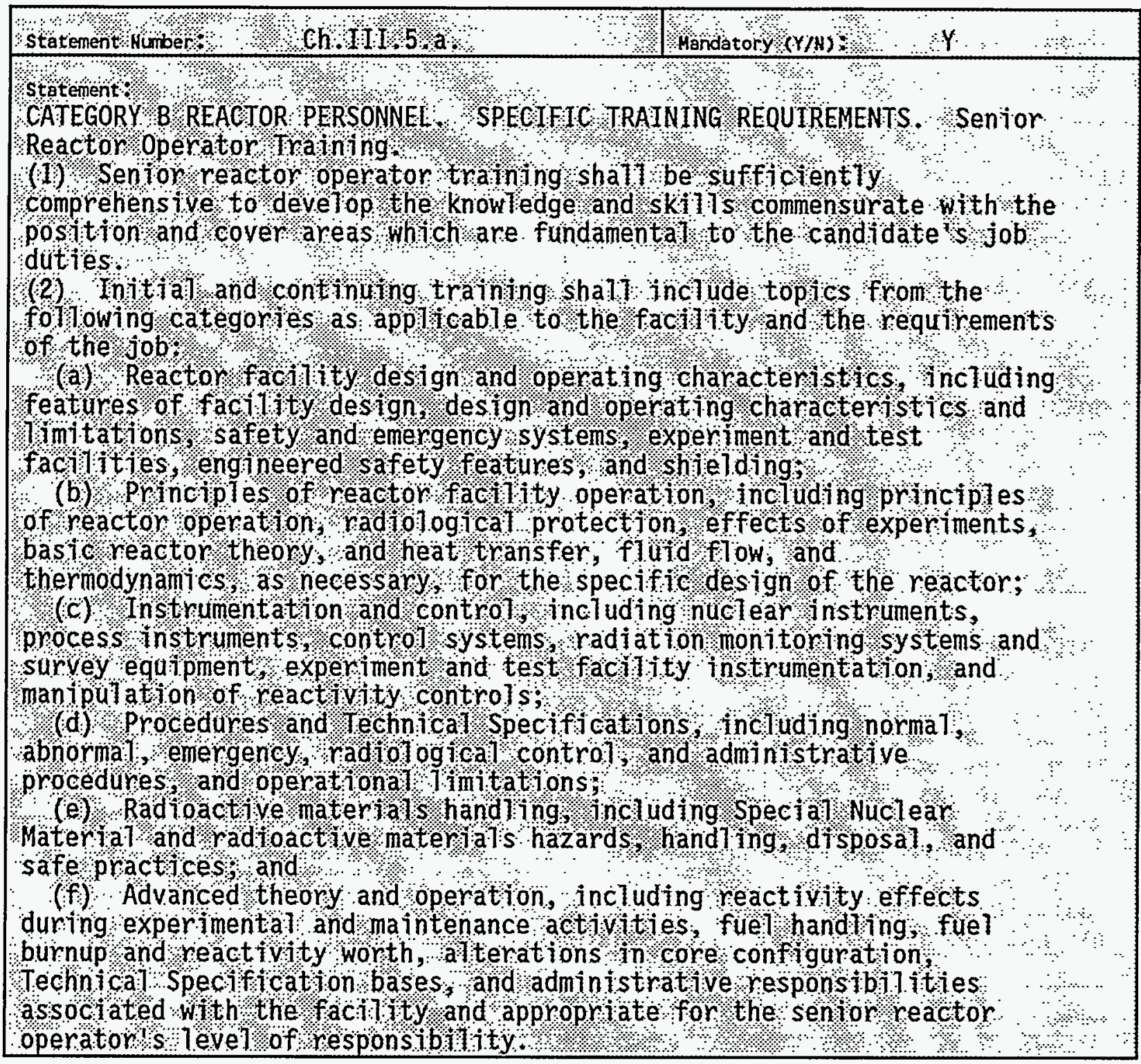

\begin{tabular}{|c|c|}
\hline 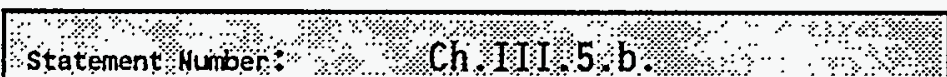 & 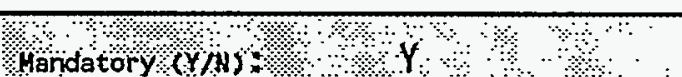 \\
\hline 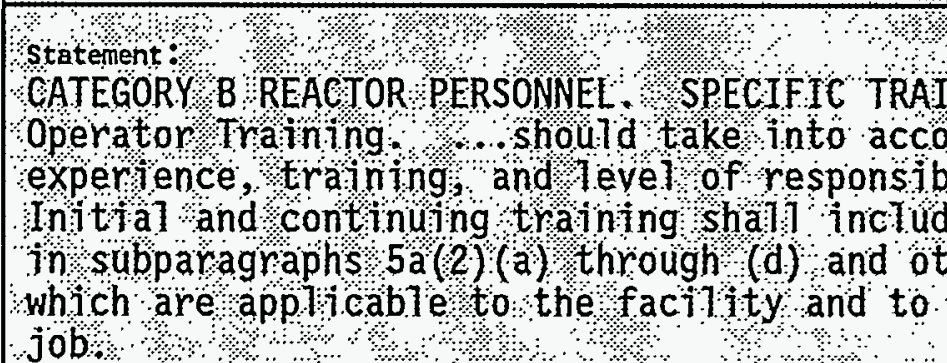 & 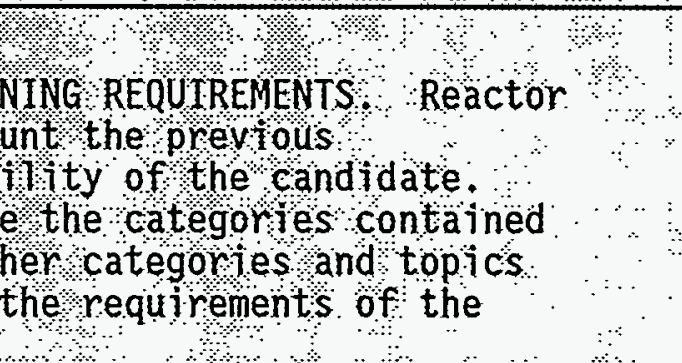 \\
\hline
\end{tabular}


WHC-EP-0822

\section{ASSESSMENT DATA COLLECTION FORM}

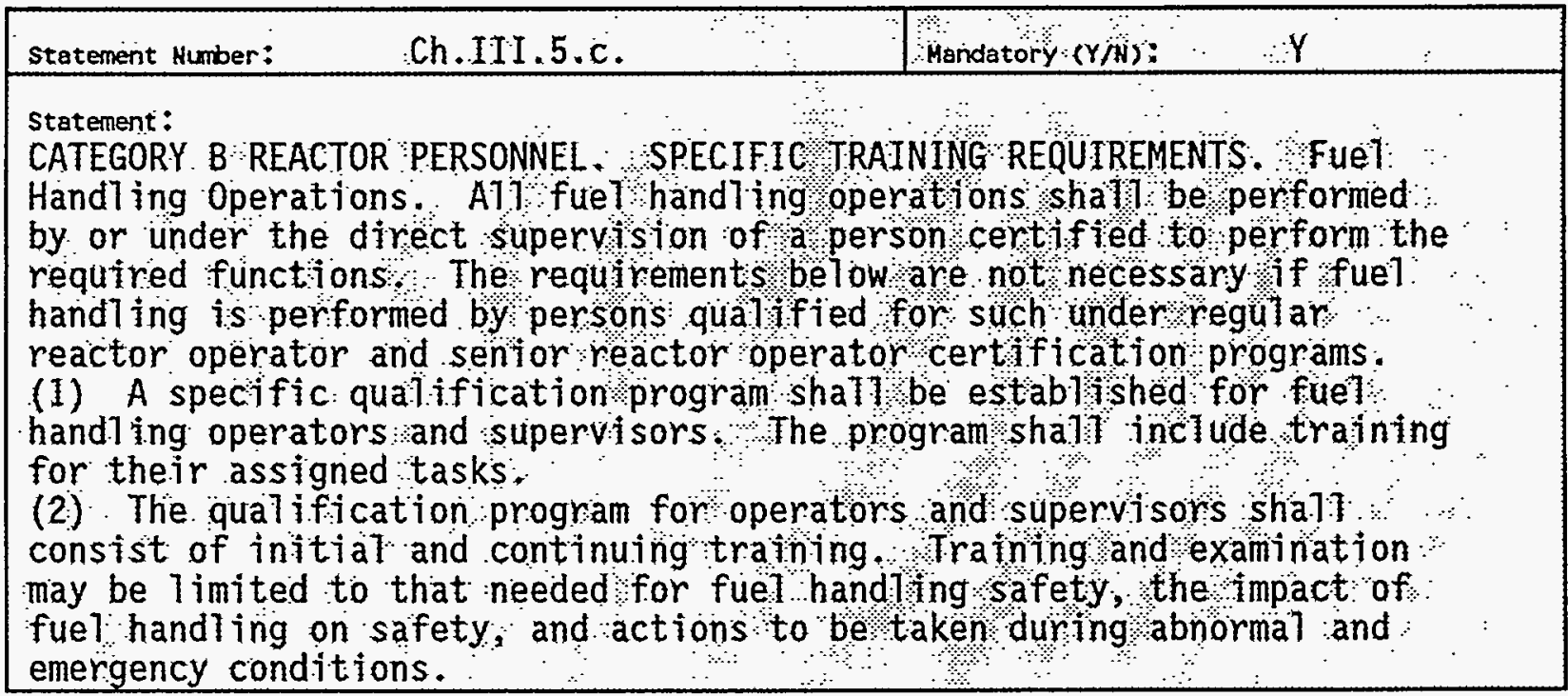

\begin{tabular}{|c|c|}
\hline Statement Number: & $\begin{array}{llll}\text { Mandatory }(Y / N) & \ddots & \ddots & Y \\
\end{array}$ \\
\hline 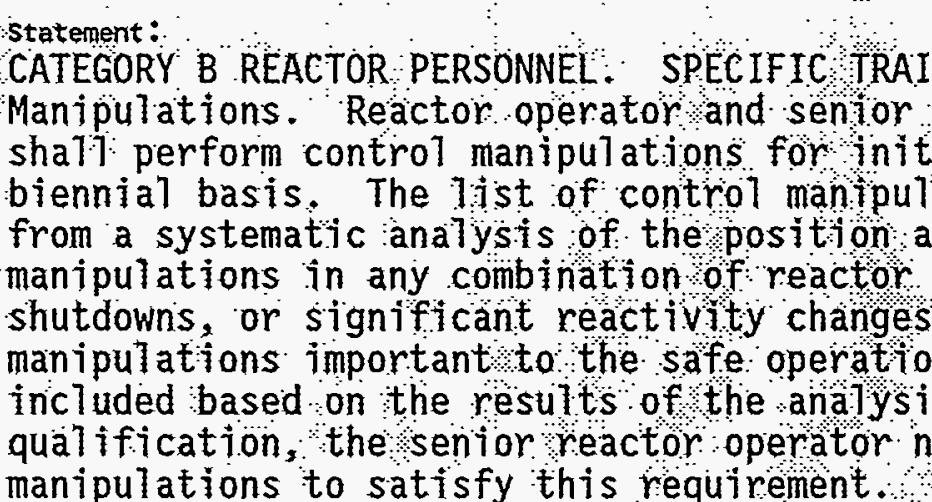 & 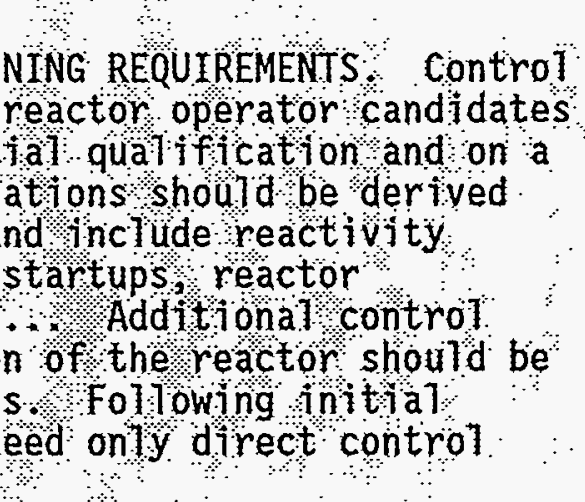 \\
\hline
\end{tabular}

Statement Number:

Ch. III.6:

Handatory $(Y / N)$

$Y$

statement:

CATEGORY B REACTOR PERSONNEL: OPERATOR PROFICIENCY REQUIREMENTS . In order to maintain proficiency, all certified reactor operators and senior reactor operators mustactively perform job. functions associated with their certification for at least four hours per calendar quarter. a. If this requirement is not met, certification shall be suspended and the person stall not be assigned certification duties unt certification is regained: Certification may be regained by performing: certified operator duties under the direct supervision of a certified operator for a minimum period of sixhours:

b. If the reactor is not operated frequent 7 enoughto meet these requirements, certification sha 17 be reinstated prior to reactor operation by administering written and ora examinations to ensure adequate operational knowledge. 
WHC-EP-0822

ASSESSMENT DATA COLLECTION FORM

The above Chapter III statements are specific to DOE Category B reactor facilities and are, therefore, $N / A$ to analytical laboratories. 
WHC-EP-0822

\section{ASSESSMENT DATA COLLECTION FORM}

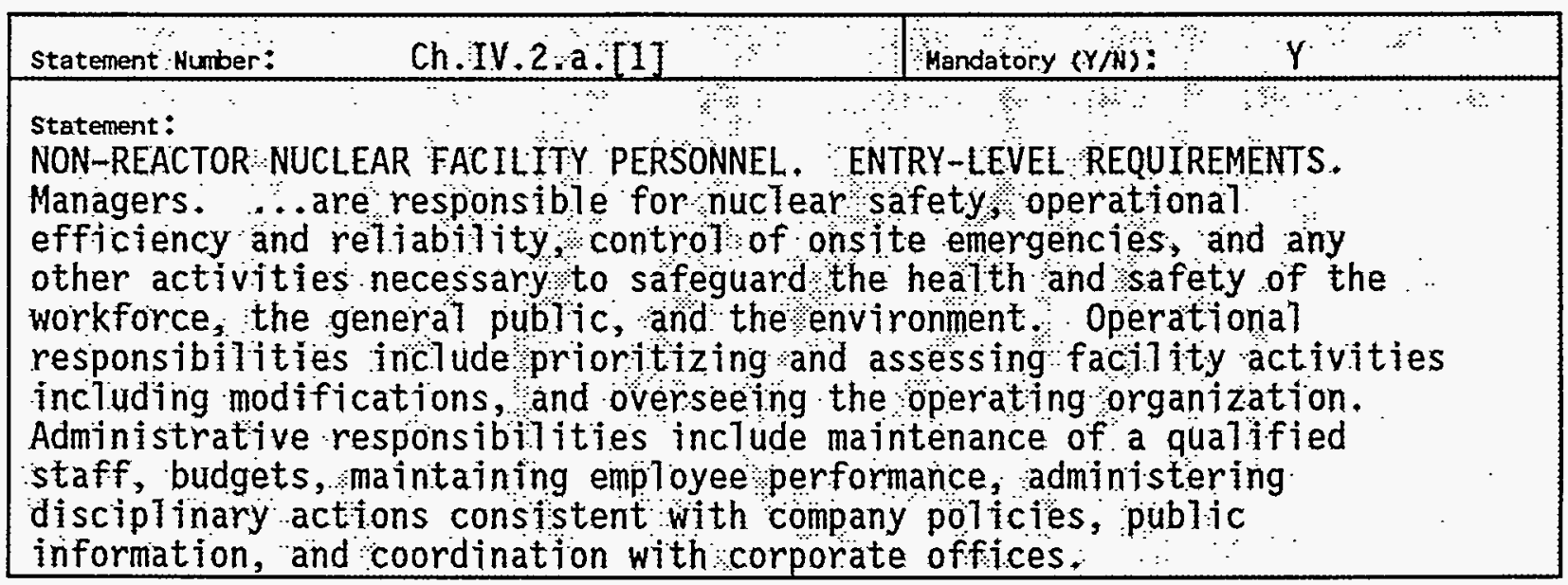

1.0 STATEMENT SATISFIED BASED ON IMPLEMENTING EVIDENCE (Y/N): NO

2.0 GENERAL DESCRIPTION OF EVIDENCE (DESCRIPTION OF NONCOMPLIANCE OR DEFICIENCY IF APPLICABLE):

Specific entry-level requirements for personnel are not addressed in the HASQAP.

3.0 CORRECTIVE ACTION: 
WHC-EP-0822

\section{ASSESSMENT DATA COLLECTION FORM}

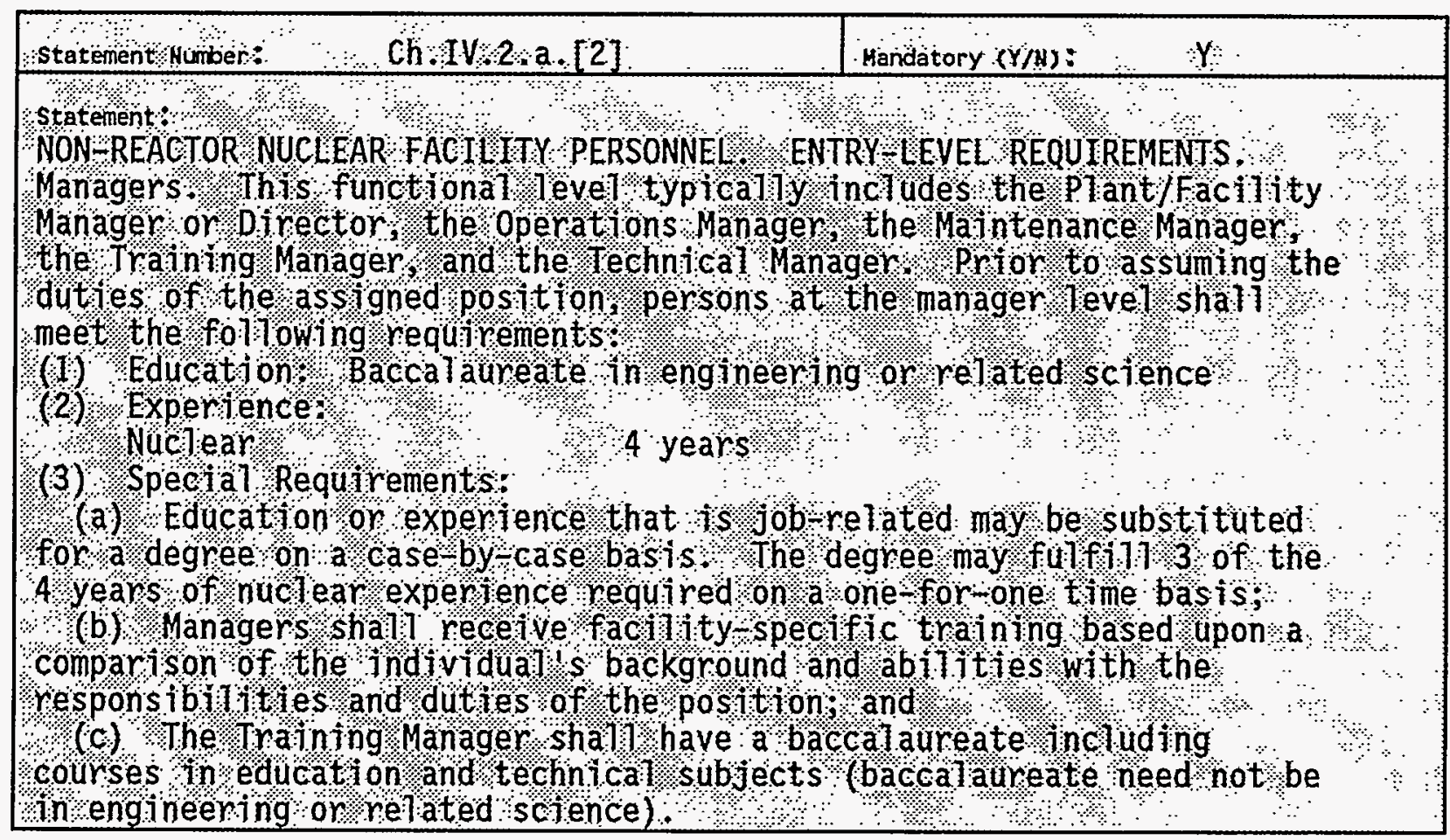

1.0 STATEMENT SATISFIED BASED ON IMPLEMENTING EVIDENCE (Y/N): NO

2.0 GENERAL DESCRIPTION OF EVIDENCE (DESCRIPTION OF NONCOMPLIANCE OR DEFICIENCY IF APPLICABLE):

Specific entry-level requirements for personnel are not addressed in the HASQAP.

3.0 CORRECTIVE ACTION: 
WHC-EP-0822

ASSESSMENT DATA COLLECTION FORM

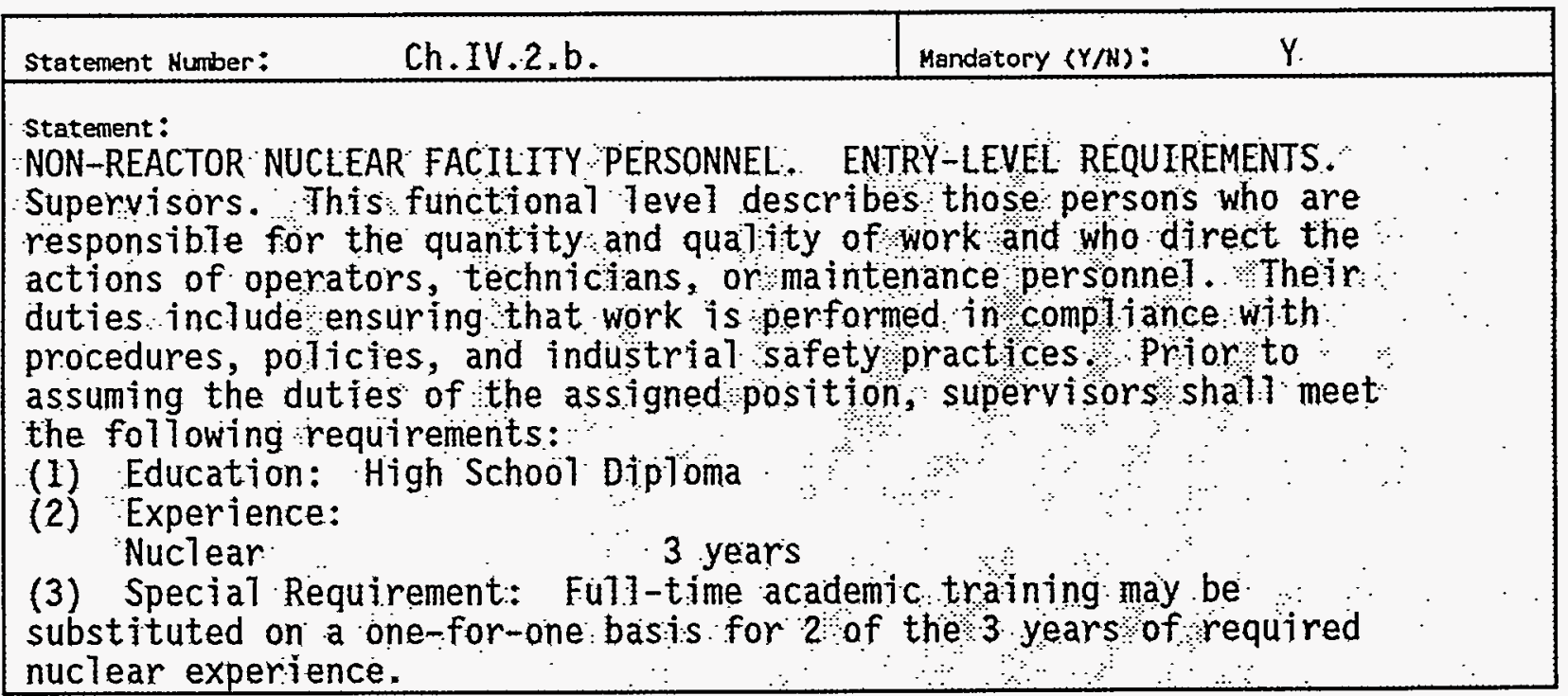

1.0 STATEMENT SATISFIED BASED ON IMPLEMENTING EVIDENCE $(Y / N)$ : NO

2.0 GENERAL DESCRIPTION OF EVIDENCE (DESCRIPTION OF NONCOMPLIANCE OR DEFICIENCY IF APPLICABLE):

Specific entry-level requirements for personnel are not addressed in the HASQAP.

3.0 CORRECTIVE ACTION: 


\section{ASSESSMENT DATA COLLECTION FORM}

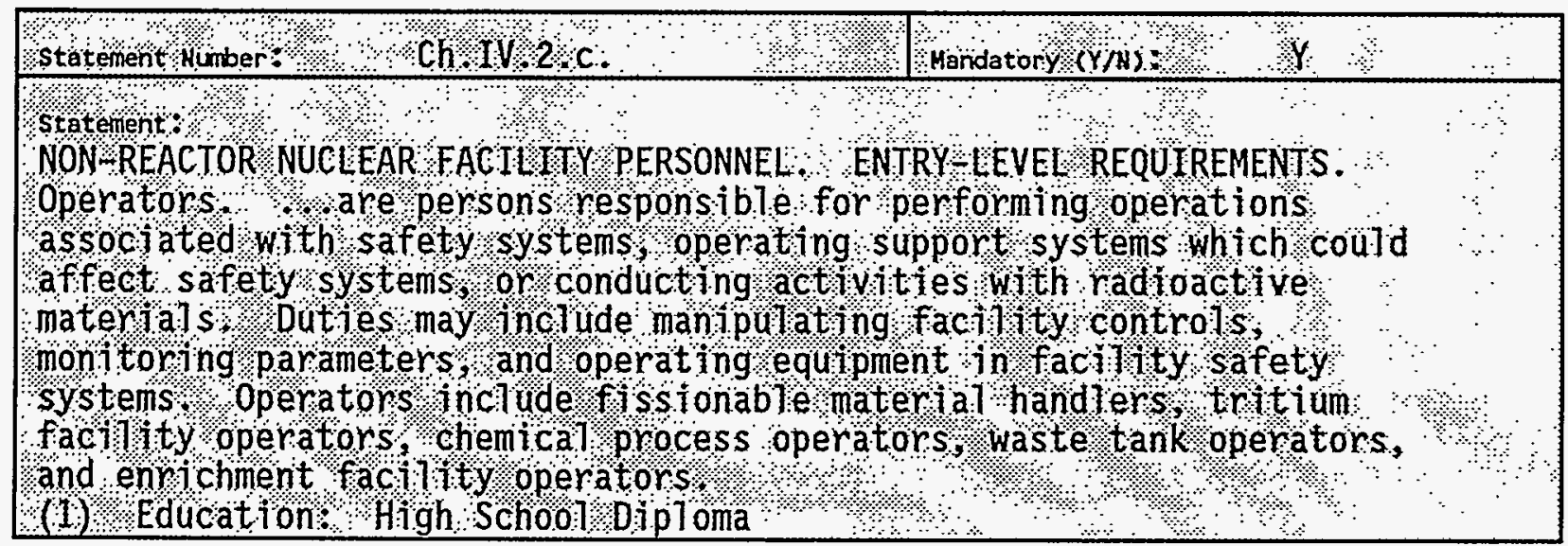

N/A 
WHC-EP-0822

\section{ASSESSMENT DATA COLLECTION FORM}

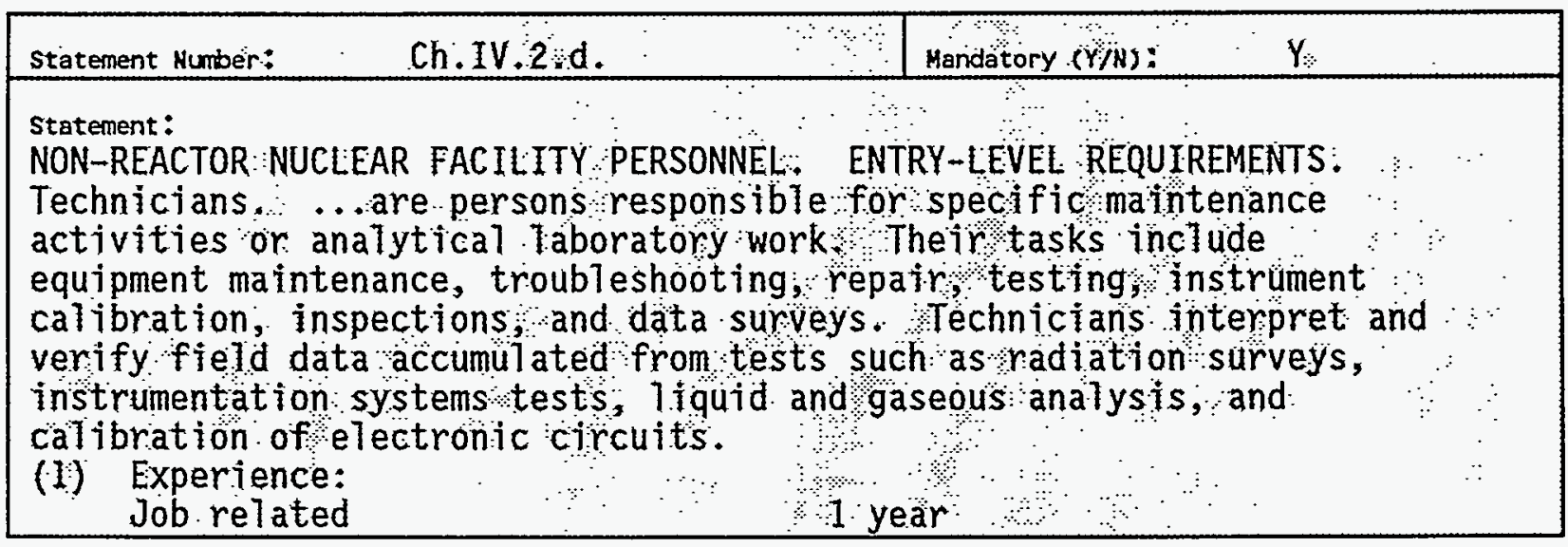

1.0 STATEMENT SATISFIED BASED ON IMPLEMENTING EVIDENCE (Y/N): NO

2.0 GENERAL DESCRIPTION OF EVIDENCE (DESCRIPTION OF HONCOMPLIANCE OR DEFICIENCY IF APPLICABLE):

Specific entry-level requirements for personnel are not addressed in the HASQAP.

3.0 CORRECTIVE ACTION: 


\section{ASSESSHENT DATA COLLECTION FORM}

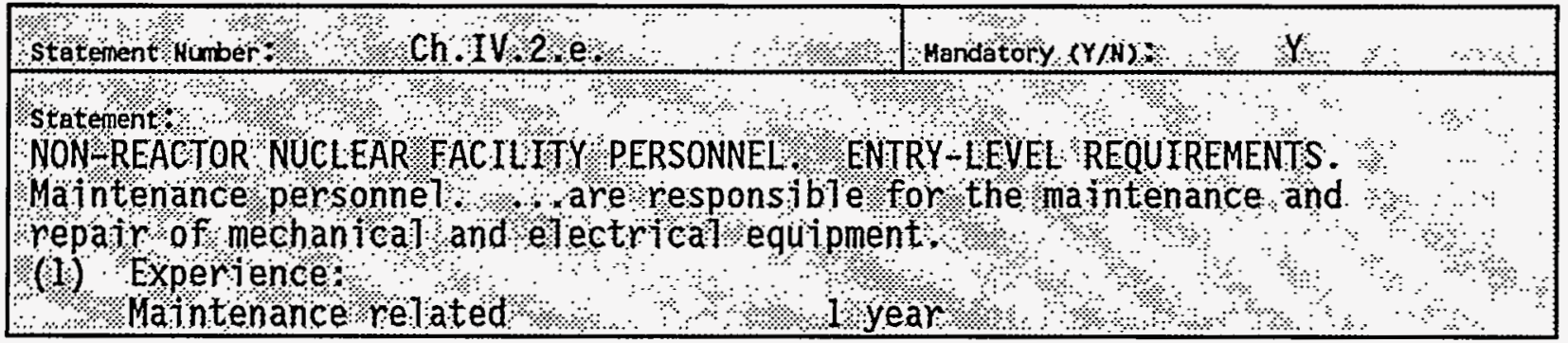

N/A 


\section{ASSESSMENT DATA COLLECTION FORM}

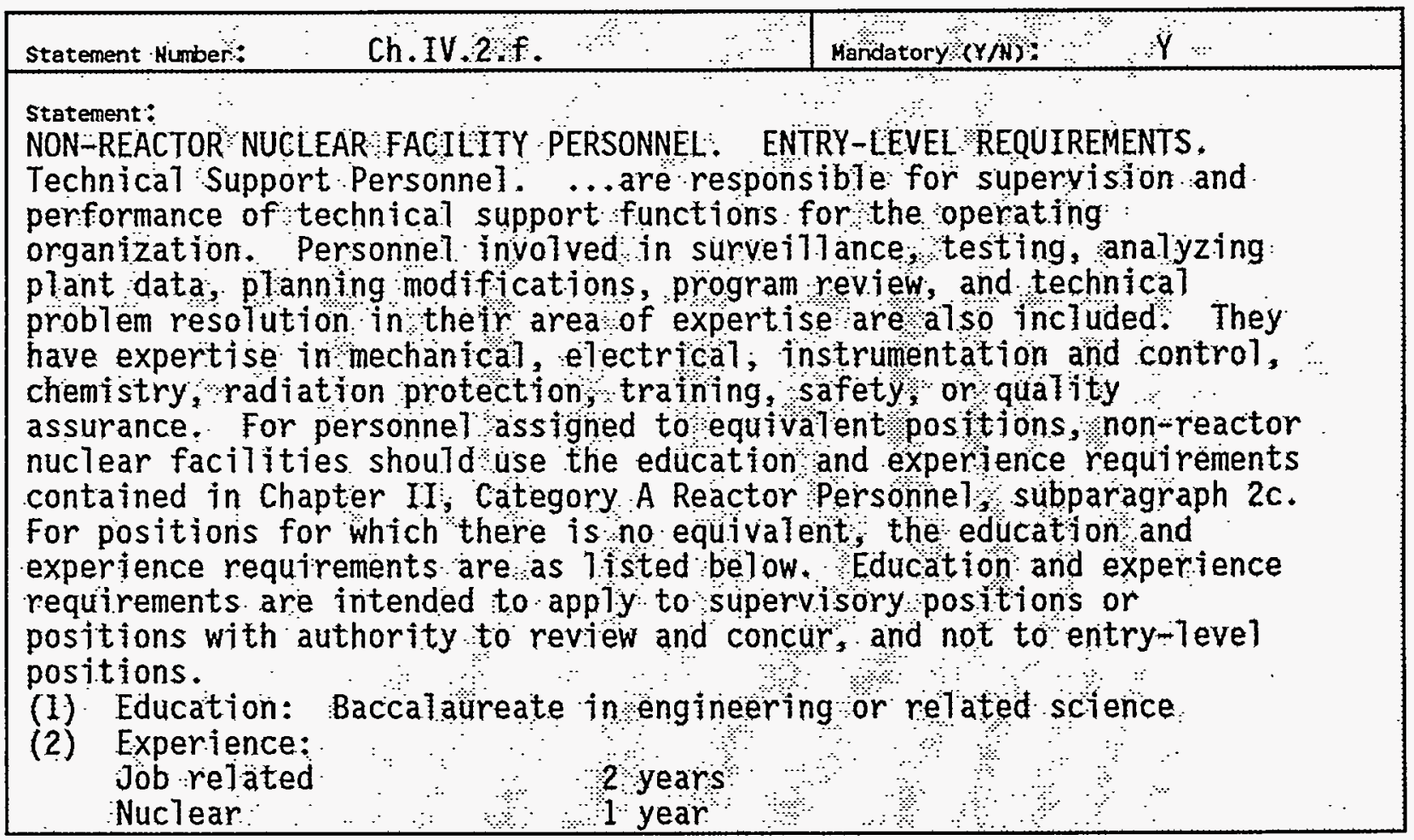

1.0 STATEMENT SATISFIED BASED ON IMPLEMENTING EVIDENCE $(Y / N):$ NO

2.0 GENERAL DESCRIPTION OF EVIDENCE (DESCRIPTION OF NONCOMPLIANCE OR DEFICIENCY IF APPLICABLE):

Specific entry-level requirements for personnel are not addressed in the HASQAP.

3.0 CORRECTIVE ACTION: 


\begin{tabular}{|c|c|}
\hline 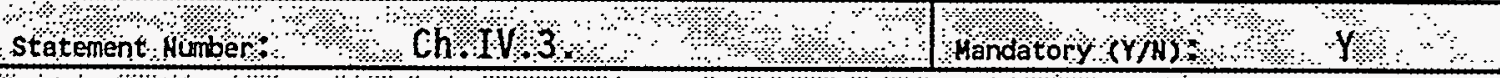 & \\
\hline 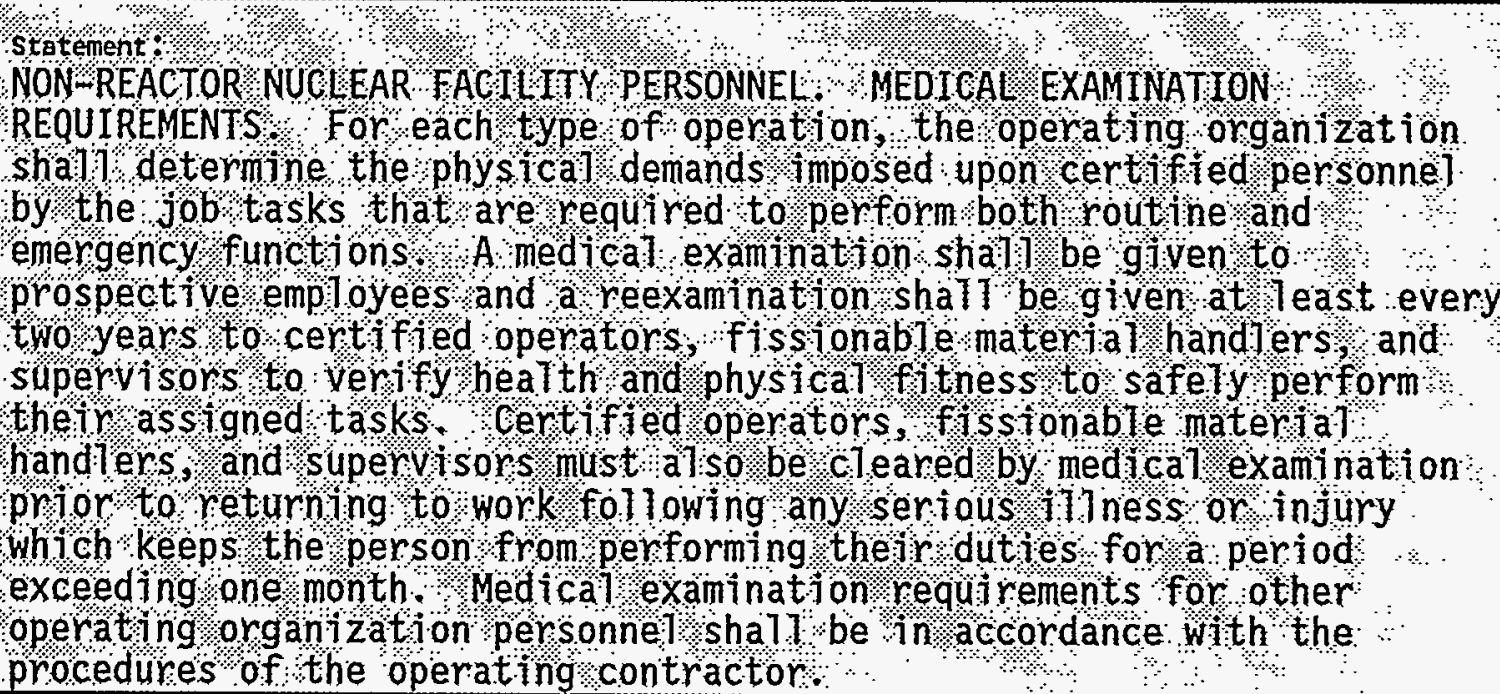 & \\
\hline
\end{tabular}

N/A

\begin{tabular}{|c|c|}
\hline 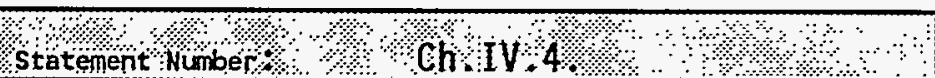 & Mandatory $(Y / N) *$ ? :y \\
\hline 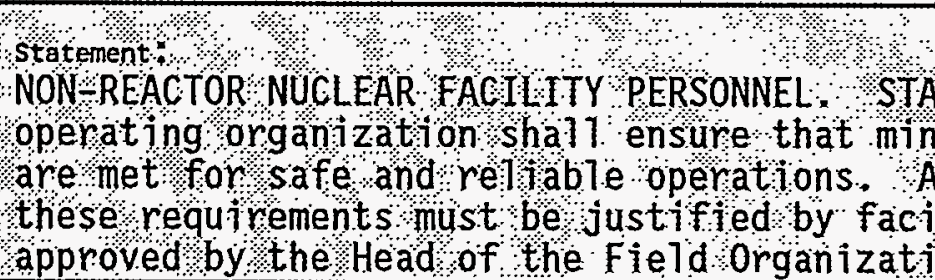 & 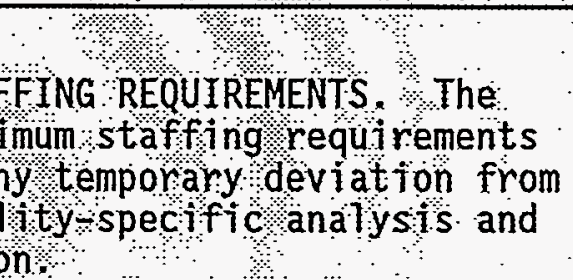 \\
\hline
\end{tabular}

\section{N/A}

\begin{tabular}{|c|c|}
\hline 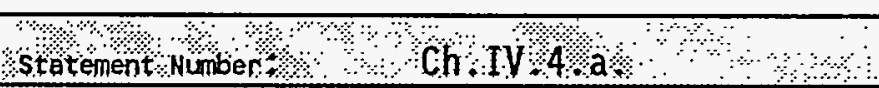 & Handatory (YIN) \\
\hline 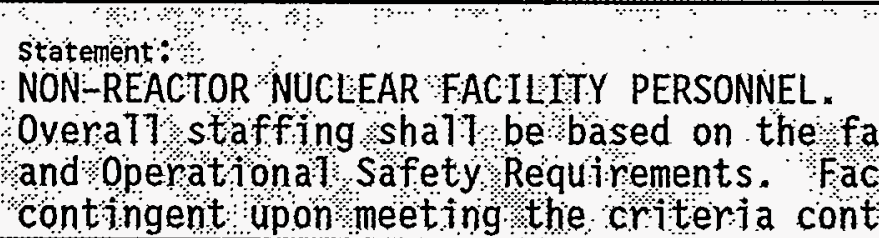 & $\begin{array}{l}\text { FFING REQUIREMENTS. } \\
\text { tyy Safety Analys is Report } \\
\text { ty operation shäl be } \\
\text { edinthese documents }\end{array}$ \\
\hline
\end{tabular}

\section{N/A}




\section{ASSESSMENT DATA COLLECTION FORH}

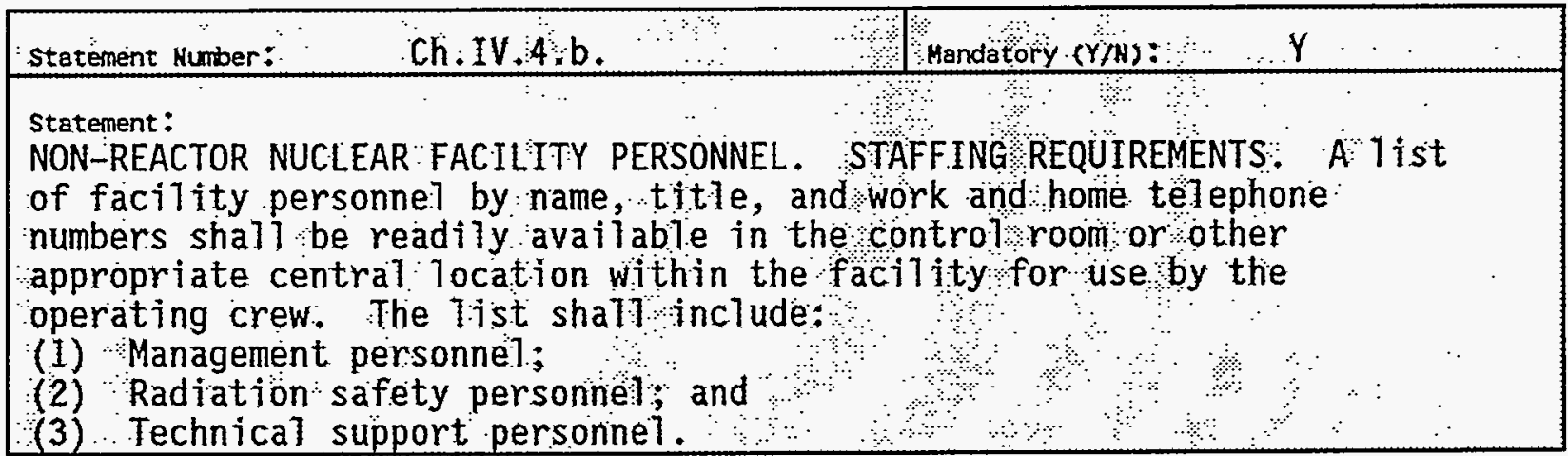

1.0 STATEMENT SATISFIED BASED ON IMPLEMENTING EVIDENCE $(Y / N):$ NO

2.0 GENERAL DESCRIPTION OF EVIDENCE (DESCRIPTION OF NONCOMPLIANCE OR DEFICIENCY IF APPLICABLE):

Statement is not addressed in the HASQAP.

3.0 CORRECTIVE ACTION: 


\section{ASSESSMENT DATA COLLECTION FORM}

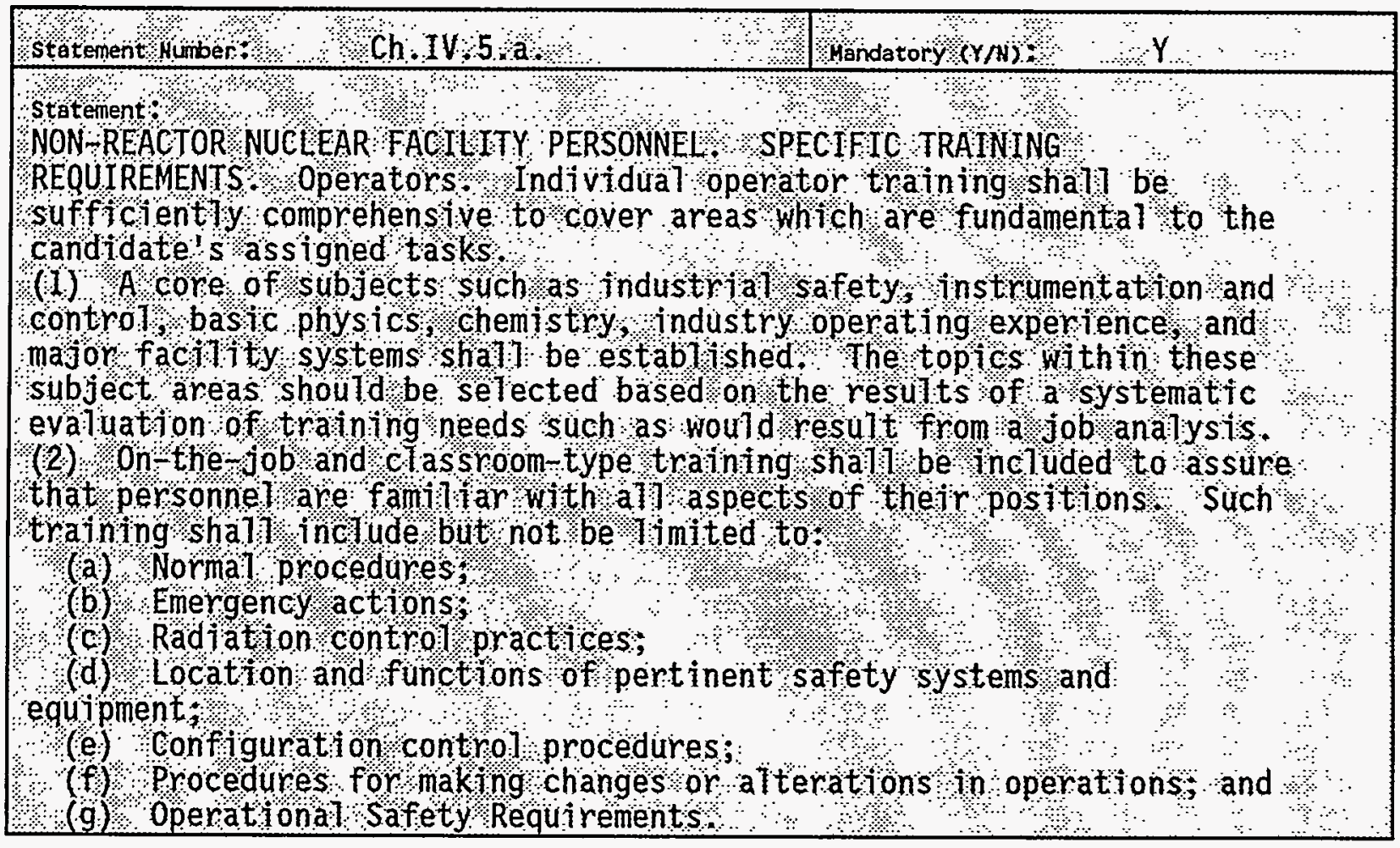

N/A

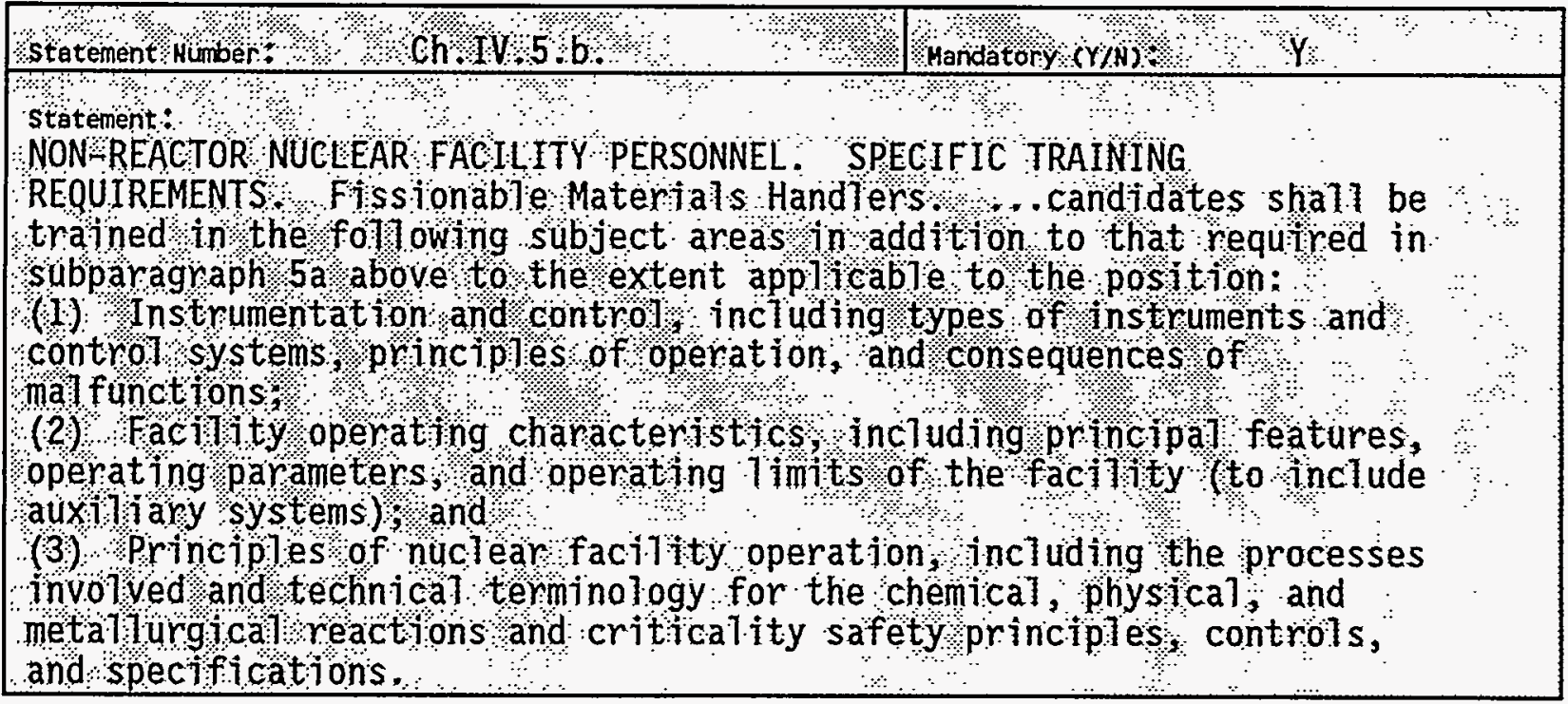

\section{N/A}




\section{ASSESSMENT DATA COLLECTION FORM}

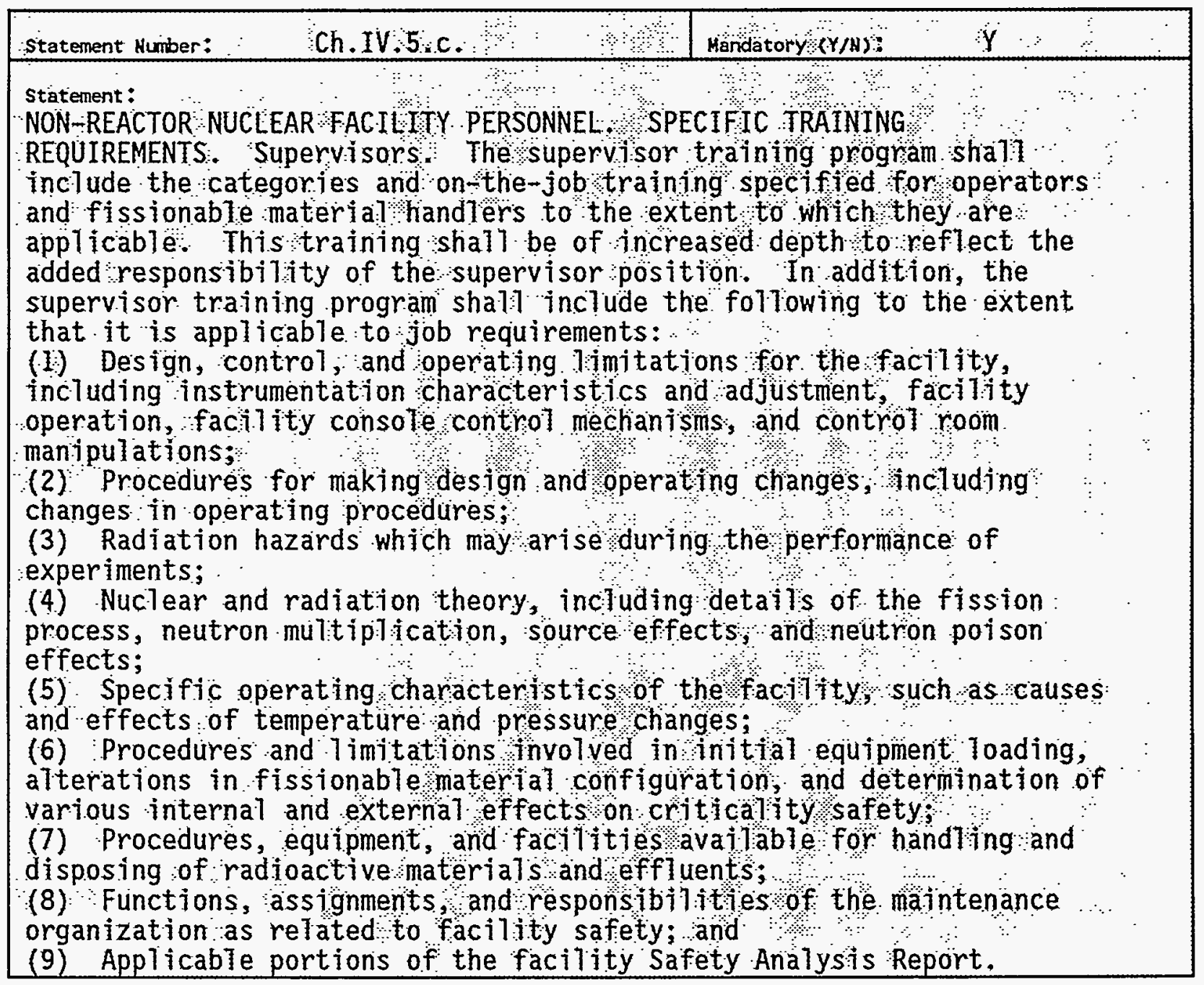

\section{N/A}


WHC-EP-0822

\section{ASSESSMENT DATA COLLECTION FORM}

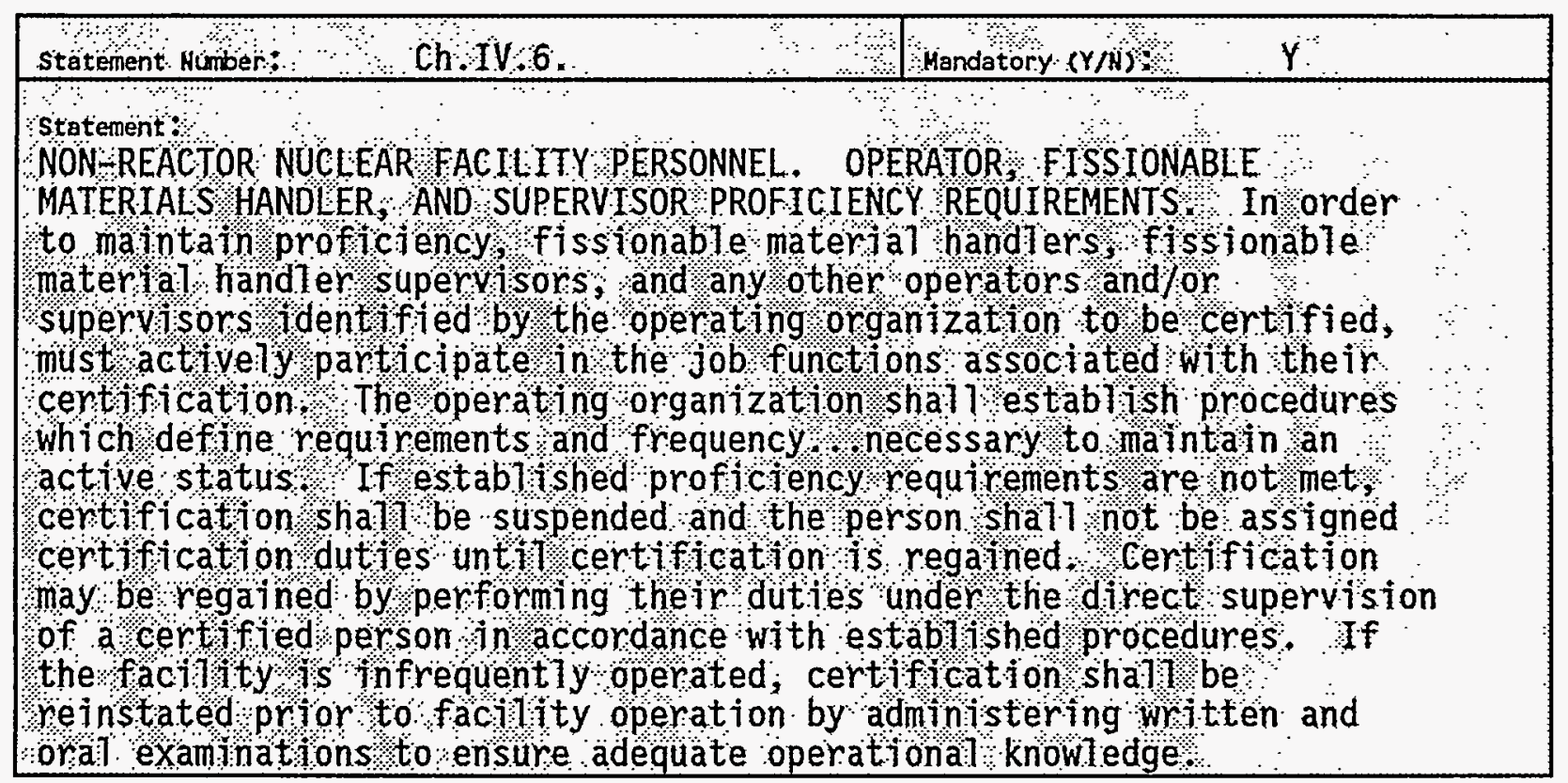

\section{N/A}




\section{DISTRIBUTION}

Number of copies

ONSITE

8

U.S. Department of Enerqy-

Richland Operations office
R. P. Carter
S7-55
C. E. Clark
A5-15
J. W. Day
A5-19
L. P. Jackson
S7-55
C. K. Kasch
A5-55
K. K. Kawabata
S7-55
T. M. Stram
S7-55
Public Reading Room
A1-65

2

Bechtel Hanford, Inc.
J. H. Kessner
H4-23
C. Stacey
H4-23

1

Hanford Environmental Health Foundation

J. K. Samuets

B1-61

4

Pacific Northwest Laboratory
A. G. King
P7-22
K. J. KuhT-K1 inger
P7-27
J. M. Latkovich
P7-27
C. D. Taylor
B1-40

14

Westinghouse Hanford Company
M. L. Be11
T6-16
J. L. Deichman
H4-19
D. G. Farwick
H4-16
R. R. Grabbe
S3-28
V. W. Hall
H4-19
E. J. Kosiancic
T6-16
R. P. Marshall
T6-14
H. K. Meznarich
T6-16
S. L. Moist
P. M. Morant
R3-56
C. T. Narquis
H4-25
T6-50
L. H. Taylor
Central Files
H4-25
O.S.T.I. (2)
L8-04
L8-07 